\title{
Becoming Muslim in Imperial Russia
}

Conversion, Apostasy, and Literacy

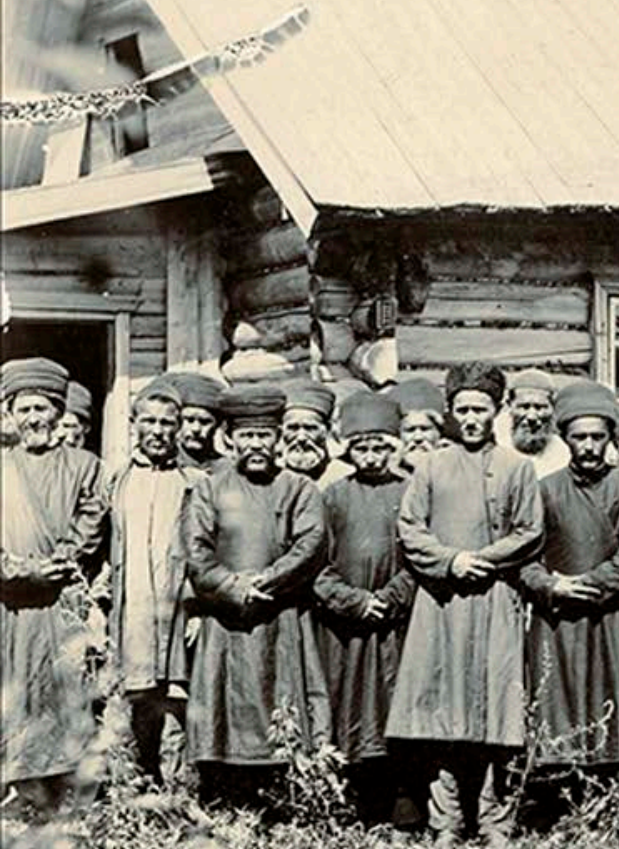

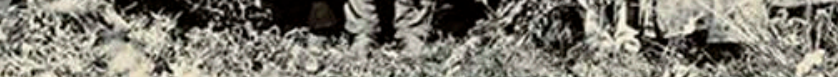

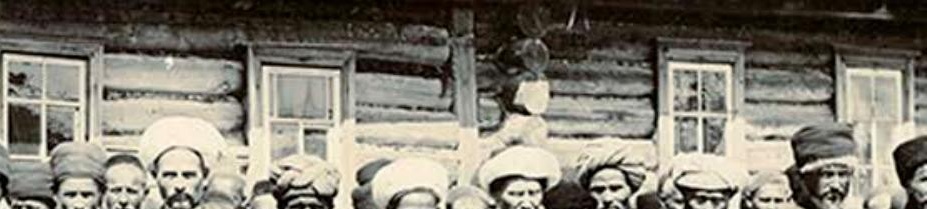

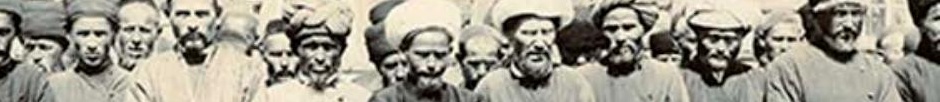

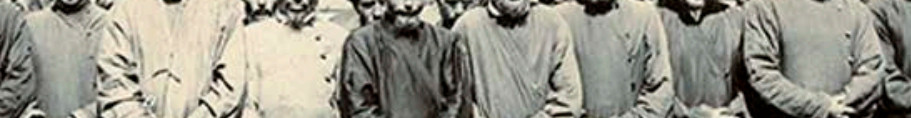

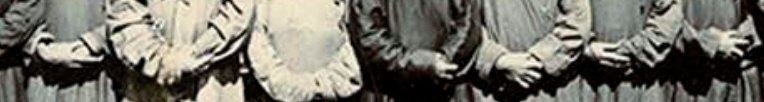
uns a

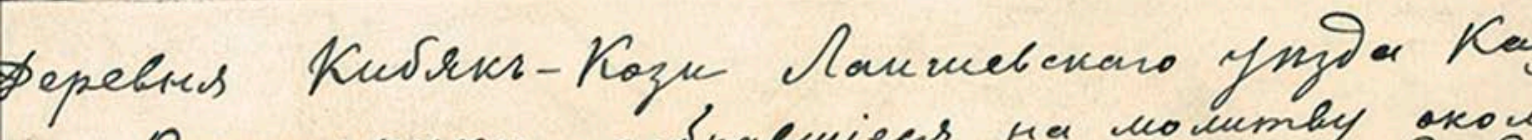

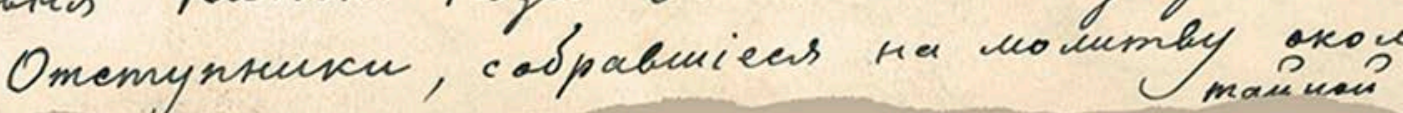

\section{Agnès Nilüfer Kefeli}


Becoming Muslim in Imperial Russia 



\title{
Becoming Muslim IN IMPERIAL RUSSiA
}

Conversion, Apostasy, and Literacy

\author{
AGNĖS NILÜFER KEFELI
}

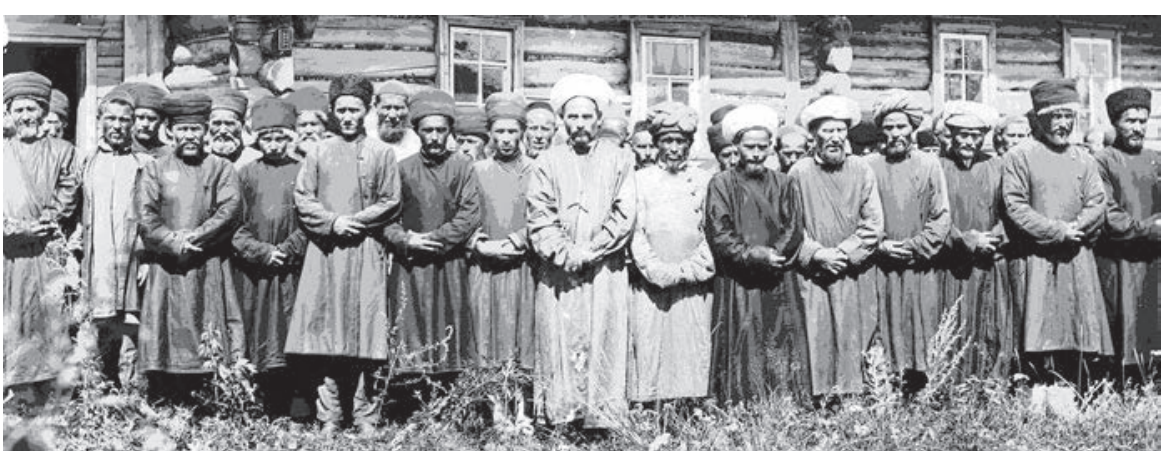


Jacket illustration: Apostates standing in front of their underground mosque in Kibiak-Kozi, Laishevo district. RGIA, f. 821, op. 4, d. 72, photograph no. 9.No date. Photograph courtesy of RGIA.

\section{Copyright $\odot 2014$ by Cornell University}

All rights reserved. Except for brief quotations in a review, this book, or parts thereof, must not be reproduced in any form without permission in writing from the publisher. For information, address Cornell University Press, Sage House, 512 East State Street, Ithaca, New York 14850.

First published 2014 by Cornell University Press

Printed in the United States of America

Library of Congress Cataloging-in-Publication Data

Kefeli, Agnès Nilüfer, author.

Becoming Muslim in Imperial Russia : conversion, apostasy, and literacy / Agnès Nilüfer Kefeli. pages $\mathrm{cm}$

Includes bibliographical references and index.

ISBN 978-0-8014-5231-4 (cloth : alk. paper)

1. Islam-Russia-History. 2. Apostasy-Islam. 3. Apostasy-Christianity. I. Title.

$\mathrm{DK}_{34 . M 8 K} 442014$

947.00882 ' $97-\mathrm{dc} 23$

$$
2014006974
$$

Cornell University Press strives to use environmentally responsible suppliers and materials to the fullest extent possible in the publishing of its books. Such materials include vegetable-based, low-VOC inks and acid-free papers that are recycled, totally chlorine-free, or partly composed of nonwood fibers. For further information, visit our website at www.cornellpress.cornell.edu. 
To Eugene 



\section{Contents}

Acknowledgments ix

List of Abbreviations $\quad$ xi

Note on Transliteration xiii

Maps xv

Introduction 1

1. Apostasy, Conversion, and Literacy at Work 7

2. Popular Knowledge of Islam on the Volga Frontier 60

3. Tailors, Sufis, and Abïstays: Agents of Change 117

4. Christian Martyrdom in Bolghar Land 161

5. Desacralization of Islamic Knowledge and National Martyrdom 213

Conclusion and Epilogue 255

Selected Bibliography 265

Index 277 



\section{Acknowledgments}

$\mathrm{P}$ erhaps because I grew up with both a Christian and a Muslim name and because I grappled from a very early age with different possible identities imposed by French schools or inherited from my parents' Celtic Breton and Turkic origins, I grew fond of the nineteenth-century Christian Tatar community whose names could also be either Christian or Muslim, depending on time, place, and context. Fortunately, no one asked me to choose between the different layers of my personal identities, and I did not have to face the hardships that this community endured for their religious commitments. In my personal scholarly journey, I had the support of many who helped me enter the world of these villagers whose imagination, faith, and endurance inspire both my admiration and sympathy.

I owe thanks to many people in the field of Eurasian and Central Asian studies who have either provided sources and material support or commented on my work: Stephen Batalden, Wladimir Berelowitch, Daniel Brower, Devin DeWeese, Robert Geraci, Fred Giffin, Shoshana Keller, Adeeb Khalid, Edward Lazzerini, Laurie Manchester, Danielle Ross, Daniel Schafer, and Paul Werth. My special gratitude goes to Allen Frank, whose passion for the Turkic literary world and sacred geography I share. I still recall our passionate conversations about Finno-Ugric and Turkic identities in Washington, DC, while I was a Kluge fellow at the Library of Congress. Finally, Uli Schamiloglu has always been my supporter and mentor since I came to the United States, giving me my first lessons of Tatar language and Arabic script, and later providing me with the opportunity to teach Tatar. This research, however, would not have taken the shape it did without the strong support of my Tatar and Kräshen colleagues, scholars, archivists, and language teachers in St. Petersburg, Orenburg, and Kazan: Iakhia Abdullin, Marsel' Akhmetzianov, Goldzhihan Biktimirova, Damira Gobaidullina, Damir Iskhakov, Radik Iskhakov, Lialia Khasanshina, Gennadii Makarov, Nikolai Petrov, Madina Rakhimkulova, Endzhe Sagidova, Raushaniia Shafigullina, Flera Urmanche, Farit Iakhin, Il'dus Zagidullin, and Fanzilia Zavgarova, who gave me access to local archives, extensive bibliographies, and the means and connections to do fieldwork in the countryside. My colleagues Jim Allen (a Europeanist), Kay Carr (an Americanist), and Pori Park (a scholar of Buddhism) were especially supportive throughout project, and I deeply appreciate the breadth of their perspectives.

My deepest gratitude and admiration go to the inhabitants of Elyshevo (Yilish), in particular the journalist Golsina Khamidullina, who shared her home, pictures of her ancestral past, handwritten diaries and epics, and introduced me to her village's sacred landscape and keeps me informed of its changes by e-mail. I was also 
greatly aided by the inhabitants of Bogatye Saby (Baylar Sabasï), in particular Saima Shafigullina and her son, Rafael, who drove me to the villages and sacred places that Russian missionaries and the police mentioned in their reports and diaries. I also remember fondly the welcome I received from the elderly Kräshen and Tatar community of Ianyli who diligently gathered around me to share their parents' and grandparents' memories and genealogies, and then took me to their cemeteries, mosque and church, and homes to show me amulets and books that belonged to their ancestors. Chura village also earned my admiration for keeping the Kräshen ways of life and rebuilding their church, and Kibiak-Kozi for restoring their mosque and finding ways to improve their knowledge of Islam, which they found faulty because of seventy years of communism. Finally, I still remember the chants of young Kräshen children, dressed in their grandparents' clothes, welcoming me to their school in Urias'bash with bread and salt.

Three International Research and Exchanges Board Grants (IREX) funded these trips. Other grants-an American Fellowship of the American Association of University Women, a John W. Kluge Fellowship at the Library of Congress in Washington, DC, seed grants from the Arizona State University Institute for Humanities Research and the Center for the Study of Religion and Conflict-freed me from teaching. Arizona State University's Melikian Center and the Faculty of Religious Studies provided a subvention for this work. At the Kluge Center, in particular, I benefited tremendously from the conversations I had with my Kluge fellows, especially Johanna Bockman and Monica Dominguez Torres, and from the kindness and expertise of Caroline Brown and Mary Lou Reker, who created the right intellectual forum for my blossoming. Washington, DC, was also the place where I had the opportunity to discuss my work with two other friends, Robert Geraci and Rita Guenther, whom I first met in Kazan and who share equal passion for the Middle Volga region. My research assistants at ASU and the Kluge Center, Katrina Koser, Lourdes Saez, Nathan Schick, Joon Sik, Timothy Swanger, and David Walsh, provided invaluable help. I am also indebted to my anonymous readers and John Ackerman for their comments, which transformed my earlier manuscript into a book.

I am also grateful for Slavic Review to have allowed me to reprint portions of an article I wrote earlier: "The Tale of Joseph and Zulaykha on the Volga Frontier: The Struggle for Gender, Religious, and National Identity in Imperial and PostRevolutionary Russia," Slavic Review 70, no. 2 (Summer 2011): 373-398.

Finally, I would like to thank my father, Beyzade Yusuf Mejid Kefeli, and my mother, Anne Toudic, who because of their origins introduced me to Ottoman history and the history of minorities in France and Russia, and to the idea that there is more than one way to tell a story. My thanks also go to my sister, Eva Hanzade, and my children, Anne Safiya and Joy Nilüfer, who-when I was too busy deciphering my sources-would sing a Tatar song they learned in Kazan to remind me of their presence. All my gratitude also goes to my adopted Tatar family, Ilkem and Glius Mustafin, who took care of me as one of their own. Finally, I would have never completed this work without my husband, Eugene Clay, who patiently endured my saying that there was nothing I could do except "Tatar stuff." This book (or rather my story of the nineteenth-century Kräshen apostasies) is dedicated to him. 


\section{Abbreviations}

\section{Archives and Published Sources}

GAOO Gosudarstvennyi Arkhiv Orenburgskoi Oblasti, Orenburg

IKE Izvestiia po Kazanskoi eparkhii

IOAIE Izvestiia Obshchestva arkheologii, istorii i etnografi pri Kazanskom universitete

MPMS Missionerskii protivomusul'manskii sbornik

NART Narodnyi Arkhiv Respubliki Tatarstan

$P B \quad$ Pravoslavnyi blagovestnik

PO Pravoslavnoe obozrenie

PS Pravoslavnyi sobesednik

PSZ Polnoe sobranie zakonov Rossiiskoi Imperii

RGIA Rossiiskii Gosudarstvennyi Istoricheskii Arkhiv, St. Petersburg

\section{Archival Citations}

f. fond (collection)

ed. khr. edinitsa khraneniia (file)

op. opis' (inventory)

d. delo (file)

ch. chast' (part)

1. or 1l. list or listy (leaf or leaves)

ob. oborot (verso)

\section{Published Source Citation}

$\mathrm{SPb} . \quad$ St. Petersburg 



\section{Note on Transliteration}

I

used the Library of Congress system of transliteration for Russian. For Kräshen texts, I applied the same transliteration system as for Russian Cyrillic. For Tatar, texts I consulted were in either Arabic script or the Cyrillic alphabet. Because there is no standardized way to transliterate either alphabet for Tatar, I adopted the following method.

For titles and personal names in Cyrillic, I used Edward Allworth's transliteration method as given in Nationalities of the Soviet East: Publications and Writing Systems (1971) with two major changes. With regard to consonants, I distinguished between $q$ before a back vowel and $k$ before a front vowel, and $g h$ before a back vowel and $g$ before a front vowel, except in Russian and international loan words.

For personal names in Arabic script, I used the standard English transliteration system for Persian as given in the International Journal of Middle East Studies (2001) but without diacritical marks in the text. However, diacritics appear in the text in the names of books and in the footnotes. Long vowels, however, appear only for words of Arabic and Persian origin, not for Turkic words and Russian loan words. In most cases, the vocalization of Tatar personal names and book titles is given as reported in modern Tatar.

In general, for the spelling of Islamic terms I used the classical Arabic-script spelling and gave their standard Romanized transcription without diacritics. Arabic words that are commonly used in English and listed in Merriam-Webster's Dictionary were not italicized.

Names of villages are usually reported in Russian, except when the Tatar name has some relevance in the text and differs completely from the Russian name. In general, the Tatar name of a location is placed in parentheses after its Russian name the first time it appears.

Dates are given according to the Julian calendar, which in the nineteenth century was twelve days - and in the twentieth century, thirteen days-behind the Gregorian calendar. 



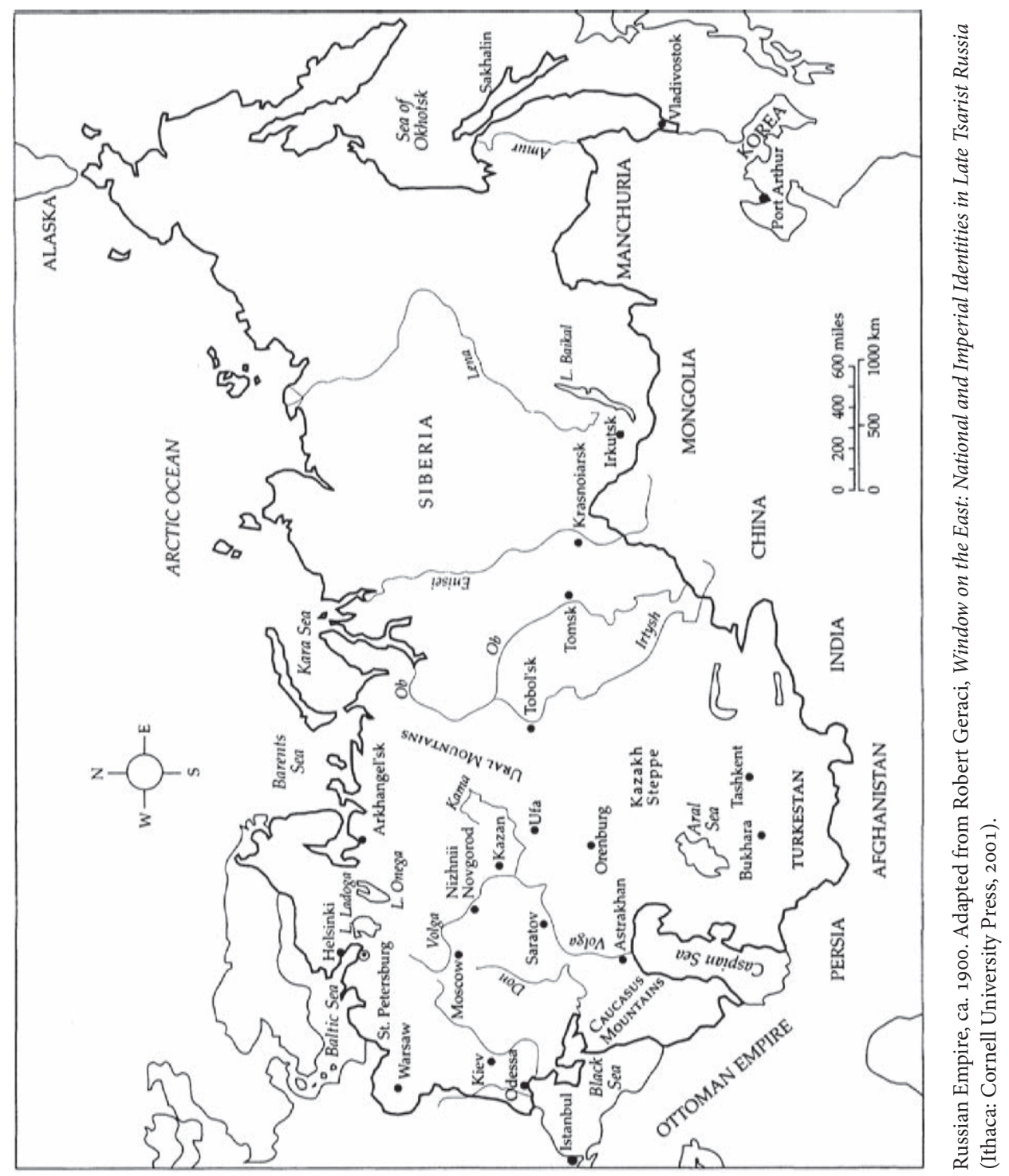




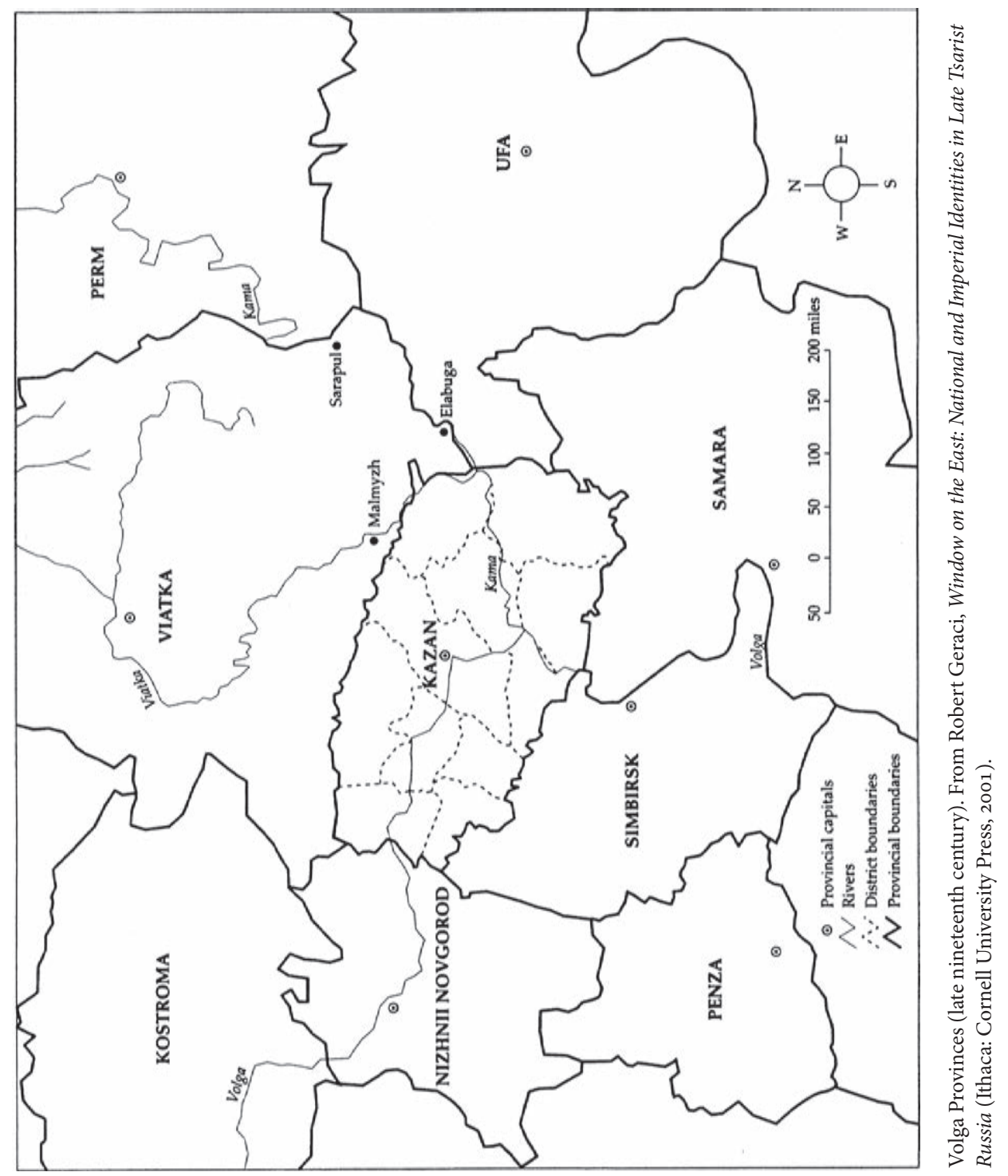




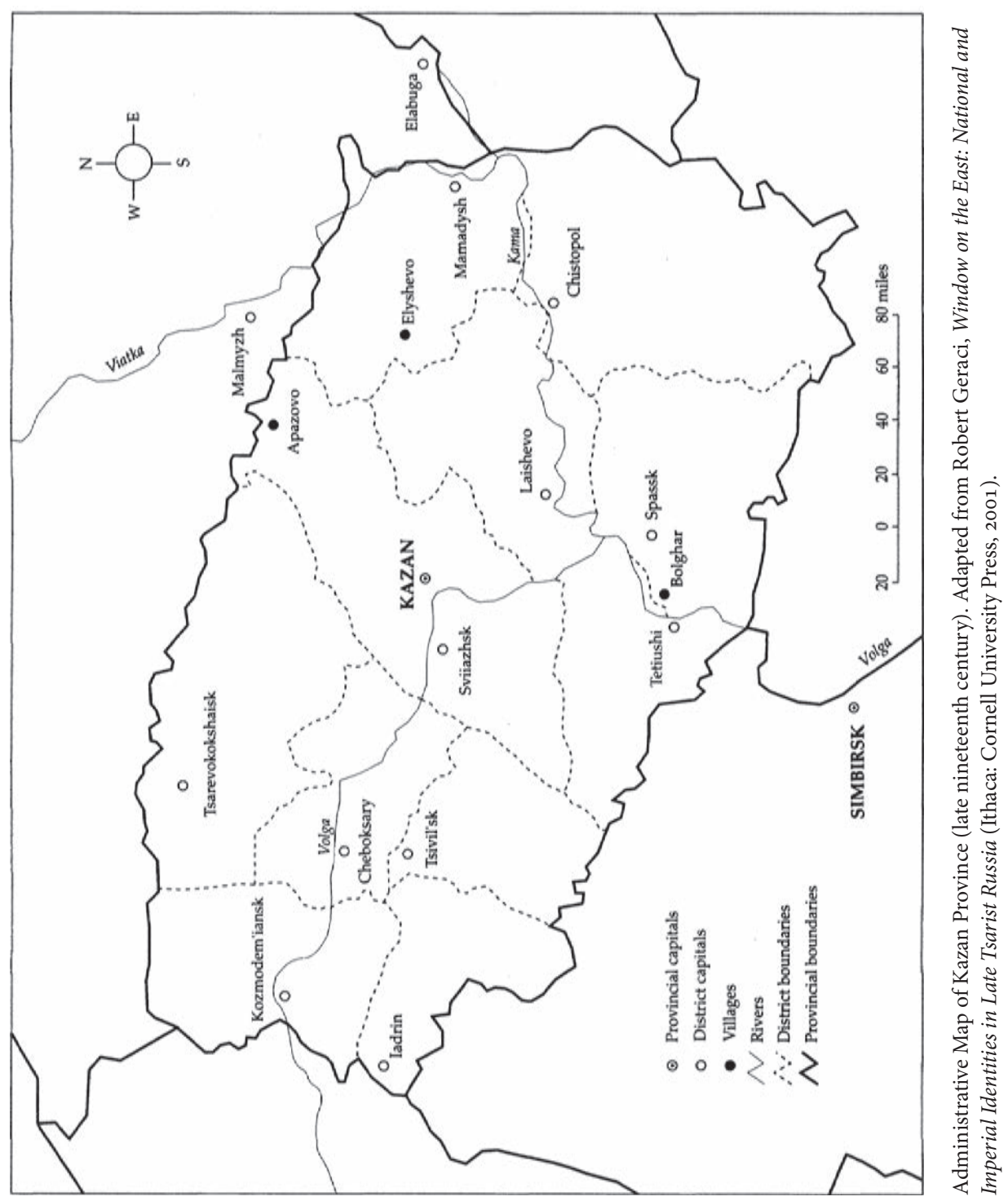




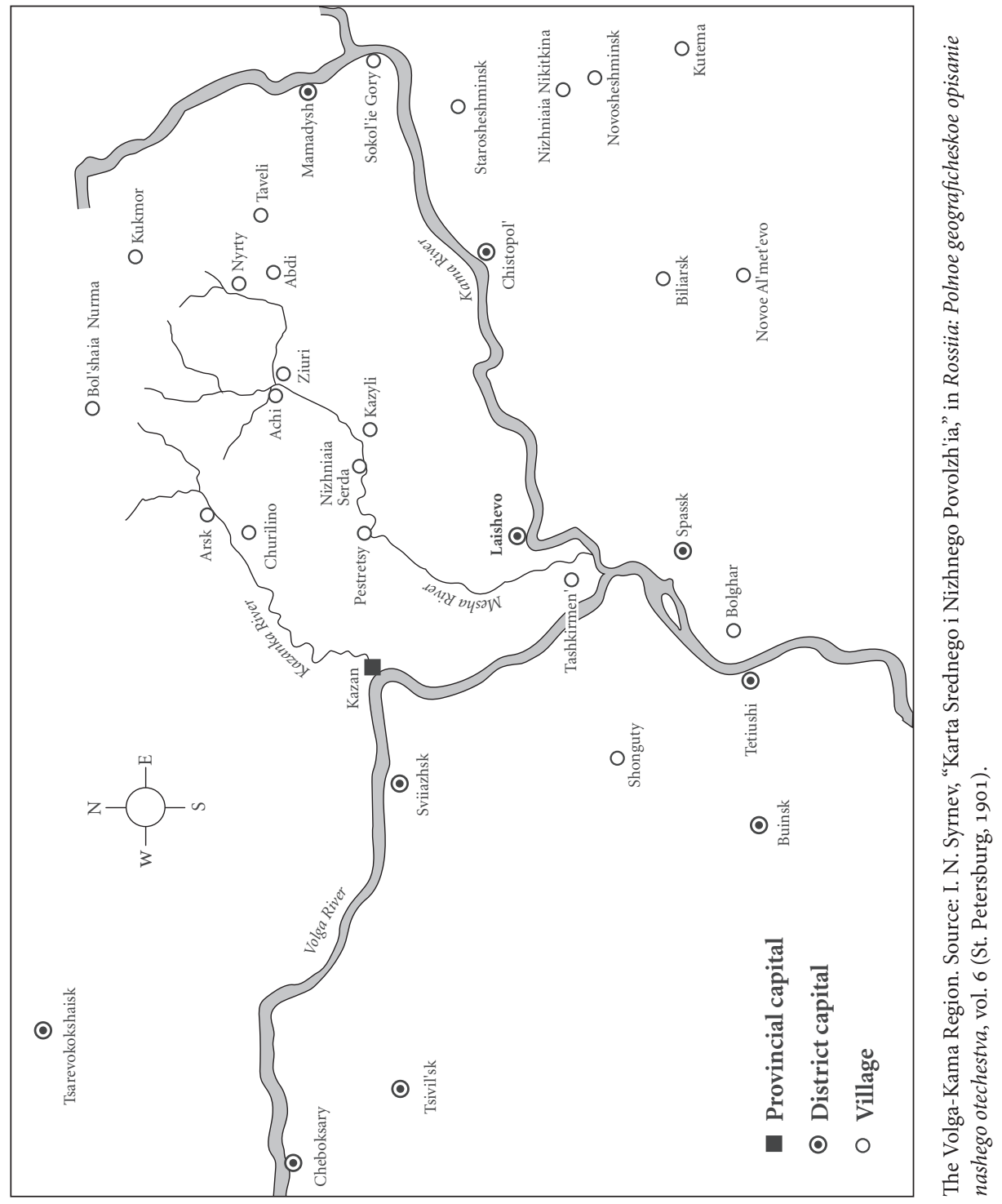




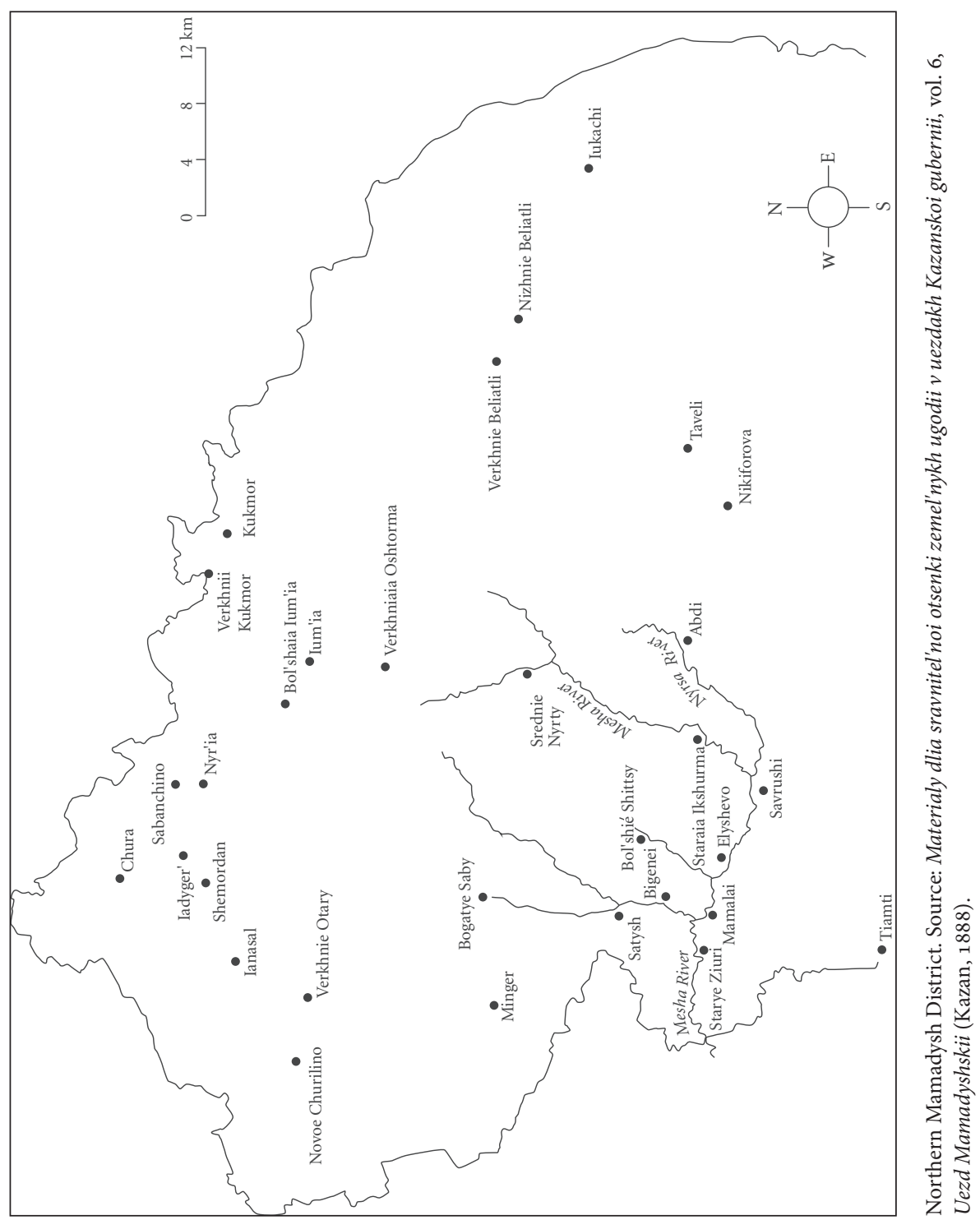




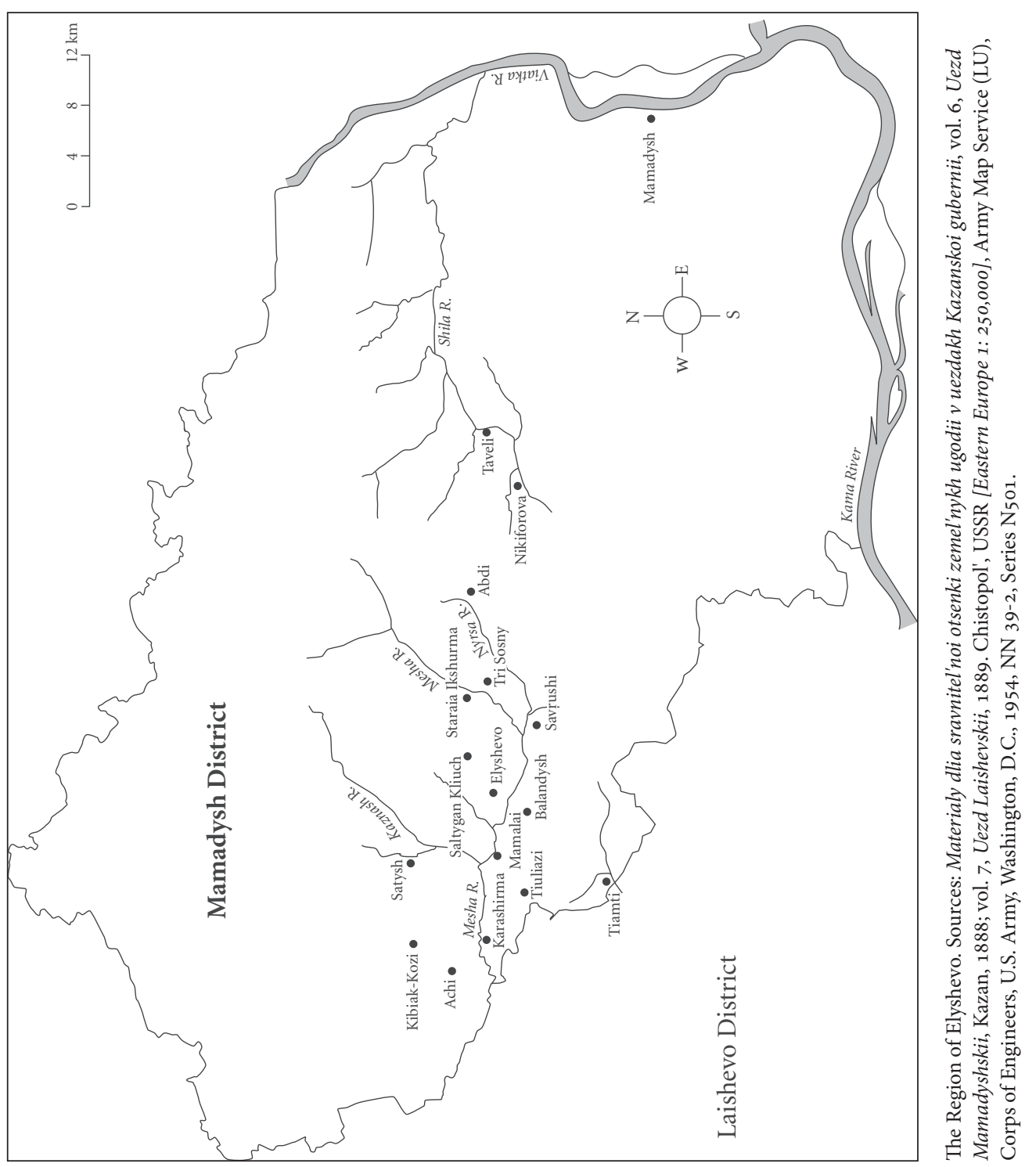


Becoming Muslim in Imperial Russia 



\section{Introduction}

$\mathrm{I}$ n 1866, the police arrested a well-to-do trader who had petitioned that his village be officially recognized as Muslim. His father, a parish elder, begged him one more time to rejoin the church, but Mikhail Matveev stubbornly refused to listen. In desperation, his father asked him to take off his fine leather boots and replace them with rude bast shoes - a vivid warning about the grim fate that awaited him in Siberia. But the father's pleas changed nothing. Matveev's wife proudly stood by his decision, repeating tirelessly that they both considered themselves Muslim. What explained this young couple's determination? What did it mean to become Muslim in Imperial Russia? ${ }^{1}$

Over the course of the nineteenth century, tens of thousands of Orthodox Christian Tatars like Matveev and his wife formally petitioned the czar to be legally recognized as Muslims. At great personal risk-including the possibility of arrest, imprisonment, deportation and exile-these "apostates" from Christianity asked to leave the favored established faith for membership in a tolerated, but second-class, religion. Many of these Tatar Christians known as Kräshens, from the Russian word for baptized, made this difficult choice through the influence of a well-developed network of Islamic primary education, brought to them by neighboring Muslim Tatars. Rooted in a thaumaturgical tradition that dated back to the fourteenth-century conversion of the Turkic peoples of Central Asia, this educational network was far from moribund but provided a cultural treasury of miraculous stories about saints and prophets that the apostates could draw upon as they fashioned their new Muslim communities. Apocalyptic stories about God's final judgment of the infidels, marvelous accounts of Muslim martyrs in pagan lands, and tales of divine deliverance fueled the apostasy movements. Filled with miracles, this literature served to expand the boundaries of Islam among Finno-Ugric and Turkic peoples of the Middle Volga, including many of the baptized Tatars who had converted to Christianity after the Russian conquest in the sixteenth century. For these Kräshen converts to Islam, becoming Muslim meant participation in the moral order described and defined in these traditional narratives: a world in which God actively and miraculously intervened on behalf of the Islamic community. These stories affirmed the possibility of divine empowerment for the most ordinary believer, and they emphasized the imminence of the final judgment.

1. Evfimii Malov, “Ocherk religioznogo sostoianiia kreshchenykh tatar, podvergshikhsia vliianiiu magometanstva," Pravoslavnyi sobesednik (hereafter PS) 18, pt. 1 (1872): 243-244. 
The apostasy movements launched a major struggle over the religious and cultural identity of entire peoples living along the Middle Volga. Some chose to remain within the Orthodox fold and rejected Islam; a small but vigorous Kräshen cultural and religious revival persists in the region to the present day. Those who remained faithful to the church responded to the influx of these pious Islamic stories by developing their own historical memory of heroic martyrs, miraculous salvation, and ethnic Turkic saints. Many baptized villages, not immune to Islamic influence but ambivalent toward their Tatar neighbors who viewed them as infidels, turned to Christian hagiographies of Roman, Greek, and Turkic martyrs to solidify their communal distinctiveness.

The Kräshens-descendants of Muslim and animist Volga Tatars who had converted to Eastern Orthodox Christianity in the sixteenth and eighteenth centuriesare located on the frontier between Islam and Eastern Orthodoxy. They provide a fascinating example for exploring how non-Russian peasants integrated and transmitted religious knowledge in Imperial Russia, and how both colonizers and colonized used religion and education to forge new identities. During the hundred years preceding the 1917 Russian revolutions, a variety of alternative identities and cultural systems, including popular Orthodoxy, mystical Islam, animism, and Islamic modernism, competed for allegiance in the Volga region. Educational policies and practices emerged from a debate- a complex one that was often difficult and heated, to be sure-among Sufi imams (Muslim mystics), Orthodox missionaries, Russian state officials, and Islamic modernists called jadids from an Arabic word meaning "new." Alarmed by the apostasies, Orthodox missionaries and Russian bureaucrats investigated these movements and left a telling record about how Muslim Tatars used traditional forms of knowledge to spread their faith. In the late nineteenth century, the Kräshens were subject to several experiments in education. While Muslim Tatars sought to win them for Islam, Orthodox Russians struggled to keep them from apostatizing from Christianity to Islam. Ultimately, both enjoyed important successes: Islam kept and/or made many converts and a Christian community, still vibrant after seventy years of atheistic communism, survived among the Volga Tatars.

The apostasies also affected other non-Russian peoples besides the Tatars. Although Moscow had conquered the Volga khanates of Kazan in 1552 and Astrakhan in 1556, this region remained in many respects a frontier until the beginning of the nineteenth century. Large populations of national minorities along the Volga, including the Tatars, Cheremis (Maris), Chuvash, Bashkirs, Votiaks (Udmurts), Kalmyks, lived in common or mixed villages, spoke languages other than Russian and often followed a faith other than Orthodoxy. The Turkic-speaking Tatars and Bashkirs were predominantly Muslim, but a portion had converted to Eastern Orthodoxy. Although many of the Chuvash, Udmurts, and Maris had adopted Orthodox Christianity as well, some continued to practice their native animistic faiths-or to integrate elements of their pre-Christian religion into their Orthodox practice. The transmission and assimilation or rejection of Qur'anic and Christian knowledge among these people played an important role in their self-definition. Although many scholars have dismissed the traditional Muslim village school as mindless rote learning, in fact this network of primary education proved extremely effective in shaping 
the religious-and, consequently, the ethnic and political-identities of the peoples of the Middle Volga. Far from being stagnant, the village Qur'anic schools introduced revolutionary changes in the religious geography of central Russia, not only among the Kräshens but also among other ethnic groups.

The study of Kräshen apostasies uncovers ways traditional Qur'anic knowledge was lived and understood. Most historians have generally adopted the Tatar nationalist view and presented the Tatars as essentially Muslim; the conversions of the sixteenth and eighteenth centuries were either forced or insincere-conversions of convenience, not conviction. In their view, the Tatars who converted to Christianity in the sixteenth century-called starokreshchenye (old converts)—-were originally Muslims or nominal Muslims, whereas those baptized in the eighteenth centurythe novokreshchenye (new converts) - were definitely Muslim. This view presents the Kräshens as crypto-Muslims who had been forcibly converted to Christianity and returned to an open confession of Islam when they saw the opportunity. As proof, these historians point out that beginning in 1800 many of the Kräshen villages petitioned the government to be recognized as officially Muslim. In their collective petitions, the "apostates" often claimed that they had never in fact been Christian at all, and that they were practicing Muslims. In other words, their "apostasy" from Eastern Orthodoxy was simply an effort to force the Russian authorities to recognize their true faith. ${ }^{2}$

This assumption that the Kräshens were superficially Christianized cryptoMuslims accorded well with Western and Soviet views of Imperial Russia as a "prisonhouse of nations," with the secularist distaste for proselytism of any kind, and with fashionable critiques of colonialism in all its forms. Western and Tatar historians continue to assume that the Kräshens were not really Christians but were simply playing a role to avoid persecution or to obtain some benefit. They continue to regard Tatar identity as fixed, defined by national heritage, and not as an evolving phenomenon, and view the apostasy movement exclusively as a political, anticolonial event in Tatar national history. This approach, however, fails to explain both the process by which indigenous peoples developed or maintained an Islamic identity and the survival of a vibrant Christian community among Kräshens. It also ignores the role of religious literacy in the baptized Tatars' internalization of Islamic and later Christian values.

The reality was much more complicated. Not all the Kräshens were secretly Muslim or were insincere Christians, for they lived in a religiously hybrid milieu; some even participated in the religious cultures of both Islam and Orthodox Christianity and at the same time continued the veneration of local and ancestral spirits. The mass

2. Ayas Ishaky, Idel-Oural (Paris, 1933), 9-14; Abdullah Battal-Taymas, Kazan Türkleri (Ankara, 1966), 53-55, 106-109; Alexandre Bennigsen and Chantal Lemercier-Quelquejay, Les mouvements nationaux chez les Musulmans de Russie (Le "Sultangaliévisme" au Tatarstan) (Paris, 1960), 24, 34-35; idem, The Evolution of the Muslim Nationalities of the USSR and Their Linguistic Problems, trans. Geoffrey Wheeler (London and Oxford, 1961), 18, 48, footnotes 39 and 44; Azade-Ayshe Rorlich, The Volga Tatars: A Profile in National Resilience (Stanford, CA, 1986); Olivier Roy, La nouvelle Asie Centrale ou la fabrication des nations (Paris, 1997), 66; Svanta Cornell and Ingvar Svanberg, "Russia and Transcaucasia," in Islam Outside the Arab World, ed. David Wersterlund and Ingvar Svanberg (New York, 1999), 412; Il'dus Zagidullin, "Prichiny otpadeniia starokreshchenykh tatar Srednego Povolzh'ia v musul'manstvo v XIX v., in Islam v tatarskom mire: Istoriia i sovremennost' (Materialy mezhdunarodnogo simpoziuma, Kazan' 29 aprelia-1 maia 1996 g.), ed. Stéphane A. Dudoignon, Damir Iskhakov, and Rafik Mukhametshin (Kazan, 1997), 34-56. 
apostasies of the nineteenth century were not a mechanical "return" to Islam, but constituted vast communal movements of conversion involving people of different ethnic and religious backgrounds and, for the Muslim Tatar community, movements of renewed commitment to their faith. They represented a major missionary effort on the part of Muslims to expand their community in Turkic and Finno-Ugric milieus. Although conversion sometimes implies a sudden and complete change of heart, in the case of the Kräshens conversion to Islam or Eastern Orthodoxy was the result of a gradual change that did not necessarily wipe out preexisting identities.

Nationalist Tatar historians have looked at apostasies of Christian Tatars from Christianity to Islam as simply a return to their original faith. However, U.S. scholarship views these apostasy movements as posing a legal challenge to the imperial Russian state which, on the one hand, promoted tolerance toward a diverse group of religions in Russia and, on the other, supported Eastern Orthodoxy as the state religion. The apostasies offer a bottom-up perspective on how non-Russian peasants manipulated and adapted the idea of citizenship, promoted by the Orthodox Church and the Russian state, to meet their own needs. But the Kräshen apostasies do more than illuminate the tensions between the peasant worldview and state priorities. They also contribute to the debate over the development of different religious strategies and discourses among the natives. Tatar modernism arose in part as a reaction to a vigorous - and not decaying - system of Muslim beliefs and knowledge characterized by popular mystical works, which attracted segments of the Kräshen, Mari, Chuvash, and Udmurt populations to Islam. This same popular Islam was also the target of attacks by Eastern Orthodox missionaries. ${ }^{3}$

Most important, a nationalistic or an exclusively legalistic approach to the apostasy movements fails to appreciate the dynamics of Islamic traditional knowledge and its noninstitutional dissemination, as well as the economic and spiritual networks inside and outside the Volga region. Apostates did not simply imitate Russian peasant revolts in order to affirm the importance of religious conviction. Their protest was also the outcome of a major reform movement within Sufism beyond the borders of the Russian Empire, which dates back to Shaykh Ahmad Sirhindi (1564?-1624) and Shaykh Wali Allah (1702-1762) of Delhi in Mughal India. Michael Kemper and Allen Frank's research reveals a great deal about the Sufi orders that spread their faith in central Russia, but not as much about their activity among the Kräshen population. ${ }^{4}$ The spread of Islam among the non-Russian peoples of the Volga region was also the outcome of major economic transformations within the Tatar community at the end of the eighteenth century, in particular the growth of wool, leather, and cotton-related industries, resulting from the increase of trade between Russia, Central Asia, and India. Women like Matveev's wife constituted another crucial element

3. Paul Werth, At the Margins of Orthodoxy: Mission, Governance, and Confessional Politics in Russia's Volga-Kama Region, 1827-1905 (Ithaca, NY, 2002); Robert Geraci, Window on the East: National and Imperial Identities in Late Tsarist Russia (Ithaca, NY, 2001); Robert Crews, For Prophet and Tsar: Islam and Empire in Russia and Central Asia (Cambridge, MA, 2006).

4. Michael Kemper, Sufis und Gelehrte in Tatarien und Baschkirien, 1789-1889: Der islamische Diskurs unter russischer Herrschaft (Berlin, 1998); Allen Frank, "The Veneration of Muslim Saints among the Maris of Russia," Eurasian Studies Yearbook 7o (1988): 80; idem, Bukhara and the Muslims of Russia: Sufism, Education, and the Paradox of Islamic Prestige (Leiden, 2012). 
in the spread and consolidation of Islamic knowledge among Christian Tatars. These women served as clandestine teachers, producers, and transmitters of religious mystical poetry. They carried with them medieval Turkic tales of the prophets and other epics, filled with miracles and Sufi metaphors. This literature, which has elicited little interest from scholars in Eurasian studies except for Tatar and Turkish linguists, offered paradigms of behavior and scripts for conversion for Muslims living in a nonMuslim environment. ${ }^{5}$

The word "apostate" (otpavshii) was a Russian legal term for any baptized native who rejected Christianity by sending a petition to state officials asking to "revert" officially to his or her so-called original beliefs. The baptized who leaned toward Islam had to affirm their elected identity against the grid constructed and imposed by Russian officials. Tatars themselves (and the inhabitants of former apostate villages) also used and still use the word apostate to identify the history of these communities. Conversely, the term Kräshen refers to baptized Tatars who had not yet petitioned to change their faith or had refused to live officially like Tatars; that is as Muslims.

To better contextualize popular Islamic and Christian religious discourse, this book draws equally on sources of Russian and native origin. These include published and unpublished Russian and Kräshen missionary and ethnographic literature; state and church reports on the Kräshen apostasies; petitions in Russian and Tatar; government legislation, reports of the local governors, education conferences sponsored by the Russian Ministry of Education; Kräshen religious prose and poetry; local epics and women's diaries from "apostate" villages; select jadid religious textbooks, memoirs, and newspaper articles on the apostasies; local interviews and field work observations in the former apostate villages of Elyshevo, Kibiak-Kozi, Ianyli, and the Kräshen villages of Chura, Staryi Karabaian (Qulbaghïsh), and Urias'bash in 1996, 2000, and 2008; nineteenth-century Tatar biographies of local Sufi teachers; and popular Sufi or didactic works that were read or recited by apostates in the Middle Volga and Urals as they could be reconstructed through the prism of missionary, police reports, and the libraries of former "apostate" families.

The first three chapters evaluate the dynamism of traditional methods of learning before the rise of Tatar reformism. The first chapter, "Apostasy, Conversion, and Literacy at Work," argues that the apostasy movement was not a simple "return" to Islam, but a genuine movement of conversion to Islam. It traces the origin and religious diversity of the Kräshen community, analyzes the mechanics and causes of the apostasy movement, and characterizes its leadership. It also shows how apostates used Russian and Islamic literacy as tools of communal resistance. The second chapter, "Popular Knowledge of Islam on the Volga Frontier," deals with the Kräshens' complex religious world and, in particular, its sacred geography. It analyzes the themes and models of behavior in Sufi literature, widely used in school and at home among Tatars and converts to Islam. The content of this literature, which also included talismans,

5. Nurmökhämmät Khisamov, Qol Ghali häm törki "Yosïfnamä”: XIII-XV yözlär (Kazan, 2006); Ildar Mökhämmätov, “Tatar-törek ädäbi baghlanïshlarï yassïlighïnda Mökhämmäd Chäläbineng 'Mökhämmädiyä kitabï” (Kand. diss., Kazan, 2006); Fanuza Nurieva, Istoricheskie i lingvisticheskie usloviia formirovaniia tiurko-tatarskogo literaturnogo iazyka zolotoordynskogo perioda (Kazan, 2004); Âmil Çelebioğlu, Eski Türk Edebiyatı Araştırmaları (Istanbul, 1998); idem, Türk Mesnevî Edebiyatı 15 yy. Kadar (Sultan II. Murad Devri): 824-855/1421-1451 (Istanbul, 1999). 
constituted one of the sources used by peasants to conceptualize their universe and their relation with the "Other" (especially with Russians). The third chapter, "Tailors, Sufis, and Abïstays: Agents of Change," examines the ways this specific Islamic knowledge, largely influenced by Sufism, spread among the Kräshens. It focuses on internal and transborder economic, Sufi, and kinship networks of transmission. The last two chapters deal with official and local Russian and native responses to the knowledge carried by apostate Kräshens and their proselytizers. The fourth chapter, "Christian Martyrdom in Bolghar Land," examines Russian missionaries' attacks against thaumaturgical Islam, their "readings" of popular Islamic literature, and the emergence of a genuine Christian community conscious of its unique identity and salvific mission. It also looks briefly at the state's attempt to play the role of a reformer of traditional Islam and its partial failure. The final chapter, "Desacralization of Islamic Knowledge and National Martyrdom," analyzes the Tatar modernists' response to Eastern Orthodox missionaries' successes in the Kräshen milieu and their criticisms of popular Islamic literature. It examines the jadid effort to introduce a more "rational" view of the universe through the recollection of older clusters of memory, modernize traditional methods of proselytism, and integrate the history of the former baptized communities into a more dignified memory of national martyrdom.

The nineteenth-century apostasies and the formation of a genuine Christian community among Tatars remain the object of politically charged debate in contemporary Tatarstan. While Kräshen nationalists ask for their recognition as a separate nation, Tatar intellectuals and some contemporary ulama, concerned with linguistic Russification (obrusenie), growing urbanization, and the current globalization of Islamic knowledge via the Internet, wish to resurrect the memories by which Tatars defined themselves in the past. They remember the forced Christianization of Tatars and contrast it with the peaceful Islamization of the Bolghars, their Turkic ancestors, and the tolerance of the Mongol khans; they reprint prejadid Sufi literature, which in the past has helped Tatars to keep their identity separate from the Russians. ${ }^{6}$ For them, Sufi medieval and eighteenth-century thaumaturgical books, now sung or staged on TV or at the theater, still constitute a valuable repository of old-Turkic metaphors and Arabic words forgotten by new generations. Once again, these books could be used as a vector of Islamization in the contexts of both major religious holidays and secular schools, where they have become part of the literature curriculum. These current developments echo the cultural competition between Orthodox Christianity and Islam so clearly exemplified in the apostasy movement of the nineteenth century. ${ }^{7}$

6. Evfimii Malov, “Krestom i mechom. Dnevnik missionera," Idel no. 5-7 (1993): 48-52, 39-41, 63-67; Mödärris Äghlämov, “Densezme min, dinsezme?” Yalqïn 12 (1993): 26-27; Rafael' Khakim, Kto ty, Tatarin? (Kazan, 2002), 11-17; Ädkhät Sinughïl-Qughanaqlï, “Tatar igosï,” in Iman ghasïrï (Kazan, 2002), 16-17.

7. Färit Yakhin, Tatar shighriyätendä dini mistika häm mifologiya (Kazan, 200o); Baqürghan kitabï: XIIXVIII yöz törki-tatar shaghïyr'läre äsärläre (Kazan, 2000), 2-8 (abstract and introduction by Färit Yakhin); Aysïlu Bashqurova-Sadïyqova, Islam häm tatar khaliq ijatï (Kazan, 2005); Flyura Khannanova (teacher of Tatar literature at the Möhämmädiyä madrasa in Kazan), Közläremdä äle yazlar kötäm (Kazan, 2006), 123-42; Rqail Zäydulla, “Din,” in Khikäyälär, ädäbi-publitsistik mäqalälär (Kazan, 1999), 288-292. 


\section{Apostasy, Conversion, and Literacy at Work}

I $\mathrm{n}$ the last quarter of the nineteenth century, Tatar reformists severely criticized the faith and morale of superstitious mullahs, itinerant dervishes, and Sufi shaykhs who taught from antiquated books, did not understand the texts that they purported to teach, and discouraged their flock from learning the Russian language and studying the secular sciences. Because of these ignorant teachers of Islam, children failed to learn how to read, write a simple letter, and perform the basic obligations of their faith. These teachers transmitted a superstitious view of Islam that did not correspond with the teachings of the Qur'an and the sayings of the Prophet Muhammad. ${ }^{1}$ The Tatar reformists' critique echoed that of the Russian missionaries, who also believed that Tatar mullahs and shaykhs, unlettered in Arabic, knew little of the Qur'an. At the same time, Russian missionaries recognized the effectiveness of these same men as pedagogues and propagandists who successfully spread elementary knowledge about Islam in Turkic and Finno-Ugric milieus and encouraged Tatar resistance to Russian assimilation. Such mullahs, shaykhs, and their students were largely responsible for preventing the spread of Christianity into the Tatar countryside.

To better elucidate this paradox, this chapter does not focus on a typical description of the traditional curriculum that has been the subject of Western, Soviet, and more contemporary Tatar or Bashkir studies. Such an approach tends to contrast premodern traditional and European-inspired modern education, minimizing the successes of primary traditional learning and its earthly practicality. ${ }^{2}$ Rather, it looks at

1. Fatikh Kärimi, Jihangir mäkhdümneng awïl mäktäbendä uquï (Tornalï awïlinïng mäktäbendä) (1898), and Ber shäkert ilä ber student (parakhodta), 1900, reprinted in Tatar mäghrifätchelek ädäbiyatï (1860-1905) (Kazan, 1979), 230-235 and 246-263; Yosïf Aqchura, Damella Ghalimjan äl-Barudi (Kazan, [1907] 1997), 15, 35-36; Fatikh Amirkhan, Moia avtobiografiia (1911), in Izbrannoe (Rasskazy i povesti), trans. G. Khantemirova (Moscow, 1975), 81-84; Ismail Gasprinskii, Mebadi-yi temeddün-i Islamiyan-i Rus, trans. Edward Lazzerini, in "Ğadidism at the Turn of the Twentieth Century: A View from Within," Cahiers du Monde russe et soviétique, 16, no. 2 (April-June 1975): 245-277; Zakir Hadi, "Jihansha khäzrät," (1908) in Tatar ädäbiyatïnnan khrestomatiya (Kazan, 1957), 205-251; Mäjit Ghafuri, “Tärjemäi khälem,” in Äsärlär: 4 tomda (Kazan, 1981), vol. 4, 365; Tärjümān, no. 10 (18 March 1890). Muslim reformers in Central Asia made similar criticisms of these traditional textbooks; see Adeeb Khalid, The Politics of Muslim Cultural Reform: Jadidism in Central Asia (Berkeley, 1998), 24.

2. Dzhamaliutdin Validov, Ocherk istorii obrazovannosti i literatury Tatar do revoliutsii 1917 (Moscow and Petrograd, 1923), 13-32; Tatary Srednego Povolzh'ia i Priural'ia (Moscow, 1967), 378; Z. A. Ishmukhametov, Sotsial'naia rol' i evoliutsiia Islama v Tatarii (Kazan, 1979), 124-128; Saliam Alishev, "Obuchenie i obrazovanie tatarskikh krest'ian v XVIII v.", in Razvitie kul'tury Tatarii v dooktiabr'skii period (Kazan, 1988), 42-57; Marsil' Farkhshatov, Narodnoe obrazovanie v Bashkirii v poreformennyi period, 6o-9o e gody XIX v. (Moscow, 1994), 54-95; Ahmet Kanlidere, Reform within Islam: The tajvid and jadid movement among the Kazan Tatars (1809-1917): Conciliation or Conflict? (Istanbul, 1997), 77-85; Reforma obrazovaniia: Tatary Nizhegorodchiny i musul'manskii mir (Nizhnii Novgorod, 2008). 
how peasants used their knowledge- understood here as both religious and secularto build a community of faith and resist state encroachment when their identity was questioned. The apostasies of the nineteenth century were more than peasant-led legalistic movements triggered by a change of state policies toward its Muslim subjects. Instead, they constituted movements of conversion and revival, a time when villagers of various ethnic and religious backgrounds made the communal choice of participating fully in the faith of Islam.

\section{The Main Actors}

\section{The Kräshens: Their Origins and Religious Hybridity}

The main participants of the apostasy movement were the baptized Tatars whom Muslim Tatars called either by their indigenous name keräshen (pl. keräshennär) or, to express their disapproval, mäkruh - an Arabic word meaning "abominable," "reprehensible," "disliked," and "not forbidden by God but looked upon with horror by Muslim teachers.” Mäkruh especially signified those crypto-Muslims who had succumbed to Russian pressures to nominally embrace Christianity. Muslims also called the Christian Tatars murtadd, another Arabic word meaning apostate, which implies that Kräshens had apostatized from Islam and were legally dead. Another favorite appellation was chuqünghannar, which means "baptized," but which became a profanity, meaning "killed" or "dead," in a number of colorful and humorous expressions still used today in former apostate villages. Literally, the reflexive verb chuqïnïrgha derived from the verb chuqïrgha, "to pick," "to knock," or "to tap," and means "to be picked" or "to be hit." For Tatars, the cross resembled a bird beak or a little hammer, thus being baptized was equated to being bitten by a bird or hit by a hammer. Only after 1905 did some Tatar newspapers, more sympathetic to the baptized cause, opt for the term mükreh ("forced to do something") to designate the Turkic-speaking converts from Eastern Orthodoxy to Islam. Significantly, mäkruh and mükreh were spelled the same way in Arabic script except for the long " $\overline{\mathrm{u}}$ " of mäkrūh, which was dropped in mükreh. In jadid literature, the ridiculed "abominable" apostates from Islam turned into victims, who had been compelled to accept baptism. ${ }^{3}$

3. "Otchet bakalavra missionerskogo protivomusul'manskogo otdeleniia Kazanskoi dukhovnoi akademii N. I. Il'minskogo o poezdke po tatarskim seleniiam (1856)," in Khristianskoe prosveshchenie $i$ religioznye dvizheniia (reislamizatsiia) kreshchenykh tatar $v$ XIX-nachale XX vv.: Sbornik materialov $i$ dokumentov (Kazan, 2011), 155; Nikolai Ostroumov, "Predvaritel'nye zamechaniia o tatarskom iazyke v sviazi s priniatym v slovare alfavitom," in Pervyi opyt slovaria narodno-tatarskogo iazyka po vygovoru kreshchenykh tatar Kazanskoi gubernii (Kazan, 1876), 5; idem, Tatarsko-russkii slovar' (Kazan, 1892), 229 ('chukï'), 230 ("chum”); Shihāb ad-Dīn b. Bahā’ ad-Dīn Märjānī, Mustafād al-akhbār fī ahwāl Qazān wa Bulghār, vol. 1 (Kazan, 1897), 31; Rizaeddin Fäkhreddinev, Bolghar wä Qazan Törekläre (Kazan, 1993), 56; definitions of makruh and mükreh in Redhouse Türkçe/Osmanlıca-Inglizce sözlük (1997), 749, 817; 'Ayn ad-Dīn Äḥmärof, "Mükrehlär hālendän," Qazān Mokhbire (Kazanskii Vestnik), no. 78 (May 1906); Otdel rukopisei Instituta iazyka, literatury i istorii Akademii nauk Tatarstana, f. 56, op. 1, ed. khr. 3, 1. 165 ob. (because of the negative connotation of the past-present participle chuqïnghan for "baptized," Russian missionaries in the second half of the nineteenth century chose to translate "baptized" as chumilghan [immersed]); Paul Werth, "From 'Pagan Muslims' to 'Baptized' Communists: Religious Conversion and Ethnic Particularity in Russia’s Eastern Provinces," Comparative Studies in Society and History 42, no. 3 (July 2000): 501. 
In the first half of the nineteenth century, Muslims who lived near the Kräshen villages often despised their neighbors for being neither Muslim nor Christian; yet at the turn of the twentieth century, Kräshens-who thanks to new missionary schools had remained Eastern Orthodox-claimed proud distinctiveness from the Tatars and viewed Christianity as their native religion. Kräshens requested not to be referred to as Tatars (tatary) or baptized Tatars (kreshchenye tatary) in the Russian press. Unlike the Tatars who were Muslim or the apostates (former baptized Tatars who had joined Islam), they argued, the Kräshens were Eastern Orthodox Christians. Nonetheless, in this book both "baptized Tatars" and "Kräshens" are used to designate a legal category of Turkic-speaking people, baptized in the sixteenth, seventeenth, and eighteenth centuries, whose religious affiliation was in the making or in negotiation until the 1920s. The term Tatar-a word that the Turkic peoples of the Volga and Kama rarely used before the twentieth century-is used as a synonym for local Turkic Muslims living in the Volga-Kama region. ${ }^{4}$

Soviet and contemporary Tatar historiographies (and also the natives of the former apostate, now Muslim Tatar, villages I visited) portray the Russian conversion campaign of the sixteenth and eighteenth centuries among the native peoples of the Middle Volga as state-initiated violence. ${ }^{5}$ However, Ivan the Terrible (r. 1547-1584), who benefited from the support of part of the Tatar elite, did not make conversion to Christianity a condition for Tatars to enter Russian service and avoided destroying all mosques in Kazan after its conquest. For this reason, and also because vibrant Christian Orthodox communities continue to exist among the native peoples of the Middle Volga, some Western historians have softened the traditional picture of aggressive Christianization. ${ }^{6}$ The origin of the Kräshen community, sitting on the fault line between Christianity and Islam that stretched through Eurasia and Central Asia, is indeed quite complex and defies twenty-first-century nationalist paradigms.

Two waves of conversion to Eastern Orthodox Christianity took place among the Tatars of the Middle Volga. Archbishops Gurii (r. 1555-1563) and German (r. 1564-1567) of Kazan, assisted by the Tatar-speaking abbot of the Transfiguration monastery Varsonofii (ca. 1495-1576), inaugurated the first wave in the sixteenth century. All three were canonized in 1595 by the Kazan metropolitan Germogen

4. Kräshen priest D. Grigor'ev, “Zovite nas kreshchenami," Izvestiia po Kazanskoi Eparkhii (hereafter IKE), nos. 14-15 (8-15 April 1906): 454; on the term Tatar as an ethnonym, see Allen Frank, Islamic Historiography and "Bulghar" Identity among the Tatars and Bashkirs of Russia (Boston, 1998), 4-9.

5. A.N. Grigor'ev, "Khristianizatsiia nerusskikh narodnostei, kak odin iz metodov natsional'nokolonial'noi politiki tsarizma v Tatarii (s poloviny XVI v. do fevralia 1917 g.)," in Materialy po istorii Tatarii, vol. 1 (Kazan, 1948), 226-285; Faizulkhak Islaev and Iskhak Lotfullin, Dzhikhad tatarskogo naroda: Geroicheskia bor'ba tatar-musul'man s pravoslavnoi inkvizitsiei na primere istorii novokreshchenskoi kontory (Kazan, 1998).

6. Matthew P. Romaniello, "Mission Delayed: The Russian Orthodox Church after the Conquest of Kazan," Church History 76, no. 3 (September 2007): 511-540; Paul Werth, "Coercion and Conversion: Violence and the Mass Baptism of the Volga Peoples, 1740-55," Kritika: Explorations in Russian and Eurasian History 4/3 (2003): 543-570; Janet Martin, "Multiethnicity in Muscovy: A Consideration of Christian and Muslim Tatars in the 1550s-1580s," Journal of Early Modern History 5, no. 1 (2001): 1-23; Allen Frank, Muslim Religious Institutions in Imperial Russia: The Islamic World of Novouzensk District and the Kazakh inner Horde, 1780-1910 (Boston, 2001), 163-167; G. N. Aidarova, "Mecheti i tserkvi Srednego Povolzh'ia vtoroi poloviny XVI-XVII vekov: Protivoborstvo i vzaimovliianiia," in Islamo-khristianskoe pogranich'e: Itogi i perspektivy izucheniia (Kazan, 1994), 167. 
TABLE 1.1 Number of Old and New Converts in Kazan Province in 1862

\begin{tabular}{lcc}
\hline District & Old Converts & New Converts \\
\hline Cheboksary & 3,292 & 250 \\
Chistopol' & 1,601 & 918 \\
Kazan & 8,150 & 960 \\
Laishevo & 13,942 & 298 \\
Mamadysh & & 871 \\
Spassk & & 161 \\
Sviiazhsk & & 4,201 \\
Tetiushi & 916 & 3,979 \\
Tsivil'sk & 27,901 & 1,055 \\
Total & & 12,693 \\
\hline
\end{tabular}

Source: Evfimii Malov, "Statisticheskie svedeniia o kreshchenykh tatarakh v Kazanskoi i nekotorykh drugikh eparkhii, v Volzhskom basseine," Uchenye zapiski Kazanskogo universiteta, vol. 4 (1866): 339.

(ca. 1530-1612) and continue to be revered as saints by both Russians and Kräshens. The Office for the Affairs of New Converts (Kontora Novokreshchenykh del), which opened in 1740 in the city of Sviiazhsk, was responsible for the second wave of conversions. The earlier converts and their descendants came to be known as "old converts" (starokreshchenye). They were mostly located along major rivers and trade routes east of the Volga in the Kazan, Mamadysh, and Laishevo districts of Kazan province, at the intersection of the Kazan and Viatka provinces, and in the Menzelinsk district in Ufa province. Some of these villages claimed baptized military servicemen of Tatar or Finno-Ugric origin among their ancestors. The converts of the second wave, called "new converts" (novokreshchenye), lived mostly south of the Volga and Kama rivers in the Kazan province and on the right bank of the Volga in Simbirsk and Nizhnii Novgorod provinces. A large portion of the novokreshchenye were of Mishar originthe Mishars being one of the Muslim Turkic-speaking groups that form the Tatar nationality of contemporary Russia. Their ancestors, without having to convert to Christianity, entered the service of Muscovite princes as early as the fifteenth century after the disintegration of the Golden Horde. The Mishar nobility joined Ivan the Terrible in his conquest of Kazan, and provided troops to protect the Russian state's expanding frontier toward the southeast.?

For some villages, the appellation of "old" or "new" converts was not fixed; the date of their baptism could not always be determined. In one document, the Russian missionary and Kazan Theological Academy professor Evfimii Malov (1835-1918) firmly designated Elyshevo (Ÿ̈lïsh) in Mamadysh district as an "old-convert" village; in another, he suggested that the village could have been baptized later. Nevertheless, if one accepts the official categorization of old and new converts in 1866, the Kazan province included 444,556 Muslim Tatars and 44,000 Kräshens, among them 27,901

7. Flera Baiazitova, Govory Tatar-Kriashen v sravnitel'nom osveshchenii (Moscow, 1986), 15-18, 21, 34-38; on the Mishars as servicemen, see Frank, Muslim Religious Institutions, 59-61. 
were starokreshchenye and 16,099 were novokreshchenye. Thus, 9 percent of the Kazan province Tatar population was officially Orthodox or "baptized."

Although methods of conversion remain scarce, Tatar historiography, popular lore, textbooks, and children's publications hold that the starokreshchenye were Christianized by force on the lines of defense in the region north of the Volga and the Kama, on the land that Ivan IV had granted to the first archbishop of Kazan and to the Zilantov and Spaso-Preobrazhenskii monasteries. ${ }^{9}$ Conversely, some Western and Russian historians have challenged the national Tatar narrative of forced conversion, citing state and church instructions sent to local representatives after the conquest of Kazan that recommended peaceful means of Christianization. The same instructions distinguished between immediately pacifying the region militarily and securing the loyalty of the conquered peoples in the long term. In general, pragmatism prevailed among the Muscovite elite. Because the Volga region was still volatile-the Maris and the Tatars repeatedly joined forces to oust their conquerors-the Muscovites refrained from a policy of aggressive conversion and awarded natives who converted to Christianity with gifts of money, clothing, food, and temporary exemption from taxes and military service. Legally, new converts to Christianity enjoyed the same rights as Russians; they could receive land in exchange for service along the major fortress lines and occupy important local administrative positions. However, until Peter the Great (r. 1682-1725) ordered Muslim servicemen to convert to Christianity or forfeit their land and princely rank, service to the czar was not tied to conversion to Christianity. In addition, these harsh measures-often used as an argument by Tatar historians to support the thesis of forced large-scale Christianization-concerned only the landholding Tatar princes, and not the peasant commoners. ${ }^{10}$

By the beginning of the nineteenth century, many of the starokreshchenye were of animist origin. Many of those who were of Muslim origin had returned to Islam

8. Narodnyi Arkhiv Respubliki Tatarstan (hereafter NART), f. 1, op. 3, d. 231, 11. 226-226 ob. In 1836, according to Il'dus Zagidullin's calculations, 11.8 percent Kazan Tatars were baptized in the Kazan province. Il'dus Zagidullin, "K voprosu otpadeniia kreshchenykh tatar Kazanskoi gubernii v musul'manstvo 1866 goda," in Natsional'nyi vopros v Tatarii dooktiabr'skogo perioda (Kazan, 1990), 66.

9. Iskändär Giljazov, "Le rôle de l'Islam dans l'évolution de la société tatare, de la conquête de Qazan aux réformes de Catherine II (1552-1788)," in L'Islam de Russie: Conscience communautaire et autonomie politique chez les Tatars de la Volga et de l'Oural, depuis le XVIIIe siècle, ed. Stéphane A. Dudoignon, Dämir Is'haqov et Räfyq Möhämmätshin (Paris, 1997), 15-25; Ildus Zahidullin, "La conversion à l'Orthodoxie des Tatars de la région Volga-Oural, aux XVIIe-XVIIIe siècles, et ses causes économiques et sociales," in ibid, 27-64; Engel' Tagirov, Na perekrestke tsivilizatsii: Istoriia Tatar v kontekste kul'tury mira (Kazan, 2007), 259; Nurulla Garif, Osvoboditel'naia voina tatarskogo naroda (Kazan, 2007), 35; Mäkhmüt Äkhmätjanov, "Keräshennär tarikhïna ber qarash" (April 2001) in Yamannï yuldash itmä (Mäqalälär, ocherklar, esselar) (Kazan, 2007), 73; Rqail Zäydulla, Tatar Tadzhï (Kazan, 2004); G. M. Däwlätshin, F. Sh. Khujin, and I. L. Izmailov, Tatarstan tarikhïnnan khikäyälär 5-6 (Kazan, 1993), 129-130; Akhmad (Dmitrii) Davletshin, "Bor'ba musul'man za svoi prava v tsarskoi Rossii v XVI-XVII vv.," Vera, Sovershenstvo, Islam (dukhovnoprosvetitel'skii zhurnal) 15, no. 1 (2007): 19-20.

10. Boris Nolde, La formation de l'Empire russe: Études, notes et documents, t. 1 (Paris, 1952), 63, 115120; Andreas Kappeler, The Russian Empire: A Multiethnic History, trans. Alfred Clayton (Harlow, England, 2001), 24-31; Werth, "Coercion and Conversion," 543-70; Dmitrii Liseitsev, "Sluzhilye tatary i novokreshcheny Posol'skogo prikaza v nachale XVII v., Ghasirlar awazï (Ekho vekov), nos. 1-2 (2003), http://www. archive.gov.tatarstan.ru/magazine/go/anonymous/main/?path'mg:/numbers/2003_1_2/o1/o1_4/(accessed 17 January 2009); A. F. Mozharovskii, "Izlozhenie khoda missionerskogo dela po prosveshcheniiu Kazanskikh inorodtsev s 1552 po 1867," in Chteniia v imperatorskom obshchestve istorii $i$ drevnostei rossiiskikh (March-April 1880), bk. 1, 10-35. 
during the 1570 s and 1580 s when the Tatars had attempted to retake power in the territory of their former khanate, and then again during the Stenka Razin rebellion (1670-1671). ${ }^{11}$ There is no indication that Russians compelled them to reenter the Orthodox Church during these uprisings. In general, the starokreshchenye were located in areas separate from both the Russians and the Muslim Tatars. The sixteenth-century founders of the village of Apazovo in Kazan district were originally Muslims from neighboring villages and converted to Christianity to escape either justice or military service. Under the pressure of either their former coreligionists or the church, or simply on their own, they left their native villages to create a new community. ${ }^{12}$ Russian religious authorities in general encouraged this type of separation, but scholars have also argued that, for some villages, such isolation could have occurred at the very time of the Russian conquest or even preceded it. Boris Nolde hypothesized that entire villages had accepted baptism collectively to avoid the consequences of war. Baptism in such a context could have been understood by the conquered as a ritual declaration of loyalty. The Tatar linguist Flera Baiazitova went further back in time and suggested that many of the starokreshchenye could have descended from the Turkic Sobekullian, Chelmat, and Temtiuzi peoples cited in twelfth-century Russian chronicles as having led a separate existence well before the Mongol invasion. But neither author adduced much evidence to back up these arguments. ${ }^{13}$

The establishment of monasteries in Kazan and Sviiazhsk as spiritual, economic, and colonizing centers in the sixteenth century probably encouraged trade and religious interaction between Russians and the non-Russian residents of the Volga Region. The region's monks and nuns had to be accommodating and needed the logistical support of the local population to survive economically. Urban and rural monasteries expanded agriculture to forested lands, which fostered new economic opportunities along major road and river routes. In the seventeenth century, native peoples in state service also participated in the construction of fortresses south of the Kama River, designed to protect cultivated lands from nomadic Kalmyk and Bashkir incursions. Agriculture could have generated new forms of communal solidarities. Baptism in this context would not have been understood as a militaristic ritual of loyalty, but rather as a new form of ecological solidarity. ${ }^{14}$

Although it is impossible to determine with certitude the methods of conversion and the reasons why starokreshchenye adopted Christianity, it is certain that

11. A. N. Grigor'ev, "Khristianizatsiia," 230; D. M. Makarov, "Khristianizatsiia narodov Povolzh'ia vo vtoroi polovine XVI veka," in Istoriia khristianizatsii narodov Srednego Povolzh'ia: Kriticheskie suzhdeniia $i$ otsenka (Cheboksary, 1988), 16-18, 20-21.

12. "Materialy dlia statistiki i istorii Kazanskoi eparkhii. I. Istoricheskoe opisanie tserkvei. O sel'skikh tserkvakh i prikhodakh Kazanskoi eparkhii. I. Kazanskii uezd. 2. O sele Apazove i tserkvi vo imia Rozhdestva Bogoroditsy," IKE no. 2 (15 January 1880): 56.

13. Nolde, La formation, 1: 118; Baiazitova, Govory Tatar-Kriashen, 16.

14. G. Peretiatkovich, Povolzh'e v XVII i nachale XVIII veka: Ocherki iz istorii kolonizatsii kraia (Odessa, 1882), 95, 100-101, 103-106, 116-117, 129-130, 141, 144, 158; Matthew P. Romaniello, "Controlling the Frontier: Monasteries and Infrastructure in the Volga region, 1552-1682," Central Asian Survey 19, nos. 3-4 (2000): 429-443; Michael Khodarkovsky, Russia's Steppe Frontier: The Making of A Colonial Empire, 1500-1800 (Bloomington, 2012), 1-6. In their need for local indigenous support, Russian monks on the Middle Volga found themselves in a position similar to that of Catholic missionaries to the Iroquois. Allan Greer, "Conversion and Identity: Iroquois Christianity in Seventeenth-Century New France," in Conversion: Old Worlds and New, ed. Kenneth Mills and Anthony Grafton (New York, 2003), 175-198. 


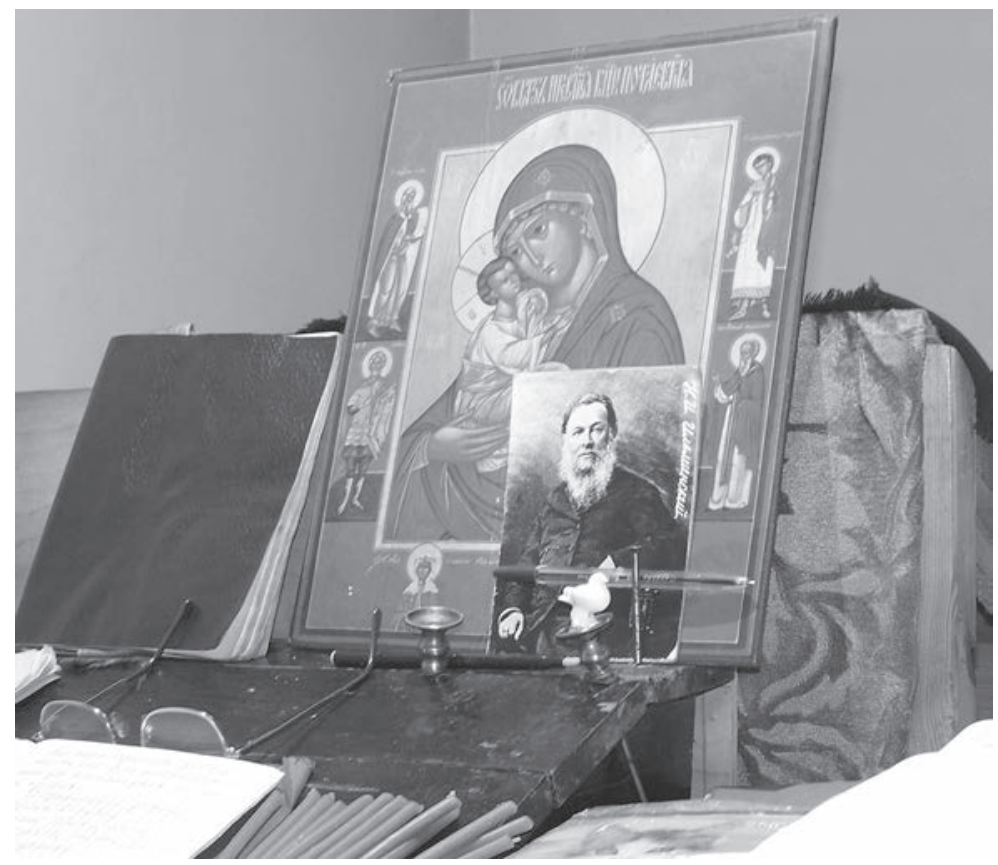

1.1: Picture of Nikolai Il'minskii in Tikhvin church on a prayer book stand, Kazan. Photograph by the author.

the external differences between the earliest group of converts to Christianity and Muslim Kazan Tatars puzzled Russian and Tatar scholars of the nineteenth century. The Russian archeologist Mikhail Iuzefovich (1802-1889) likened the Kräshens with Finns, and the Tatar historian and theologian Shihab ad-Din al-Märjani (1818-1889) underlined the differences between Kräshen and Kazan Tatar women's clothing. Kazan Tatar women did not wear the süräkä, a hard headdress with four angles that married Kräshen wore, nor the tüshlek, a decorative cloth with rows of coins attached covering their chest, whose value could reach up to seventy rubles (roughly fifty-three U.S. dollars in 1890), a substantial sum for a peasant household. Märjani advanced the conjecture that either Kazan Tatars wore such clothes before their Islamization or that Kräshens could be Tatarified Maris superficially Islamized before the Russian conquest. ${ }^{15}$ The orientalist and missionary Nikolai Il'minskii (1822-1891) hypothesized that Kazan Tatars were not fully Islamized in the sixteenth century

15. Märjānī, Mustafād, 1: 31; N. Odigitrievskii, Kreshchenye tatary Kazanskoi gubernii: Etnograficheskii ocherk (Moscow, 1895), 7, footnote 2. For discussions of the value of the ruble over time, see Jacob R. Eckfeldt and William E. Dubois, A Manual of Gold and Silver Coins of All Nations Struck within the Past Century (Philadelphia, PA, 1842), 109-12; Thomas C. Owen, "A Standard Ruble of Account for Russian Business History, 1769-1914: A Note," Journal of Economic History 49, no. 3 (September 1989): 699-706; Boris Nikolaevich Mironov, Blagosostoianie naseleniia i revoliutsii v imperskoi Rossii (Moscow, 2010); idem, The Standard of Living and Revolutions in Russia, 1700-1917 (New York, 2012); Tracy Dennison and Steven Nafziger, "Living Standards in Nineteenth-Century Russia," Journal of Interdisciplinary History 43, no. 3 (Winter 2013): 397-441. 
(which might explain why this Turkic group joined Christianity, the religion of the conqueror); in addition, Islam took firmer root in the countryside after the Russian conquest and grew stronger during the second half of the eighteenth century. ${ }^{16}$

Based on the Kräshens' language, clothing, history, and genealogies, Soviet and post-Soviet scholars reaffirmed Märjani's hypothesis that some starokreshchenye could have Finnic roots and descended from linguistically Tatarified baptized Finno-Ugric or Turkic Chuvash peoples. Kräshen prerevolutionary women's dress exhibited Mari, Udmurt, Mordvin, Bashkir, or Chuvash characteristics depending on their location. The Kräshens of Urias'bash in the Kukmor region, although inclined toward Islam, dressed and lived like their Udmurt neighbors and their language was very much influenced by the Udmurt language. ${ }^{17}$ In Elabuga district, Kräshen music also showed great affinities with the music of Udmurts. In other regions, Chuvash influence was more prominent. Although Kräshens' embroidery in the village of Tashkirmen', a village famous for its pre-Islamic sacred site in Laishevo district, did not differ from that of the Mordvins, their language contained many calques from the Chuvash language and some of their fertility rituals were very similar to those of their Chuvash neighbors. Oral traditions in Tashkirmen' confirmed that Chuvash people moved into the area in the eighteenth century, which explained why their dialect differed substantially from other Kräshen dialects and contained Chuvash verbal endings. Another baptized Tatarspeaking village, Dragun Bekhmetevo, was also originally founded by Chuvash people of Cheboksary district who came to work as laborers among rich Muslim Bashkirs. ${ }^{18}$

Finally, the Nagaibak Kräshens of Orenburg province, in the western part of present-day Republic of Bashkortostan, were a conglomerate of different cultures and peoples of animist and Muslim origin: baptized Nogays, Bashkirs, Kazan Tatars, Udmurts, Ural Cossacks, and even Central Asians. After they remained faithful to the crown during the Bashkir rebellion of 1735, Empress Anna Ivanovna (r. 17301740) appointed them Cossacks on the Bashkir frontier in 1736 to guard the new burgeoning towns near Menzelinsk. Some of them descended from baptized Kazan Tatar nobles, former landholding military servicemen of the czar at the Arsk fortress, but unlike members of the Chingisid dynasty who married into prominent Russian boyar families, they did not merge culturally and linguistically with other Russian landholding servicemen. They kept their language and developed a unique sense of communal identity based on Eastern Orthodoxy separate from their neighbors, both Muslim Bashkir and Russian. ${ }^{19}$

16. N. Runovskii, "Ocherk istorii khristianskogo prosveshcheniia inorodtsev Volzhsko-Kamskogo kraia v sviazi s istoriei perevodov na ikh iazyki do poloviny XIX st.", Simbirskie eparkhial'nye vedomosti, no. 2 (15 January 1901): 56.

17. Nikolai Il'minskii, ed., Kazanskaia tsentral'naia kreshcheno-tatarskaia shkola. Materialy dlia istorii prosveshcheniia kreshchenykh tatar (Kazan, 1887), 162.

18. Tatary Srednego Povolzh'ia i Priuralia, 51-53; Damir Iskhakov, "Kriasheny (istoriko-etnograficheskii ocherk)," in Tatarskaia natsiia: Istoriia i sovremennost' (Kazan, 2002), 108-125; idem, Etnograficheskie gruppy tatar Volgo-Ural'skogo regiona: Printsipy vydeleniia, formirovanie, rasselenie i demografiia (Kazan, 1993), 117-144; Baiazitova, Govory Tatar-Kriashen, 15-48; on Dragun-Bekhmetevo, still Kräshen today, see NART, f. 93, op. 1, d. 128 b, ll. $13-18$.

19. In the second half of the eighteenth century, Nagaibaks faithfully kept icons in their houses. Petr Rychkov, Topografiia Orenburgskoi gubernii (Ufa, [1762] 1999), 269-270; Damir Iskhakov, "Etnodemograficheskoe razvitie Nagaibakov do pervoi chetverti XX v.", in Nagaibaki: Kompleksnoe issledovanie gruppy kreshchenykh tatar-kazakov, ed. Damir Iskhakov (Kazan, 1995), 4-18. 
The population makeup of apostate settlements in the nineteenth century did not differ much from the villages that have remained Christian. Apostate villages were conglomerates of different ethnic groups, whose members voluntarily joined to form new village units in the seventeenth and eighteenth centuries. Apazovo was made up of baptized Muslims and animist Udmurts who shared ancestry with the Nagaibak Kräshens of Menzelinsk. Elyshevo on the Mesha River, listed as an old-convert village in missionary statistics but whose Christianization could have occurred as late as the 1740s, was composed of Tatars and Udmurts who moved to the area in the first half of the eighteenth century. Verkhniaia Nikitkina (Yugharï Tubilghïtaw) in Chistopol' district included Tatars, Chuvash, and even Russians; two Russian sisters in 1849 asked to return to "the religion of their ancestors," Islam. Finally, Ianyli in the Kukmor region, founded in the sixteenth or seventeenth century, was originally established by a Russian family and Udmurts from the Mamadysh and Arsk regions, and joined later by baptized Tatars. ${ }^{20}$

Baptism came to form a common bond between various ethnic communities partially dislocated by the Russian conquest but still attached to their indigenous beliefs. Even if pressure and material motives could have played a role in the initial process of Christianization of the starokreshchenye, forced conversion alone cannot explain the survival of a vital Christian community to the present day. Dogmatic assertions that sixteenth-century Tatars were so firmly Muslim that they could not have sincerely converted to Christianity fail to consider the very rich animistic religious tradition of the old converts that can be only tentatively reconstructed through Russian and Kräshen missionary prisms. Moreover, in both Christian and Islamic history, conversion through conquest, acculturation, and gradual transformation of sacred space led to the constitution of vibrant communities of faith in Europe and Northern Africa, as well as in Ottoman lands. ${ }^{21}$ The theory of forced conversion in national Tatar histories also gives precedence to the conquering representatives, relegates non-Christians to passive roles, overlooks the way communities develop and interact with one another on a practical daily basis, and denies that communities of the past could be made of mobile and ethnically diverse individuals. More specifically, it does not explain why a community like Apazovo village in Kazan district, made up of baptized Muslims and animist Udmurts, petitioned to keep its church in 1827 but after the 1917 February Revolution asked to construct a two-story mosque in its central market place. ${ }^{22}$ Nor

20. Interviews of elderly people by author, May 2008, Ianyli, Tatarstan; on the complex ethnic origin of Apazovo, see Rossiiskii gosudarstvennyi istoricheskii archiv (hereafter RGIA), f. 821, op. 133, d. 454, 1.6 and Iskhakov, "Etnodemograficheskoe razvitie," 8; on Verkhniaia Nikitkina, "Izvlecheniia iz otcheta bakalavra Kazanskoi dukhovnoi akademii N. I. Il'minskogo o poezdke po tatarskim seleniiam (August-September 1849)," in Khristiankoe prosveshchenie, 108.

21. Marc Baer, Honored by the Glory of Islam: Conversion and Conquest in Ottoman Europe (New York, 2008), 17-18; James Muldoon, ed. "Introduction: The Conversion of Europe," in Varieties of Religious Conversion in the Middle Ages (Gainesville, 1997), 1-10; John Howe, "Conversion of the Physical World: The Creation of a Christian Landscape," in ibid., 63-78; Nehemia Levtzion, "Toward a Comparative Study of Islamization," in Levtzion, ed., Conversion to Islam (New York-London, 1979), 1-23.

22. "Materialy dlia statistiki i istorii Kazanskoi eparkhii," IKE no. 2 (15 January 1880): 60-61; Istoriko-statisticheskoe opisanie tserkvei i prikhodov Kazanskogo uezda. Vypusk III-i (Alaty-Ivanovskoe) (Kazan, 1916), 67-69 (the wooden church suspiciously burned in 1907); Archa töbäge tarikhï. Istoriia Arskogo kraia (Kazan, 1996), 72; NART, f. 2, op. 7, d. 2393, 11. 2-3. 
does it explain why in 1766, the Udmurts and Tatars of Elyshevo petitioned for a chapel in the middle of their village, and a century later asked to be officially Muslim. Nor does it shed light on why the starokreshchenye villages of Apazovo and Elyshevo opted for Islam, while other villages-like Nikiforova (Shiyä-Bash), Mamadysh district, and the village of Iantsovary, Laishevo district-surrounded by Muslims and prestigious mosques, chose Christianity as their communal faith in the last quarter of the nineteenth century. It dismisses individual agency and communal volition, and does not recognize the power of Eastern Orthodox proselytism or the resourcefulness and flexibility of traditional Qur'anic learning that proved extremely effective in shaping the religious and, consequently, the ethnic and political identities of these newly formed baptized communities.

Without minimizing the sufferings apostate baptized Tatars endured in the nineteenth century for the legal recognition of their Muslim identity, the clan history of Taveli village helps unlock this persistent image of fixed communities and compulsory conversion as well as elucidate the role of pre-Christian indigenous beliefs in the forging of these communities. Indeed, most people in Taveli, a Kräshen village in Chistopol' district exposed to animistic, Christian, and Islamic influences, were not indigenous to the area but came initially as migrants and married outside their ethnicity or their original religion. The village's ancestors-Apakov, Ütägän, Andrei, Bikmän, Dimitri, and Bikbaw-were outsiders. Villagers could not say why their first ancestor Apakov, a landowner, accepted baptism, but at least there was no allusion to his being forcibly baptized. The elders had more knowledge of Ütägän and Bikmän's Christianization. Ütägän and his son Yuldïy, originally Muslims, came from Orenburg province and Bikmän, also Muslim, originated from Menzelinsk district. They first worked as laborers among the Kräshens of Taveli, liked the place, and accepted baptism in order to marry local Kräshen women. Andrei, another ancestor, was already baptized when he came to the village. His adopted son left to work in the village of Iamashi, married a baptized Mordvin, and their descendants became Russians. ${ }^{23}$ By contrast, the descendants of a Christian ancestor, Dimitri, leaned toward Islam. After one of them worked for a rich Muslim Tatar in the village of Kamenkina, they adopted Turkic names-Bikay, Biktimer, Ishäy, Bikkenä-in addition to their Russian Orthodox names. ${ }^{24}$ Although these ancient Turkic names were not of Arabic origin, Taveli villagers considered these appellations to be signs of religious otherness. In contrast, the Muslim Bikbaw (also named Kukara), originally from the district of Kazan and an itinerant carpenter, used to build houses and even churches before his conversion to Christianity. After working near Taveli, Bikbaw decided to be baptized. Later he married a Russian while he was working in the

23. All information on Taveli's kinship clans comes from Mikhail Apakov, Rasskazy kreshchenykh dereven' Tavelei i Alekseevskogo vyselka Iamashevskogo prikhoda, Chistopol'skogo uezda, o proiskhozhdenii kiremetei (Kazan, 1876), 1-5, 8-9; and from Il'ia Sofiiskii, a Kräshen student of the Kazan Theological Academy, "O kiremetiakh kreshchenykh tatar Kazanskogo kraia (Lektsiia v Kazanskom missionerskom priiute)," IKE no. 24 (15 December 1877): 681-682.

24. Kräshens leaning toward Islam bore two names-one Christian and one Muslim. When questioned by missionaries, they often pretended not to remember their Christian names (Il'minskii, ed., Kazanskaia tsentral'naia, 297). 
Karamaly village and his descendants became Russian or Kräshen depending whom they married..$^{25}$

Despite the presence of both Christianity and Islam, Taveli's kinship history indicates that animistic traditional religion through the work of female religious specialists (küremche) exerted a much more powerful influence than either Christianity or Islam in the making of its communal boundaries. Andrei's second son was married to Irina, a küremche, who, according to family tradition, introduced the practice of elevating one particular kirämät (a protective clan tutelary spirit) above other kirämäts. Thanks to her, each family, depending on its ancestry, came to worship a particular kirämät. After the death of several of her babies, Irina turned to a spirit named Täre ügeze (divine bull) and asked for his blessing; she purified her newborn child in the outer bath house (muncha), wrapped him tightly in a white piece of cloth and after placing him before the house icon, addressed her tearful prayers to the kirämät: "Äy tärem (oh, my God)! Give me a child and I will sacrifice a bull in your honor and a goose in honor of the other saints (izgelär)." ${ }^{26}$ Every year she killed a bull and the kirämät granted her five healthy children. Irina gained the respect of her community and shared names of other kirämät with villagers in distress. Although Andrei's family tended to present their female ancestor Irina as the one who brought multiplicity of kirämät to the village and assisted families in their choice of a particular spirit for protection, the Apakov branch claimed that a spirit called qür kirämäte (field spirit, neither good nor bad) had chosen their family as its host through one of their female ancestors. The spirit had left offerings in the family field. Intrigued, the Apakovs' ancestress sacrificed a red cow to the kirämät and saw immediate results: the land yielded more. Thus, each clan worshiped the kirämät in its own way, according to their ancestresses' guidelines. To complicate the picture further, one of the descendants of Andrei married a Chuvash, learned to speak the language, and observed his wife's religious practices.

Thus, Taveli's clan genealogies shatter the unilateral theory of forced conversion that implies the existence of already formed Muslim communities who were subjected to violent baptism in the sixteenth century. Their history demonstrates that up until the middle of the nineteenth century, religious affiliations mutated from one generation to the other, depending on work, location, and choice of community and life partner. It also suggests that before or even concomitant with Islam and Eastern Orthodoxy, the animistic cult of the kirämät at family shrines guaranteed order through the work of female religious specialists who, elected by the spirits to be their intermediaries, shared their knowledge of the spiritual world with other female clan heads, and determined their husbands' connection to the supernatural world.

25. Apakov, Rasskazy kreshchenykh dereven' Tavelei, 1-5; Ghomär Sattar-Mulille, Tatar isemnäre ni söyli? Tatar isemnäreneng tuli anglatmalï süzlege (Kazan, 1998), 61, 62, 122.

26. Täre comes etymologically from Tängre (the Turkic god of the earth and sky). It also means "icon." When Irina worshiped Täre ügeze, the icon was understood as the spirit's residence. Usually Kräshens did not make the sign of the cross when they addressed their clan spirits. See Semen Maksimov (Kräshen), "Ostatki drevnikh narodno-tatarskikh (iazycheskikh) verovanii u nyneshnikh kreshchenykh tatar Kazanskoi gubernii," IKE 10, no. 19 (1 October 1876): 567; Apakov, Rasskazy kreshchenykh dereven' Tavelei, 10. 
The cult of the kirämät was also linked to the history of a particular village. In Al'bedino, Laishevo district, inhabitants claimed that there were seven kirämät brothers. Each of them flew from the sky and took residence in the neighboring Kräshen, Russian, and Tatar villages. Once every three or five years, the villagers collectively bought a white cow and sacrificed it to their kirämät, Al'bedino, near the spring, its residence, pleading for protection from hail, frost, and locusts. Such sacrifices were called kurman. ${ }^{27}$ Russian missionaries viewed the kirämät as evil, vengeful spirits. However, native Turkic and Finnic teachers and priests remembered some of these spirits as good beings who brought blessings and healing to the family or community they chose to protect, but because of people's sinfulness they were often forgotten; only when hardship struck did people come back to them for protection. It was only in the mid-nineteenth century that starokreshchenye communities in Mamadysh and Laishevo regions had to face the difficult question of defining their religious affiliation. Not only did they have to choose between Islam and Christianity, but they had to renegotiate their relationship with the kirämäts. Their adoption of Islam or Christianity, however, did not lead to an immediate erasure of preexisting indigenous identities and worldview. In fact, Kräshens attached to their indigenous religion integrated Islam and Christianity on their own terms, first borrowing their practices-recitation of Muslim and Orthodox prayers-to lend more power to their worship of domestic and communal spirits. ${ }^{28}$

Unlike the starokreshchenye, the novokreshchenye-converted to Eastern Orthodoxy by the Office for the Affairs of New Converts under the watch of the Kazan bishop Luka Konashevich (r. 1744-1755) - had come from peoples who were originally Muslim. Historians hold different views of the conversion campaign of the 1740 s. $^{29}$ Most emphasize the harshness of the methods of conversion, but others point to the church and state's use of positive material incentives for conversion-temporary tax relief, gifts of clothes and salt, and draft exemption. If abuses occurred, they came more from local overzealous hierarchs and functionaries than from St. Petersburg, often unable to control its periphery adequately. Although church and state supported each other in their Christianization campaign, occasionally local Russian state authorities supported non-Russians against missionary abuses. All historians agree that the Russian state and the church were not concerned about the genuine character of the conversion. As was the case in medieval Europe, the state viewed conversion as a way to integrate the peoples of the Middle Volga into the bureaucratic structure of

27. Arkhip Ilarionov (Kräshen deacon), "Iz zhizni kreshchenykh inorodtsev Kazanskogo kraia za 1887 god," IKE no. 1 (1 January 1888): 22-23; Mikhail Mashanov, Religiozno-nravstvennoe sostoianie kreshchenykh tatar Kazanskoi gubernii Mamadyshskogo uezda (Kazan, 1875), 21-22.

28. Timofeev, "Moe vospitanie," in Kazanskaia tsentral'naia, ed. Il'minskii, 16-23; A. Andrievskii, "Dela o sovershenii iazycheskikh obriadov i zhertvoprinoshenii kreshchenymi inorodtsami Viatskoi gubernii," in Stoletie Viatskoi gubernii, sbornik materialov k istorii Viatskogo kraia, t. 2 (Viatka, 1881), 565; R. G. Akhmet'ianov, Obshchaia leksika dukhovnoi kul'tury narodov Srednego Povolzh'ia (Moscow, 1981), 31-33; Werth, At the Margins of Orthodoxy, 29; story on a kirämät tree in Flera Baiazitova, "Traditsionnye obriady i narodnye verovaniia mol'keevskikh kriashen na fone dialektnogo iazyka," in Mol'keevskie kriasheny, ed. Damir Iskhakov (Kazan, 1993), 151.

29. Faizulkhak Islaev, Islam $i$ Pravoslavie $v$ Povolzh'e XVIII stoletiia: Ot konfrontatsii $k$ terpimosti (Kazan, 2001); Michael Khodarkovsky, "The Conversion of Non-Christians in early Modern Russia," in Of Religion and Empire: Missions, Conversion, and Tolerance in Tsarist Russia, ed. Robert P. Geraci and Michael Khodarkovsky (Ithaca and London, 2001), 115-143. 
the empire and churchmen regarded it as the foundation for future spiritual growth under their authority. ${ }^{30}$

Socioeconomic tensions in these agrarian communities help explain their adoption of Eastern Orthodoxy. Novokreshchenye often came from the lowest strata of Tatar villages, including poor peasants unable to pay communal taxes, people who wanted to avoid penalties as prescribed by the sharia (Islamic law), horse thieves who wished to escape corporal punishment, and men evading military service. ${ }^{31}$ Local evidence suggests that novokreshchenye joined earlier communities of converts as laborers and were drawn into the Russian and baptized labor market. Tatars in the mixed Tatar-Kräshen-Russian village of Bikovo, Tetiushi district, worked with Russians as barge haulers on the Volga River and asked to be baptized, but later apostatized. ${ }^{32}$ Old and new converts also worked in Russian- or baptized-owned copper foundries, opened between the 1740 s and the 1770 s along the Mesha, Kama, and Viatka rivers, in the Kukmor, Nyrty, and Menzelinsk regions. Baptized Tatars of this particular economic zone traveled extensively and shared goods and brides. ${ }^{33}$

By the beginning of the nineteenth century, the novokreshchenye in Transkazania, eastern Trans-Kama, and the right bank of the Volga, rarely formed isolated villages (except when they had moved to starokreshchenye villages), and instead generally lived in small numbers in predominantly Muslim villages. When more than three families had accepted baptism, the Office for the Affairs of New Converts was unable to transfer them to Russian villages as they had originally intended to do. ${ }^{34}$ Such a state policy would have rendered baptism a hardship for many potential converts; it also would have cost the state and the church too much. As a result, many of the new converts to Orthodoxy remained a minority in a Muslim environment. Even in mixed Russian-Tatar-Kräshen villages of Simbirsk and Nizhnii Novgorod provinces, baptized Tatars did not join the Russian communes, but remained within their original Tatar commune. The elders, elected commune officials, and heads were all Muslim Tatars, and the well-being and claims for justice of the baptized Tatars depended on the whims of their Muslim brethren. This fact greatly increased the risk that these new Christians might switch to Islam. ${ }^{35}$

30. Werth, "Coercion and Conversion," 543-70; Gennadii Makarov, "Perspektivy razvitiia traditsionnoi kul'tury Kriashen v sovremennykh usloviiakh," in Materialy nauchno-prakticheskoi na temu "Etnicheskie i konfessional'nye traditsii Kriashen": Istoriia i sovremennost' (Kazan, 2001), 17-44.

31. See the documents of the Holy Synod published in N. I. Il'minskii, ed., Opyty perelozheniia khristianskikh verouchitel'nykh knig na tatarskii i drugie inorodcheskie iazyki $v$ nachale tekushchego stoletiia: Material dlia istorii pravoslavnogo russkogo missionerstva (Kazan, 1883), 36-70; Qayyum Nasïyri, "Yugharï Shïrdan," in Saylanma äsärlär (dürt tomda), vol. 3 (Kazan, 2005), 195.

32. Roza, native of Bikovo, interview by author, May 2008, National Archive of the Republic of Tatarstan, Kazan.

33. As soon as Russians entered the Volga and Ural regions, Ivan IV ordered to search for copper which constituted the basis of their monetary system (Nolde, La formation, 236). For this reason, Tatars could not own metallurgical factories. Khusain Khasanov, Formirovanie tatarskoi burzhuaznoi natsii (Kazan, 1977), 33-34, 49, 51, 302; Faizulkhak Gazizullin, Dorogoi k pravde (sotsial'no-ekonomicheskie interesy klassov $i$ tatarskaia ekonomicheskaia literatura 1880-1917) (Kazan, 1979), 18; Istoriia Tatarskoi ASSR: S drevneishikh vremen do velikoi oktiabr'skoi sotsialisticheskoi revoliutsii, vol. 1 (Kazan, 1955), 197; Istoriia Tatarskoi ASSR: s drevneishikh vremen do nashikh dnei (Kazan, 1968), 132, 135.

34. Evfimii Malov, “O Novokreshchenskoi kontore," PS 24, no. 12 (December 1878): 46.

35. Il'minskii, Opyty perelozheniia, 24. 
However, even if the new converts were originally Muslim, their acceptance of Christianity indicated that these new Christians did not hold completely to Islam and for some socioeconomic reason, were not fully integrated into their original communities of faith. Once they adopted Orthodoxy, many experienced further ostracism from their respective milieus. Some left and settled in old convert villages after their former brothers demanded that they pay back the taxes from which they were exempted. Other converts had no other choice but to stay in their original community and, because access to the village mosque was forbidden to them (by both the church and their former brethren), their descendants engaged their own "baptized mullahs," formed their own mahallas (neighborhoods) in separate streets, and opened their own cemeteries. ${ }^{36}$

Most novokreshchenye apostatized in the nineteenth century. One notable exception was Mol'keevo and eight other new convert villages located in Tsivil'sk and Tetiushi districts, who apostatized in part in 1826 and 1866, but in the 188 os, petitioned for the construction of four churches in their midst. These communities shared many affinities of the old converts, participating in both the culture of Islam and more actively in the animistic culture of their Chuvash neighbors whom they occasionally married. From 1910 to the 1930s, villagers claimed either Muslim Tatar or animist Chuvash ancestry, and the genealogies of Mol'keevo, Staryi Kyrbash, Khozesanovo (Quyasan), and Iangozino-Surinskoe confirmed their Muslim origin. Local songs and traditions referred to the presence of previous mosques; thus, along with many other nature kirämäts, Iangozino-Surinskoe worshiped a divinity called mächet urïndagh ̈̈ $\ddot{\text { rrese }}$, the god who resides at the place where the mosque once stood. The villagers also visited their former Muslim cemeteries, even after the opening of an Eastern Orthodox school. On one of the days of Easter week (which coincided with the celebration of the spring agrarian festival of the plow, called Sabantuy by Muslim Tatars and Sörän by Kräshens) the Khozesanovites prayed for a good harvest to their village's founder Khoja Hasan, a Sufi saint responsible for the region's colonization and Islamization, at the cemetery where two other saints were buried. They also avoided greeting each other with the usual Easter greeting "Khristos Voskrese" (Christ is risen), since, in their view, it would have offended the saint. Such respect for the Sufi saint did not mean that they were secretly Muslim or syncretic; they were simply mindful that their founding saint was entitled to a different form of prayer on the day of his feast. Likewise, they were not Chuvash animists. If their spirits fulfilled the same functions as the spirits of their Chuvash neighbors, they bore Tatar names and their place of residence was tied to their village's toponymy, not to that of their neighbors. Thus, even communities classified as novokreshchenye could live in some form of religious hybridity, navigating between Islam, Orthodoxy, and various ethnic forms of animism or fertility cults. As among the starokreshchenye, there was no automatic return to Islam, no blind acceptance of Christianity as the conqueror's religion, and no accidental mixing of beliefs. Kräshens articulated their own relationship

36. N. Firsov, Inorodcheskoe naselenie prezhnego Kazanskogo tsarstva v novoi Rossii do 1762 goda $i$ kolonizatsiia zakamskikh zemel' v eto vremia (Kazan, 1869), 196-197; Priest Gr. L'vov, "Religioznoe sostoianie otpadshikh tatar v derevne Iangil'dinoi Cheboksarskogo uezda," IKE, no. 21 (1 November 1896): 407. 
to the sacred, applying different modes of religious action and discourse to different times, locations, and ecological contexts, which enabled them to create a safer communal space, despite colonial or local encroachment. ${ }^{37}$

In the first half of the nineteenth century, Islam seemed to take the upper hand in the religious solidification of individual baptized communities. Apostasies first broke out mainly among new converts, but then, in the second half of the century, they reached a much larger number of old converts. To complicate the picture further, they included non-Tatar indigenous groups, which signified a victory for Muslim proselytism. These new communities of faith, however, had a unique history that kept them from merging completely with the surrounding Tatar villages. Despite their official "return" to Islam, descendants of Elyshevite apostates in 2008 complained that Tatars from the kolkhoz center of Shittsy still referred to them contemptuously as keräshennär.

\section{Other Participants}

Several other indigenous peoples of the Middle Volga region accepted Islam as their faith and participated in the apostasy movements of the nineteenth century: the Finnic Udmurts (called Votiaks before the Revolution), the Mari (known as the Cheremis before the Revolution), and the Turkic Chuvash. ${ }^{38}$ This historical process of conversion to Islam dated probably as far back as the tenth century. The nineteenth-century Tatar historian Märjani noted that Muslim graves predating the Russian conquest had inscriptions with Chuvash, Mari, and Udmurt names. ${ }^{39}$ According to one Tatar tradition, the sixteenth-century Russian invasion had driven Tatars north into the territory of the Udmurts and Maris, which could have encouraged the Islamization of a portion of these small minorities. ${ }^{40}$ In the 1850 s, the Udmurts of Malmyzh and Elabuga districts of Viatka province began to turn away from Christianity to adopt Islam. By 1869, Mamadysh district in Kazan province had become the area with the largest number of Udmurt converts to Islam. Even after the introduction of Udmurt literacy through the work of Russian missionaries in the 186os, villages in the Kukmor region were still strongly attracted to Islam. In 1912, about 4,00o Udmurts had adopted Islam in the provinces of Perm', Ufa, and Kazan. ${ }^{41}$

37. Gurii Filippov, "Iz istorii khristianskogo prosveshcheniia kreshchenykh tatar-meshcheriakov Tetiushskogo i Tsivil'skogo uezdov Kazanskoi gubernii," IKE no. 37 (1 October 1915): 1038-1042 and nos. 39-40 (15-22 October 1915): 1080-1084; idem, "Kreshchenye meshcheriaki v Tsivil'skom i Tetiushskom uezdakh, Kazanskoi gubernii (Istoriko-etnograficheskii ocherk)," Pravoslavnyi Blagovestnik (hereafter PB), no. 4 (April 1915): 167-182; Nikolai Vorob'ev, "Otchet o poezdke s etnograficheskoi tsel'iu v Svizhskii [sic] i Tetiushskii kantony TSSR letom 1927 g.”,Vestnik nauchnogo obshchestva tatarovedeniia no. 8 (1928): 102; Damir Iskhakov, ed., "Mol'keevskie kriasheny: Problema formirovaniia i demograficheskoe razvitie v XVIII-nachale XX veka," in Mol'keevskie kriasheny, 4-25; Baiazitova, Govory Tatar-Kriashen, 44.

38. Il'minskii's letter in NART, f. 93, op. 1, d. 128 v, 1l. 159-160 ob. On the demography, economy, and religion of these groups, see Werth, At the Margins of Orthodoxy, 17-22; Geraci, Window on the East, 30-40; Andreas Kappeler, "Lethnogénèse des peuples de la Moyenne-Volga (Tatars, Tchouvaches, Mordves, Maris, Oudmourtes) dans les recherches soviétiques," Cahiers du Monde russe et soviétique 17, nos. 2-3 (AprilSeptember 1976): 311-334.

39. Märjānī, Mustafād, 1: 29.

40. Nikolai Vorob'ev, Material'naia kul'tura Kazanskikh tatar (Kazan, 1930), 26-27.

41. Istoriia Tatarii v dokumentakh i materialakh (Moscow, 1937), 349-350; M. Reshetnikov, "Nuzhdy pravoslavnoi missii sredi magometan v Viatskoi gubernii," Missionerskoe obozrenie 14, no. 3 (March 1909): 396; 
Islam also had great success among the Maris in Kazan and Mamadysh districts of Kazan province, Malmyzh district of Viatka province, and Birsk and Menzelinsk districts of Ufa province. Märjani, with undisguised satisfaction, noticed that Maris, even after their baptism, borrowed nothing from Christianity but their names. Yet, while being in constant contact with Muslims, they uttered Bismillah (in the name of God) in Arabic before starting an action, rested on Fridays, consumed horse meat against Orthodox priests' command, and considered pork meat inedible. ${ }^{42}$ To their great consternation, Russian missionaries found many of the baptized Maris still attached to their indigenous beliefs and more familiar with the Sufi versions of Biblical stories than they were with the Christian scriptures. ${ }^{43}$ There were even mosques in villages populated entirely by Maris. In 1912, according to official statistics, there were 1,477 Muslim Maris. ${ }^{44}$ The actual number was probably much greater, especially in Ufa province, where the Maris had immigrated after the Russian conquest of Kazan. As early as 1900, the ethnographer Sergei Rybakov (1867-1921) spoke of 40,000 unbaptized Maris who were being assimilated into the Tatar community. ${ }^{45}$

The people most marked by Tatar Islamization were the Chuvash. According to them, God had given humanity seventy-seven religions, of which the best, morally speaking, was that of Muhammad. By contrast, Orthodoxy was one of the worst. The famous Chuvash pedagogue and disciple of Il'minskii, Ivan Iakovlev (1848-1930), recalled that before the age of eight he used to play kickball with Eastern Orthodox icons in the street of Koshki village in the Buinsk district of Simbirsk province. Ailing adults of this village turned for help to Islam rather than Christianity and called the Tatar mullah to their houses for prophylactic purposes. In general, animist Chuvash of Simbirsk province in the 1850 s who wished to keep their ancestral beliefs and communal autonomy often preferred to be listed as Muslims than be baptized. The Chuvash proved most amenable to Islamization for historical and linguistic reasons. The Chuvash language was a Turkic language related to Tatar. Even after the Christianization of the Chuvash in the mid-eighteenth century, the Tatars continued to convert and assimilate the Chuvash. ${ }^{46}$ In the village of Verkhniaia Nikitkina, which played a pivotal role in the apostasy movement of 1865, 101 Chuvash lived among 195 new converts

Iakov Koblov, "O tatarizatsii inorodtsev privolzhskogo kraia," in Missionerskii s"ezd v gorode Kazani 13-26 iiunia 1910 goda (Kazan, 1910), 352, 373; Andrei (Aleksandr Alekseevich Ukhtomskii, former bishop of Mamadysh) and N. V. Nikol'skii, Naibolee vazhnye statisticheskie svedeniia ob inorodtsakh vostochnoi Rossii i zapadnoi Sibiri, podverzhennykh vliianiiu islama (Kazan, 1912), 241; Z., "K sud'bam votiakov," Okrainy Rossii 7, nos. 29-3o (21-28 July 1912): 437-439; Aleksandr Kremlev, K voprosu ob otatarivanii votiakov Kazanskoi eparkhii i o merakh prosveshcheniia ikh (Kazan, 1913), 1-6.

42. Märjānī, Mustafād, 1: 24-25.

43. "Otchet o deiatel'nosti soveta Bratstva Sv. Guriia, s 4 oktiabria 1870 g. po 4 oktiabria 1871 goda," IKE no. 4 (15 February 1872): 112.

44. Koblov, "O tatarizatsii," 352, 372; Il'minskii, ed., Kazanskaia tsentral'naia, 381, 383; A. F. Rittikh, Materialy dlia etnografii Rossii. Kazanskaia guberniia (Kazan, 1870), 107; Petr Eruslanov, "Magometanskaia propaganda sredi cheremis Ufimskoi gubernii (iz lichnykh nabliudenii)," PB 3, no. 8 (1895): 424; Andrei and Nikol'skii, Naibolee vazhnye statisticheskie, 241.

45. Sergei Rybakov, Islam i prosveshchenie inorodtsev v Ufimskoi gubernii (SPb., 1900), 8.

46. I. Ia. Iakovlev, Moia zhizn': Vospominaniia (Moscow, 1997), 56, 62; Aleksandr Kobzev, "Islamizatsiia pravoslavnykh chuvashei i chuvashei-iazychnikov Simbirskoi gubernii v XIX-nachale XX veka," Otechestvennaia istoriia, no. 5 (2007): 121; Leonid Braslavskii, Islam v Chuvashii: Istoricheskie i kul'turologicheskie aspekty (Cheboksary, 1997); Qayyum Nasïri, Saylanma äsärlär, vol. 3 (Kazan, 2005), 189. 
and married according to Islamic ritual. The historian G. N. Volkov concluded that between 1826 and 1897, 400,000 Chuvash in Kazan province alone had been Islamized. Tatar influence over the Chuvash was significant in other provinces as well. Before 1870, Russian Orthodox missionaries were most concerned with Tatar influence in Chuvash villages of Kazan and Simbirsk provinces, but afterward they also looked with alarm at the Tatarization of Chuvash in Belebei district of Ufa province. ${ }^{47}$

Demographic prerevolutionary evidence and Soviet calculations suggest that the Tatars were absorbing part of these smaller minorities, who often adopted not only the Muslim religion but also the Tatar language. This increase included Maris, Udmurts, and those Mordvins who had adopted Islam and eventually became Tatars. In the nineteenth century, the natural growth of the Tatars was far above normal-115.8 percent compared to 40.3 percent for the Chuvash. ${ }^{48}$

Missionary observers, however, tended to exaggerate the assimilatory power of Tatar Islam. There is evidence that the new converts' native language and ethnic identity were not entirely lost. Tatars in Tsivil'sk district shared their faith in the Chuvash language, and Märjani humorously noted that during the scholastic debates between Muslim scholars, two mullahs of Mari origin discussed strategies in their ancestral language, not in Tatar, to fool their opponents. ${ }^{49}$ Russian observers in Simbirsk province also noted that Chuvash and Maris (especially women) kept their language and clothing despite their growing attachment to Islam. A priest in Belebei district, Ufa province, even warned local police authorities that baptized Chuvash who had studied secretly in the madrasa of a local Tatar mullah formed their own underground Muslim congregation (mahalla) with a Chuvash mullah. Islamized Chuvash, he wrote, did not lose their Chuvash identity; on the contrary, they looked for brides in neighboring baptized Chuvash, and not Tatar villages. The same phenomenon also took place among apostates of Kazan province, who developed their own Islamic marital networks separate from the Tatars. ${ }^{50}$

\section{Laws and Measures against Apostasies}

Once subjects of the empire accepted baptism, there was no other choice but to remain Eastern Orthodox. Russian law severely punished apostasy from Christianity,

47. NART, f. 4, op. 80, d. 6o, 1l. 59 ob., 61 ob., 96; f. 4, op. 84, d. 263, 1. 15; G. N. Volkov, Etnopedagogika chuvashskogo naroda (Cheboksary, 1966), 289; "Iz vospominanii protoiereia A. Baratynskogo," Simbirskie eparkhial'nye vedomosti, no. 21 (1 November 1905): 530-531; G. I. Komissarov, "Chuvashi Kazanskogo Zavolzh'ia," Izvestiia Obshchestva arkheologii, istorii i etnografii pri Kazanskom universitete (hereafter IOAIE) 27, no. 5 (1911): 320; Rybakov, Islam i prosveshchenie, 9-10; S. M. Matveev, O kreshchenykh inorodtsakh Ufimskoi eparkhii (Ufa, 1910), 25-27.

48. In the beginning of the twentieth century, a group of Mordvins in the Nizhnii Novgorod district asked to be officially recognized as Muslims. M. Vasil'ev, "Rasprostranenie khristianstva v Kazanskom krae," IKE no. 32 (22 August 1904): 1054. For statistics related to Tatar population growth, see Volkov, Etnopedagogika, 289.

49. Pavel Rufimskii, K voprosu o pravoslavnoi missii sredi inorodtsev Kazanskogo kraia (Kazan, 1908), 2, 5; Iz zapiski N. I. Il'minskogo "O rasprostranenii magometanstva sredi Kazanskikh tatar" (188o), in Khristianskoe prosveshchenie, 247; Shihāb ad-Dīn b. Bahā’ ad-Dīn Märjānī, Mustafād al-akhbār fī ahwāl Qazān wa Bulghār, vol. 2 (Kazan, 1900), 185.

50. "Kratkaia zametka ob inorodtsakh Volzhsko-Kamskogo kraia," Simbirskie eparkhial'nye vedomosti, no. 1 (1 January 1897): 24-26; letter and report of priest Andrei Petrov (Belebei district) in NART, f. 93, op. 1 , d. 128 v, 1l. 34-34 ob., 45-45 ob. 
conversion to Islam, and all forms of Muslim proselytism among the animists and Christians. In 1593, Czar Fedor (r. 1584-1598) ordered apostates from Christianity to be thrown in prison, beaten, and placed in chains. Severe measures were also taken to isolate the Christian converts from Muslims by placing them in special settlements. A Christian convert married to a non-Christian was legally separated from his or her spouse..$^{51}$ Later, the Law Code of 1649 condemned any Muslim judged guilty of having converted an Orthodox Christian to be burned to death without pity. The "victim" was sent to the patriarch for further instruction and then to a monastery for penitence. ${ }^{52}$ In 1722, the Kazan metropolitan Tikhon III (r. 1699-1724) ordered the destruction of old cemeteries that attracted Kräshen and Tatar pilgrims. ${ }^{53}$ His successor, Sil'vestr Kholmskii (r. 1725-1731) discovered cases of conversion to Islam among Chuvash, Mordvins, Maris, and Udmurts, which prompted the promulgation of a new law in 1728 condemning Muslim proselytism among animists. ${ }^{54}$ Finally, in the 1740 , the Office for the Affairs of New Converts punished converts to Islam with fines, beatings, separation from families in cases of mixed marriage, deportation to monasteries, or exile. Circumcisers of Chuvash, who otherwise kept their indigenous way of life-that is language, customs, and even the worship of their indigenous spiritswere moved from Sviiazhsk province to Siberia. ${ }^{55}$ The Tatars, for their part, had their mosques destroyed especially in areas populated by Christian converts. In two years $(1742-1744), 418$ out of 536 mosques were destroyed, and the construction of new ones was strictly limited. ${ }^{56}$

After the second Bashkir revolt in 1755 and the 1773-1775 Emelian Pugachev rebellion that Volga Muslims had supported, the state made concessions. Catherine II proclaimed religious liberty and favored the economic and spiritual expansion of Tatar merchant colonies. She also authorized the construction of mosques in Bashkiria, Siberia, and in the Kazakh steppes, but maintained the restrictions placed on the opening of new mosques near converts to Christianity. State representatives, and not local bishops as before, would investigate and decide whether to have a mosque erected. From that point on, the power to favor or to hinder the growth of Islam lay with the state. ${ }^{57}$

51. Mozharovskii, "Izlozhenie," 26-27.

52. M. N. Tikhomirov and P. P. Epifanov, eds., Sobornoe ulozhenie 1649 goda (Moscow, 1961), chap. 22, art. 24, p. 291; M. Arkhangel'skii, O Sobornom Ulozhenii Tsaria Alekseia Mikhailovicha 1649 (7156) g. v otnoshenii k pravoslavnoi russkoi tserkvi (SPb., 1881), 28.

53. Opisanie dokumentov $i$ del, khraniashchikhsia $v$ arkhive Sviateishego pravitel'stvuiushchego sinoda, vol. 1, 1542-1721 (SPb., 1868), p. CCCXIII (prilozhenie no. XXIX); Firsov, Inorodcheskoe naselenie, 178, footnote. 3 .

54. Polnoe sobranie zakonov Rossiiskoi imperii (hereafter PSZ), first series, 45 vols. (SPb., 1830), 8 (1728-1732), 5333, no. 19: 100.

55. PSZ 11 (1740-1743), no. 8236: 248-256; Malov, “O Novokreshchenskoi," 107.

56. PSZ 11 (1740-1743), no. 8664: 719-720; Priest K. Prokop'ev, “K istorii prosveshcheniia inorodtsev Kazanskogo kraia v XVIII veke. L'goty obrashchaiushchimsia v khristianstvo inorodtsam i stesneniia inorodtsev, kak sil'neishii faktor $\mathrm{v}$ dele obrashcheniia inorodtsev $\mathrm{v}$ khristianstvo v XVIII veke," Simbirskie eparkhial'nye vedomosti, no. 6 (15 March 1905): 151; Tatary Srednego Povolzh'ia $i$ Priural'ia, 376.

57. PSZ 19, no. 13996: 775-776; Evfimii Malov, “O tatarskikh mechetiakh v Rossii," PS, pt. 1 (1868): 11; Chantal Lemercier-Quelquejay, "Les missions orthodoxes en pays musulmans de moyenne-et basse-Volga," Cahiers du Monde russe et soviétique 8, no. 3 (July-September 1967): 369-403. 
During Catherine's reign, Tatars' proselytism among animists was encouraged only in regions that presented a political and economic interest for Russians, but never in the Middle Volga where the Orthodox Church had the undisputed monopoly on converting non-Christians. Until 1905, state laws strictly forbade interconfessional marriages and the return of baptized inorodtsy (non-Russians, literally, "those of other origin") to their previous faith, as well as proscribed and punished by exile those who converted animists (in Russian, iazychniki [pagans]) to any other confession but Eastern Orthodoxy. Although state laws did not prohibit animists from converting to Islam, administrative practice discouraged such conversions to protect Orthodox supremacy. ${ }^{58}$ Until 1917, eighteenth-century laws that banned the opening of mosques with a minaret in proximity of or inside villages populated by former apostates or Kräshens (even a few) were still in force on paper, but occasionally bent in practice. ${ }^{59}$

After the first 1802 apostasy, the Orthodox Church confronted with an ever more vigorous Islam understood that top-down coercion was not the best way to bring apostates back to Christ and sought more peaceful ways to keep its converts. The Holy Synod ordered the translation of religious texts into native languages, which resulted in the publication of a Tatar catechism in 1803. Tatar was introduced into the curriculum of Kazan's religious and state schools. In 1830, the Synod ordered that on Sundays and feast days, the Gospel, creed, and various prayers be read in the language of the novokreshchenye. It encouraged priests to use non-Russian native languages in their preaching and, in 1842, after the outbreak of a new mass apostasy, it instituted a special chair of indigenous languages-Tatar, Arabic, Mongol, and Kalmyk-at the Kazan Theological Academy, reopened the same year. The academy's aim was to recruit students from the seminaries and train them as local seminary teachers, missionaries, or church officials. Five years later, Czar Nicholas I (r. 1825-1855) ordered that the most important parts of The Divine Liturgy and The Liturgy of the Hours be translated into native languages. But the language of translation for Tatar was too far from the vernacular, and restricted the listeners' understanding of the divine truths. ${ }^{60}$

In the 1850 , one of the most brilliant students of the Kazan Theological Academy, Nikolai Il'minskii, changed the whole church approach to mission in the Volga region, after Kazan Bishop Grigorii (Postnikov) (r. 1848-1856), concerned with reports of

58. Svod zakonov Rossiiskoi Imperii (SPb., 1832), vol. 14, art. 40; "O preduprezhdenii i presechenii otstupleniia ot pravoslavnoi very," Svod zakonov Rossiiskoi Imperii (SPb., 1857), vol. 14, ch. 3, section 1, art. 47-54, pp. 11-12 (apostasies from Orthodoxy in general); section 2, art. 55-59, pp. 12-13 (apostasies from Orthodoxy into paganism, Islam, and Judaism); M. N. Palibin, Ustav dukhovnykh konsistorii (SPb., 1900), 23-30; Paul Werth, "Tsarist Categories, Orthodox Intervention, and Islamic Conversion in a Pagan Udmurt Village, 1870s-189os," in Muslim Culture in Russia and Central Asia from the 18th to the Early 2oth Centuries: Inter-Regional and Inter-Ethnic Relations, vol. 2, ed. Anke von Kügelgen, Michael Kemper, and Allen Frank (Berlin, 1998), 389-393.

59. PSZ 4 (1700-1712), no. 1946: 226-227; 11 (1740-1743), no. 8664: 719-720; Malov, "O tatarskikh" (December 1867): 296; RGIA, f. 821, op. 133, d. 459, 1l. 1-167; f. 821, op. 133, d. 505, 1l. 1-6, 76, 137-144.

6o. Geraci, Window on the East, 49-61; Il'minskii, Opyty perelozheniia, 3; N. A. Spasskii, Prosvetitel' inorodtsev Kazanskogo kraia Nikolai Ivanovich Il'minskii (Samara, 190o); "Svedeniia o missionerskom otdelenii," vol. 1, Missionerskii protivomusul'manskii sbornik. Trudy studentov missionerskogo protivomusul'manskogo otdeleniia pri Kazanskoi dukhovnoi akademii (hereafter MPMS) (Kazan, 1873), IXVI; “Ob otkrytii v g. Kazani Bogosluzheniia na tatarskom iazyke," IKE no. 2 (15 January 1870): 48. 
new apostasies, sent him to visit baptized Tatar villages in 1848. Born in Penza to a priest in April 1822, Il'minskii initiated a new and daring missionary strategy-to develop an Orthodox Christian culture among the non-Russian peoples of the empire in their vernacular languages. Two basic principles guided his work: first, to teach natives in their local languages; and second, to train native teachers, missionaries, and Orthodox priests. In 1863, Il'minskii founded the Kazan Central Baptized-Tatar School with the indispensable help of Vasilii Timofeev (1836-1893), a Kräshen from Mamadysh district, and the collaboration of Evfimii Malov, a deacon's son from Simbirsk province who first studied and then taught anti-Islamic studies at the Academy. Il'minskii worked closely with the Brotherhood of St. Gurii, which he helped to found in 1867 with church hierarchs, merchants, government officials, and pedagogues. The Brotherhood, a private organization, financed Kräshen, Chuvash, Mari, and Udmurt schools in Kazan, Ufa, and Orenburg provinces, and the translation of religious books and pedagogical material in Kräshen Tatar, Chuvash, Mari, and Udmurt languages. Two decrees from the Synod facilitated the work of Il'minskii: the Synod allowed training and ordination of non-Russian clergy in 1867, and the celebration of the liturgy in non-Russian languages in 1883. Furthermore, the Ministry of Education backed up Il'minskii's work. In 1872, Il'minskii became the director of the newly opened Native Teachers' Seminary in Kazan. Today, the Kräshen community of Tatarstan is composed of former starokreshchenye and a small portion of novokreshchenye who have remained faithful to Christianity thanks to Il'minskii and especially to his Kräshen disciples. ${ }^{61}$

\section{Apostasies as Movements of Conversion and Faith Renewal}

\section{Chronology and Statistics}

Despite legal measures forbidding apostasy from Orthodoxy, many descendants of the baptized Tatar state peasants began to apostatize en masse as they embraced Islam. These collective apostasies occurred every decade, following one another in rapid succession in 1802-1803, 1826-1830, 1842, 1856, 1865-1866, 1870, 1882-1883, 18951896 , and 1905. Entire villages sent petitions to the czar to allow them to confess their true faith. The apostasies corresponded to Russo-Turkish wars, changes in reign, or to the periodic tax censuses (revizii) introduced by Peter I and local parish censuses that obliged the Kräshens to identify themselves as "Tatars" or "Kräshens," that is Muslims or Christians. ${ }^{62}$ They also coincided with outbursts of cholera in 1830 , 1849, and 1853; bad harvests in 1864-1865, 1867-1868, 1870, and 1873; the building of new churches; or the introduction in 1870 of new education laws that rendered

61. Werth, At the Margins of Orthodoxy, 183-193, 223-235; Geraci, Window on the East, 47-85, 86-115, 116-136; Wayne Dowler, Classroom and Empire: The Politics of Schooling Russia's Eastern Nationalities, 1860-1917 (Montreal, 2001), 17-61; D. Zelenin, N. I. Il'minskii i prosveshchenie inorodtsev (SPb., 1902).

62. The parish censuses triggered anxiety among the Tatars themselves who feared that they would be counted as baptized. P. B. Znamenskii, "Kazanskie tatary," in Zhivopisnaia Rossiia, otechestvo nashe $v$ ego zemel'nom, istoricheskom, plemennom, ekonomicheskom i bytovom znachenii, vol. 8, Srednee Povolzh'e $i$ priural'skii krai, pt. 1, Srednee Povolzh'e (SPb. and Moscow, 1910): 144-145. 
the teaching of Russian obligatory in Qur'anic schools. Apostate Kräshens read all these events as confirmation of their apocalyptic expectations for a restorer of the true religion who would liberate them from the Christian yoke. ${ }^{63}$

Each successive apostasy involved an increasing number of baptized Tatars over a larger geographical area. The very first one broke out in Nizhnii Novgorod province in the novokreshchenyi village of Moklokovo, which comprised several baptized Tatars of Mishar origin and Chuvash families, and spread to thirteen villages. The second wave of apostasies, between 1827 and 1856, affected a larger territory comprised of essentially novokreshchenye in the Kazan, Simbirsk, Samara, Viatka, Ufa, and Orenburg provinces. In Kazan province, the most committed apostates lived in Chistopol' and Spassk districts. The third apostasy of 1865-1866 also began in the Kazan diocese, touching not only the areas of the previous movement (Simbirsk and Nizhnii Novgorod provinces in particular), but also incorporating Chuvash, Udmurts, Maris, and for the first time starokreshchenye in Mamadysh and Laishevo districts. The most affected of all parishes was Achi where 1,000 starokreshchenye-among them Elyshevo and Kibiak-Kozi-apostatized for the first time between 2 April and 15 May 1866. Novokreshchenye from Chistopol' district led the apostasy, but baptized Tatars in the districts of Tetiushi and Sviiazhsk of Kazan province left the church in greater numbers than the years before. Starting in the 1870 s and continuing well into the 1890s, new apostasies broke out among the novokreshchenye, the starokreshchenye (especially Kazan and Mamadysh districts), baptized Udmurts, Maris, and Chuvash of Kazan province, Orenburg (Orsk district in particular), and Ufa region (Belebei and Menzelinsk districts). The last apostasy, between April 1905 and December 1907, embraced all fourteen bishoprics in the Volga-Ural region and Western Siberia. After that date, cases of apostasy affected mainly starokreshchenye villages in the Mamadysh area in Kazan province, animist Chuvash and Finno-Ugric peoples in Ufa and Samara provinces, and Nagaibak Cossack families, who were moved in 1842 from Belebei district to Orenburg district to guard the farther eastern frontier. In their new settlements, Nagaibaks shared living with other Mishar Cossacks of the Muslim faith, and embraced Islam. ${ }^{64}$

63. The construction of a church prompted baptized Chuvash of Byzlyk Vasil'evka to apostatize in 1891 in Belebei district. An Islamized Chuvash woman spread the word that after the building of the church it would rain for forty days as in Noah's story and to make sure that the church did not sink into the earth, Christians would sacrifice a newborn or a virgin under its foundation, NART, f. 93, op. 1, d. 128 v, 1.36 ob.; on cholera epidemics, see Privolzhskie goroda i seleniia v Kazanskoi gubernii (Kazan, 1892), 132-133; on bad harvests, see Il'dus Zagidullin, "Tatarskie krest'iane Kazanskoi gubernii vo vtoroi polovine XIX v. (60-90-e gg.)" (Kand. Diss., Kazan State University, 1992), 67.

64. RGIA, f. 821, op. 8, d. 763, 1. 119; Il'minskii, Opyty perelozheniia, 36, 64; Mozharovskii, "Izlozhenie," 116; Evfimii Malov, "Pravoslavnaia protivomusul'manskaia missiia v Kazanskom krae v sviazi s istorieiu musul'manstva v pervoi polovine XIX veka”, PS, no. 8 (1868): 338; Porfirii Men'shikov, "Achinskii prikhod, Laishevskogo uezda, v nastoiashchem sostave,"IKE no. 16 (15 August 1868): 442; B. Znamenskii, "Zapiska N. I. Il'minskogo po voprosu ob otpadeniiakh kreshchenykh tatar Kazanskoi gubernii 1881 goda," PS (1895): 259; Sofiia Chicherina, U privolzhskikh inorodtsev. Putevye zametki (SPb., 1905), 132-134; I. Zlatoverkhovnikov, Ufimskaia eparkhiia. Geograficheskii, etnograficheskii, administrativno-statisticheskii ocherk (Ufa, 1899), 209-211; “Otpadeniia iz pravoslaviia v magometanstvo i ikh prichiny”, PB 16, no. 16, bk. 2 (August 1908): 314; Antonii Ivanov, "Otstupnicheskoe dvizhenie kreshchenykh i nekreshchenykh Chuvash Samarskoi gubernii v magometanstvo. Derevnia Alekseevka, Bugul'minskogo uezda," PB 22, no. 1 (1914): 160; Iskhakov, "Etnodemograficheskoe razvitie," 10, 13-16. 
TABLE 1.2 Number of Apostates in Kazan Province

\begin{tabular}{lcrr}
\hline District & Kräshens (1862) & Apostates (1862) & Muslim Tatars (1858) \\
\hline Cheboksary & 427 & 3,152 & 55,940 \\
Chistopol' & 3,996 & 16 & 89,567 \\
Kazan & 2,561 & 9 & 21 \\
Kozmodem'iansk & & 623 & 42,634 \\
Laishevo & 12,353 & 2,267 & 80,563 \\
Mamadysh & 15,304 & 260 & 36,162 \\
Spassk & 562 & & 22,426 \\
Sviiazhsk & 5,302 & 42 & 52,968 \\
Tetiushi & 3,782 & & 20,474 \\
Tsarevokokshaisk & & 897 & 6,673 \\
Tsivil'sk & 1,090 & 7,266 & 409,257 \\
Total & 45,377 & & \\
\hline
\end{tabular}

Source: Compiled from Malov, "Statisticheskie svedeniia o kreshchenykh tatarakh v Kazanskoi i nekotorykh drugikh eparkhii, v Volzhskom basseine," Missionerstvo sredi mukhammedan i kreshchenykh tatar (Kazan, 1892), 400, 405-406.

Despite many lacunae in the Kazan Ecclesiastical Consistory records and parish registers, the missionary Malov calculated that in 1862 in Kazan province there were 7,266 apostates from Orthodoxy and 45,377 other Kräshens who had officially remained Christian. According to the calculations of students at the Kazan Native Teachers' Seminary, in 1898 there were 32,000 apostates and 42,000 Kräshens: 90 percent of Tatars were Muslim, 4 percent apostates, and 6 percent Kräshens. In 1901, the governor's statistics showed 31,737 apostates and 43,570 Kräshens, and just before 1905, the same source showed 34,092 apostates and 47,044 Kräshens. Finally, between 1905 and 1907, missionary sources registered a slight increase to 36, 299 apostates, and in 1910, the Ministry of Interior counted even more-38,999 apostates. $^{65}$

Obviously, the population growth among the baptized population did not explain the increased number of apostates. Islam had made new converts. Those statistics also show that after 1905, more than half of the Kräshens in the Kazan province had remained Christian. Such success of Orthodoxy suggests that Kräshens actually debated the formulation of their communal identity, whether Muslim or Orthodox, and ultimately made a conscientious choice between the two faiths. ${ }^{66}$

65. Nikolai Bobrovnikov, Nuzhny li tak nazyvaemye protivomusul'manskie $i$ protivoiazycheskie eparkhial'nye missionery v guberniiakh evropeiskoi eparkhii? (Kazan, 1905), 7-8; N. Kugleev, "Missionerskaia ekskursiia v kreshcheno-tatarskie seleniia Elabuzhskogo uezda," Viatskie eparkhial'nye vedomosti, no. 49 (8 December 1911): 1040; RGIA, f. 821, op. 133, d. 472, 1. 47 ob.; NART, f. 93, op. 1, d. 618, 11. 3-6, 57; Il'dus Zagidullin, Perepis' 1897 goda i tatary Kazanskoi gubernii (Kazan, 2000), 40.

66. For more statistics including Kazan, Ufa, Simbirsk, Penza, Orenburg, Viatka, Samara, Saratov, Tambov, Astrakhan, Riazan, and Nizhnii Novgorod provinces, see Damir Iskhakov, Istoricheskaia demografiia tatarskogo naroda (XVIII-nachalo XX vv.) (Kazan, 1993), 94-99. 
TABLE 1.3 Number of Apostates in Kazan Province in 1901

\begin{tabular}{lccc}
\hline District & Kräshens & Apostates & Muslim Tatars \\
\hline Cheboksary & & 800 & 3,040 \\
Chistopol' & 5,565 & 8,200 & 91,193 \\
Kazan & 1,521 & 1,541 & 151,576 \\
Laishevo & 12,957 & 1,746 & 63,027 \\
Mamadysh & 22,125 & 3,515 & 115,050 \\
Spassk & 1,397 & 514 & 55,647 \\
Sviiazhsk & 5 & 6,743 & 37,462 \\
Tetiushi & & 6,531 & 94,237 \\
Tsarevokokshaisk & & 195 & 29,472 \\
Tsivil'sk & 43,570 & 1,952 & 12,950 \\
Total & & 31,737 & 653,654 \\
\hline
\end{tabular}

Source: Pamiatnaia knizhka Kazanskoi gubernii na 1901 g. (Kazan, 1901), 18-23.

\section{Islamic Communities in Formation: Pattern and Main Characteristics}

In 1801 Czar Alexander I (r. 1801-1825) reinstituted the practice of accepting collective petitions. By doing so, he not only opened the doors of upward communication between the ruled and their ruler, but he unintentionally facilitated the work of Islamized Kräshens who sought to bring their whole community closer to Islam, forcing individual clans to assert their religious identity more exclusively, at least in legal terms. Signing the petition did not actually mark the time when baptized Tatars converted to Islam, which would imply a sudden change of heart as in Evangelical Christianity. Nevertheless, it signaled the moment when, as a group, villagers announced publicly their assimilation into the community of the Prophet or their willingness to participate more fully in the religious community of Islam. As in many other religious transformations, "participation" or "adhesion" are better words than conversion because they denote a more gradual process of acculturation involving communities rather than individuals. Tatars said of Kräshen communities leaning toward Islam that they "were becoming white" (agharïp kilälär), referring to the purifying effect of Islamic ablutions and denoting a process of assimilation into the culture of Islam, not a simple automatic return to the faith of their forefathers. But the word "conversion" is worth retaining here since apostates took the fundamental step to switch collectively and spectacularly from one "legal" category of faith to the other. After all, many could have simply opted for religious intermediateness and continued living as Muslims underground without going through the trouble of apostatizing officially. ${ }^{67}$ Tellingly,

67. NART, f. 10, op. 2, d. 1383, 1. 250; Arthur Nock, Conversion: The Old and the New in Religion from Alexander the Great to Augustine of Hippo (Oxford, [1933] 1961), 7; Michael Lambek, "Localizing Islamic Performances in Mayotte," in Islamic Prayer Across the Indian Ocean: Inside and Outside the Mosque, ed. David Parkin and Stephen C. Headley (Richmond, Surrey, 2000), 65-70; Maurus Reinkowski, "Hidden Believers, Hidden Apostates: The Phenomenon of Crypto-Jews and Crypto-Christians in the Middle East," in Converting Cultures: Religion, Ideology and Transformations of Modernity, ed. Dennis Washburn and A. Kevin Reinhart (Boston, 2007), 409-433. 
Kräshens who remained Christian called apostates tatargha chïqqan keshelär ("people who left to be with the Tatars"), implying that they had stepped outside their communal boundaries and, in their view, had become "other." In other words, apostates had left a community defined by its baptism for another. ${ }^{68}$

Culture as a producer of symbols, myths, and rituals played an important role in the shaping of the baptized Tatars' group identities and imagination. Yet, before investigating further the sources and conduits of Islamic knowledge based on Turkic literary texts, spiritual songs, and missionary encounters, the study of the outward development of the apostasy movement-its inception, climax, and repression-as attested in provincial, clerical, and missionary reports helps to uncover the centrality of literacy in the Islamic expansion. Usually, apostate leaders, who sought to gain the support of all family clans, were the most exposed to Islamic and, to some extent, Russian literacy. Their skills allowed the movement to grow rapidly in size and ultimately transformed the religious landscape of the Middle Volga. But apostasy leaders met many obstacles inside and outside their village commune, since not all baptized Tatars were willing to give up their legal status and join Islam officially. Violence and fear, although present, were not the only factors that explained the refusal of some communities to sign the petition. Islamic literacy had not penetrated all Kräshen communities, indigenous beliefs still played an important role in the maintenance of communal boundaries, and later in the 1870s, Orthodox literacy in vernacular languages presented a new challenge to the further expansion of Islam. However, each apostasy brought new hearts to Islam.

At first glance, apostasies presented striking similarities with Russian peasant riots. Like former serfs and religious dissenters, the apostates did not attempt to rebel against the prevailing czarist order. In fact, they turned to the tsar'-batiushka (little father) as their supreme arbiter and ally. Like the Old Believers (Orthodox Christians who rejected the liturgical reforms introduced by Patriarch Nikon [1652-1658]) in Cheliabinsk district in 1866, they referred to a pseudo-ukaz permitting them to profess their religion officially. ${ }^{69}$ At times the apostates' cause even merged with that of the Old Believers. In 1865, the parishes of Bishevo and Isheevsk, Simbirsk province, which had a high number of religious dissenters, were rife with rumors that the czar had allowed both Kräshens and Old Believers to declare their true faith. ${ }^{70}$ Russian contemporary police reports and missionary diaries also hint at the direct or indirect participation of important Naqshbandi Sufi figures and disciples in the Chistopol', Sviiazhsk, and Mamadysh districts, as well as the use of two important Islamic religious concepts as decisive impetuses for the mobilization of those who wanted their Muslim identity recognized by the Russian state: the jihad and Mahdism.

Although the early history of Sufism in Eurasia is incomplete, it is well established that two orders played a central role in the Islamization of Volga Tatars: the Yasawiyya and the Naqshbandiyya, both known for their flexibility toward local customs

68. Letter in Tatar of a Kräshen teacher, Andrei Vasil'evich (13 November 1872), NART, f. 968, op. 1, d. 175 , ll. 1-1 ob.

69. Gosudarstvennyi arkhiv Orenburgskoi oblasti (hereafter GAOO), f. 55, op. 3, d. 4/1, 11. 38 ob.-40; Daniel Field, Rebels in the Name of the Tsar (Boston, 1989), 1-26.

70. NART, f. 4 , op. 97 , d. 1, 1. 87 ob. 
and their use of vernacular languages to make converts. At the end of the eighteenth century and beginning of the nineteenth century, the Naqshbandiyya-which came to eclipse the Yasawiyya-took firmer root in the Kazan province thanks to the disciples of two major shaykhs, Niyaz Quli b. Shah Niyaz at-Turkmani (d. 1821), located in Bukhara, and Fayd Khan al-Kabuli (d. 1802), who taught in Kabul. ${ }^{71}$ While their disciples brought Tatars to a stricter, more observant form of Islam, the Naqshbandiyya also defied Russian law and proselytized in non-Russian and baptized communities. By calling for jihad and using Mahdist elements in their discourse, they invited the Muslim Tatar community to revitalize their faith, the baptized community "to recommit themselves to the religion of their ancestors," and the non-Muslims of Turkic and Finno-Ugric origin to adhere to Islam.

Jihad signifies a continuous struggle on the path of God. It comes from an Arabic verb jahada, which means "to strive." On a personal level, it may be a peaceful, continuous spiritual striving toward moral perfection. At the collective level, it may be an armed or peaceful struggle-either offensive or defensive-for the spread of Islamic virtues inside and outside Muslim society. ${ }^{72}$ Alternatively, Mahdism, an apocalyptic myth, called for action in the immediate future to restore justice before the end of time. According to Islamic traditions, the Mahdi or the "guided one" would unite all forces to fix the problems of this world according to Islamic law. The Mahdi is supposed to appear during a period of anarchy when men and women have turned away from their faith. Thanks to the Mahdi, the pure original Islamic faith will be reestablished before the coming of the imposter Messiah (al-Masih ad-Dajjal), called by Sufis "the final deceiver," and his defeat by "Isa (Jesus), who then will follow the Mahdi and acknowledge Muhammad's authority. In times of alien domination or social and political injustice, Muslims often turn to the hope of a Mahdi. During Bonaparte's occupation of Egypt (1798-1801), a Mahdi movement arose against the French, and in the nineteenth-century Sudan, the Mahdi Muhammad Ahmad (1845-1885) rose against General Charles Gordon $\left(1833^{-1885}\right)$ and the Turks. ${ }^{73}$

Before the Crimean War, again in $1865-1867,1884$, and around 1905, vagabond Tatars, mullahs, Sufis, and indigenous elders inclined to apostatize began to preach in a very specific, Mahdist apocalyptic form. Because in Muslim apocalyptic literature the signs of the final hour could include the replacement of Islam by Christianity, the Kräshens' mere existence in the land of the former Bolghar and Kazan kingdoms constituted a thorn in the heart of Islam and signaled the imminence of the final hour when people would turn away from the true faith. Itinerant Sufis reminded believers of their obligation to realize the will of God on earth, the jihad, and announced that time would end with the final victory of Islam. If all Kräshens adopted Islam, Muslims would outnumber Russians. Recalling the hijra of the Prophet (when opposition

71. Frank, Muslim Religious Institutions, 151-153.

72. Nazif Shahrani and Robert Canfield, eds., Revolutions and Rebellions in Afghanistan: Anthropological Perspectives (Berkeley, 1984), 28.

73. The Qur'an says nothing about the Mahdi. The Mahdi apocalyptic myth is developed in the hadith literature in Abu Da'ud (d. 888), Ibn Majah (d. 887), and Abu 'Isa at-Tirmidhi (d. 892). Timothy Furnish, Holiest Wars: Islamic Mahdis, Their Jihads, and Osama bin Laden (Westport, Conn., 2005), 7, 13. For Sudan, see P.M. Holt, The Mahdist State in the Sudan, 1881-1898 (A Study of Its Origins, Development and Overthrow) (Oxford, 1958), 22-23. 
to his message forced Muhammad to flee from Mecca to Medina), itinerant Sufis encouraged their listeners to go to Turkey or Bukhara and await the Day of Judgment. They spoke in passionate terms of the coming of the Mahdi. The Ottoman sultan, according to them, would take possession of the Muslim lands and restore the Khanate of Kazan before the coming of the imposter Messiah and his defeat by the Prophet 'Isa. Islamic traditions foretold that Jesus would punish Christians who deified Him, smash crosses, and kill their pigs. Not only did this type of discourse in the 1860 s fuel the apostasies, but it also encouraged Islamized Chuvash to migrate to Turkey, which they did in the Saratov province, along with Kräshens, mostly novokreshchenye from Tetiushi, Sviiazhsk, Spassk, and Chistopol' districts who sold their houses and cattle. Crimean and Kazan Tatars also joined them in their migration to the Ottoman Empire. $^{74}$

In Sunni Islam, the Mahdi was not rigorously defined, which led to a large variety of popular interpretations. ${ }^{75}$ Although already born, he could not be identified because of the believers' sinfulness and lack of unity. Only after all believers united, would he reveal himself, pass judgment on the purity of their faith, and crush the infidels. Concretely for the apostates, it meant that the Mahdi would appear only if all peasants inside and outside their village boundaries had joined the "apostasy." Some Kräshens leaning toward Islam were more specific and identified the Ottoman sultan, the head of the world Islamic community, as the Mahdi. The sultan would restore right governance in the immediate future, and the Kräshen apostates would be able to live like Muslims openly, without fear. But in 1905, the sultan of Turkey was not at war with Russia. The Tatars then spread new rumors, this time among Islamized and nonbaptized Chuvash of Buguruslan district, and gave the Ottoman leader a new substitute-the "Japanese czar," who had agreed to free Tatars from the threat of "baptism."76

Unlike the Mahdist movement in Sudan, the apostate movements did not end with the organization of a theocratic kingdom and the emergence of a territorial state. However, once the petition was sent but before the troops arrived, apostates formed an extraterritorial distinct community aware of its specific identity. Thus, after the arrival of those itinerant Sufi preachers, they spread rumors of an imperial edict that would permit them to profess Islam officially. These rumors might have had an actual basis in a new czar's routine confirmation of his subjects' religious rights (which, of

74. M. Laptev, Materialy dlia geografii i statistiki Rossii, sobrannye ofitserami general'nogo shtaba: Kazanskaia guberniia (SPb., 1861), 232; Ivanov, “Otstupnicheskoe dvizhenie . . Derevnia Alekseevka," 151; Nikolai Ostroumov, Sudanskii Makhdi i voznikshee v 1881 godu vosstanie sudanskikh musul'man (Offprint from Strannik, 1890) (SPb., 1889), 3; S. Bagin, "Ob otpadenii v magometanstvo kreshchenykh inorodtsev Kazanskoi eparkhii i o prichine etogo pechal'nogo iavleniia," PS 46, no. 2 (February 1910): 227; G. Komissarov, "Religioznoe sostoianie chuvash v XIX veke," $P B$ 2, bk. 1, no. 21 (November 1913): 620-621; NART, f. 1, op. 3, d. 3048, 11. 31-31 ob.; and f. 1, op. 2, d. 2111, ll. 11 and 27-27 ob.; on Jesus's role in the Mahdi apocalyptic myth, see Furnish, Holiest Wars, 18.

75. R. Hrair Dekmejian, "Charismatic Leadership in Messianic and Revolutionary Movements: The Mahdi (Muhammad Ahmad) and the Messiah (Shabbatai Sevi)," in Religious Resurgence: Contemporary Cases in Islam, Christianity, and Judaism, ed. Richard Antoun and Mary Elaine Hegland (Syracuse, NY, 1987), 98; Jan-Olaf Blichfeldt, Early Mahdism (Politics and Religion in the Formative Period of Islam) (Leiden, 1985), 10.

76. Eruslanov, "Magometanskaia propaganda," no. 16 (1895): 387-388; A. Ivanov, “Tsarstvo islama sredi chuvash," $P B$ 15, no. 19 (October 1907): 110. 
course, would not have included the right of Christians to convert to Islam) or in new laws permitting Muslims to open new mosques. Although such laws did not apply to them, the apostates interpreted them in their favor and opened their own clandestine prayer houses. The ukaz of 20 February 1764, which forbade forced conversions to Orthodoxy, served as the basic foundation of these rumors. The Kräshen apostates were only pointing out the state's inconsistencies in its policy toward the indigenous population. ${ }^{77}$

The news of the edict was then discussed in the local Orthodox parishes. First, the communes met to check the news, sometimes openly and sometimes in secret at night. Villagers elected and sent envoys to nearby villages, usually close relatives since Kräshen villages practiced exogamy. Occasionally they turned to a mullah whom they trusted for more information. ${ }^{78}$ Upon the envoys' return, the commune met again to decide, depending on its degree of attachment to Islam, whether to join other villages in an open apostasy from Orthodox Christianity. Those most convinced chose a representative who could write the villagers' Muslim names on a piece of paper and/or "read" the villagers' clan symbols (tamghas). Villagers who could not sign their names inscribed their tamgha on a stick, after which the representative brought the list of names, the signatures, and the stick to scribes who wrote the petition in Russian and in Tatar. ${ }^{79}$ In the latter, they asked not for their return to Islam, but for the recognition of their Islamic identity inherited from their ancestors, even if their ancestors were of animistic Chuvash origin. The petition went on to claim that in order to increase their emoluments, Russian priests had enlisted them as Orthodox Christians. They then sent the petition to St. Petersburg, told the parish priest of their desire to live as Muslims, and in the interval, before the answer arrived from the czar, they ceremoniously opened their mosque and Qur'anic school. At the same time, they destroyed all signs that they belonged to Orthodoxy, stopped going to church, and refused to pay parish taxes or let the priest enter their homes with his icons. They got rid of their belts, cut their long hair, shaved their beards, donned Muslim skullcaps (the käläpüsh or tübätäy), discarded their icons, and burned books printed in Cyrillic characters. ${ }^{80}$

During the Kräshen apostasies of the 1860s, the spiritual jihad mobilized entire villages. Believers put the Muslim religious law into practice and experienced it collectively for the first time. If the month of Ramadan started after they apostatized, the villagers fasted together. In Elyshevo, people still remember that neighbors made sure to wake up at the same time before dawn to eat breakfast (säkhär ashï). The night before, women, who were in charge of the meal, pulled a string across the street and attached a small rattle at the windows, which awakened neighboring families. ${ }^{81}$

77. PSZ 16, no. 12126: 704-707; Mozharovskii, "Izlozhenie," 125-126; Malov, "Pravoslavnaia protivomusul'manskaia," 16, no. 5 (May 1870): 234; Runovskii, “Ocherk istorii khristianskogo prosveshcheniia," no. 11 (1 June 1911): 385 .

78. NART, f. 1 , op. 3 , d. 3272 , 1. 3; f. 13, op. 1, d. 1003, 1l. 9-9 ob.

79. The tamghas had jurisdictional value among all peoples of Russia. They indicated kinship and served to mark property (land, cattle). They took various geometric shapes. E. T. Solov'ev, Znaki sobstvennosti $v$ Rossii: Istoriko-arkheologicheskii ocherk s prilozheniem 6720 znakov (Kazan, 1885), 125, 149, 194; NART, f. 13, op. 1, d. 1010, 1. 3; f. 13, op. 1, d. 943, 1. 8.

8o. Malov, “Ocherk," 17, pt. 3 (1871): 245, 252, 410; 18, pt. 1 (1872): 134; and pt. 2 (1872): 41; NART, f. 13, op. 1, d. 1003, 1. 9 ob.; f. 4, op. 101, d. 11, 1. 114 ob.; f. 13, op. 1, d. 938, 1l. 13-16.

81. Tälghat Näjmiev and Mäghsum Khujin, Yashä, Saba-Yort (Kazan, 1999), 171. 
Elders collected both religiously prescribed and voluntary alms (zakat and sadaqa). In August 1865, the Chuvash and novokreshchenye of Verkhniaia Nikitkina erected their own prayer house (without a minaret) with their own donations; those who could not give alms volunteered their work. When there was no mosque, village elders instituted collective prayer five times a day, sometimes outside in the prairies as in Kibiak-Kozi, Laishevo district, or inside the most spacious houses. ${ }^{82}$ They also forbade fermented drink, created a separate cemetery for the Muslim dead, and buried their dead the Muslim way-that is, in a kafn (a white sheet in which the dead were wrapped) and not in a coffin. In one memorable event in June 1866, four starokreshchenye villages-Shepsheik, Nurma, Sulabash, and Bitoman in Kazan district-joined together to oppose the transfer of the body of a common kin, Akulina Pavlova, which laid in a ditch and was already giving off an unpleasant smell, to the Christian cemetery of Alaty. "We would prefer to die near the body than let you take the deceased away," cried the villagers to the police. After a successful fistfight, they buried the body near the village of Shepsheik in a secret place and had their own representative recite the appropriate prayers. ${ }^{83}$

Apostates also elected a muezzin to call for prayer and an imam to lead communal worship, keep their vital records, arbitrate disputes about inheritance, and teach their children. In some cases several literate apostates took turns as imams. Villagers also dared to attend the nearby Tatar mosque on Fridays. ${ }^{84}$ Since apostates in starokreshchenye villages were often not circumcised, adults and children submitted themselves to circumcision, inviting a Tatar circumciser called baba from outside. (In the novokreshchenye baptized villages of Verkhniaia Nikitkina and Verkhniaia Kamenka in Chistopol' district many villagers had already been circumcised in the 1840 os by elderly women.) $)^{85}$ Thus, around 1865 , a baba came to the starokreshchenyi village of Kibiak-Kozi, Laishevo district, from Staraia Ura village in Tsarevokshaisk district. In 1872, a Tatar from Masra village, Kazan district, a village known for its ritual hereditary specialists in circumcision, stayed two weeks in Ianasal, Laishevo district, and performed his work, not without casualties: the unofficial muezzin died from the surgery and another adult almost perished. Both Masra and Ianasal were situated on the Arsk road, an important trade route, sensitive to Mahdist rhetoric. ${ }^{86}$

At the same time that apostates built a new society in conformity with the tenets of Islam, they also sought to convince waverers to convert "officially" to Islam, sometimes forcibly. If the village did not present a united front, as in the case of Otary parish in 1866 where covillagers denounced the leaders of the apostasy to the police, there was a strong chance that the apostasy would fail. ${ }^{87}$ The coexistence of two faiths

82. NART, f. 1 , op. 3 , d. 231 , 1l. 148,215 ob; f. 13 , op. 1, d. 943 , 1. 371 ; f. 2 , op. 2, d. 5136, 1l. 6 ob. -7.

83. NART, f. 13 , op. 1 , d. $938,11.48-67$.

84. NART, f. 1 , op. 3 , d. $3272,1.12$.

85 . When questioned by police, apostates made the point to say that they were not circumcised. NART, f. 13, op. 1, d. 938, 1l. 71, 102. On Verkhniaia Kamenka, NART, f. 2, op. 1, d. 1998, 1. 6 ob.

86. RGIA, f. 821 , op. 8 , d. 763 , 1l. 218 ob., 288 ob.; and NART, f. 1, op. 3 , d. 2812 , 1l. 78,85 ; f. 13, op. 1 , d. 943 , 1. 376 ; f. 1, op. 3 , d. 3272 , 1. 7 ob.; f. 1, op. 3, d. 227, 1l. 89-89 ob.; and f. 1, op. 3, d. 3068, 1. 24; on Masra village, see Qayyum Nasïyri, Saylanma äsärlär, vol. 3 (Kazan, 2005), 243.

87. Compare Otary parish (NART, f. 13, op. 1, d. 1010, 1l. 3-14 ob.) and Azbaba (NART, f. 13, op. 1, d. 1119, 1. 26), where villagers remained united and supported their representatives even after they were arrested. As a result the leaders of Azbaba could not be prosecuted. 
in the village also implied a division of resources between the maintenance of both church and mosque. Some also worried that they would not be properly buried if they belonged to the minority religion in the village. For all those reasons, declared Muslims put a lot of pressure on other members of the community, either economically, by controlling the minority's mode of subsistence, or symbolically, by marking the space between believers and infidels. ${ }^{88}$

Thus, at the start of the apostasy movement, symbolic markers-a stream, a road, a bridge, or the opening of a new cemetery-divided the village space into two different worlds: the clean and the unclean. In Ianasal village, Laishevo district, apostate women threw stones at nonapostate women who sought to have access to the stream. "Do not make our water unclean," they yelled in an attempt to sacralize part of the village space. ${ }^{89}$ Water indeed plays an important purifying role in Muslim rituals. Converts to Islam must perform the ghusl, the greater ablution, in which the whole body is washed to remove impurity. Tatars, as well as Islamized Kräshens and Chuvash, believed that Christians-and Russians in particular-were dirty because they did not perform ritual ablutions before entering a sacred space or praying. Kräshens and their Tatar neighbors called Islamized Kräshens aq (white) and Kräshens who adopted the Russian ways qara (black). Aq also referred to the customs of removing one's shoes before entering the sacred space of the mosque, and the habit of cutting hair very short (Russians and Kräshens grew their hair long). Late nineteenth-century Tatar reformers contested this habit of shaving one's head as a sign of differentiation between Muslim believers and infidels. For the reformist theologian Riza' ad-Din b. Fäkhr ad-Din (1858-1936) the length of hair had nothing to do with religion, but for apostate Kräshens its length was of ultimate importance..$^{90}$

With the same desire to clean themselves from bodily impurities, the apostates of Elyshevo village in 1866 shaved their head on the bridge, a reminder of Judgment Day when all men and women would have to cross the Sirat bridge over hell. ${ }^{91}$ After the building of a church and the opening of a Christian school in 1869, a woman stood on the same bridge that led to the church and warned that this bridge led to hell. Later on, the children of apostates jealously guarded their street that Kräshens of Saltygan Kliuch (Köyek) had to take to reach the church: "Do not tread on our street. We are Tatars now." After their official conversion to Islam, apostates considered nonbelievers as pollutants and sought to remove them from the village just as they removed impurities from their body before engaging in daily prayers. ${ }^{92}$

Besides symbolic intimidation, Muslim converts also used economic pressure against the Christian minority. In Elyshevo, Kondratii Filippov (d. 1873?), a noncommissioned officer, opposed the apostasy of 1865 . After twenty-five years of military

88. NART, f. 1, op. 3, d. 3272, 1. 40; f. 1, op. 3, d. 9740, 1l. 1-15 ob. (In Ianasal, Laishevo district, frictions existed between apostates and Kräshens. In 1895, apostates continued paying for the priest and Eastern Orthodox teacher's expenses because of the persistent presence of Kräshens, who were also their relatives.)

89. NART, f. 1, op. 3, d. 3272 , 11. 7 ob.-8, 32.

90. "Kakim sposobom tatary uvlekaiut chuvash iazychnikov v mukhammedanstvo," IKE 11, no. 8 (15 April 1877): 231; Sofiiskii, “O kiremetiakh kreshchenykh tatar Kazanskogo kraia," 687; Riżäa ad-Dīn b. Fäkhr ad-Dīn, Jäwāmi‘ al-kälim shärhe (Orenburg, 1917), 368-370 (hadith no. 229).

91. NART, f. 1, op. 3, d. 3272, 1. 24; Malov, “Ocherk," 17, pt. 3 (1871): 246-247.

92. Saltygan Kliuch is also spelled Satlygan Kliuch in archival and missionary accounts. NART, f. 1, op. 3, d. 3272 , ll. 7 ob. -8 ob., 32; f. 1, op. 3, d. 3697 , 1l. 5 ob., 9. 
service, Filippov had become an outsider, and at the time of the apostasy, the elders and his own son kept him from participating in the affairs of the commune or in the games and dances of the spring feast. ${ }^{93}$ In the case of Semen Stepanov, a Kräshen of Tatarskie Azeli in Sviiazhsk district, who refused to apostatize, the apostates went even further and asked the volost' bureau to transfer his family to another village. ${ }^{94}$ Both men constituted a threat to their villages' homogeneity. They were living proofs that apostates of both villages had baptized ancestry. (Officially, Kräshen apostates presented themselves as Muslims, falsely mistaken for baptized Tatars.) But more important, they could report on the apostates' activities to the governor's police in case of an inquiry. Furthermore, Filippov epitomized the czar's power, and Stepanov's literacy in Russian challenged the authority of other representatives who offered their own interpretation of Russian law. Finally, apostates were aware that if the whole village united, Russian authorities would be unable to deport them collectively. ${ }^{95}$

Even after the Cossacks arrived and crushed any chance the apostates had of ever becoming officially Muslim, the need to form a homogeneous Islamic society and the desire to experience Islam collectively did not die. Within the village borders and beyond, convinced apostates sought to win the support of those who had feared to declare their apostasy officially, or had shown more attachment to their clan tutelary spirits. The religious landscape of a community was in constant flux, depending on the interests of the commune and the pressure of kinship networks inside and outside the village unit. It could take decades to evolve. The novokreshchenye of the village of Tavliar in Mamadysh district declared their apostasy in 1869, after experiencing pressure first from their Tatar Muslim fellow villagers, who threatened to take their land and expel them from the commune and, later, from apostate relatives living in other villages who had declared their Islamic identity earlier in 1866 . When in 1892 two families decided to return to Orthodoxy, the village assembly refused to allocate them land. A similar incident occurred at about the same time in the parish of Shemorbashi, also in Mamadysh district. ${ }^{96}$

Conversely, other starokreshchenye communes guarded themselves from any Islamic influence. In 1875, two rich apostates from Nikiforova, petitioned to be transferred to a Tatar Muslim village to profess Islam freely. ${ }^{97}$ In other cases, Kräshens who remained Christian wished to found separate villages or separate communes. Thus Tatar-speaking baptized Chuvash and Kräshens of the village of Baimurzino, Tetiushi district, who constituted the majority in 1884, asked for the creation of two communes-one Christian and the other Muslim-claiming that life had become intolerable. Local Russian authorities, despite episcopal pressure, refused to grant the Kräshens' request under the pretext that keeping up two communes would be too costly for them. ${ }^{98}$ More drastically, the commune of Tiamti, Mamadysh district, now

93. Malov, “Ocherk," 17 , pt. 3 (1871): 414 and 18, pt. 2 (1872): 69, 77; NART, f. 1, op. 3, d. 231, 1. 137 ob. 94. NART, f. 1, op. 3, d. $227,11.82$ ob. -83 ob.

95. NART, f. 1 , op. 3 , d. $228,1.87$.

96. NART, f. 4, op. 101, d. 23, 1l. 12-12 ob.; Istoriko-statisticheskoe opisanie tserkvei i prikhodov Kazanskoi eparkhii, vol. 6, G. Mamadysh i Mamadyshskii uezd (Kazan, 1904), 383, 385-386.

97. NART, f. 1, op. 3, d. 3697, 1. 2; Istoriko-statisticheskoe opisanie tserkvei i prikhodov Kazanskoi eparkhii, 161.

98. NART, f. 1 , op. 3 , d. 6810 , 1l. $1-4$. 
in the hands of Kräshens faithful to Christianity, petitioned to keep two deported apostate families from returning to their village in $1908 .^{99}$

In general, if two-thirds of the village households had chosen Islam, the last third had no other choice but to follow their neighbors. Likewise, especially after the introduction of Il'minskii's schools in the 1870s, Kräshen villages that remained predominantly Christian discriminated against would-be Muslims in their midst. In apostate villages, village councils threatened to increase the taxes, and to expropriate and redistribute the land of those who did not want to sign the petition. They denounced recalcitrants as troublemakers to the volost' authorities, who often happened to be Muslim Tatars, and frightened elderly opponents by saying that they would not bury them in the event of their death. ${ }^{100}$

Officially, the apostasy upheaval ended with the intervention of the police and the arrival of priests and missionaries. Apostates though were not easily intimidated. In 1866, they refused to accept the police verdict and when asked did not give their Christian names. Many stubbornly kept their Muslim skullcaps on and listened distractively. Despite their mute resistance, the leaders of the Kibiak-Kozi movement in Laishevo district were imprisoned, exiled to Siberia, and/or subjected to corporal punishment. In Elyshevo, men were submitted to the whip and women to the withe (willows still grow on the riverbank.) In 1868, eleven apostates from Simbirsk province and forty-seven from Kazan province were sent to Siberia. Even after their arrest, apostate leaders of Laishevo district continued to pray five times a day in their cells. ${ }^{101}$

Until the 1850 s, whole families could be deported to all-Russian villages. Unmarried cohabiting couples (usually two baptized Tatars or, more rarely, a baptized woman and a Tatar man) were systematically separated. The women and children were sent back to their native village, but sometimes their children were placed with Russian families. ${ }^{102}$ These separations had tragic consequences. In March 1855, sixteen children in Sluzhilaia Maina, Chistopol' district, were taken away. When two teenagers returned to the village and a mother tried to retrieve her two small children at their foster home, the police intervened immediately. Parents and relatives barricaded a house with the children inside, and armed themselves with spears and pitchforks, but in vain. The police chief forced the parents to sign a paper that stipulated that they would not take their children back unless they remained Orthodox. ${ }^{103}$

In 1866, soldiers sought to erase all visual signs of Islam. In Saltyganovo, Sviiazhsk district, they collected and destroyed all skullcaps and in Verkhniaia Nikitkina, the vice governor of Kazan, Emel'ian Rozov, sealed the prayer house, despite the cries

99. NART, f. 4, op. 1, d. 123760 , 1l. 1-3.

10o. NART, f. 1 , op. 3 , d. 2563 , ll. 13 ob. -14 ; f. 4, op. 101 , d. 23 , 1l. $12-12$ ob.; f. 1, op. 3 , d. 3272 , 1. 40 ; f. 1, op. 3, d. 228, 1. 42; and f. 13, op. 1, d. 1003, 1. 27 ob.; petition of a Kräshen opposed to the apostasy in Tatarskie Azeli, Sviiazhsk district, in NART, f. 1, op. 3, d. 227, 1l. 82 ob.-85.

101. NART, f. 13, op. 1, d. 938, l. 11; f. 13, op. 1, d. 945, 1l. 46-46 ob., 71; f. 1, op. 3, d. 227, 11. 62-63; f. 1, op. 3, d. 227, 1. 79; Näjmiev and Khujin, Yashä, Saba-Yort, 171; RGIA, f. 821, op. 8, d. 763, 11. 89-90; Rizaeddin Fäkhreddinev, Bolghar wä Qazan Törekläre, 54.

102. In general Russian families were reluctant to foster children who had not been raised in the Orthodox faith and feared their parents' retaliation. NART, f. 4, op. 84, d. 45, 1l. 187-188 ob.

103. NART, f. 1, op. 2, d. 943, ll. 10-11, 17 ob.; f. 1, op. 2, d. 944, ll. 15-15 ob.; f. 1, op. 2, d. $1119,11$. 14-15; f. 1, op. 3, d. 12201, l. 6 ob. 
and supplications of the villagers who knelt down before him. ${ }^{104}$ Rozov argued that even Muslims had to petition for a permit to build a mosque. But to his amazement, apostates continued arguing on legal ground that their building was not a mosque, but a prayer house without a minaret, which, according to law, did not require special permission. After Rozov's departure, village lore recalled, they broke the seals and performed their prayers. A year later, the judge ordered the village to pay a fine of 150 rubles for opening the mosque illegally. ${ }^{105}$ As for the mullahs living in neighboring villages, they were required to give written promises that they would not let Kräshens attend their mosques nor teach Kräshen children. Apostates were forbidden to leave the village. ${ }^{106}$ Finally, clerics arrived with new crosses and icons. They baptized children, preached to the adults, and organized a ceremony of reunification with the church during which petitioners swore faithfulness to Eastern Orthodoxy and declared Muhammad a false prophet. ${ }^{107}$ Only after the apostasy of 1866 , thanks to Il'minskii, were schools opened in sensitive areas. Although Il'minskii condemned the common practice of converting native peoples by force or bribery and called for the opening of schools, he also urged the state officials to exile the leaders of the apostasies to Siberia even if they were undoubtedly practicing Muslims. With the support of the Procurator of the Holy Synod Konstantin Pobedonostsev (r. 1880-1905), the missionary succeeded in preventing any relaxation of the law against apostates despite some local officials' appeals for grace. ${ }^{108}$ After Il'minskii's death, the Brotherhood of St. Gurii continued supporting this line of thought, assigning in 1899450 rubles to help displace ten apostates from the Kazan province to Samara province; among them was a native of Elyshevo volost' who had represented his village during the collective apostasy in the $1860 .^{109}$

Despite the efforts of both church and state authorities, individual petitions continued to pour in, a woman asking for the liberation of her husband or a man asking for the right to get his internal passport back. Further, apostates adopted strategies of

104. NART, f. 1, op. 3, d. 231, 1. 215 ob. (from vice-governor Rozov's report); "Donesenie Kazanskogo gubernatora B. Ia. Skariatina ministru vnutrennikh del P. A. Valuevu," in Materialy po istorii Tatarii vtoroi poloviny 19-go veka: Agrarnyi vopros i krest'ianskoe dvizhenie v Tatarii XIX veka (MoscowLeningrad, 1936), 249.

105. NART, f. 1 , op. 3 , d. 231 , 1l. 148,217 ; f. 4, op. 98 , d. $34,11.81,84$. The restrictions concerning the opening of mosques targeted cathedral mosques where the whole community gathered on Fridays and on the days of Islamic festivals (200 to 300 parishioners were required and a petition had to be signed). Prayer houses were simple izbas. People gathered there for the performance of their everyday prayers. No permission was required. PSZ 19, no. 13490: 101-102; Znamenskii, "Kazanskie tatary," 130; Malov, "O tatarskikh," (December 1867): 296, (January-April 1868): 3; Rorlich, Volga Tatars, 41; on the history of Verkhniaia Nikitkina (Yugharï Tubïlghïtaw), see Ähmärof, "Mükrehlär hālendän," col. 6 .

106. NART, f. 1, op. 3, d. 230, 1. 48; f. 13, op. 1, d. 945, 1. 59; and f. 1, op. 3, d. 231, 1. 215 ob.

107. Malov, "Ocherk," 18 , pt. 2 (1872): 43; Materialy po istorii Tatarii vtoroi poloviny 19-go veka, 251258; samples of sermons in NART, f. 4, op. 72, d. 72, 11. 171-171 ob., and f. 4, op. 77, d. 56, 11. 85-85 ob. The same policy was applied between 1827 and 1830. V. Zelenetskii, "Ocherki missionerskoi deiatel'nosti nekotorykh Kazanskikh arkhipastyrei, Arkhiepiskop Iona (1826-1828)," PB 1, bk. 1, no. 1 (January 1901): 21-24; idem, "Arkhiepiskop Filaret (1828-1836)," PB 1, bk. 1, no. 5 (March 1901): 196-201; Malov, "Pravoslavnaia protivomusul'manskaia," no. 9 (1868): 27-29, 29-47; no. 10 (1868): 135-140; pt. 1 (January-February 1870): $115-126$.

108. Pis'ma N. I. Il'minskogo k ober-prokuroru sviateishego sinoda K. P. Pobedonostsevu (Kazan, 1895), 213-214.

109. NART, f. 93, op. 1, d. 671, 1l. 2, 5-6. 
passive resistance. They refused to wear their crosses and pretended to have forgotten them at the steam bath, turned icons to face the walls or covered them with hats or towels; if a priest made a remark, they blamed mischievous children. Parents also hid their children when a priest passed by. Finally, when missionaries came to teach them, they often encountered an obstinate silence. ${ }^{110}$

More important, links between those arrested or deported and the original community were not easily broken. When wives were sent to their parents' village, they often came back to live with their husbands. Apostate men managed to obtain temporary passports from the volost' bureau (often headed by Tatars who winked at this violation of the regulations) and spent winters in Muslim villages where they earned a living; at harvest time, they returned to their families. To keep their property and ties with their original community of faith, deported parents also married their children into families living in their native villages. ${ }^{111}$ Finally, local epics immortalized the fate of apostates who had been exiled and awaited their return. In the 1878 bäyet (epic) of Elyshevo, Ismail-the deported leader of the village-sings his sorrow, reminding his countrymen and women to continue to observe their duties as Muslim believers. ${ }^{112}$

\section{Preconditions and Accelerators for Apostasies}

The apostasies partly arose from the reforms attempted by Catherine II, partly from the reinvigoration of Islamic education and Sufism. Catherine's reforms allowed the Tatar community to prosper and extend its economic and cultural networks among the Kräshens and other peoples living in the Middle Volga, the Bashkir area, and the Kazakh steppe. The empress forbade the Orthodox Church to proselytize among her Muslim subjects and established the official Muslim Spiritual Assembly of Orenburg in Ufa in 1788. At the same time, she favored the economic and spiritual expansion of Tatar merchant colonies in Central Asia closed to Christian merchants. Tatars seized on the occasion to open trade as far as India and China and complete their theological studies in the great Islamic centers of Bukhara, Samarkand, and Kabul. Mosques and schools, headed by Sufi shaykhs, opened in the villages of Maskara (Mächkärä), Kurmanaevo (Kizläw), Al'met'evo (Yanga Älmät), and Tiunter (Tüntär), bringing neighboring Turkic and Finno-Ugric villages to Islam. In one century, the number of mosques increased 60 percent. There were 536 mosques in the Middle Volga in 1742. In 1858, the number of mosques rose to 430 in Kazan province and 418 in Orenburg province. ${ }^{113}$

110. NART, f. 4, op. 98, d. 9, 1l. 32-32 ob., f. 4, op. 101, d. 11, 1. 114 ob; and f. 1, op. 3, d. 228, 1. 48; Chicherina, U privolzhskikh inorodtsev, prilozhenie no. 1, p. 10.

111. NART, f. 1, op. 3, d. 1835, 1l. 3-3 ob.; f. 1, op. 3, d. 3048, 1l. 31-31 ob.; f. 4, op. 77, d. 17, 11. 61-61 ob.

112. I am fortunate to have procured two copies of this epic thanks to the kindness of Gölsinä Khämidullina in Elyshevo: one can be found in Mahisärwär Ibrahim qïzï Bikmökhämmätova's manuscript notebook (däftär) in Arabic script, 1. 71 and the second is an unpublished and printed "Ismäghïyl bäyete," as sung by Ghajilä Khanova, an inhabitant of Elyshevo on 18 November 1947 (Elyshevo, 1991). Published portions can be found in Gölsinä Shärifullina’s article, "Urïs-kyäfer kilgänder Yïlïsh awïlï ilenä," Idel, no. 5 (May 1993): 69, and in Näjmiev and Khujin, Yashä, Saba-Yort, 175-176. In a sad repetition of history, Ismail's grandson was sent to Siberia as a kulak during the collectivization in the 1930s. Personal communication, G. Khämidullina (Ismail's direct descendant), Elyshevo, May 2008.

113. PSZ 16, no. 12126: 704-707; Mozharovskii, "Izlozhenie," 125-126; Malov, "Pravoslavnaia protivomusul'manskaia," 16, no. 5 (May 1870): 234; S. Kh. Alishev, Istoricheskie sud'by narodov Srednego Povolzh'ia XVI-nachalo XIX veka (Moscow, 1990), 215. 
Modernization of Russia implied a broadening of the notion of citizenship, and Muslims were invited to participate in the effort of Westernizing Russia. The economic and cultural development of the Tatars had an important impact on the Kräshens, Chuvash, and Udmurts who lived in their proximity. The Kräshens, in particular, spoke the same language and could take advantage of the new opportunities that Tatar trade and schooling offered to them. Because of the low fertility of their fields, many of the Kräshen peasants in Kazan province left their villages during fall and winter to earn money elsewhere and returned for the spring planting and summer harvest. Baptized seasonal workers chose trades that were not popular among Tatars, such as tailoring. Hired by Tatars, they conformed their life to their immediate Muslim environment. After their return to the village, they spread their knowledge of Islam to their families and became the main leaders of the apostasy movements. ${ }^{114}$

Tatars and baptized seasonal workers leaning toward Islam became increasingly aware of the political changes that had followed Catherine's reforms. The closing of the Office for the Affairs of New Converts led Tatars to believe that the tsar'-batiushka was their ally against the Orthodox Church and local administrators who did not know the law. Tatars contended that the Kazan archbishop Luka had been sent to Siberia after they complained to Catherine II's ministers of Luka's attempts to make them Russian. Apostate Kräshens similarly believed that the ruler was on their side. ${ }^{115}$

Two cases, one in Simbirsk and the other in Kazan province, confirmed the apostates' expectations. In 1807, the plaintiff Alifa from Simbirsk province denied that she had been brought up in the Christian faith, and the Senate concluded that, based on Catherine II's legislation (in particular the 1764 law that forbade forcible conversion of non-Christians), she was allowed to remain officially Muslim. The Simbirsk court followed the Senate's instructions and, later, the Kräshens of Simbirsk claimed that an imperial edict (that is the final decision of the Simbirsk court) had permitted them to profess Islam officially because they too knew nothing about Christianity. ${ }^{116}$ Later, in 1824, the Romashkina and Azeeva villages in Chistopol' district argued that during the last tax census they had been mistakenly categorized as Orthodox Christians. The provincial administration (upravlenie) looked at their request favorably partly because the consistory in charge of baptismal records could not determine the date of baptism of half of the inhabitants. Although parish registers showed that the villagers had attended church previously, those Kräshens were allowed to be Muslim. Other baptized Tatars in Kazan province used this case as proof that the ruler allowed them to be Muslim. Church officials, however, did not accept this judgment and continued to visit the two villages until the 1860 s. Twenty years later, the district chief of Spassk city allowed a new convert from the village of Kargapol, who was first married in a church, to become a bigamist according to Islamic law. Such decisions confirmed the apostates' belief that the state could serve as their ally in the struggle against the church. ${ }^{117}$

114. NART, f. 1, op. 3, d. 231, 1. 131 ob.

115. Malov, "O novokreshchenskoi," 165.

116. PSZ 16, no. 12126: 704-707; Malov, "Pravoslavnaia protivomusul'manskaia," no. 10, pt. 1 (1869): 151-154; Mozharovskii, "Izlozhenie," 125-126.

117. Malov, "Pravoslavnaia protivomusul'manskaia," no. 8 (1868): 328-334; idem, "Prikhody starokreshchenykh i novokreshchenykh tatar v Kazanskoi eparkhii," Pravoslavnoe Obozrenie (hereafter PO), 
Apostates constantly played on the fact that the state, not the church, had the power to favor or to hinder the growth of Islam. They often complained about parish priests who, supposedly, made them Christian to increase their emoluments. In the parish of Sheshma, Chistopol' district, converts claimed that they paid no less than five rubles for a baptism and five to fifteen rubles for a funeral, which the priest did not even conduct, since they quickly buried their dead the Islamic way and informed the priest only after the fact. Russian peasants also criticized greedy priests who extorted money from the poor. Apostates added that priests rarely talked about the Christian faith, except during the celebration of religious rites (baptism, marriage, and funerals). ${ }^{118}$

In fact, contrary to what baptized Tatars leaning toward Islam believed or wanted to believe, there was not a real dichotomy between church and state policies. In general, the state fully backed the church. Until the 1917 Revolution, the Orthodox faith was the main component of Russian nationality. However, the Ministry of State Domains (the agency responsible for the state peasants), despite some pressure from the Ministry of Interior and the Orthodox Church, was not willing to pay the full cost of "protecting the baptized natives" from Islam. When the Russian government exiled Christian converts from Spassk, Tetiushi, and Chistopol' districts, as it did in the 1830 s through the 1850 , it encountered a number of practical problems. First, the converts refused to leave their land; in their reports the local police expressed their fear that the baptized and their Muslim neighbors whom they believed to be sympathetic to their plight would revolt; they suggested sending the army, but sending the army was expensive. Second, the transfer of natives to Russian villages disrupted local economies. As a sign of protest, the deported apostates often refused to work on their new land and pay taxes, which contributed to an increase of the tax share for the rest of the commune. Third, it was difficult to find a village in Kazan province not surrounded by other Tatar villages. Fourth, when deported, a family was entitled to the same amount of land that it owned previously. In Spassk district, the Kräshens who apostatized were poor. They had small land holdings, and their transfer was easier than in the case of the Kräshens living in the Chistopol' district. The result was that in 1848 the minister of state domains, Count P. D. Kiselev stopped the transfers of 1,600 apostates in Chistopol' district and ordered the creation of an itinerant church (pokhodnaia tserkov'). Later the Ministry of Interior in 1861 ordered an end to transfers of Kräshens who had shown their discontent. This act of weakness was then interpreted by the Kräshen apostates as another sign of the czar's support for the Islamic cause. ${ }^{119}$

vol. 17, no. 8 (August 1865): 464, and vol. 18, no. 12 (December 1865): 480-481; idem, Prikhody starokreshchenykh i novokreshchenykh tatar v Kazanskoi eparkhii (Moscow, 1866), 30; Mozharovskii, "Izlozhenie," 127-130.

118. NART, f. 2, op. 1, d. 1976, 1l. 2-2 ob.; f. 2, op. 1, d. 2153, 1. 13; and f. 13, op. 1, d. 943, 1l. 331-337; I. S. Belliustin, Description of the Clergy in Rural Russia: The Memoir of a Nineteenth-Century Parish Priest, trans. Gregory L. Freeze (Ithaca: Cornell University Press, 1985); Malov, "Pravoslavnaia protivomusul'manskaia," no. 9 (1868): 27-47; no. 10 (1868): 135-140.

119. NART, f. 1, op. 2, d. 590, 1l. 13-15 ob.; f. 1, op. 2, d. 717, 1l. 20-21; f. 1, op. 2, d. 943, 1. 12; f. 2, op. 1, d. 1907, 1l. 10-12, 45 ob., 80; and f. 2, op. 2, d. 259, 1. 25; RGIA, f. 821, op. 8, ed. khr. 733; and f. 821, op. 133, d. 454, 1l. 298-302 ob.; Mozharovskii, "Izlozhenie," 190-213, 251; Malov, "Prikhody starokreshchenykh," vol. 18 , no. 12 (December 1865): 464-466, 490. 
Among Russian official documents found in apostate hands in 1866 was one referring to Kiselev's order. This was probably the famous "decree" that apostates in 1865 read in the markets of Kazan province to convince their fellow peasants that the state supported their cause. However, the reluctance of the Ministry of State Domains to deport Kräshens did not mean that the Ministry supported their cause; in fact in its reports, deportation to Siberia was the ultimate option to get out of the legal impasse. ${ }^{120}$

Furthermore, local representatives of the state considered the church responsible for its flock, but around the same period, local church representatives showed similar uneasiness at resolving the problem posed by the apostasy outbreaks. Forced Christianization or re-Christianization was not an option, but before the emergence of Il'minskii's network of schools, conversion by the word was a difficult task. Distance between the parish village and Kräshen hamlets was in general substantial and, in many cases, the language barrier prevented priests from being effective preachers. Other doubts of a deeper moral nature emerged among some local hierarchs. Nikodim (Kazantsev), bishop of Cheboksary (r. 1854-1861), boldly suggested in 1858 that the petitioners' requests should be considered favorably. If a baptized Tatar believed himself to be a Muslim, why should the authorities continue to call him a Christian? Submitting those "Muslims" to such torture was a sin committed by the authorities. Perhaps for uttering such radical ideas, Nikodim was reassigned to Eniseisk in Siberia three years later. ${ }^{121}$

In 1864, the judicial reforms introduced by Alexander II (r. 1855-1881) made it more difficult to prosecute apostasy. At the local level, the Kazan circuit courts showed some reluctance to pursue cases against the petitioners. The latter could not be accused of writing petitions that were simply the expression of a general consensus within their respective communities. ${ }^{122}$ Moreover, prosecutors had trouble distinguishing between proselytizers and proselytized because those arrested came from the same Kräshen milieu. Tatar mullahs and Sufi shaykhs had succeeded in promoting a native form of Islam among the Kräshens. If the village was united (which was not always the case) and fully supported its representatives even after their arrest, the prosecution was unable to argue that villagers were under their representatives' influence. ${ }^{123}$ As a result, prosecutors believed that jury cases would be won by the apostates. Only clerics could remedy the situation by spreading the Gospel more effectively. At the very beginning of the apostasy of 1865 , this resulted in the release of a number of baptized representatives, which later intensified the course of the apostasy. Once again, according to the apostates, the czar had shown his support. ${ }^{124}$

120. Kiselev's order was confiscated by the local police in the house of the representative of the districts of Cheboksary, Tsivil'sk, and Kazan districts, Aleksei Fedorov (Gizetulla Abdiushev). NART, f. 13, op. 1, d. 938 , 11. 174-175. In ca. 1890 at Karaduvan, district of Kazan, an apostate representative had access to a similar document that referred to the apostasy in Chistopol' district of four families in 1840 whose transfer was canceled because of its cost. Iapei Babai (pseud. Evfimii Malov), "O kreshchenykh tatarakh (iz missionerskogo dnevnika)," IKE no 20 (15 October 1891): 637-638. For the Ministry of State Domains' reports, see RGIA, f. 821, op. 8, d. 763, 1l. 48-58 ob.; and NART, f. 1, op. 2, d. 754, 1. 20.

121. Malov, "Prikhody starokreshchenykh," vol. 18, no. 12 (December 1865): 509; Pavel M. Stroev, Spiski ierarkhov i nastoiatelei monastyrei Rossiiskoi tserkvi (SPb., 1877), cols. 291, 1019.

122. NART, f. 4, op. 134, d. 16, 1. 19 ob.

123. NART, f. 4, op. 98 , d. 34, 1. 173; f. 13, op. 1, d. 1119, 11. 20-22.

124. RGIA, f. 821, op. 8, d. 763, 1l. 49-58 ob.; and NART, f. 1, op. 3, d. 2812, 11. 25-25 ob.; Il'minskii, ed., Kazanskaia tsentral'naia, 296-297. 
In 1874 , the prosecutor of the Kazan circuit court freed two Kräshen privates who had refused to attend church services in the army and who came from villages that had petitioned the government for official recognition of their Muslim faith in 1865 . According to the prosecutor, the laws against apostasy did not apply to individuals who had been baptized at an age when they had no understanding of their deeds. ${ }^{125}$ This rule could only increase the number of apostates as it contradicted earlier state policies; retired soldiers often led the apostasies. But in 1888, the Orenburg Criminal Chamber used the same reasoning to dismiss a case against Sil'vestr Andreev, an accused apostate. ${ }^{126}$ Two other obvious contradictions, pointed out by the authorities themselves and the church, was that judges allowed apostates called at the witness stand to swear on the Qur'an in the presence of a mullah, and that apostates had their internal passports issued under their Muslim names, and not their baptized Russian names. ${ }^{127}$ Finally, in 1881 , apostates in Chistopol' district signaled to the Kazan provincial authorities that in Ufa province, the governor's office had allowed neighboring mullahs to register the births and deaths of apostates, and even officiate among them. This only pointed to local variations in the enforcement of the law and to the apostates' capacity of keeping themselves updated of any change in its application. In general, Kazan authorities showed less flexibility than those in Ufa; they permitted volost' heads, not mullahs, to keep metrical books-Imperial Russia's system for keeping track of vital statistics - for the apostates. (Normally, the local clergy-Christian, Muslim, Jewish, and Buddhist-maintained the metrical books for their communities.) As a result, some apostates preferred to register themselves at the local volost' boards under their Muslim names rather than wait for a collective petition, thus officially rejecting Orthodoxy at a lower cost. ${ }^{128}$

In 1895, new petitions reached the desk of the Kazan governor Petr A. Poltoratskii (1842-1909), who, overwhelmed by their number (30,000 altogether), first proposed a general amnesty, and then retracted his offer. His administration agreed that allowing apostates to become officially Christian would jeopardize the supremacy of the Eastern Orthodox Church over other confessions; yet it also admitted that keeping apostates from being registered legally as Muslims deprived them of their rights. Apostates could not officially inherit according to the sharia. Even more problematic was the fact that with no recognized clergy to keep the metrical books, the apostates were drafted into the army based on their appearance rather than their actual age. Keeping apostates from becoming officially Muslim would not make them into good Christians. Because the petitioners were the grandchildren or great-grandchildren of apostates and were not cited in the Orthodox parish registers as baptized, Poltoratskii proposed that apostates be permitted to register as Muslims before a certain

125. NART, f. 4, op. 97, d. 1, 1. 393.

126. NART, f. 1, op. 2, d. 399, 1. 13 ob.; f. 1, op. 2, d. 1119, 1. 88; and f. 1, op. 3, d. 228, 1. 125 ob.; GAOO, f. 55 , op. 3 , d. $278,11.5-6$.

127. NART, f. 2, op. 1, d. 2256, 1l. 26-27; f. 2, op. 2, d. 5136, 1l. 128 ob.-129; f. 2, op. 2, d. 1429, 11. $1-1$ ob.; Petr Troitskii, "Novokreshchenskie prikhody Kazanskoi eparkhii v ikh proshlom i nastoiashchem” (Kursovoe sochinenie, 1915) in NART, f. 10, op. 2, d. 1383, 1l. 234-235.

128. NART, f. 2, op. 2, d. 1921, 11. 2-3 ob.; "Otchet o deiatel'nosti Soveta Bratstva Sv. Guriia ot 4 okt. 1871 g. po 4 okt. 1872 g.”, IKE, no. 3 (1 February 1873): 90; Paul Werth, “The Limits of Religious Ascription: Baptized Tatars and the Revision of Apostasy, 1840s-1905," Russian Review 59, no. 4. (October 2000 ): 95. 
deadline; after the deadline, petitions would not be considered. Against strong church opposition, Poltoratskii's proposal failed. However, because of the governor's initial willingness to compromise, in 1894-1896 some apostates from the city of Chistopol' and the districts of Spassk and Chistopol' were granted the right to become Muslim officially. But in 1897 the apostates' luck had run out and the governor systematically declined all requests, discouraging further police investigation at the local level. ${ }^{129}$

Despite their defeat, though, the apostates' tenacity in promoting confessional self-identification through legal channels succeeded in destabilizing the official conception of religious affiliation and demonstrated the natives' legal knowledge and capacity to exploit the inconsistencies of Russian law. On the one hand, no one could be forcibly converted to Orthodox Christianity, the dominant religion of the Russian state; on the other, apostates to Islam claimed that because they had always been Muslim, they should not be forcibly categorized as Christians.

\section{Mobilizers of the Apostasy Movements}

Among those arrested by the clerical and state authorities in 1803, 1827-1830, and the 1860 s, there were Tatar and Kräshen students of charismatic Sufi leaders, Tatar mullahs who taught Kräshens in their schools (often denounced by their Tatar Muslim parishioners but not by the apostates), baptized men (among them veterans and seasonal workers) who represented their villages, and baptized women who were accused of spreading rumors from village to village. They constituted the intellectual elites, legal experts, and voices of their villages. All of them participated in the broadening of the apostate umma (the Muslim community of faith) beyond their territorial boundaries.

The apostates' petition movement proves Robert Crews's argument that Muslim communities of Russia did not live in cultural autarky but used Russian institutions of power to construct their Islamic identity and consolidate their communal boundaries. Writing petitions to the czar or the governor required knowledge outside Islam-first of the Russian language, then of administrative technicalities, and finally, legal precedents. Apostates and some of the mullahs who supported them worked within the Russian legal system and learned from previous individual and collective attempts to change the legislation. In the 1830 s they sent their petitions on a simple piece of paper, which according to Russian law could have detrimental consequences - the petition then could be disregarded without being read. But, by the 1860s, they had learned their lesson; they followed the rules to the letter and used the special, more costly, official paper (gerbovaia bumaga) for their petitions. ${ }^{130}$

Would-be Muslims also quickly learned how to present themselves to authorities adequately. In 1802 they admitted that they had been baptized and so were immediately classified as criminal apostates. However, by 1827 many claimed that they had always been Muslim, that their ancestors had been Muslim, and that their

129. NART, f. 2, op. 2, d. 4452, 1l. 90, 96-98; f. 2, op. 2, d. 4960, 1l. 4, 8-9, 15, 25; f. 2, op. 2, d. 5134, 11. 5-6, 49; f. 2, op. 2 , d. 5136, 1l. 128 ob. $-129,132-133$, 181-181 ob.; f. 2, op. 2, d. 5133, l. 35; f. 2, op. 2, d. 5132 , 1. 35 ; f. 2 , op. 2 , d. 5131 , 1.47 ; f. 2 , op. 2 , d. $5137,1.16$; f. 2 , op. 2 , d. $5141,1.45$; f. 2 , op. 2 , d. 5142 , 1. 20 ; f. 2 , op. 2 , d. 5143 , 1. 13 ; f. 2 , op. 2 , d. 5144 , 1. 26; f. 2 , op. 2 , d. 5145 , 1. 139; f. 2, op. 2 , d. 5350, 1l. $66-66$ ob.; f. 2 , op. 2, d. 5353, 1. 22; and f. 2, op. 2, d. 5355, 11. 16-16 ob.; Otdel rukopisei Instituta iazyka, literatury i istorii Akademii nauk Tatarstana, f. 56, op. 1, d. 4, 1l. 137 ob.-138; Werth, "Limits of Religious Ascription," 504.

130. NART, f. 1, op. 2, d. 134, ll. 1, 4 . 
classification as Christians was simply an unfortunate clerical error or the result of the priests' cupidity. They pursued the same strategy in the 1865, using their Muslim names exclusively and occasionally including a summary of the main tenets of the Islamic faith. Even baptized Chuvash villages in Tetiushi district claimed that their ancestors had always been Muslim. ${ }^{131}$

The leaders' dilemma consisted in gathering petitions the fastest way possible to create a sense of urgency and collective unity. Apostatizing was risky business and not everyone was ready to pay for the extra financial expenses it entailed. Villagers had to acquire copies of the decrees or pseudo-decrees that justified their appeal. In 1827 , apostate leaders of Sviiazhsk district paid four rubles for a copy of the 1807 decision of the Senate that had allowed Alifa from Simbirsk province to adopt Islam officially. Apostates also typically had to pay administrative fees (in general, thirty to fifty kopecks per family), hire Russian translators, bribe local authorities, remunerate their own mullah, buy Islamic primers (two kopecks each), and purchase clothing that distinguished them as Muslims. In 1866, the Elyshevites paid twelve rubles to send a petition and about three rubles for the Muslim skullcaps sewn by one of their villagers and informers in Kazan. ${ }^{132}$ Leaders thus had to gather signatures and gain the consensus of several villages in various provinces in order to gather the required sum. As a result, they did not choose villages at random. In 1802, Vasilii Estifeev (b. 1779) from the mixed Baptized Mishar-Chuvash village of Moklokovo, whose grandfather accepted baptism when marrying a Kräshen, visited other villages in Nizhnii Novgorod province, claiming that in Kazan district, Kräshens had been allowed to become Muslim. During his trip, he chose to go to Kräshen villages that could afford the cost of writing a petition. But in 1865 , representatives of villages that could not afford the cost of the petition because of the small number of apostates traveled themselves to popular trading places such as Tetiushi and the Hay Market of Kazan where representatives of larger villages gathered signatures. ${ }^{133}$

Kinship and trade networks helped to propagate the news about the pseudo-edict and extend the apostate movement. The leaders of apostasies were often related by marriage; father-in-law and son-in-law signed petitions together. Like Tatars, the Kräshens practiced exogamy. The bride rarely remained in her home village and so linked two communities together. This facilitated the flow of rumors from one village to another before, during, and after the rebellion. In December 1865, the village of Varangush in Tsarevokokshaisk district learned about a gathering of signatures at the

131. Petitions (1827-1829) in Otdel rukopisei Kazanskoi nauchnoi biblioteki im. Lobachevskogo, f. 7, ed. khr. 28, 11. 1-256; Malov, Prikhody starokreshchenykh i novokreshchenykh tatar $v$ Kazanskoi eparkhii, 24; published petitions for the 1860 s in Materialy po istorii Tatarii vtoroi poloviny 19-go veka, 242, 244, 247; NART, f. 4, op. 72, d. 12, 1l. 334-335; f. 13, op. 1, d. 943, 11. 331-337; on Chuvash villages in Tetiushi district [Kukshum, Belaia Voloshka, and Uteeva], see Rozov's report in Il'minskii, ed., Kazanskaia tsentral'naia, 299.

132. NART, f. 13, op. 1, d. 1003, 1l. 1-1 ob., 11. The representative of apostate villages in Kazan district paid about the same price (sixteen rubles) for their petition, NART, f. 13, op. 1, d. 938, 1. 20 ob.

133. Evfimii Malov, "Nyneshnee religioznoe polozhenie kreshchenykh tatar Zavolzhskogo kraia," $P O$ 7 (1866): 123; Il'minskii, Opyty perelozheniia, 21-22, 40; V. Magnitskii, "Nechto o Chuvashakh, Tatarakh i Mishariakh," Deistviia Nizhegorodskoi Gubernskoi uchenoi Arkhivnoi komissii (Sbornik statei, soobshchenii, opisei i dokumentov) 3 (Nizhnii Novgorod, 1898): 39; NART, f. 1, op. 3, d. 222, 1l. 32-32 ob.; f. 1, op. 3 , d. 859 , 1. 4 ob.; f. 13, op. 1, d. 938, 20-20 ob. 
Hay Market of Kazan through their wives who were natives of Iabash and Nurma, two apostate villages of Kazan district. ${ }^{134}$

By exiling Christian converts to Islam, the Russian government contributed to the greater spread of the apostasy movement. Petitioners of different parishes and provinces found themselves exiled to the same Russian villages; their common experience only strengthened their resolve to fight for their religious rights. They learned about the existence of other Islamized Kräshen communities, and established new connections between hitherto isolated villages. Thus, in the 1840s, apostates from Almurzina and other villages in the southern part of Spassk district were displaced to the Russian village of Kutema, east of Chistopol' district; there they came to contact with apostate villages in Chistopol' district, north-west of Kutema, which resulted in the formation of a much compacter group of 712 individuals, ready to petition again. ${ }^{135}$ Similarly, in the suburb of Novosheshminsk in Chistopol' district, there were baptized Tatar families transferred from Sredniaia Biktemirova in Spassk district, Sluzhilaia Maina in Chistopol' district, and Maris from Tsarevokokshaisk district. Single apostate families were also exiled to the same village from different districts and villages at different times. In the suburb of Starosheshminsk, there was a family from Tetiushi district deported in 1847 , three other families from three different villages of Chistopol' district deported in 1849,1852 , and 1857 , and one more transferee from Mamadysh district in $1855 .{ }^{136}$ What was worse for the Russian authorities, the contacts between the exiles and their native villages did not cease. In the village of Omara, Mamadysh district, lived apostates from Almurzina, Spassk district. When a priest came to inspect them, only five of seventeen individuals resided in Omara; the others lived in Almurzina. Because apostates from Almurzina were also displaced to the Russian village of Kutema in Chistopol' district, exiles served as informants between hitherto isolated baptized communities in Spassk, Chistopol', and Mamadysh districts. Finally, when the local authorities transferred novokreshchenye to the baptized Chuvash village of Shemursha in Buinsk district, Simbirsk province, to be instructed in the Christian faith, it only furthered the Islamization of the native Chuvash. ${ }^{137}$

The biography of the most important apostate representative, Egor Fedorov (1826after 1906), alias 'Alim Ismä' il ughlï, also called Samigulov, reveals even more vividly the significance of these exiles and their revolutionary tactics. A close-cropped darkhaired man with gray eyes and light brown eyebrows, about five foot six, Samigulov was born in 1826 in Verkhniaia Nikitkina before the first apostasy of his village, composed of baptized Chuvash and novokreshchenye, in $1829 .{ }^{138}$ A decade later, Samigulov's village apostatized a second time and received the visit of a priest who explained to them the principles of the Orthodox faith in Tatar. But the villagers refused to give their Russian names, and insisted on educating their children in the Islamic

134. NART, f. 13, op. 1, d. 1003, ll. 9-9 ob.; f. 1, op. 3, d. 859, 1. 5.

135. NART, f. 4, op. 84, d. 263, l. 10 ob.; Karta narodonaseleniia Kazanskoi gubernii po plemenam. Sostavlena po mestnym istochnikam General'nogo Shtaba Polkovnikom A. Rittikh (SPb., 1870).

136. NART, f. 1, op. 2, d. 541, 11. 3, 17 ob.; f. 4, op. 99, d. 20, 11. 67-70 ob.

137. NART, f. 4, op. 134, d. 33, 1. 10; Runovskii, "Ocherk istorii khristianskogo," no. 7 (1 April 1901): 242 , footnote 25 .

138. NART, f. 13, op. 1, d. 938, 1l. 351-353, 385; on the history of Verkhniaia Nikitkina (Tubilghitaw village), see Ähmärof, "Mükrehlär hālendän," col. 2. 
faith. ${ }^{139}$ In 1849, the Russian authorities deported the village leaders from Chistopol' to Mamadysh, a district spared by the apostasy movement, where other exiles from Spassk district had been moved. Around the same time, leaders of other apostasies in Spassk were also transferred to Chistopol' district, which encouraged new exchanges of information between apostates of various origins. The result was that in Mamadysh district, partially under Samigulov's leadership, starokreshchenye-who had not previously participated in the apostasy movement-joined Islam for the first time in 1865 along with the Chistopol' and Spassk apostates. ${ }^{140}$

In 1856,1858 , and 1859 , Samigulov, who was also the disciple (murid) of a famous Naqshbandi shaykh in Chistopol' district, served as the unofficial mullah of his village and sent petitions to St. Petersburg, and even made special trips to the capital, asking the government to allow his exiled countrymen and countrywomen to return to the village. Each time his requests were denied. But in August 1865, the deported apostates defied authorities, and without authorization came back to their village where they founded a mosque and a Qur'anic school. ${ }^{141}$ Then, between September and December 1865, Samigulov-who repaired watches and samovars, and occasionally sold lemons to finance his trips-visited Kräshens, Chuvash, and Maris and convinced whole villages in Tetiushi, Kazan, Mamadysh, Tsivil'sk, Cheboksary, and Laishevo districts that the emperor had authorized his village to erect a mosque. ${ }^{142}$ His strategy for convincing other Kräshens to apostatize can be seen clearly in his 1865 visit to Karatun village, Tetiushi district. Karatun was a market village and thus offered an opportunity to reach a wider audience. Earlier apostate leaders had also preached their message in markets; in 1827 the Kräshens had heard calls to convert to Islam at the market in Shonguty, Tetiushi district. ${ }^{143}$ To create a sense of urgency and rally as many people as possible in the most spectacular way, Samigulov used the support of prominent local apostates, employed Mahdist rhetoric, and chose a symbolic date-the beginning of the Muslim fast of Ramadan - as the deadline for collecting signatures. In 1843, Samigulov's village had apostatized during Ramadan. ${ }^{144}$ Overall,

139. The exact date of their apostasy was 1843 , NART, f. 2, op. 1, d. 1911, 1l. 2-2 ob., 13 .

140. Evfimii Malov, "Statisticheskie svedeniia o kreshchenykh tatarakh Kazanskoi i nekotorykh drugikh eparkhii, v volzhskom basseine," in Uchenye zapiski Kazanskogo universiteta, vol. 4 (1866): 339; idem, "Prikhody starokreshchenykh," vol. 18, no. 12 (1865): 466; on the Chuvash apostates of Verkhniaia Nikitkina, see NART, f. 4, op. 8o, d. 6o, 1. $62 \mathrm{ob}$.

141. The underground mosque of Verkhniaia Nikitkina existed earlier but had burned in 1858 and was rebuilt in 1861 and then in 1865 . RGIA, f. 821 , op. 8 , d. $763,11.73$ ob.-74.

142. RGIA, f. 821 , op. 8 , d. 763 , 1l. 73 ob.-82, $218-219$ ob.; and NART, f. 1, op. 3, d. $227,1.81$ ob.; f. 1 , op. 3, d. 231, ll. 102-102 ob., 232 ob.-233; f. 4, op. 134, d. 16, 1l. 19 ob.-20; and f. 13, op. 1, d. 938, 11. 134-134 ob., 148 ob., 150 ob., 215, 217, 249-273, 256-256 ob., 402; Il'minskii, ed., Kazanskaia tsentral'naia, 291292, 304 (Rozov's report); Malov, "Nyneshnee religioznoe polozhenie kreshchenykh tatar Zavolzhskogo kraia," Strannik 7, tom 3, no. 8 (August 1866): 73; Materialy po istorii Tatarii vtoroi poloviny 19-go veka, 233-236, 250-251 (Samigulov's petitions and police reports); Sergei Rybakov, "Otpadenie kreshchenykh inorodtsev v Islam i ikh prosveshchenie," PB 2, no. 14 (July 1899): 245.

143. Mozharovskii, "Izlozhenie," 123-124.

144. Samigulov let a prominent local apostate figure, 'Abdryafik Mökhammätev, introduce him and support his story-that in 1856 Alexander II had issued an edict allowing the Kräshens to declare themselves Muslim. He also used the same tactic in the village of Saltyganovo, Sviiazhsk district, and in KibiakKozi, Laishevo district where he stayed in the house of a prominent apostate whose son shortly became the village unofficial mullah. NART, f. 1, op. 3, d. 227, 1l. 81-81 ob.; and f. 13, op. 1, d. 945, 1. 55 ob. 
the underground mullah's strategy proved extremely successful. At this one meeting in Karatun, he gathered 800 signatures, and later another 1,000 Kräshens joined the ranks of the rebellion. ${ }^{145}$

Back in Kazan, shortly before Christmas 1865 , Samigulov wrote new petitions in a Tatar hotel and made another important and symbolic step to prove that apostates could live according to sharia rules, taking a Muslim Tatar widow as his second wife. ${ }^{146}$ Samigulov was then arrested, but for lack of incriminating evidence-the law condemned Muslim but not Kräshen proselytism among Eastern Orthodox-he was released, and returned promptly to his village, where in May 1866 he faced the authorities one more time. As the police made its first attempt to seal his mosque, Samigulov boldly climbed on its roof and urged everyone to enter the building and pray. The villagers complied and the police were unable to close the prayer house. Only upon the vice-governor Rozov's arrival was the prayer house finally sealed, and Samigulov, sent to the prison of Chistopol', where he continued to appeal his case. Four years later, unable to bring formal charges against Samigulov under the new legal regime of 1864, the Ministry of Internal Affairs exiled him to Siberia by administrative fiat. The legendary underground mullah was still alive in 1906, when finally his native village obtained the right to profess Islam openly. At the age of eighty, the former leader of the 1865 apostasy movement lived in the city of Semipalatinsk, where an important Volga Tatar trading colony was located along the Kazakh steppe frontier. ${ }^{147}$

Leaders of Kräshen apostasies were seasonal workers, traders, or craftsmen like Samigulov who, freed to some extent from the vagaries of weather and field cultivation, constituted a relatively well-to-do and literate segment of the population concerned with bringing apostate communities into the broader community of the Prophet. In the 1870s, baptized seasonal workers from Elyshevo convinced Kräshens in Menzelinsk to join the apostasy movement, pushing the apostasy movement eastward. ${ }^{148}$ In general, very successful seasonal workers could earn enough to open their own shops in the city, hire their covillagers, even build mosques in Tatar villages, and advance the money to their poorest fellow villagers for signing the petition, which resulted in the fastest gathering of signatures. They were the ones who brought Muslim stories to the village and bought Muslim books at the fairs they visited for their trade. In short, it was they who interpreted Russian and Islamic law, consolidated Islamic knowledge at the village level, and broadened their communities' sacred territory. ${ }^{149}$

145. Malov, “Nyneshnee religioznoe," Strannik (August 1866): 73-74; Mozharovskii, “Izlozhenie," 82.

146. NART, f. 13, op. 1, d. 938, 1l. 134-134 ob. In another case of polygamy, a father-in-law denounced his son-in-law for taking a second wife, NART, f. 1, op. 3, d. 228, 1l. 32 ob.-33 ob.

147. RGIA, f. 821 , op. 8, d. 763 , ll. 2 ob. $-4,49-58$ ob.; f. 821, op. 8, d. 780, 1. 10 ob.; and NART, f. 13 , op. 1, d. 938, 11. 340-341 ob.; Il'minskii, ed., Kazanskaia tsentral'naia, 297, 305, 311 (Rozov's report); Ähmmärof, "Mükrehlär hālendän," col. 6; on Muslim merchant colonies, see Frank, Muslim Religious Institutions, 71.

148. RGIA, f. 821 , op. 8, d. $763,1.300$; and NART, f. 1 , op. 3 , d. $3272,1.9$.

149. Malov, "Ocherk," 18, pt. 1 (1872): 399; NART, f. 1, op. 3, d. 3697, 1. 2; NART, f. 4, op. 133, d. 7 , 1. 16; f. 13, op. 1, d. 1003, 1l. 1-1 ob.; f. 1, op. 3, d. 231, 1. 138 ob.; Istoriko-statisticheskoe opisanie tserkvei $i$ prikhodov Kazanskoi eparkhii, 36. 


\section{Literacy and Its Practicality among the Apostates}

Islamic knowledge, both oral and written, provided a tool to understand the universe, but it also played an essential technical part in the orchestration of the apostasy movement. At the same time, access to Islamic knowledge did not preclude the acquisition of Russian literacy which, even before Il'minskii's reforms, was available to Kräshens in some limited form through church or Ministry of State Domain schools. Indeed, not all leaders could read or write like Samigulov, but they still knew the importance of literacy and looked for Russian clerks or literate Tatars to perform the tasks they needed for the gathering of as many names as possible in the shortest time possible.

For the first half of the nineteenth century, it is not easy to determine the level of literacy, both in Tatar and Russian, among the apostate communities. When questioned by the police, apostates usually answered that they could not read or write due to their lack of access to Qur'anic schools and mullahs. During the apostasy of 1866, Gizetulla Abdiushev (Aleksei Fedorov) (b. 1820), the representative of Cheboksary, Tsivil'sk, and Kazan districts, fluent in Russian, declared to the police that he could neither read nor write in Russian or Tatar, and signed his deposition with a tamgha. When the police searched his home, though, they found official Russian documents about the Chistopol' district apostasies of 1846, the 1859 petitions of Chistopol' district in the Tatar language, and a diary detailing the number of printed Islamic primers distributed in the apostate villages of Tsivil'sk district (1,304 primers), when officially Tsivil'sk district had but 897 apostates. This discovery was a clear indication that Abdiushev, like other "apostate" missionaries valued print, a technology long employed by European missionaries to spread Christianity and embraced by Naqshbandi Sufis weary of contesting the Russian state religious boundaries. Whether literate or not, Abdiushev's memory was also impressive. The representative of Cheboksary could name the apostate villages in his and Tsivil'sk districts, give the number of apostates for each village, and "read" their tamghas, an indication of preliteracy. ${ }^{150}$

Other evidence shows that most Kräshen representatives were literate in Tatar, and even Russian. Many in Tetiushi and Chistopol' districts had studied in Islamic schools, sometimes beyond the elementary level, and some in local Russian parish schools. ${ }^{151}$ In marketplaces, apostate leaders encouraged their followers by publicly reading and translating copies of the spurious edict granting the Kräshens permission to declare themselves Muslim. In the 1820 s some apostates hired Russians to write their petitions, but in the 1860 os apostates copied the petitions in Russian and Tatar in their own hand. In 1827, two representatives from the Sviiazhsk district,

150. Tamgha, common to one clan, took various geometric forms and occasionally exhibited the shape of Arabic letters. When a son married and built a house, usually close to his parents, the latter adopted his father's tamgha with very slight variations. RGIA, f. 821, op. 8, d. 763, 11. 81 ob.-82; and NART, f. 13, op. 1, d. 938, 11. 102-103, 197; Nicholas Ostler, “The Social Roots of Missionary Linguistics", Missionary Linguistics/Lingüística Misionera, ed. Otto Zwartjes and Even Hovdhaugen (Amsterdam and Philadelphia, 2004), 33-46; Naqshbandi Sufis favored the use of print to spread Islamic education. Michael Laffan, "The New Turn to Mecca: Snapshots of Arabic Printing and Sufi Networks in Late 19th Century Java," in the special issue of Revue des mondes musulmans et de la Méditerranée, titled "Langues, religion et modernité dans l'espace musulman" (124 [November 2008]: 113-131.

151. NART, f. 1, op. 3, d. 228, 1. 25 ob.; f. 10, op. 1, d. 1655, 1l. 19, 21 ob. 
Larion and Vasilii Ivanov, hired a mail clerk to write their petition, and a soldier to write down the names of the plaintiffs in each village they visited. In 1836, the apostates of Chistopol' and Sviiazhsk districts still turned to two Russians, a retired clerk and a chancellarist, for composing and copying their petition. ${ }^{152}$ But within fifteen years, Kräshens were copying their own petitions. When police surprised nine Kräshens in a Tatar hotel in Kazan, one of them, Samigulov, was reading aloud in Tatar, while another Kräshen, Iarofei Grigor'ev from Simbirsk province, was writing in Russian. The police seized Russian legal texts and a petition from Simbirsk. The Kräshens of Kazan province had made substantial progress in Russian literacy since their first apostasy. ${ }^{153}$

Most of the 1866 petitions had been composed according to the model of the 1856 Verkhniaia Nikitkina petition in Chistopol' (Samigulov's village). Their literate language indicated that a Tatar educated in a madrasa had authored the text, rather than a self-educated Kräshen. This Tatar appeared to be from Bugul'ma district. ${ }^{154}$ But, if the Kräshens did not have the skills to compose the original text, they had enough literacy to copy hundreds of petitions. The judicial investigator of the Kazan Criminal Chamber was impressed that so many villagers in Kibiak-Kozi, Laishevo district could read and write. ${ }^{155}$ Samigulov's handwriting in Arabic script by far excelled his writing in Cyrillic, which was at the level of a first-grader. Copying petitions themselves kept the Kräshens' expenses down as it was quite costly to hire a public scribe. Once the Kräshens had the basic text of the petition, they could introduce the names of their village, representatives, and covillagers. In 1865-1866, Kräshens of Verkhniaia Nikitkina remodeled Samigulov's 1856 petition, and their new copy ended up in the hands of the literate representatives of Elyshevo, who used it to draft their grievances. ${ }^{156}$

The practice of copying petitions greatly speeded up the process of apostatizing. After 17 April 1905, thanks to the new Edict on Strengthening the Principles of Religious Toleration, mullahs distributed printed petition forms in the name of the Spiritual Assembly of Orenburg. Petitioners who had learned to read and write in Il'minskii's elementary schools could just enter their names in Cyrillic letters individually. The Ministry of Interior, however, continued to receive petitions copied or even composed by the apostates themselves. A twenty-seven-year-old woman from Verkhnie Otary, Mamadysh district, copied a petition with many spelling mistakes,

152. NART, f. 1, op. 2, d. 134, l. 9; f. 1, op. 3, d. 231, 1l. 102-102 ob.; and f. 13, op. 1, d. 938, 1l. 102, 172, 197; Materialy po istorii Tatarii vtoroi poloviny 19-go veka, 236; Il'minskii, ed., Kazanskaia tsentral'naia, 285; Mozharovskii, "Izlozhenie," 123-125.

153. NART, f. 10, op. 1, d. 1655, 1. 18 ob.; Materialy po istorii Tatarii vtoroi poloviny 19-go veka, 234-236.

154. NART, f. 1, op. 3, d. 231, ll. 233 ob., 234 ob.

155. In 1868, three men and a woman taught Islamic literacy in four different houses. Parents also sent their children to the elementary Qur'anic school in a nearby village of Kazaklar (also called Verkhnie Kibiak-Kozi) until Bol'shie Kibiak-Kozi obtained the right to build its own mosque. (NART, f. 1, op. 3, d. 1818 , 1l. 1 ob., 4; and f. 13 , op. 1, d. 945, 1. 22.) The father of the historian Yakhya Abdullin, born in Bol'shie Kibiak-Kozi in 1885 , studied at Kazaklar in the 1890 s. Yakhya Abdullin, interview by author, 30 May 2000, Institute of History, Kazan.

156. Petition of Aul-Urmat, Kazan district, in 1866, NART, f. 13, op. 1, d. 938, 1l. 13-17; Samigulov's deposition, NART, f. 13, op. 1, d. 938, 1. 402; Shärifullina, "Urïs-kyafir," 67. 
but her childish handwriting was perfectly readable. And a thirteen-year-old boy, who attended a Russian school in the same district, wrote six lines about his wish to become Muslim and signed for his mother, a widow, who had her own portion of the petition typed. ${ }^{157}$

Literacy in Tatar also helped representatives to organize the movement and stay in touch with their native community when they brought the petition to the state or provincial capitals. During his 1802 stay in St. Petersburg, Estifeev-the only literate person in his family-wrote letters encouraging his fellow villagers to resist local priests and police. In May 1866, a native of an apostate village who ran a business in the Tatar neighborhood of Kazan wrote home to explain to his fellow villagers what they should do after sending their petition. They should give children Muslim names, buy Muslim skullcaps, and open a Muslim cemetery. The same year, Kräshen emissaries from neighboring districts distributed the same type of written instructions to Kräshens of Sviiazhsk district, warning parents not to turn to the priest for baptizing their newborns or burying their infants, but to proceed according to Islamic law. ${ }^{158}$

Although literacy was an important tool of resistance, it is difficult to date the appearance of Muslim books among Orthodox Tatars. Nevertheless, the age of the first apostate leader, Vasilii Estifeev-literate in Tatar, Persian, Arabic, and Russianwho was twenty-three in 1802, shows that the Kräshens had access to Muslim schools even before the establishment of the Asian printing house (Aziatskaia tipografiia) in Kazan in 1801, at a time when such schools used manuscripts that Tatar merchants had brought from Central Asia. ${ }^{159}$ According to Russian Orthodox missionaries, the printing house facilitated further access to Tatar literature without the necessary help of a religious specialist and thus accelerated the further spread of Islam among the Kräshens, who officially could not have immediate access to a religious expert and could potentially instruct themselves and become teachers in their own milieu. Naqshbandi Sufis favored the use of print to spread Islamic education, and Russian statistics provide support for the popularity of published Islamic literature in the Volga region. In 1802, 11,000 copies of the Muslim primer Sharä'it al-İmān (Foundation of Faith, composed in 1776?) were published; in 1806, 19,000; and between 1855 and 1864, 147,000. Likewise the Häft-i Yäk (a Persian word that means "one seventh" or "the seventh part" of the Qur'an) appeared in 1802 in 7,000 copies, in 1806 in 3000, in 1842 in 6,400, in 1846 in 4,000, in 1847 in 5,400, and finally between 1855 and 1866 in 70,000. The story of Joseph (Qïșsa-yi Yüsuf), a mystical book well-known among the Kräshens, appeared in 21,00o copies between 1854 and 1864, and Ākhïr Zamān Kitābï (The Book of the End of Time), an eschatological book sold 9,500 copies between 1855 and 1864 . This literature, popular at home and in primary schools, was extraordinarily cheap. In the 1860s, the Muslim primer cost only two kopecks, and a Qur'an between seventy-five kopecks and a ruble. In addition to printed religious

157. NART, f. 1 , op. 3, d. 231, 1. 234; f. 2, op. 2, d. 12824, 1. 11; f. 2, op. 2, d. 12825, ll. 251-252; f. 2 , op. 2, d. 12826, ll. 430, 450; RGIA, f. 821, op. 133, ed. khr. 455, d. 6, ch. II, 1l. 27-29, 35-38; and f. 821, op. 133, ed. khr. 454, d. 6, ch. I, 1l. 84-87; Il'minskii, ed., Kazanskaia tsentral'naia, 305-306.

158. Il'minskii, Opyty perelozheniia, 21, 40; Malov, "Ocherk," 18, pt. 1 (1872): 77; NART, f. 1, op. 3 , d. 228, 1l. 9-9 ob.; and f. 13, op. 1, d. 1003, 1. 1 ob.

159. Rybakov, “Otpadenie kreshchenykh inorodtsev v Islam i ikh prosveshchenie," 243. 
books, manuscript copies of the story of Joseph and other popular religious literature could be found in Kräshen milieu. ${ }^{160}$

It is also difficult to determine the scope of Tatar proselytism among the baptized population, because Kräshens did not volunteer such information. Kräshen apostates refused to provide the names of their Tatar mullahs and teachers because they knew that their "educators" could be prosecuted and sent to Siberia. They would rather name a dead mullah who taught them the tenets of Islam. It was not until 1895 that some apostates, surer of their rights and eager to show that they were true Muslims, gave the names of the mullahs and shaykhs who let them visit their mosques. In most cases though, they argued that because they were "officially" baptized, the mullahs forbade them to go to their schools; consequently, they had to perform all the rituals on their own. ${ }^{161}$

Still novices in the art of apostatizing, the Kräshens of the 1802-1803 apostasy were more vocal about the Tatar mullahs' involvement in their acquisition of Islamic knowledge. They mentioned that Tatar abizlar (probably from the Arabic hafiz, mullahs or educated Muslims who knew the Qur'an by heart) opened schools to their children and visited them at home, sometimes three times a day. Those abizlar criticized them for having Russian icons in their homes and said repeatedly that if Kräshens had to live like Christians on the outside, they should at least keep the Muslim faith alive in their heart. ${ }^{162}$

Contrary to the Russian priests who taught everything in Russian, mullahs translated the prayers from Arabic into Tatar, which encouraged the Kräshens to read and learn more about the Muslim faith. Estifeev, the leader of the 1802-1803 apostasy, knew Arabic and Persian, which shows that he had access to higher learning because these languages were not taught as subjects in the primary Islamic schools. In the mixed Mishar-Chuvash village of Moklokovo there were two mosques. It is possible that Estifeev studied there, but his age and his unmarried status suggest that he might have studied in a more distant madrasa. Peasants encouraged early marriages to increase production, and those who married early often worked on the land and had no time for going to school. Estifeev, on the contrary, fitted the pattern of those Muslim students who left home to pursue their studies in a distant land and married upon their return. The training in madrasa was particularly long and strenuous.

160. Eruslanov, "Magometanskaia propaganda," no. 14 (1895): 276; Nikolai Il'minskii, "O kolichestve pechataemykh v Kazani magometanskikh knig i o shkole dlia detei kreshchenykh tatar," in Kazanskaia tsentral'naia, ed. Il'minskii, 113-114; Malov, "Pravoslavnaia protivomusul'manskaia," 14, pt. 2, no. 7 (1868): 230, 232, 242-244, 246-249, 250-253; M. N. Farkhshatov, "Ob uchebnykh posobiiakh mektebov i medrese Bashkirii do nachala XX veka," in Sotsial'nye i etnicheskie aspekty istorii Bashkirii (Ufa, 1988), 45; on the cost of books, NART, f. 10, op. 1, d. 1655, 1. 16 ob.; Evfimii Malov, Akhyr zaman kitaby: Mukhammedanskoe uchenie o konchine mira (Kazan, 1897), 38; Timofeev's diary in Il'minskii, ed., Kazanskaia tsentral'naia, 72; for a detailed history of the printing of Tatar religious books, Abrar Karimullin, $U$ istokov tatarskoi knigi (Kazan, 1971), 177; Geoffrey Roper, "Faris al-Shidyāq and the Transition from Scribal to Print Culture in the Middle East," in The Book in the Islamic World: The Written Word and Communication in the Middle East, ed. George N. Atiyeh (Albany, 1995), 216.

161. NART, f. 1, op. 3, d. 231, 1. 228 ob. (Rozov's report); and f. 2, op. 2, d. 5129, 1. 2.

162. Il'minskii, Opyty perelozheniia, 23-24; "Abyzy," in Islam na Nizhegorodchine. Entsiklopedicheskii slovar' (Nizhnii Novgorod, 2007), 8-9. 
It is likely that Estifeev studied at the madrasa of Ovechii Vrag, where the founder, Abdul Zhälil Bikkinin (b. 1740?), well known for bringing Kräshens to Islam, taught Islamic sciences, Arabic, Persian, and mathematics. According to one story, when the famous abiz learned that his Tatar-speaking coachman's name was Semen, he stopped his carriage abruptly, instructed the coachman in the tenets of Islam, and changed his name to Süläyman. The teacher of Ovechii Vrag invited Kräshen children to his school. At his request, the son of a Kräshen woman from Bazlovo village stayed three months (probably free of charge or in exchange for light labor) at his school, leaving his father and mother behind. Bikkinin wanted the boy to pursue his studies, but his father needed him for work. Nevertheless, the mullah's efforts were not spent in vain. Once back at the village, his former student taught his family what he had learned at school. ${ }^{163}$

Although not all Kräshens had access to higher learning, some had access to one form or another of primary schooling. Proportionally, in Kazan province in the 1850 s, the number of mosques was higher per capita than the number of churches. There were 731 mosques with schools attached for about 400,000 Muslims, which did not include official and clandestine prayer houses, and there were 950 churches for $1,076,744$ Orthodox Christians. ${ }^{164}$ The same could be said about Viatka province where in 1902 Kräshens lived mainly in two districts, Elabuga and Malmyzh, and often apostatized. There was one mosque in the province for every 799.5 Muslims and one church per 3,640.5 Christians. More important, there was one Qur'anic school per 594.1 inhabitants and one church school for every $1,362.3$ inhabitants. Similarly in Ufa province in the 188 os there was one Russian school (either a Ministry of Education, zemstvo, private, missionary, or church school) for every 3,160 inhabitants and one Qur'anic school per 784 inhabitants. ${ }^{165}$

Islamic schooling was both a tool of conversion and resistance. Each time Kräshens declared their apostasy, they publicly opened a school, invited madrasa students to teach their children, or appointed a literate Kräshen. Baptized children who lived in mixed villages in Tetiushi or Sviiazhsk districts, where Muslim Tatars constituted the majority, attended the Qur'anic school assiduously. Kräshens also participated physically or financially in the construction of the mosques and schools. ${ }^{166}$ But in some cases, the rest of the Tatar community refused to provide for the educational needs of the baptized families and barred them from their schools and mosques. Literate Tatars of the same villages, then, took upon themselves the function of

163. Il'minskii, Opyty perelozheniia, 23-24, 68; "Bikkinin, Abdulzhalil," in Islam na Nizhegorodchine, 28-29; Damir Mukhetdinov, “Traditsii sufizma na Nizhegorodchine: Istoki i evoliutsiia," Sufizm kak sotsiokul'turnoe iavlenie v Rossiiskoi umme (Nizhnii Novgorod, 2007), 67-68; idem, Iz proshlogo religioznogo musul'manskogo obrazovaniia na Nizhegorodchine v XVIII-nachale XX vv. (Nizhnii Novgorod, 2004), 10-11, 18.

164. According to Nikolai Il'minskii and Gordii Sablukov (1804-1880), a professor at the Kazan Theological Academy, in the late 1850s, NART, f. 10, op. 1, d. 1655, 1. 17.

165. M. Reshetnikov, "O nuzhdakh pravoslavnoi missii sredi magometan Viatskoi gubernii," Viatskie eparkhial'nye vedomosti, no. 20 (16 October 1905):1097, 1099-1100; B. Iuzefovich, Khristianstvo, magometanstvo i iazychestvo $v$ vostochnykh guberniiakh Rossii (Moscow, 1883), 32-33.

166. NART, f. 4, op. 97, d. 1, 11.87 ob, 148 ob. 
unofficial mullahs, visited families in their homes, and instructed their children separately from the other Muslim children. ${ }^{167}$

In all-Kräshen villages where there was neither mosque nor official mullah, the situation was more complicated. Itinerant Tatar mullahs, among them artisans and shakirds (students), who often hid their identity, taught Kräshen adults and children. Because the state imposed a strict quota on the number of mosque congregations (mahalla) and limited their proximity to Kräshen, baptized Finno-Ugric, or Chuvash villages, the opening of new mosques was a very delicate operation. Shakirds were often unable to find a permanent position in a village school or mosque after completing their education. But villagers welcomed them to serve as their unofficial mullahs. In the 1840s, a Muslim Tatar from Spassk district regularly visited the Kräshens in Baitiariakova village, Chistopol' district, and read them prayers at home. Later, in the 1860 s, a Muslim skullcap maker from Tetiushi district who had studied in Kazan taught Kräshen and Tatar children in the mixed Tatar-Kräshen-Chuvash village of Azbaba, Sviiazhsk district, and at the villagers' instigation, served as their unofficial mullah. Finally, in 1865, a teacher named Muhi ad-Din, assisted by his wife, taught both boys and girls in the village of Elyshevo, Mamadysh district, for several months before leaving for another village. ${ }^{168}$

These itinerant teachers' pedagogy was quite effective. Muhi ad-Din's students in Elyshevo had learned to reject all images, drawings, portraits, icons, and crosses - the symbols of the Orthodox world. His main textbook was the Muslim primer Sharä'it al-İmān or as it was popularly known among the Tatars, Imān Sharțī (Principles of the Faith) by which the children learned not only reading but also the personal and communal obligations of their faith during the first year of primary school. Although they could not translate their Arabic prayers into Tatar, Muhi ad-Din's students mastered the rudiments of literacy and the Muslim faith. These results were comparable to those of the schools attached to the Tatar mosques. ${ }^{169}$

Among the 1860 s leaders of the apostasies whose ages varied between thirty and sixty, the level of literacy was the highest-demonstrating knowledge equivalent to at least four years of primary schooling. One such leader in Elyshevo could read the Häft-i Yäk almost without error and was able to translate Arabic words into Tatar. Another, who was particularly respected by the villagers, took the Häft-i Yäk and read it with the aid of the tafsir (commentary on the Qur'an or exegesis), which existed in Turkic language. ${ }^{170}$ But the students of Qur'anic schools could advance far beyond the mere recitation of certain religious texts. The Kirilov (in Tatar, Wälitov) brothers of Udmurt origin, who played a critical role in the apostasy of Elyshevo, and had an impressive quantity of Islamic works including the Häft-i Yäk and the tafsir,

167. NART, f. 1 , op. 3 , d. 846 , ll. $1-2$; f. 1 , op. 3 , d. $228,1.151$.

168. NART, f. 1, op. 2, d. 399, 1. 14 ob.; and f. 13, op. 1, d. 1044, 1l. 4 ob.-6, 15, 27, 32 ob.; Malov, "Ocherk," 18, pt. 1 (1872): 65, 396.

169. Malov, "Ocherk," 17, pt. 3 (1871): 240, 243-244, 247-248, 406.

170. Malov, “Ocherk," 17 , pt. 3 (1871): 241-242. In the tafsir, every word, every verse is glossed. The tafsir provides grammatical and historical information helpful in understanding the text. The Volga Tatars preferred the tafsir of Jalal ad-Din al-Mahalli (d. 1459) and his disciple Jalal ad-Din as-Suyuti (d. 1505) (Iakov Koblov, "Konfessional'nye shkoly Kazanskikh tatar," Inorodcheskoe obozrenie 2, no. 1 [1915], supplement to PS [December 1915], published in PS, January-February 1917: 28, footnote 2). 
demonstrated their literacy at their trial by reading aloud the petition and Tatar notes sent to them from Kazan. By doing so, the Kirilovs proved their ability to make the connection between the Arabic characters and the Tatar sounds they represented, to decipher a message whose form was not fixed by tradition or dictated by God, and finally to create their own text. One of the criticisms advanced by Russian missionaries and later Tatar modernists was that in traditional schooling, students could read only the texts that they had read with the mullah. ${ }^{171}$

Literacy undoubtedly played a crucial role in consolidating the apostasy movement. Not only did it allow apostates to write petitions or exchange strategic messages, but it also allowed families of neighboring villages to strike important marital alliances to consolidate Islam in their communities. During the apostasy of 1866, an Islamized family of Kibiak-Kozi conducted marital negotiations by mail; in a letter they offered their daughter to a young Kräshen man of Elyshevo on the condition that he officially convert to Islam. ${ }^{172}$

As a rule, the higher their level of education, the more the Kräshens resisted church intrusion. In 1866, the undecided in Elyshevo were often illiterate, mixed Russian and Arabic prayers together, and remained attached to their animist beliefs. Consequently, when Russian authorities and missionaries arrived to put an end to the apostasy, villagers did not show a united front, and allowed the police to question them separately, which led to the arrest and exile of the main leaders. Higher levels of Islamic knowledge could also lead to another form of internal strife: a new mullah with a deeper understanding of the texts could threaten the position of previous underground mullahs. As a result, villagers' knowledge of Islam constantly changed. ${ }^{173}$

Very often clandestine schools were headed by women, partly because they usually took care of the farm during the months their husbands were away; partly thanks to the separation of the sexes, the woman's world was closed to the male-dominated Russian state and clerical authorities. It is also possible that women who traditionally directed ancestral indigenous worship of the kirämät, as was the case in the village of Taveli, enjoyed special authority and once they partook in the civilization of Islam, they became its most enthusiastic carriers. After 1865 (the year Muhi ad-Din left the village), a baptized woman who had studied in Kazan before moving to Elyshevo secretly taught the village girls. ${ }^{174}$ In 1870 , another Kräshen woman replaced her. Some nearby villages such as Tri Sosny (Öch Narat), Staraia Ikshurma, Savrushi, Sosnovyi Mys (Jänäy), Tokhtamyshevo in Mamadysh district, Kibiak-Kozi and Ianasal in Laishevo district, and Aziak in Kazan district also had clandestine Qur'anic schools. In Tokhtamyshevo, Elena Iakovleva, a widow and mother of eight (the oldest was nineteen and the youngest three) taught apostate and nonapostate Kräshen and even Muslim Tatar children. In 1883-1884, Kräshens who remained faithful to Christianity asked for the Kazan Consistory to close the clandestine Qur'anic school of Evdokiia Petrova in Bol'shie Savrushi, which attracted children of officially apostate and nonapostate parents. Even the village of Nikiforova where Il'minskii's system of

171. Malov, “Ocherk," 18 , pt. 1 (1872): 72, 76-78; NART, f. 13, op. 1, d. 1003, 1l. 12-12 ob.

172. NART, f. 13 , op. 1 , d. 1003 , 1l. $28-28$ ob.

173. Malov, Missionerstvo sredi mukhammedan i kreshchenykh tatar (Kazan, 1892), 114-117.

174. Il'minskii, ed., Kazanskaia tsentral'naia, 153. 
education was fully adopted, hosted a clandestine school for well-to-do apostates who numbered only twelve in the 188 os. Sometimes villages had two or three schools in private houses, allowing children to come surreptitiously in very small groups early in the morning or in the evening, since the schools' fragile existence was constantly threatened by priests, police, and disgruntled neighbors who denounced the clandestine teachers to the authorities. ${ }^{175}$

However, it was not just the privilege of women to teach in this underground network of Islamic primary schools. Any person who knew how to read and write could become a teacher. In the apostate village of St. Kiremet' (Iske Qarmät), Chistopol' district, Fäkhrulla Tahir (1849-1924), the father of the famous poet Khäsän Tufan (1900-1981), taught children basic Islamic literacy with other literate fellow villagers. ${ }^{176}$ If necessary, villagers sent gifted children away to acquire a more sophisticated knowledge of Islam. In 1883-1885, an adolescent from Elyshevo, son of the unofficial mullah, studied in the madrasa of Toygil'dino (Töygel) in the district of Menzelinsk, Ufa province, where tailors from Elyshevo liked to work. Upon his return, the young man, Ibrahim Bikmökhämmät ulï (Bikmökhämmätov) (d. 1933), was appointed mullah, taught boys and girls at his house, kept marriage registers, and a strict account of the mähär (bride price) and alms given in nature and money by his parishioners between 1899 and $1903 .{ }^{177}$ If bothered by the authorities, unofficial mullahs argued that they collected birth, marriage, and death data for the volost' ${ }^{178}$ Ibrahim's mother, a teacher herself, married him to a literate woman, who became responsible for the girls' education. ${ }^{179}$

The oldest visible date on Elyshevo's tombstones, 1887, confirms that roughly at the time when the young Ibrahim Bikmökhämmätov was sent south to study, Islamic literacy had become much more generalized, or at least more visible in the village landscape. To mark the location of their relatives' tombs, the Elyshevites (literate or illiterate) used to inscribe the more discrete tamghas, which also identified their clan in their petitions to the czar, on small size elongated narrow flat boards or on a stone. ${ }^{180}$ But in the 188 os, richer apostates had more elaborate tombstones erected.

175. RGIA, f. 821 , op. 8 , d. 763 , 1l. 288 ob., 289 ob., 299-299 ob., 301-301 ob.; and NART, f. 1, op. 3, d. 1818 , 1. 4; f. 1, op. 3, d. 5720, 1. 5; f. 4, op. 101, d. 16, 1l. 17-18, 21-21 ob.; and f. 967, op. 1, d. 8, 1. 6; Otchet o deiatel'nosti Bratstva Sv. Guriia za semnadtsatyi bratskii god s 4 oktiabria 1883 goda po 4 oktiabria 1884 (Kazan, 1884), 20; “Zakladka tserkvi v derevne Staroi Ikshurme," IKE no. 15 (1 August 1891): 468.

176. Khatip Ghosman, “Zur khislär häm tirän ideyalär shaghïyre," in Khäsän Tufan, Saylanma äsärlär (Kazan, 1964), 6; Mäsghud Ghaynetdinov, Dawillarda jillärdä: Khäsän Tufannïng tormïsh häm ijat säkhifäläre (Kazan, 1989), 8; Maksim Glukhov, "Khasan Tufan,” in Tatarica: Entsiklopediia (Kazan, 1997), 468; Tufan (Kazan, 2000), 16.

177. Otchet o deiatel'nosti Bratstva Sv. Guriia za dvadtsat' tretii bratskii god s 4-go oktiabria 1889 g. po 4-e oktiabria 1890 goda (Kazan, 1890), 43. The boys' parents gave the mähär to the girls' parents to pay for the marriage ceremony and guarded it for their daughter in case of divorce. Bikmökhämmätov's records indicated that Elyshevites in 1903-1905 paid between 15 and 400 rubles for the mähär. See marriage and alms registers in Gölsinä Khämidullina’s private collection. On the meaning of mähär in Islam, see G. N. Akhmarov, Svadebnye obriady Kazanskikh tatar (Kazan, 1907), 17, 19, 20.

178. Chicherina, $U$ privolzhskikh inorodtsev, 143. Other examples of underground mullahs keeping registers for their parishioners in the 1890 can be found in NART, f. 2, op. 2, d. 5133, 1. 5; f. 2, op. 2, d. 5136, 1. 6 ob.; and f. 2 , op. 2 , d. $5137,1.3$.

179. NART, f. 1, op. 4, d. 4775, ll. 4-5 ob.; and f. 1, op. 3, d. 7798, 1l. 178-179; Ildus Zahidullin, "Jilïsh awilï mäk'ruhlarï," Miras 48, no. 11-12 (1995): 138-139.

180. Tomb of Iskhaq Bäshir ughlï of Udmurt descent, Elyshevo cemetery. 
Another tomb dated from 1898 quoted the shahada (the witness of faith). Such funerary inscription invited the literate passerby to read the prayer, and earn salvific merit for himself and the deceased. These tombs made clear to the public, be it Tatar, Kräshen, or Russian, that Islam was meant to stay in Elyshevo, despite the presence of a church. They also witnessed that the Elyshevites of the 1880 os-189os, who had seen their neighbors and kin depart in chains for Siberia in 1866 and 1878, were not fearful of the police anymore. Indeed, a bride from Elyshevo, who had married a baptized apostate from Chistopol' district had her family petition approved in 1895 due to the Kazan governor Poltoratskii's willingness to contemplate the possibility of a general amnesty for descendants of apostate families. ${ }^{181}$

At the turn of the twentieth century, Elyshevo had five unofficial teachers for 275 inhabitants; that is one teacher for every 55 villagers-an impressive ratio. In April 1907 , the village finally received the official authorization to open a mosque. But the history of the teaching of Islam underground did not end there. During the collectivization, the revered daughter of Mullah Ibrahim Bikmökhämmätov, Mahisärwär (1902-1988), who died in a state of purity after performing her ablutions, revived her father's work and fulfilled the function of underground female teacher (abïstay). ${ }^{182}$

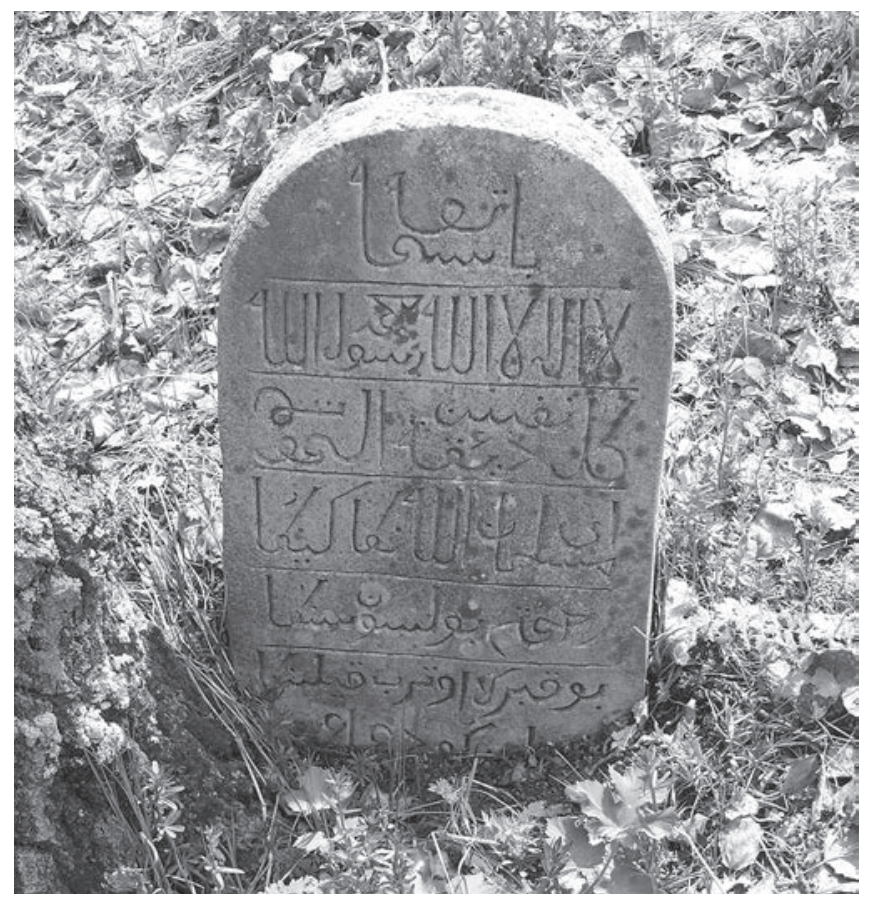

1.2: Tombstone in Elyshevo cemetery. Photograph by the author.

181. NART, f. 2, op. 2, d. 5129, 1l. 20-21, 25, 28-29.

182. Volost' statistics in 1883 in NART f. 1, op. 3, d. 5720, 1l. 17-17 ob.; G. Khämidullina, interview by author, May 2008, Elyshevo. 
As a result of this permanent thirst for and accumulation of knowledge from one generation to another, a literate native elite arose not only among the Elyshevites, but also among other Turkic and Finno-Ugric villages of the Volga-Ural region, spreading Islam in their midst and beyond. In the 186os, a baptized Chuvash served as a teacher and mullah in the Chuvash village of Kukshum, Tetiushi district, listed as a Tatar village in 1912; during a raid at his father's home, the police confiscated eleven Qur'ans, as well as a manuscript and religious books in Tatar. Even more impressive was that these new teachers taught not only within their own communities, but also in distant lands. For example, the descendant of apostates and future official mullah of Verkhniaia Nikitkina in 1909, taught around 1905 as a private teacher in the home of a rich Kazakh. ${ }^{183}$

Baptism prior to the reforms of Catherine the Great served initially as a cement between various ethnic communities and individuals, dislocated by the conquest. Many Kräshens were still attached to their indigenous beliefs and exposed to some degree to Islam, but wished to partake of their new conqueror's economic and spiritual power. However, after Catherine's reforms, many, but not all, baptized Tatars chose to apostatize from Christianity to Islam, revealing the presence of a strong Islamic missionary movement in their midst. Gradually, apostates to Islam moved from identifying themselves with their immediate village to a more geographically expansive sense of religious identity, which linked them to other apostatizing villages and to the civilization of Islam. Like the peasants in Algeria during the French rule, Islamized baptized Tatars also learned to cope with the colonial administration by absorbing some rudiments of the dominant state language and studying the intricacies of the legal system. Baptized peasants and merchants learned from their colonizers and challenged the way they constructed their religious identity. ${ }^{184}$

The mechanics of the apostasy movement showed that even though conversion to Islam was the result of a slow and gradual process of acculturation, the time of the apostasy constituted an important cathartic moment when apostates publicly proclaimed their detachment from Christianity, argued for their Islamic renewed identity, invited other hesitant villages to join them, and changed the religious landscape of their village. In some specific areas, the converted made a choice between not only Islam and Christianity, but also-less abruptly for sure-between their own indigenous beliefs (whose strength should not be underestimated) and the two universal religions. Even in the cases when it could be argued that apostates were cryptoMuslim, the apostasies can still be regarded as movements of intra-faith conversion. They involved the revitalization of one's faith by using Islamic eschatological rhetorical devices and obliged the baptized Tatars to defend and articulate their religious beliefs through their conquerors' legal grid.

One of the key explanations for the expansion and consolidation of Islam in the baptized milieu was the spread of literacy and religious print. Their diffusion

183. NART, f. 1, op. 3, d. 222, ll. 1-3 ob.; f. 1, op. 3, d. 231, 1. 229; f. 93, op. 1, d. 128 v., 1. 45; Spisok selenii Kazanskoi gubernii. Vypusk 7. Tetiushskii uezd (Kazan 1912), 15; Leonid Abramov, ed., Na Zasechnoi cherte: Iz proshlogo i nastoiashchego novosheshminskogo raiona Tatarstana (Kazan, 2007), 138.

184. Ouarda Siari-Tengour, "Requêtes paysannes et Résistance culturelle," in Pratiques et résistance culturelles au Maghreb, ed. Noureddine Sraiev (Paris, 1992), 237-246. 
encouraged the formation of an indigenous elite who complemented the teaching of sympathizing neighboring Tatar peasants, mullahs, Naqshbandi shaykhs, and itinerant students who came sporadically to their villages. Apostate villages also had their own teachers: fathers who tailored in Muslim areas or Islamized Kräshen milieus, mothers who had been in contact with Tatar women in everyday life, blind teachers who knew prayers by heart. The result was that in 1901, the mullah of the parish village of Meleuz in Sterlitamak province, Ufa district, was a Kräshen who had a higher Islamic education and gone to Mecca on the pilgrimage. ${ }^{185}$

Qur'anic schooling not only confirmed what Kräshens had heard of Islam at the market, sacred places, or at popular festivals, where they met Tatars, but it also gave them the ability to copy petitions, write names of petitioners, and decipher messages that were not of a religious content. Most important, the books used in Qur'anic schools, also sung at family reunions or popular festivals, prepared the way for their religious transformation. Apostate representatives drew images and metaphors from this literature, which struck people's imagination and strengthened their resistance to foreign encroachment. The following chapter examines the content and impact of this prose, which late nineteenth-century modernist Tatars blamed for introducing superstitions and false legends into popular discourse. These literary works, however, molded their childhood, the context they lived in, and penetrated the baptized milieu. They were the result of earlier processes of Islamization in the Turkic world and the product of a major Islamic revival of Sufi origin in the eighteenth century, which influenced the individual and collective consciousness of the converted communities and prepared them to respond to the Mahdist rhetoric of the vagabond Sufis who pressed them to join the community of their ancestors: Islam.

185. Otdel rukopisei Kazanskoi nauchnoi biblioteki, f. 7, ed. khr. 18, 1l. 160-16o ob. 


\section{Popular Knowledge of Islam on the Volga Frontier}

$\mathrm{I}$ $\mathrm{n}$ addition to playing an important role in the spread of the apostate movement, Islamic knowledge, both oral and written, provided an important tool for baptized Tatars to understand the universe and their place in it. The principal agent of Tatars' spiritual conquest among starokreshchenye and novokreshchenye was "popular Islam." This was an Islam understood, lived, and spread by ordinary peasants, artisans, or traders who had spent time at the primary Qur'anic school or who had heard the image-filled sermons of itinerant Sufis. This Islam combated the attachment of the Volga peasants to their ancestral animism, drew a sharp line between Christianity and Islam, and prepared the hearers to take the quest for the truth into the madrasas of Bukhara and Samarkand. Popular Islamic discourse always appealed to the written word as the ultimate guarantee of its authority. It thus contributed to the introduction of literacy into the villages and encouraged animists and Christian Tatars to become familiar with Islamic teaching and writings. These men and women then became the leaders of ever larger movements of collective apostasy. By incorporating new villages in the Dar al-Islam, or the house of God, they triumphed over the assimilationist policy of the infidel Russians and strengthened the Tatar Muslim identity. These victories prompted Orthodox missionaries of the $1860 \mathrm{~s}$ to promote aspects of Eastern Orthodox spirituality that could match the popular understanding of the afterlife as expressed in the context of the apostasies to Islam.

An analysis of popular Islamic discourse and knowledge among the Christian Tatars and their proselytizers permits us to evaluate the religious culture of the Tatar Muslim peasantry, appreciate its methods of defense against the Russian state, define the cultural and economic networks that connected the Christian Tatars to the Muslim world, and finally reveal the ways literacy spread in the Middle Volga. Although the state and the church interfered in the baptized Tatars' practice of Islam, "baptized" Islam was no less "Muslim" than "Tatar" Islam. ${ }^{1}$ Paradoxically, Tatar reformers of the late nineteenth century rejected this popular expression of Islam, despite its success in preserving and extending the Muslim community. Like the Russian Orthodox missionaries, they regarded popular Islam as pure superstition. Above all, they held it responsible for Western Islamophobic attacks and for Muslim misinterpretations

1. For a different perspective, see Aleksandr Kobzev's work on the new converts of Simbirsk province, Islamskaia obshchina Simbirskoi gubernii vo vtoroi polovine XIX-nachala XX vv.: Monografiia (Nizhnii Novgorod, 2007). Kobzev argues that since the new converts of Simbirsk province did not have full access to Islamic knowledge, their Islam was not as "orthodox" as their Muslim brethrens, who could freely and uninterruptedly attend the mosque and benefit from their mullahs' advice and teachings. 
of the Qur'an, without seeing it as a veritable Islamic code of life conditioned by the religious environment of the Volga countryside and as a precursor of their own reforms. Nevertheless, the reformists' critical reading of popular knowledge of Islam did not keep their publishing houses from disseminating the literary foundations of the knowledge that they sought to change.

Apostates, both men and women, used scriptural tools to imagine their universe and resist the imposition by Russian missionaries of a cultural code alien to them, and incorporated the written word into their oral culture. This chapter demonstrates that the apostate Kräshens and their Tatar neighbors' knowledge of Islam had a scriptural basis imbedded in Sufism, which constituted a model of action for men and women in an environment hostile to the expansion of Islam. The literary, visual, and oral foundations of popular Muslim Tatar discourse-sacred images, talismans, books, songs, legends surrounding sacred places-provided a repertoire of metaphors and edifying stories that apostates and Tatars used to answer for their faith in everyday encounters with non-Muslims and Christian missionaries.

\section{Oral and Written Sources of Islamization}

Signing a petition to be recognized legally as Muslims was the final stage in a long process of Islamization of the Orthodox Christian Tatars and their animist neighbors, a process that would have been impossible without cultural networks that connected them to the Tatar Muslim community. Islamization began orally, at the family table, between parents and children, older and younger siblings, at the market place or eating houses (kharchevnia in Russian), and during major religious festivals between neighbors of various ethnic origins and occupational backgrounds. ${ }^{2}$ Originally, the "book" of popular Islam consisted of stories taken from the Qur'an, the hadith (the "traditions" about the practices and sayings of the Prophet Muhammad transmitted through a chain of authorities), Sufi inspired tales of the prophets, chanted prayers, mural images, and legends surrounding sacred places. It was an Islam based on mystical literature that sought to define itself against its closest competitors-Christianity and indigenous beliefs.

Most of the stories were recorded by traveling native Christian missionaries and teachers, such as the Kräshens Vasilii Timofeev from Nikiforova village, Mamadysh district, and Stefan Matveev (b. 1879) from Menzelinsk district, Ufa province, the Mari Petr Eruslanov, Russian orientalists and pedagogues including Nikolai Il'minskii, Evfimii Malov, Mikhail Mashanov (1852-1924), and Sofiia Chicherina (1862-1921), and the Hungarian linguist Gábor Bálint (1844-1913). Ethnographers were more interested in the animist side of the old convert cosmology or Islamic practices among the Muslim Tatars, but they rarely examined Islamic beliefs among the baptized Tatars. Orthodox missionaries, threatened by Islamic proselytism, were more sensitive to the different levels of Islamization among the Kräshens, but they recorded few stories and even eliminated from their diaries those that they considered too extravagant-not only because of their Christian bias but also because they judged them to be heterodox from an Islamic point of view. Despite the scarcity of sources

2. Iapei Babai, "O kreshchenykh tatarakh," no. 20 (15 October 1891): 633-635. 
and their partiality, it is possible to reconstruct the Kräshens' Islamic worldview just by taking the so-called superstitious stories seriously and reestablishing their Islamic meaning. This can be done by retracing the literary Sufi origins of the Tatar missionary discourse and looking at the books that were known to the apostate Kräshens in the nineteenth century, as reflected in Russian missionary sources. Some of these prerevolutionary books mentioned in Christian missionary diaries survived the antireligious campaigns of the 1930s and the academic expeditions of the 1960s and 1970s, and can still be found in the villages of former apostates in the Kukmor and Bogatye Saby (Baylar Sabasi) regions in either manuscript or printed form.

Entering the Volga from Central Asia, Sufi teachers of the Yasawiyya and Naqshbandiyya orders had introduced many important popular religious texts to the local population from the twelfth century on. Both orders, well known for their use of native languages as a tool of conversion and their flexibility toward local customs, played an important role in the conversion to Islam of Mongol and Turkic tribes in Eurasia. These epics and poems reflected earlier encounters between Islam, Christianity, and shamanism in Eurasia and Central Asia in the fourteenth century. Muslim missionaries of different ethnic backgrounds reappropriated these works to construct normative models for dealing with their Russian overlords in the nineteenth century. Analyses of these texts-and the ways in which they were used-offer more than a view of peasant Tatars' knowledge of Islam in nineteenth-century rural central Russia. They also provide another perspective on popular imagined worlds created through storytelling, and reveal a particular thaumaturgical understanding of Islam that persists today in Tatarstan.

\section{Myths, Objects, and Literature as Sources of Islamic Knowledge}

A conversion myth, known to Tatars and Kräshens of nineteenth-century Mamadysh district, lamented that Ivan the Terrible had locked Tatars in an overheated muncha (steam bath) to force them to accept baptism. ${ }^{3}$ By contrast, oral and written narratives of the Bolghars' Islamization emphasized healing, fecundity, and knowledge. According to tradition, Tuy Bikä, the daughter of the Bolghar king Aydar, was miraculously cured of her paralysis in the muncha by three companions of the Prophet Muhammad. Because the companions arrived in winter, the birch trees were bare of their healing leaves, so the three men used the gifts the Prophet gave them before their departure-a staff, an inkwell, and a turban. They placed the staff in the inkwell-a clearly phallic image-and an enormous birch tree sprouted from the inkwell; next they made whisks from the tree and used them to brush the king's daughter, who was healed. Her father, in gratitude, embraced Islam. ${ }^{4}$

Whereas the Christianization story emphasized death, forceful conversion, and spiritual emptiness, the Islamization narrative stressed bodily purification

3. "Otchet bakalavra Kazanskoi dukhovnoi akademii N. I. Il'minskogo o poezdke po tatarskim seleniiam (August-September 1848)," in Khristianskoe prosveshchenie, 84; Mikhail Mashanov, "Zametka o religiozno-nravstvennom sostoianii kreshchenykh tatar Kazanskoi gubernii Mamadyshskogo uezda, IKE, no. 2 (15 January 1875): 51.

4. Husām ad-Dīn b. Shäraf ad-Dīn al-Bolghārī, Risālä-yi täwārīkh-i bolghāriyya wä zikr-i Mäwlānā Häżrät-i Āqsāq Timur wä khärāb-i shähr-i Bolghār (Kazan, 1887), 15-17; Frank, Islamic Historiography, 62-63. 
and fertility. By inserting the staff into the inkwell, the companions symbolically connected the Bolghars to the time when the first Pen inscribed God's Word on the divine Tablets and contractually sealed the Bolghar people to the Prophet's community. The birch tree reaching the skies was reminiscent of two mythical trees in Islamic cosmology: the Tree of Certainty (shajarat al-yaqin), which held the Light of Muhammad from where God created the whole universe, and the Tree of Life in paradise, a symbol of the good and a promise of eternal bliss. Its presence in the VolgaUral region and especially on women's tombs constituted a powerful reminder of the time when the Bolghar land adopted Islam and was impregnated with the Prophet's knowledge. Legends claimed that the Khan Aydar's daughter married one of the companions and became an itinerant teacher of the law. ${ }^{5}$

The conversion myth of the Bolghar land was the central piece of a popular history of the first Muslim state in the Volga-Ural region, Täwārìkh-i Bolghāriyya. Although attributed to the sixteenth-century author Husam ad-Din b. Shäraf ad-Din al-Bolghari, the work was probably composed much later, in the late eighteenth or early nineteenth century. In the context of the apostasy movement, his book's shrine catalogue constituted a "missionizing map" for bringing baptized Tatars to Islam. It included the tombs of taba' at-tabi' in (followers of the followers of the Prophet Muhammad) in the very large baptized communities of Melekes in Krugloe parish and Bol'shie Aty, Verkhnie Chelny and Aksarino in Lebiazh'e parish, Menzelinsk district, Ufa province-indicating that these communities-initially composed of mid-seventeenth-century migrants from baptized villages along the Ziuri and Arsk roads in the Kazan and Mamadysh districts-belonged to the sacred territory of Bolghar Islam. These villages were composed mostly of starokreshchenye, Muslims, and Finno-Ugric peoples, who built the Trans-Kama fortified lines at the heart of the former Bolghar kingdom from the seventeenth century on. Except for Samigulov's native village Tubïlghïtaw (Verkhniaia Nikitkina), which apostatized in the 1820s, the other villages cited by Husam ad-Din al-Bolghari, including Baigulovo and Baidankino in the Zay Valley, remain Kräshen. The chronicler's list of shrines included the names-fabricated or real-of followers of the Prophet after whom the villages were named, implying that these villages were-or would soon become-Muslim. Despite the presence of a small number of apostates in their midst, the communities of Melekes and Aty welcomed the construction of churches in 1888 and 1890, after Il'minskii's reform of Eastern Orthodox literacy in native languages contested and transformed Husam ad-Din's “imagined” religious topography. ${ }^{6}$

5. Annemarie Schimmel, Deciphering the Signs of God: A Phenomenological Approach to Islam (Albany, 1994), 17. It was customary to plant a birch tree on women's graves. People believed that its leaves sang prayers to God for the benefit of the deceased. Aristarkh Speranskii, Kazanskie tatary (Istorikoetnograficheskii ocherk) (Kazan, 1914), 27; R. K. Urazmanova and S. V. Cheshko, eds., Tatary (Moscow, 2001), 370-371. On Tuy Bikä, see Tatar khaliq ijatï. Riwayätlär häm legendalar (Kazan, 1987), 27.

6. Husām ad-Dīn al-Bolghārī, Risālä-yi täwārīkh-i bolghāriyya, 19-20; Frank, "Qāsim Shaykh al-Qazānī: A Muslim Saint in Tatar and Bulghar Tradition," Asiatische Studien/Etudes Asiatiques 58, no.1 (2004): 123-124; Ähmärof, "Mükrehlär hālendän," cols. 1-2; Malov, "Statisticheskie svedeniia," Uchenye zapiski Kazanskogo universiteta, 378-379; Baiazitova, Govory Tatar-Kriashen, 29-31, 40; Iskhakov, Etnograficheskie gruppy tatar, 130; Glukhov-Nogaibek, "Perechen' kriashensko-nagaibatskikh i besermianskikh selenii," in Sud'ba gvardeitsev Seiumbeki (Kazan, 1993), 281, 283. 
Muslim proselytizers of baptized and Tatar origin-Sufi shaykhs, female teachers, and seasonal workers-knew of Husam ad-Din's work, which was the most widely read history in the Middle Volga in the nineteenth century, and believed that the "lost" Kräshens could be reconnected to the power of God through the dissemination of Islamic knowledge. This knowledge took oral, written, and topographical forms. It included shama'il (sacred illustrations with Arabic text), talismans, and books, often printed by the University of Kazan as well as manuscripts and tombstone inscriptions.

During the Russo-Japanese War (1904-1905), the missionary and amateur ethnographer Sofiia Chicherina found shama'il in Kazan province apostate homes in places where icons were supposed to hang. These Islamic drawings, sold at village markets, appeared in the Middle Volga at the beginning of the nineteenth century. The most popular ones among Tatars were images of the Ka'ba (the cubic building that stands in the center of the Grand Mosque of Mecca) or objects said to belong to the Prophet Muhammad, in particular the sandals he wore when ascending to heaven. ${ }^{7}$ Another popular shama'il was the Möher-i Shärif (the sacred seal) whose original drawing was composed in the nineteenth century by Haji Shams ad-Din b. Hösäyen, a Tatar from Nizhniaia Kursa in the region of Arsk, Kazan province, where many baptized villages were located. The drawing consisted of five circles, a large one in the center and four smaller ones in each corner, with the names of Hasan and Husayn-the martyred grandchildren of the Prophet-at the epicenter of one of the circles. The Elyshevites placed it on the chest of a deceased person to appease her torments in the tomb and ease her passage to bliss; its drawing reminded viewers of the solar system with its series of concentric circles, symbolizing the layers of heaven crossed by the Prophet Muhammad during his ascent ( $\mathrm{mi}^{\mathrm{r}} \mathrm{raj}$ ). Tatars as well as apostates believed that after judgment the soul of each believer would travel through the same layers when ascending to God after death-emulating the Prophet Muhammad's midnight journey to heaven. ${ }^{8}$

Other talismans contained Qur'anic verses. In Ufa province, the mullah of Biagitinovo, famed for his sanctity and healing powers, provided the Maris of two nearby cantons (volost') with abbreviated Suras and prayers inspired by the Qur'an for protection against evil spirits. Many descendants of apostate tailors in the Mamadysh and Kukmor regions have kept talismans (doghalïq-bötilär) that belonged to their fathers and grandfathers. One tailor in Elyshevo wore a necklace, with four small leather pockets containing prayers; another, from Ianyli village, kept the book of Ism- $i$ Ázam (The Great Names of God), near his heart while traveling and sowing in Tatar villages. The book's introduction assured its owner that the angel Gabriel had promised Muhammad that reading-or even carrying — the names of God would absolve all sins. ${ }^{9}$

At the beginning of the twentieth century, missionaries also noted that Mamadysh district's tailors eagerly bought Islamic books. These books can still be found in

7. Chicherina, U privolzhskikh inorodtsev, 155; Il'minskii, ed., Kazanskaia tsentral'naia, 59.

8. Gölsinä Khämidullina's private collection, Elyshevo. According to Il'minskii's statistics this shama'il was printed every year in impressive quantities, see Kazanskaia tsentral'naia, 113; Rustem Shamsutov, Slovo i obraz $v$ tatarskom shamaile ot proshlogo do nastoiashchego (Kazan, 2003), 98, 178.

9. Eruslanov, "Magometanskaia propaganda," no. 18 (1895): 83; Gölsinä Khämidullina, “Jätmä (“Zöläykha” fil'mïn qaraghannan song tughan uylar)," Idel 186, no. 2 (2005), 33-35; Do'ā-yi ism-i äzam häm bashqa shärîf dóálar (Kazan, 1898), 2-4; Räshidä Il'yäsova, interview by author, 13 May 2008, Ianyli. 


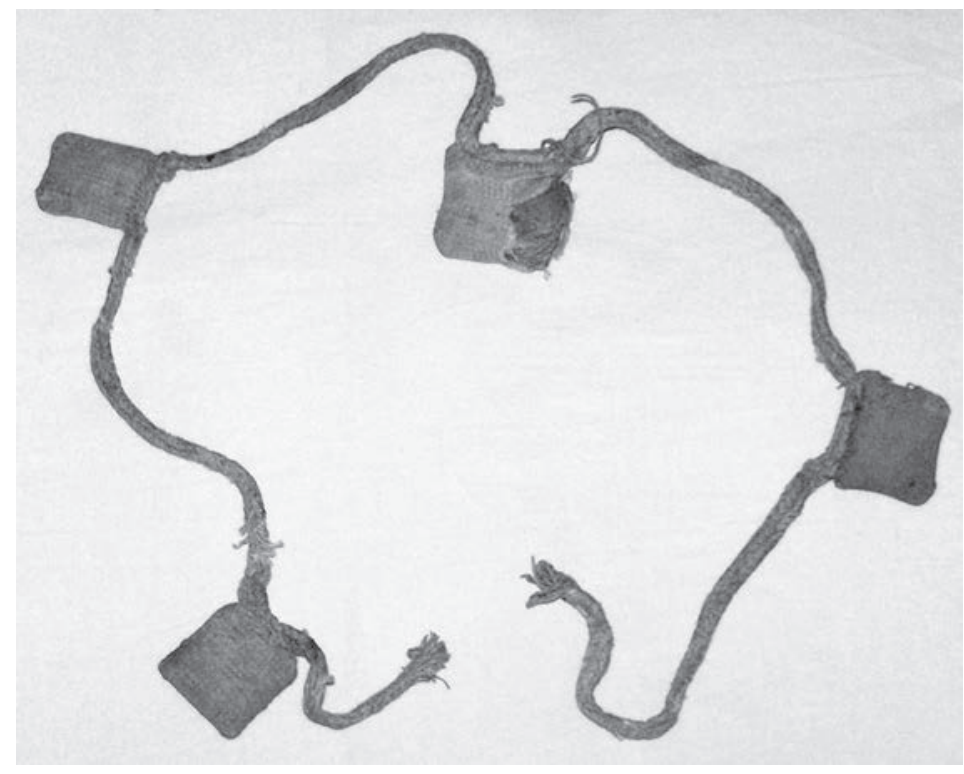

2.1: Talisman in Elyshevo. Photograph by the author.

the homes of former apostate families in Elyshevo and Ianyli villages. They included manuscript collections of munajat (spiritual songs) related to the End of Times and jadid publications of traditional Sufi literature. Yet, even when villagers did not possess such books, they regarded them with respect and were often familiar with their contents. Tatars and Kräshens, literate or not, often affirmed that there were many more Tatar than Russian books. Muslim literature also appeared during funerals when a mullah or a literate Kräshen secretly read or recited the Yā Sìn, the thirty-sixth Sura of the Qur'an, which talks about death, Judgment Day, immortality, heaven, and hell. Yā Sìn is part of the Häft-i Yäk and its commentary, both of which the Russian missionary Evfimii Malov discovered in 1866 in the possession of apostate Elyshevite tailors and representatives. Usually, Tatar children learned to recite the $Y \bar{a} \operatorname{Sin}$ by heart by the end of the first year of Qur'anic school. ${ }^{10}$

Popular knowledge of Islam among the Tatars and Kräshens consisted mainly of stories found in mystical poetry or their commentaries and histories of the prophets. These stories were the subject of animated polemics between Russian missionaries, Kräshens, and their Muslim neighbors. Baptized Tatars, inclined to apostatize or not, knew about Adam, Eve, Abraham, Moses, and Solomon from the Qur'anic tradition, which was sometimes strikingly different from the Hebraic-Christian traditions. Most popular was the tale of the biblical patriarch and Muslim prophet

10. NART, f. 4, op. 133, d. 7, 1. 16; "Zapiska ob otpadenii kreshchenykh tatar ot khristianstva v islam, sostavlennaia na osnove dokumentov arkhiva Kazanskoi dukhovnoi konsistorii (2 February 1849)," in Khristianskoe prosveshchenie, 6o; Tajetdin bin Mulla Yakhshïqol Äshtäki, Häftiyäk shärif täfsire (Berenche tapqür Kazan universitetï tipografiyasendä 1848 yïlda basildi) (Kazan, 2003), 12-54; Validov, Ocherk, 16. 
Joseph, son of Jacob, as recited in Qïsșa-yi Yüsuf (Tale of Joseph), a mystical poem written by the Bolghar Qol 'Ali (b. 1172), and recorded in the Transoxanian Stories of the Prophets (Qișaș al-Anbiyā') by the fourteenth-century judge Nasir ad-Din arRabghuzi. Qïsșa-yi Yūsuf, also called “the Book of Joseph” (Yosïf kitabï), was so well known among the Kräshens and so cheap to buy that Aleksandr Miropol'skii, a Russian archpriest in the baptized village of Apazovo and a diocesan missionary after 1891, suggested writing a small brochure in vernacular Tatar, to be distributed freely, that would contrast the biblical "truths" about Patriarch Joseph against the Qur'anic distortions of his story. ${ }^{11}$

Indeed, Joseph's story was most popular among Muslims, baptized Tatars, and their Russian neighbors. It had all the ingredients of an adventure novel: family betrayal, exile in a foreign land, sexual temptation, sorcery, premonitory dreams, ambition, and final victory over evil. A common script could be drawn from the Bible and the Qur'an: Joseph enjoyed a special place in his father's heart; out of jealousy, his older brothers sold him into slavery. The pharaoh's courtier and chief steward Potiphar bought him, and Potiphar's wife-unnamed in the Bible and the Qur'an but known as Zulaykha in Turkic poetry-attempted to seduce him. Joseph's resistance enraged Potiphar's wife so much that she denounced him to her husband, who threw Joseph into prison. Thanks to his ability to interpret dreams, Joseph attracted the pharaoh's attention and was raised to power. Such was the basic narrative that all could agree on, but for Eastern Orthodox Christians and Muslims it had different meanings, and for Kräshens and apostates, it became the hermeneutical locus for the further development and crystallization of their religious identity, be it Orthodox or Islamic. ${ }^{12}$ For Christians, the Joseph of Genesis was an archetype of Jesus-both were tempted and falsely accused, and both saved their people. However for Muslims, Joseph was an archetype of the Prophet Muhammad: both were orphaned early and exiled; both brought the true faith to pagan polytheists; both had to struggle to be recognized as prophets; both became rulers of great nations; and both were known for their incredible beauty. In the book of Genesis and Russian folk religious songs, Joseph refused to go to bed with his master's wife of his own free will, but in the Qur'an he escaped sin only through divine intervention. ${ }^{13}$ Muslim exegetes argued that Joseph was actually attracted to Potiphar's wife, whose beauty was second only to his own. Had he not seen the figure of his father, Joseph would have succumbed to

11. The Tatar reformist theologian Märjani and later, Tatar Soviet historians have argued that the lexicon of Qișşa-yi Yüsuf (The Tale of Joseph) belonged to the Bolghar period. Märjānī, Mustafād, 1: 13. Alessio Bombaci, however, considers that Qïsșa-yi Yüsuf was probably written in a later period, during the Golden Horde. Alessio Bombaci, Histoire de la littérature turque (Paris, 1968), 92. According to E. R. Tenishev, the language of this work is largely Khorezmian-Oghuz with evidence of Volga Qipchak influence. See "O iazyke poemy Kul Gali 'Kyssa-i Iusuf,'” in Turcologica (Leningrad, 1986), 268-276. Finally, there is no evidence that Miropol'skii's project was ever realized. Nikanor Bobylev, Patriarkh Iosif po Biblii $i$ Koranu, vol. 16, MPMS (Kazan, 1882), 8-10; Nikolai Ostroumov, Kriticheskii razbor mukhammedanskogo ucheniia o prorokakh (Kazan, 1874), 69.

12. Genesis, 39: 1-23; Qứān, 12:23-35.

13. Bobylev, Patriarkh Iosif po Biblii i Koranu, 8-10; Miropol'skii's report to the Bishop of Kazan in NART, f. 4, op. 134, d. 33, 11. 8-9; Genesis 39:10; "Iosif Prekrasnyi," in Belomorskie stariny i dukhovnye stikhi: Sobranie A. V. Markova, ed. T. G. Ivanova, S. N. Azbelev, and Iu. I. Marchenko (SPb., 2002), 165; Qur'ān, 12: 24 . 
her charms. ${ }^{14}$ While Christian interpreters emphasized Joseph's chastity as parallel to that of Jesus, Turkic authors underscored Joseph's manliness as a parallel to the Prophet Muhammad's love for women. "Three things from your world have been made pleasant unto me," said the Prophet, "perfume, and women, and ritual prayer." The same hadith was quoted by the great Andalusian philosopher Muhyi ad-Din Ibn al-Arabi (1165-1240) in The Meccan Revelations to prove that women were not obstacles on God's path; on the contrary, they could lead to God. In other words, loving women was equated to loving God. ${ }^{15}$

Apostates were convinced that the Tatars had the best version. Miropol'skii's projected brochure was meant to denounce the Islamic deviations from the biblical account to guard Kräshens from Muslim influence, especially in Mamadysh, Laishevo, and Kazan districts, which he visited often as part of his mission to stop further apostasies. Early Muslim commentators, among them the collectors of prophets' tales Abu Ishaq Ahmad ath-Thalabi (d. 1036) or the nonidentifiable Muhammad b. 'Abdullah al-Kisa'i (twelfth century?), had used the story of Joseph in a polemical manner to assert the superiority of the Qur'an over the Torah, quoting various prophetic traditions in support of the idea that God had revealed the complete version of Joseph to Muhammad alone as proof of his prophethood. Apostates fully shared their opinion. ${ }^{16}$

Long before the spread of printing among the Tatars, the story of Joseph and other popular religious literature were available in written form. Permeated by Sufi symbolism and traditions, they were written in türki, a literary language close to Ottoman Turkish or Central Asian Chagatay Turkish, the literary language of Central Asia, occasionally reflecting local phonetic and grammatical peculiarities. ${ }^{17}$ These manuscripts and books, also found in Turkey, Central Asia, Afghanistan, and India, made the high tradition of Islamic knowledge available not only to peasants who had little exposure to Islamic schooling, but also to muezzins and future village mullahs. To Malov's astonishment, Shakir Ähmäd—an unofficial Tatar mullah from Abla villageplanned to go to Ufa and apply for the title of "official mullah" (ukaznoi mulla) despite his primitive knowledge of Arabic. The mullah replied that his grasp of religious books written in türki sufficed for the office, especially because his village was isolated and badly in need of an official mullah. These basic primers included key prayers and samples of the Qur'an in Arabic and Turkic languages. They also contained Sufi heroic tales and love stories in the form of poems, describing the lives and miraculous deeds of prophets, saints, padishahs, exemplary women, and martyrs of the faith. ${ }^{18}$

14. Al-Rabghūzī, The Stories of the Prophets: Qișaṣ al-Anbiyä, an Eastern Turkish Version, vol. 2, trans. H. E. Boeschoten, J. O'Kane, and M. Vandamme (Leiden and New York, 1995), 205-206.

15. Ahmad ibn Hanbal, Al-Musnad, 3:128; Valerie Hoffman-Ladd, "Mysticism and Sexuality in Sufi Thought and Life," Mystics Quarterly 18 (1992): 86-87; al-Rabghūzī, Stories, 2: 206.

16. The Tales of the Prophets of al-Kisa'i, trans. from Arabic by W. M. Thackston (Boston, 1978), 192; Marc S. Bernstein, Stories of Joseph: Narrative Migrations between Judaism and Islam (Detroit, 2006), $36-40$.

17. After the conquest of Kazan in 1552, the Tatars, forced to move east, took their manuscripts with them and proselytized among the Bashkirs. Local copyists then bashkirized the language of these manuscripts and thus greatly facilitated the dissemination of Islamic beliefs. R. Ignat'ev, "Skazaniia, skazki i pesni, sokhranivshiesia v rukopisiakh tatarskoi pis'mennosti i v ustnykh pereskazakh u inorodtsev-magometan Orenburgskogo kraia," Zapiski Orenburgskogo otdela Imperatorskogo russkogo geograficheskogo obshchestva (Orenburg, 1875), 3: 185. 
Even an illiterate Tatar knew the content of these texts by heart as many of them were sung as munajat. The munajat, which literally means "word to Allah" in Arabic, sometimes translated as "intimate or private conversations," "whispered prayers," "prayers within the heart," "inward supplication to God," or "silent and fervent prayer," were rhymed and chanted prayers that could be transmitted orally or in written form. ${ }^{19}$ Women of all ages, including apostate women, liked to copy them by hand in their personal diaries and, after performing their ablutions at the bathhouse and wearing their prettiest clothes, recite them orally, either at major commemorative religious holidays, or during the long winter evenings. Those spiritual hymns consisted of stanzas of different length, and in some cases, as in Bädäwām Kitābï (Forever, composed between the twelfth and eighteenth centuries), the same verse (usually a direct appeal to God) closed each stanza. ${ }^{20}$ Bashkirs and Kazakhs accompanied the chanting of Bädäwām with their qobuz, a two-string fiddle, and each time the singer repeated the refrain, the player struck the strings of his instrument more loudly. The munajat genre was quite flexible, personalizing religious teachings in the first person, telling stories about the prophets and sacred places, and integrating the works of different Sufi Turkic poets with variations of its own. Likewise, in Rabghuzi's Qïs as al-Anbiyā' (Stories of the Prophets, 1310), each prophet's cycle was introduced by versified eulogies that summarized the main deeds and events in the life of a prophet, and could be recited as spiritual songs. Thus, the munajat and other poems' stereotypical meter and rhythm, whose authors and dates of composition were often unknown, helped peasants and young students to memorize the prophets' deeds and the main tenets of Islam. As noted by Malov in the 186os, starokreshchenye women of Apazovo village enjoyed listening to them and eagerly memorized their melodies and words. ${ }^{21}$

Authors of popular religious books demonstrated a high level of education. Imam Jamal ad-Din Biktashi (1798-1873), who authored Fäżà'il ash-Shühūr (The Qualities

18. Malov, "Beseda s mulloi," in Missionerstvo sredi mukhammedan, 112-113; Sherif Mardin, Religion and Social Change in Modern Turkey: The Case of Bediuzzaman Said Nursi (Albany, 1989), 5-6; Adeeb Khalid, The Politics of Muslim Cultural Reform, 20-28; Nazif Shahrani, "Local Knowledge of Islam and Social Discourse in Afghanistan and Turkistan in the Modern Period," in Turko-Persia in Historical Perspective, ed. Robert L. Canfield (Cambridge, 1991), 161-188; Annemarie Schimmel, As through a Veil: Mystical Poetry in Islam (New York, 1982), 135-169.

19. John Renard, Seven Doors to Islam: Spirituality and the Religious Life of Muslims (Berkeley and London, 1996), 55; S. I. Raimova, "K voprosu o tatarskom detskom muzykal'nom fol'klore," in Voprosy istorii, teorii muzyki i muzykal'nogo vospitaniia in the series Uchenye zapiski Kazanskogo gosudarstvennogo pedagogicheskogo instituta 104 (1972): 43; Älfinä Sibghatullina, “Tatar ädäbiyatïnda sufichïlïq (chïghanaqlar, tematika häm zhanr üzenchälekläre)" (doctoral dissertation, Alabuga, 2000); "Mönäjät," in Ädäbiyat beleme süzlege, ed. A. G. Äkhmädullin (Kazan, 1990), 116-117; R. A. Iskhakova-Vamba, Tatarskoe narodnoe muzykal'noe tvorchestvo (Kazan, 1997), 138-149.

20. Bädäwām kitābü (Kazan, 1861). On the dating of Bädäwām, see Tatary Srednego Povolzh'ia $i$ Priural'ia, 343 (the Tatar historian Märjani argued that Bädäwām was composed in the time of the Bolghar period of Tatar history). Based on Tatar traditions, Malov suggested that Bädäwām could have been composed at the end of the eighteenth century. Märjānī, Mustafād, 1: 13, 23; Malov, Akhyr zaman kitaby, 36.

21. Examples of munajat can be found in Nikolai Katanov, "Otchet o poezdke sovershennoi s 1 iiunia 1897 goda po 20 avgusta togo zhe goda v Belebeevskii i Menzelinskii uezdy Ufimskoi gub.,” Uchenye zapiski Imperatorskogo Kazanskogo universiteta 65, no. 11 (November 1898): 18-33; Shamil Shärifullin, Borïnghi khaliq mongnar-Starinnye narodnye melodii: Fortepiano öchen p'esalar jïyïntïghï-sbornik p'es dlia fortepiano (Kazan, 1994), 3; Mönäjätlär, dini khikäyätlär (Kazan, 1995); al-Rabghūzī, The Stories of the Prophets: Qiṣas al-Anbiyä, an Eastern Turkish Version, vol. 1, ed. H. E. Boeschoten, N. Vandamme, and S. Tezcan (Leiden and New York, 1995), 12, 40, 46, 63, 76, 94, 123, 131; NART, f. 4, op. 98, d. 34, 1. 23 ob. 
of the Months) - a book later disparaged by modernist Tatars-was originally from Mämäshir village in Malmyzh district. He had a thorough, classical background in Islamic studies. After studying morphology and syntax in the Köyek madrasa, law in the Chistopol' madrasa, and logic in the Maskara madrasa, which was well-known for its successful proselytism among the Udmurts, he became an imam at the village of Shadchi, in Ziuri volost', Mamadysh district, an area predominantly inhabited by Tatars, Kräshens, and Maris. ${ }^{22}$

These compilers of religious books consciously aimed at teaching the basic duties of a Muslim in words comprehensible to the masses. They sought to reach illiterate villagers who had no access, time, or ability to read theological works in Arabic or Persian. Biktashi wrote Fäżä'il ash-Shühūr in the 1840 s to introduce his wife, who was not proficient in Arabic and Persian, to the meaning of the rituals. According to the Tatar pedagogue and encyclopedist 'Abd al-Qayyum Nasïri (1825-1902), the Tatars of the merchant colony of Kargala near Orenburg asked a famous teacher from Khorezm, Ishniyaz b. Shirniyaz (d. 1790/91), to write a book in the Bolghar language about Islam. It is unlikely that Ishniyaz was the author of Sharä'it al-İmān, its language being Ottoman Turkish; yet Tatars of the nineteenth century understood the book as an attempt to instruct ritualized prayers in a language accessible to all. The primer contained instructions to perform the ritualized prayers and a versified Muslim creed in türki, and assured believers that they could perform funerary prayers in their native language if they could not recite them in Arabic. ${ }^{23}$ Likewise, the daughter of Taj ad-Din Yalchïghol (1767/68-1837), a Bashkir shaykh and musicologist known for his miracles and historical works, convinced her father to continue his family's education by writing a clear commentary in the vernacular on the poetry of the famous Samarkandi Naqshbandi Sufi Allahiyar (d. 1723?). ${ }^{24}$ Such works in local languages greatly aided proselytism among animist and baptized Tatars whom Yalchïghol, also a Naqshbandi, visited and instructed, preparing the way for the modernists who advocated the use of the mother tongue. $^{25}$

Religious Tatar literature was filled with Persian and Arabic words and was the product of educated elites who had studied in the madrasas of the Middle Volga and Central Asia. However, its morphology (in particular the nominal declensions, the verbal nouns in -u/ü and -ghan/gän, and the infinitive in -rgha/rgä), was of Qüpchaq

22. Biktashi's book constitutes a valuable source for the study of Islam as taught and propagated among Muslims and non-Muslims in the first half of the nineteenth century. First it circulated in manuscript form as a compilation of his students' class notes until 1854, when it was finally published in Kazan. Riżä' ad-Dīn b. Fäkhr ad-Dīn, Āsār (Orenburg, 1908), 2, section 15, no. 458: 549-550; Märjānī, Mustafād, 2: 156-160. Nikolai Bobrovnikov, Shkol'naia set' Kazanskoi gubernii (proekt) (Kazan, 1905), 86-97; idem, Inorodcheskoe naselenie Kazanskoi gubernii, vol. 1, Tatary, Votiaki, Mordva (Kazan, 1899), 15.

23. Sharäit al-ìmān (Kazan, 1904), 14-15, 17, 26, 31-32; Kemper, Sufis und Gelehrte, 44-45.

24. Tāj ad-Dīn Yālchïghol, Risālä-yi 'Azīzä. Shärh Sabāt al-Ājizīn (Kazan, 1905), 3; Frank, Islamic Historiography, 95-96; Kemper, Sufis und Gelehrte, 98-99.

25. Children of baptized tailors memorized Allahiyar's poems in the maktabs of the Kazan Tatar quarter ("Otchet bakalavra Kazanskoi dukhovnoi akademii N. I. Il'minskogo [August-September 1848]," in Khristianskoe prosveshchenie, 84). According to the Tatar historian and archivist Marsel' Äkhmätjanov, Yalchïghol proselytized in the region of Al'met'evo (today Zainskii Raion). Interview by author, 16 July 2008, Kazan. See also Mäsghud Ghaynetdin, Khaqüyqat' yulïnnan. Ädäbi tänqüyt' (Kazan, 2001), 37. 
origin, and its word order was close to modern spoken Tatar. Authors relied on direct speech (Allah, the prophets, or the angels spoke directly to the believers) and used apostrophes to address their listeners. There were archaic suffixes borrowed from Chagatay and Oghuz languages, but once children knew their equivalents in vernacular Tatar, those suffixes did not constitute a major obstacle to understanding. The main novelty was the lexicon borrowed, for the most part, from Arabic. But even there, the lexicon was limited to the religious sphere. Practice of Islam at home and in the community-ablutions, basic prayers, and various forms of greeting-helped the believer to memorize those Arabic words at a very early age. Spiritual songs (munajat) also contained many arabisms, a large array of bookish expressions, the names of God and the prophets in Arabic, and samples of basic prayers. Compound formulas, which combined an Arabic or Persian word and its synonym in Tatar, eased the process of understanding religious texts even more. An explanation of the Arabic word in Tatar could also precede the actual word in Arabic. ${ }^{26}$ Finally, the repetition of vocabulary allowed children and adults to assimilate foreign words and use them in their everyday speech. One student in Kargala reported in his memoirs that after encountering an Arabic word three or four times, he could remember its meaning. ${ }^{27}$

Symptomatically, the old convert milieu was far from being immune to the Arabization of its language. In the 1860s, the Islamized wife of a Kräshen in Nikiforova preferred to use the Arabic greeting "as-salamu 'alaykum" (Peace be upon you) than the usual Tatar “äle isän mesez?” or "aru mïsïz?” (hello; literally, are you in good health?), and in the 189os, the Kräshens of Apazovo occasionally talked about tawfik (accommodation to the will of God, divine guidance, or God's making one successful). But, at the beginning of the twentieth century, the tailors of Elyshevo, who were the most exposed to Islam through their work, constantly used words of Arabic origin in their speech. ${ }^{28}$

Not only did the writers of popular Islamic works compose in a language accessible to the peasants, but they also "turkified" the Qur'anic stories. Qol 'Ali, the author of Qïssa-yi Yūsuf, used metaphors from the old Turkic poetic tradition, in particular the ancient Oghuz epics that were popular at that time for retelling the story of Joseph. He also turkified Joseph, who wore braids, a Turkic custom, and alluded to the animist past of the Turkic peoples by including figures such as silver statues of bulls. In addition, he appealed to the climate and landscape of the Volga region when he described the realm of the pharaoh. For example, the caravan that led Joseph to Egypt was caught in a snow storm after the slave driver whipped him for going astray to his mother's tomb. ${ }^{29}$ Furthermore, the author inserted Turkic names into the narrative: the name of the slave driver, who later repented for hit-

26. Jamil Zäynullin, XVIII-XX yöz bashïnda tatar rukhani ädäbiyatï: Qor'än täfsirläre, khädislär $h$. $b$. chïghanaqlar. Tärjemä printsiplarï häm tel üzenchälekläre (Kazan, 1998), 149-152; idem, Vo imia Allakha... Tatarskaia bogoslovskaia literatura XVIII-nachala XX vekov i ee iazykovye osobennosti (Kazan, 1999), $78-98$.

27. "Ghabdräkhim Ghabdrakhman ughlï Wälidovnïng tereklektäge khäle häm Qarghala tarikhï," unpublished autobiography (Kargala, 1924) in Mädinä Räkhimqulova's private collection, Orenburg, 11. 5,7 .

28. Il'minskii, ed., Kazanskaia tsentral'naia, 70; Iapei Babai, "O kreshchenykh tatarakh," no. 20 (15 October 1891): 635; Ostroumov, Tatarsko-russkii slovar', 21, 99-100; NART, f. 4, op. 133, d. 7, 1. 16. 
ting Joseph, was Qilïch (sword) and Joseph's nephews bore Turkic and not Islamic names. These names-Dingez (sea), Qurt (wolf), Qan (blood), Arslan (lion)unknown in the Qur'an, referred to Joseph's ordeal and summarized his life in a way that made the twelfth Sura more familiar and easier to remember for the Tatar reader or listener. ${ }^{30}$

Finally, the text, which underwent many changes between the twelfth century and the time when the Sufi poet and theologian 'Abd ar-Rähim al-Utïz Imäni (1754-1835) attempted to stabilize it, sought not only to convert "pagans," but also to address an audience living in a predominantly animistic and Christian environment. When an idol recognized Joseph as God's prophet, the ruler of Jerusalem became a believer and took off his zünnar - a rope girdle worn by Christians and also associated with animism. The same word zünnar was also used in Bädäwām to designate the tiny ropes or scarves Turkic or Finno-Ugric animists used to tie on sacred trees when they made a wish. In the Central Asian work of Rabghuzi, there was no allusion to taking off one's belt at the time of conversion. Similarly, in the work of Sheyyad Hamza, a thirteenth-century wandering Anatolian dervish poet, the ruler of Jerusalem, convinced of the truth, destroyed his idol with a hammer and, in a sign of total submission and awe, adorned Joseph with his own belt (not zünnar, but qushaq). But in the context of the Volga region, taking off one's belt was a definite sign of turning away from paganism as well as from Eastern Orthodoxy. Russian peasants wore belts at the waist while Tatars dressed in longer shirts without belts. At the sight of a priest, unbelted Islamized Kräshens who worked in the fields hastily used a cluster of compressed rye as belts; once the priest was gone, their improvised garment was quickly discarded. Likewise, after sending their petition to the emperor, starokreshchenye in Mamadysh district, emulating the ruler of Jerusalem, symbolically got rid of their belts to mark their entrance into the realm of Islam. ${ }^{31}$ Thus, Volga copyists and Utïz Imäni, who was known for proselytizing among the Kräshens and who grew up in his mother's village, Staraia Kadeeva (Utïz Imän or “the thirty oak trees”) addressed an audience clearly exposed to Christianity. One of his poems rebuked a Grishka, probably a baptized Tatar, who agreed that Islam was the true faith but still could not

29. Bombaci, Histoire, 88-89; N. Sh. Khisamov, Poema Kyssa-i Iusuf Kul Ali (Moscow, 1979), 50-51, 71, 170-174; Kitāb-i qüsṣa-yi Häżrät-i Yüsuf an-nabī 'alayhi as-salām (Kazan, 188o), 18; Khisamov, Poema, 118; G. Tahirjanov, "Firdäwsi häm Qol Ghali," Qazan utlarï, no. 12 (1968): 126.

30. See Qïlïch in Kitāb-i qüșsa-yi Häżrät-i Yūsuf, 17-18; Turkic names of Joseph's nephews are not included in the prerevolutionary printed versions of the Story of Joseph, but in manuscripts. Fazil Fäsiev, ed., Qol Ghali: Qïyssai Yusuf: Yusuf turïnda qüyssa (Kazan, 1983), 246.

31. The first printed copy of Qol 'Ali's work, done in 1839, was based on Utïz Imäni's editing in 1824 of various manuscripts. N. Sh. Khisamov, "Itogi i zadachi izucheniia 'Kyssa-i Iusuf' Kul 'Ali," Tatarica (Vammala, 1987), 354, 361; Kitāb-i qïșșa-yi Häżrät-i Yūsuf, 20; definition of "Zünnar” in New Redhouse Turkish-English Dictionary (Istanbul, 1987), 1292; Bädäwām kitābï, 3; in a Tatar tradition recorded by the nineteenth-century scholar Nasïri, the word "zünnar" designated the belt that the Kazan bishop Luka Konashevich distributed along with vodka and crosses to convert indigenous peoples to Christianity, "Aqsaq Qaratun ärkhäräy khaqïnda riwayätlär," in Qayum Nasïyri, Saylanma äsärlär (Kazan, 2005), 3:178; Şeyyad Hamza, Yusufve Zeliha (Istanbul, 1946), 29; on clothing differences between Russians and Tatars, see Rittikh, Materialy dlia etnografii Rossii, 20; "Otchet bakalavra missionerskogo protivomusul'manskogo otdeleniia Kazanskoi dukhovnoi akademii N. I. Il'minskogo (1856)," in Khristianskoe prosveshchenie, 155. Jadids later ridiculed mullahs who objected to their wearing belts, Amirkhan, Poznakomilis' ot togo, chto ne byli znakomy (1909), in Izbrannoe (Rasskazy i povesti), 67. 
resist the call of church bells. Coincidentally, the baptized Tatars of Utïz Imän apostatized officially in the 1840 s and were the target of repeated unsuccessful missionary visits well into the 1860 s. $^{32}$

Until the rise of jadid schools, these books constituted the main core of primary Islamic education. Märjani, in his construction of the past, associated some of them with the Bolghar period, but most were edited in the eighteenth century and solidified in print after the opening of the Asian printing house of Kazan. Children in traditional schooling moved from one book to another at their own pace. They sat on the floor around the mullah and repeated their lesson in chorus. After they had memorized one book, they began another. A special ceremony, organized by the parents, celebrated the completion of each book. Depending on the size of the school, children were assigned to older students (khalfas) who helped them to memorize their prayers and understand words of Arabic or Persian origin that were not common in vernacular speech. ${ }^{33}$

Children studied Sharā'iț al-İmān during their first and sometimes second years of school. In a Tatar village located near the Kräshen village Apazovo, which first apostatized in the 1870s, Malov overheard a woman teach her two-year-old grandchild to chant the names of the Arabic letters and the abjad (meaningless combinations of letters that followed the ancient Semitic sequence of the alphabet and bore a numerical value). When the grandmother asked the child to repeat the letters over and over, the girl responded to her gaily: "Beldem, beldem (but I know already)." In this manner, children often knew the book by heart before reading the actual letters. For a Europeanized jadid who promoted functional literacy and the new phonetic method of reading (usul-i jadid), learning the abjad was a waste of time. However, learning it prepared the child to connect with the divine, chant prayers in Arabic (a language they did not know), and approach the Qur'an not as a casual book, but as the Word of God-the meaning of which was not readily available. ${ }^{34}$

When children learned to read, they did not start by sounding out the Arabic letters; first they learned their names. The names themselves helped the children to connect with God's Creation, the Word of God, and God's qualities. The letter "bä" (Roman "b") was not just any letter, but the very first letter encountered in the Qur'an; the very first letter inscribed into the Well-Preserved Tablet by the Pen; the very first letter that begins Bismillah, a word that every Muslim should pronounce before starting an action; and the letter that referred to God's Glory (Baha Allah). From this letter came a light, the light of God's magnanimity toward his beloved

32. Malov, Prikhody starokreshchenykh i novokreshchenykh tatar v Kazanskoi eparkhii, 34; idem, "Statisticheskie svedeniia," Uchenye zapiski Kazanskogo universiteta, 342; Ghaynetdin, Khaqïyqat' yulinnan, 37; Kemper, Sufis und Gelehrte, 197-198. Utïz Imäni abhorred Russian borrowings so much that he considered the presence of chairs and dining tables in Tatar merchant houses as dangerous innovations. Such furniture was also present in Kräshen villages. In fact, Russian missionaries determined the level of Christianization or Islamization of a baptized family by its presence or not. Ghabderäkhim Utïz Imäni äl-Bolghari, Shighïr'lär, poemalar (Kazan, 1986), 87-88, 99.

33. Märjānī, Mustafād, 1: 13; "Ghabdräkhim Ghabdrakhman ughlï," 11. 5, 7.

34. Iapei Babai, "O kreshchenykh tatarakh" no. 18 (15 September 1891): 563-564; Riżä' Fäkhr ad-Dīn, 'Áilä (Orenburg, 1902), 66; Ghayaz Iskhaqïy, "Möghallim (Drama bish pärdädä)” and "Jämghïyat (Komediia ike pärdädä)," in Äsärlär, vol. 4 (P'esalar, 1900-1918) (Kazan, 2003): 159-160, 264-268; Schimmel, Deciphering the Signs of God, 152. 
community. The second letter inscribed into the Tablet was "sin" (Roman "s"), composed of three strokes. From each stroke a light came out: the first stroke reached the Throne ('arsh); the second, the footstool (kursi); and the third, paradise. The first light belonged to those among the faithful who act piously, the second to those who do not squander, and the third to those who harness their nafs (passion). The third letter was "mim" (Roman "m"), signifying the Light of the Prophet Muhammad from which everything — cosmos, hell, paradise, prophets, and humankind-was created. ${ }^{35}$

The letters constituted the primordial keys to understand God's nature and creative powers. In Rabghuzi's Stories of the Prophets, a teacher asked Jesus, who was seven years old at the time, to repeat the alphabet and the abjad by rote. Jesus objected that he could not learn anything he could not understand. He then miraculously taught the alphabet's mystical meaning to his teacher. Each letter, he explained, referred to a particular divine attribute: God's blessing, eternity, and beauty. And the abjad helped retell the story of Adam, his worship of God, his disobedience, and God's forgiveness. Thus when learning the names of the letters and the abjad, the children learned about God's creative power and unique qualities, as well as His works through the lives of His servants, the prophets. The meaning of the letters was not fixed and depended largely on the teacher's choice of emphasis in his daily pedagogical encounters. Popular belief held God would grant wishes to those who recited the abjad. ${ }^{36}$

Before the rise of modernist Islam, reading at the primary level did not have a merely utilitarian value. Learning to read connected a child to a higher reality, absolute and fundamental, and gave her a script to understand both how the world came to be and how it ought to be. If the Qur'an was God's uncreated word, the Arabic alphabet was one of God's first creations, and appropriating it through rote memorization of meaningless combinations of letters or naming each letter of the words before sounding them out was a way to access God's creative power, albeit indirectly. This, however, did not keep mischievous children from making up and repeating silly rhymes out of the unintelligible Arabic phrases they had to memorize. ${ }^{37}$

Because Sharā'it al-İmān was short and to the point, illiterate parents could learn passages from their children, who repeated lessons at home. Illiterate baptized Tatars also could learn from their children who studied with literate neighbors. There also existed manuscript translations of the book's Arabic prayers to facilitate understanding. After assimilating the letters, a child was called kitapkhan (reader of a book). In the second and third years, students switched to the Häft-i Yäk. At the same time they read through the Häft-i Yäk in Arabic, they turned to its tafsir, a verse-by-verse commentary of each chapter in Turkic, to aid comprehension. A baptized tailor from Elyshevo affirmed to Malov that it was impossible to read the Häft-i Yäk and the Qur'an without the tafsir. Children also memorized and learned to read Sufi poetry in türki. From those works already sung in the village or in the family context - the jadid poet

35. Ähmäd Bījān, Änwār al-āshïqīn (Kazan, 1898), 9-10; Risālä-yi nurnāmä (Kazan, 1910), 2-3.

36. Al-Rabghūzī, Stories, vol. 2: 494; see various interpretations of the meaning of Arabic letters in Sufi literature in William C. Chittick, Ibn al-Arabis' Metaphysics of Imagination: The Sufi Path of Knowledge (Albany, 1989), 128; Juan R.I. Cole, "The World as Text: Cosmologies of Shaykh Ahmad al-Ahsa'i," Studia Islamica no. 80 (1994): 145-163; Evfimii Malov, Mukhammedanskii bukvar'. Missionersko-kriticheskii ocherk (Kazan, 1894), 46-50.

37. 'Abdullāh Tuqay, Isemdä qalghanlar (Kazan, 1909), 21. 
'Abdullah Tuqay (1886-1913) recalled that when he was little he would be lulled to sleep by their melody-mullahs extracted and developed stories about the history of Islam, lessons on morality, parables, and fables with appropriate interpretations. As explained by an old imam in Kargala, Orenburg province, the goal for the children was to live like the Prophet Muhammad. These lessons alternated with the learning by rote of prayers in Arabic. Again, the students brought the stories back into their homes and thus contributed to reinforcing and spreading Islamic culture. ${ }^{38}$

When he was older, Tuqay refused to salute a respectable neighbor who was drunk, and justified his behavior by quoting two verses from Bädäwām, a munajat about the consequences of sin and pagan idolatry. In addition to offering paradigms of behavior, Sufi religious literature offered great solace for both Muslims and Muslims-to-be. It took different levels of religious knowledge into consideration, and taught that any man or woman, literate or not, could be granted extraordinary prophetic and intercessory powers. Most important, popular Islamic literature proposed that Tatars could prosper in a non-Muslim state without losing their religious integrity, and even extend the boundaries of their faith. ${ }^{39}$

\section{Belief, Knowledge, and Intercession in Traditional Muslim Literature}

The main dilemma that illiterate or semiliterate peasants faced was how they could earn salvation without the theological knowledge of a learned person. Popular Islamic literature offered consoling answers to their anxieties as well as ways to improve their learning. It emphasized the supernatural powers of the prophets and Sufi shaykhs, the basic duties of a believer, the struggle against paganism, the differences between Christianity and Islam, and the belief in one God. At the same time it outlined the virtue of forgiveness, the power of faith alone, the importance of spreading the faith in a hostile environment, and the divine satisfaction from learning even one word of the Law. This kind of teaching, which at times inflated the Qur'anic narrative but was closer to the hadith narratives, was instrumental in the conversion of animist peoples and highly appropriate in the case of the Kräshens who, in some areas, had internalized the general perception that their ancestors had apostatized from Islam for greed.

\section{Prophethood}

Prejadid Tatar books and in particular tales of the prophets often diverged from the Qur'anic narrative to demonstrate the prophets' supernatural powers. They used the work of the famous Baghdad historian and theologian Abu Ja'far Muhammad ibn Jarir at-Tabari (d. 923) as a source of inspiration. Various scholars of Islam, dating from the Kharijites and the Mutazilites to the modernist Tatar theologian Riza' ad-Din Fäkhr ad-Din, have been critical of Tabari and Turkic extrapolations of his work. Yet there is

38. Malov, Mukhammedanskii bukvar', 59-60; B. Zorin, "Maktaby i medrese russkikh musul'man," Vestnik Orenburgskogo uchebnogo okruga no. 1 (1914): 41-49; Koblov, "Konfessional'nye shkoly Kazanskikh tatar," 1-48; Ghabdulla Tuqay, "Saghïnïr waqïtlar," in Shighïr'lär, äkiyätlär, poemalar (Kazan, 1990), 160; Validov, Ocherk, 14; "Ghabdräkhim Ghabdrakhman ughlï, 1. 7.

39. Tuqay, Isemdä qalghanlar, 33; Bädäwām kitābï, 7 . 
no question that these stories and their hyperbolic metaphors played an instrumental role in the spread of Islam among the Turkic people of Eurasia and Central Asia. ${ }^{40}$

According to Qïsșa-yi Yüsuf, the Prophet Joseph showed signs of his divine calling even as a child. In a fantastic, extra-Qur'anic episode, a wolf who had refrained from attacking the boy explained that God had forbidden him to eat the flesh of the prophets. The Sufi Yalchïghol called this type of miracle irhas (a sign that indicated the presence of a future prophet). ${ }^{41}$ In some cases, the prophets were so powerful that they could change the natural order. In Qișșa-yi Sulaymān (Tale of Solomon), an anonymous story that was popular among the Tatars, the sun and the moon asked Solomon to pray that God would change their orbit. The narrator implied that Allah would blindly and automatically respond to Solomon's prayers whatever the consequences. This interpretation was quite different from the Qur'an where nature was submitted to God's unique order. ${ }^{42}$ By contrast, in Qïsṣa-yi Yūsuf, Joseph could change the natural order, but only as a passive tool of God, who was willing to bestow his messengers with extraordinary signs of grace; this view was much closer to the doctrine of Hanafi Islam as represented by the maturidite Central Asian scholar Nasafi (d. 1142). ${ }^{43}$ Qol 'Ali also exaggerated the secular power of the Prophet Joseph by naming him king or sovereign (padishah, sultan) of Egypt instead of mere prime minister, as written in the Qur'an. Finally, prophets' tombs were thought to be blessed with baraka (grace, divine gift, sacred power). When Joseph's tomb was removed from his city, faithful Egyptian believers endured hardship. Although such doctrines contradicted the Qur'an from a strict Hanbali perspective, they pleased a popular audience that looked for magical mediators between humanity and God. ${ }^{44}$

The Sufi books portrayed Muhammad as a miracle worker even though the Qur'an explicitly denies this. In Kisekbash (The Severed Head), a thirteenth- or fourteenthcentury Sufi epic, Muhammad resurrects both Kisekbash-a Muslim martyr whose decapitated head could still recite the Qur'an and his son who had been devoured by the Div (dew), a mythological giant. ${ }^{45}$ In 1908 , the jadid poet Tuqay ridiculed this type of fantastic miracle story by composing a satire using the same rhythmic structure. In his version, the decapitated head recovered its human body thanks to a satanic ishan (shaykh, Sufi master) and not to the Prophet Muhammad. ${ }^{46}$

40. A.M. Akhunov, Arabskii istochnik srednevekovoi tiurko-tatarskoi literatury (Kazan, 2001), 96.

41. Kitāb-i qüșṣa-yi Häżrät-i Yūsuf, 12; Yālchïghol, Risālä, 53.

42. A. Mikhailov, "Kriticheskii razbor i perevod s tatarskogo iazyka na russkii broshiury 'Rasskazy o Solomone," Orenburgskie eparkhial'nye vedomosti 17, no. 10 (15 May 1889): 280-284.

43. Imam an-Nasafi, Akïa: simvol very, trans. Said Damir Shagaviev, pp. 5-6, available at http:// www.imancentre.ru/iman.htm (accessed 17 February 2006). This short book was studied in Middle Volga schools before 1917 .

44. Kitāb-i qïșsa-yi Häżrät-i Yūsuf, 45-46, 58-59, 64. The Hanbali jurists Ibn 'Aqil (d. 1119) and Ibn Taymiyya (d. 1328) opposed visits to the saints' graves to seek blessings. Leor Halevi, Muhammad's Grave: Death Rites and the Making of Islamic Society (New York, 2007), 227.

45. Kisekbash kitābï (Kazan, 1846), 15-16. According to Tatar historians, it was composed in the thirteenth century: Ia. S. Akhmetgaleeva, Issledovanie tiurkoiazychnogo pamiatnika "Kisekbash kitaby" (Moscow, 1979), 27. For Turkish scholars, though, the book was composed a century later. Mökhämmätov, “Tatar-törek ädäbi baghlanïshlarï,” 30 .

46. Tuqay, Pechän bazarï, yakhut yanga Kisekbash, in Äsärlär, vol. 1 (Kazan, 1955): 199. Tuqay used the same literary device to mock other Sufi works, conservative mullahs, and ishans. In Isuli Qadimche, 
However, these hyperbolic descriptions of prophets served a very specific religious didactic purpose, which proved to be instrumental in the spread of Islam among baptized and nonbaptized Finno-Ugric and Turkic communities. In particular, the prophets' life stories helped draw a sharp line between Christianity and Islam and affirm the superiority of Islam. Rabghuzi, who wrote his book in the fourteenth century for the recently converted Mongol elite of the Chaghatay kingdom in Transoxiana, enjoyed exaggerating the powers of the prophets, but only to a point. When people stunned by Joseph's beauty prostrated themselves before him, Joseph stopped them, so that no confusion would occur between himself and the divinity. The main lesson-underlined by the commentator himself-was that Muslims should not confuse the human with the divine, as Jesus's disciples did with their prophet. ${ }^{47}$

In addition, prophets of Islam taught their faith in a clear vernacular language and revealed the Word of God in the context of their own culture. The Prophet Adam knew seventy-two languages and named all things in Arabic, Persian, and Turkish. Joseph was also a polyglot, and spread his message in all languages. In order to cope better with changing mentalités, the prophets' messages took various forms. In Abraham's time, according to Rabghuzi, people honored wealth, so God made Abraham wealthy. In Moses's time, people held magic in higher esteem, and consequently God gave Moses his magic staff. Finally, when Jesus was born, medicine was most important to people. Thus Jesus resurrected corpses and gave life to a bird of mud. Likewise, Tatar proselytizers used local languages and metaphors to spread their understanding of Islam. ${ }^{48}$

Most important for the Kräshens, whose ancestors might have accepted baptism for material incentives, prophets who led exemplary lives in a dangerous world populated with nonbelievers were not perfect, and their gifts were not unique to them. Satan put their faith to the test, and sometimes they failed miserably. Adam ate the forbidden fruit; Solomon trusted his pagan wife and lost his seal that gave him power over spirits; and Joseph took pride in his beauty, but God forgave each of them..$^{49}$ Popular religious literature invited its readers and listeners to identify themselves with the prophets' ordeals and struggles in hostile, sinful, and polytheistic environments. Job's story, for instance, encouraged people to submit to God and show patience. ${ }^{50}$ Although Joseph and Muhammad were exiled from their native lands-as were apostate leaders deported to Siberia-their faith increased and became stronger. More important, Yalchïghol, the author of Risālä-yi 'Azizzä (Treatise for 'Azizä), insisted that any man or woman, by God's grace and power, could enjoy the gifts bestowed on the prophets and the saints. Those gifts, essential to the spread of Islam, included the power to travel long distances in an instant, the strength to conquer hostile forces, a direct understanding of God's message, incorruptibility after death, and financial

\footnotetext{
he imitated the scansion of Muhammädiyä Kitābï ("The book of Muhammad," the work of the fifteenthcentury Ottoman poet Muhammad Chelebi), and in Khätirä-yi "Baqürghan," he made fun of Bāqürghān Kitābï (ibid., 32-33, 160, 251, 270).

47. Robert Dankoff, "Rabghūzīs Stories of the Prophets," Journal of the American Oriental Society 117, no. 1 (January-March, 1997): 118; Al-Rabghūzī, Stories, vol. 2: 189-19o.

48. Al-Rabghūzī, Stories, vol. 2: 15, 489; Yālchïghol, Risālä, 9.

49. Al-Rabghūzī, Stories, vol. 2: 415; Kitāb-i qïṣsa-yi Häżrät-i Yūsuf, 21.

50. Fäżäil ash-shühūr (Kazan, 1869), 25-31; al-Rabghūzī, Stories, vol. 2: 290-299.
} 
self-sufficiency. Popular belief, for instance, held that the body of muezzins did not decay. Thus, anyone could, by God's will, act and be rewarded like a prophet. ${ }^{51}$

\section{Eschatology}

In Tatar popular literature, prophets were not only God's messengers, but also powerful intercessors whose prayers could turn aside God's righteous wrath. The Qur'an is ambivalent about the ability of the prophets to intercede for others. On the one hand, it affirms the individual responsibility of every person and that men and women will face God alone $(2: 48 ; 6: 51)$. On the other hand, it assures believers that angels, true witnesses, and people who have made a covenant with God (this includes prophets) may intercede for the believing sinners $(5: 26 ; 43: 86 ; 19: 87)$. This ambivalence led to early theological disputes, provoked by concern for the believers who had received God's message in their heart but had failed to follow all of His commandments. The hadith literature was less ambivalent and put the stress on communal affiliation instead of emphasizing individual accountability. It asserted that Muhammad would act as an intercessor for his whole community. Over time, all schools, except for the Mutazilites, affirmed that the prophets and angels could intercede for Muslims if they had God's permission to do so. ${ }^{52}$

Turkic Islamic literature faced the same dilemma and provided different, at times contradictory, answers that allowed greater flexibility of discourse for the preachers of Islam. Overall, the Prophet Muhammad appeared to be highly compassionate, but the Turkic authors were also aware that too much compassion could lead to a relaxation of religious practice. Näșịhät aṣ-Ṣālihīn (Pious Admonitions), composed around the thirteenth century or modified later, opened with terrifying images of hell. No one escaped God's wrath: neither young, nor poor, nor rich, nor old, nor women, nor slaves. The book urged believers to strictly obey the law because one day they would face God and face Him alone. Allah would not forgive those who missed one prayer (unless they had been killed by an infidel), forgot to give the sadaqa (alms) to the dervishes and the poor, spread false rumors against their fellow Muslims, or drank alcohol. Those sinners would be sent straight to hell, even if they repented. ${ }^{53}$ However, in the same religious work, the Prophet Muhammad dispatched the faithful Abu Bakr, the first caliph (r. 632-634), to the place where the path to hell and paradise separate. The Prophet commanded him to keep his people from entering hell. Later, in an open transgression of the Qur'an (2:48), the Prophet asked Umar, the second caliph known for his wisdom, to cheat the judgment; if a Muslim was in trouble, Umar was to climb on the right side of the eschatological scale (mizan) to ensure that good deeds would seem to outweigh the bad. Finally, Muhammad ordered the renowned warrior 'Ali, the fourth caliph (r. 656-61), to fight those ready to enchain one of his followers. Only then did Muhammad himself approach God and remind Him of the promise to spare the Prophet's followers. But even at that crucial moment, God did not appear to

51. Yālchïghol, Risālä, 9, 11, 15; Malov, “Chetyre dnia sredi musul'man,” Missionerstvo sredi mukhammedan, 9.

52. Yvonne Haddad and Jane Smith, The Islamic Understanding of Death and Resurrection (Albany, 1981), 26-27; Louis Gardet, L'Islam, Religion et Communauté (Paris, 1967), 98-99.

53. Kitāb 'izzät ma’āb näṣịhät aṣ-șālihīn (hereafter Näṣīhät aṣ-ṣālihīn) (Kazan, 1908), 3-5. 
be the ultimate judge. Only those who pleased Muhammad, and thus God indirectly, would be automatically saved. ${ }^{54}$

On the one hand, Näșinhät aṣ-Ṣālihīn held that only a few would be blessed. Performing prayers was not enough to escape from hell, but neglecting them was unforgivable. Proof of genuine faith and social justice (such as giving alms to the poor) has to be demonstrated on the Day of Judgment. If those proofs happened to be deficient, the eternal benefits acquired from praying would be automatically annihilated. On the other hand, as baptized local peoples were often told, it was enough to recite the shahada ("there is no God but God and Muhammad is His Messenger") once to be counted among the saved, or to repeat Astaghfirullah (I seek pardon and forgiveness from Allah) during the month preceding Ramadan and during the fast. Fäżä il ashShühür, a much later work, included a longer list of exemptions. Those who called people to prayer, studied, brought their children to school, founded schools or mosques, had children of good religious standing, left a Qur'an to their descendants, taught for free, or helped needy fellow Muslims would not burn in hell. Those who fasted during certain months of the Muslim calendar would be spared, and those who were excluded from paradise in Näșīhät aṣ-Ṣâlihīn, such as penitent alcoholics and gossips, would be forgiven. One of Biktashi's stories went as far as to include repentant sorcerers and nonbelievers who respected Muslim rituals; one story related how before his death, an unbeliever reprimanded his son for eating during the month of Ramadan, and so gained paradise. ${ }^{55}$

The list of exceptions continues to widen when one looks at the popular twelfthcentury works of Sulayman Baqïrghani, also called Hakim Ata (d. 1186) and a disciple of Sufi Ahmad Yasawi (d. 1166). Thanks to Muhammad's entreaties, God forgave the Prophet's pagan parents-an apparent contradiction of the Qur'an (9:113). A popular tradition among the Tatars held that Muhammad came to his parents' tomb, resuscitated them, taught them Islam, and converted them; this again contradicted revealed scripture. But Rabghuzi's account of the Prophet's ascent to heaven hewed closer to the Qur'an (9:81, 114-15); for Muhammad, despite his efforts, failed to save his parents from hell. However, the Qur'an also allows prayers for the dead, and intercession constitutes one of the prophets' inherent qualities. Again, individual missionaries of Islam could play on this discursive ambivalence in order to gain more converts among animists who worshiped their ancestors. ${ }^{56}$

At the Last Judgment, the ultimate intercessor between believers and God was Muhammad. Compassionate, the Prophet wept for both the martyrs and those weak in faith. In Ākhïr Zamān Kitābü, attributed to Baqürghani and very popular among women, Muhammad commanded both angels and hellfire. ${ }^{57}$ The Prophet ordered the fires of hell not to burn his followers and asked Gabriel to climb on the scale

54. Näșihhät aṣ-ṣālihīn, 6-7; Annemarie Schimmel, A Two-Colored Brocade: The Imagery of Persian Poetry (Chapel Hill, NC and London, 1992), 104-105.

55. Näșîhät aṣ-ṣâlihīn, 8; Fäżàill, 17-18, 21-22, 38, 44, 53-54, 69.

56. Malov, Akhyr zaman kitaby, 24; al-Rabghūzī, Stories, vol. 2: 614 (Yalchïghol shared the same position, Risālä, 20-21); Denise Masson, Monothéisme coranique et monothéisme biblique: Doctrines comparées (Paris, 1976): 294-295, 305, 550-552.

57. According to Malov, the author of Ākhïr Zamān Kitābï could be Baqürghani or Utïz Imäni. Malov, Akhyr zaman kitaby, pp. 34-35, 39. 
on the side of the good deeds. More strikingly, God delegated to Muhammad His power to judge humanity; in the Qur'an the Prophet had no such authority. Even the angels and the prophets Adam, Abraham, and Jesus asked for his help. Although the Qur'an specifically declared that Muhammad would face God's judgment like any other man, the author took pains to deemphasize this doctrine, which he mentioned only at the end of his poem. His understanding of the Prophet's unique intercession echoed-rather dimly for sure - the works of Abu Hamid Muhammad al-Ghazali's (1058-1111) and classical Ashari and Hanafi creeds of Islam studied by older students in the Volga madrasa, which affirmed that Muhammad would be the only one authorized to speak for the faithful on Judgment Day. ${ }^{58}$

Besides Muhammad, Sufi books referred to other possible intercessors. One of Yalchïghol's stories emphasized Muhammad Baha' ad-Din Naqshband (1317-1389), the eponymous founder of the Naqshbandi Sufi order, rather than the Prophet Muhammad. In Näșinhät aṣ-Ṣālihīn, the circle of intercessors was more indefinite: any teacher, mullah or shaykh, could intervene for his or her former students. Finally, Biktashi enlarged the number of intercessors further by including other less extraordinary protectors: any man who had fasted and prayed during the month of Rajab (the revered month during which the Prophet Muhammad completed his ascent to heaven) could save 70,000 men and women from hell. Yalchïghol and Biktashi's common position on intercession echoed the theologian and mystic al-Ghazali's, but differed sharply from the conservative scholar Taqi ad-Din Ahmad ibn Taymiyya (1263-1328) who contested the efficacy of intercessory prayers. ${ }^{59}$

No sharp line divided the living and the dead in the books read at home or taught in primary schools. Angels of paradise and hell could be seen around tombs, and the dead visited the living in their dreams. In Näșînät aṣ-Șalihìn, spirits came to earth with God's permission to visit their relatives and give them advice. This went against the Qur'anic notion of barzakh (the barrier between the living and the dead that will remain until the day of resurrection), but echoed many similar stories in the hadith literature and other eschatological works in the Arab world. ${ }^{60}$ In the same way, human beings could have an impact on the destinies of the dead. Rabghuzi and Biktashi mentioned the story of a man who was in hell but entered the state of the blessed thanks to his son who studied well in the madrasa and recited Bismillah. ${ }^{61}$ In fact, in accordance with the spirit of hadith literature, popular Islamic books considered all members of the believing community morally responsible for assuring their fellows and relatives' salvation. In Fäżà il ash-Shühür, when someone noticed fumes around the tomb of a young girl who had lived an immoral life, the Muslim community prayed for her and offered sacrifices to alleviate her suffering in the grave; later, through a dream, she revealed to her intercessors that her torments had ceased and she was at peace. At the Last Judgment, Biktashi contended, the good works and prayers of one's pious descendants form a mountain of "sacred deeds" that are

58. See text of Ākhïr zamān kitābï on pp. 10-11, 15, 19-20, and 22 in Malov, Akhyr zaman kitaby; Haddad and Smith, The Islamic Understanding, 80-81.

59. Yālchïghol, Risālä, 240; Fäżäil, 34; Smith and Haddad, The Islamic Understanding, 27.

60. Näșînät aṣ-ṣālihīn, 5, 15; Qurān, 23: 100; Smith and Haddad, The Islamic Understanding, 48.

61. Fäżàill, 12-14; al-Rabghūzī, Stories, vol. 2: 494. 
added to a person's good works on the eschatological scale. This, again, emphasized intercession and forgiveness over a much stricter reading of the Qur'anic message on individual responsibility for one's sins. ${ }^{62}$

Tatar funerals reflected the same sense of collective responsibility toward personal salvation. At home, relatives paid the fidyä (alms) to redeem the deceased's missed prayers. The poor could offer a Qur'an instead of money or flour. At the cemetery, the community actively helped the deceased during the crucial moment when the two angels of the grave interrogated him or her, and weighed the answers on the eschatological scale of judgment. The grave diggers distracted the devil by pretending to argue over the burial cloth, and the mullah or relative stood forty feet from the grave whispering the right answers: "Do not be afraid, say, 'my God is Allah, my prophet Muhammad, and my faith Islam. "63

The sense of responsibility for both the living and the spirits of the dead ancestors had an important impact on villagers who held to their animist beliefs and believed that their ancestors' souls were active on earth. It was believed that spirits if neglected could threaten the village's cohesiveness and well-being with diseases and natural catastrophes. In this environment, the teachings of Näșînät aṣ-Ṣālihìn and Fäżà'il ash-Shühūr presented a consoling view. Ancestors' spirits were seen as God's servants descending to earth to warn about the Last Judgment. As for evil spirits who rebelled against Allah, they could be conquered only if the community united, repented, turned to God, and followed the sharia scrupulously. As the baptized often heard from Muslim itinerant preachers, the ring of Solomon-a present from God created out of the Light of Muhammad-lost its powers over the demons when Solomon allowed one of his wives to worship idols in his palace. ${ }^{64}$

In Muslim tales, objects could also intervene for a person's salvation or a believer's temporary relief from eternal sufferings. Everyday utensils such as mattresses, clothing, shoes, water, and qomghans (bronze ritual vessels used for ablutions) prayed to God to save those who got up early and performed their ablutions and prayers. The Qur'an and other religious books of a student who fell asleep in a Jewish cemetery provided relief from the torments of the grave for the Jews buried there. ${ }^{65}$ Biktashi also ascribed supernatural powers to talismans. An alcoholic who, before drowning, swallowed a piece of paper with the word "Bismillah" ended up in paradise thanks to his amulet. The angels of God's judgment, Munkar and Nakir, had not touched him, and God immediately forgave him. The drunkard escaped the usual test that everyone has to endure - the weighing of one's good and bad deeds. The sinner did not owe his salvation solely to the magic powers of the talisman, but to his acknowledgment of the power of the written word on the amulet. The story recalls a well-known hadith: "God will say: Let those leave hell whose hearts contain even the weight of a

62. Fäżäil, 68-69.

63. Qayyum Nasïyri, Saylanma äsärlär, vol. 1 (Kazan, 1974): 115; Iakov Koblov, "Religioznye obriady i obychai tatar magometan," IOAIE 24, no. 6 (1909): 521-564; Sh. S. “Tatary-musul'mane. Smert' i pokhorony," Inorodcheskoe obozrenie, supplement to PS, bk. 2 (March 1913): 117-120.

64. Boris Gavrilov, "Pogrebal'nye obychai i pover'ia starokreshchenykh tatar derevni Nikiforovoi Kazanskoi gubernii Mamadyshskogo uezda," IKE, no. 9 (1 May 1874): 250-258; M. Vasil'ev, “O kiremetiakh u chuvash i cheremis," IKE, no. 8 (22 February 1904): 240-242; Risālä-yi nurnāmä, 3.

65. Fäżàil, 43; Näșị̂ät aṣ-șālihīn, 30. 
mustard seed of faith."66 The amulet was the "mustard seed of faith," but even in the context of this hadith, Biktashi's narrative went beyond expectations: the sinner had not endured the torments of the grave even for a limited time, but went directly to the Garden. Furthermore, the sinner had not verbally repented, and even if he had, the Qur'an specifies that after committing evil, last-minute repentance on one's deathbed is not enough to be absolved from punishment. In general, Biktashi's Fäżä'il ashShühūr was a much more optimistic work than Näșîhät aș-Șālihīn. The latter book focused on frightful images of hell and insisted on punishment, while Biktashi who taught in an area populated by starokreshchenye, focused more on rewards. ${ }^{67}$

\section{Knowledge, Miracles, and Faith}

Tatar popular religious literature indicated that there were two different levels of adherence to Islam: faith and religious praxis. Failure to observe rituals could send one to hell, but observance of devotional rituals without faith had the same consequence. Faith was the ultimate key to salvation. However, what distinguished a Muslim from a non-Muslim in this world was praying five times a day, fasting during Ramadan, performing the $z i k r$ (perpetual remembrance of God as one of the foundations of the Sufi path), giving alms to the poor, learning and teaching about Islam, and having the capacity to perform miracles through God's power. Constant religious praxis held the whole community together. What is more important is that it guaranteed the community's future salvation as a collective body and its protection from the arrival of an evil satanic despot. The correct fulfillment of religious duties implied a commonly shared obligation to learn about the contents of the Qur'an from mullahs, shaykhs, and more knowledgeable kin.

Näșîhät aș-Ṣalihīn devoted more pages to learning than to other religious obligations. By seeking knowledge, Muslims would accumulate enormous rewards and blessings in the afterlife. The author of Näșîhät aṣ-Ṣālihìn was not too demanding. He wrote that learning a single word brought a blessing, and learning one hadith awarded the equivalent of seventy prophets' good deeds. For each letter read, one would receive the blessing of a prophet. Students of an 'alim (teacher, scholar) would be blessed on Judgment Day: angels would place a mountain of 40,000 gold coins on the right side of their eschatological scale. At the end of time, scholars of Islam would be forgiven thanks to the angels' intervention and would stand by the Prophet Muhammad. ${ }^{68}$

In the same book, learned men of Islam, especially Sufis, whom baptized Tatars held in high esteem were called "the prophets' successors." Like the prophets, they were endowed with two great gifts: knowledge of God and the power to perform miracles in the name of Allah. Their mission, though, was not to carry a new revelation, but to educate and fortify people's faith. Their knowledge of God was equal to, even greater than that of, the prophets of Israel. In one anecdote, Moses questioned al-Ghazali and Abu Hanifa, the eighth-century eponymous founder of the

66. Muslim, book 1, hadith 165 and al-Bukhari, vol. 8, book 76, hadith 565, trans. in Cyril Glassé, The Concise Encyclopedia of Islam (San Francisco, 1989), 109.

67. Fäżàil, 12; Qurān, 4:18.

68. Näșịüt aṣ-ṣālihīn, 27-35. 
Hanafi school of law to which Turkic Muslims adhered. Everyone, including Moses, marveled at their answers. In another story, the mythical saint, prophet, and guide on the spiritual path, al-Khidr (the "Ever Green" or the "Green One" in Arabic), whom Tatars believed to be immortal, appalled Moses by committing apparent atrocities. Ignorant of the hidden reasons behind al-Khidr's actions, Moses showed his inability to understand God's will beyond external appearances. While Moses represented external knowledge, al-Khidr personified esoteric knowledge. Yalchïghol went a step further, considering Sufis' knowledge superior to all prophets except for Muhammad. According to him, Shaykh Naqshband bluntly told al-Khidr that Muslim teachers were superior to him, even if he was a prophet and was still alive. The reason for their superiority was that after the coming of Muhammad, Muslims could draw all knowledge, both external and esoteric, directly from the Qur'an. The time of prophethood had passed; consequently Naqshband's and his followers' teaching was superior to that of the prophets. ${ }^{69}$

Among the most venerated spiritual guides in the Tatar and baptized communities were the dervishes, shaykhs, and hermits. At times, authors of religious books praised the principles of asceticism and poverty, and denounced intellectual knowledge as a tool to challenge God. They demonstrated bias against family ties, accumulation of riches, and men of knowledge, who sought to realize the dreams of this world instead of the next. When the final hour came, they insisted, men of learning would succumb to death as well. In other words, knowledge did not have to be bookish, but could derive directly from God without any intermediary. The Prophet Muhammad was the best example of an illiterate (ummi) who became the vessel of God's word. Likewise, in Risālä-yi 'Azizzä, the future shaykh Habibullah, then a young boy who sold cantaloupes and watermelons at a market in Bukhara, was distressed by the lack of faith among the inhabitants of his city and, after seeing Muhammad Baha' ad-Din Naqshband in a dream, became the Sufi disciple of Andirjan in Samarkand. Later, Andirjan asked him to go back to Bukhara in order to instruct his kind, despite the young boy's doubts: he was only twenty years old, had no knowledge of the miracles and theology, and needed to learn more from his teacher. But the boy prayed and Allah gave him direct understanding of the divine message in one day. Apart from intellectual knowledge, kinship and riches could also be a hindrance on the straight path, and at the Last Judgment, Sufi authors reminded sinners that fortune, parents, spouses, and children would not serve as intercessors or mediators. ${ }^{70}$

In texts used in primary Qur'anic school, signs and miracles-not intellectual or polemical arguments-revealed the superiority of Muhammad over other prophets. A cloud of glory, indicating the presence of God and often mentioned in Sufi biographies, followed Muhammad wherever he went and a seal (möher) on his neck said that God would always support him and respond to his requests. After witnessing those signs, a Christian monk converted to Islam. Later, Muhammad entered a Jewish house and all the menorahs flew into pieces. ${ }^{71}$

69. Näșîhät aṣ-ṣālihīn, 27, 32-33; Yālchïghol, Risālä, 240-241.

70. Näșịhät aṣ-ṣālihīn, 13; Yālchïghol, Risālä, 3-6, 9; Qur'ān, 29:48.

71. Fäżààl, 5-6. 
Central figures in Turkic Islam were presented as possessing appropriate signs of sainthood or proofs of their superiority. When Imam al-Ghazali and Abu Hanifa answered Moses's questions, the audience marveled, but the author did not expand on the topics discussed. Amazement and wonder sufficed to explain al-Ghazali's and Abu Hanifa's understanding of divine reality. Abu Hanifa's death was also surrounded by wonders. When a certain Muhammad b. Masak washed his corpse, Abu Hanifa's head turned to him and showed a sign on the forehead, saying "Eh, quiet soul, come back to me." On each part of his body shined a divine inscription, and a secret voice came down to sing his glory. The caliph, who doubted that Abu Hanifa's legal school was a true reflection of the Divine Law, heard the voice and repented. ${ }^{72}$

Signs and miracles were essential proofs of God's support. They demonstrated the superiority of Islam over Judaism and Christianity, heightened the awareness of religious duties, and showed that God could work through his most humble servants. The attribution of miracles to saints did not necessarily go against Sunni orthodoxy. Even Ibn Taymiyya, known as one of the strictest commentators who vigorously opposed saint worship, recognized the saints' miracles as signs of divine support. ${ }^{73}$ The Sufi Yalchïghol did not separate himself from the traditional understanding of miracles in Islam. He carefully distinguished between miracles attributed to prophets ( $m u^{\prime}$ jiza) and miracles connected with saints (karamat). According to his categorization, the $m u$ 'jiza (which literally means "disabling") referred to a phenomenon that defied physical laws such as flying in the sky, making water flow from one's fingers, making trees and animals talk, or walking on water. The karamat - which in practice did not differ from the $m u^{\prime} j i z a$-were gifts from God at a given moment, when needed. By allowing a karamat, God acknowledged the qualities of the saint: love for God, conscientious religious observance, and abhorrence of sin (fornication, lying, pride, and neglecting ritual prayers). Yalchïghol made the point of attacking the presumption of "men without religion" who claimed that shaykhs did not need to pray and follow basic religious practices. Those unbelievers falsely held that holy men who have reached the highest level of sanctity could pray silently and observe external rituals in their heart. ${ }^{74}$ Miracles committed by men who did not follow the sharia were called istidraj; God granted them success at the beginning of their sin, allowing them to work miracles only in order to hasten their way to perdition. The believers' responsibility in such instances was to recognize the falsity of these miracles by identifying the so-called saint as an unworthy servant of God. Yalchïghol also attacked the popular idea that shaykhs could perform miracles on their own, for even holy men could not read humans' heart and interpret the future. Miracles came only by God's grace. Finally, Yalchïghol did not limit the working of miracles to the shaykhs; God could grant the power to work miracles to any man close to Him who followed the sharia to the letter. But the devil could also work miracles, and those who did not obey Islamic law, that is the infidels, could perform wonders only by Satan's power. Such was the case of the pharaoh who ruled during Moses's time, who successfully performed

72. Näșîhät aṣ-șālihīn, 33-36.

73. Julian Johansen, Sufism and Islamic Reform in Egypt: The Battle for Islamic Tradition (Oxford, 1996), 48.

74. Yālchïghol, Risālä, 58-59. 
miracles but then perished. Although the text did not refer to Russians and their adoration of miraculous icons and crosses specifically, the pharaoh, as a pagan ruler, could easily substitute for the Russian czar, protector of the Russian "pagan" church. When missionaries visited apostate villages, their inhabitants yelled to them: "How come your crosses do not perform miracles anymore?"75

Contrary to what later jadid critics implied, the authors of those books did not advocate ascetic principles of poverty and mendicancy as the only sure way to gain salvation. Not all of their readers had the ability to become hermits or dervishes; most believers lived in the world, earned a living, and had families. In a number of anecdotes, mullahs acted as veterinarians or doctors and Sufi shaykhs were not supposed to depend on people's earnings; they had many trades. Shaykh Naqshband was a tailor, a weaver, and a skullcap maker. Shaykh Andirjan herded cows, and his student, Shaykh Habibullah, had a shop and proselytized among the Bukharan merchants. ${ }^{76}$ Social responsibility, which included giving alms, adopting orphans, founding schools and mosques, praying for the whole community, and teaching the sharia, was another way to be counted among the blessed. The rich could earn salvation by giving to the poor and the teachers of Islam. In fact, according to Biktashi, the first to enter paradise will not be the learned, the shahids (witnesses, martyrs of the faith), or those who performed the pilgrimage to Mecca, but the generous patrons whose alms supported the schools. All proselytizers of Islam in the baptized milieu had a small trade. ${ }^{77}$

Turkic religious books also showed ways simple believers could surpass the shaykhs and shahids of the biblical times. Biktashi portrayed the Prophet Muhammad as deeply concerned about God's judgment on his people; after all, their deeds could hardly compare with those holy Jewish and Christian hermits who had spent hundreds of years in prayer inside a white mountain, waiting for Muhammad's coming. Worse, Muhammad's people could not compare with the shahid Samson who fought 10,000 lunar months in jihad. Fortunately, the angel Gabriel revealed that Muhammad's followers could surpass previous nations by spending the month of Ashura (the first month of the Islamic year during which Husayn, the grandson of Muhammad, was murdered at Karbala in 680), the month of Rajab, the fifteenth day of the month of Shaban (the month of division in which sins are absolved), and the night of Laylat al-Qadr (the Night of Power in which the Qur'an was first revealed) in repentance, worship, and fasting. However, the performance of those rituals should come directly from the heart. More than once, Biktashi reminded his reader or listener that only faith-not the mechanical performance of rituals-brought future rewards in the afterlife. ${ }^{78}$

Although the author of Näsīhät aṣ-Ṣālihīn exhibited some initial mistrust toward knowledge, he advised his readers on how to begin the study of the sharia. Students of Islam, he warned, should not have access to higher forms of learning before having first a good grasp of 'ibadat or acts of worship. Shaykh Naqshband was quoted as

75. Yālchïghol, Risālä, 15, 53-54; NART, f.4, op. 98, d.9, 1. 82 ob.

76. Yālchïghol, Risālä, 5 .

77. Fäżäil, 51-52.

78. Fäżàil, 23-25, 34-36, 38-39, 48. 
saying that the study of logic (mantyq) should not start before integrating the rules governing acts of worship. A man who skipped this important stage would be incapable of following the straight path from his heart. ${ }^{79}$ The knowledge of devotional rituals constituted the bulk of the teaching contained in popular Islamic literature. These books provided proofs of the Muslim faith and enumerated the obligations of the believers toward God, family, and community. They included samples of prayers, the Muslim calendar, rules of purity for women, and comportment toward family members, fellow Muslims, and nonbelievers. The primer Sharä'it al-İmān listed the key prayers in Arabic and instructions to perform them in türki, specifying each time the number of prostrations, but without the support of stories or marvelous deeds found in Näșihät aș-Ṣālihīn and Fäża'il ash-Shühūr that appealed more to the believers' imagination, often by quoting from Rabghuzi's tales of the prophets. The prayers in those two books were more succinct and in Turkic. Prayers in Arabic were reduced to short Islamic expressions, repeated a number of times such as Bismillah, Astaghfirullah (I seek pardon and forgiveness from Allah), Subhanallah (Glory to be to Allah), or Al-Hamdulillah (Praise be to Allah). Those expressions, commonly used in the entire Islamic world, were already part of the folk's spoken language among both apostates (especially women) and Tatars. They were believed to make people's dreams and wishes come true. ${ }^{80}$ In the very last chapter of his book, Biktashi encouraged believers to perform the $z i k r$ after the obligatory prayer in order to remove all sins, by repeating thirty-three times, one after another, each of the three following litanies: Subhanallah, Al-Hamdulillah, Allah akbar (God is great), and by closing the hundredth incantation with the shahada. (The number of invocations corresponded to the ninety-nine Divine Names, with the hundredth still unknown.) After the 'ibadat, Näșîüt aș-Ṣalihìn mentioned the importance of studying the tafsir, hadith, and fiqh (jurisprudence) before moving into the study of any other sciences, including the sciences of this world, and especially trade. ${ }^{81}$

\section{Living in a Non-Muslim State}

Besides offering consolation for a lack of knowledge and tools for overcoming it, Tatar religious literature also provided a paradigm of behavior for Muslims living in a predominantly non-Muslim state. Any relaxation of proper religious or social behavior could lead to the coming of a despot or false prophet (ad-Dajjal, literally, "the deceiver" or "the imposter"). As elsewhere in the Islamic world, preachers often attributed defeat by invaders as a sign of religious decline in the community. The books remedied such decline by offering four possible models for living in a world dominated by non-Muslims.

The first model related to solitary figures living in a kafir (infidel) world. Biktashi's Fäża' il ash-Shühūr opened with the image of a Christian monk (rahib) who had converted to Islam but, for fear of persecution, pretended to be a Christian while secretly observing the tenets of Islam. ${ }^{82}$ The second model was that of the imprisoned Prophet

79. Näṣīhät aṣ-ṣālihīn, 35 .

8o. Mashanov, “Zametka," IKE, no. 1 (1 January 1875): 29.

81. Fäżàìl, 70; Näșîhät aṣ-ṣālihīn, 35.

82. Fäżàil, 2-3. 
Joseph, who spoke about his faith to fellow prisoners. Thus, even under foreign rule, Islam could expand its territory and even convert pagan rulers. Similarly mullahs and abïstays of baptized origin could emulate Joseph and teach underground. Copying Qol 'Ali who claimed that the pharaoh could have converted to Islam, Tatars spread rumors among Kräshens that their pharaoh, the czar of Holy Russia, had converted to Islam, had allowed Kräshens to become Muslims, and even had sent them a Muslim skullcap as a present. ${ }^{83}$

The third model demonstrated the possibility of cooperation with non-Muslim authorities. In Qïșsa-yi Yüsuf, the Prophet Joseph served his infidel masters as a slave in Egypt; by so doing, he rose to a high position and brought many to Islam. He nonetheless obeyed the pagan pharaoh's law even as he continued to proselytize. But when cooperation demanded abandoning some vital part of Islam, the Sufi ethic offered a fourth model-complete and total separation from the non-Muslim populace. Thus when the King of Egypt asked Joseph to stop proselytizing, Joseph instead founded a city where only Muslims could reside. The book of Bädäwām went further and urged true believers not to drink or eat with non-Muslims. By extension, the Sufi teaching contained in these books encouraged resistance to Russians when the latter tried to impose legal prohibitions on Tatar proselytism, but, as the example of Joseph showed, it did not prohibit Muslims from working within the Russian political system-using legal means to help protect and expand God's rule. In 1916, the reformist theologian Fäkhr ad-Din cited Joseph as a model of action for all Tatars to follow. ${ }^{84}$

\section{Female Scripts of Action in Traditional Islamic Literature}

Tatar religious books also provided models of action for women living on the KräshenTatar-Russian frontier. Apart from the mullahs, shaykhs, and itinerant Sufis, women constituted another category of spiritual guides. Without the support of wives and mothers, the apostasy movements could not win. As much as for men, Sufi-inspired books constituted the bulk of Islamic knowledge among peasant women who, in their turn, propagated their content in the form of munajat. Actually, women were the main (but not exclusive) carriers and producers of the munajat genre, which in a poetic and succinct form recalled the prophets' trials and the believers' duties.

Boys interested in becoming mullahs could pursue their schooling in prestigious madrasas, but women's education did not go beyond the maktab (primary Qur'anic school). Peasant girls did not follow the madrasa curriculum, but did read and sing popular Sufi poetry, which made the high tradition of Islamic knowledge available to them. Mullahs' daughters were more privileged. Because of their fathers' position and the chance of a better marital match in the future, they had access to other more advanced forms of religious knowledge. For example the mother of the Bashkir historian Zeki Velidi Togan (1890-1970) who was the daughter of a village imam educated

83. Akhunov, Arabskii istochnik, 63; Iapei Babai, "O kreshchenykh tatarakh," no. 18 (15 September 1891): 558-559, and no. 20 (15 October 1891): 622; Kitāb-i qüsṣa-yi Häżrät-i Yūsuf, 63-64.

84. Kitāb-i qüșșa-yi Häżrät-i Yūsuf, 63; Bädäwām kitābï (Kazan, 1861); Fäkhr ad-Dīn, Jäwāmi', 127 (hadith no. 89). 
in Bukhara and Khiva, became fluent in Persian. She kept samples of Farid ad-Din Attar (1119?-1223), Jalal ad-Din Rumi (1207-1273), Nizam ad-Din Mir Alisher Navoi (1441-1501), Ahmad Yasawi, and Allahiyar's Sufi poetry in a notebook and taught them to her son in Persian and in Chagatay Turkish. Women liked to integrate and recycle these poems into their munajat repertoire, moving freely from oral to written form and vice versa. Togan's mother secured her position as her husband's only wife, by recycling a love poem to remind him of his promise not to marry any other. Authorship was not an issue as the main function of the munajat performance in commemorative religious festivals was to cause the listeners to remember prophetic knowledge and reawaken the feeling that they belonged to a higher divine reality and a common community of faith. ${ }^{85}$

Traditional Sufi-inspired prose and poetry did not address a female audience specifically. Faithful to the letter of the Qur’an, Bädäwām Kitābï and other books demanded the same piety from men and women. ${ }^{86}$ They nevertheless included powerful female characters and offered valuable paradigms of behavior in the religious sphere, despite Muslim mystics' ambivalence toward women. Early on, a majority of Sufis viewed sex with women as a hindrance on the path to God and considered "the weaker sex" as inferior, unclean, and dangerous. But later, some Sufis developed a more positive attitude toward sex and women, considering love for a woman as a manifestation of the Deity. Al-Ghazali in particular, who reconciled Sufism with mainstream theology, used love for a woman as a metaphor of the loving relationship between the believer and God. Both traditions were present in Eurasia and Central Asia. ${ }^{87}$

Rabghuzi, who otherwise presented very positive images of women, retained an early view that women were unclean. He thanked God for "creating us as males," and considered women's cunning greater than Satan's. ${ }^{88}$ Although Eve (Hawwa) was not specifically mentioned in the story of the fall in the Qur'an, Rabghuzi's work echoed earlier Arabic tales of the prophets and held her responsible for causing it. A woman's heart, said Rabghuzi, was softer than a man's and so more apt to listen to Satan. As a result of her disobedience, menstruation-thus uncleanness and inability to perform all rituals at all times-remained her lot until Judgment Day. ${ }^{89}$ This unflattering portrayal of women was also rampant in other popular eschatological works in the Middle Volga. In Näșîhät aṣ-Ṣālihīn, an ugly old woman

85. Zeki Velidi Togan, Hâttralar (Istanbul, 1969), 24-26. (Male students recorded Persian poetry in their journals while studying in madrasas. Validov, Ocherk, 14-15.) Michael Frishkopf, "Authorship in Sufi Poetry," Alif: Journal of Comparative Poetics, no. 23 (2003): 78-108.

86. Bädäwām kitābï, 2-3.

87. Annemarie Schimmel, Mystical Dimensions of Islam (Chapel Hill, 1975), 426-435 ("The feminine element in Sufism," appendix 2); idem, "Eros-Heavenly and Not So Heavenly-in Sufi literature and Life," in Society and the Sexes in Medieval Islam, ed. Afaf Lutfi al-Sayyid Marsot (6th Georgio Levi della Vida Conference, UCLA, 1977; Malibu, CA, 1979): 119-141.

88. Al-Rabghūzī, Stories, vol. 2: 3, 213-214.

89. Qửān, 2:35-39; al-Rabghūzī, Stories, vol. 2: 30-31; Annemarie Schimmel, My Soul is a Woman: The Feminine in Islam (New York, 1997), 56-58; 23-25. A Muslim Tatar woman shared the story about Adam and Hawwa, and the origin of menses with a Kräshen teacher from Il'minskii's seminary. Stepan Danilov, "Razgovor uchitelia kreshcheno-tatarskoi shkoly na parokhovom zavode, bliz Kazani, s mokhammedankoi," IKE, no. 13 (1 July 1872): 405. 
appeared at the end of the world and was thrown into hell as the symbol of earthly temptations. And in Qisșsa-yi Sulaymān, the writer warned men not to follow women's advice because they were stupid and ignorant. In the first pages of the story of Joseph, Rabghuzi also presented the love of Potiphar's wife for the beautiful Joseph, her adoptive son, as adulterous, incestuous, and unclean. Zulaykha had betrayed the trust of her husband, a believing Copt (here means Egyptian) who worked for the pharaoh of Egypt only on the condition that he could freely practice his faith. Rabghuzi insisted that Zulaykha desired Joseph but did not really love him because she told lies about him and sent him to prison. This narrative echoed earlier Arabic expansions of the story of Joseph, such as the tafsir and tarikh (History of the Prophets and Kings) by Tabari during the Abbasid period, where Potiphar's wife was nothing but a figure of temptation, a symbol of women's guile and uncontrolled sexuality. ${ }^{90}$

Although the superiority of men is affirmed in the Turkic stories of Joseph, both Rabghuzi and Qol 'Ali catered to a female audience. Qol 'Ali's narrative was not only a tale of Joseph, but a tale of Joseph and Zulaykha. The latter was not responsible for her insatiable sexual appetite because her infatuation with Joseph's beauty sprang from a divinely inspired dream she experienced while a mere child. Her marriage with Potiphar was not even consummated: God had placed a female jinn in his bed. In Rabghuzi's first pages of the story, Zulaykha did not differ much from the Joseph narratives in the Bible and the Qur'an. That is, she was not an innocent child, tormented by a dream, but a cunning woman whose "bad deeds would always be remembered by all preachers." Later, however, the author claimed that, in fact, Zulaykha could not do anything against her love for Joseph. God, and not Satan, had affected her heart. Men and animals also fell under Joseph's spell. Even in the most sinful moments of the story, Zulaykha sang of her desperate love for Joseph in beautiful love poems in Arabic, Persian, and Chaghatay Turkish that in no way indicated that her passion was impure. On the contrary, these lyrical rhymes could easily be taken out of their context and serve as models of love letters for young people, eager to express their feelings in writing. ${ }^{91}$ In the last pages of the cycle of Joseph, Rabghuzi added-at the risk of contradicting himself-that Zulaykha's husband was an unbeliever (and not a believing Egyptian as he had stated earlier) and more important, impotent. God had sent angels who resembled lions to protect Zulaykha's virginity, which was promised to Joseph. ${ }^{92}$

A female audience could also object that trickery was not an exclusively female feature. Although in the Qur'an Potiphar was quick to generalize his wife's cunning behavior to all women, the story of Joseph provided many other examples of trickery that involved men. Joseph's brothers lied about his death when they told their father, Jacob, that a wolf had devoured his favorite son. Finally, Joseph was not as perfect as

90. Näṣihhät aṣ-șālihīn, 3; Mikhailov, "Kriticheskii razbor," 280-284; Al-Rabghūzī, Stories, vol. 2: 198, 201, 205, 207, 211; The History of al-Tabari (ta'rīkh al-rusul wa'l-mulūk), vol. 2, Prophets and Patriarchs, trans. William M. Brinner (Albany, 1987), 148-185.

91. Al-Rabghūzī, Stories, vol. 1: 154-156, 168-169; in the nineteenth century, the famous physician and former rector of the University of Kazan, Karl Fuks prided himself for having received such passionate poems from female Tatar admirers. Fuks, Kazanskie tatary, 52-56.

92. Kitāb-i qïșsa-yi Häżrät-i Yūsuf, 28, 31-37; al-Rabghūzī, Stories, vol. 2: 187, 194, 197, 276. 
he seemed at first glance. At times he showed pride in his beauty. If in the Qur'an, Jacob's favorite son was shown as the victim par excellence, in Qol 'Ali and Rabghuzi, he was surpassed by Zulaykha, who, contrary to Joseph, did not enjoy the protection of angels in her sufferings. Had not Gabriel intervened to save Joseph from temptation, he would have failed the test of prophethood miserably. ${ }^{93}$

Zulaykha in both Qol 'Ali's and Rabghuzi's work was an extraordinary model of Sufi practice in an overwhelmingly pagan environment. Although in Tabari's work, there was no character development, in Qol 'Ali's poem, Zulaykha's conversion was described as a gradual and triumphant process. First, Potiphar's wife used her idols to seduce Joseph, but instead her idols recognized Joseph's authority, declaring him Prophet of the Truth. As punishment, Zulaykha's love for Joseph was not returned, and she became an old blind woman. She, however, continued to love Joseph until she finally concluded that his God had paralyzed her idols' powers. She broke her idols, gave away her riches, and declared to Joseph: "I believe in one God and in you, Prophet Joseph." These words reminiscent of the shahada purified Zulaykha who regained her youth and beauty. Joseph married her, and twelve children blessed their union. Only after her recognition of Allah's Oneness, did she find happiness in marriage and childbearing. Before she broke her idols, her love for Joseph was pure lust, but after she had decided to follow the sharia, she finally entered the path (tariqa) on which mystics walk. She went through the classical stations of the Sufi ladder (repentance, abstinence, poverty, patience, love, and fear) before she met Joseph again, and surrendered her heart in the contemplation of the divine beloved. Zulaykha was no less than a traditional Sufi disciple in search of unity with God. ${ }^{94}$

In the particular tradition that Qol 'Ali represented, Sufism did not exclude women from the path. In fact there was no distinction between men and women in their ability to reach the divine. Neither miracle worker nor prophet, Zulaykha was nevertheless a mirror image of Joseph. Both had to learn patience, abstinence, and trust in God before being united. Both were marked by their extraordinary beauty and enjoyed a close relationship with their fathers. Zulaykha slept on her father's lap the same way Joseph did in Jacob's arms. ${ }^{95}$

In Rabghuzi's history of the prophets, Zulaykha reached the highest level of the Sufi path in an even more striking way. Rabghuzi, under the influence of the famous Persian Sufi poet Farid ad-Din Attar, compared her to a moth who cast herself into a candle flame to know the divine. ${ }^{96}$ Not only did Zulaykha overcome the limitations of her carnal soul, but she came to surpass the Prophet Joseph in her quest for God. The story indeed took an unusual, humorous twist. One tradition related that after they married, God gave Zulaykha's passion to Joseph, and Joseph's love for God to Zulaykha. The whole drama was then reversed: Joseph became the one who pursued Zulaykha, and Zulaykha, empowered with her new love, ignored Joseph and prayed

93. Al-Rabghūzī, Stories, vol. 2: 181, 182, 208, 232; Kitāb-i qüșsa-yi Häżrät-i Yūsuf, 35.

94. Kitāb-i qüsșa-yi Häżrät-i Yūsuf, 31, 46-49; Martin Lings, What Is Sufism? (Berkeley and Los Angeles, 1977); Schimmel, Mystical Dimensions of Islam, 98-186.

95. Kitāb-i qüșsa-yi Häżät-i Yüsuf, 3, 25.

96. Farid Ud-Din Attar, The Conference of the Birds: Mantiq Ut-Tair, trans. C. S. Nott (Boulder, 1971), 125; al-Rabghūzī, Stories, vol. 2: 219. 
days and nights uninterruptedly. Joseph came to experience Zulaykha's pain and Zulaykha Joseph's joy. Only later did they both unite sexually. ${ }^{97}$

On another occasion, Rabghuzi took the women's side against the quintessentially male Joseph. At one time the ladies of Egypt (including some believers in the one true God) complained that Joseph pursued them and attacked their honor; they even called him a sorcerer. In earlier Sufi texts and folk literature, women were more likely to be associated with magic and sorcery. Zulaykha was not the only one to conquer her lower self or carnal soul. Joseph also had to overcome his lower instincts to resist Zulaykha and become a prophet. Finally, not only was Zulaykha a mirror image of Joseph, she was also a mirror image of Jacob. Both had lost their sight when separated from their beloved. Because Joseph's father recognized himself in Zulaykha, he gave her back her youth and fertility. Jacob himself had erred earlier by separating a slave mother from her son; for that reason, he was separated from his beloved child. Both Zulaykha and Jacob had repented and gained or regained possession of the divine light embodied in Joseph. ${ }^{98}$

Interestingly, Rabghuzi continued to refer to Zulaykha positively in later cycles devoted to other prophets. In medieval Arabic literature, Aisha-the Prophet Muhammad's youngest wife whose active participation in the fights following his death met the community's resentment, was associated with the cunning Zulaykha. In the Stories of the Prophets, Potiphar's wife became the prototype of all pagan women who had recognized God's true messengers, including Khadija, the Prophet's first wife, whom Rabghuzi explicitly compared to Zulaykha. Both Zulaykha and Khadija were older, wealthier, and politically more powerful than their consorts, but nevertheless recognized them as the prophets of God and became their servants. ${ }^{99}$

Concretely, Zulaykha's example did not mean that women yielded all power to their husbands after conversion and remained in ecstatic contemplation. In fact, when Zulaykha was filled with God's love, her husband could not have sex with her. Rabghuzi's prose showed that if God willed, women could have the upper hand in matters of physical love: they could make their mates submit to their desires and experience happiness; they could even refuse to have sex. If necessary, women could also challenge male authority to expand Islam, introduce and enforce sharia rules in the pagan milieu. Thus, at the very beginning of the cycle of Ayyub (Job), Rabghuzi introduced a new feminine character, Qïz Qïsun, whose Turkic name means the mutilated girl. Significantly, Rabghuzi chose to recount the tale of Qiz Qisun-a character who appears nowhere in the Qur'an-just after Joseph's story. In doing so, Rabghuzi inspired women to think of themselves as bearers of Islam outside their households. Like Zulaykha, Qïz Qïsun was a pagan. Her father, Bahil, was Job’s uncle and an idol worshiper. When the angel Gabriel came to her in the form of a dove, she converted

97. Qịṣaṣ-i Rabghūzī (Kazan, 1859), 206; Al-Rabghūzī, Stories, vol. 2: 274. Zulaykha’s attitude was in accordance with the doctrine of some Sufis who felt unnecessary to pursue a life of asceticism once they had reached the summit of spiritual life. Margaret Smith, Rabia: The Life and Work of Rabia and Other Women Mystics in Islam (Oxford, 1994), 73.

98. Al-Rabghūzī, Stories, vol. 2: 216, 264-265, 272-273; Jamal J. Elias, "Female and Feminine in Islamic Mysticism," Muslim World 78 (1988): 214.

99. Fedwa Malti-Douglas, Woman's Body, Woman's Word: Gender and Discourse in Arabo-Islamic Writing (Princeton, NJ, 1991), 51-52; Al-Rabghūzī, Stories, vol. 2: 534-536. 
to Islam, destroyed the idol her father gave her, and distributed its ornamental jewels to the poor. For this crime, her father had her right hand cut off, and expelled her from her homeland. But Qïz Qïsun endured the pain and later met her future husband, the pagan king Mathwil, whom she refused to marry unless he converted first. (According to sharia rules, a woman cannot marry a nonbeliever.) Zulaykha experienced God's love but did not make new converts; but Qiz Qisun was the channel by which her husband, her father, and the whole kingdom came to God. Like the Prophet Muhammad and earlier the Prophet Joseph, she was exiled and built a new community of believers in a pagan milieu. Coincidentally, the story of the mutilated girl was also popular in sixteenth-century Spain among baptized Muslims. There she was called the handless maiden of Carcayona. In both contexts, Eurasian and Morisco, the tale offered a means of resistance to Christian attempts to control Islam. ${ }^{100}$

Qiz Qïsun prepared the way for another important female character, the Queen of Sheba or Bilqis, who converted to Islam, thanks to Solomon, and whose beauty, according to Tabari, matched Joseph's beauty. Although neither the Hebrew Bible nor the New Testament indicate that the Queen was an idolatrous gentile, in the Qur'an Bilqis is a sun worshiper who receives a message from Solomon, summoning her to surrender. She fails Solomon's tests of knowledge, and therefore converts to Islam. In Rabghuzi, the emphasis was not so much on the Prophet's superior knowledge as on Bilqis's wisdom. In fact, the cautious queen tested Solomon before he tested her. When she received the letter commanding her to renounce everything, she knew that the letter came from God and that Solomon was a prophet, but, concerned for her people's safety, the queen opted to verify its content-after all, Solomon could have been a false prophet. Bilqis ruled that if Solomon were a true prophet he would not care for her riches. Solomon passed her test and she converted, and through her, as with Qïz Qïsun, her nation did so as well. However, Solomon failed Bilqis's very last test. When he told his new wife that a far greater prophet named Muhammad would appear, the queen asked whether she would get a chance to meet him. Jealous, Solomon felt challenged and sent his wife back to her kingdom, where she died as a true believer. Thus, in Rabghuzi, both Bilqis and Zulaykha, despite the "softness of their heart" and the limitations of their gender, came to surpass their prophet-husband in their love for God; and both Bilqis and Qiz Qïsun led their people to recognize the true faith and observe its laws. ${ }^{101}$

The stories of Zulaykha, Qïz Qïsun, Bilqis, and Khadija, to whom Rabghuzi devoted a significant portion of his text, came to provide a missionizing model of conduct beyond Central Asia and beyond his own time for women on the Volga frontier. Turkic peoples in the Middle Volga practiced exogamy, and brides-to-be carried their Islamic knowledge to their new families and peoples on the frontier, as Qïz Qïsun and Queen Bilqis did. Rabghuzi and his predecessor Qol 'Ali had access to various sources of Qur'anic and extra-Qur'anic origin, as well as Sufi and classical

100. Qïṣaṣ-i Rabghūzī, 209-216; Al-Rabghūzī, Stories, 1: 227-234; idem, Stories, 2: 281-288; Mary Elizabeth Perry, The Handless Maiden: Moriscos and the Politics of Religion in Early Modern Spain (Princeton and Oxford, 2005).

101. Qur'ān 27: 23-34; Fabrizio A. Pennacchietti, Three Mirrors of Two Biblical Ladies: Susanna and the Queen of Sheba in the Eyes of Jews, Christians and Muslims (New Jersey, 2006), 78-79; Al-Rabghūzī, Stories, vol. 2: 423-435. 
Arabic exegetic material. They opted for stories that could please a female audience without challenging male dominance. In the tenth and eleventh centuries, stricter Muslim theologians had criticized the popular tales of the prophets for adding too much material to the Qur'anic text. But these criticisms did not deter writers from composing these books for the benefit of new converts. ${ }^{102}$

Apart from stories of religious conversion in the pagan milieu, marital relations and motherhood constituted other important key themes in Turkic religious literature. Again, the texts presented dissenting portrayals of women's duties toward their consort: on the one hand, wives were to serve their husband almost unconditionally; on the other hand, they were taught that God came first and their husband second. Thus, wives were reminded to treat their husbands with loyalty and submission in the same way a murid obeyed his shaykh. Strong metaphors, involving sexual symbols (e.g., hair) and polluting bodily fluids (e.g., blood, pus) were used to emphasize the wives' marital duties. In one home, after all the candles had been used up, a woman lit one of her braids to provide comfort for her husband's eyes while he was eating. When suffering befell the Prophet Job, his wife sold two of her braids for a piece of bread to feed her husband, and carried him on her back while his pus ran over her face. According to one hadith, cited by Biktashi, a wife was expected to lick the bloody wounds of her husband, if necessary-but even this act, according to the hadith, would not be enough to fulfill her duty. Conversely, if a woman caressed her husband's face, asked for advice, and showed understanding, she would be surrounded by the divine light in the hereafter. ${ }^{103}$

But Job's wife was not her husband's "slave." She chose to stay with her husband voluntarily (the prophet's other wives had left him after he had granted them divorce). Popular religious literature took great care to limit women's allegiance to their husbands. "Allah would have asked women to revere their husband if $\mathrm{He}$ had not said 'There is no deity save God,'" commented Biktashi in his section about women's duties. ${ }^{104}$ Household chores could not interfere with women's religious duties, which included the five daily prayers, the Ramadan and other days of fast, the performance of the $z i k r$, the reading of the Qur'an and other religious texts, and service to the poor. And wonderful stories illustrated women's deeper love for God and Muhammad than for their husbands. For example, a woman defied her consort's sexual dominance by giving one of her braids covered with emeralds to the Prophet Muhammad, asking him to sell its precious stones for the sake of the poor. The husband, enraged, planned to kill her and invited her brothers for dinner. They asked her to remove her scarf, but her braid had miraculously grown back, more beautiful than ever, and ornamented with brighter stones. The light from the stones, indicating the presence of God, illuminated the whole room and dazzled her husband and brothers who repented and became Muslim. Another woman, Asiya, a famous martyr of the faith, lived under the terror of her husband, the pharaoh, with whom Moses dealt. She prayed at night in secret and her husband, who epitomized pure evil, had her killed in the middle

102. Shalom Goldman, The Wiles of Women/The Wiles of Men: Joseph and Potiphar's Wife in Ancient Near Eastern, Jewish, and Islamic Folklore (Albany, 1995), xvi.

103. Fä̈̇a'il, 28-29, 31-33.

104. Fäżàil, 28, 33. 
of her prayer. Such a story could easily delight an apostate feminine audience: Asiya lived in a hostile pagan environment and pharaoh could be identified with any representative of Russian power. ${ }^{105}$ However, even when partners were Muslim, a woman still had to choose God over her husband and had the right to quit any relationship with her mate if the latter failed to be a good Muslim, in particular if he drank alcoholic beverages or strayed away from the Muslim path. Women were also entitled to revolt if they were subjected to abuse..$^{106}$

A closer look at relationships between men and women in Sufi books shows that women's devotion to their husbands mirrored their husbands' devotion to God, and their patience and self-denial also played an active role in their husbands' spiritual journey. Their stories served as models of behavior for both men and women. In the fantastic Turkic epic, Kisekbash, which children memorized at the maktab, a wife and mother cried and prayed until 'Ali, Muhammad's son-in-law, came with his sword and freed her from the Div. Spiritually active, her prayers echoed her husband's reading of the Qur'an-the latter had lost his body while fighting the demon, but his decapitated head could still pray-and her unique devotion kept the giant from raping and devouring her, giving her husband and 'Ali enough time to reach the well where she was kept prisoner. Without her spiritual participation, the tale would have ended with the giant's victory, 'Ali would not have killed the Div, and the Prophet Muhammad would have been unable to repair her husband's body and resuscitate her son. Popular consciousness could easily substitute the Div for the Russian colonial power, and the deliverer, 'Ali, for the Ottoman Sultan. After the troops entered apostate villages to stop the rebellion and divide families, separated couples prayed together from their prison's cell or place of exile to paralyze their enemy's powers-expecting the coming of a more powerful eschatological deliverer, as promised to them by itinerant Sufi preachers. ${ }^{107}$

Women could also compete with men in matters of religious knowledge. Even shaykhs could learn lessons from their wives. Against his violent objection, Naqshband's wife proved to her husband that learning was essential to spiritual advancement. Disguising herself as the angel Gabriel, she told two students that each would be a prophet: the ignorant student believed her, but the learned one saw through her deception, called her "devil," and chased her with a knife. Again in this story, the woman played a satanic role that corroborated with an earlier image of women in Sufi literature, but her natural "devilishness" by then had been transformed into an instrument of faith. This transformation echoed the one experienced by other actors in Sufi works. Like the inhabitants of the supernatural or pre-Muslim world (spirits of dead ancestors or pagan gods who converted to Islam), women came to serve the prophets and their close friends. ${ }^{108}$

Mothers were also models, guardians, and nurturers of the faith. In The Book of Mary by Sulayman Baqïrghani, a disciple of Khoja Ahmad Yasawi, Mary set the norm

105. Fä̇̇àil, 55-56; Näșīhät aṣ-ṣālihīn, 5.

106. Näșīhät aṣ-șālihīn, 24; Fäżä̉il, 33.

107. Kisekbash kitābï, 9. Apostates continued praying five times a day in their prison cells and once liberated, boasted that noone kept them from doing it, NART, f. 1, op. 3, d. 227, 1. 79.

108. Yālchïghol, Risālä, 140-141. 
for segregated prayer. She asked her son to build a mosque so she could retire and pray separately. She also rose from the dead in response to the prayers of her desperate and lonely son, gently reproached him for his lack of faith and summoned him to continue his mission. Similarly, when Joseph cried on his mother's tomb, her voice sounded forth from the grave and taught him patience and hope. In these accounts, mothers' role consisted in strengthening their children's faith when the latter was challenged by adversarial forces. They were the ones who brought up their children to serve God, and reminded them of their religious duties. In Rabghuzi's tales, Mary took her son to school, advising the teacher to beat less and teach more. ${ }^{109}$

Mothers' discontent could have devastating effects on their children's life and afterlife. Mothers who felt offended could perform evil prayers. Their prayers would be automatically granted in the same way God answered the prophets' requests. A son who used to call his mother names was changed into a donkey after his mother prayed to God; others were ashamed in public for sexual misconduct and ended up in hell. The degree of the offense could be relatively trivial (a mother remembered that her son did not appreciate one of her dishes), but outweighed any good actions that the son could have previously done. A mother's anathema could also strike an exemplary worshiper. Biktashi reported that a hermit neglected to answer his mother's request while he was performing a supererogatory prayer. Furious, she asked God to throw him in prison with other debauchees. As a result of her prayer, the hermit was accused of having made the king's daughter pregnant. Suspecting that his mother had cursed him, the innocent hermit prayed to God who made the newborn speak. As in the tale of Joseph, the baby exonerated the hermit from the crime. ${ }^{110}$

The children's unconditional deference to their mother is also attested in other Islamic cultures. On Lamu, an island belonging to Kenya, entrance to paradise was conditional upon the mother's consent. People warned children not to displease their mother by referring to a hadith that says: "Paradise is under the feet of the mothers." There is, however, a difference between the Lamuans' and the Tatars' understanding of this hadith. The mothers in Fäż' $i l$ ash-Shühūr actually pronounced a curse, which indicates that women could, with the help of God, exert their influence over men by supernatural means. At first glance, Biktashi's women appear to be "sorceresses," hardly controllable even by those who strictly followed the Sufi path. On the one hand, the hermit's story associated women with illicit sex, magic, and evil; on the other, it acknowledged the power of women in their progeny's lives. The author even justified the hermit's mother's anathema by saying that a mother's request superseded a supererogatory prayer. This suggests that women's magic powers, as much as pagan spirits, were under the control of Islamic law. Although they sent their children to the local parish schools, apostate Kräshen women of Buinsk district threatened to curse them if they read Russian books after school. Likewise, apostates in Staraia Ikshurma expressed their unwillingness to

109. Al-Rabghūzī, Stories, vol. 2: 494-495; Kitāb-i qüșsa-yi Häżrät-i Yūsuf, 18; Ostroumov, Kriticheskii razbor, 179; Häżrät-i Märyäm rażī Allah táālā 'anhā (Kazan, 1909), 8; S. M. Matveev, "Mukhammedanskii rasskaz o Sv. Deve Marii. Tekst i perevod," IOAIE 13, no. 1 (1895): 22, 30. (Matveev's version differs slightly from the 1909 edition.)

110. Fä̈̇àill, 65-67; Kitāb-i qüsṣa-yi Häżrät-i Yūsuf, 37. 
return to Christianity by declaring to the missionary Mashanov that they feared their mother's anathema. ${ }^{111}$

In Sufi tradition, not only could women be seekers of God and powerful mothers, but their religious duties were not tied to marriage. If God wished, they could live alone as dervishes. In Qïșsa-yi Yüsuf, one rich woman converted to Islam after seeing Joseph and distributed her wealth to the poor and dervishes before she herself became a seeker of God and retired in a cell. Women could also be equal to the prophets as miracle workers. Fatima, the Prophet's daughter, known as the first qutb (great Saint) in Sufism, was a popular intercessory female figure. It was said that after she prayed, invisible hands built a mosque in one night and that on Judgment Day she would intercede for all pious women. ${ }^{12}$ Tombs of female Sufi saints, quite common in the Middle Volga but rarely entered into Russian archeological descriptions of the Kazan province, did not fail to attract pilgrims of multiethnic origin. Such was the case of 'Ayshä Bikä's grave, daughter of a Prophet's companion near the village of Tatarskaia Aisha, whose tomb had such charisma that even Russian peasants feared to till the lands around it. ${ }^{113}$

Stories involving pious, anonymous women were also used as models for proper Islamic behavior. One woman, who had no kinship with any prophet or saint, refused to interrupt her prayers even when the devil threw her child into a burning pit; miraculously, the child suffered no harm. When Jesus learned of this, he told her husband: "If your wife were a man, she would be a prophet." In Fäżàil ash-Shühūr, popular traditional Sufi symbols such as a tree, light, and gems beautifully enhanced Rabghuzi's more sober narrative: not only did the child play with burning charcoal, but he was shaded and nourished by a fruit tree that sprang up in the pit; even the fiery coals became precious stones in this version of the story. Similar to the Tree of Life with its roots in heaven (an image frequently used in Sufism), the tree in Biktashi's story reflected the presence of God in the heart of the believer (as if the woman's constant prayer had watered the tree), and the precious stones mirrored the divine light. Images of trees and gardens appear in other miraculous stories, involving masculine figures such as the Prophet Muhammad or al-Khidr. ${ }^{114}$

Tatar epics, tales, and historical traditions reinforced the positive image of women in religious literature and demonstrated that women's actions were far from being limited to the domestic sphere. They showed in actual accounts how important the women's mission was in both spreading Islam and resisting foreign invaders. Before the Mongol invasion, historical traditions reported that itinerant women dervishes, armed with iron sticks, traveled each day between Bolghar and Bülär (now Biliarsk village), instructing people in the sharia. The head of the order was no less than Tuy Bikä, who was symbolically impregnated with Islamic knowledge in the steam bath

111. Abdul Hamid M. el Zein, The Sacred Meadows: A Structural Analysis of Religious Symbolism in an East African Town (Evanston, IL, 1974), 66; Otdel rukopisei Kazanskoi nauchnoi biblioteki im. Lobachevskogo, f. 7, ed. khr. 2, 1. 23 ob.; NART, f. 967, op. 1, d. 8, 1. 12 ob.

112. Kitāb-i qïṣ̦a-yi Häżrät-i Yūsuf, 24-25; Ignat'ev, "Skazaniia”, 191-192; Aisylu-khadzhi Sadekova, Ideologiia islama i tatarskoe narodnoe tvorchestvo (Kazan, 200o), 47.

113. Otdel rukopisei Kazanskoi nauchnoi biblioteki im. Lobachevskogo, f. 7, ed. khr. 1, 1. 189/1 ob.; A. Iablokov, “O pochitanii sviatykh v Islame," PS 29, pt. 3 (1883): 424; Frank, Islamic Historiography, 71.

114. Fäżàil, 19; al-Rabghūzì, Stories, vol. 2: 493-494. 
conversion story. Like male shaykhs, she sent her female students off to other lands to teach Islam. Tatar historical tales spoke also of khans' daughters sent to neighboring cities to receive proper instruction and used their knowledge to fight their enemies. Thus, the twelve daughters of a Bolghar king who reigned over the city of Märjän first studied in the madrasa of Rabiya, a female teacher in the ancient city of Bülär, before fighting Mongol pagan invaders who took them prisoners. Thanks to their piety, God saved them from being buried alive and changed them into twelve stars. ${ }^{115}$

The Tatar folklorist Fatykh Urmancheev has rightly emphasized the importance of these heroic maidens in Tatar epics. The Bolghar khan's daughter, Altïnchäch (literally, gold hair), refused to marry the Mongol khan, armed herself, and entered the battle. Although wounded, she never subjugated herself to the infidel. ${ }^{116}$ The same type of legends flourished against Russians. Queen Söyem Bikä (ca. 1516-after 1554?), who ruled the Khanate of Kazan from 1549 until 1551 in the name of her minor son Ütämesh-Gäräy, was and remains an important symbol of resistance. Both because of her tragic destiny and because of her relation to important figures who played a role in the Islamization and defense of the land against invaders, she came to echo her ancestors' epic struggle for Islam. Daughter of Yusuf (d. 1554), the ruler of the Noghay horde, one of the kingdoms that arose after the breakup of the Golden Horde, she descended from the famous Khan Idegäy (1352-1419), founder of the Noghay confederation and a subject of popular epics, who fought for the integrity of his domain against Khan Tokhtamïsh (1350-1406), ruler of the Golden Horde and Central Asia. Idegäy was also depicted in Turkic historiographical mythology as a descendant of the first successor to the Prophet Muhammad, the Rightly-Guided Caliph Abu Bakr, and as a figure responsible for the Islamization of his own people. Legends also affirmed that he descended from Baba Tükles, a Sufi saint who was responsible for the Islamization of the Golden Horde. ${ }^{117}$

Among Tatars and Islamized Kräshens, Queen Söyem Bikä embodied her ancestors' exploits for the spread of Islam and struggle for freedom. Popular traditions liked to recall that she predicted the fall of the Kazan Khanate, brought poisoned food to Shah 'Ali who was Ivan the Terrible's candidate on the throne of Kazan, and appeared in arms to defend her beloved city of Kazan in $1550 .{ }^{118}$ Her famous epic, written in the first person and chanted by the apostate women of Elyshevo, told her tragic ordeal before and after the fall of the khanate. Because Tatar nobles refused to listen to her, Ivan the Terrible took Kazan in $\mathbf{1 5 5 2}$ and had her son baptized a year later. As if

115. Tatar khaliq ijati, 27, 36-37, 38-39; Tuy Bikä is believed to be buried in Bolghar. "Shähri Bolghar äwliyalarï,” in Qotdus Khösnullin, Mönäjätlär häm bäyetlär (Köyläp uqugha nigezlängän janrlar) (Kazan, 2001), 521.

116. F. I. Urmancheev, Epicheskie skazaniia tatarskogo naroda (Kazan, 1980), 81-82; Karl Reichl, Turkic Oral Epic Poetry: Traditions, Forms, Poetic Structure (New York and London, 1992), 298-301.

117. Mikhail Khudiakov, Ocherki po istorii Kazanskogo khanstva (Kazan, [1923] 1990), 179-182; Hādī Āṭlāsof, Söyön-bīkä (Kazan, 1914); Fatikh Ämirkhan, Khaliqq qïzlarï (Kazan, 1997), 10-15 (originally printed in 1913); M. Sadekov, "Plach khanshi Siuiumbike," Ghasïrlar awazï (Ekho vekov), nos. 1-2 (1998): http:// www.archive.gov.tatarstan.ru/magazine/go/anonymous/main/?path=mg:/numbers/1998_1_2/02/02_3/ (accessed 18 January 2009); Devin DeWeese, Islamization and Native Religion in the Golden Horde: Baba Tükles and Conversion to Islam in Historical and Epic Tradition (University Park, PA), 409-490.

118. Kanäfi Näfïykov, Ütkängä säyakhät (Kazan, 1993), 39. 
history repeated itself, the Cossacks and representatives of the Orthodox Church took the children of apostates away from their parents to baptize them forcibly. ${ }^{119}$

Tatar religious and historical narratives suggest further that women had the potential to change history in the public and political sphere. As seen before, women did leave the domestic sphere when necessary; first, if their husbands were unable to provide for the family's well-being; second, if they were called by God to live a celibate life or engage in proselytizing. In historical narratives, women even engaged in battle if their father, husband, faith, or people were endangered, but in most cases, their lives ended tragically. Women could also exercise enough influence to achieve their political objectives successfully. A Bolghar queen, also well known for her courage and intelligence, whose husband had been killed by Tamerlane, knew how to talk and surround herself with good advisers. After hearing that Tamerlane spared those who acknowledged that God had punished them for being bad Muslims, she took her two sons to Tamerlane, repented and reported to the blood-thirsty invader that he was the true representative of the Muslim path. Tamerlane let her settle down in the land of her choice (Kazan), where the queen built new mosques and madrasas. The Bolghar queen's legend illustrated and added a new dimension to the historical significance of women in the society. It showed that women could exert influence on strong political figures, be the promoter of an ever-perfecting Islamic society even in the context of foreign domination, and play a role in the symbolic reconstruction of the past. The queen-not her sons-mediated between two different periods of Tatar history, as a crucial genetic and historical link. ${ }^{120}$

There is no doubt that Sufi and historical legendary accounts described women as being inherently limited in the religious sphere by their nature. They could not be prophets, but they could overcome their natural limitations, unite with the divine, and perform miracles. They could also act like prophets, but without bearing the title. More important, they exercised control over male relatives in matters of marital alliances as well as social and religious customs, by playing a special role in the transmission of proper Islamic behavior $(a d a b)$. They could also be a threat in the supernatural sphere. God accepted mistreated mothers' prayers automatically in the same way He responded to His prophets' wishes. Women also understood the importance of knowledge. Finally, their activities went much beyond the domestic sphere; they were defenders and reproducers of their faith and played their part in the history of their people against pagan, infidel, and ruthless Muslim invaders.

\section{Sacred Topography as a Source of Islamic Knowledge}

Along with books, talismans, and sacred images, Sufi legends attached to sacred places and funerary inscriptions helped diffuse Islamic conceptions of the afterlife to a larger audience. The earliest childhood memories of Khäsän Tufan, born in an apostate village, included the fantastic tales of the prophets and the tragic stories connected to the sacred graves. Almost every Tatar village had a cemetery with one, two,

119. The text of Söyembikä bäyete can be found in the diary of Mahisärwär, daughter of the underground mullah of Elyshevo, Ibrahim Bikmökhämmätov (1. 71).

120. Tatar khaliq ijatï, 46. 
or even three tombs of Muslim saints. Any simple tombstone with an epitaph dating from the Bolghar kingdom or Kazan Khanate, cemetery, spring, qurghan (tumulus), or ditch that signaled the presence of ancient dwellings attracted numerous Tatar pilgrims from Kazan and the surrounding districts. Objects found on these sites, such as human bones, arrows, pottery, or coats of mail, were attached to children's necks or to their käläpüsh and functioned as talismans. Biktashi's marvelous stories supported the belief in the sacredness of this geography: Jewish shaykhs prayed to God inside a hill (taw) or a huge rock on top of a hill, waiting for Muhammad to come. Both the hill and the rock could talk about their hosts, who hundreds of years ago had fallen in love with the Prophet and his disciples. These saints, as a sign of support from God, were adorned with precious stones and grapes. ${ }^{121}$

Jadids looked at these sacred places with great skepticism, fearing that the saints' miracles could be interpreted as manifestations of their own power, although Sufi literature such as Risālä-yi 'Azīzä drew a very strict distinction between miracles performed in the name of God and tricks performed by magicians. The first disagreement that the historian Togan had with his father, a Naqshbandi shaykh, regarded the healing power of Shaykh Muhammad Baha' ad-Din Naqshband's tomb near Bukhara. Shocked, his mother, a well-educated woman, blamed his skepticism on Russian schooling. But it was not Russian influence. The reformist theologian Fäkhr ad-Din ridiculed the villagers' inability to explain the origins of those shrines, relying on specific strong hadith. Another reformist, the novelist Zahir Bigiyev (1870-1902), characterized Astrakhan Tatars' fascination with their sacred cemeteries as a form of polytheism, comparing it to the Nazarenes' (i.e., Christians) worship of images and their view of Jesus, a fatherless child, as God. The burgeoning number of sacred tombs, he wrote, was akin to the high frequency of Marian apparitions. But Fäkhr ad-Din or Bigiyev's observations had little impact. In 1914, the historian 'Ali Räkhim (1892-1943) reported that his countrymen continued to hang scarves and sacrifice roosters at the site of ancient Bolghar city, abandoning themselves to what he called "fetishism." 122

Despite the jadids' criticisms, those sites and the legends that surrounded them played an important role in delineating communal boundaries between those who adhered to Islam and those who had departed from it. In the Tatar-Kräshen apostate village of Bakyrchy, Sviiazhsk district, a tradition related that a sixteenth-century saint who had taught in the neighboring Chuvash village of Azbaba, Sviiazhsk district, had asked specifically to be buried in Bakyrchy and not in Azbaba. Disappointed that his Chuvash disciples had reverted to their old pagan ways while he was away in Mecca and Istanbul, the saint rejected these backsliders and chose Bakyrchy as his final resting place. The tradition, which dated back to the seventeenth century, still reflected actual divisions on the ground. Thus the Tatar scholar Nasïri, who recorded

121. Khasan Tufan, "O sebe," in Stikhotvoreniia (Moscow, 1970), 5, 10; S. M. Shpilevskii, Drevnie goroda i drugie bulgarsko-tatarskie pamiatniki v Kazanskoi gubernii (Kazan, 1877), 496; Fäżàil, 35-36, 38-39.

122. Togan, Hâturalar, 68-69; Fäkhretdin, Jäwami', 224-228 (hadith no. 144), 348-349 (hadith no. 214), 367-368 (hadith no. 228), 434-444 (hadith no. 285); Mawäraennärherdä säyakhät (1908) in Zahir Bigiyef, Zur Gönahlar: Romannar, säyakhätnamä (Kazan, 1991), 160-161, 187, 306, 321; "Bolghar khärabälärendä: Yul khatiräläre," in Ghali Räkhim: Saylanma äsärlär (Kazan, 2004), 178. The article appeared originally in Ang no. 15 (1914): 280-284. 
the story in 1873 , neglected to report the presence of a "new convert" community in Bakyrchy, suggesting that his native informants (and himself) understood these baptized Tatars to be part of the village's Islamic space. Conversely, Azbaba was still living in religious liminality: baptized Tatars had indeed apostatized but Orthodox Chuvash remained faithful to the church. (At the beginning of the twentieth century Chuvash welcomed the opening of a St. Gurii school while Muslim Tatars and apostates succeeded in opening a mosque and a maktab in 1914.) Most important, the shrines served as meeting points for all people of the Middle Volga, regardless of their faith. In the same way Qol 'Ali's tale of Joseph claimed that the Prophet Joseph's grave had the same beneficial influence on Muslims and non-Muslims and drew many converts, the sacred shrines of Kazan province could potentially serve as a conduit for further Islamization. ${ }^{123}$

Until the 1870s, Tatars had more authority than Russians over the baptized religious landscape. They had recuperated many centers of animist cults, and their myths of origin often dominated the local discursive account of their sacrality. When questioned by archeologists and missionaries about the origin of the sacred places, Kräshens who were still attached to their indigenous beliefs, referred to the Muslim Tatar traditions rather than to animist traditions even though these places had been and were still kirämät (a term that signified both protective spirits and the sites where those spirits were worshiped). Near Vladimirova village in Mamadysh district, a little hill was sacred to both starokreshchenye and Muslims. With its forest and spring, the site had all the characteristics of a kirämät: Tatars and Kräshens affirmed that in thirty years the hill had grown, the sign of a saint's presence (this belief echoed Biktashi's stories of shaykhs praying inside rocks). Both Kräshens and Tatars near the village contended that Allah had elevated this hill to remind people of His presence, and women during the first signs of labor climbed it ten times, repeating the name of God, a ritual that had all the characteristics of a Sufi litany. Starokreshchenye who venerated a nearby spring of "living water" used a story recounted by their Muslim neighbors to explain the spring's sacrality. (According to the Muslim Tatars, God had created "living water" that would assure humanity eternal life, but the Devil tasted it before man, and so condemned him to death.) Kräshens sacrificed white bulls to the spring's spirit and ate botqa (cream of wheat) in order to ensure a good wheat harvest, and Muslim Tatars came to the site to pray their Muslim prayers and participated in the communal ceremonies surrounding the hill. ${ }^{124}$

Until the late 1850s, Muslim Kazan Tatars used to bring offerings (money, food, or animals) to the kirämät. Those sites-a spring, a lake, a river, or a small forest, usually fenced-were found near Tatar, Kräshen, Mari, and Chuvash hamlets. Tatar families in Kazan province hung bags in one corner of their houses, as did Kräshens, placing change in them; with those savings, they bought animals, white horses or geese, and sacrificed them on a kirämät site. A special group in the village called

123. "Baqürchï, in Tatar khaliq ijatï, 157-158; "Baqürchï awilï, in Qayum Nasïyri, Saylanma äsärlär, vol. 3 (Kazan, 2005), 197-199; Malov, "Statisticheskie svedeniia," Uchenye zapiski Kazanskogo universiteta, 331-332; Ilgizär Timershin, Ak"eget awili tarikhï säkhifäläre (Kazan, 2001), 14-19; "Azbaba," in Tatarskaia Entsiklopediia (Kazan, 2002), 1: 57; Azbaba village in 1868, NART, f. 13, op. 1, d. 1044, 11. 4 ob., 32 ob.

124. Il'minskii, ed., Kazanskaia tsentral'naia, 143-146. 
qart (elders) performed the sacrifice in order to appease the kirämäts and gain their blessings: good health, healthy livestock, and favorable harvest. Mullahs shared the meal and received the skin of the sacrificed animal whose unbroken bones were carefully buried in a purified space. Muslim küräzä (medicine men, sorcerers) also served as intermediaries between men and the spirits' world. Even superficially Islamized Kräshens visited them whenever they or their cattle got sick. ${ }^{125}$

The common belief in the kirämät or spirits was so strong in Mamadysh district in the middle of the 1860 os that one of Timofeev's students, a Kräshen boy, roused a Kräshen and a Tatar woman to indignation when he argued that the kirämät did not exist. Fäkhr ad-Din, then a young teacher in the village of Nizhnie Shelcheli, stirred the same outrage among other teachers of the madrasa when he declared that no päris (a word of Persian origin that designated house spirits with a dark human face and one eye on their forehead) or jinns haunted the baths and the library. Shocked, his opponents exclaimed: “The Qur'an mentions the existence of evil spirits. How will you prove the contrary?" 126

Until the late 188 os, Tatars believed that spirits brought diseases. When a child got sick, he or she was asked to write the name of a man he saw, and then the paper was burned, but if the child remained quiet, people screamed "why don't you see anybody?" and even went as far as hitting the child until "the spirit came out." In 1875 , Tatars still sacrificed chickens, cows, and fish, but on a much smaller scale. Kräshens, those who had not apostatized, continued to perform those ceremonies actively, following a Christian agrarian calendar, but uttering their prayers in Arabic, to reinforce their efficacy. ${ }^{127}$ At the beginning of the twentieth century, Kazan Tatars, under the strong influence of little Islamic brochures and Bädäwām denouncing the cult of kirämät trees, were less inclined to bring sacrifices to the protective, potentially harmful spirits. But in 1914, the reformist theologian Fäkhr ad-Din still felt it necessary to warn Tatars against sacrificing animals on fenced spaces, frightening children with local spirits, and visiting village sorcerers. ${ }^{128}$

In apostate Elyshevo, which included baptized converts of Tatar and Udmurt origin, the sacred landscape did not differ much from that in other villages attached to the cult of the kirämät. It also had a sacred hill, spring, and tree. Elderly people still recall that Udmurts, Tatars, and Kräshens visited their sacred kirämät tree, which is still of an impressive size with its four trunks emerging from a single basis and a spring flowing underneath. In "pagan times," I was told, Udmurts prayed to the

125. Il'minskii, ed., Kazanskaia tsentral'naia, 16-23, 62; Iakov Koblov, "Mifologiia Kazanskikh tatar," Tsirkuliar po Kazanskomu uchebnomu okrugu, prilozhenie 43, no. 9 (September 1909): 425-427.

126. Il'minskii, ed., Kazanskaia tsentral'naia, 135; Ivan Ptitsyn, "Religioznoe nravstvennoe sostoianie pravoslavnykh Tatar" (Kursovoe sochinenie, 1916), in NART, f. 10, op. 2, d. 1360, 1. 182; Rizaetdin Fäkhretdin, Tärjemäi khälem (Ufa, September 1905), in Rizaetdin Fäkhretdin: Fänni-biografik jïyïntïq (Kazan, 1999), 23-26. Fäkhr ad-Dīn also warned mothers not to frighten children with spirits (päri, jinns) in Tärbìyäle ana (Kazan, 1898), 7, and forbid them to turn to Chuvash, Cheremis, or Mordvin female healers in Tärbìyäle khātūn (Kazan, 1899), 29.

127. Fäkhretdin, Tärjemäi khälem, 23; Mashanov, “Zametka," IKE, no. 1 (1 January 1875): 29-32, 46.

128. Bädäwām kitābï, 3; Märjānī, Mustafād, 1: 23; Iakov Koblov, Mifologiia Kazanskikh tatar (Kazan, 1910), 38; Fäkhr ad-Dīn, Jäwāmi', 160-166 (hadith no. 104), 224-228 (hadith no. 144), 322-323 (hadith no. 200), 328-332 (hadith no. 204), 332-334 (hadith no. 206), 348-349 (hadith no. 214), 367-368 (hadith no. 228), 373 (hadith no. 235), 396-401 (hadith no. 256), 522-523 (hadith no. 336). 
healing spirit who resided in the tree and whose story is long forgotten. People of Elyshevo still apply water from the spring to ailing parts of their body, but only after offering Muslim prayers. In times of drought, women led by Mahisärwär, the daughter of the underground mullah Ibrahim Bikmökhämmätov, read Muslim prayers at the top of the kirämät mount and near the sacred tomb of an orphan girl whose name has been forgotten. As was the case in villages still attached to the worship of nature spirits, people continued the practice of cooking and eating botqa at this special event. ${ }^{129}$

Besides kirämät centers of worship, Muslims, Christian Tatars, and other indigenous peoples visited Muslim sacred tombs. These shrines belonged to ascetics who had performed miracles as evidence of their sanctity, great teachers who had founded new settlements and played an important role in the Islamization of their region, or martyrs killed by the pagan Mongols, Tamerlane, or the infidel Russians. The Qur'an's comforting words affirmed that God's martyrs were not really dead, and various hadith supported the idea by asserting that the friends of God could even hear their visitors' petitions. ${ }^{130}$ Through Uwaysi spiritual communication, as was the case of shaykh Habibullah in Yalchïghol's treatise, dead saints could initiate new disciples in prayer or in their dreams. Such miraculous gifts-prophecy, teaching, and healing-were perceived as God's power working for or through his friend, dead or alive. These could happen from the saint's own volition or involuntarily. ${ }^{131}$

While reciting their primer Sharā'iț al-İmān, Tatar and baptized children learned that the inhabitants of these sacred tombs and their ancestors had a privileged Central Asian spiritual link to the Prophet Muhammad through the Yasawiyya initiatic chain (silsila). They also learned to identify themselves with three other Sufi Central Asian communities: the Naqshbandiyya through Muhammad Baha' ad-Din Naqshband's dead Uwaysi elder, 'Abd al-Khaliq Ghijduwani (d. 1179-1180), born near Bukhara, who introduced the constant practice of the silent $z i k r$; the Kubrawiyya through Najm ad-Din Kubra, killed in 1221 during the Mongol invasion of Khorezm, whose disciples converted many Mongols to Islam; and the 'Ishqiyya through Abu'lHasan 'Ishqi, a possible contemporary and competitor of Muhammad Baha' ad-Din Naqshband in the fourteenth century. ${ }^{132}$

If sacred places served as a source of immediate Qur'anic knowledge and as a meeting point between Muslims and their "pagan" (animist) prospects, they were not strictly speaking Islamic centers for all visitors. Starokreshchenye, for their part,

129. Khädichä Khisamieva (seventy years old, descendant of Yaghfär Wälitov or Efrem Kirilov of Udmurt origin, who bore the title of ishan), interview by author, May 2008, Elyshevo. Just recently, Elyshevites have placed a sacred fence at the tree site. G. Khämidullina, e-mail communication, May 2013.

130. Qurān, 2:154, 3:169; Smith and Haddad, The Islamic Understanding, 51-53, 55.

131. According to Sufi tradition, Uways al-Qarani, a contemporary of the Prophet Muhammad, converted to Islam through spiritual communication without meeting him in person (Julian Baldick, Imaginary Muslims: The Uwaysi Sufis of Central Asia [Washington Square, 1993], 21-24); Arthur Buehler, Sufi Heirs of the Prophet: The Indian Naqshbandiyya and the Rise of the Mediating Sufi Shaykh (Columbia, SC, 1998), 13-14.

132. Sharā'it al-īmān (Kazan, 1904), 27-28; Devin DeWeese, "Spiritual Practice and Corporate Identity in Medieval Sufi Communities of Iran, Central Asia, and India: The Khalvatī/'Ishqī/Shațtārī Continuum," in Religion and identity in South Asian and Beyond: Essays in Honor of Patrick Olivelle, ed. Steven E. Lindquist (London and New York, 2011), 271-272. 
rendered Muslim saints the veneration due to dead ancestors and clan or village founders. Thus, in Mamadysh district, even Kräshens who diligently fulfilled their Christian obligations after the implementation of Il'minskii's schooling brought offerings to the tomb of saint Idris Khalifa, near the village of Teberdi Chally (or Chelny in Russian) in Laishevo district, and to his female descendants, the caretakers, to ward off disease and poor harvests. The mother of the famous Kräshen historian and publicist Maksim Glukhov (1937-2003) recalled that the saint whom she named "Kälpä babay" or "Khafiz äwliyä Khälfä babay" had brought her people, the Kräshens, from beyond the Kama to the safe and prosperous Chally area with his magic staff, which led the way. For Tatars, saint Idris trained many other itinerant teachers and for fifteen years was a "Bolghar" student of the Eastern Turkestan Yasawian teacher Shaykh Hidayatullah (d. 1694), who spread Islam and founded new settlements among "pagans" in the Chally area. Some sources indicated that among Idris's most famous students was Shaykh Qasim Khoja who proselytized in the Kukmor, Alaty, and Saratov regions, and whose tomb in Kazan also inspired the starokreshchenye of Tashkirmen' village in Laishevo district and novokreshchenye of Chistopol' district to bring alms, chickens, geese, and eggs to his descendants. ${ }^{133}$ Well after the Russian Revolution of 1917, starokreshchenye of Mamadysh district still came to the tomb of shaykh Idris in time of personal or communal strife, or whenever they saw the saint in their sleep despite Märjani's critique of the saint's veneration in Kazan. The Kräshens' attitude toward the saint was comparable to the Maris who brought offerings to their gods or warrior ancestors in order to conciliate them whenever they saw them in dream. ${ }^{134}$

Indeed, Kräshens, Chuvash attached to their indigenous beliefs, Muslims, and apostates who made pilgrimages to the same sacred sites came for different reasons. At the Khojas' mountain near Biliarsk lay the resting place of three Muslim saints. The Chuvash considered one of them, Maghlum Khoja, as a Chuvash spirit, a prophet, and an ancient king; but for the apostates of Samigulov's village, Biliarsk was the burial site of a saint not mentioned in Tatar hagiographies, who was the commander-in-chief for a princess who ruled the Bolghar town of Tubïlghïtaw

133. The veneration of Qasim Shaykh in Kazan did not please Märjani. For him, the real Qasim Shaykh lived in the sixteenth century and was buried near Bukhara. Frank, Islamic Historiography, 119; Frank, "Qāsim Shaykh al-Qazānī" 115-129. On the Kräshens' veneration for Idris and Qasim Shaykh, see Otdel rukopisei Kazanskoi nauchnoi biblioteki im. Lobachevskogo, f. 7, ed. khr. 1, 1l. 162, 189/2; Mikhail Ivanov, O pochitanii sviatykh $v$ Islame s tochki zreniia pravoslavnykh bogoslov. Bogoslovskoe issledovanie (Kazan, 1914), 74-75; Maksim Glukhov-Nogaibek, "Khelfe-babai," in Kazanskii retro-leksikon: Pervyi opyt rodoslovno-biograficheskoi i istoriko-kraevedcheskoi entsiklopedii (Kazan, 2002), 529; idem, "Allabïz bergä yaratqan," in Bez ber tamïrdan: Keräshen tatarlarïnїng etnogenezïn häm etnografiiasen öyränü buÿ̈ncha urta ghomumi belem mäktäpläre öchen uqu yardämlege (Kazan, 2002), 44; Nurulla Gharif, "Khälfä babay," Miras 27, no. 2 (1994): 109-111.

134. N. Odigitrievskii, "Kreshchenye tatary Kazanskoi gubernii (etnograficheskii ocherk)," $P B$, no. 3 (February 1894): 110-111; Chicherina, U privolzhskikh inorodtsev, 107; Mashanov, "Zametka," IKE, no. 4 (15 February 1875): 113-114; T. A. Ivanitskii, "Pochitanie sviatykh v mukhammedanstve voobshche i u Kazanskikh musul'man v chastnosti (chitano v obshchem sobranii chlenov Obshchestva arkheologii, istorii i etnografii, 21 sent. 1895)," Deiatel' no. 1 (January 1896): 32; Frank, Islamic Historiography, 119; Jean N. Smirnov, Les populations finnoises de la Volga et de la Kama. Études d'ethnographie historique, pt. 1, I: Les Tchérémisses, trans. Paul Boyer, Publications de l'Ecole des langues orientales vivantes, 4th Series, vol. 8 (Paris, 1898), 190. 
(in Russian, Verkhniaia Nikitkina). After Ivan the Terrible took her city, apostates recalled, the czar forcibly baptized her army, but her commander-in-chief refused to give up his faith and became a famous shaykh. ${ }^{135}$ Even if animistic Kräshens and Chuvash regarded these saints as village founders, they still recognized the mullahs' intercessory powers and entrusted their sacrifices to them. Mullahs killed the desired animal (a sheep, goat, goose, duck, rooster, or a chicken depending on their means), recited the thirty-sixth Sura Yä Sìn, and asked God to fulfill their wishes. The sacrifices took place after pilgrims had reached the foot of the hill where the friends of God were buried. The pilgrims performed several prostrations, climbed the hill on their knees, prayed, and descended back on their knees always facing the tomb. They also drank at the sacred spring and had a copious meal in honor of their saintly hosts. Of utmost importance, the meals included both Muslims and non-Muslims. ${ }^{136}$

Finally, sacred sites, no matter how pilgrims related to the saint, succeeded in forging a common native religious culture, capable of containing Russian encroachment. If necessary, Kräshens and Muslims joined forces to protect their sacred sites against Russian intrusion. Thus, in 1870, the starokreshchenye of Tashkirmen', otherwise despised by their Muslim neighbors as having no religion at all, and whose genealogies included Chuvash kin, allied with Muslim Tatar pilgrims from Kazan to stop archeological excavations at a nearby ancient cemetery, located on Russian land, containing the grave of a saint whom they venerated on different days. In general, because of the cosmology and history they shared with the other indigenous peoples of the Middle Volga, the Muslim Tatars, represented by the mullah or the heirs of a saint, possessed far greater authority over pilgrimage sites than did the Orthodox Church. Even after the discovery of a miraculous icon, the clergy of Biliarsk was still unable to compete successfully with the shrine complex of the Khojas' mountain, which Kräshens, Chuvash, and Mordvins continued to visit. ${ }^{137}$

\section{Islamic Knowledge Tested}

In past historiographical studies of Tatar education, there has been no attempt to evaluate the level of retention of students' knowledge and determine how Kräshens and their Tatar neighbors read and interpreted Muslim books and legends surrounding their sacred places. Because apostates or baptized Tatars failed to refer to explicit Quranic texts or passages in their speech, Eastern Orthodox missionaries generally

135. Il'ia Sofiiskii, "O kiremetiakh kreshchenykh tatar iz derevni Tavel', Chistopol'skogo uezda Kazanskoi gubernii," Trudy chetvertogo arkheologicheskogo s"ezda v Rossii (Kazan, 1891), 2: 73-75.

136. Those sacrifices were called khuja keläwe (literally, prayer to the shaykh) or khuja kirämäte (sacrifice to the shaykh). Sofiiskii, "O kiremetiakh kreshchenykh iz derevni Tavel'" 73-75; Akhmet'ianov, Obshchaia leksika, 31-32; Shpilevskii, Drevnie goroda, 62-63; F. V. Tarzimanov and A. Rakhim, "Khuzialar Tauy," Vestnik nauchnogo obshchestva tatarovedeniia 8 (1928): 175-176; N. I. Ashmarin, Bolgary i Chuvashi (Kazan, 1902), 20-21; Frank, Islamic Historiography, 76; Räfik Nasïyrov, "Mäghlüm khuja-tarikhi shäkhes," Ghasirlar awazï (Ekho vekov) nos. 3-4 (2003), http://www.archive.gov.tatarstan.ru/magazine/go/ anonymous/main/?path=mg:/numbers/2003_3_4/05/05_2/ (accessed 19 January 2009); Otdel rukopisei Kazanskoi nauchnoi biblioteki im. Lobachevskogo, f. 7, ed. khr. 1, 1l. 164-166.

137. I. A. Iznoskov, "Materialy dlia istorii khristianskogo prosveshcheniia inorodtsev Kazanskogo kraia," $P B$ (February 1893): 35-36; V. Okhotin, "Makarovskii kurgan v Laishevskom uezde Kazanskoi gubernii," IOAIE 5 (1884): 6; Shpilevskii, Drevnie goroda, 355-356; Frank, Islamic Historiography, 76. 
held that apostates spoke in their name, which in their view meant that they knew nothing of Islam. Actually, the Kräshens' religious discourse, be they at different stages of Islamization or Christianization, reflected much of the spirit of the oral and written culture that neighboring Tatars were exposed to at home, in primary Qur'anic schools, and at the site of their shrines. In other words, traditional education fulfilled its basic function of gaining more converts to the faith and solidifying communal boundaries in the case of infidel encroachment. ${ }^{138}$

The Kräshens' religious knowledge, as reconstructed from Kräshen and missionary diaries or local "apostate” village traditions, was indeed a complex mix of Islamic, Christian, and animist beliefs in ancestor and nature spirits. It varied from one individual to another or one village to another. Even Kräshens who held more firmly to their animist beliefs and later remained strongly Christian acknowledged some particularities of the Islamic faith. Others, the "apostates" who had officially declared their Islamic identity, posited more firmly the superiority of Islam over ancestral beliefs and Christianity. Their discourse, however, presented unique particularities in great part because they continued to experience some form of ostracism from their immediate Tatar neighbors, which they conveyed through their village traditions and tales. Not only were apostates obliged to defend their faith against Eastern Orthodox missionaries' critics, but they were also drawn to define it against the prejudice held by some, but not all, of their Tatar neighbors who still looked at them as "traitors" or murtadd, that is "apostates from Islam."

A Kräshen anecdote humorously exemplified the converts' ambivalent situation in the 186os-1870s. A tailor (kiyimche), it said, could not find a shelter in a Tatar village until he pretended to know how to pray the Islamic way, but when it came time to do the congregational prayer, the Kräshen stood helpless until his Tatar host, upset by his attitude, kicked him in the behind to bow appropriately. Instead, he kicked the prayer leader in exactly the same place. When the surprised mullah asked why he was kicked, the Kräshen's answer was that he thought this was the way Muslims prayed. The mullah though did not scold the Kräshen, but the Tatar parishioner. Clearly the anecdote praised the Kräshens' cunning, mocked the Tatars' exclusiveness, but dignified the mullah for his sense of justice. Indeed, to their Tatar neighbors, apostate Kräshens and individuals committed to their salvation reminded that divine mercy was universal and not tied to history. ${ }^{139}$

Popular Islamic discourse among the Kräshens and their Tatar neighbors, with its Sufi and anti-Christian components, can be reconstructed with all its complexities and shades around three areas of belief: God and his attributes, the divine revelation, and the Last Judgment. Apostates held a view of God similar to that of Sunni Islam but they stressed His differences with the Christian God and His mercy. God was unique, omniscient, and omnipotent, a view, in their minds, quite different from and superior to that of the Russian Orthodox. Christians believed that God had a human body and occupied a defined space called heaven. In fact, God was not a created being,

138. Priest Stefan Matveev, "Dva dnia sredi kreshchenykh i otpavshikh inorodtsev (iz dnevnika missionera)," $P B$ 10, no. 1 (1902): 23.

139. "Äkejätlär," no. 17 in Gábor Bálint, Kazáni-Tatár Nyelvtanulmányok: Kazáni-Tatár Szövegek és Forditás, vol. 1 (Budapest, 1875), 30; NART, f. 968, op. 1, d. 35, 11. 5-5 ob. 
limited in space by a material body. No one could indicate where He lived, whether in heaven or on earth, to the right or to the left, said a Tatar of Artyk, Mamadysh district, who proselytized among Kräshens. ${ }^{140}$ Allah saw everything, heard everything, and knew everything. A baptized seasonal tailor told the missionaries that a shaykh once ordered three of his disciples to steal a hen and eat it in secret. The first two did as the shaykh commanded, but the third brought the hen to his teacher. When asked why he had not eaten the hen, the disciple answered, "I could find no place to do it in secret; even where no man could see me, God could see me." The teacher responded, "You have chosen well; the two others did not know that God sees everything." ${ }^{141}$ As the only true God, He could not have a son or a wife, as did pagan gods. As for 'Isa (Jesus), the Russians identified him as the Son of God or even-a greater blasphemy!-God himself. ${ }^{142}$ To the horror of the Orthodox missionaries, the apostates considered the Christian mysteries of the Trinity and the Incarnation as pure idolatry. For the apostates, the cross was no more than a ladder that permitted Mary's son to climb into heaven (a story reported by a seasonal tailor of Elyshevo village); to venerate it, as the Orthodox did, was to violate the first commandment. ${ }^{143}$

Kräshens often heard from itinerant preachers that God was merciful. He did not hold the Kräshens responsible for the sins of their fathers. If they repented, they would have first place in the house of God. Moreover, God did not demand great efforts from his creatures. He asked only that the Kräshens recite the shahada as often as possible, when they arose and when they went to bed, and they would go to paradise with the Muslims because God knew that they were simple creatures. ${ }^{144}$ Of the Maris of Ufa, who found the Arabic prayers of the Muslims very difficult to learn, God asked only that they repeat the Tatar phrase Äy, Alla saqlasin (God preserve us!) ninety-nine times without stopping. Such constant repetition of the same short prayer was reminiscent of the vocal and silent techniques the Sufi brotherhoods used during their congregational prayers. ${ }^{145}$ Islamic discourse in the non-Muslim milieu echoed the primer Sharā'iț al-İmān's recommendation to pray in türki, using a tafsir, in case the Arabic language presented problems; however, the author's advice related specifically to prayers at funerals. If one compares the 1860 and the 1890 , however, a larger number of starokreshchenye in Apazovo knew the time, the direction, the words, and the names of the five Muslim prayers in Arabic, along with their Christian prayers in Il'minskii's vernacular translation. ${ }^{146}$

Finally, God was on the side of the Kräshens who had been ostracized from their Muslim brothers after their baptism. A legend in Bol'shie Kibiak-Kozi (Olï KibäKhuja in Laishevo district, also called before the Revolution Keräshen Kibä-Khujasï

140. Il'minskii, ed., Kazanskaia tsentral'naia, 52.

141. Il'minskii, ed., Kazanskaia tsentral'naia, 132.

142. Znamenskii, "Kazanskie tatary," 140.

143. Malov, “Ocherk," 18, pt. 2 (1872): 42.

144. Il'minskii, ed., Kazanskaia tsentral'naia, 39; Iapei Babai, “O kreshchenykh tatarakh," no. 20 (15 October 1891): 637.

145. Eruslanov, "Magometanskaia propaganda," no. 18 (1895): 87. The text mentioned ninety-six times, but it is a typographical error. The Muslim prayer bids which the Tatars gave to the Maris contained ninety-nine beads, corresponding to the ninety-nine names of God.

146. NART, f. 4, op. 98, d. 34, 1. 22 ob.; Iapei Babai, “O kreshchenykh tatarakh," no. 18 (15 September 1891): 566; no. 20 (15 October 1891): 625. 
in Tatar) narrates that before the time of Ivan the Terrible, there was one village, Kibä-Khuja. When Ivan the Terrible invaded the Kazan state, some accepted to be baptized but others resisted. The village then divided in two: Verkhnie Kibiak-Kozi (Yugharï Kibä-Khuja), which remained Muslim; and Bol'shie Kibiak-Kozi, which was comprised of Kräshens. On the site of the original village now abandoned two stones fell from the sky. The inhabitants of Muslim Verkhnie Kibiak-Kozi wished to appropriate the miraculous stones since Bol'shie Kibiak-Kozi had shamed itself by apostatizing from Islam. But a hurricane prevented the villagers from taking the stones. The village elders, taking it as a sign from God, decided to leave the stones on the site of the original village, a pilgrimage destination for inhabitants of both villages. Besides illustrating the tensions between the nonbaptized and the baptized, the legend taught that even when men had shown signs of contempt and abandonment, God still cared for the Kräshens' salvation, a message also spread by itinerant Sufi teachers. The "flying stone" was a motif frequently mentioned in the popular Sufi culture of the Ottoman Empire, near Skopje and in Asia Minor. People attributed healing properties to them and believed that they had been "flown" from Mecca on a saint's request. ${ }^{147}$

According to a starokreshchenyi of Elyshevo, who repeated a line from Risālä-yi Nurnāmä, a popular treatise about the Light of Muhammad, God had revealed himself several times, in four divine books: the Torah (the Law of Moses), the Zäbur (the Psalms of David), the Injil (the Gospel), and the Qur'an. ${ }^{148}$ The last book was the object of special veneration by both literate and illiterate Kräshens. The missionary Malov offended an old woman of Elyshevo when he pointed out her inability to comprehend the second Sura he was reading. She answered sharply, "maybe so, but I know that it's the Word of the Qur'an." 149 The Qur'an, the Word of God, was the last and most highly elevated of the divine books. It replaced all the revealed books that had preceded it, which according to the Muslims had been distorted by the Christians and the Jews. The Muslims spread the rumor among the Kräshens that the Russians had changed the names of the prophets Ibrahim, Iskhak, Yusuf, and Süleyman mentioned in the Injil; Ibrahim, for example, had been changed to Abraham. ${ }^{150}$ When Malov tried to read Il'minskii's translation of the Gospel in Tatar, the same old woman retreated to the woman's area of the house and hid behind a curtain. Some literate Kräshens familiar with Muslim teaching and the Russian language compared the Bible and the Qur'an to the advantage of the latter. A Kräshen of Nikiforova, a village later regained for the cause of Christianity, told Timofeev that in The Book of Joseph the story of the prophet was far more detailed than in Genesis and would not listen to the missionary's counterarguments. ${ }^{151}$

Kräshens, both apostates and nonapostates, knew that God spoke through prophets. They recited a number of stories about Adam, Noah, Abraham (Ibrahim's

147. NART, f. 2, op. 2, d. 5136, 1.11 ob.; Näbiulla khäzrät Khämidulla (mullah at Bol'shie Kibiak-Kozi) and his wife Tänzilä Möteghulla qïzï, interview by author, 11 July 2000, Bol'shie Kibiak-Kozi. The two stones date from the time of the Golden Horde. Firdäüs Gharipova, Awillar häm qalalar tarikhïnnan (Kazan, 1997), 202-203; F. W. Hasluck, Christianity and Islam under the Sultans, vol. 1 (New York, 1973), 198-199.

148. Malov, “Ocherk," 17, pt. 3 (1871): 412; Risālä-yi nurnāmä, 12.

149. Ibid., 18 , pt. 1 (1872): 75 .

150. Ibid., 18, pt. 2 (1872): 42 .

151. Il'minskii, ed., Kazanskaia tsentral'naia, 72; Malov, “Ocherk," 18, pt. 1 (1872): 76. 


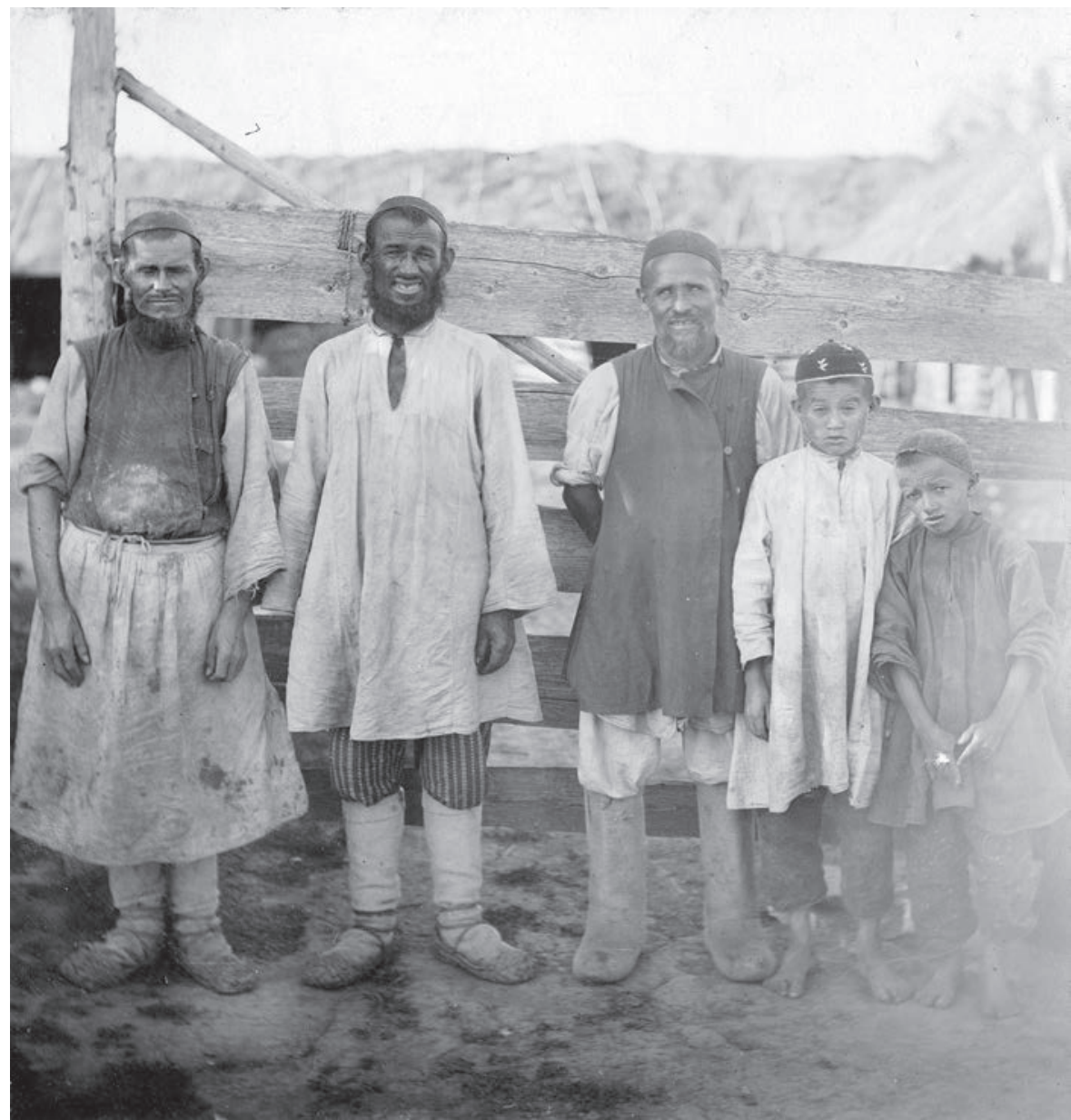

2.2: Apostates in Kibiak-Kozi, Laishevo district. RGIA, f. 821, op. 4, d. 72, photograph no. 12. No date. Photograph courtesy of RGIA.

sacrifice of Ishmael was particularly popular), Joseph, Job, Moses, Solomon, and Jonah from the Qur'anic tradition, which differed from the Hebraic-Christian traditions. Thus Kräshens, who continued to adhere to their indigenous beliefs, did not use the Babel tower story from Genesis to explain why people spoke different languages but rather used popular tales of the prophets, which claimed that the Prophet Adam had seventy sons from whom originated multiple languages. Apostates of Elyshevo liked to narrate stories about how the Prophet Solomon dominated the demons and about the power of his seal, a gift from God. ${ }^{152}$ One of the Kräshens' main sources of information was Rabghuzi's book of the prophets found on the shelves of apostate homes 
in Ufa province. There, readers and listeners learned that Solomon had dominion over fairies, demons, and birds (but not over angels as the Prophet Muhammad did) until he lost his seal as a punishment for marrying a pagan woman who worshiped a statue of her dead father at home. The story itself could serve as a criticism of ancestral worship as practiced by Kräshens in their houses. ${ }^{153}$ Other books served as references. A Kräshen from Tri Sosny asked a Kräshen teacher, a former student of Il'minskii, whether it was true that the bee originated from Job's body, a story found in Fäża'il ash-Shühūr. The legend told that when Job was sick, two worms attempted to eat his heart and tongue, but Job called God and asked Him to stop the worms, otherwise he would be unable to pursue his zikr. God intervened immediately and transformed one of the worms into a bee (in Tatar, bal qortï, which literally means "worm of honey"). ${ }^{154}$

Missionaries learned to their distress that the Christian Tatars, even superficially Islamized, considered Jesus Christ to be merely one of the prophets and a lesser figure than Muhammad. When the police came to arrest him, a literate wealthy apostate who used to accompany his father to church services refused to give up Islam and declared to the police that 'Isa (Jesus) lived in the fourth sphere of heaven. Heaven-as described in post-Qur'anic works, Rabghuzi's tales of the prophets, and Baqïrghani's work-was divided into seven levels, which were sometimes assigned to particular prophets. According to a legend mentioned very early in Sufism, 'Isa did not reach the highest sphere of paradise because after making the vow of poverty, he still carried a needle in his robe. That this successful apostate tailor mentioned the fourth heaven suggests that in his mind Jesus held a subordinate place in the rank of prophetsMuhammad had gone beyond the seven layers of heaven and faced God alone-and for this reason he could not abjure his faith. It also suggests that in this unequal power struggle, the tailor rather drew his knowledge from Bāqürghān Kitābï, where Jesus in the fourth heaven bowed to Muhammad, than from Rabghuzi's tale of the Prophet's ascension, where Jesus-although in the second heaven at an even lower levelhappily greeted Muhammad for being such a good prophet. Although in Baqïrghani's work Jesus was truly subordinate and recognized Muhammad's presence with deference, in Rabghuzi's narrative Jesus, who even evaluated Muhammad's performance as a prophet, greeted him as a new member of the prophets' club. In the particular apostate context, which involved a more acute struggle between Islam and Christianity than in Transoxiana where Christianity did not hold power and Christians were to be convinced of Muhammad's prophethood, Baqïrghani offered a better mental tool of resistance. ${ }^{155}$

Stories about the prophets, as told by Muslim Tatars, were sometimes so well integrated into the popular consciousness that they could serve as an argument against the missionaries. Tatars and their animist and Christian proselytes often argued with Eastern Orthodox missionaries that the tale of Joseph as told in the Bible was

153. Al-Rabghūzī, Stories, vol. 2: 399, 416; Matveev, "Dva dnia," no. 7 (1902): 307.

154. "Dnevnik uchitelia Trekhsosenskoi shkoly Il'i Andreeva za oktiabr', noiabr' i dekabr' 1874 goda," IKE 11, no. 18 (15 September 1877): 495; Fäżäil, 30.

155. Znamenskii, "Kazanskie Tatary," 140; Malov, "Ocherk," 18, pt. 1 (1872): 243; Bāqürghān kitābi (Kazan, 1904), 59; al-Rabghūzī, Stories, vol. 2: 594, Qurān, 4: 156-157 (mentions only heaven); Schimmel, Two-Colored Brocade, 79; Frederick S. Colby, Narrating Muhammad's Night Journey: Tracing the Development of the Ibn 'Abbās Ascension Discourse (Albany, 2008), 3. 
incomplete: Zulaykha in "Tatar books" married Joseph, but not in "Russian books." They pointed out that Jews and Christians added to the Islamic tradition. In Genesis Joseph boasted to his brothers that he had a dream in which they bound sheaves and theirs bowed in homage before his. However, the "Book of Joseph" mentioned only one dream-eleven stars turning around Joseph's star. ${ }^{156}$ The Islamized converts also turned to the story of Joseph to attack the Orthodox practice of venerating icons which, according to Muslims, the Russians regarded as gods. As one Muslim woman explained to a Christian Tatar, when Joseph lived with the pharaoh, the latter's wife fell in love with him and fervently prayed to her idols that he return her passion. ${ }^{157}$ When her prayers failed, she broke the idols in a fit of rage; in the same way Russians' "wooden gods" would not respond to their worshipers' pleas. By underscoring the impotence of these images, Tatar peasants advanced a sharp critique of the Russians' icon veneration. More powerfully, by associating Russians with Zulaykha, and thus feminizing the encounter, they implied that Russians, like Zulaykha, would ultimately submit themselves to the one God and join Islam. Once Russians and Kräshens would turn away from their idols, as Zulaykha did, they, too, would merge with the divine. In this interpretation, both male and female believers could identify with Zulaykha, whose positive portrayal in these tales marked an important departure from early Sufi depictions of women as unclean. ${ }^{158}$

For the most Islamized Kräshens, Muhammad was the true and Last Prophet, which indicated to them that his message was unchangeable. Before he ascended to the sky, said an apostate, a former parish elder, 'Isa had promised to send another messenger of God to the pagan Arabs. According to some of the Kräshens, Muhammad was born a Greek; to others, a Tatar; and to the most Islamized, an Arab. A Kräshen woman from Bol'shie Savrushi even instructed other fellow villagers that 'Isa was the son of Muhammad, and for that reason they should pay more respect to Muhammad than to 'Isa. ${ }^{159}$ In any case, for all, Muhammad was the true prophet because his faith was "ancient." In Sufi traditions, God created Muhammad's Light from his own light, and from it He created Adam and Eve and the other prophets. ${ }^{160}$ Some apostates, more knowledgeable of Islamic history, could indicate the age of the Prophet at the time of his death and give the names of his parents. They knew about other members of Muhammad's family. His son-in-law 'Ali had a miraculous twoedged sword, which measured forty arshins (28.4 meters). It was the same sword that had delivered Kisekbash's family from the Div. ${ }^{161}$

Even Kräshens less advanced in the apostasy revered Muhammad as a prophet or saint. His miraculous deeds had attracted a large number of followers and the hand of God intervened in his life many times. Returning from Ufa province, the Kräshens of

156. Genesis, 37: 7; “Čin den kenägäsennän alyän bülek,” in Bálint, Kazáni-Tatár Nyelvtanulmányok, 71; Ilminskii, ed., Kazanskaia tsentral'naia, 72.

157. In Tabari's work, the woman who tempted Joseph was presented either as the pharaoh's wife or the wife of the pharaoh's prime minister. The History of al-Tabari, 154-155, 158.

158. Il'minskii, ed., Kazanskaia tsentral'naia, 59; al-Rabghūzī, Stories, vol. 2: 273; Kitāb-i qïșsa-yi Häżrät-i Yūsuf, 31, 47.

159. Malov, "Ocherk," 17, pt. 3 (1871): 412; 18, pt. 1 (1872): 67; 18, pt. 2 (1872): 44; Il'minskii, ed., Kazanskaia tsentral'naia, 45; "Eparkhial'naia khronika," IKE, no. 43 (1904): 1463.

160. Al-Rabghūzī, Stories, vol. 2: 522; Risālä-yi nurnāmä, 4 .

161. Malov, “Ocherk," 18, pt. 2 (1872): 45; Il'minskii, ed., Kazanskaia tsentral'naia, 155; Kisekbash, 6. 
Mamadysh district repeated the stories that they had heard there, such as the account of Muhammad's ascension to heaven (mi'raj), a legend based on numerous hadith, which in the Islamic world has been the focus of Sufi piety since the eighth century. For Sufis, this episode-fully developed in Rabghuzi's tales of the prophets and in Yalchïghol's Risālä-yi 'Azīzä-represented their own thirst for seeing and uniting with God. ${ }^{162}$ Very interestingly, Kräshens and their Tatar teachers added new details to the account in conformity with the Kräshens' particular situation: a great stone had followed the Prophet into the sky and remained suspended in midair from that time on. For those weak in the faith, God had established four pillars under the rock. These four pillars did not touch the suspended stone, but did protect those who struggled in their faith, in particular the baptized Tatars. The stone (as described by the Kräshens) is not mentioned in Rabghuzi's, Baqïrghani's, or Yalchïghol's works. However, in Muhammad al-Bukhari's collection of hadith (d. 870), a stone relentlessly crushes the head of a man who rejected the Qur'an. Likewise, in Qara Dawud's sixteenth-century Ottoman commentary of the Moroccan Sufi Abu 'Abdullah Muhammad b. Sulayman al-Jazuli's prayer book, known to the Tatars of Buinsk district, the Prophet during his ascent saw angels smash with stones the heads of a group of people who had given up the practice of daily prayer. The baptized could easily be identified with these Muslims who had abandoned the practice of their ancestral faith. The stone might also refer to Jacob's stone (the shakra) in the al-Aqsa mosque, from whence arose a ladder to heaven-the same ladder that Muhammad borrowed to make his ascent to paradise. Another story, closer to the Kräshen tale, found in Qara Dawud's mi'raj, claimed that when the prophet wished to raise his foot from the stone and climbed to mount the Buraq, the stone could not let the Prophet go, became one with the ladder, and followed its beloved to the sky. But, as in the story reported in Russian missionary sources, the Prophet commanded it to stay and since then the stone had remained suspended in midair. When applied to the Kräshen context, the story underscored that if the Kräshens obeyed the Prophet's command as the stone did, the stone would not crush them for failing to apply the external aspects of the law. God, who was forgiving, and not Muhammad, who was only a man, protected them by placing pillars underneath the stone. The pillars might allude to the pillars of the al-Aqsa mosque that the Prophet had to describe for the skeptics who did not believe that he ascended to heaven. Interestingly, the Kräshens of Mamadysh district also believed that the Ka'ba, the sacred black stone in Mecca was suspended in mid-air. Thus, in this case, Turkic Sufi oral imagery-as embodied in the "flying stone" motif_-had enriched the classical mi'raj narrative with new developments, akin to the baptized's ambivalent situation. ${ }^{163}$

162. Znamenskii, "Kazanskie Tatary," 140; Al-Rabghūzī, Stories, vol. 2: 593-623; Yālchïghol, Risālä, 45; Raymond Lifchez, ed., The Dervish Lodge: Architecture, Art, and Sufism in Ottoman Turkey (Berkeley, 1992), 22.

163. Tikhon Chizhov, "Migradzh: Puteshestviie Mukhammeda po nebesam” (Kursovoe sochinenie, 1890), in NART, f. 10, op. 2, d. 1145, 1. 7; Il'minskii, ed., Kazanskaia tsentral'naia, 52; Malov, "Ocherk," 18, pt. 1 (1872): 67; Hasluck, Christianity, vol. 1, 198-199; Halevi, Muhammad's Grave, 213; Tatar ädäbiyati tarikhï, t. 1 (Kazan, 1984), 210; Delâil-i hayrat şerhi Kara Davud, ed. Abdulkadir Akçiçek and Veli Ertan (Istanbul, 1999), 266, 279. Concerned with the growing threat of the Portuguese in the Maghreb and the Christian advance in Andalusia, the Sufi Jazuli (d. 1465) called for internal revival and wrote popular prayer 
Timofeev recorded other stories about Muhammad that also emphasized his compassion for those weak in the faith, and thus were relevant to the Christian Tatars. Moved by the plight of a poor man, Muhammad, in an act of great compassion, offered himself as the poor man's slave to be sold to a wealthy person. After the poor man had completed this transaction and was returning home with his money, he suddenly saw Muhammad praying in a magnificent garden. Frightened, the poor man asked, "Who are you?" The Prophet replied with the words of the shahada: "Say of me, 'there is no God but God and Muhammad is his Messenger." "164

Finally, God revealed himself through his "Friends," the shaykhs. Kräshens of Tomasov-Pochinok in Mamadysh district, strongly influenced by Islam in the 1860 s but later won over to Orthodoxy, used to visit the tomb of Idris Khalifa, who brought Islam to their region in the seventeenth century and whose miraculous stories offered hopes of liberation for the baptized leaning toward Islam. Thus, one of the Kräshens' favorite tales was the saint's incarceration by the governor of Kazan who doubted that a simple Tatar could ever perform a miracle. "Yes, indeed," confirmed the shaykh, "My miracles are not my own but come directly from God." The saint invited the governor to go to Lake Kaban with him. There, Idris took his own ring, gave it to the Russian functionary and asked him to throw it into the water. To the amazement of all, the ring sprang up back again from the water, pushed by an incredible force, and ended up on the saint's finger. Convinced, the governor freed the shaykh. Such a story reaffirmed the superiority of Islam in the eyes of the Kräshens (apostates and nonapostates), confirmed that Islam empowered simple men, but also reflected the apostates' conviction that they, too, could be freed by the emperor who would, like the governor of Kazan, recognize the wonders of Islam..$^{165}$

Life after death was another important subject of discussion between Muslims and non-Muslims. Tatars affirmed to the nonbaptized Chuvash that if they converted, it would be easier for them to reach paradise than for the Russians, partly because their ancestral religion was closer to Islam than Christianity. Unlike Russians who did not purify themselves before going to church, nonbaptized Chuvash and starokreshchenye performed ablutions at the muncha before they proceeded with sacrifices to the gods and spirits of their ancestors. Although all Muslims would ultimately reach paradise, Tatars affirmed that Russians would burn eternally for the priest had chrismated them. Chrismation-or anointing with holy oil that has been consecrated by the presiding bishop of the church-is one of the sacraments of the Eastern Orthodoxy. It represents the reception of the Holy Spirit; during the sacrament, which is usually performed immediately after baptism, the priest anoints all five sense organs with the holy oil. Tatars argued that nonbaptized such as the "pagan" Chuvash would

\footnotetext{
books to spread the Light of the Prophet in all strata of society. In this way, books would fulfill the role of Sufi masters in places where there was no Sufi center. Jan Just Witkam, “The Battle of Images: Mekka vs. Medina in the Iconography of the Manuscripts of al-Jazūlìs Daläil al-Khayrät," in Theoretical Approaches to the Transmission and Edition of Oriental Manuscripts: Proceedings of a Symposium held in Istanbul (March 28-30, 2001), ed. Judith Pfeiffer and Manfred Kropp (Beirut, 2007): 67-69.

164. Il'minskii, ed., Kazanskaia tsentral'naia, 68. This story appears in Näșîäat aṣ-Ṣālihīn (pp. 31-32) with two differences: the poor man was a student and Muhammad the immortal Prophet al-Khidr.

165. Mashanov, Religiozno-nravstvennoe sostoianie, 56; Nurulla Gharif, "Borïnghï Challï," Qazan utlarï 880, no. 3 (1996): 182 .
} 
enter paradise more easily than their Christian brethren once they became Muslim because their body had not been anointed by the holy oil. The Kräshens' position was more delicate. They run the same risk as Russians to have their skin-or at least those parts of the skin that had been chrismated-burn forever in hell even if they converted to Islam. A woman from Elyshevo who let her son study with Malov believed that to become Muslim, one needed to remove all the parts of the body that the priest had anointed. Tatars also told converts to Christianity that at baptism their protective angel had left them. For all these reasons, parents, committed to Islam, sought to hide new births from the priest as long as they could or pleaded the priest to inscribe their children's name in the books but not baptize them. But when baptism was inevitable, as in Ianasal village, mothers washed up the anointed parts of the children's body at the muncha, with lukewarm water and soap to ensure their passage to paradise. For boys, parents waited to circumcise them after baptism. ${ }^{166}$

Even nonapostate Kräshens in Mamadysh district believed that when a man or a woman died, two angels came to the tomb and asked about his or her faith. Those two angels, Munkar and Nakir, were the divine agents of God's righteous judgment. Inside the tomb, they showed the way to paradise for the righteous and the way to hell to the nonbelievers. Many Kräshens did not use coffins but buried their dead the Muslim way: wrapped in a shroud, the body was turned on its right side facing Mecca. The belief was that the deceased would answer the final questions sitting up as a sign of respect for the angels. When a Kräshen mother talked to Timofeev about her daughter's funeral (she had been buried the Christian way), she could not help express her anxiety about seeing her daughter's body in such a narrow coffin. Clearly, the apostate woman viewed the coffin as a violation of her daughter's spiritual space and as an obstacle on her way out to the other world. ${ }^{167}$

The Kräshens' description of the afterlife did not differ from that of Biktashi's. When challenged by missionaries, Kräshens proved their point by referring to what they called a true story. A Muslim woman in a neighboring village had gone to the cemetery to visit the tomb of a relative, recently buried, but when she approached the tomb, a horrible cry came out from the deceased and she heard the voices of his divine questioners. She fainted from fear and recovered only much later. The same type of story recurred in mystical books as a reminder of the ultimate Judgment Day. ${ }^{168}$

Kräshens believed that the two angels appeared to the Muslims as well as to the Christians. Some who were more attached to their ancestors' animist beliefs than to Christianity or Islam, retained the same basic story, but instead of the angels spirits armed with clubs and spears of fire asked the deceased about his/her good actions on earth. If one lay down at a distance of forty steps from the grave, it was possible to hear the spirits' questions and the deceased's answers. ${ }^{169}$ Like Muslim Tatars, nonapostate

166. T. S., "Kakim obrazom Tatary uvlekaiut chuvash iazychnikov v mukhammedanstvo?” IKE no. 8 (15 April 1877): 230; Il'minskii, Opyty perelozheniia, 29; Otdel rukopisei Kazanskoi nauchnoi biblioteki im. Lobachevskogo, f. 7, ed. khr. 14, 1. 33 ob.; and NART, f. 10, op. 1, d. 1655, 1. 15; f. 93, op. 1, d. 619, 1. 5 ob.; and f. 93, op. 1, d.128 v, 1.41.

167. NART, f. 4, op. 101, d. 11, 1. 85 ob.; Aleksei Grigor'ev (priest), "Pogrebal'nye obriady inorodtsev Vostochnoi Rossii i Sibiri” (Kursovoe sochinenie, 1918), in NART, f. 10, op. 2, d. 1380, 1. 5 ob.

168. Mashanov, “Zametka," IKE no. 1 (1 January 1875): 25-26.

169. Gavrilov, "Pogrebal'nye obychai," 254; Ivan Ptitsyn, "Religioznoe nravstvennoe sostoianie pravoslavnykh Tatar," in NART, f. 10, op. 2, d. 1360, 1. 152. 
Kräshens also believed that after death, the souls lived under earth, inside the horns of a gigantic bull upon which rested the earth. At Judgment Day, they said, the horns will break open and the souls will be released in order to be judged. In the 188os, those beliefs, popularized in Risālä-yi 'Azīzä and other books, would be condemned by modernists as "unscientific." 170

Tatars, concerned about the Kräshens' salvation, ceaselessly repeated to them that they could attain paradise if they recited the shahada, especially before they die. The baptized tailors of Staraia Ikshurma, Mamadysh district, affirmed to the inhabitants of Kreshchonskie Biliatli that Muslim Tatar prayers guaranteed paradise, unlike Russian prayers. And the starokreshchenye of Mamadysh district, still attached to their indigenous beliefs, knew the consequences of not following the five pillars of Islam. According to them, Muslims who went on the Meccan pilgrimage had to descend into a long and narrow cavern. Only those who believed in God and followed all Qur'anic prescriptions to the letter would gracefully traverse the cavern. The cavern for the elect would get bigger and brighter while it would become narrower and darker for those who had sinned and failed to follow all Qur'anic prescriptions. The test of the cavern in some regard constituted a pretest for the ultimate test of the Sirat bridge, which awaited all believers and nonbelievers after death. Perplexed, Kräshens wondered whether Christians could go to Mecca and pass the test. ${ }^{171}$

To answer this question, Kräshens leaning toward Islam believed that God would pardon the sins of converts to Islam. According to priest Miropol'skii, Tatars told starokreshchenye that if they returned to the faith of their ancestors, they would be as innocent as newborns. ${ }^{172}$ Baptized apostates also believed that if soldiers put them to death, they would automatically enter paradise as shahids: "If Russians fire on us, we will die promptly, and upon us, there will be no sin.” Indeed, in Näșīhät aṣ-Ṣālihìn, those who died in the hands of kafirs had all their sins forgiven, included missed prayers. ${ }^{173}$ Apostates also believed that the sins of people whom God had caused to perish suddenly would be forgiven: women who died in childbirth, those struck by lightning, or people who had drowned. According to Yalchïghol women who died in childbirth would not have their past deed weighed on the scale and would enter paradise without being questioned by the angels. ${ }^{174}$ While arguing with a Christian missionary, a Kräshen tailor observed that Tatars could absolve themselves of sin in the same way that the Russians did, through confession. According to this tailor, someone who wished to free himself of his sin could offer a horse or a cow to another, who, in return, would bear the punishment for his sin in the next world. Despite the bizarre nature of this transaction, which apparently violated the Qur'an (31:33), the exchange was closely linked to the idea that God was merciful, a theme constantly repeated in

170. Mashanov, “Zametka”, IKE no. 1 (1 January 1875): 25-26; Yālchïghol, Risālä, 7-8 (in Islamic mythology, the world lay on a bull who stood on the whiskers of a mythical fish); Fäkhr ad-Dīn was a critic of this mythology, Jäwāmi', 260-273 (hadith no. 166).

171. Aleksandr Miropol'skii (priest and missionary in Apazovo), "Sposob mukhammedanskoi propagandy sredi kreshchenykh tatar," IKE, nos. 5-6 (1-15 March 1894): 161; Il'minskii, ed., Kazanskaia tsentral'naia, 50; Mashanov, Religiozno-nravstvennoe sostoianie, 18.

172. Miropol'skii, "Sposob mukhammedanskoi propagandy," 160.

173. NART, f. 1, op. 3, d. 3048, 11. 31-31 ob.; Näșîhät aṣ-șālihīn, 19.

174. Malov, “Ocherk," 18, pt. 2 (1872): 65-66; Yālchïghol, Risālä, 63. 
the sermons of the Muslim missionaries. The exchange could also refer to the Tatars' custom, called fidyä, which allowed relatives and members of the community to "pay back" the deceased's missed prayers and fasts. The payment could be done either in kind or in money. ${ }^{175}$

Although apostates revered ascetic ishans, they also believed that asceticism was not the automatic key to paradise. Feodor (Aptrakhimov), whose father had been exiled to Siberia, told a missionary the story of an ishan who spent years in a cavern to please God, but God promised him paradise only after he came out of the cavern and said Bismillah before removing an obstacle from the road he trod upon. This story perfectly mirrored Baqïrghani's, Yalchïghol's, and Biktashi's teachings about the Islamic obligation of uttering "In the name of God" before starting any action, the necessity for the friends of God to live in this world, and the possibility of earning salvation through worldly prosaic acts, useful to society. At the same time, when placed in the context of the apostate and missionary encounter, the story takes an even more interesting turn. Whereas the missionary sought to revert Feodor to Christianity by denouncing Islam as a sensuous, worldly religion and Christianity as more spiritual and celestial, the apostate identified Christianity with strict asceticism that Naqshbandi Sufis condemned and Islam with the world, understood as a space where God's will could operate through human agency. Feodor's conclusion obviously was that Islam was superior to Christianity because it acted for the good of the community. ${ }^{176}$

Finally, at the Last Judgment, the message of Muhammad would be reaffirmed. According to one Tatar informant, at the Last Judgment, each Muslim could throw two infidels into hell, but a Muslim's intercession could also save an unbeliever. Like other eschatological stories favored by the Kräshens, this one underlined the possibility of redemption and God's mercy. This also underscored that any Muslim, like the Prophet Muhammad, could be an intercessor for others. Tatar eschatology encouraged all Kräshens to abandon Christianity by declaring the future unconditional global victory of Islam. Only when all Muslims would unite-including the Kräshenswould the Mahdi appear. "Before the end of the world," said one "baptized" abistay, "the whole world will become Muslim." The Kräshens of Elyshevo village knew of the Mahdist tradition that 'Isa would return to earth and live a happy life for forty years before the end of the world. A baptized tailor thus concluded that Muhammad and 'Isa must be equal since believers would pray to both to be saved from hell at the Last Judgment. ${ }^{177}$

The missionaries' main argument was that Kräshens "returned" to Islam without knowing anything about either Islam or Christianity. They advocated that the language of Christian proselytism among Kräshens should be vernacular Tatar, purged of Arabic and Farsi loan words, which they believed Kräshens did not understand. Later Tatar reformists argued that traditional religious textbooks failed to instill faith in

175. Il'minskii, ed., Kazanskaia tsentral'naia, 157; Aleksei Grigor'ev, "Pogrebal'nye obriady inorodtsev Vostochnoi Rossii i Sibiri," in NART, f. 10, op. 2, d. 1380, 1l. 10 ob.-12.

176. Priest D. Grigor'ev, "Sredi otpavshikh tatar (sluchainye besedy)," IKE 36, no. 17 (1 September 1902): 791, 795 .

177. Ivan Ptitsyn, "Religiozno-nravstvennoe sostoianie pravoslavnykh Tatar," in NART, f. 10, op. 2, d. 1360, 1. 143; Il'minskii, ed., Kazanskaia tsentral'naia, 39, 55, 75, 157; Malov, “Ocherk," 18, pt. 1 (1872): 387. 
children. From both sides, Russian missionaries and reformist Muslims, the position was that literary language with its Arabic and Persian loan words and archaisms was alien to Tatar or Kräshen peasants. Both missionaries and modernist Tatars made a strong distinction between folk oral Tatar traditions and elitist bookish literature, but evidence shows that the munajat and other story telling devices served as a bridge between literates and illiterates.

Sufi books allowed different readings that applied to different levels of interiorization of the Muslim faith and different communal contexts. A number of hadith and early theologians introduced the idea that believers sent to hell would ultimately be saved. As in the Middle East, authors of Tatar religious prose and poems often deemphasized individual responsibility and stressed intercession by Muhammad or other nonprophetic mediators such as men of learning, the community as a whole, or talismans containing the Word of God. Missionaries for Islam used both ideaspersonal responsibility for one's fate and forgiveness-to gain converts. Kräshens were told that they were not liable for their ancestors' sins. At the same time, Sufi authors' visions of the Last Judgment promised the apostate Kräshens that, as Muslims, they would have a powerful patron before God in the person of Muhammad. Kräshens also learned that by paying the sadaqa and praying for the dead, their kins' fate could be alleviated in the afterlife. They also learned that even if they remained faithful to their so-called pagan beliefs but honored Islamic customs, they could gain a seat in the Muslim paradise. If shunned by their immediate Tatar neighbors, apostates could identify themselves with Joseph, who despite his own brothers' rejection became a charismatic prophet and ruler. The same books made the Tatar Muslims sensitive to the idea that the community, as a whole, was responsible for those who have sinned, and should act on it by praying for their salvation and spreading the knowledge of God. As outlined in Risālä-yi 'Azizzä, Allah would grant missionaries of Islam with the gifts and rewards due to the prophets. Finally, not only did the fulfillment of Islamic rituals bring salvation in the afterlife, but it also had medicinal properties in this world. Kräshens and other Finno-Ugric peoples held Tatar mullahs in great esteem for their healing powers.

Although Sufi books emphasized forgiveness and Muhammad's intercession, they also advocated a stricter observance of rituals and social responsibilities. Hell awaited those who did not observe their prayers or act in a Muslim way. By allowing different readings - one stricter, the other more lenient-popular religious literature took different levels of Islamization into consideration, and left room for continuous self-improvement. If one compares popular discourse and the content of Sufi books regarding rituals, it appears that at times proselytizers of Islam showed an even greater flexibility toward rituals, allowing Kräshens and Maris to pray exclusively in Tatar or repeat just the name of God because they were illiterate. This did not go against the teaching contained in the Sufi books, but once the believer had access to some form of literacy, the path to God implied personal and communal reform through study, under the guidance of a relative, a shaykh, or a learned scholar.

In the case of a baptized community, evidence shows that access to a spiritual guide was not always readily available. Those who desired to partake in the civilization of Islam had to go after the knowledge they aspired to grasp. Eager to understand the Qur'anic truth, they even asked Russian missionaries who could read the 
Qur'an to translate it for them. When in one case the missionary refused to comply, the apostate simply turned to his tafsir, which provided an approximate translation or commentary in Turkic. Besides the manuscript production and reproduction of Muslim texts by madrasa students, their printing by the University of Kazan provided self-help tools, which greatly facilitated further reproduction of Islamic knowledge in the baptized milieu. As a result, apostates were quite articulate; they could explain, compare, and argue different practices and rituals at their meeting with Russian missionaries, using earlier encounters between Islam, Christianity, and shamanism in Turkic-language literature as their scripts.

More than political and economic factors, epics, tales of the prophets, poems, and sacred places as lieux de mémoire deeply affected the individual and collective consciousness of Muslims and would-be Muslims. They shaped the actions of their listeners and carriers, who, besides prominent charismatic shaykhs, included anonymous men and women who read, chanted, and interpreted their content in their homes and beyond. These stories constituted a considerable source of discursive power, which cemented disparate communities together through elaborate economic, educational, and kinship networks. How these networks were strongly interconnected is the subject of the next chapter. 


\title{
Tailors, Sufis, and Abïstays
}

\author{
Agents of Change
}

1

Throughout the nineteenth century, the Christian-Muslim divide in the Tatar countryside was far from being absolute. From one apostasy to another, the confessional map changed depending on the work of local missionaries of Islam, the level of commitment of each community, and the way the apostasy movement was repressed. Although Russian missionaries often held that Kräshens were despised and ignored by their Muslim brethren, the frontier between Islam and Christianity was continuously defined and redefined at the microlevel, often at the expense of Christianity. Places where Kräshens met Muslim Tatars and kinship networks constituted potential sites of further Islamic acculturation. Shaykhs, mullahs, traders, craftsmen, exiles punished for their violation of Russian laws on religion, Sufi itinerant preachers, and women, who were the carriers and "readers" of marvelous stories of Islamic redemption and individual empowerment, played a decisive role in turning various ethnic groups to Islam, creating the contexts for Islamization and strengthening people's attachment to their newly adopted faith. Those networks spread over twelve different districts, initially escaping the eyes of Russian bureaucrats who vainly sought to stop the spread of Islam by isolating apostate families from their original communities, but later preoccupying members of the Orthodox Church, who wished to further the process of adhesion to Christianity through increasing spiritual development.

A closer study of Kräshen apostasies as a process of identity formation, and not simply as an essentialist return to Islam, showed that the apostasy movement was more than a peasant revolt urging the imperial state to reconsider its religious policies and boundaries. The apostasies were also the product of a global Sufi movement, major economic developments within the Tatar community, and the underground work of female local missionaries who spread and consolidated Islamic knowledge in their clandestine schools. Trade, Sufi, and gender networks were all strongly interconnected and became vectors of myths and symbols-weaving the cultural and religious fabric of apostatizing villages. Only through the transmission of a different but still familiar set of myths was the famous Russian missionary Nikolai Il'minskii capable of challenging and transforming these knowledge networks to the benefit of Orthodoxy.

\section{Economic Networks}

The apostasy movement among the starokreshchenye was the outcome of important economic developments in the Tatar communities of Buinsk, Laishevo, Mamadysh, 
Kazan, and Malmyzh districts. Although missionary accounts tended to attribute apostasy to pecuniary motives, trade networks actually played a critical role in introducing and maintaining Islamic beliefs among the baptized Tatars. Indeed, the direct role of Tatar merchants in the nineteenth-century apostasy movements remains unclear. Missionaries argued that Tatar merchants helped apostates financially by giving them credit, but there is no direct proof of such generosity. Apostate Kräshens, however, considered it important to spread rumors about their gaining the support of Tatar merchants. In 1866, a representative of the apostates of Buinsk district (who included merchants) declared that upon his return from St. Petersburg, the famous Tatar merchant Yunusov had congratulated and covered him with presents. At the bazar, he triumphantly displayed them - a robe (khalat) and morocco leather bootsas proof of the Tatar community's support. ${ }^{1}$

The Yunusov family was indeed an important symbol of success for the apostate community. The merchant 'Abd al-Kärim 'Abd ar-Räshid Yunusov (d. 1859) was the owner of a leather and soap factory in Kazan and was responsible for building a stone mosque in 1841 in Bogatye Saby, a village where prominent Tatar theologians taught and supported the apostate cause well into the $188 \mathrm{os}^{2}$ While in sixteenth-century Bengal Islam was associated with deforestation and agriculture, Islamic expansion in eighteenth-century Mamadysh, Laishevo, and Kazan districts was linked directly with the development of wool, cotton, and leather industries. Already in the last quarter of the eighteenth century, the region of Bogatye Saby, which roughly included the apostate villages of Elyshevo, Kibiak-Kozi, Staraia Ikshurma, and Ianasal, became known as an important center for wool storage and treatment. The preparation of sheepskin and wool threads constituted an important industry of this region, which could also boast of being a major manufacturer of clothing and footwear. In the beginning of the nineteenth century, cotton arrived in Mamadysh district from Central Asia and India, thanks to the Tatar merchants in Orenburg and Kargala whose ancestors originated from Bogatye Saby. While Kräshen and Tatar women in Mamadysh and Laishevo regions sewed underwear and casual everyday clothes at home, men specialized in the making of upper clothes (tulup), hats, gloves, and felt or leather boots-first fulfilling local demands, and then leaving for Viatka, Perm', Simbirsk, Ufa, Orenburg, and Samara provinces or Kasimov district to sell their wares. ${ }^{3}$

As a result of the textile boom in the Bogatye Saby and Satysh areas, many came from other provinces to find work, which prompted another trader, Khaji Nasïybullin, the owner of a felt boot workshop, to finance the construction of a madrasa in Satysh village at the end of the eighteenth century. In the middle of the nineteenth century, the madrasa of Satysh comprised three buildings and was known for its high quality of teaching. Its imam taught not only girls and boys from neighboring Tatar villages, but also Kräshen children from the baptized villages of Nikiforova and Elyshevo. Because

1. Report of the governor of Simbirsk province in Materialy po istorii Tatarii vtoroi poloviny 19-go veka, 272-273; petitions of Kräshen merchants living in the city of Buinsk in ibid., 244-245, 265, 271, 273.

2. Khasanov, Formirovanie, 298-299; Mashanov's report in Nikiforova (1881) in NART, f. 967, op. 1, d. $8,1.5 \mathrm{ob}$.

3. Richard Eaton, The Rise of Islam and the Bengal Frontier, 1204-1760 (Berkeley, 1993), 305-315; Mashanov, Religiozno-nravstvennoe sostoianie, 54; Men'shikov. "Achinskii prikhod," 448; Chicherina, $U$ privolzhskikh inorodtsev, 152-153; NART, f. 2, op. 2, d. 12788, 1. 73. 
Satysh and Bogatye Saby offered work in their factories, starokreshchenye villages took advantage of these new opportunities and accumulated a certain amount of wealth. Thus, successful apostates in Nikiforova and Staraia Ikshurma offered lavish gifts of flour, grain, and beautiful clothes to neighboring Tatar mullahs. In the 1850s, an Elyshevite apostate was rich enough to participate in the financing of the mosque and school of Savrushi, where children from the baptized villages of Elyshevo, Nikiforova, and Tri Sosny occasionally took lessons. Other entrepreneurial tailors of Elyshevo opened their own shops in Kazan, Chistopol', or in the Orenburg province, coordinating apostasy efforts or avoiding police questioning back home, in their native villages. In the 1870 , a Kräshen, who had a female relative in Elyshevo, owned an important weaving factory in Bogatye Saby and stopped the erection of an iron cross in Elyshevo. ${ }^{4}$

Because of the low yield of the fields in the region of Bogatye Saby (to this day the land there is stony and hilly), many of the Kräshen peasants left their homes during fall and winter months to earn an income elsewhere. They returned to their families for the spring planting and summer harvest. The duration of their travels varied from two to seven months, but as a general rule, these peasants worked as seasonal laborers from October to March. In the Buinsk, Kazan, Mamadysh, and Laishevo districts, a majority worked as tailors, but some entered the service of important Tatar entrepreneurs such as the Rämiev brothers, who owned gold mines in the Orenburg region. ${ }^{5}$

By the end of the first quarter of the nineteenth century, all males in Elyshevo and Kibiak-Kozi were involved in tailoring. They traveled in pairs, master and apprentice. The apprentice was a boy old enough to work (between the ages of nine and fourteen), whose presence was not necessary at home. The mullah of Kibiak-Kozi in 2000, whose grandfather and father were tailors before the 1917 Revolution, learned to sew at home; first, his father, who always started his work with Bismillah, made him stitch buttons. Once he became more capable, the young boy sewed linings of garments in winter clothes and then cut the cloth himself. Apart from certain minor differences, clothes that Kräshen men wore were the same as those of the Muslim Tatars: the kazakin (a very long robe with sleeves worn by men as an undergarment), the tun (fur coat), and bishmät (sheepskin coat) were of a similar cut. It took very little time for Kräshen tailors to familiarize themselves with the more ample and longer shirts of the Tatar men and to make the käläpüsh, or Muslim skullcap. Later in the first decades of the twentieth century, tailors used Singer sewing machines and loaded them on a small cart to travel. ${ }^{6}$

Master and apprentice traveled sometimes by horse but more often by foot. Paid at piece rate-not by the hour-they remained at their employer's home until they had filled the orders. As the elderly villagers of Ianyli told me, the rich prepared the

4. NART, f. 967, op. 1, d. 8, 1l. 4 ob., 6; Il'minskii, ed., Kazanskaia tsentral'naia, 71, 74, 75; Men'shikov, "Achinskii prikhod," 448; Näjmiev and Khujin, Yashä, Saba-Yort, 171.

5. "Otpadeniia iz pravoslaviia," 356; "Bälki, shaghïyr' bulmas ta idem," in Aq chäkchäk atar ide: Khäsän Tufan turïnda istäleklär (Kazan, 1989), 4.

6. Istoriko-statisticheskoe opisanie tserkvei i prikhodov Kazanskoi eparkhii, 108; RGIA, f. 821, op. 8, ed. khr. 763, 1. 5; Näbiulla khäzrät Khämidulla, interview by author, 11 July 200o, Bol'shie Kibiak-Kozi; Iu. G. Mukhametshin, Tatary-kriasheny. Istoriko-etnograficheskoe issledovanie material'noi kul'tury-seredina XIX-nachalo XX vekov (Moscow, 1977), 103-107; Tatary Srednego Povolzh'ia i Priural'ia, 118-126. 
cloth before the tailors arrived. On average, the master and the apprentice earned about five rubles per month or fifteen to twenty-five rubles during the period from October to March. This was the average price of a cow or a horse. The orientalist Mikhail Mashanov's figures were even more generous. According to his calculations, the Islamized Kräshen tailors of Shemutbashi, Mamadysh district, a village inclined toward Orthodoxy, earned between fifty and eighty rubles per person, and did not pay for their food, which allowed each of them to save twenty more rubles. If they had stayed in the village during the winter, they would have earned five times less. A large family could count on three or four salaries to increase its income. ${ }^{7}$

The Kräshen tailors of the Kazan area naturally sought customers among the Muslim Tatars of Kazan, Simbirsk, Astrakhan, Orenburg provinces and the Bashkirs of Ufa province. In the town of Buinsk, the home of staunch Islamized Kräshen merchants, an important market and leather industries attracted apostate tailors from Achi parish in Mamadysh district. And the Islamized Nagaibak Kräshens of the Orenburg province went as far as Tashkent to do business. They were hired by mullahs, shaykhs, and even the mufti himself, the official leader of the entire Muslim community in the Russian Empire. ${ }^{8}$ To gain access to both Tatar and Bashkir markets, tailors left their hometowns already having donned the Muslim skullcap they kept safely all summer in the family chest, shaved their heads, and removed the belts from their clothing. Once hired, they conformed to the rules of their host family or workshop: they performed their ritual prayers (namaz) five times a day, observed the fast during the month of Ramadan, and attended the mosque. During 'Id al-Fitr (the festival of breaking the fast), which occurs at the conclusion of Ramadan, the Kräshen tailors working in the suburbs of Kazan dressed in their best clothes to go to the mosque while their wives prepared the feast. At work, the adult and apprentice immersed themselves in stories and legends about the Prophet. The child went to the maktab to ensure that he could earn his living in the future. It was with the intent of teaching his fellow villagers' sons literacy that an Islamized tailor of Nizhnii Aziak, Kazan district, offered to take them as apprentices. ${ }^{9}$

Because of their extra earnings, Kräshen tailors formed the wealthiest strata in the village and their success constituted a proof of Islam's truth and a sign of their religious devoutness. If they earned enough, they could open their own shops in the main cities of the Middle Volga and hire other covillagers. If necessary, they could lend enough money for signing the petition, and their shops provided lodging for those apostates who needed a translator for their legal documents. ${ }^{10}$

The Kräshen villages of Mamadysh and Laishevo districts affected by the mass apostasy of 1865 were located in those areas with a high proportion of tailors. Starting

7. Materialy dlia sravnitel'noi otsenki zemel'nykh ugodii v uezdakh Kazanskoi gubernii, vol. 6: Uezd Mamadyshskii (Kazan, 1888), 61; Mukhametshin, Tatary-kriasheny, 54; Mashanov, "Zametka," IKE, no. 3 (1 February 1875): 91-92.

8. Il'minskii, ed., Kazanskaia tsentral'naia, 131; Pis'ma N. I. Il'minskogo k ober-prokuroru, 57; Men'shikov, "Achinskii prikhod," 448; P. Lebedinskii, "Buinsk," in Simbirskii sbornik, vol. 2 (Simbirsk, 1870), 124-126, 139.

9. NART, f. 4, op. 98, d. 34, 1. 159; "O shkole dlia pervonachal'nogo obucheniia detei kreshchenykh," in Kazanskaia tsentral'naia, ed. Il'minskii, 92; Chicherina, U privolzhskikh inorodtsev, 152-153.

10. Malov, "Ocherk," 18, pt. 1 (1872): 399. 
at the end of the eighteenth century, Kräshens of Elyshevo and Saltygan Kliuch left for the cities of Kazan and Chistopol', or Menzelinsk district. In the same area, villagers of Savrushi started tailoring later, in the 1840s, and, coincidentally, apostatized later under the influence of Elyshevite relatives, in 1879. In the volost' of Elyshevo, sixteen of twenty-one villages had seasonal laborers among their populations. In some villages, itinerant laborers comprised half the inhabitants. In general, the greater the proportion of itinerant tailors, the greater the Islamization of a given village. In Nikiforova, a village slightly touched by the apostasy movement in the 1860 os and 1880 s, the peasants enjoyed a higher yield, and because of the proximity of dense forests, involved themselves in woodwork. Unlike the villagers of Elyshevo volost', only a very few left the village. Significantly, the peasants of Kibiak-Kozi volost', with the largest number $(1,122)$ of seasonal tailors in Laishevo district, proved to be more obstinate in their apostasy than their neighbors; unlike nearby Elyshevo village, Kibiak-Kozi refused to rescind its petition to be recognized as Muslim, even when the governor came with his troops in June 1866 . The only family in Kibiak-Kozi who refused to apostatize well into the 1890 os was headed by a miller who worked among Russians. ${ }^{11}$

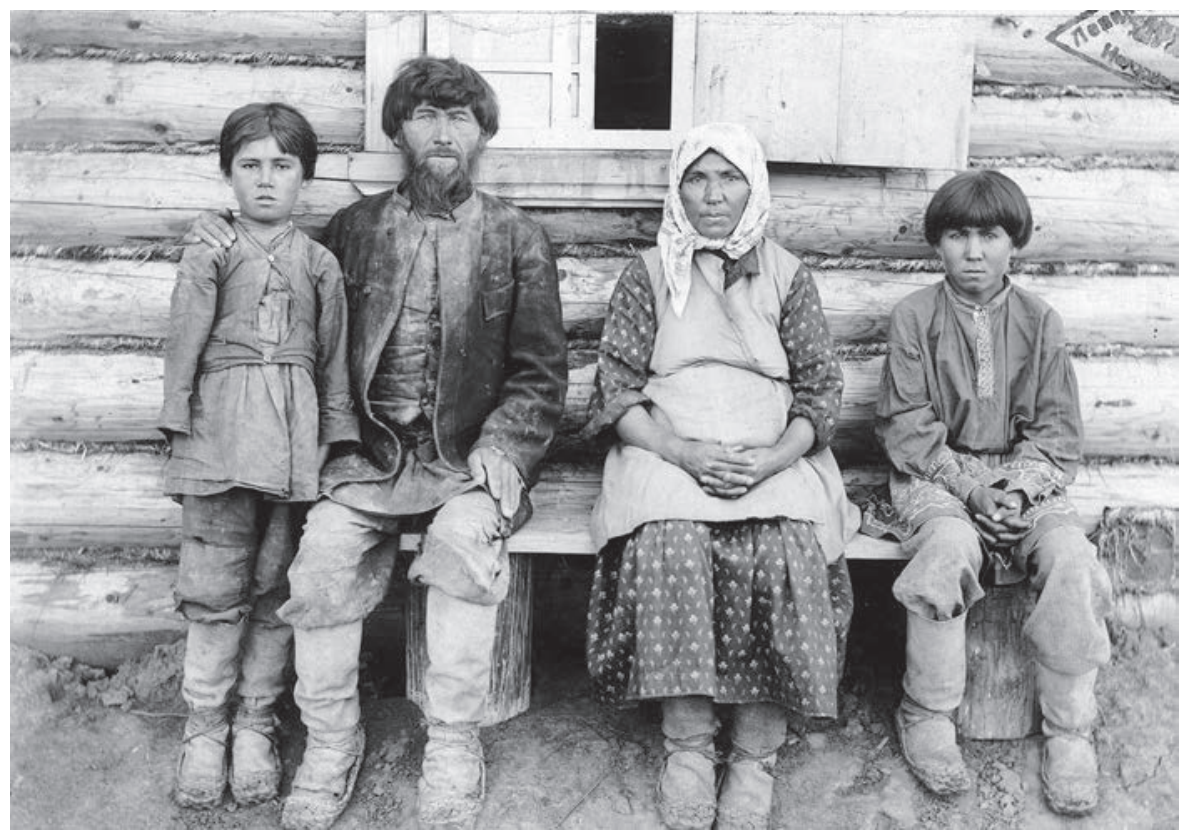

3.1: The only family in Kibiak-Kozi that did not apostatize. RGIA, f. 821, op. 4, d. 72, photograph no. 7. No date. Photograph courtesy of RGIA.

11. Istoriko-statisticheskoe opisanie tserkvei i prikhodov Kazanskoi eparkhii, 108, 161, 164, 268; Materialy dlia sravnitel'noi, 6: 61; 7: 119; Il'minskii, ed., Kazanskaia tsentral'naia, 275; Khasanov, Formirovanie, 225; NART, f. 2, op. 2, d. 5136, 1l. 8 ob.-9. 
Overall, the villages in Mamadysh and Laishevo districts that did not show strong signs of Islamic influence until the Revolution were those whose land was relatively richer, with a more diversified economy, including apiculture, forestry, pottery, or joinery. Villages in areas often dominated by Russians, animistic, or Christian FinnoUgric or Chuvash peoples also tended to resist Islamization. In Kovali, the Kräshens never left the land and remained Christian. ${ }^{12}$ If the land decreased its yield, suffered savage deforestation or drought, villagers turned to seasonal work that could potentially expose them to the Tatar textile and leather market, unless they opted to work in areas predominantly populated by Udmurts or Maris who shared their beliefs in the kirämät spirits, and were also baptized. Thus, Verkhnie Meretiaki in Laishevo district, whose land was no richer than in Elyshevo and whose men worked as tailors to complement their earning, never apostatized. Unlike the Elyshevites, the villagers worked among the nonbaptized Chuvash of Chistopol' district who shared their cosmology. They also found work in Russian factories and coal mines, as did the Kräshens of Verkhniaia Serda and Chura. ${ }^{13}$

Because Russians lived nearby, the villages of Selengush, Panovka, Serda, Kazyli, Meretiaki, Karabaian, and Iantsovary in Laishevo district were less exposed to Islamic influence and embraced Il'minskii's school enthusiastically. However, they were not totally immune to Islam's influence. In the 189os, three well-to-do families in Iantsovary and another one in Kazyli were strongly Islamized. They covered their icons and crosses with towels, and even shared marital links with the apostate village of Kibiak-Kozi. Only when Christian schooling took firmer root did these villages stop sharing brides. ${ }^{14}$

Missionaries often blamed the Kräshens' attraction to Islam on their mobility. The Kazan Theological Academy professor Ivan Pokrovskii (1865-1941) suggested opening libraries in Kräshen villages with books on agriculture and apiculture in their native language to keep men from leaving the village and turn them into successful farmers. Indeed, at the beginning of the twentieth century, one pood (approximately sixteen kilograms) of honey was sold for six rubles and fifty kopecks, and could match the thirty to sixty rubles tailors earned during fall and spring in Muslim land, if produced at a reasonable quantity. Not just a food product, honey could also serve to make candles for worship at home or at church. ${ }^{15}$

Kräshens of Mamadysh, Chistopol', and Laishevo districts who remained faithful to Christianity made furniture, window frames, beehives, threshers, and wheels. They also prepared charcoal that could be sold at local markets and to middle men. The Kräshen village of Pestretsy (Peträch), Mamadysh district, had its ceramics, parquets, dishes, and pots exhibited in Kazan during the 1912 all-Russian fair. Aware of the connection between tailors and Islamization, the Brotherhood of St. Gurii tried to create economic alternatives that might keep Christian Tatars in the Orthodox faith.

12. "Kratkie svedeniia o religioznom sostoianii inorodtsev Kazanskoi eparkhii," IKE, nos. 27-28 (15-22 July 1911): 832 .

13. Istoriko-statisticheskoe opisanie tserkvei i prikhodov Kazanskoi eparkhii, 364; G.P. "Skromnye torzhestva v prikhode sela Meretiak, Laishevskogo uezda," IKE, no. 23 (1 December 1901): 1083. Interviews by author of elderly Kräshen people in Staryi Karabaian (May 1996), Chura (12 May 2008), and Urias'bash (14 May 2008); Nikolai Petrov (Kräshen from Verkhniaia Serda), April 2008, National Archive of the Republic of Tatarstan, Kazan. 


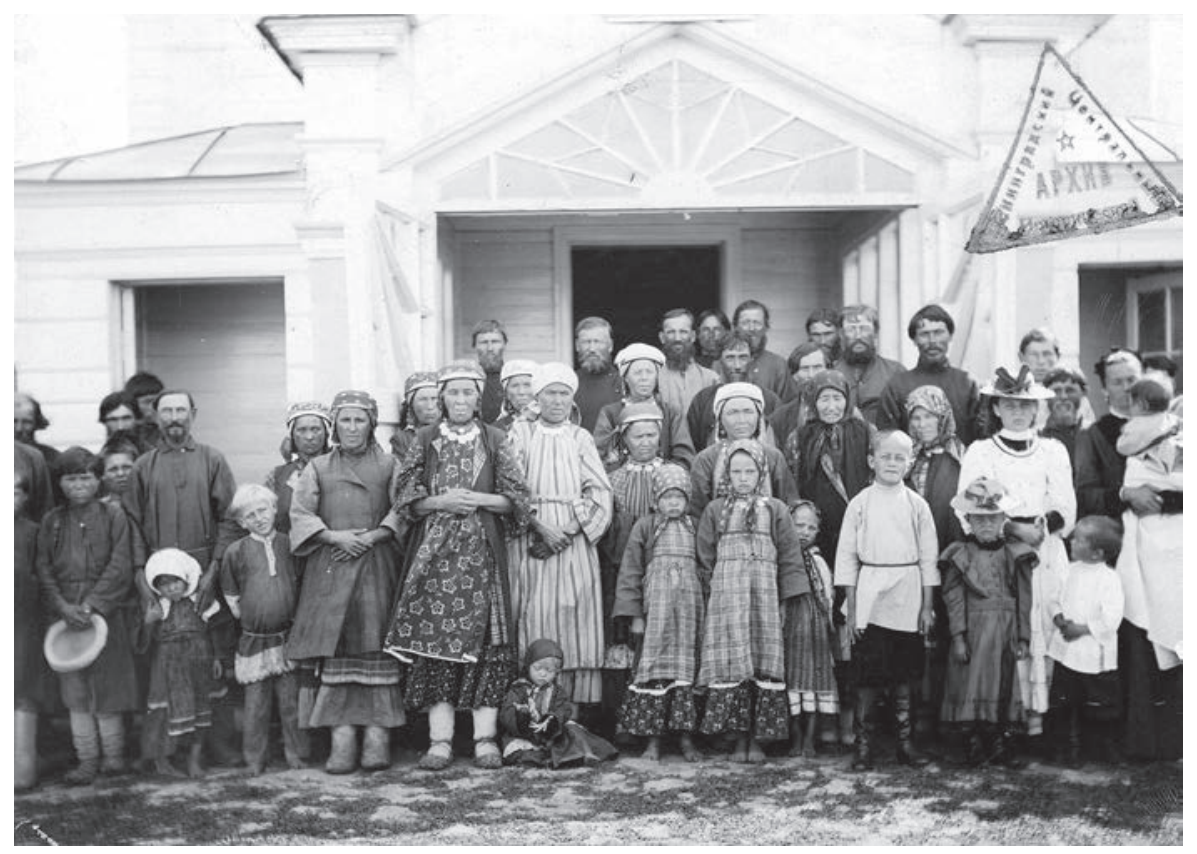

3.2: Kräshens standing in front of their church in Iantsovary, Laishevo District. RGIA, f. 821, op. 4, d. 72, photograph no. 2. No date. Photograph courtesy of RGIA.

Concerned by the increasing number of apostates in Apazovo, Kazan district, missionaries opened a carpentry-turnery school in 1907 to keep the boys from tailoring with their fathers. In the same spirit, the Brotherhood school of Staraia Ikshurma started a cobbler workshop and the school of Subash (Gorokhovoe Pole, Mamadysh district) opened a workshop manufacturing wheels and sleigh runners, but all in vain. ${ }^{16}$

Marital links provide further evidence of interconnection between the spread and consolidation of Islam in baptized villages and the growth of textile and leather activity in the Laishevo, Mamadysh, and Kazan districts. Marriage alliances connected Elyshevo and Kibiak-Kozi with other major centers of the textile and leather industry in the northern part of the district of Mamadysh and Kazan district. According to the Chura parish priest in northern Mamadysh district, the starokreshchenye of Otary showed no sign of Islamization until the 186os. Unlike the starokreshchenye of Shemordan who lived among Muslims, they resided in a predominantly Russian area. There was no mosque close by, and they neither shaved their heads nor observed Ramadan. Before the 1860 s, they had even asked for the opening of a parish school.

14. NART, f. 4, op. 131, d. 34, 1l. 1-1 ob.; Chicherina, U privolzhskikh inorodtsev, prilozhenie no. 1, pp. 7, 10; Nikolai Petrov, interview by author, National Archive of the Republic of Tatarstan, Kazan, April 2008.

15. Istoriko-statisticheskoe opisanie tserkvei i prikhodov Kazanskoi eparkhii, XXVIII; Mukhametshin, Tatary-Kriasheny, 51.

16. Mukhametshin, Tatary-Kriasheny, 50-55; Pavel and Mikhail Apushev, Piträch-bezneng tughan jïr (Kazan, 2000), 6-7; Istoriko-statisticheskoe opisanie tserkvei i prikhodov Kazanskogo uezda, 72. 
But in 1872, fifty families apostatized under the leadership of the underground mullah Kiril Vasil'ev, who was later exiled to Siberia. Clerics discovered that the men of Otary worked in the nearby lamb and sheepskin factories located in Tatar villages of Shemordan and Tarlau, and also as tailors in Tatar and Udmurt villages, also "affected" by Islam. Otary's daughters-in-law came from nearby Shemordan but also from the more distant villages of Verkhniaia Oshtorma and Ianyli near Kukmor, east of Shemordan, a city founded in the second quarter of the eighteenth century and an important center for wool industry in the second half of the nineteenth century. Other daughters-in-law originated from more distant villages, such as Kibiak-Kozi and Elyshevo, whose economic development was closely connected to Satysh and Bogatye Saby. The area covered by the kinship-economic network of Otary was impressive, roughly 2,500 square kilometers, and was sandwiched between two important centers of wool and leather industries, Bogatye Saby and Shemordan. ${ }^{17}$

Seven Tatar factories in Shemordan and Tarlau (with a combined work force of 1,400-2,800 persons) attracted some Russians, but mostly Muslim Tatars, Kräshens, apostates, and animistic Udmurts. Kasimov merchants, who found it easier to process Siberian and Central Asian sheepskins from Shemordan than from Riazan', were partly responsible for opening these factories. Missionaries and clerics in the second half of the nineteenth century blamed the Musaev, Davletkil'deev, Maksiutov, and Kostrov families, whose yearly revenue ranged from 18,000 to 50,000 rubles, for hiring Kräshen tailors and turning them Muslim. A number of Kräshens worked with Tatars in the tailors' guild ( $a r t e l$ '), sewing hats and fur coats, and currying lambskin. While in close contact with Tatars, those Kräshens participated in Muslim daily rituals, and mullahs visited their workshop. Together they shared meals which, to the clerics' indignation, included horse meat. The Kräshen missionary Timofeev bitterly noted that, while Orthodox Russians and Kräshens had to stand respectfully before their clerics, mullahs simply sat, ate, and shared their faith in a language accessible to all, which to his view, greatly favored the spread of Islam. ${ }^{18}$

The Sufi scholar and poet 'Abd ar-Rähim Utïz Imäni insisted that all steps in sheepskin tanning and leather manufacturing be placed in Muslims' hands, perhaps to better integrate the baptized Tatars and animists into the Islamic domain. His position was extreme and not shared by all Hanafi jurists in Central Asia, who allowed Muslims to buy skins tanned by Christians. There was even a joke transmitted by Märjani that illustrated Utïz Imäni's intransigence: anyone who possessed anything that looked like a cross faced his disapproval; even a window transom did not escape his wrath. Such an uncompromising position, shared by some in the Middle Volga, meant that Kräshens who wished to access or benefit from the Muslim market had to live exclusively by Muslim rules. This position could have accelerated the Kräshens'

17. NART, f. 4, op. 98, d. 9, 11. 44-45; f. 4, op. 98, d. 23, 1. 156; f. 4, op. 138, d. 12, 1. 1 ob. Topograficheskaia karta: "Respublika Tatarstan," masshtab 1:200 ooo, 2000 (2nd ed.), 14-15; Tatary, ed. Urazmanova and Cheshko, 188; Valentin Berkutov, Nyr'inskaia starina v oblike Kukmorskogo regiona (liudi, sobytiia, fakty) (Kazan, 2003), 11.

18. NART, f. 1, op. 3, d. 9736, 1. 7; f. 4, op. 98, d. 9, 11. 44-73; f. 4, op. 101, d. 11, 11. 114-119 ob.; f. 10, op. 2, d. 1383, l. 126; Vasilii V. Doronkin, "Kasimovskaia protivomusul'manskaia missiia," PB 6, no. 16, bk. 2 (August 1899): 370-73; N. A. Khalikov, Khoziaistvo tatar Povolzh'ia i Urala (Kazan, 1995), 179-180; Farida Sharifullina, Kasimovskie Tatary: Istoriko-etnograficheskoe issledovanie traditsionnoi narodnoi kul'tury serediny XIX-nachala XX vekov (Riazan, 2004), 36. 
involvement in Tatar economy and their acculturation in the first part of the nineteenth century. ${ }^{19}$

But not all Kräshens involved themselves in the Tatar market. Others in Shemordan preferred to work in Russian Orthodox artel' where icons were displayed prominently. Such a preference indicates that associating Christianity among the Kräshens solely with agriculture and Islam with manufacture and economic development is misleading. In general, Soviet and Tatar historiographies have viewed Kräshen society as essentially fixed in time, rural, rather poor, and strongly egalitarian. This image stemmed from the Christian missionaries themselves, who feared that the Tatar market, and in some way the Russian market, would lure their flock away. They hoped to protect them from both Islam and the growing religious indifference of the Russian bourgeoisie. $^{20}$

In the eighteenth century, baptized Tatars living along the road of Arsk were involved in Kräshen mining industries. ${ }^{21}$ They worked in the copper foundries of the Inozemtsevs, a famous entrepreneurial Kräshen family who also owned distilleries. Their foundries were located near Kukmor, north of Mamadysh district on Taishevka River, and in Ishteriakovo, Menzelinsk district, Orenburg province, fifteen versts (about sixteen kilometers) from the Nagaibak fortress where baptized Tatars served as Cossacks. For strategic reasons, Muslim Tatars were forbidden to open such factories but converts to Christianity could, and they hired their coreligionists; thus in 1751, Semen Inozemtsev, and then his brother Petr, used free baptized labor to dig and transport copper on the Ik, Kama, and Viatka Rivers from Ishteriakovo to near Kukmor. In Malaia Chura, an old convert village originally founded by Chuvash, Maris, or Udmurts in the Kukmor region, the copper tranches are still visible; the villagers used to dig copper, melt it, and make dishes and other indispensable tools well into the nineteenth century. ${ }^{22}$

The elderly of Elyshevo still remember that there were two copper mines in their village at the foot of their hills along the spring. The street-long village located at

19. “Traktat o vydelke kozh (Risala-i dibaga)," in Antologiia tatarskoi bogoslovskoi mysli: Gabdrakhim Utyz-Imiani al-Bulgari (Kazan, 2007), 79-89; Shikhab ad-Din Mardzhani, Wafiiat al-aslaf va takhiiat al-akhlaf (Podrobnoe o predshestvennikakh i privetstvie potomkam), trans. from Arabic by A. N. Iuzeev (Kazan, 1999), 84.

20. Nikolai Vorob'ev, Kriasheny i Tatary: Nekotorye dannye po sravnitel'noi kharakteristike byta (Kazan, 1929), 6; Geraci, Window on the East, 127-129.

21. The baptized villages on the Arsk road comprised Abdi, Aivan, Apazovo, Ianasal, Verkhnii Aziak, Bol'shie Kibiak-Kozi, Verkhnii Kitiak, Verkhniaia Ura, Verkhniaia Chura, Durga, Kyrbash, Mamsia, Nizhnii Aziak, Nizhnii Otar, Nizhniaia Ura, Nizhnii Urias', Novoe Churilino, Nurma, Oshtorma-Ium'ia, Panovaia Gora, Staryi Aivan, Staroe Grishkino, Chura, Ianyli, and others. Many of these villages are listed in the seventeenth-century cadastres of Kazan district and have a history of apostasy. Pistsovaia kniga Kazanskogo uezda 1602-1603 (Kazan, 1979), 123-131.

22. Khasanov, Formirovanie, 33-34, 49, 51, 302; Pavel Liubomirov, Ocherki po istorii metallurgicheskoi i metalloobrabatyvaiushchei promyshlennosti v Rossii (XVII, XVIII i nach. XIX vv.) (Leningrad, 1937), 108, 122-124; Istoriia Tatarii v dokumentakh i materialakh, 230-233; Rychkov, Topografiia Orenburgskoi gubernii, 269-270; Nikolai Pavlenko, Razvitie metallurgicheskoi promyshlennosti Rossii v pervoi polovine XVIII veka: Promyshlennaia politika i upravlenie (Moscow, 1953), 453; idem, Istoriia metallurgii v Rossii XVIII veka: Zavody i zavodovladel'tsy (Moscow, 1962), 282-284, 422-426; Iskhakov, "Etnodemograficheskoe razvitie Nagaibakov," 7, 5, 9 (Nagaibak Kräshens and Kräshens from Apazovo on the Arsk road shared kinship ancestry); "Keche Chura," unpublished memoirs collected by the head of the after-school Kräshen program of Chura High School, Galina Azina, n.d. 
the bottom of impressive hills indeed exhibited all the necessary conditions for the proper working of copper mines or foundries: it had water, minerals, and forests (now depleted). Malov, who was quick to determine the Kräshens' source of income, failed to mention the mines in his 1866 diary. It is likely that the mines produced very little and that their decline coincided with the steady development of textile and leather industry in the Bogatye Saby region during the last quarter of the eighteenth century. Usually, copper mines or foundries were fragile, and textile-related jobs brought a higher and more reliable supplementary income. Although one village tradition recalled the forced baptism of the Elyshevites in the Mesha River (which implied that they had always been Muslim), another mentioned that the village was formed by migrant baptized individuals (including Udmurts). These individuals could initially have been attracted by the presence of copper in their hills: the very first baptized settlement was close to the river and the hills. Coincidentally, until the twentieth century, the tailors of Elyshevo traveled to the village of Toygilde (Tuykilde) in Menzelinsk district, which was famous for its copper mines. Well into the Soviet period, Kräshens left their villages temporarily to work in the mines of Donbas and the copper mines of Perm' and Viatka provinces. This was the case of Kräshens in the villages of Chura and Verkhniaia Serda, still strongly Christian today. ${ }^{23}$

Trade routes undoubtedly played a central role in the extension of the apostasyconversion movement. They provided the necessary tools of resistance for the forcefully displaced baptized Tatars or those who wished to avoid arrest. Itinerant tailors who led the mass apostasies were able to draw on their knowledge of the area to survive economically. Some apostates exiled in 1837 did not report to their new parish priests until 1846. Others, such as the apostate Kräshens of Spassk district who were exiled in 1843,1849 , and 1856 , never did. Still others only remained for a short period at their place of exile before they, too, disappeared. They neither worked the land allotted to them nor used the communal fodder. The baptized Tatar Ivanov family, who had been exiled from Almurzina, Tetiushi district, to Bol'shaia Taiaba village, appeared in Taiaba only to pay their communal taxes and renew their internal passports. Exiled apostates preferred to support themselves by tailoring in Muslim villages or by marrying their children to those who had not been deported from their native villages, and in this way kept kinship links with their former communities. Finally, after their representatives were exiled to Siberia, tailors from Elyshevo and Kibiak-Kozi continued to urge Kräshens of Menzelinsk district, among whom they resided and worked, to apostatize. ${ }^{24}$

Apostate tailors, exiled or not, came back to their village at spring and summer agrarian festivals. These festivities offered them valuable economic and communal support, and represented another conduit for the spread of Islamic knowledge.

23. Istoriko-statisticheskoe opisanie tserkvei i prikhodov Kazanskoi eparkhii, 104, 364; interviews by author of elderly people in Elyshevo and Chura, May 2008; Khasanov, Formirovanie, 33-34; Tahir Kärimov, “Tuykilde awili," Miras no. 3 (1994): 141.

24. NART, f. 1, op. 2, d. 1372, ll. 1-2 ob.; f. 1, op. 2, d. 399, 1l. 13 ob.-14; Malov, "Prikhody starokreshchenykh," 17 , no. 8 (1865): 479; and 18, no. 10 (1865): 286-89; RGIA, f. 821, op. 8, d. 763, 1. 300.

25. Jìūn qüșsasï (1881) in Nikolai Katanov, Materialy k izucheniiu kazansko-tatarskogo narechiia, pt. 1 (Kazan, 1898), 82-92. Some mullahs sent petitions to the governor of Kazan and the Ministry of Interior to stop the jïyïns, NART, f. 1, op. 3, d. 6030, ll. 1-6 ob.; NART, f. 1, op. 3, d. 7233, 1l. 1-3; Raufa Urazmanova, Obriady i prazdniki tatar Povolzh'ia i Urala (Godovoi tsikl XIX-nach. XX vv.) (Kazan, 2001), 9, 73-74. 
Nineteenth-century Russian missionaries suspected that these festivals played an essential role in the Islamization of Kräshens. However, Soviet historians and even present-day Tatar folklorists have minimized their religious importance and interpreted them as pagan relics. Nineteenth-century mullahs, who decried their hybridity, alcohol, and dubious trade practices, petitioned to the local Russian authorities to ban them. Still, agrarian festivities constituted a very important religious network for the apostates, who besides doing business gathered as a community to share news about the development of their cause, inquire about the possibilities of joining Islam openly, gain community support, find appropriate matches for their children, and openly declare their religious identity. Before the beginning of the festivities, mullahs, despite their criticisms, often agreed to visit homes with their wives and read the Qur'an. ${ }^{25}$

In the village of Elyshevo, the spring festival of the plow, called Sabantuy by Muslim Tatars and Sörän by Kräshens, signaled the beginning of their 1866 apostasy. Other than the Sabantuy, the villagers of Elyshevo also celebrated the jïyin summer festival, which began at the end of May or the beginning of June and lasted from four to seven weeks. These agrarian festivals were occasions for relatives to meet, merchants to sell their goods, bards to sing epic poems, displaced apostates to exchange news and connect with other coreligionists, tailors to display their riches and run their business, and young Tatars and Islamized Kräshens to choose an appropriate spouse. The summer festival linked Elyshevo to a wider network of support. Beginning on a Friday, summer jïyïn festivals, unlike spring festivals, moved between villages that belonged to an established kinship network; each village hosted the fair for three or four days. The apostate village of Elyshevo belonged to the jïyin of Mamalai, a very small Muslim village, which included other Tatar villages, Satysh, Balandysh, and Kazanchi Bigeneevo (Qazanchï Bigänäy). All three played a part in the Islamization history of Elyshevo and provided comfort for the mind and body: the butcher of Balandysh provided halal (canonically lawful) meat for the Elyshevites, and the wife of its mullah educated some of the children; the mullahs, abistays, and students of the famous Satysh madrasa also taught; and in the 188 os, the road to Kazanchi Bigeneevo led the Elyshevites to visit its famous Sufi shaykh when they fell sick. ${ }^{26}$

According to the Soviet ethnologist Nikolai Vorob'ev, the jïyïns originally corresponded to the territorial divisions of the tenth-century Volga Bolghar state. The village at the center of the jïïn network often, but not always, contained the oldest cemeteries and other monuments; and some of these villages were often the focus of local pilgrimages. Most interestingly, they came to serve as a point of contact between Islamized Kräshens and the Tatars. ${ }^{27}$ From 1839 through 1849, the Ministry of Internal Affairs and the Holy Synod, not realizing that the Russian village of

26. Epic of Elyshevo in Malov, “Ocherk," 18, pt. 1 (1872): 403; Zahidullin, "Jilïsh awiilï mäk'ruhlarï," 46, no. 9 (1995): 113; information gathered by author in Qazanchï Bigänäy and Elyshevo, May 20oo; Malov, “Ocherk," 17, pt. 3 (1871): 408 and 18, pt. 1 (1872): 241; Yakhya Abdullin, “Milli bäyrämebez," in Millät yazmïshï: Uylanular (Kazan, 1999), 75-84; Firdäüs Gharipova, Rukhi bashqalabïz: Mäshhür tatar awïlarï (Kazan, 2005), 32.

27. Otchet o deiatel'nosti Bratstva Sv. Guriia za dvadtsat' vtoroi bratskii god s 4-go oktiabria 1888 g. po 4-oe oktiabria 1889 goda (Kazan, 1889), 34; Tatary Srednego Povolzh'ia i Priural'ia, 202. 
Blagoveshchenskoe (known as Omar among the Tatars) was a jïyïn center, exiled some of the apostate leaders there. Instead of being isolated from Muslims, these apostates found themselves at the center of an important kinship and economic network of the Muslim Tatars. Thus the time of the fair, St. John's Day (Ivanov den'), coincided with the time of the jïyin festival (Omar jïyini) and every Sunday during the winter season the Russian village hosted a market. Tatars visited the fair, and the displaced apostates found the contact they needed to conduct basic Muslim rituals. Because Omar had no Muslim cemetery, apostates turned to the mullah of Urazbakhtino, a village located on the same river as Blagoveshchenskoe. Urazbakhtino belonged to the Omar jïyin network and also dated from the times of the Khans. Its mullah Möhämmäd Shärif b. Säyf ad-Din, knowingly or unknowingly defying the law, buried their dead in the village cemetery. A generation later, during the apostate movement of $1865-1870$, Muslim Tatars and apostates used the same strategic position of the fair to help spread news of the apostasy of the Chistopol' novokreshchenye among the starokreshchenye of Mamadysh district, who for the first time officially began to renounce their Christianity. ${ }^{28}$

The Kräshens of Staraia Ikshurma, which was part of another jïyïn network that involved both Kräshen and Tatar villages, also gradually moved toward Islam despite the presence of Russians (who constituted more than half of the population), the opening of a Brotherhood school in 1867-1868, the construction of a separate building for the school in 1874, and the consecration of a church in 1891 with mixed liturgies in Tatar and Russian. Its market attracted neighboring Muslim Tatars who stayed overnight in Kräshen houses. The visitors included the mullahs of Bogatye Saby, who were well known for their knowledge of Islamic sciences, and apostates from Elyshevo village. As for the Russian residents, they usually avoided the market, which they contemptuously labeled "pagan" because it sold horse meat. However, the presence of Russian sectarian Molokan laborers in Staraia Ikshurma further complicated the picture for Eastern Orthodox missionaries: the iconoclastic Molokans told Kräshens that worshiping man-made icons was a sin, which only confirmed apostate Tatars in the veracity of Islam. ${ }^{29}$

Similar to the jïyin of Staraia Ikshurma was that of Ianyli in the Kukmor region. Like Staraia Ikshurma, Ianyli was a mixed village of Kräshens and apostates involved in tailoring whose weekly fair attracted both Tatars and Kräshens from neighboring villages. Its jïyïn included the villages of Tarlau, Shemordan, Kainsar, Porshur, Malaia Chura, all involved in leather and textile industries and all responsible for the Islamization of surrounding Kräshens and Udmurts. The market of Ianyli, which attracted Tatars from three important economic and scholarly centers-Maskara, Tiunter, and

28. Malov, "Prikhody starokreshchenykh", no. 12 (1865): 464-66, 482-483, 487-488, 491; idem, “Ocherk," 18, pt. 1 (1872): 239; Kazanskaia guberniia. Spisok naselennykh mest po svedeniiam 1859 goda (SPb., 1866); Urazmanova, Obriady i prazdniki tatar, 163; NART, f. 2, op. 1, d. 1954, 11. 1-2.

29. Otchet o deiatel'nosti Bratstva Sv. Guriia za semnadtsatyi bratskii god, 13-14; "Iz zhizni kreshchenykh inorodtsev Kazanskogo kraia," 31; "Zakladka tserkvi," no. 15 (1 August 1891): 468-470; N. N., "Osviashchenie khrama v sele Staroi Ikshurme," IKE, no. 22 (15 November 1891): 678-685; Urazmanova, Obriady i prazdniki tatar, 160. 
Bogatye Saby-was so well known to the Russian missionaries for selling Muslim religious literature and artifacts that it prompted them to distribute Christian books in Tatar language, icons, and crosses at no cost to the baptized of the same village in the $1890 .^{30}$

Potentially, any village or town market could serve as a link between the Kräshen apostates and the Muslims, and as a conduit for the spread of Islamic literature and artifacts. Sokol'ie Gory, Mamadysh district, which had become the new home of deported apostates from Spassk district, constituted an important transitory passage on the Kama River. Its pontoon bridge allowed Tatars from Orenburg to go to Kazan district. They stayed overnight in the apostates' homes or eating houses as they did in Staraia Ikshurma or Apazovo. In 1839, the minister of state domains, and in 1866, the governor of Simbirsk recommended deporting apostates to more remote areas than to neighboring Russian villages in Kazan province. ${ }^{31}$

\section{Religious Sufi Networks}

The apostasy movement in Kazan province was more than the outcome of important economic developments in the Tatar communities of Laishevo, Mamadysh, Kazan, and Malmyzh districts; it was also the product of a powerful Sufi reform movement beyond the borders of Imperial Russia. Aside from economic networks, sacred networks and their guardians played a significant role in the spread of Islam. As Sufi books suggested, Sufi spiritual leaders or shaykhs (also called ishans), living or dead, were potent figures who could change the natural order. Besides having a tremendous impact on the imagination of the Tatar and non-Muslim indigenous peoples of the Middle Volga, some of the community Sufi leaders were powerful businessmen located in major textile centers. No less than Russian missionaries, however, Tatar modernists were very critical of the shaykhs and itinerant Sufis whom they called "dervishes." They ridiculed their use of talismans and antiquated methods of healing, called them parasites and charlatans, blamed them for neglecting basic Islamic rituals, and considered them to be obstacles in the way of economic progress. However, those same shaykhs were involved in textile and leather industries, actively proselytized among the baptized and nonbaptized Turkic and Finno-Ugric peoples of the Kazan and Viatka provinces, and played an active role in the orchestration of the apostasy movement. 32

30. Otchet o deiatel'nosti Bratstva Sv. Guriia za dvadtsat' sed'moi bratskii god s 4 oktiabria 1893 goda po 4 oktiabria 1894 goda (Kazan, 1894), 55-56; Urazmanova, Obriady i prazdniki tatar, 162; interviews of elderly people in Ianyli by author, May 2008.

31. Malov, "Prikhody starokreshchenykh," no. 10 (1865): 287; idem (Iapei Babai), "O kreshchenykh tatarakh," no. 20 (15 October 1891): 633-635; NART, f. 2, op. 1, d. 1907, 1. 80 ob.; Materialy po istorii Tatarii vtoroi poloviny 19-go veka, 269.

32. Otdel rukopisei Kazanskoi nauchnoi biblioteki im. Lobachevskogo, f. 7, ed. khr. 1, 1. 191-195; "Möritlär qaberstanïnnan ber awaz" and "Maqtanïshu” (1906), in Ghabdulla Tuqay, t. 1 (Kazan, 1955), 21, 57-58; "Dinne ashap beterä yazghan ishan wä mullalar khaqïnda" (1906), in Näjip Dumawi, Tormïsh säkhifäläre (Kazan, 1985), 48-49; Thierry Zarcone, "Un aspect de la polémique autour du soufisme dans le monde tatar, au début du XXe siècle: Mysticisme et confrérisme chez Mûsâ Djârallâh Bîgî”, in L'Islam de Russie, 227-236. 
Sufi ishans were quite popular among the Muslim Tatars, the Kräshens, the Chuvash, and the Maris for their thaumaturgical gifts. Two Tatar workers asked a young Kräshen teacher, trained in Il'minskii's school, whether Christian priests had the power to read peoples' thoughts and heal the sick as their local saint did. The teacher answered that in Christianity, saints were not physically alive, but could be recognized as saints after their death. This answer did not satisfy the two Muslims, for whom the powers of the shaykhs were proof that Islam was the true faith. Many communities indeed recognized the ishans' healing powers. Near the villages of Elyshevo and Kibiak-Kozi, the shaykh of Kazanchi Bigeneevo, Mamadysh district, Wäli Ähmäd (1848-1919), had a thorough knowledge of medicinal herbs and owned a hospital that attracted neighboring Kräshens and Udmurts. ${ }^{33}$ In the district of Buinsk, Simbirsk province, Islamized and Christian Chuvash brought children suffering from epilepsy and rickets to local mullahs who prayed over them. And in Menzelinsk district, the Tatar ishan of Bogady village even attracted Maris from Elabuga and Sarapul' in Viatka province, Birsk and Belebei in Ufa province, at the expense of local Mari and Chuvash sorcerers who enjoyed good reputations. During his meeting with a patient, witnesses reported, the Tatar ishan stressed the superiority of his prayers. Whereas local sorcerers' magic formulas were effective only once, his own prayers, drawn from the Qur'an, had a universal character and a continuous effect against evil spirits. The ishan's discourse echoed the language of newly converted Maris who presented their conversion to Islam as a liberation from evil spirits: "When you become a Muslim, the kirämät does not touch you anymore."34

The Islamic discourse on the spirits had a certain impact on native traditions, without necessarily displacing them. Under the influence of Muslim Bashkirs, Teptiars, and Mishars, Kräshen sorcerers in Belebei district added Bismillah to their own formulas to enhance their efficacy. As in other animist cultures, the ishan's popularity could be attributed to the power of literacy in a predominantly illiterate or semiliterate environment. Kazan typographies furnished mullahs or any Muslim with books of exorcism and interpretation of dreams, composed of short chapters of the Qur'an that could be either copied or cut into the form of talismans. Itinerant mullahs and students sold these brochures and other types of religious literature in the countryside. This trade constituted another channel by which Islamic literacy gained publicity in the Kräshen milieu. ${ }^{35}$

Russian sources indicated that in Spassk district literate itinerant beggars helped Islamized "baptized" Tatars get married or bury their dead the Islamic way. These beggars were itinerant Sufis who played an important part in the spread of rumors

33. Interview by author of elderly people in Qazanchï Bigänäy, May 200o; NART, f. 1, op. 3, d. 9603, 1. 117; Otdel rukopisei Instituta iazyka, literatury i istorii Akademii nauk Tatarstana, f. 56, op. 1, ed. khr. 3, 1l. 83 ob.-84; Idiyä Sälimova, "Bigänäy ishanï turïnda riwayätlär," Saba Tangnarï, no. 84 (3 August 1995): 2; no. 86 (8 August 1995): 2; Näjmiev and Khujin, Yashä, Saba-Yort, 29-34.

34. K. Prokop'ev, "Vliianie tatar-musul'man na chuvash," $P B$ 1, no. 7, bk. 1 (April 1906): 319; similar cases could be observed among the Kräshens, see NART, f. 1, op. 3, d. 3272, 1. 46 ob.; Nikolai Katanov, "Narodnye sposoby lecheniia u bashkir i kreshchenykh tatar Belebeevskogo uezda Ufimskoi gubernii," IOAIE 16, no. 1 (1900): 1-14; Eruslanov, "Magometanskaia propaganda," no. 16 (1895): 385.

35. Katanov, "Narodnye sposoby lecheniia," 1-14; Malov, "Pravoslavnaia protivomusul'manskaia," 14, pt. 2, no. 7 (1868): 246-249, 250-253. 
preceding the apostasies. They chanted the Qur'an and munajat and explained God's word in a language accessible to all. Similar to the world-renouncing Qalandars (Sufi vagabonds) of the Ottoman Empire in their scandalous dress and ascetic practices, these mysterious Sufis, whose identities and sociological background remain obscure, preached among Kräshens, Chuvash, and Maris. They reminded their audiences of the end of times, vividly described pious deeds and future rewards in paradise, and claimed that any subject in Russia could freely choose Islam. In 1901, one of them walked barefoot in freezing weather through the Chuvash villages in Buguruslan district. In their speech, they liked to draw metaphors from local cultures. Thus, a Tatar wanderer among the Chuvash of Samara province quoted their favorite dishes as future treats in their afterlife. To the clergy's dismay, Kräshens, animist Maris, and baptized Chuvash highly respected those wanderers for their clairvoyance and offered them presents. Some of them, however, did not live on alms alone, but also sold little household articles, such as scissors. ${ }^{36}$

Besides those itinerant Sufis, important heads of Qur'anic schools were shaykhs who let Kräshens approach them and attend their teaching. Although there is no direct evidence of Sufi initiation (bay'at, "oath" pledged to a Sufi master) among the Kräshens, Mari converts to Islam did undergo an initiation that had Sufi characteristics. New male converts had to fast thirty days and pray five times prior to a special ceremony at the mosque. Dressed in white and barefoot, they swore fidelity to their new faith and promised to educate their children as Muslims. The women's ceremony took place in the mullah's house or in a private home. Submission to God's rule, purity, and austerity, as suggested by the clothing, were important features of Sufism. ${ }^{37}$

If no direct evidence of a Sufi initiation can be found among the Kräshens, they nevertheless had strong connections with Sufism. Among the books confiscated by the police in the mixed Kräshen and Chuvash village of Azbaba, Sviiazhsk district, was a manuscript describing the rules of Sufi orders-which revealed a local interest in Sufism. On the road to Elyshevo, near Tokhtamyshevo, a priest witnessed funerals accompanied with prayers and "chants," which might suggest that the baptized attendees chanted Sufi litanies (zikr). Even if there is no direct nineteenth-century witness that apostate tailors performed Sufi methods of concentration and prayer during their long hours of work, indirect oral evidence suggests that they did. The descendants of Elyshevite tailors still remember that, while sewing, their grandparents sang munajat, which involved the repetition of simple Qur'anic verses, and in particular the repetition of La Ilaha illallah (There is no God but Allah), the first part of the shahada or profession of faith, which was also a central component of Sufi litanies. Sufi shaykhs also hired baptized tailors, who while working could learn from the shaykh and also identify themselves, physically and mentally, with the prophet-tailor Enoch and the

36. NART, f. 2, op. 2, d. 4960, 1. 4; f. 4, op. 99, d. 20, 1. 6 ob.; Antonii Ivanov, “Otstupnicheskoe dvizhenie ... Derevnia Alekseevka," 151; idem, "Otstupnicheskoe dvizhenie kreshchenykh i nekreshchenykh chuvash Samarskoi gubernii v magometanstvo," PB 16, no. 14, bk. 2 (July 1908): 253; idem, "Tsarstvo islama," 108-109; Bagin, “Ob otpadenii," 227; Eruslanov, "Magometanskaia propaganda," no. 16 (1895): 389; "Izvlechenie iz otcheta eparkhial'nogo inorodcheskogo missionera o sostoianii inorodcheskoi missii v Viatskoi eparkhii za 1909," Viatskie eparkhial'nye vedomosti, no. 22 (2 June 1911): 464; Ahmet Karamustafa, God's Unruly Friends: Dervish Groups in the Islamic Later Middle Period, 1200-1550 (Salt Lake City, 1994).

37. Eruslanov, "Magometanskaia propaganda," no. 18 (1895): 88. 
eponymous founder of the Naqshbandi order, Muhammad Baha' ad-Din Naqshband. In Rabghuzi's tales of the prophets, Enoch recited prayers every time he made a stitch with his needle and, in Yalchïghol's work, Shaykh Naqshband, whose name meant "one who casts patterns upon cloth" (naqsh, design; band, affixing), won the right to reign over the six layers of hell thanks to his art as a tailor and method of recollection. In Central Asia, makers of Muslim hats often belonged to Sufi brotherhoods. ${ }^{38}$

What can be firmly documented is the Kräshen tailors' and their progeny's access to the teaching of Tatar Naqshbandi shaykhs who scrupulously followed the sharia, lived a modest life, and who, in most cases, had the financial ability to help the needy. From the names of these shaykhs, among them 'Abd ar-Rähim al-Utïz Imäni, it can be inferred that the apostasy movement was the product of a global Sufi reform movement, which dated back to the Indian shaykhs Ahmad Sirhindi and Wali Allah. The Mujaddidiyya branch of Naqshbandism started in the Mughal Empire with Ahmad Sirhindi, whose disciples recognized him as the mujaddid, or renewer of the second millennium. Well-known for criticizing the Mughal Emperor Akbar (r. 1556-1605) for his syncretism, Sirhindi helped synthesize earlier trends in Central Asian Sufis' perception of their mission in the world. According to Sirhindi, Sufis did more than teach the path and perform a mediatory function between humanity and the divine; they had the responsibility to transform the world, to make it closer to the pristine community of the Prophet. Concretely, this meant that a Sufi could call political leaders to account, remind them to enforce Islamic duties, even deprive them of power if their rule did not conform to the sharia. These ideas were not fundamentally new since the Central Asian Naqshbandi Khoja Nasr ad-Din 'Ubaydullah Ahrar (d. 1490), critical of asceticism, had earlier claimed that the best way to protect the Islamic community from the arbitrariness of rulers was for Sufis to advise them. (Muslim and baptized Tatars knew of Ahrar and visited his tomb that they believed to be in the village of Verkhniaia Nikitkina or Tubïlghïtaw in Tatar, a village famous for leading the 1860 s apostasy movement. $)^{39}$ Sirhindi's successor, Shah Wali Allah, drew new emphasis on the Prophet's sociopolitical role. In the same way the Prophet established a new society after his ascent to heaven, Sufis too had to return to the world, look after its proper civic and economic management, and expand the realm of God. Transplanted into the Russian imperial and Kräshen contexts, Sirhindi and Wali Allah's approach to the world offered hopes of possible restoration of God's will through communal and political reform. ${ }^{40}$

38. NART, f. 10, op. 1, d. 1863, ll. 4-4 ob. (Azbaba); f. 4, op. 101, d. 16, 1. 17 (Tokhtamyshevo); Al-Rabghūzī, Stories, vol. 2: 50; Yālchïghol, Risālä, 240; Buehler, Sufi Heirs of the Prophet, 55; G. Khämidullina, interview by author, 9 May 2008, Elyshevo; Khösnullin, Mönäjätlär, 76-81.

39. According to Husam ad-Din al-Bolghari, the author of Täwärikh-i Bolghāriyya, it was the tomb of the Central Asian Naqshbandi shaykh Khoja Ahrar (d. 1490). But as noted by Märjani, his tomb was in Samarkand, where his madrasa was located. Märjānī, Mustafād, 1: 214; Frank, Islamic Historiography, 75.

40. On Sirhindi, see Muhammad Abdul Haq Ansari, Sufism and Shari'ah: A Study of Shaykh Ahmad Sirhindi's Effort to Reform Sufism (Leicester, 1986); Buehler, Sufi Heirs of the Prophet, 60-61; Jo-Ann Gross, "Multiple Roles and Perceptions of a Sufi Shaikh: Symbolic Statements of Political and Religious Authority," in Naqshbandis: Cheminements et situation actuelle d'un ordre mystique musulman. Historical Developments and Present Situation of a Muslim Mystical Order. Actes de la Table ronde de Sèvres, 2-4 mai 1985, ed. Marc Gaborieau, Alexandre Popovic and Thierry Zarcone (Istanbul and Paris, 1990), 109-121; Annemarie Schimmel, And Muhammad Is His Messenger: The Veneration of the Prophet in Islamic Piety (Chapel Hill, NC and London, 1985), 220-222. 
The situation in India and Russia in the eighteenth century presented many similarities. Just as Mughal power was slowly disintegrating, threatened on all sides by Sikhs, Hindus, and Christians, the Tatars had lost their sovereignty long ago and remembered the destruction of their mosques by the infamous Kazan archbishop Luka Konashevich. Subcontinental Mujaddidi teachings of political involvement found fertile ground in the Volga region through Afghanistan and Central Asia. By the end of the eighteenth century, a suborder of the Mujaddidiyya, the Khalidiyya, named after its Kurdish founder Mawlana Khalid Baghdadi (d. 1827), also reached the Volga region through Dagestan and the Ottoman Empire. This new lineage firmly held that the sharia was the guarantor of independence from foreign encroachment and was fundamentally hostile to the British rule. ${ }^{41}$ Once transplanted to Russia, the Mujaddidiyya and Khalidiyya lineages came to offer new hopes of possible restoration, even expansion, of God's realm under non-Muslim domination. Two teachersone in Kabul, the other in Bukhara-introduced Tatar students to the Mujaddidiyya in the eighteenth and beginning of the nineteenth century: Fayd Khan al-Kabuli and Niyaz Quli at-Turkmani. ${ }^{42}$ Little is known about Fayd Khan al-Kabuli's teachings, except that he trained about fifteen disciples from the Volga-Urals region. ${ }^{43}$ More is known about the Bukharian shaykh Niyaz Quli. Faithful to the teachings of Central Asian Sufi Ahrar, Shaykh Niyaz Quli invited Sufis to maintain contact with rulers, even the most oppressive ones, as a way to guard the purity of Islam and alleviate people's sufferings. Mujaddidi shaykhs in Bukhara also served as mediators between political leaders and people, personally relaying people's petitions to the emir. In the context of Russia, Mujaddidi shaykhs did not have the opportunity to instruct the czar, a non-Muslim, in the ways of the sharia, but they could play a role as mediators between the czar and the community, in order to protect it against abuse. ${ }^{44}$

Besides Utïz Imäni who was an avid reader and copyist of Sirhindi's work, a number of Mujaddidi shaykhs were involved in the spread of Islam among the Kräshens, baptized and animist Udmurts, Chuvash, and Maris: Shaykhs Ni'mätullah al-Älmäti (1771-1852) in Chistopol' district, Ni'mätullah b. Biktimur al-Istärlibashi (1773-1844) in Ufa province, and 'Ali Säyfullah (1794-1874/75) of Tiunter village in Malmyzh district, Viatka province. ${ }^{45}$ All three were students of Shaykh Möhämmäd Rähim b.

41. In the Caucasus, Khalidi Naqshbandis led hostilities against Russia's invasion and in Istanbul, the Khalidi shaykh Ahmad Ziyauddin Gümüşhanevi (1813-1893), who was responsible for introducing many Tatars and Bashkirs to the Khalidi path, enlisted with his students in the Russo-Turkish war of 1877 . See Hamid Algar, "Political aspects of Naqshbandi history", in Naqshbandis: Cheminements et situation actuelle, 136-138, 144; idem, "Zaynullah Rasulev: The Last Great Naqshbandi Shaykh of the Volga-Urals Region," in Muslims in Central Asia: Expressions of Identity and Change, ed. Jo-Ann Gross (Durham and London, 1992), 117-118.

42. Kemper, Sufis und Gelehrte, 90-91; Frank, Muslim Religious Institutions, 152-153.

43. Michael Kemper, "Entre Boukhara et la Moyenne-Volga: Abd an-Nasir al-Qursawi (1776-1812) en conflit avec les oulemas traditionalistes," Cahiers du Monde russe 37, no. 1-2 (January-June 1996): 42; Anke von Kügelgen "Die Entfaltung der Naqšbandīya muğaddidīya im mittleren Transoxanien vom 18. bis zum Beginn des 19. Jahrhunderts: Ein Stück Detektivarbeit," in Muslim Culture in Russia and Central Asia, vol. 2, 142.

44. Baxtiyor M. Babadžanov, "On the History of the Naqšbandìya Muğaddidìya in Central Māwarā'annahr in the late 18 th and early 19th centuries", in Muslim Culture in Russia and Central Asia from the 18th to the early 2oth centuries, vol. 1, ed. Michael Kemper, Anke von Kügelgen, Dmitriy Yermakov (Berlin, 1996), 390-408.

45. Märjānī, Mustafād, 2: 161-163, 203-204, 254-255; on Utïz Imäni, see Kemper, Sufis und Gelehrte, $177-178$. 
Yusuf al-Ashiti (d. 1816/17) in the village of Maskara in Viatka province. The village's history exemplified Naqshbandi ideals of religious sobriety and worldly action. Very early on, its merchant and religious elite had defied Russian law and taught the Sufi path in non-Tatar milieu. ${ }^{46}$ 'Abdullah Utyamïshev, the rich owner of the Maskara leather factory (he came from a noble family that refused to convert to Christianity during the reign of Peter the Great), was responsible for building a two-story brick mosque in 1791, despite the presence of a Russian factory in nearby Kukmor and the opposition of the Russian clergy. His son Musa (d. 1835), both scholar and merchant, built a wooden mosque for sixty newly converted animist Udmurts in 1800 . The support of local Tatar and Udmurt merchants undoubtedly facilitated Musa's work. As a former student of Maskara and Bukhara, Musa had also distinguished himself for supporting the candidacy of imams of Udmurt origin and debating the superiority of Islam over Christianity with Russian Orthodox priests, even writing books on the subject. ${ }^{47}$

The madrasa of Maskara trained many students who, after leaving for Bukhara, Kabul, or India, became active missionaries in Turkic and Finno-Ugric milieus. Upon his return from Bukhara in 1829-1830, Shaykh 'Ali Säyfullah, a famous horse rider, emulated the merchant-scholars of Maskara in his village of Tiunter and proselytized among nonbaptized Chuvash, Udmurts, Maris, and baptized Tatars. Ignoring the law prohibiting converting "pagans" to Islam, Shaykh "Ali asked for the permission of the Spiritual Assembly of Orenburg and the Ministry of State Domains to register nonbaptized Chuvash and Udmurts as Muslims in 1848-1849, but his efforts failed. Russian authorities arrested him and forced him to sign a form stipulating that he would never again petition for the inclusion of nonbaptized into the mosque registries. As for the Udmurts and Chuvash, they received twenty lashes and were sentenced to jail. Despite his arrest, the shaykh, assisted by his wife, an imam's daughter and abïstay who knew Farsi and Arabic, continued proselytizing among Christians and animists. Because Shaykh 'Ali owned a mill in Balandysh village, Mamadysh district, he occasionally visited Balandysh and Staraia Ikshurma, the center of an important fair, and spoke to the old converts of Elyshevo, Staraia Ikshurma, and Tokhtamyshevo. The literate fifty-year-old Yaghfär Wälitov (Efrem Kirilov) of Udmurt origin, an ishan who was one of the leaders of the 1866 apostasy movement in Elyshevo, may have been connected to his chain of Sufi initiation (silsila). ${ }^{48}$ Shaykh 'Ali's school indeed taught starokreshchenye of Elyshevo, Mamadysh district, Apazovo, Kazan district, and even Timofeev's native village, Nikiforova, along with baptized Chuvash, Udmurts, and

46. All information about Maskara (Mächkärä) is taken from Märjānī, Mustafād, 2: 156-16o. On Shaykh Möhämmäd Rähim Akhun al-Ashiti and his students, see Fäkhr ad-Dīn, Āsār, vol. 1, pt. 3, no. 114 (1903): 142 .

47. Khasanov, Formirovanie, 296; S. Kh. Alishev, "Sotsial'naia evoliutsiia sluzhilykh tatar vo vtoroi polovine XVI-XVIII vekov," in Issledovaniia po istorii krest'ianstva Tatarii dooktiabr'skogo perioda (Kazan, 1984), 67; "Mökhämmädjan bine äl-Khösäyen bine Ghabderrakhman" (biographical entry, 1900), in Rizaeddin Fäkhreddin, Asar, vol. 1 (Kazan, 2006), 98; Märjānī, Mustafād, 2: 184-185, 159-160.

48. See biography of Shaykh 'Ali in the history of Tiunter by a supporter of the jadid method Möhämmäd Näjip Tüntäri (1863-1930) in "Mökhämmätnäjip khäzrät yazmasï, Ghasïrlar awazï (Ekho vekov), nos. 1-2 (2003): 51-52; Istoriia Tatarii v dokumentakh i materialakh, 349-350; NART, f. 1, op. 3, d. 226, 1. 1; f. 4, op. 101, d. 16, ll. 1-2; f. 13, op. 1, d. 1003, 1. 32; Malov, "Ocherk," 18, pt. 1 (1872): 403-404 (epic of Elyshevo in Tatar). 
Maris, who found work in Tiunter's leather factories and tailor shops. The shaykh's incredible wealth also allowed him to serve food to the needy every day of the week and hire Kräshen tailors, the main agents of Islamization in Mamadysh, Laishevo, and Kazan districts. Even after his death in 1874, the school of Tiunter continued to attract Kräshen students from the Mamadysh district villages of Elyshevo and Ianyli, who then studied with his successors. ${ }^{49}$ Another former student of Maskara and Möhämmäd Rähim al-Ashiti was Shaykh Ni'mätullah b. Biktimur, who taught in the famous madrasa of Sterlibashevo in Bashkir land in the beginning of the nineteenth century. The madrasa, founded in the 1720 s and also known for introducing Russian into its curriculum before the Russian state required it in 1869 , was a major center of Sufi activity among baptized Chuvash and Kazakhs. Russian sources indicate that the ishans of Sterlibashevo, among them the sons of Ni'mätullah, Haris (d. 1870) and Harras (d. 1871) who liked to perform the $z i k r$ in market places, continued attracting and teaching many baptized Chuvash underground up to the $188 \mathrm{os}$ and 1890 s. $^{50}$

Finally, another graduate from Maskara, Shaykh Ni'mätullah al-Älmäti and his family, played a central role in the apostasy movements of the 1850 and 1860 . The main actors of the petition movement of 1856-1866 were connected to his silsila. The Tatar muezzin 'Abd al-Latif Alkin (1817?-after 1867) from the village of Chechkab, district of Sviiazhsk, the famous bigamist baptized leader Samigulov from Verkhniaia Nikitkina who had written petitions since 1856, and 'Aynullah, a Tatar volost' scribe in Tetiushi district who had composed petitions for the baptized at the Hay Market of Kazan, were all disciples of Shaykh Ni'mätullah al-Älmäti. This Sufi dynasty was of Mishar Tatar descent. Their ancestors came originally from the village of Shonguty, an important market place in the district of Tetiushi district, where Kräshens of thirty villages gathered around Samigulov to collect signatures and money. ${ }^{51}$ Shaykh Ni'mätullah's father, 'Ubäydullah b. Jä'fär (1751-1822/23), taught at Kurmanaevo (Kizläw), a village on the Cheremshan River, and was responsible for initiating a number of disciples to the Mujaddidiyya after studying in Kargala with Wälid b. Möhämmäd al-Ämin, a disciple of Fayd Khan al-Kabuli and also teacher of the poet Utïz Imäni, who was greatly concerned about the Kräshen question. 'Ubäydullah wrote a book in Turkic on Sufism and as a result of his proselytism, the Kräshens of Kurmanaevo, which was also the home of Muslim Tatars and Chuvash, apostatized in the 1850 s. $^{52}$ His older son Ni'mätullah (d. 1852), who studied first with his father in Kurmanaevo, then in Kargala and Baghdad, taught in Al'met'evo and encouraged his students, male and female, to spread literacy among Kräshens. Baptized Tatars of

49. NART, f. 1 , op. 16, d. 661, 1. 12; f. 4, op. 98, d. 34, 1l. 22 ob.-23; Mashanov's report of his trip to Nikiforova in 1881, NART, f. 967, op. 1, d. 8, 1. 12; Otdel rukopisei Kazanskoi nauchnoi biblioteki im. Lobachevskogo, f. 7, ed. khr. 1, 1l. 189/3, 190; Iapei Babai, "O kreshchenykh tatar," no. 18 (15 September 1891): 604; Märjānī, Mustafād, 2: 159-160, 184-185, 203-204.

50. Märjānī, Mustafād, 2: 254-255; NART, f. 93, op. 1, d. 128 v, 11. 27-28; on the history of Sterlibashevo, see Zäki Zäynullin, "Esterlebash Mädräsäse," in Mädräsälärdä kitap kishtäse (Kazan, 1992), 175-185 and Farkhshatov, Narodnoe obrazovanie, 59; Gennadii Makarov, Därwishlärneng sökhbätendä (Bäyetlär häm mönäjätlär) (Kazan, 2011), 23-24.

51. Märjānī, Mustafād, 2: 228; Samigulov in Shonguty, NART, f. 4, op. 134, d. 16, 1. 15 ob.

52. NART, f. 4, op. 72, d. 72, 11. 52-57, 176, 178-178 ob.; Fäkhr ad-Dīn, Āsār, vol. 1, pt. 3, no. 126 (1903): 159-160. 
Chistopol' district, impressed by his ability to interpret people's dreams and healing powers, visited him often and brought him alms, which partly supported his schools in Al'met'evo. Ni'mätullah's proselytism was so successful that, starting in 1828 , the Kräshens of nearby villages refused to let the priests marry them and baptize their children, opposing the police when it intervened. But other neighboring mullahs, who preferred the status quo, called him a "heretic" and denounced him to church authorities. Shaykh Ni'mätullah ignored their slander and as he grew older he chose the shaykh of Perevo (Paraw), 'Abd al-Jäbbar b. Jä 'fär b. 'Abd al-Ghafur (1784-1864) as his successor and made him promise to continue his teaching of $a d a b$, formal rules of the Sufi life, and law among those he called "poor unfortunate Kräshens." 53

Shaykh Ni'mätullah died in 1852 but his sons, 'Ata'ullah, Khäyrullah, and Sön'atullah, in Al' met'evo and his successor, Shaykh 'Abd al-Jäbbar, in Perevo continued to proselytize among Kräshens. In December 1865, before the beginning of the Ramadan, 'Ata'ullah visited Saltyganovo village, Sviiazhsk district, and gathered all Kräshens for prayer. Accompanied by his wife, brothers, two sons, and the mullahs of Berlibash and Burunduk in Sviiazhsk district, he traveled in five or six carriages through Tatar and Kräshen villages, in the districts of Sviiazhsk, Tetiushi, Buinsk, Cheboksary, and Tsivil'sk. The passage of 'Ata'ullah's family in the southern districts of Kazan province coincided with the geographic extension of the apostasy movement, and the migration of a number of Kräshens and Tatars to Turkey and Bukhara. His father's most faithful murid, the Kräshen petitioner of Verkhniaia Nikitkina Samigulov from Chistopol' district, was spotted in Tetiushi district, as well as in Laishevo (Kibiak-Kozi) and Kazan districts (Shepsheik and Bol'shie Sulabashi), which helped extend the apostasy movement to starokreshchenye villages for the first time. ${ }^{54}$

Among Shaykh Ni'mätullah's students was another fascinating ishan, Alkin, from the village of Chechkab in the district of Sviiazhsk, who at the age of thirty, accompanied by his wife, called Tatars and Kräshens to leave Russia for Istanbul. If Tatars did not migrate to Ottoman lands, they would be forcibly baptized. Alkin encouraged Kräshens to embrace Islam by claiming that the Ottoman sultan had already promised to support the Kräshens. Soon the sultan would rid Kazan of the infidels. If Kräshens persevered in their rebellion, the czar-under the pressure of the sultan-caliph-would promulgate a law favorable to their official conversion to Islam. Alkin traveled frequently between Al'met'evo village and the residence of Shaykh 'Abd al-Jäbbar, in Samara Province, who carried the spiritual Sufi lineage (silsila) of Shaykh Ni'mätullah, three years after his death. Malov suspected that the ishan of Samara personally visited Kräshens in the Sviiazhsk and Tetiushi districts. Besides urging Kräshens to apostatize, Alkin also collected money for petitions in Sviiazhsk province. He had a close disciple, an apostate Kräshen of Chechkab village, Shärafi, who accompanied him everywhere and visited 'Ata'ullah. Their travels, usually of

53. Märjānī, Mustafād, 2: 228-229; Fäkhr ad-Dīn, Āsār, vol. 2, pt. 13, no. 384 (1907): 399; NART, f. 1, op. 3, d. 230, 11. 84-85 ob., 87; "Izvlecheniia iz otcheta bakalavra Kazanskoi dukhovnoi akademii N. I. Il'minskogo o poezdke po tatarskim seleniiam (August-September 1849)," in Khristianskoe prosveshchenie, 109; Malov, Prikhody starokreshchenykh i novokreshchenykh tatar v Kazanskoi eparkhii, 49.

54. NART, f. 1, op. 3, d. 228, 1. 72; f. 1, op. 2, d. 2111, 1l. 1-49; f. 1, op. 3, d. 230, 1. 85 ob.; Otdel rukopisei Kazanskoi nauchnoi biblioteki im. Lobachevskogo, f. 7, ed. Khr. 1, 1l. 187-188; RGIA, f. 821, op. 8, ed. Khr. 763, 11. 4,73 . 
three or four months, led them to Buinsk district, where Alkin had connections with Tatar merchants, and even to the district of Saratov. ${ }^{55}$

Alkin's subversive actions began in the mid-1850s, the period between the death of Shaykh Ni'mätullah and the time Samigulov started writing petitions for his native village. Denunciations from an unsympathetic mullah of Tetiushi district claimed that Alkin and his supporters proselytized among the animist Chuvash and Kräshens of Simbirsk and Kazan provinces, performed $z i k r$ outside the mosque, circumcised children, gave new converts Muslim names, visited sacred shrines near the Russian village of Biliarsk, and distributed "holy water" from their spring. ${ }^{56}$

Founded in the tenth century, Biliarsk was the site of the largest city of the former Bolghar kingdom and a symbolic place for both Muslim Tatars and the Kräshen followers of Shaykh Ni'mätullah and his son 'Ata'ullah. Residents of Samigulov's village believed that the commander-in-chief of a virgin princess, who ruled the ancient city of Tubilghitaw nearby, was buried at the Khojas' mountain (Khojalar tawi) in the Tatar cemetery situated north of Biliarsk. An oral tradition claimed that, after Ivan the Terrible took his city, the commander-in-chief was forcibly baptized with his army but refused to give up his faith, attached himself to a famous teacher, and soon became known for his divine insight. Although destroyed by the Mongols in 1236, Biliarsk, like Samigulov's village, also bore the scars of Russian conquest. The new invaders, who found the place empty in the seventeenth century, built a village near the ruins of the ancient town of the Bolghars. Because no other stones could be found nearby, they laid the foundation of their church with stones from the sacred ruins of the mosque and minaret. ${ }^{57}$

When Alkin and his followers, employing Mahdist rhetoric, preached in Kräshen villages, the story of the princess's commander-chief repeated itself. The Russian police had separated sixteen children from their apostate parents in Sluzhilaia Maina, Chistopol' district, and placed them in foster care in Biliarsk to be baptized and raised in the Christian faith. Desperate children fled to rejoin their parents, but tearful mothers brought them back to their Russian foster families. As predicted in $\bar{A} k h \ddot{r}$ Zamān Kitābï and Rabghuzi's Stories of the Prophets, people believed that the

55. Il'minskii, ed., Kazanskaia tsentral'naia, 303-305 (vice-governor Rozov's report); Materialy po istorii Tatarii vtoroi poloviny 19-go veka, 245; Malov, "Nyneshnee religioznoe polozhenie," PO 7 (1866): 118-119; Otdel rukopisei Kazanskoi nauchnoi biblioteki im. Lobachevskogo, f. 7, ed. khr. 1, 1l. 182/1 ob., 183; NART, f. 1, op. 2, d. $2111,1.45$ ob.; f. 1, op. 3, d. 227 , 11. 86-87; f. 1, op. 3, d. 228, 1l. 22, 25-25 ob., 36-36 ob., 54 ob., 50-51 ob., 53-55; and f. 1, op. 3, d. 1823, ll. 74-77; Märjānī, Mustafād, 2: 228-229.

56. Crews, For Prophet and Tsar, 134-140.

57. According to the Kräshen Il'ia Sofiiskii who reported the story, the commander-in-chief's name was Khoja Nasreddin, some sort of holy fool known for his eccentric behavior. It seems unlikely that the Khoja of Tubilghïtaw could be the famous Sufi of Konya whose stories still entertain people in the Turkic world. It was possible that Sofiiskii confused Khoja Nasreddin with the Central Asian Naqshbandi Khoja Nasr ad-Din 'Ubaydullah Ahrar who according to local historiographies was believed to be buried near Tubilghïtaw (although buried in Samarkand). Sofiiskii, however, clearly understood that the famous commander-in-chief was buried near Biliarsk. Sufi Tatar shrine catalogues and Russian geographers, Petr Rychkov (1712-1777) and Sergei Shpilevskii (1833-1907) though, did not mention Khoja Nasreddin, but three other saints: Khoja Asghar, known as Ma'lum Khoja, 'Abdullah Khoja, known as Chubar, and Shaykh Muhammad b. Bayterak Baghanawi. All three lived well before the conquest of Kazan by the Russians. Sofiiskii, "O kiremetiakh kreshchenykh iz derevni Tavel', 73-75; Shpilevskii, Drevnie goroda, 61-64, 349-356; Frank, Islamic Historiography, 76. 
first signs of the eschaton had come. As the last hour approached, said the books, legitimate wives would be "forbidden" (haram) to their husbands. Children of Muslims would be made bastards and prisoners. Thus, Russian police separated couples who had not been married in church and children of apostates were forced to bear their mothers' maiden names. The landscape around Biliarsk, however, held the promise of deliverance. Its ruins, sacred tombs, and holy spring-a legend said that a Muslim saint drank its water and bathed in it-offered strength, blessings, and promises of a brighter future. The saints of the Khojas' mount, as in popular Sufi stories, were not dead, but listened to their petitioners' requests. Soon, thanks to their intercession and blessings, the Mahdi would come and Islamic order would be reestablished. ${ }^{58}$

The Muslim Spiritual Assembly of Orenburg in Ufa, when notified about Alkin's activities, saw nothing wrong or deviant with his teachings and visits to the shrines. Followers of the Mujaddidiyya led an exemplary moral life and conformed to the requirements of the sharia; they performed the silent $z i k r$ in circle, joining hands and invoking the tawba (repentance), the first station of the Sufi path. Because Alkin's whereabouts disturbed communal peace, the Assembly decided to strip Alkin from his position of muezzin, but did not have him prosecuted. In other words, Alkin was free to wander until 1866, when finally, concerned by the size of the apostasy, the Ministry of the Interior intervened and sent him to Siberia. ${ }^{59}$

Thus, the schools of Maskara, Kurmanaevo (Kizläw), Al'met'evo, and Tiunter trained many students and mullahs who did not necessarily carry the silsila, but taught in areas where Kräshens lived. Biktashi, whose book Fäżàil ash-Shühūr molded the children's representations of the afterlife and their religious duties, was a graduate of Maskara. Another student of both Shaykh 'Ubäydullah in Kurmanaevo and 'Abdullah b. Yahya al-Chirtushi in Maskara, Jarullah b. Bikmöhämmäd b. Biktimer (1784-1869), who was the mullah of Satysh near Elyshevo, let Kräshen children study in his madrasa, a very important school built in the eighteenth century to respond to the needs of migrant families. Jarullah impressed his students by his clarity, and Malov suspected that the epic of Elyshevo was the work of his students, although there is no reason to doubt that villagers themselves or their literate children could have composed it themselves. ${ }^{60}$

Every time the petition movement failed, Naqshbandi shaykh activity renewed. Around 1867, the disciple of Shaykh Ni'mätullah, 'Ismätullah b. Ähmäd encouraged the baptized villagers of Azbaba, Sviiazhsk district, to return to Islam after they had been forced by the police to remain Christian. Another ishan from the district of Buinsk, Simbirsk province, visited the village of Nogaevo, Karsun district, and reminded novokreshchenye apostates not to succumb to Russian pressure. Passionately, he insisted on the superiority of Islam over Christianity, claiming that the resurrection of Jesus was a Christian lie and reminding people that the Qur'an was not a man-made creation as missionaries contended it, but the Word of God. Finally, to counteract the effect of Tatar translations of the Bible, a literate Muslim affirmed in

58. NART, f. 1, op. 2, d. 119, 1l. 12, 14-15, 18; Al-Rabghūzī, Stories, vol. 2: 769; Malov, Akhyr zaman kitaby, 3; Ghosman, "Zur khislär," 6; NART, f. 2, op. 2, d. 3454, 1. 3; Shpilevskii, Drevnie goroda, 63.

59. Crews, For Prophet and Tsar, 134-141; NART, f. 1 op. 3, d. 228, 1. 65; f. 1, op. 3, d. 230, 1l. 86-87.

6o. Fäkhr ad-Dīn, Āsār, vol. 2, pt. 14, no. 425 (1908): 488-489. 
Elyshevo and other surrounding villages that Il'minskii's translation of the Gospels spoke of the Central Asian Sufi figure Khoja Baha' ad-Din Naqshband, the eponymous founder of the Naqshbandiyya. ${ }^{61}$

\section{Kinship Networks}

Besides tailors and shaykhs, other powerful agents of Islamization were women of Tatar and Kräshen origin. As demonstrated earlier, there was a positive vision of women in popular oral and written Tatar traditions. In these books, women united with the divine, encouraged and reproached the prophets in their roles as mothers, became dervishes, performed miracles, set proper rules for behavior, and even took up arms to defend the faith. The wife of one of the 1867 representatives of Saltyganovo, Sviiazhsk district, embodied this attitude, begging her imprisoned husband to stay firm in his faith. "Please do not cover us with shame," she wrote in hasty Arabic script on a small piece of paper, "If you give up, everyone will say that you are Russian and spit on you. If you choose to be Russian, then what is the point of living on this earth? If they send you to Siberia, I will go with you. Say that you are married." Just as the wives of the nineteenth-century Decembrists left for Siberia with their husbands, the wives of apostates were fully committed to their cause. Without their active support, the apostasy movement was likely to fail. Family, sacred, and educational networks led by women were essential to the spread and consolidation of Islam on the frontier. ${ }^{62}$

\section{Tatar Women as Holders and Transmitters of Islamic Knowledge}

Contrary to what Russian missionaries often implied, peasant women did not have a shallower, more superstitious understanding of their faith. Because missionaries had a bookish, rationalized idea of Islam, they tended to oppose "low" and "high" Islam. "Low" Islam referred to popular Sufi books in Tatar and superstitious beliefs in amulets, charms, and evil spirits. "High" Islam was the Islam taught in the madrasas of the Middle East or Central Asia, in Arabic or Persian. In their approach to women, missionaries often associated the female worldview with "low" Islam. However, contrary to what missionaries believed, the borders between high and popular Islam were often blurred. Learned men in Algeria, Anatolia, India, or the Balkans used folk tales as media for popular instruction of Islam, since Arabic was not accessible to the average peasant. ${ }^{63}$ Women did not defend or explain their faith differently. In discussing Islam, they referred to images that were drawn from Sufi books and tales that echoed their pre-Islamic belief in spirits. After reading a passage of Bāqürghān Kitābï (The Book of Baqïrghan, an anthology of Sufi poetry) about the necessity of saying Bismillah before meals, a Tatar woman from Artyk, in Mamadysh district, explained that if one failed to say Bismillah, the päri (evil spirits) would steal the food. If a woman left her child in the field without saying Bismillah, the päri would likewise steal the child and replace

61. NART, f. 1, op. 3, d. 228, 1. 130; Otdel rukopisei Kazanskoi nauchnoi biblioteki im. Lobachevskogo, f. 7, ed. khr. 1, 1. 188; Malov, Missionerstvo sredi mukhammedan, 417; idem, “Ocherk," 18, pt. 1 (1872): 69.

62. NART, f. 1, op. 3, d. 228, 1l. 111-112.

63. Matveev, "Dva dnia," no. 1 (1902): 21-24; and no. 7 (1902): 304-307; Schimmel, As through a Veil, 137; Fanny Colonna, Savants paysans: Éléments d’histoire sociale sur l’Algérie rurale (Algiers, 1987). 
him with one of their monstrous offspring. The päri among the Tatars, Kräshens, and other peoples of the Middle Volga were known for living in abandoned houses or baths. For this woman, any action was incomplete without praising God, and such incomplete actions attracted the päri who chose to live in empty places. Tatar tales, as well, contained numerous stories in which the hero got rid of the päri by saying Bismillah. ${ }^{64}$ For the Orthodox missionary who recorded the woman's comments, this was proof that Tatar females did not know their religion and that Islam was no more than a sophisticated written form of paganism or polytheism. But in fact, this woman gave a clear metaphoric explanation of the text she read. Like the Sufis in the Middle Volga, India, and Anatolia who spread the word by using images from daily life, this woman from Artyk resorted to imagery taken directly from Tatar folk culture. As in the Qur'an, she believed that the spirits could be domesticated rather than annihilated, and served a unique God. Even students of the madrasas used the same device to demonstrate the power of Muslim prayers against evil spirits. This kind of discourse had a powerful impact on the non-Islamized starokreshchenye in Mamadysh district, and on other peoples like the Maris in Ufa province or the Chuvash and Udmurt in Kazan province. It often constituted the first step in their Islamization. ${ }^{65}$

Female schooling was the next important step in establishing popular Sufi knowledge. In Näșịhät aș-Șālihīn, learning about the Islamic faith was a religious obligation for both men and women. According to the turkologist, physician, and former rector of the University of Kazan, Karl Fuks (1776-1846), it was rare to find a girl who did not know how to read and write. Girls studied with an abistay, a female teacher, until the age of ten or received private lessons. Parents did not hesitate to send their daughters to a nearby village if there was no school in their village, or if a neighboring abïstay was better known for her ability to teach. Thus, a coachman from the Kräshen village of Elyshevo sent his daughter to the Tatar abïstay of Balandysh (a village situated at two versts from Elyshevo). ${ }^{66}$

Very often small children of both sexes studied side by side before the mullah took over the boys' education. The elementary program for girls and boys was not fundamentally different; they read and recited the same Sufi poetry that they had heard in their early childhood when women gathered on Fridays, or when they cooked meals. It was a common belief among peasants that girls had no need for higher learning; writing was also considered superfluous. However, in the 1840s, Fuks met an abïstay who taught her students to write popular songs. Biographies of early jadid women show that mullahs' and also merchants' daughters had access to higher learning. Mullahs' daughters, like the poetess 'Alimätelbänat Biktimeriya (1876-1906), studied under their father, and merchants' daughters took private lessons. The poetess 'Azizä Sämitova (1862-1929), a merchant's daughter, kept a diary, learned Arabic and Persian, and read classical oriental poetry. Fuks again noticed that mullahs' children, boys and girls, could read the Qur'an and understand as much as their father. Since a

64. Il'minskii, ed., Kazanskaia tsentral'naia, 57; Bāqürghān kitäbï, 13; Maksimov, "Ostatki drevnikh," no. 20 (15 October 1876): 610-614; Akhmet'ianov, Obshchaia leksika, 40; A. N. Nasyrov and P. A. Poliakov, Skazki Kazanskikh tatar i sopostavlenie ikh so skazkami drugikh narodov (Kazan, 1900), 91.

65. Koblov, "Mifologiia Kazanskikh tatar," 407.

66. Näșihhät aș-sālihīn, 29; Karl Fuks, Kazanskie tatary v statisticheskom i etnograficheskom otnosheniiakh (Kazan, [1844] 1991), 49; Malov, “Ocherk," 17, pt. 3 (1871): 407. 
mullah's daughters were likely to marry a mullah and become an abïstay, their thirst for knowledge was encouraged. ${ }^{67}$

According to statistics of the Ministry of State Domains and the Spiritual Assembly, almost as many girls as boys studied in Qur'anic schools. In 1860, in Kazan province, 682 mosques had established 483 Qur'anic schools, which were training 16,326 boys and 13,946 girls. Police statistics in 1875-1876 painted an even better picture of the extent of schooling among girls by giving the number of women involved in their teaching. They indicated that there was no large gap between the number of abistays and mullahs, abistays being either the wife of a mullah or muezzin, or simply a dedicated literate woman. In Laishevo district, seventy-eight mullahs and sixty abïstays taught 2,021 boys and 1,063 girls; but Mamadysh district was even more impressive, with 136 mullahs and 119 abïstays teaching 3,808 boys and 3,080 girls. Missionaries, who worried about the role women played in the spread of Islam, often pointed out that the number of schools for Tatar girls was much higher than for Russian girls. The 1902 official statistics of the Viatka province confirmed their worries; while there was only one school for every 50.2 Russian girls, Tatars had one for every 19.9 Muslim girls. Worse, these statistics underestimated the number of Muslim schools because they did not include clandestine schools among Kräshen apostates or Islamized Chuvash, Udmurts, or Maris; private courses for girls that could not be inspected; or the schools attached to Tatar factories. ${ }^{68}$

In discussions reported by missionaries, women in an average peasant family often appeared to be more knowledgeable about Islam than their husbands, probably because they had the advantage of having had the same teacher for a longer time during the year. Their education was not interrupted by seasonal work. Among Islamized Kräshen women, many could read even when their husbands were illiterate. The Kräshen women in the village of Verkhnie Mashliaki in Mamadysh district strictly observed Islamic rites, despite their husbands' indifference. ${ }^{69}$

The prolonged absence of male traders from their community forced women (both literate and nonliterate) to assume an important role in the transmission of Islamic knowledge, in addition to being managerial, communal, and economic heads of the family. In the village of Elyshevo, an old, illiterate, blind female of Kräshen origin imparted the basics of the Islamic faith to the local children. Mothers taught their children to sing and read Sufi books before going to the maktab. A Tatar craftsman of peasant origin from Kargala, near Orenburg, wrote in his memoirs that his mother, and not his father who was busy trading, made him recite Sharä'it al-İmān when he was five years old. His mother also made him copy the alphabet. At the traditional maktab, writing was taught long after reading, sometimes after three or four years of schooling. Partly thanks to his mother, the boy was able to compose and sell talismans containing Qur'anic verses. Women's involvement in their children's education

67. Fuks, Kazanskie tatary, 38, 132; Ömet yoldizlarï: XIX yöz akhïrï häm XX yöz bashï tatar khatïn-qïz yazuchïlarï äsärläre (Kazan, 1988), 18, 40.

68. RGIA, f. 383 , op. 24, ed. khr. 37141, 1l. 1, 2 ob.; RGIA, f. 821, op. 8, ed. khr. 1093, 1. 1; and NART, f. 1, op. 3, d. 3538, 1l. 14-15, 33-35; M. Reshetnikov, "O nuzhdakh pravoslavnoi missii sredi magometan Viatskoi gubernii," Viatskie eparkhial'nye vedomosti no. 20 (16 October 1905): 1100.

69. Mashanov, “Zametka," no. 2 (15 January 1875): 47. 
was such that in non-Muslim areas where Islamized mothers had the choice between Russian missionary schools and clandestine maktabs, they had enough authority to keep their husband from giving their children to Russian missionaries. ${ }^{70}$

Finally, women's role was not confined to the house. Some were true missionaries of Islam and proselytized outside their village limits. A Tatar woman from Meteski visited the Kräshen houses of Ianasal village regularly in the 1870 s and read the Qur'an to the village residents. Two Tatar women from Alichtarkhan village taught starokreshchenye in Aziak village, Kazan district: twenty boys and twenty-three girls attended their lessons. The learned Tatar women of Artyk were also known for visiting the Kräshen village of Nikiforova, Mamadysh district. ${ }^{71}$ Missionary accounts claimed that Tatar women promised paradise to Kräshens who repeated the shahada several times every day. Nothing else could be asked of them because they were believed to be simple-minded. (Among Tatars, Kräshens had the reputation of being illiterate and ignorant of the Russian faith.) This type of proselytism reflected the experience of $z i k r$, the recollection of God, used by many Sufi orders. It also reflected the idea dear to Sufi mystics that knowledge from God could be immediate, and not acquired through books and formal education. ${ }^{72}$ Furthermore, women in Mamadysh and Laishevo districts with small businesses had contacts with other women of different faith and proselytized as well. Some sold sugar, tea, or candies in local markets, which offered vast opportunities of communication. Tatar women of Satysh made and sold beautiful dishes and the entire female population of Nyrty embroidered towels, which served as decorative objects, alms for the dead, gifts for the saints, and awards for the victors in various Kräshen or Muslim sport competitions at agrarian celebrations. Frequent economic exchanges in the villages of Vladimirova or Staraia Ikshurma, Mamadysh district, between Kräshens and Tatars of both sexes, favored the spread of Islamic conceptions of life among starokreshchenye who were attached to their animistic beliefs. ${ }^{73}$

Women who kept sacred shrines enjoyed great authority in their village and beyond. In Chally (Täbärde Challïsï), the female heirs of Idris Khalifa (1645-1710), student of the Naqshbandi Shaykh Hidayatullah of Turkestan, took care of his sacred shrine. After his death, the saint's female descendants inherited his healing powersKräshens told missionaries that miraculous berries grew under the shaykh's house, and that the shaykh died when one of his patients broke his pledge of silence and revealed their existence. The shaykh's female descendants continued attracting many Kräshens who brought them offerings consisting of sheep, goose, chickens, butter, eggs, and clothing until the beginning of the twentieth century, even after Il'minskii

70. Malov, “Ocherk," 17, pt. 3 (1871): 243; Iapei Babai, “O kreshchenykh tatarakh," no. 18 (1891): 563-564; "Ghabdräkhim Ghabdrakhman ughlï, 11. 1, 16; Il'minskii, ed., Kazanskaia tsentral'naia, 81.

71. NART, f. 1, op. 3, d. 2812, 1.78 ob.; f. 1, op. 3, d. 3272, 1l. 11 ob., 41; letter of Kräshen teacher of Aziak village in Tatar, NART, f. 968, op. 1, d. 175, 1l. 1-2 ob.; Malov, Missionerstvo sredi mukhammedan, 237.

72. Ibn al-Arabi connected the bipartite profession of faith with the Divine breathing (Schimmel, As through a Veil, 59, 139); Il'minskii, ed., Kazanskaia tsentral'naia, 39.

73. Il'minskii, ed., Kazanskaia tsentral'naia, 146; Firdäüs Gharipova, Awïlar häm qalalar tarihïnnan, vol. 2 (Kazan, 2003), 297; Urazmanova and Cheshko, eds., Tatary, 190, 206; David L. Ransel, "Infant-Care Cultures in the Russian Empire," in Russia's Women: Accommodation, Resistance, Transformation, ed. Barbara Evans Clements, Barbara Alpern Engel, and Christine D. Worobec (Berkeley, 1991), 124. 
introduced Christian schooling in their milieu. These women saints visited Tatar and Kräshen houses outside Chally, read them the Qur'an, and spread the word. Thus in the 1870 , the orientalist Mikhail Mashanov personally spotted one of them at eight versts from Chally, in the Kräshen village of Tomasov-Pochinok, a village in Mamadysh district still strongly attached to its ancestral beliefs but already exposed to Islamic literacy (three Kräshens could read and write in Arabic script and used their skills for trade). To Mashanov, the woman appeared quite witty and dangerous. ${ }^{74}$

\section{Mechanisms of Transmission on the Frontier}

Exogamy The importance of women in the carrying of Islamic knowledge inside the family and in the community appears even greater in the light of the apostasy movements. Although endogamy was favored in the Middle East and Turkey, Kräshens like Tatars and Bosnian Muslims who lived in a Christian-dominated environment, practiced exogamy. ${ }^{75}$ The bride rarely remained in her home village, and so constituted an element of exchange between two communities. This practice had two possible consequences: either it strengthened the integrity of the Kräshen community as a separate Tatar Christian group or, in the case of families already somewhat inclined to Islam, it contributed to further internalization of Islam. If a community were small and had limited choice of brides in surrounding villages, this deficiency could lead its members to join the apostasy movement. If their petition were approved, they could marry their children officially to Muslims, and if not, they could still have access to underground kinship networks that connected apostate villages with one another. When the neighboring mullah refused to be implicated in the baptized Tatars' lives and the weather permitted it, exogamy allowed villages to instead call their wives' mullahs secretly to their house for marriages and funerals. ${ }^{76}$

Parents in Kräshen families had the right to choose their offspring's spouse. Theoretically, both father and mother had equal responsibility for this choice, though, in practice, the mother usually had the last word. The parents considered the potential spouse's village of origin, the family, and the degree of Islamization of the village that would receive the bride. On this point, the prospective groom's village often proved to be more important than his family. In 1866, the underground mullah Ivanov in Elyshevo thought about marrying one of his daughters to one of the sons of Arkhipov of Savrushi village. This family had not definitively accepted Islam and showed signs of being influenced by the proselytism of Orthodox missionaries. Meanwhile, Ivanov did not cancel the plans for the wedding until the village of Savrushi decided to remain officially Christian. ${ }^{77}$

74. Odigitrievskii, "Kreshchenye tatary," no. 3 (Feb. 1894): 110-111; Mashanov, "Zametka," IKE, no. 4 (15 Feb. 1875): 113-115; Mashanov, Religiozno-nravstvennoe sostoianie, 57. The village of Chally in Laishevo district was also called Kazaklary or Kazinskie Chelny in prerevolutionary sources; present-day Koziakovo-Chelny. "Otchet bakalavra Kazanskoi dukhovnoi akademii N. I. II'minskogo (August-September 1848)," in Khristianskoe prosveshchenie, 85.

75. Carol Delaney, The Seed and the Soil: Gender and Cosmology in Turkish Village Society (Berkeley, 1991), 100; Tone Bringa, Being Muslim the Bosnian Way: Identity and Community in a Central Bosnian Village (Princeton, NJ, 1995), 143.

76. NART, f. 2 , op. 2 , d. 4284, 1l. 13-15; f. 4, op. 94, d. 22, 1. 57 ob.

77. Malov, “Ocherk," 18, pt. 1 (1872): 126; Il'minskii, ed., Kazanskaia tsentral'naia, 132. 
At the same time, in Nikiforova, a village that became strongly attached to Christianity in the 1870 , lived a well-to-do Islamized Kräshen, named Gavriil, whose father, Semen, was outwardly Christian, but continued to observe "pagan" (animist) rituals. Gavriil's mother, on the contrary, favored the Tatars. When the time came to marry their son Gavriil, Semen proposed a young lady of Nikiforova, but the mother opposed this because she felt that the village was too Christian. She ultimately convinced her husband to choose a girl from Elyshevo, where the families were more Islamized. The children born of this marriage were raised by their illiterate mother in the Islamic faith with the agreement of their father, even though he had attended the Russian parish schools. The mullah of Satysh village taught the boys, and an Islamized Kräshen of Staraia Ishkurma taught the daughter. Later, one of the boys was married to a Kräshen of Staraia Ishkurma who had studied with Biksutana (Evfimiia Ivanova), a Kräshen abïstay of Tri Sosny, and with the abïstay of Savrushi village. Thanks to these two women, the young bride was able to read and recite her prayers. ${ }^{78}$

Semen's family was Islamized in only two or three generations. Similar cases could be observed in the village of Verkhnie Mashliaki, Mamadysh district, where husbands showed less inclination to Islam but their wives, who came from Tri Sosny (where Biksutana taught), faithfully observed Islamic rituals. As the persons responsible for the physical and spiritual well-being of their children, mothers had to consider prospective daughters-in-law very carefully. Wanting to approach the Qur'anic ideal as closely as possible, they chose a daughter-in-law whose Muslim culture was superior to their own. Often, an illiterate mother-in-law would choose a daughter-in-law trained in the Muslim sciences. ${ }^{79}$

Summer jïÿ̈ festivals allowed Muslim Tatars to find the right spouse for their children. A greater degree of gender integration in the games permitted the young to get acquainted, which greatly upset conservative mullahs. Although Russian witnesses emphasized that men and women did not mix in the games (boys simply exhibited their physical strengths while girls in their best attire watched them from afar), imams complained that girls and boys hurried to the woods afterward and sang, danced, held hands, and kissed without elders' supervision. If matchmakers came from neighboring villages, the girls hurried to meet them and expressed their wishes or, worse, gave their consent without consulting their parents. ${ }^{80}$

To help their children find suitable mates, the Islamized Kräshens constituted their own jïyïn. By converting to Christianity, the Kräshens' ancestors had excluded themselves from the Muslim jïyin traditional kinship networks. This did not keep them from participating in the traditional Muslim jïyins and their games, but they could not marry their daughters to Muslim boys. On 18 June 1865, the Kräshen villagers of Elyshevo celebrated the jïyin along with their Muslim neighbors. According to one witness, the Elyshevites had begun to celebrate the jïÿ̈ fifty years earlier, which corresponded approximately to the apogee of the development of textile and leather industries in the Mamadysh, Laishevo, and Malmyzh districts at the end of

78. Il'minskii, ed., Kazanskaia tsentral'naia, 70-72.

79. Mashanov, “Zametka," IKE, no. 2 (15 Feb. 1875): 47.

8o. Jiyūn qüșșasï, 82-92; Fuks, Kazanskie tatary, 47, 49, and Rittikh, Materialy dlia etnografii Rossii, $35-36$. 
the eighteenth century. To find brides, though, Elyshevites had to turn to another kinship network of purely Kräshen lineage, which the jïyïn of Kibiak-Kozi, another apostate village of starokreshchenye, provided. ${ }^{81}$

In the 1870s, the jïyin of Kibiak-Kozi in Laishevo district involved a very large territory of apostate villages across several parishes and even districts: Elyshevo, Kanissar and Sabanchino in Nyr'ia parish, Verkhnie Otary in Novoe Churilino parish in Mamadysh district, Kibech' (Kibäsh) in the parish village of Verkhniaia Serda, Ianasal in the parish of Venetino in Laishevo district, and Khaivani and Nurma in Kazan district. This list was far from being complete. Verkhnie Otary village, in turn, had marital connections with the villages of Shemordan in Nyr'ia parish, Verkhniaia Oshtorma in Oshtorma parish, and Ianyli in Chura parish, Mamadysh district—all connected by textile and leather industries. Marital links in the jïyïn of Kibiak-Kozi, Elyshevo, and Verkhnie Otary corresponded to trade routes. To reach the market of Arsk, the inhabitants of Kibiak-Kozi had to cross Ianasal. Tailors who dominated the work force in this area used to sew in villages such as Nurma village in Kazan district. They also worked in the fourteen lambskin and sheepskin factories of Shemordan, which made hats and sleeves and belonged to Kasimov Tatar merchants. ${ }^{82}$

Besides being located on the same Arsk trade route, many of these villages shared a common Udmurt history, indicating that Islamized Udmurts may have played a role in their Islamization. The most literate and committed villagers to the apostate cause in Elyshevo were of Udmurt lineage; and local traditions reported that Udmurts originally founded the ethnically and religiously mixed villages of Ianyli, Porshur, Chura, and Oshtorma, which were the sites of intense competition between Islam and Orthodoxy well into the twentieth century. Although Tatar-speaking, the villagers shared kinship terms with their Udmurt neighbors. In addition, the famous Utyamïshev Tatar merchant family of Maskara known for supporting education in Udmurt milieu connected some of these villages together: 'Abdullah Utyamïshev had opened a potassium factory in Kibiak-Kozi in 1795 and his descendants supported a madrasa in Bol'shaia Nurma in the 1870 s. $^{83}$

Apostate kinship networks were far from being fixed. Their mapping changed overtime depending on the villages' decision to remain officially Islamic. A wedding could be called off if a village had decided to rejoin the church. When Il'minskii's school took root in many Kräshen villages, previous kinship networks ceased to exist. After Verkhniaia Serda village opted for Christianity and Kibiak-Kozi for Islam, there was no more exchange of brides between the two communities. Most interestingly, after Elyshevo was officially recognized as Muslim and during the Soviet period, the apostate jüyin network remained active. The inhabitants of Elyshevo married within

81. Il'minskii, ed., Kazanskaia tsentral'naia, 152-54.

82. Yakhya Abdullin, interview by author, 30 May 2000, Kazan. His grandfather, Biktimer, apostatized in 1864 at the age of eighteen; NART, f. 1, op. 3, d. 3538, 1l. 16-16 ob.; f. 1, op. 3, d. 1818, 1. 4; f. 1, op. 3, d. 3538 , 1l. 16-16 ob.; f. 1, op. 3, d. 12201, l. 6 ob.; f. 4, op. 98, d. 9, 1l. 44 ob.-45, 222; f. 4, op. 98, d. 23, 1. 156; f. 4, op. 101, d. 11, 1l. 17, 28; and f. 4, op. 138, d. 12, 1. 1 ob.; on bride prices, NART, f. 2, op. 4, d. 574, 1. 1 ob.

83. Iskhakov, Etnograficheskie gruppy tatar, 124; Baiazitova, Govory Tatar-Kriashen, 18, 28-29; Khasanov, Formirovanie, 50, 94; Il'dus Zagidullin, "Makhallia v promyshlennykh poseleniiakh v evropeiskoi chasti Rossii i Sibiri (XIX-nachalo XX v.)," in Tatarskie musul'manskie prikhody v Rossiiskoi imperii: Materialy Vserossiiskoi nauchno-prakticheskoi konferentsii g. Kazan', 27-28 sentiabria 2005 g. (Kazan, 2006), 70. 
their former "apostate" network and did not wed girls or boys to neighboring Tatar villagers, who regarded them as different Muslims still scarred by their "forced baptism in the Mesha River." The Elyshevites themselves like to emphasize their differences, claiming that elements of paganism such as the custom of drinking beer have survived in their midst. ${ }^{84}$

Not unlike the sacred places of the Middle Volga, agrarian festivals constituted open spaces of interaction between different ethnic groups. Russians, Kräshens, Udmurts, and Maris gathered to watch the games. If festivals did not automatically lead to Islamization, they did help generate and consolidate communal ties between separate apostate and Tatar communities. During that special time, married women returned to their native villages and met with their families while newly wedded brides departed from their native villages to their husbands' villages. Kräshen and Muslim Tatars of different areas met and exchanged news about the progress of the apostasies. In 1890, such festivities marked a new wave of apostasies in the villages of Karaduvan, Aziak, and Apazovo in Kazan district. ${ }^{85}$

Various activities helped to strengthen not only the Muslim faith of those who were already officially Muslim, but also of those who were inclined to Islam yet not fully committed to change their religious affiliation. Merchants sold their wares, and blind bards sang epics (bäyet). Other Tatars sold Sufi books such as Bädäwām Kitābi or Qissṣa-yi Yüsuf. All marriage negotiations strengthened the links between deported apostates and the rest of the apostate community in an unexpected way. Thanks to the jïyins, exiled families could marry their daughters within their original community, making the consequences of their exile obsolete, or they could wed their sons to apostates of other villages, which considerably broadened the apostate network.

Fathers, while away on seasonal work, often discussed possible marital alliances with coworkers from other villages. Mixed Kräshen-Tatar monogamous and sometimes polygamous marriages rarely occurred, but did happen. If caught, husbands declared to the police that their "wives" were domestic servants. Most often such mixed marriages happened among exiled apostates and novokreshchenye living as a minority in Tatar villages, especially in Sviiazhsk and Spassk districts and, to a lesser degree, among the starokreshchenye villages of Mamadysh and Laishevo districts. As a general rule, a "baptized girl" married a Muslim Tatar and left her parents' home. Such marital alliance was possible according to the Qur'an (5:5); however, Tatar theologians of the eighteenth century and first half of the nineteenth century wondered whether Eastern Orthodoxy's iconodulism did not prevent its members from being part of the "People of the Book." If from a Tatar theological position, there was no consensus on the validity of such marriages, from the Russian state's point of view there was no doubt that these marriages were invalid. When caught, baptized parents simply said that their daughter had eloped..$^{86}$

84. NART, f. 13, op. 1, d. 1003; Nikolai Petrov (from Verkhniaia Serda), interview by author, April 2008, National Archive of the Republic of Tatarstan, Kazan; interviews by author of elderly people in Elyshevo, May 2008.

85. Iapei Babai, "O Kreshchenykh tatarakh," no. 19 (1 October 1891): 600.

86. Interviews by author of elderly people, May 2008, in Ianyli; NART, f. 1, op. 3, d. 2812, 11. 49 ob.-50, 54; f. 2, op. 1, d. 347 , 11. 8, 10, 13; f. 4, op. 72, d. 12, 11. 325-335; and f. 4, op. 133, d. 7, 1. 30 ob.; Kemper, Sufis und Gelehrte, 286-290. 
Beside Muslim Tatar festivals, Christian festivals also helped consolidate kinship and neighborly ties between baptized communities of different religious inclinations. A villager from Elyshevo claimed that fifty years before their first apostasy in 1866, Elyshevites did not celebrate Muslim festivals. There is indeed oral and written evidence that apostates in this area celebrated Christian festivals, but that they, far from serving the cause of Orthodoxy, worked more toward the consolidation of Islam. When the apostates of Kibiak-Kozi learned of Elyshevo's official return to Orthodoxy, they refused to visit their relatives on the Kazan Mother of God icon's feast day (22 October) as they used to do in the past. Orthodox devotional pamphlets claimed that the icon, found by a nine-year-old girl in the Kazan kremlin after Ivan IV conquered the city, had protected the faithful from the false teachings of the Prophet Muhammad; ironically, apostates of Kibiak-Kozi used the icon's feast day as a way to rebuke those who did not remain faithful to the Prophet. ${ }^{87}$

Another festival, little known to the Kazan Tatars of the nineteenth centuryRussian missionaries and ethnographers referred to this festival only in the Kräshen context-but very popular among Kräshens, Udmurts, Chuvash, Maris, and Mishar Tatars, also served to consolidate kinship and religious ties in Mamadysh, Kazan, and Laishevo districts. Unlike their Kazan Tatar neighbors, Kräshens of Elyshevo, Ianyli, Apazovo, and Bol'shie Savrushi celebrated Nardughan, a pre-Christian festival that fell between Christmas and the Epiphany on the Christian calendar. Called the devil's wedding (shäytan tuyï) by its critics, Nardughan welcomed the new year and helped the young from various Kräshen villages to get acquainted. It consisted of various games deemed unorthodox by both priests and mullahs. First, boys borrowed their mothers' summer clothes and, dressed up like girls, visited houses to approach girls, especially those who came from other villages as guests. Next, boys and girls gathered in a place rented for the occasion to sing songs, play games, and read the future with little adult supervision. Because boys and girls rarely mixed in Kräshen villages, except for special religious celebrations, and girls stayed indoors during the cold months, the Nardughan festival, which temporarily relaxed the established gendered hierarchy, gave them the unique opportunity to get to know each other. Even after joining Islam officially in 1907, Elyshevo continued celebrating Nardughan well into the 1950s - many of the brides of Elyshevo still originate from proximate prerevolutionary "apostate" villages_-while surrounding Tatar villages celebrated the "Russian" New Year more soberly by baking special treats (Kazan Tatars had their New Year celebration, called Näwrüz, in March). Conversely, in areas where Il'minskii's school took root, Nardughan served to strengthen bonds between Orthodox Christians and communities still imbedded in their animistic culture. ${ }^{88}$

87. Malov, "Ocherk," 18, pt. 1 (1872): 389; Vera Shevzov, Russian Orthodoxy on the Eve of Revolution (Oxford, 2004), 245.

88. Interviews by author of elderly people in Elyshevo and Ianyli, May 2008; R. Daulei, Sviatki $u$ kreshchenykh tatar Mamadyshskogo i Laishevskogo uezdov Kazanskoi gubernii (Kazan, 1903), 1-8; Diakon Iakov Emel'ianov, "Nardugan," in Stikhi na kreshcheno-tatarskom iazyke (Kazan, 1879), 17-20; Urazmanova, Obriady i prazdniki tatar, 99-108; idem, "Osobennosti traditsionnykh narodnykh prazdnikov tatar Srednego Povolzh'ia (K voprosu etnicheskogo raionirovanna kul'tury)," Etnokul'turnoe raionirovanie tatar Srednego Povolzh'ia (Kazan, 1991), 91-93; Iskhakova-Vamba, Tatarskoe narodnoe, 16-20; Flera Bayazitova, Tatar khalqünïng bäyräm häm könküresh yolalarï (Kazan, 1995), 57-64. 
The Emergence of an Underground Female Class of Teachers Exogamy facilitated the emergence of a new class of pedagogues who were exclusively Kräshen and, for the most part, women. The education of children occurred in two stages. In the first stage, mothers or grandmothers taught children the basic Muslim prayers at home. In the second, better educated women opened underground maktabs. In 1871, the police learned about the existence of two such schools in the villages of Ianasal, Laishevo district, and Tokhtamyshevo, Mamadysh district. ${ }^{89}$

Information about these female teachers is scarce. However, one of them stands out: Biksutana or Evfimiia Ivanova. A sixty-year-old abïstay, she was originally from Elyshevo and had married a Kräshen of Tri Sosny, Mamadysh district. Her grandfather, a rich baptized Tatar, had founded numerous mosques in the area and notably that of Savrushi. In August 1864, she was teaching two boys and fifteen girls for free in her husband's village, and accepted only occasional presents for her labor from her students' parents. Biksutana herself had studied with the abistay of Ziuri village in the Mamadysh district, and after educating her eldest daughter, she sent her to the abïstay of Savrushi village to continue her studies. Later, this daughter married a Kräshen of Staraia Ikshurma, where she taught the children of her village. In this way, Biksutana established a dynasty of remarkable female pedagogues. ${ }^{90}$

The Tatar practice of exogamy encouraged the expansion of Islam over an ever greater territory. Biksutana understood the role she played in the spreading of her faith. She explained to Timofeev that according to the Qur'an, everyone would become Muslim before the end of the world. The mass conversions of the Kräshen confirmed her apocalyptic hopes. Biksutana herself was deeply religious. She regularly visited the mosque in Savrushi, especially during Ramadan. Her life was an example of Muslim piety to the Kräshens in Tri Sosny village. Her reputation as a teacher of Islam was such that Kräshens called her Biksultan (a real queen), a title of respect and affection. ${ }^{91}$

Biksutana also understood the threat that Il'minskii's schooling posed to the spread of Islam among the Kräshens. Il'minskii had introduced a phonetic method of reading Tatar texts in the Cyrillic alphabet that competed dangerously with the traditional method of imparting literacy in the maktabs. Thanks to this new approach, Il'minskii's students were able to read unfamiliar Tatar texts more quickly, while students from the maktabs first named each letter, without sounding them out. When Il'minskii opened the school for Christian Tatars in Kazan in the fall of 1864, Biksutana spread rumors against the school, partly because some of her students had been influenced by Timofeev's teaching. Biksutana's activism was such that the state and the church made an example of her. In 1864, the vice-governor Rozov confiscated the Qur'an that a Tatar from Tatarskie Savrushi had given her, and when she died, the local priest buried her in the Christian cemetery. ${ }^{92}$

Female teachers such as Biksutana helped their covillagers understand the importance of establishing permanent schools. In Elyshevo, for example, a woman from a

89. NART, f. 1, op. 3, d. $2812,11.78-78$ ob., 82 ob., 83 ob., 85 .

90. Il'minskii, Kazanskaia tsentral'naia, 74-75.

91. Istoriko-statisticheskoe opisanie tserkvei i prikhodov Kazanskoi eparkhii, 34.

92. Il'minskii, ed., Kazanskaia tsentral'naia, 79, 88; Istoriko-statisticheskoe opisanie tserkvei i prikhodov Kazanskoi eparkhii, 34 . 
Kräshen village Tiamti, Laishevo district, taught children from 1860 to 1864 . She was replaced by the itinerant shakird Muhi ad-Din; and when he left Elyshevo, another woman, Matrena Ivanova, took his place as the local educator. To avoid unnecessary attention children came to their teachers at various times alone or in groups of two and used the säke, large seats along the walls that could serve as a place to eat or relax, as desks. If surprised by the priest or the police, they said that they came as guests. Significantly, these underground schools attracted girls from both neighboring villages and nonapostate parents, which helped speed up the Islamization of a given village or area. ${ }^{93}$

In general, when missionaries looked for female students for their newly opened schools, they encountered greater resistance than when they tried to educate boys. Boys needed to learn Russian to transact business, but girls did not. A girl was supposed to stay in the village unit, her parents' or her husband's, and be in charge of her children's religious education. Islam sufficed. Besides, sewing and other feminine crafts were being taught in girls' maktabs. In Ianasal, parents, under the influence of apostate neighbors, took their daughters away from the Christian school, but boys continued to attend as the knowledge of Russian could be handy while trading outside the village. ${ }^{94}$

\section{Women's Role in the Apostasy Movement}

The place that women occupied during marriage negotiations helped to facilitate the flow of rumors from one village to another. The leaders of apostasies were often related by marriage; father-in-law and son-in-law stood side by side. Rumors spread by women were crucial before, during, and after the rebellion. Avdot'ia Fedorova in the village of Kibiak-Kozi, Laishevo district, was arrested because of her involvement in spreading rumors about a law supposedly allowing Kräshens to become officially Muslim. Women also gathered information about the development of the apostasies in the neighboring villages through family ties (this could involve several villages). One woman in Elyshevo brought fresh news about the apostasy movement from her parents, who lived in Kibiak-Kozi. While visiting relatives in Elyshevo, another woman of Savrushi learned about the arrival of an Orthodox missionary and she immediately reported the news to her fellow villagers. This information was carefully debated in homes and during elders' meetings. Finally, to secure the support of all women in the village-there is evidence that some in Elyshevo still held firm to their icons-apostate women spread rumors that Russians would force them to wear Russian clothes-the sarafan (a sleeveless dress) and the kokoshnik (a headdress with a crest and a decorated hard base) - if they did not sign the petition. ${ }^{95}$

After the arrival of the Russian authorities, women came forward in villages where the decision to apostatize was not yet unanimous, swearing to the investigators that

93. RGIA, f. 821 , op. 8, ed. khr. 763, 1. 289 ob.; NART, f. 1, op. 3, d. 3272, 1. 22 ob.; Il'minskii, ed., Kazanskaia tsentral'naia, 153; Priest D. Grigor'ev, "Neskol'ko slov o prichinakh uspeshnogo rasprostraneniia magometanstva sredi inorodtsev-iazychnikov," $P B$ 1, no. 2 (January 1905): 88; Mashanov's report in 1881 , NART f. 967 , op. 1 , d. $8,1.6$ ob.

94. NART, f. 4, op. 98, d. 23, 1. 156; Malov, “Ocherk," 17, pt. 3 (1871): 243; Fuks, Kazanskie tatary, 132; Speranskii, Kazanskie tatary, 30.

95. RGIA, f. 821, op. 8, d. 763, 1. 2 ob.-3; Malov, “Ocherk," 17, pt. 3 (1871): 242, and 18, pt. 1 (1872): 66; NART, f. 1, op. 3, d. 231, ll. 137 ob.-138. 
their husbands had never participated in the apostasy movement and knew nothing about Islam. If their husbands had already gone on seasonal work, they refused to say where they were. When the priest came to visit, women pretended that they were alone at home, and refused to allow a male to cross the threshold. They also used other methods to avoid the authorities. In the village street, some women kept silent and refused any contact with missionaries. When priests came to preach to the villagers about the superiority of Christianity over Islam, they refused to go to the meeting, despite the priests' exhortations. Only widows or soldatki (wives of soldiers gone to the army) came, but as the representatives of their family unit. One of them climbed on the large seat along the walls (säke) of the house where the meeting was held and showed to the missionaries that there was only one way to pray. As she prostrated and recited the Islamic prayer on a higher ground, the baptized elders who were angered by the missionaries calmed down and remained silent. ${ }^{96}$

When missionaries dared to pass the threshold of apostate houses, women hid behind the curtain dividing the house into women's and men's quarters, and came out only if the missionary showed them the Qur'an or other Muslim books. If the missionary started reading the Gospel of Matthew in Tatar, they hid again. In other instances, women gathered around the missionary to get more information about the investigation going on in the village. They also asked him to read some specific texts in the Bible that would answer some of the questions they asked themselves about Islam (not about Christianity). Those texts referred to the story of Joseph, so popular in the Tatar villages. Since the biblical account almost completely ignored Zulaykha (known only as Potiphar's wife in Genesis), Tatars and Islamized Kräshens concluded that Christians had indeed falsified the Word of Allah, as the Qur'an claimed. On the other hand, Jesus's miracles and Mary's miraculous pregnancy reconfirmed what Kräshens had heard from Tatars. Enthusiastic missionaries did not always detect that apostate Kräshens were interested in their readings not because they suddenly felt moved by the Gospel, but because of possible connections with what they knew about the Qur'an. Kräshens who owned Muslim books even asked the missionaries to translate some of the more difficult Arabic words. ${ }^{97}$

A woman's role was not confined to the gathering of information about police investigations or knowledge about Islam. When necessary, women actively defended their Islamic identity. They sent new petitions to have their husbands freed, using their Muslim names and explaining the main tenets of their faith. They wrote their own petitions to the government to be recognized as Muslim. One of them, approved by the Senate in 1807 , served as a legal precedent for the Kräshens who apostatized en masse in $1827 . .^{98}$

Even after the arrival of the police or the missionaries, women did not stop proselytizing. In 1872, a married couple in the village of Elyshevo went door to door,

96. NART, f. 1, op. 3, d. $3048,1.28$; and f. 4, op. 101, d. 11, 1.86.

97. Malov, "Ocherk," 18, pt. 1 (1872): 125; idem, "Prikhody starokreshchenykh," no. 12 (1865): 502; Iapei Babai, "O kreshchenykh tatar," no. 18 (15 September 1891): 560.

98. NART, f. 1, op. 3, d. 227 , 1l. 53-54; f. 1, op. 3, d. 222, 1. 70; f. 1, op. 3, d. 3697, 1. 45; and RGIA, f. 821, op. 8, d. 763 , 1. 208 (petition of Samigulov's first wife in September 1869); Malov, "Pravoslavnaia protivomusul'manskaia," no. 10 (1869): 151-154; Mozharovskii, "Izlozhenie," 125-126; PSZ 16, no. 12126 : 704-707. 
urging people to convert to Islam. The wife stood on the bridge leading to the newly built church, and dissuaded women from going to services. As a result, women ceased to attend the newly created Orthodox Tatar liturgy. Another courageous woman, known as Bibei (Evfimiia Efremova), taught Tatar, Kräshen, and apostate children in Bol'shie Savrushi for more than fifteen years after her husband was exiled to Siberia in 1874-strongly interfering with the work of the Brotherhood school. ${ }^{99}$

\section{Women and Death Rituals}

Besides disseminating Islamic knowledge underground, apostate women played an important (but not exclusive) role in the conduct of religious rites. In Verkhniaia Nikitkina, Chistopol' province, women circumcised boys; and in Elyshevo village, Mamadysh district, they conducted funerary wakes or congregational prayers for the benefit of the dead (pominki in Russian, puminky in Kräshen, ta'ziya in Arabic, iskä alu in popular Tatar) during which they called for God's mercy on the deceased. Because the practice of reading prayers for the dead developed outside Medina in the eighth century, nineteenth-century Tatar reformist theologians and the earlier Naqshbandi Sufi Utïz Imäni, faithful to the eighth-century legal scholar Abu Hanifa's opinion, considered the wakes as suspicious innovations. However, the practice of reading prayers for the dead grew in the cities of the expanding Islamic empire, and in the context of Imperial Russia, served to maintain Tatar and apostate communal cohesiveness. ${ }^{100}$

Death constituted a special event in the history of the apostasies. This was the time when apostates affirmed or reaffirmed their attachment to Islam. The village of Shepsheik, Kazan district, in 1866, announced their official decision to apostatize by sharing with the police and the priest their intention to bury a certain Akulina Pavlova the Islamic way. But when the police arrived to take the already decomposed body to the Christian cemetery of Alaty, three women-the body's washers who were guarding the deceased-threw themselves onto the boards that covered her temporary burial site, and the men got into a fistfight. In baptized as well as Tatar villages, it was customary not to leave the deceased alone, partly because the soul might resent it and become hostile, partly because it needed the intercessory prayers of the living in the period between the death and resurrection. The three women were later imprisoned, but their intervention managed to buy time for Akulina Pavlova, whose body was later secretly buried in a Muslim cemetery. ${ }^{101}$

When Russians inquired about who conducted the last funerary rites, apostates usually gave the names of neighboring dead mullahs, their wives' village mullahs, or indicated that they conducted the funerals themselves at home with the help of fellow baptized villagers who could recite the $Y \bar{a} \sin$, the thirty-sixth chapter of the Qur'an about the resurrection of the dead. Only in the period from 1890 to $1905 \mathrm{did}$

99. RGIA, f. 821, op. 8, d. 763, 1. 299 ob.; and NART, f. 1, op. 3, d. 3272, 11. 20-21 ob.; Otchet o deiatel'nosti Bratstva Sv. Guriia za dvadtsat' tretii bratskii god s 4-go oktiabria 1889 g. po 4-e oktiabria 1890 goda (Kazan, 1890), prilozhenie k IKE, 1890 goda, nos. 22-24: 42.

100. Halevi, Muhammad's Grave, 28; Ghabderäkhim Utïz Imäni äl-Bolghari, 89-90; Aydar Iuzeev, Filosofskaia mysl' tatarskogo naroda (Kazan, 2007), 65.

101. Police report in Materialy po istorii Tatarii vtoroi poloviny 19-go veka, 236; NART, f. 13, op. 1, d. $938,11.48-52,70,92-93$ 
the apostates begin to occasionally mention a living mullah. During this period, local authorities, overwhelmed by the large numbers of petitions to apostatize, considered granting an amnesty for the apostates; but these good intentions came to nothing.

Besides complicating the villagers' access to a mullah, the baptized status of apostate villages occasionally interfered with the conduct of funerary rites. If the Russian state law demanded bodies to be buried within three days for the police to determine the cause of death, the Islamic law required the bodies to be buried as soon as possible, within a day, to preserve the body's state of purity. In Muslim villages, the police usually hesitated to enforce the law, but in Russian and baptized villages, if the cause of death was not determined before burial, the body could be unearthed and submitted to autopsy. The result was that baptized Mishar Tatars of Nizhnii Novgorod province, who were strongly attached to Islam, called the priest for the last sacrament to avoid the autopsy; that is, in their view, the desecration of the deceased's body. ${ }^{102}$

But after sending the petition, apostates had the unique opportunity to publicly direct their funeral rites. In 1866, four people died in Elyshevo and their unofficial mullah buried them the Islamic way. The men opened a new cemetery on a hill named Shïtsu and helped dig the tombs. Today, except for one chardughan (fence), there are no tomb markers left on the hill overhanging the village's only street, still unpaved, named after Lenin. By its form, the hill reminds an observer of the many other sacred qurghans that dot the region. When the army came to crush the apostasy movement, the site became known as izgelär ziratï (the Saints' cemetery), a name usually given to places where martyrs of the faith or Sufi saints are buried. At the time of the collectivization, silos were built on that sacred site. ${ }^{103}$

As noted by Malov, who visited the village in 1866, the baptized of Elyshevo did not hire a grave digger, as did the Russians, but invited the whole male community, even those who did not approve of the apostasy, to dig the tombs. According to Islam, men receive sawab (religious merit that will be counted in the afterlife) for praying at the cemetery. Women, as in Tatar villages, did not attend the ceremony but prayed at home to increase the deceased's merits in God's eyes. In Fäżä'il ash-Shühūr, Biktashi warned women not to visit cemeteries, lest they be cursed; if they visited a cemetery and died on the same day, they would be damned forever. Usually, in Tatar villages, while the men attended the deceased at the cemetery, elderly women and the mullah's wife gathered at home in one room and mediated for the dead, asking for God's forgiveness. Together they recited the tahlil (La Ilaha illallah, "There is no God but Allah"), the first part of the shahada, with the rosary (tasbih) in hand and lamented that the deceased wept while being washed, that she cried while being taken away from her home. ${ }^{104}$

Malov reported that women in Elyshevo conducted wakes for the dead. Men and women in Elyshevo still conduct such wakes separately on the third (öchese), seventh (jidese), fortieth (qürïghi), fifty-first (ille ber köne) days, and on the first anniversary

102. Materialy po istorii Tatarii vtoroi poloviny 19-go veka, 259; Mashanov, Religiozno-nravstvennoe sostoianie, 27.

103. NART, f. 13, op. 1, d. 1003, ll. 12 ob., 25; Malov, "Ocherk," 17, pt. 3 (1871): 410; Shärifullina, "Urïskiafer kilgänder Yïlïsh awilï ilenä," 67; Zahidullin, "Jilïsh awïlï mäk'ruhlarï," 48-49, nos. 11-12 (1995): 147.

104. Malov, "Ocherk," 17, pt. 3 (1871): 409, and 18, pt. 1 (1872): 246; Fäżäil, 32; Sh. S. "TataryMusul'mane. Smert' i pokhorony," 118. 
of the death (yili), despite imams' condemnation of this ritual. In 1866, the women of Elyshevo invited friends and relatives, cooking pancakes (qoymaq) and curd tart (durchmaq). They also prepared beer. ${ }^{105}$ Like their Tatar neighbors, the women of Elyshevo started the wake with Bismillah, prayed the tahlil, chanted passages in turn from the Qur'an, and performed baghïshlaw (dedication) in Tatar. Baghïshlaw is a very special time during the wakes when participants offer prayers mainly in Tatar for the Prophet Muhammad, the local Sufi saints, the deceased, any dead and surviving relatives, neighbors, and guests, giving their names and kinship ties, asking for God's mercy and forgiveness. At the wake I attended in Kazan in 1996, the oldest woman initiated the chanting, then the youngest women continued, and occasionally, at the recitation of the tahlil, their voices joined in unison. At times, a woman would stand up and collect alms (sadaqa) in the name of the dead. All these actions were understood as merit or God's recompense (sawab) for the dead and meant to ease the deceased's suffering in the grave. After baghïslaw and the sadaqa, there was another special time devoted to the recitation of the munajat. ${ }^{106}$ In Ufa province, the Mari missionary Eruslanov noted that Maris heard Muslim tales of the origin of the world, the Prophets and famous Sufi saints, the Mahdi, the terrible fate of unbelievers, and God's mercy at judgment day through the monotonous singing of Tatar and Bashkir munajat at marriages, funerals, and wakes. After reciting munajat, villagers shared important news. Such was the case in Elyshevo when women discussed whether to send their children to Il'minskii's school in Kazan, expressing their fear that if their sons left they would be drafted. ${ }^{107}$

There is no doubt that through the wakes, the women of Elyshevo who came originally from neighboring Kräshen villages gained considerable intercessory power. By earning merit for the deceased and their families, they played an important role in strengthening communal ties not only between the dead and the living, but also between the living of both their native and adopted villages. The wakes of Elyshevo did not exclude female neighbors whose husbands had not signed the petition, leaving the door open to further integration into the community of the Prophet. Domna, the wife of Kondratii Filippov in Elyshevo known for his unconditional commitment to Christianity, attended the wakes. Such inclusiveness opened the way for further

105. Malov, “Ocherk," 18, pt. 1 (1872): 73. Prayers for the dead developed in the eighth century outside Medina. Halevi, Muhammad's Grave, 28. Wakes are performed in former Ottoman- or Turkic-speaking territories such as Bosnia, Albania, Turkey, and Central Asia, and also in Indonesia. But in Saudi Arabia, where Wahhabis in the eighteenth century opposed the giving of alms or the recitation of prayers on behalf of a person already dead, they are condemned because they constitute an attempt to interfere with God's judgment. Bringa, Being Muslim the Bosnian Way, 188, 248, n. 20; Eleanor Abdella Doumato, Getting God's Ear: Women, Islam, and Healing in Saudi Arabia and the Gulf (New York, 2000), 91. For wakes among the Tatars, see Rittikh, Materialy dlia etnografii Rossii, 31; Speranskii, Kazanskie tatary, 27; Fäkhr ad-Dīn, Jäwāmi', 160-166 (hadith no. 104); R. G. Mukhamedova, Tatary-Mishari (Moscow, 1972), 185; Raufa Urazmanova, Sovremennye obriady tatarskogo naroda: Istoriko-etnograficheskoe issledovanie (Kazan, 1984), 120; Raziyä abïstay Zakirova, Ärwakhlarïbïznï shatlandïrïyq! Ille berenche könendä ütkärelüche täghzïyä mäjlese (Kazan, 2002). The wakes are currently the target of mullahs' attacks in Tatarstan. See, for instance, Nurulla Muflikhun Arïslanï, Jännät häm jähännäm yullarï (Chistopol, 200o), 81.

106. "At Färidä's place," recording by author, 13 May 1996; Urazmanova, "Semeinye obychai i obriady," in Tatary, 368.

107. Eruslanov, “Magometanskaia propaganda," no. 12 (1895): 181-184; Malov, “Ocherk," 17, pt. 3 $(1871): 406$. 
consolidation of the apostate movement and expansion of the Islamic space, despite the physical presence of the Russian police and the Russian missionary. As a result of such discussions, Domna hesitated for a long time before sending her son to Kazan, who later became a priest. ${ }^{108}$

Although non-apostate Kräshens' wakes included both genders, apostate female wakes excluded men. For this reason, Christian missionaries did not have easy access to the women's world. Malov planned to read the Bible in vernacular Tatar when he unintentionally stepped into one of the women's wakes. He promptly realized that he was out of place and left; the husband, he noted, was gone and women arrived steadily one after the other. Lack of direct evidence makes the reconstitution of such gatherings in apostate villages very difficult. However, the most intriguing aspect of the "wakes" in Elyshevo as recorded in Malov's diary, was that one of them lasted over two or three weeks and the starting date was the first of October, which in this case, coincided with the Christian celebration of the Feast of Pokrov (Pukraw in Tatar), or the Protection of Our Most Holy Lady Theotokos and Ever-Virgin Mary. This feast celebrated the apparition of the Mother of God to St. Andrew in tenth-century Constantinople. St. Andrew saw Mary descend, kneel down, and pray, asking her son to intercede for all Christians in the world and, as a form of protection, spread her veil over the people attending the church where she appeared. Women in Elyshevo also celebrated Pokrov. Besides praying at the deceased's house, which was the rule for the wakes, they took turns for further parties. Thus, Malov learned that the wife of a prominent apostate performed the Muslim wakes and simultaneously celebrated the day of Pokrov. At first glance, such combination of commemoration and festival seems strange. The woman from Kibiak-Kozi, a leading center of the apostasy movement, lived in a fully furnished Islamized house without icons and with a curtain separating the women's quarters from other rooms. She was literate and refused to hear Malov read the Gospel to her in Tatar, pretending to be sick. It is doubtful that the woman had gone to church for the night vigil: the church was far and women in villages strongly inclined to Islam never went to church or the chapel except to get officially married. Only men visited the church annually to perform their legal obligation to confess and take communion, for if they did not fulfill the rites, they could not get their bilet or authorization to travel and work outside their village. It is also possible that those who informed Malov about the wakes wanted to appease his curiosity or suspicions by associating the Muslim wakes with the celebration of Pokrov. After all, many in the village viewed him as a spy or regarded him as a man who could help them to escape possible deportation to Siberia. ${ }^{109}$

The celebration of Pokrov, however, was not a cover up. Pokrov was an important day in the Eastern Orthodox religious calendar, commemorating the Intercession of Mary, which Russians, Kräshens, and even Muslim Tatars (especially Mishar Tatars) celebrated in Mamadysh, Menzelinsk, Elabuga, Karsun, and Tetiushi districts. During Pokrov Tatar families invited each other and went to the market, which on that

108. Malov, "Ocherk," 18, pt. 1 (1872): 125; 18, pt. 2 (1872): 47.

109. Gavrilov, "Pogrebal'nye obychai," 255; Malov, “Ocherk," 18, pt. 1 (1872): 73-74, 128; Il'minskii, ed., Kazanskaia tsentral'naia, 153; NART, f. 1, op. 3, d. 3272, 1. 28; Urazmanova, "Semeinye obychai i obriady," in Tatary, 369. 


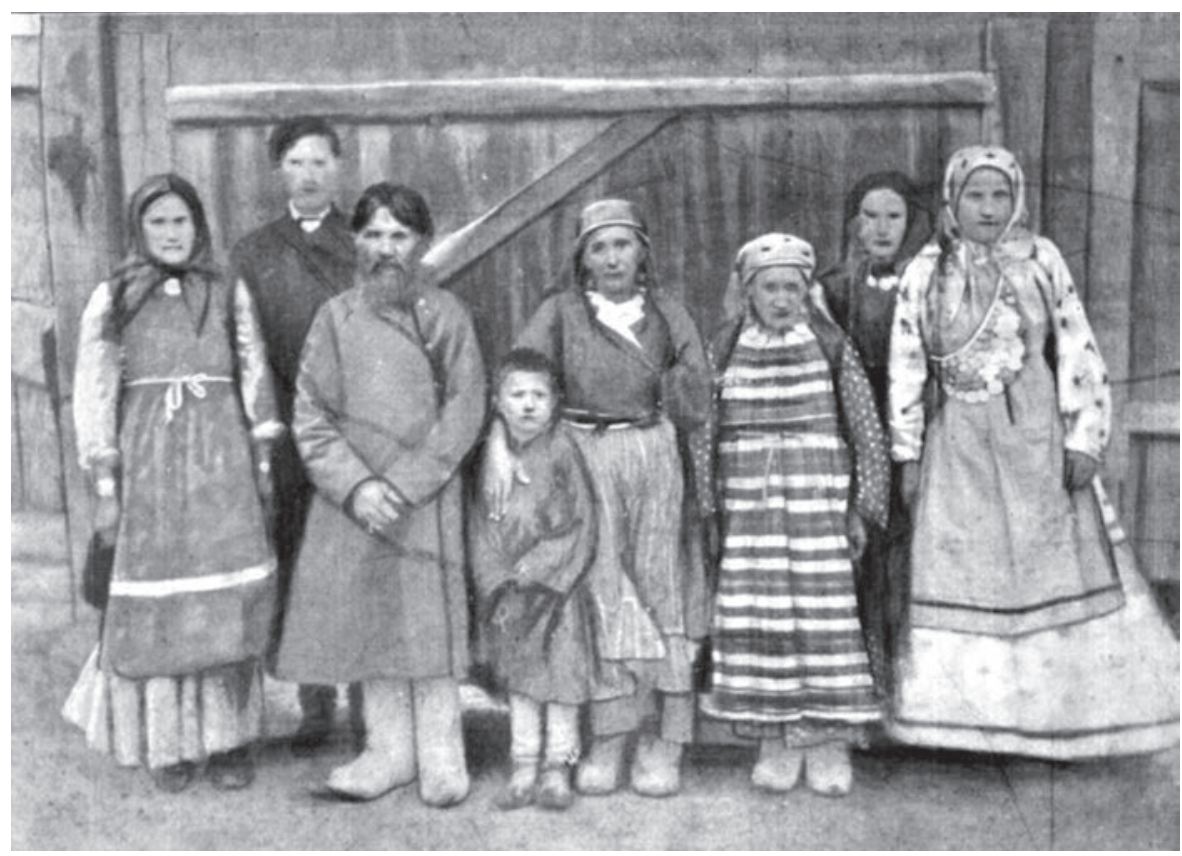

3.3: Kräshens from Nikiforova, Mamadysh district. S. Chicherina, U privolzhskikh inorodtsev. Putevye zametki (SPb., 1905), unnumbered page.

particular day (1 October) took place in the Russian village (selo). Thus in Mamadysh district, not far away from Elyshevo, the Tatar villages of Ishkeevo, Sartyk, and Kräshen Nikiforova celebrated Pokrov (Pukraw jïyïnï) with the Russians of Taveli. Pokrov, for all ethnic groups, signaled the preparation for winter-time supplies. Such was the case for the retired soldier Kondratii Filippov and his second wife, a native from Nikiforova, who had remained faithful to the church during the apostasy of 1866 and took Malov to the fair of Taveli. ${ }^{110}$ Kräshen villages leaning more toward Christianity than Islam but still attached to their indigenous beliefs remembered their dead on the days of major Christian festivals, before Easter in spring, and before Pokrov in fall. At Pokrov, families in Nikiforova village had a special meal consisting of pancakes, eggs, wine, and beer at home and at the cemetery. People sprinkled food and liquid on the graves to keep the deceased happy. Kräshens also remembered their dead ancestors weekly at home, on Thursdays, adding an extra plate at the table and pillows around the table, as well as opening the door for the deceased to enter. ${ }^{11}$

110. Malov, “Ocherk," 17, pt. 3 (1871): 408; Otdel rukopisei Kazanskoi nauchnoi biblioteki im. Lobachevskogo, f. 7, ed. khr. 1, 1. 151 (Malov noted that Mishars in Drakino, Karsun district, celebrated Pokrov in the company of Russians); Urazmanova, Obriady i prazdniki tatar, 95.

111. Istoriko-statisticheskoe opisanie tserkvei i prikhodov Kazanskoi eparkhii, 323; Gavrilov, "Pogrebal'nye obychai," 257; Il'minskii, ed., Kazanskaia tsentral'naia, 22; Urazmanova, "Semeinye obychai i obriady," in Tatary, 369 . 
As was the case of Tatar festivals, Russian festivals like Pokrov could also serve as meeting places for different ethnic and religious groups, and therefore become venues of either Christianization or Islamization. Vera Shevzov's work on Marian festivals shows that stories about Mary and her icons involved Russian and nonRussian actors. They had multiple functions, either to set boundaries between Russians and the "Other," or unite Russians with the "Other." Thus, icons of Mary saved Russians from the Muslim Tatar yoke, or resulted in the conversion of non-Russians, as was the case for a group of Bashkirs who, blinded by her image, recovered their vision only after converting. According to church tradition, miracles surrounding Mary's icon of Kazan in 1571 convinced Tatars and Chuvash to convert to Christianity. In other cases, Tatars recognized the power of Mary's icons but did not convert: a Crimean Tatar khan would pray to her image before going to battle. Obviously, these stories came from a Russian perspective and were meant to reaffirm Christianity's superiority. However, despite their iconoclasm, Muslim Tatars regarded icons as Russian gods who could potentially bring harm if ill treated. Thus, in the village of Uluiaz, Kazan district, Tatars remembered that a drunk fellow villager stole an icon of Mary on the day of Pokrov from the chapel of a nearby Russian village and threw it away, cursing it. His parents commanded him to find the icon and place it back where it belonged, which he did; nonetheless, he got sick for a week, was drafted, and died, leaving no descendants. If Marian stories cannot tell us much about the sentiment of Tatars or apostates toward Mary and festivals linked with her, they could at least speak to a Kräshen audience, still wondering about its real place in the multireligious landscape of Mamadysh district. Mary could be a powerful, edifying figure for all peoples, no matter what their language or ethnic background was. Thus, in the dry summer of 1900, the starokreshchenye of Biletlibash, district of Mamadysh, strongly believed that their prayers to Mary's icon had stopped a fire from engulfing their entire village. ${ }^{112}$

Although it is difficult to define the meaning of Pokrov in Elyshevo, one thing was sure. The women's gathering did not take place on a Thursday as in other Kräshen villages but on a Friday, on the day when Muslims believe that the doors of hell are locked. Nevertheless, the celebration of Mary's intercession for the faithful fitted well with the intercessory purpose of the Muslim Tatar wakes. Sufi poets ranked Mary as one of the best women of Islam. She was the only female name cited in the Qur'an, and a hadith claimed that she would be the first to enter paradise. In Tatar munajat, Mary appeared as an intercessory figure for the faithful, along with other important female figures-Eve, Asiya (Moses's adoptive mother), Sara (Abraham's wife), Haygar (Abraham's concubine, mother of Ismail), Halima (Muhammad's wet nurse), Khadija (the Prophet's first wife), Aisha (the Prophet's younger wife), and Fatima (the Prophet's daughter). Besides the munajat composed by women, there was also an important Sufi work devoted to Mary and Jesus that Tatar children knew by heart and whirling dervishes sung in Central Asia as part of their zikr ceremonies; its popular

112. Shevzov, Russian Orthodoxy, 243-244; S. M. P., "Polozhenie inorodtsev v Volzhsko-Kamskom krae i prosvetitel'naia sistema N. I. Il'minskogo," in Nikolai Ivanovich Il'minskii: Sbornik statei po povodu 25-letiia so dnia konchiny ego († 27 dek. 1891 g.) (Kazan, 1916), 6; Malov, Missionerstvo sredi mukhammedan, 96-97; Istoriko-statisticheskoe opisanie tserkvei i prikhodov Kazanskoi eparkhii, 364. 
name was The Book of Mary by Sulayman Baqïrghani. Its eight- to eleven-syllable meter, similar to Yasawi's poems and borrowed from folk Turkic poetry, praised Jesus and his mother as wandering ascetics, and was sung at various religious celebrations. Despite its antiquity, the book could speak to the broken heart of many Elyshevites when forced to bury their dead the Christian way. ${ }^{113}$

The reciters of The Book of Mary could fully identify with the characters' encounter with death and their struggle to obey God's law in an environment hostile to the spread of the true faith. The story goes that both mother and son, sensing that death was near for one of them, retreated to a mountain top. They built a cell to pray and fast. One day while Jesus was searching for food to break the fast, 'Azra'il, the angel of death, appeared to Mary and took her soul away. Upon his return, Jesus fell in complete despair and took the road to find proper burial. But to his deepest sorrow, the children of Israel refused to give him the piece of cloth he needed for the shroud. "Your mother should remain in the same state she died (that is, in a state of pollution, without proper ablution and burial)," they yelled. Others shouted that no one should come close to the deceased. Mary's soul did not deserve the community's intercession. ${ }^{114}$ This refusal to offer proper Islamic burial was well too familiar to apostate Kräshens who, legally, could not bury their dead in Muslim cemeteries. If caught, they could be submitted to corporal punishment. When forced to bury their dead the Christian way, apostates deported from Spassk district to Mamadysh district bitterly complained that local Russian authorities had their dead buried in the garments they wore at the time of death and on the bed they laid in, without proper washing and shrouding. If necessary, church and government authorities did not hesitate to dig out the bodies of apostates buried the Islamic way and have them reburied in Christian cemeteries, but not without meeting resistance. ${ }^{115}$ Thus apostates of Urmaeva, Tsivil'sk district, in 1867 kept the police from digging out the bodies of a woman and a young boy by yelling: "It is better for us to go to Siberia than let you bury our dead in the Christian rite."116

But the poem provided further comfort for the reciters of the wakes. When Jesus returned to his mother, he saw houris, beautiful eternal maidens, descend from paradise. Away from his gaze, they washed his mother, wrapped her in a burial shroud (kafn), and buried her. Then, 70,000 angels led by Gabriel came to pray at her tomb. Such a story could only speak to the apostates of Elyshevo and other villages. That houris provided proper ablutions and clothing brought definite comfort to those in the apostate community who had relatives entombed in coffins. The dead of Elyshevo could also receive the visit of the houris and angels for the washing and shrouding of their body, because they had died at a time when the community was under

113. Halevi, Muhammad's Grave, 226; Schimmel, My Soul Is a Woman, 22, 55; Khösnullin, Mönäjätlär, 50 (on Fatima); Sadekova, Ideologiia islama, 45-46; Häżrät-i Märyäm, 1-8; Matveev, "Mukhammedanskii rasskaz," 34.

114. Häżrät-i Märyäm, 7; Matveev, "Mukhammedanskii rasskaz," 28-29.

115. NART, f. 2, op. 1, d. 493, 1. 2; Malov, Prikhody starokreshchenykh i novokreshchenykh tatar $v$ Kazanskoi eparkhii, 45; Radik Iskhakov, "Metody bor'by samoderzhavno-tserkovnoi vlasti protiv dvizheniia kreshchenykh tatar za vozvrashchenie v Islam 1800-1870 gg. (na materiale Kazanskoi gubernii)," in Tatarskie musul'manskie prikhody $v$ Rossiiskoi imperii, 295.

116. NART, f. 1, op. 3, d. 1252, ll. 1-1 ob. 
nonbelievers' siege. Significantly, the story of Mary's burial in Rabghuzi's Stories of the Prophets, also known to the Kräshens exposed to Islam, did not mention the Jews' refusal to provide proper funerals for Mary. Rabghuzi's emphasis was more on the mourning of an orphan and life after death. Jesus saw his mother in a dream, dressed in a celestial garment, surrounded by houris. Then Jesus went to the city and found women to wash his mother's body. In Baqïrghani's Book of Mary, there was no dream, but reality. Jesus actually saw the houris wash and shroud his mother. Although Baqïrghani lived in the twelfth century, it is curious to note that Rabghuzi did not mention this other version of the story. Usually Rabghuzi liked to provide his readers with several possible plots. It is likely, as Alessio Bombaci has suggested, that the Baqïrghani's poems were recast at the end of the seventeenth century under stronger Naqshbandi influence, in the context of Russian farther expansion into Turkic territory. Nevertheless the Baqïrghani's version of The Book of Mary was more popular in the Middle Volga than Rabghuzi's account: partly because it was in verse while Rabghuzi's text was in prose, partly because The Book of Mary was shorter and spoke more vividly to the Volga Tatars and the apostates who lived under non-Muslim rule. ${ }^{117}$

Despite the important role that wakes played in the apostate villages' commitment to Islam, eighteenth- and nineteenth-century Muslim scholars questioned their orthodoxy. The Sufi Utïz Imäni and the scholar Nasïri attacked the consumption of beer, arguing on the basis of other schools of law, that all types of alcohol were prohibited in Islam, not just fermented drinks from grapes of dates as all of them could cause intoxication. The theologian and judge Fäkhr ad-Din classified as innovations (bid'a) the intercession of Prophet Muhammad and saints on Judgment Day, the repetition of the tahlil or shahada with the rosary, the visits to the cemetery on the first, seventh, fortieth-day and year anniversary of death, and the giving of alms to those who read prayers for the dead. ${ }^{118}$

The wakes, however, and the important (but not exclusive) role women played in them allowed apostates to defy police intrusion in their lives and connect with the grace of God. They constituted special occasions for them to retell the stories of their faith, become mediators between the living and the dead, their village and the community of the Prophet, and strengthen their community's commitment to Islam in the face of Russian presence on their ground. In the same way that the catalogue of Sufi graves in local historiographical manuscripts delineated a sacred territory that included Kräshen villages on ancient Bolghar land, the baghïshlaw or dedication prayers contested orally the imperial grid of religious identity and connected the living and the dead apostates to the Prophet and the saints, whose tombs dotted the Volga-Kama landscape.

The study of Islamization networks in the nineteenth century among the natives of the Middle Volga shows that the conversion to Islam was not the result of an articulated

117. Al-Rabghūzī, Stories, vol. 2: 489; Häżrät-i Märyäm, 7; Bombaci, Histoire, 88-89.

118. "Risala-i irshadiyya (Nastavitel'nyi traktat)," in Antologiia tatarskoi bogoslovskoi mysli: Gabdrakhim Utyz-Imiani al-Bulgari, 173-174; Nikolai Katanov, "Povolzhskie tatary v ikh proizvedeniiakh i v zhizni. Obzor literaturnoi deiatel'nosti tatar za XIX vek," in "Povolzh'e": Khudozhestvenno-literaturnoe izdanie, ed. B. Rozova-Tsvetkova, vol. 1 (Nizhnii Novgorod, 1903), 10; Fäkhr ad-Dīn, Jäwāmi', 160-166 (hadith no. 104). 
and systematic missionary work. The fascination for Islam was supported by literary images of sainthood contained in books or sung in the form of spiritual songs, and by legends surrounding shrines of ancient and contemporary saints. The bearers of those stories were not solely Sufis, but common peasants or merchants-male and female. Sufism was a commonly shared culture that permeated children's upbringing, village communal life, and traditional Qur'anic education. Some Naqshbandi shaykhs of the Mujaddidi lineage did proselytize among the Kräshens, but most often the believers of indigenous origin, the apostates themselves, carried the message of Muhammad to their brethren.

Consequently, Russian missionaries were unable to prosecute Islamic propagandists efficiently. Tailors were indigenous proselytizers of Islam. They constituted the wealthiest strata of the village and its intellectual elite. Women's elaborate communication network was also responsible for the continuous expansion of the apostate movement. Contrary to the claims of the jadids, the traditional woman's world was not limited to the house. First, thanks to the Tatars and Kräshens' practice of exogamy, the wife served as a link between her native village and that of her husband. Often, information and rumors about the apostasies spread from village to village because of these links. Second, mothers-in-law generally chose Islamized Kräshens as the only suitable wives for their sons. They helped to organize the jïyïns, local festivals that encouraged the contact between the Kräshens and their Muslim Tatar neighbors. Those jïyins constituted the common denominator between economic, sacred, and kinship networks. In Tatar villages, the center of the jïyin where festivities started was often the site of a market and of a local pilgrimage. Among Kräshens attracted to Islam, the jïyïns emerged to allow marriages between Islamized families that could not officially marry Tatars. Finally, women served as indigenous abïstays, or teachers in clandestine Qur'anic schools.

At the turn of the twentieth century, modernist Tatars used the same female networks observed in the Kräshen apostate villages to spread their revolutionary ideas about schooling in the countryside. After having been exposed to jadid schooling, literate women taught in their husbands' villages. Jiyins as well as other popular festivals of the agrarian calendar became places where jadid literature was sold and where money was collected for the building of new schools. ${ }^{119}$

Sufism, with its charismatic and supernatural qualities, also provided women with opportunities for religious action. It offered the framework that Muslim women used to understand their world and act in it. By validating the woman's role as a seeker of God, guardian of the faith, and teacher in works such as Qïsṣa-yi Yūsuf, it gave women a vocabulary of images, metaphors, and behaviors. They used these images for the mystical and ritual instruction of the common people, and to prepare the young believer for formal theological training in the madrasas. Also, due to the separation of the sexes, the woman's world was closed to the male-dominated Russian authorities. Among the apostate Kräshens, the police could not easily check on female teachers' clandestine schools. This gave women greater freedom to teach and proselytize. Thus, Sufism, the Tatar kinship structure, and even the separation of the sexes created 
opportunities for women to change their world for the better. In the end, though, it was the individual women who actively exploited these opportunities to hasten the victory of Islam and (as they saw it) the triumph of a just order.

Finally, the relentless effort of the Russian Orthodox Church hierarchy to control and limit thaumaturgical and charismatic religion inside the ranks of its own flock left the network of holy places in the hands of the Tatar mystical leaders. By 1850, the Orthodox Church had developed an effective bureaucracy that looked with suspicion at contemporary miracles. "Official" Islam had no comparable bureaucracy. The Spiritual Assembly of Orenburg had no such ability to check the activity of itinerant village mullahs. Only sporadically did police receive letters of denunciation against Sufi leaders from official mullahs who disagreed with local shaykhs' activities. Thus, Orthodox missionaries did not invest in thaumaturgical networks, at least not until a friend and supporter of Il'minskii's schooling Antonii Amfiteatrov Iakov (1815-1879) became archbishop of Kazan and Sviiazhsk. But mullahs, largely independent of any centralized authority, thought it normal and necessary to maintain and develop holy sites. This led to the partial Islamization or continuing Islamic monopolization of the sacred geography of the Kräshen and Finno-Ugric country. ${ }^{120}$

Only in the second half of the nineteenth century did Russian missionaries and statesmen seek to meet the challenge of popular networks of Islam in the Volga-Kama region. For the first time, they used modern tools of education, in particular functional literacy in the native vernacular, to educate Kräshens; but most important, they tapped into Christianity's thaumaturgy and martyrology to challenge Sufi literary metaphors and models of action. The ancient city of Bolghar, which attracted so many pilgrims for being the place of their original conversion to Islam, became for Kräshens who had chosen not to apostatize, the site of their original conversion to Christianity - the site where St. Avraamii, a Christian Turkic Bolghar, met martyrdom in the hands of his Muslim captors, well before the conquest of Kazan.

120. Gregory L. Freeze, The Parish Clergy in Nineteenth-Century Russia: Crisis, Reform, Counter-Reform (Princeton, 1983); idem, “The Rechristianization of Russia: The Church and Popular Religion, 1750-1850," Studia Slavica Finlandensia 7 (1990): 101-136; Shevzov, Russian Orthodoxy. 


\section{Christian Martyrdom in Bolghar Land}

K räshens did not simply, naturally, or automatically "return" to Islam, their so-called ancestral religion. In Mamadysh district, villages were often a conCeriog periods intermarried and lived together with Udmurts and Chuvash. In fact, each village at different points in its history argued about its identity. To win their case, declared apostates had to gain the support of those who still hesitated. Occasionally Tatar communities themselves did not always welcome the apostasy movement, and were often likely to opt for the status quo. Some mullahs even consulted missionaries before allowing a Kräshen to visit their mosque, or complained to the authorities that Kräshens prayed at the mosque without their permission. Neighboring Muslims also sent denunciations against mullahs they disliked for personal reasons who were actively involved with the Kräshen community and often despised Kräshens who were neither Russian, Tatar, Udmurt, nor Mari. In general it was up to individual courageous mullahs and shaykhs to seek to reattach baptized Tatars to what they considered their previous umma. ${ }^{1}$

It would be wrong to reduce Eastern Orthodoxy among the baptized Tatars solely to a simple administrative formality. In some localities, stories about miraculous icons and crosses competed successfully with Sufi legends, and in the 1860 , Il'minskii offered to the Kräshens new tools to construct their identity outside the Tatar community. When in 1905 starokreshchenye apostates insisted that they were forcibly converted by Ivan the Terrible, the Kräshens of Chura who diligently went to church, spoke of their ancestors' natural inclination toward Christianity. The founder of their village, Chura khan, they said, enjoyed making crosses out of wood and molding little humanlike clay figurines as a child, and his father quickly realized that he would never make a good Muslim. To ensure the happiness of all his children, the concerned father decided to build a separate house for his Christian son, around which grew the village. The names of the two Muslim brothers, Iadyger-khan and Aty-khan, refer to Tatar neighboring villages. ${ }^{2}$ In the 1870 , Chura's region was a major center of the apostasy movement. Villagers who had not apostatized earlier joined Islam during that decade and continued to do so throughout the Soviet period. Although some baptized Tatars persevered in their fight for their recognition as Muslims, others embraced Il'minskii's school wholeheartedly. Of course Il'minskii was not in favor

1. Petition of a mullah who refused to respond to the needs of apostates, NART, f. 2, op. 2, d. 1948, 11. 4-7; Iapei Babai, "O kreshchenykh tatarakh," no. 18 (15 September 1891): 555.

2. Istoriko-statisticheskoe opisanie tserkvei i prikhodov Kazanskoi eparkhii, 369. 
of allowing Kräshens to make a free choice between the two faiths. Whenever he dealt with the Russian administration, Il'minskii accepted the use of judicial punishment as a last resort to prevent Kräshens from apostatizing. Keeping apostates within the legal boundaries of Christianity, he argued, would later facilitate the dissemination of Christian literature and schooling and ultimately keep them Christian. Judicial

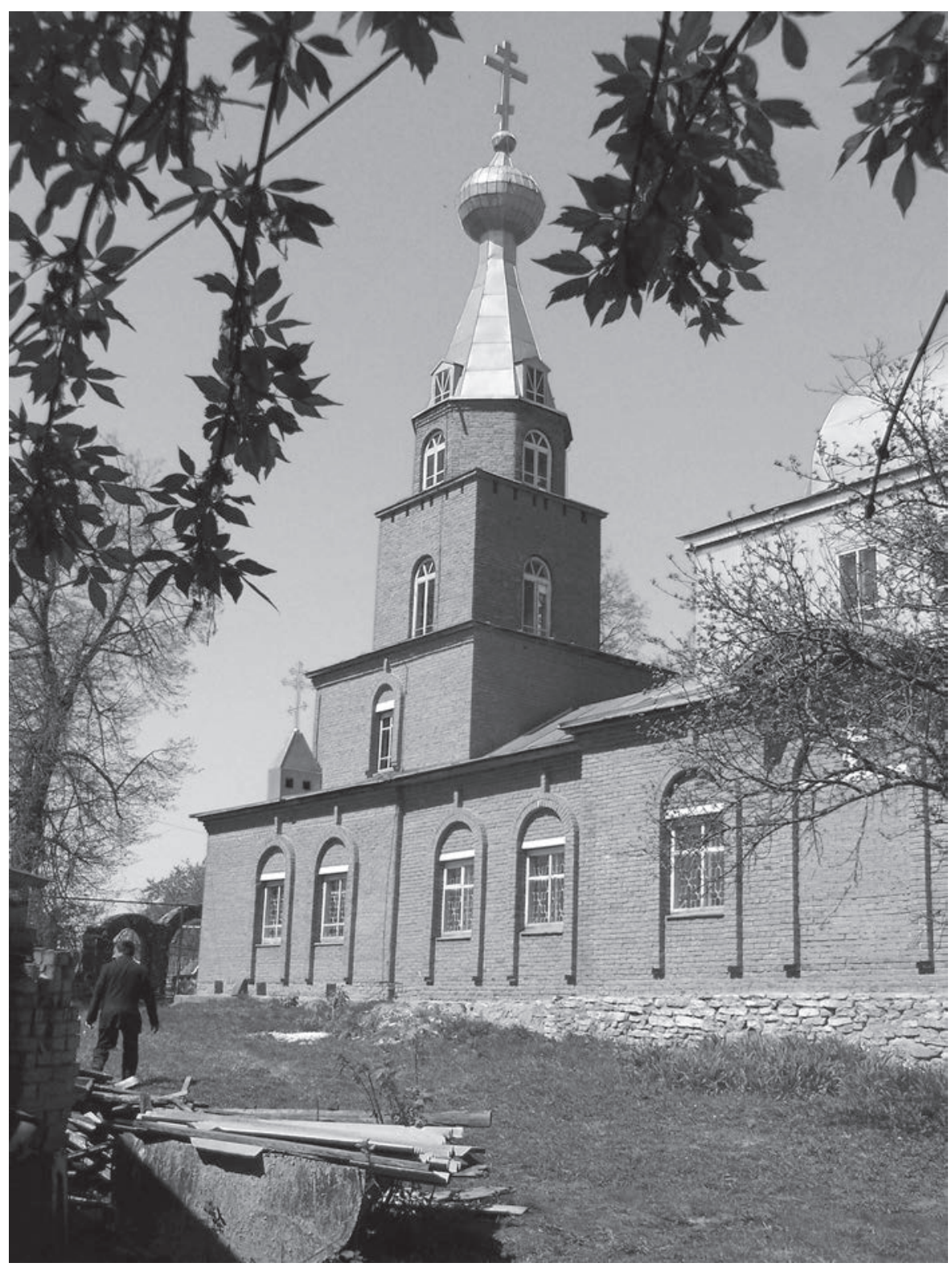

4.1: Chura church restored and reopened in 1993. Photograph by the author. 
punishment, however, did not work; baptized Tatars who fought for their recognition as Muslims managed to win their cases by sending petitions, evading the police, opening clandestine maktabs and prayer houses in their villages, and engaging in far-flung trade. Nevertheless, a slightly greater portion of Kräshens chose to remain Christian; they continue to constitute a dynamic Orthodox Christian community in twenty-first century Tatarstan. They now have their own newspaper Keräshen süze and have created an association of Kräshens that regroups "brothers" from inside and outside Tatarstan. Their main argument is that Christianity does not belong to Russians alone.

The foundation of Il'minskii's schools in Mamadysh district did not stop the spread of Islam in some areas but did slow down the processes of Islamization in villages still strongly attached to their indigenous beliefs in the Kukmor, Mamadysh, and Laishevo regions. It also transformed the composition of some kin networks. After the opening of a Christian school in 1872, Kibech' village no longer participated in the jïÿn of Kibiak-Kozi, an apostate village. ${ }^{3}$ By the beginning of the twentieth century, Kräshen families offered an interesting conglomeration of either strongly committed Muslims or Christians. Some of the Kräshen priests initially educated in Il'minskii's Christian schools, came from villages inclined toward Islam, such as Bol'shie Savrushi, Tri Sosny, and Serdous, and helped consolidate Christianity in the villages where they served but their relatives back home continued to live as Muslims and even led their fellow villagers to apostatize again. ${ }^{4}$ Thus, choices were made at two different levels: individually and collectively. In the end, Kräshens came to view themselves as Christian Turkic martyrs in the land of Tatar Muslim darkness, spreading Christianity in the Finno-Ugric and Turkic milieu, and successfully competing with "apostate" missionaries of Islam. Kräshen Christianity was far from being a carbon copy of Russian Christianity; it reverberated Muslim and animistic conceptions of the world and the afterlife.

\section{Knowledge of Russian and Orthodoxy among the Kräshens before the 1870 s}

Literacy in Russian and knowledge of Orthodoxy were important elements in the making of a Muslim or Christian identity for the Kräshens. The apostates argued that their ignorance of Russian kept them from understanding the priests and church services. By the same token, Russian academics and functionaries believed that if Tatars and apostate Kräshens knew Russian, they would understand Russian customs and religion better, stop living in cultural autarky, and even adopt Russian values and the Russian worldview. ${ }^{5}$

But, contrary to what apostate Kräshen representatives often affirmed to the police and to the priests, or in their petitions, apostates, particularly men, knew at least some Russian and when necessary used their linguistic abilities to demonstrate

3. Yakhya Abdullin, interview by author, 30 May 2000, Institute of History, Kazan; Narodnye uchilishcha $v$ Kazanskoi gubernii: Materialy dlia istorii narodnogo obrazovaniia: Laishevskii uezd (Kazan, 1887), 86.

4. "O sostoianii missionerskogo dela v Kazanskoi eparkhii za 1903 (Otchet Eparkhial'nogo protivomusul'manskogo i protivoiazycheskogo missionera)," IKE 38, no. 43 (15 November 1904): 1463.

5. NART, f. 4, op. 98, d. 34, 1. 157 ob.; f. 10, op. 1, d. 1655, 1. 19 ob. 


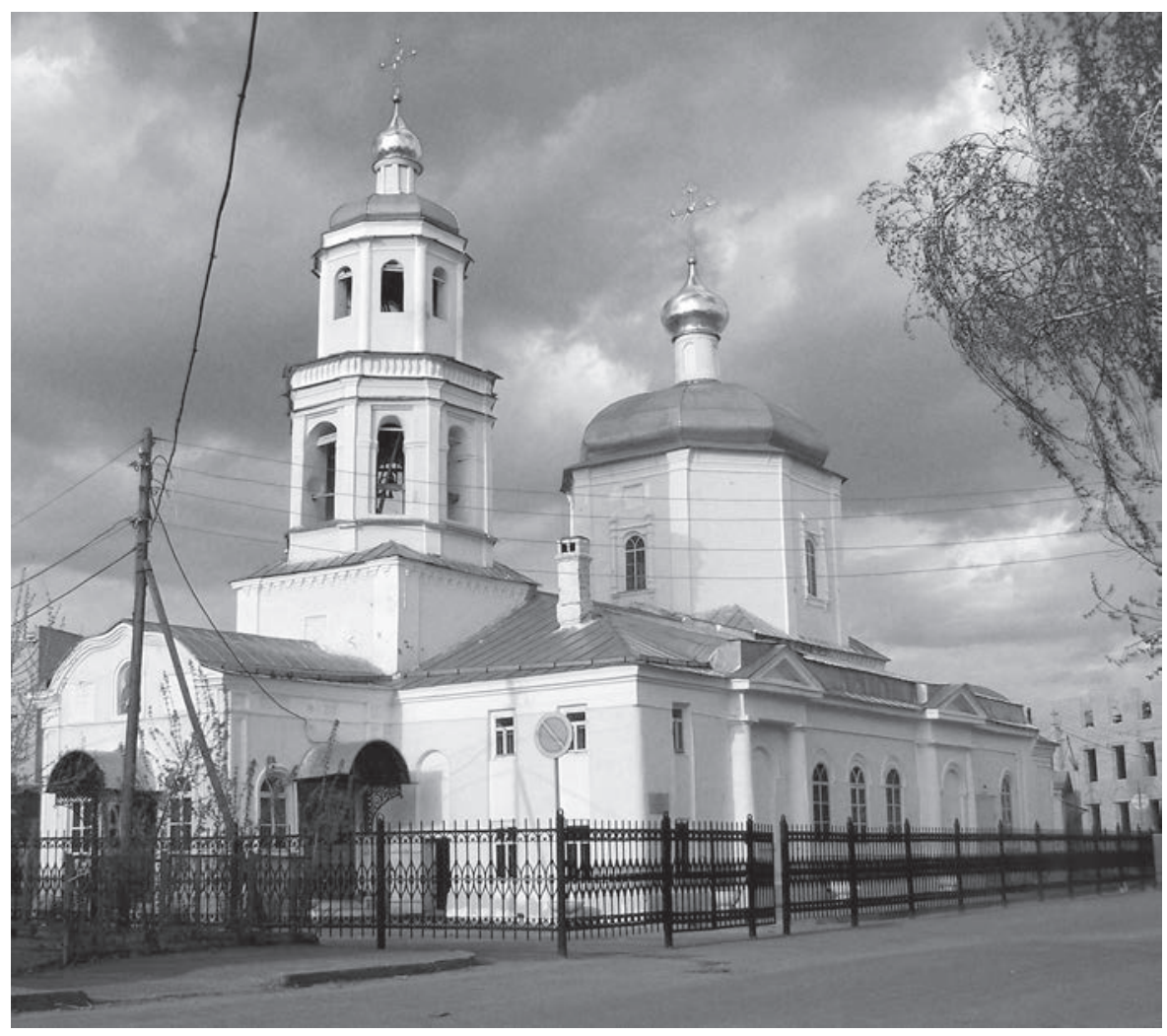

4.2: Tikhvin church today. Photograph by the author.

the superiority of the Qur'an to the Gospel. Russian books were not absent in their milieu. A family of Islamized Kräshens in Nikiforova possessed the Calendar of Saints (sviattsy), the liturgical Book of Hours (chasoslov), and a book of illustrated Russian tales. ${ }^{6}$ In fact, many of the Russian speakers among apostates were tailors and seasonal workers who used the state language for their trade. They also knew how to count in Russian and the Cyrillic alphabet. One of the apostate leaders of Elyshevo in 1865-1866 had studied at the Russian school of Mikhailov not far away from the Tikhvin church situated in the Tatar quarter of Kazan, before entering the madrasa and opening his own shop. Knowledge of Russian permitted apostate leaders to compose and copy drafts of petitions to defend their rights; it did not conflict with their Islamic worldview. If necessary, the Kräshen apostates of Kuiuki village in Spassk district, Suncheleeva village in Tsivil'sk district, Azeeva and Kulmaksa villages in Chistopol' district, or the Kräshens of Sungur parish in Kazan district could explain themselves in fluent Russian. Also, among the Kräshens who were arrested in 1866 and later in the 1870 s and 188 os, some could answer the police questions without 
the help of an interpreter or sign their petitions in Russian with well-formed letters. When the archbishop of Kazan visited the church of Elyshevo in 1891, an apostate remarked to him in plain Russian that if Jesus suffered for the Christians, the Prophet Muhammad suffered for the Muslims. ${ }^{7}$

As early as the eighteenth century traces of Russian literacy can be found among the Kräshens. The Moklokovo leader, Estifeev learned to read and write among Russians when he was a child, perhaps in the local parish church school. Significantly, he continued his learning with a Russian retired townsman and a volost' court clerk, who probably taught him to write and submit petitions. His teachers, the Tatar abizlar who taught Christian Tatars of Nizhnii Novgorod, knew Russian partly because they represented their communities for the Russian administration. Interestingly, some of the apostates' Tatar informants in Kazan district-among them the akhund Kämal ad-Din Iskändärev (d. 1872) of Semitbash village, who confirmed the rumors about the pseudo-ukaz allowing Kräshens to be Muslims-did know Russian. Others, like the mullah Taz ad-Din of Bikovo village, Tetiushi district, who visited Kräshens often, was also a supporter of the Russian new laws of 1870 concerning the introduction of Russian classes in the madrasas. ${ }^{8}$

Before 1803, attempts to educate natives in Russian were few. In the seventeenth and eighteenth centuries, schools for baptized children were open in the monasteries of Sviiazhsk, Cheboksary, Kazan, and Novgorod to train church servitors. They learned Slavonic and Russian grammar. In 1707, Metropolitan Tikhon of Kazan (r. 1699-1724) opened a school at his residence that lasted no more than two years. Because parents refused to let their children go, Tikhon took them by force, but some died from hunger and loneliness. The Office for the Affairs of New Converts applied the same methods and opened schools in Kazan, Tsivil'sk, Elabuga, and Tsarevokoshaisk. Catherine II (1763-1796) did not abolish the schools, but forbade involuntary recruitment. With no financial plan, these schools disappeared around 1800. Baptized children could go to the parish schools with other Russian children, but the priests rarely knew the local language. Even when they had some knowledge of it, they had no real training to explain the truths of the Gospel in the native idiom. Before the introduction of Il'minskii's school and its phonetic method of reading in the 1860 , parents also complained that their children could hardly read in Russian even after three years of schooling and after one winter of studying, their knowledge was limited to the names of the letters. ${ }^{9}$

7. "Otchet bakalavra Kazanskoi dukhovnoi akademii N. I. Il'minskogo (August-September 1848)," in Khristianskoe prosveshchenie, 74; Malov, “Ocherk," 17, pt. 3 (1871): 241 and 18, pt. 1 (1872): 399; NART, f. 4, op. 84 , d. 45 , 1. 24 ; f. 4, op. 97, d. 1, 1. 255; f. 4, op. 95, d. 29, 1.8 ob.; f. 4, op. 98, d. 34, 1. 16; f. 13, op. 1, d. 938 , 11. 67 ob., 71, 102; RGIA, f. 821, op. 8, d. 763, 1l. 185, 190-191; N. N., "Osviashchenie khrama v sele Staroi Ikshurme," IKE, no. 22 (15 November 1891): 687.

8. Il'minskii, Opyty perelozheniia, 22, 67; NART, f. 1, op. 3, d. 3272, 1l. 43-44; f. 4, op. 3, d. 3272, 11. 43, 45 ob.-46; Sergei Seniutkin, Istoriia tatar Nizhegorodskogo Povolzh'ia s poslednei treti XVI do nachala XX vv. (Istoricheskaia sud'ba misharei Nizhegorodskogo kraia) (Nizhnii Novgorod, 2009), 303. (Akhund was an official title in Russia for the head of Islamic affairs in a given district.)

9. K. V. Kharlampovich, "Kazanskie novokreshchenskie shkoly", IOAIE 21, 1 (1905): 5, 39; PSZ 11 (1740-1743), no. 8236: 255; S. M. P., "Polozhenie inorodtsev," 14; Mikhail Apakov, "Missionerskie besedy s kreshchenymi i nekreshchenymi tatarami i Votiakami Kazanskogo kraia," IKE, no. 13 (1 July 1881): 331. 
In 1837 , the state established volost' (canton, township) schools for state peasants including the Kräshens, under the Ministry of State Domains. These schools trained future clerks for rural administration. But they had a bad reputation among both Russians and non-Russians. Students suffered separation from their parents, abuse, and poor teaching. Non-Russian children were alienated from their milieu, customs, and native language. Far from encouraging the Kräshens to remain Orthodox, the volost' schools provided them with the inclination and the tools to resist and fight the Russian administration. In 1866, in Buinsk district, Simbirsk province, and in the 1870 s in Kanibekovo village, Belebei district, Ufa province, the Kräshens who had learned to read and write in those schools apostatized. Clearly, for those who had experienced the teaching of the Qur'anic primary schools, where everything was explained in their native language and where the mullah constantly referred to their immediate environment, the teaching of the volost' schools inclined them to embrace Islam, or confirmed them in their choice. ${ }^{10}$

Nevertheless, when in the late 1850 s, Il'minskii became convinced that the best way to teach the Christian faith was to translate the scriptures into popular and not literary Tatar, he chose to do it in the Cyrillic alphabet, first to shield Kräshens from Islam, and second to diffuse the books more easily, through the help of Kräshens already literate in Russian. His main collaborator, the Kräshen carpenter Vasilii Timofeev, was a product of the parish village school (prikhodskoe uchilishche) of Taveli, a village known for its miraculous icon. In his case Russian Eastern Orthodox schooling had turned to be so positive that before meeting Il'minskii in 1856, he had entered the Ivanov monastery as a novice. Another exceptional case was Timofei Ivanovich Timei (d. 1891/1892), who later helped to restore Christianity in the village of Mol'keevo, a village that partly apostatized at the end of the 1860 s. Before he visited Il'minskii and Timofeev at the Kazan Central Baptized-Tatar School, Timei had met an old Russian deacon who had introduced him to the beauty of the Eastern Orthodox liturgy, the lives of famous saints, and Russian literacy. ${ }^{11}$

For the baptized Tatars, the army constituted another source of information about the Russian world. In 1869, Afanasii Ivanov, a Kräshen noncommissioned officer from Bersut-Ilga, Mamadysh district, who had served in St. Petersburg and learned to read and write in Russian, returned to his village and announced that in St. Petersburg he had never heard of laws against apostasies. In the capital, on the contrary, Old Believers, Catholics, and Lutherans lived peacefully side by side and were not persecuted by the dominant Eastern Orthodox Church. Ivanov's statements prompted his village to apostatize. In general former soldiers and noncommissioned

10. K. P. Prokop'ev, Shkol'noe prosveshchenie inorodtsev Kazanskogo kraia v XIX veke do vvedeniia prosvetitel'noi sistemy N. I. Il'minskogo (Kazan, 1905), 10-11, 26; Sbornik dokumentov i statei po voprosu ob obrazovanii inorodtsev (SPb., 1869), 8; Isabelle Teiz Kreindler, "Educational Policies Towards the Eastern Nationalities in Tsarist Russia: A Study of Il'minskii’s System" (Ph.D. diss., Columbia University, 1969), $37-43$.

11. Vladimir Vitevskii, "Nikolai Ivanovich Il'minskii, director Kazanskoi uchitel'skoi seminarii $(† 27$ dekabria 1891 goda)," IKE, no. 4 (15 February 1892): 70; N. Ch-skii, Pamiati o. Vasiliia Timofeevicha Timofeeva (Moscow, 1896), 2-3; Il'minskii, "O primenenii russkogo alfavita k inorodcheskim iazykam," in Nikolai Ivanovich Il'minskii: Sbornik statei, 107, 112; Roman Daulei (Kräshen), "O dobrom uchitele," in Chicherina, U privolzhskikh inorodtsev, prilozhenie no. 23, 189-190. 
officers enjoyed extraordinary authority upon their return: they had seen the world beyond the Middle Volga, earned medals for their courage, and gained the reputation of knowing the laws of the Empire better than the local authorities who, according to popular belief, distorted them. These soldiers often played a leading role in the further Islamization of their village, occasionally teaching literacy or serving as underground mullahs. Such was the case of Vasilii Iakovlev (Bäshir Ya'qubov) in Staraia Ikshurma who at the turn of the twentieth century taught apostate and nonapostate children underground and built a clandestine mosque in his yard, covering a section of its roof with hay, to better call his parishioners for prayer, in the absence of a minaret. ${ }^{12}$

Usually baptized Tatars, because of their common language with Muslim Tatars, associated themselves with other Tatars in the army, but only in a few extraordinary cases did the army serve the cause of the church. In 1845, a retired soldier in Verkhniaia Nikitkina, and in 1866 a noncommissioned officer in Elyshevo and a former soldier in Kibiak-Kozi faced alone the reproach of their communities for not joining the apostasy movement. In 1902, the consistory's local statistics listed ten households of soldiers among the apostates of Elyshevo, and only one faithful to Eastern Orthodoxy. In the neighboring village of Sosnovyi Mys, five families of soldiers were listed as apostate and one as Eastern Orthodox. The soldiers' exceptional faithfulness to Eastern Orthodoxy and the czar in the Mamadysh and Laishevo districts facilitated the work of the police and the gathering of information by church clerics. ${ }^{13}$

Although they often denied it, apostates were familiar with the calendar, prayers, rituals, and symbols of Russian Orthodoxy, well before the introduction of Il'minskii's reforms. Kibiak-Kozi tailors donned their skullcaps and left for the Bashkir lands after celebrating the parish festival of St. Cosmas and St. Damian, third-century martyred twin brothers and physicians, with other Kräshen villages. Parish elders, who played a direct or indirect role in the apostasy movement, oversaw church property and exhibited knowledge of church liturgy. A ninety-eight-year-old tailor in Tashliar village knew Christian prayers well enough to recite them for young couples who wanted to get married. Frustrated apostates in Buinsk district used their knowledge of the differences between Christian Orthodox and Muslim funerals to dare the local authorities to dig up their dead. Orthodox priests, they argued, place a petitionary prayer in the hand of the dead, pleading for the remission of past sins, whereas their dead have no parchment in their hand, no paper wreath, and no coffin. ${ }^{14}$

It would be wrong to assume that the apostates' knowledge of Christianity was superficial. In some cases their very close relatives exhibited signs of a deeper, emotional attachment to the religious symbols of Eastern Orthodoxy. An Islamized tailor from Elyshevo recalled that his mother who died in 1856 was fond of the Christian

12. Materialy po istorii Tatarii vtoroi poloviny 19-go veka, 269, 273, 278; RGIA, f. 821, op. 8, d. 763 , 1. 239; NART, f. 1, op. 3, d. 2195 , 1l. $1-1$ ob.; f. 1, op. 3, d. $227,1.88$ ob.; f. 4, op. 101, d. 11, 1. 52; and f. 4, op. 132, d. 7, 1l. 1-6 ob; Stepan Danilov, "Vospominaniia starokreshchenogo Tatarina iz ego zhizni," Strannik 3 (1872): 8 .

13. NART, f. 2, op. 1, d. 1911, 1l. 8-9; NART, f. 4, op. 134, d. 58, 1. 1778 ob.

14. "Otchet bakalavra Kazanskoi dukhovnoi akademii N. I. Il'minskogo (August-September 1848)," in Khristianskoe prosveshchenie, 75; Malov, “Ocherk," 18, pt. 1 (1872): 399; Timofeev's diary in Il'minskii, ed., Kazanskaia tsentral'naia, 170; published petition in Materialy po istorii Tatarii vtoroi poloviny 19-go veka, 275 . 
faith, liked to light candles before her icons, and taught him a few prayers that he could still recite. In apostate Shepsheik, Kazan district, the old convert Akulina Pavlova, who was buried against police instructions in a Muslim cemetery after her body laid in a ditch for days, had confessed several times before her death, desperately trying to find a cure for her long-term disease. Likewise, well before the opening of a Christian school in the divided village of Tri Sosny, a couple who used to go to church assiduously during the winter season, had such strong faith in the healing powers of icons that they brought them home from church and tearfully prayed to them after their son got sick. This did not keep their son, once he had recovered, from siding with Islam. ${ }^{15}$

Moreover, in some areas, there was no linguistic barrier between Russian and Tatar villagers, the priests, and the native parishioners. Just as Kräshen men knew some Russian, some Russians knew Tatar in mixed villages and some clergymen in Kazan province had a basic knowledge of the indigenous language. In the 1820s, when the villagers of Apazovo, which apostatized in 1871, asked the authorities to allow them to keep their church, the deacon Ivan Bishevskii could read and write in literary Tatar. ${ }^{16}$ Before 1868 , eighteen of the ninety-one parishes with a strong Kräshen presence had a Russian priest fluent in Tatar, and fifty-three others had a priest who could understand at least some Tatar. In Sviiazhsk or Chistopol' districts, most Russian Orthodox priests did not speak Tatar, but the majority of clerics in Mamadysh and Laishevo districts spoke, read, and even wrote in Tatar. If they did not, one of their deacons was usually fluent in Tatar and could serve as a translator. In some cases, aided by their Kräshen parishioners, clerics came up with their own translations, which did not always please the young Il'minskii who found them either grammatically incorrect or badly influenced by Islamic terminology. Thus, well before the creation of Il'minskii's schools, the priests of the northern and eastern parts of Mamadysh district and the priests of Karabaian, Serda, Uraevo-Chelny, and Sharmash in Laishevo district knew the language of their Kräshen parishioners. Their churches contained very cheap candles that poorer Kräshen parishioners could easily buy to place before their favorite icons. Coincidentally, these villages did not apostatize in the 1860 s, embraced Il'minskii's reform wholeheartedly, and have remained Eastern Orthodox, despite some Islamic victories. ${ }^{17}$

The Kräshen religious world was an intricate blend of Islam, Christianity, and animism. Before the 1860 , starokreshchenye peasants in Mamadysh district had adopted the Christian calendar for their agrarian festivals and on their own prayed in front of their icons, mixing Russian and Tatar. If during their collective sacrificial

15. Malov, "Ocherk," 18, pt. 1 (1872): 402; NART, f. 13, op. 1, d. 938, 1. 76 ob.; "Otchet bakalavra missionerskogo protivomusul'manskogo otdeleniia Kazanskoi dukhovnoi akademii N. I. Il'minskogo (1856)," in Khristianskoe prosveshchenie, 153.

16. Il'minskii, ed., Kazanskaia tsentral'naia, 174; NART, f. 10, op. 2, d. 1283, 1. 190 ob.

17. "Otchet bakalavra Kazanskoi dukhovnoi akademii N. I. Il'minskogo (August-September 1848)," in Khristianskoe prosveshchenie, 83; "Otchet bakalavra missionerskogo protivomusul'manskogo otdeleniia Kazanskoi dukhovnoi akademii N. I. Il'minskogo (1856)," in Khristianskoe prosveshchenie, 154, 156; N. I. Il'minskii, "Ukazanie otnositel'no chteniia i voobshche upotrebleniia sviashchennikami knig na tatarskom iazyke, sostavlennykh N. I. Il'minskim," IKE 3, no. 11 (1 June 1869): 327-328; NART, f. 4, op. 95, d. 29, 11. 1-1 ob.; f. 4, op. 97 , d. 34 , 1. 15 ob.; f. 4, op. 98 , d. 23 , 1. 93; f. 1, op. 3 , d. 231 , 1. 132; f. 13, op. 1, d. 945 , 1l. 80 ob. -81 ; f. 4 , op. 84 , d. 263 , ll. $18-18$ ob. 
ceremonies they turned the head of the animal to be sacrificed in the direction of Mecca and pronounced Islamic prayers, they also crossed themselves. In a funeral held in Nikiforova in 1855, the superficially Christianized widower, who held strongly to his animist beliefs, nevertheless opened his wife's coffin to make sure that her chest was covered with a cloth cross. Sometimes, instead of the more popular Arabic formula "Bismillah ar-Rahman ar-Rahim" (In the name of God, the Compassionate, the Merciful), Kräshen sorcerers started their incantations with the Russian "Gospodi blagoslovi!" (God, bless us!). At the table, when lightning struck, starokreshchenye, depending on their degree of exposure to Islam or Christianity, either crossed themselves or repeated Bismillah several times. They believed that Tängre babay (Grandfather sky; literally, "God-grandfather" or the Creator), chased Satan away with lightning. Finally, one could escape an ill-famed spirit (päri) by crossing oneself and reciting a prayer. ${ }^{18}$

According to Timofeev, the old converts' strong attachment to their ancestral beliefs-which were close to the Finno-Ugric peoples-might have prevented large numbers of them from being Islamized. Kräshen Tatars in the parish village of Ium'ia brought sacrifices to Udmurt spirits (beside theirs) and showed little attraction to Islam. Conversely, Kräshens of nearby Serdauch lived separately from the Udmurts and were more exposed to Islamic influence. ${ }^{19}$ Animistic beliefs, be they of Kräshen, Chuvash, or Udmurt origin, however, did not always work in favor of Christianity. First, Muslim Tatars and Kräshens shared the same spirits, which could serve as a conduit for Islamization. Tängre babay for instance was the pre-Christian and pre-Islamic sky god among the Kräshens. He was a long-bearded old man who sent the rain to make plants grow and hail to those who had committed evil deeds. He also sent lightning to chase evil forces. In his childhood memoirs, the jadid theologian and pedagogue Fäkhr ad-Din remembered his (Tatar) street friends alluding to Alla babay, another way of saying Tängre babay, when lightning struck. ${ }^{20}$ Second, the Kräshens' attachment to their ancestral faith should not be underestimated. The starokreshchenye of Kazan province brought offerings to the spirit of the house (öy khujasi), and murmured prayers in front of their icons, not to the Christian God, but to the spirit itself. When they communicated with the spirit they made sure not to cross themselves. In the fall, after the harvest, they lit a candle in front an icon in honor of Tängre babay, who had blessed them with a good harvest and a good stock. During collective ceremonies in honor of a particular kirämät, the old converts of Tashkirmen' on the Kama River also prayed in front of icons, while those in charge of the sacrifices uttered prayers known only to them. The icons were not understood as windows to heaven, but as the residence of a particular spirit or kirämät.

18. Il'minskii, ed., Kazanskaia tsentral'naia, 39; NART, f. 10, op. 2, d. 1360, 11. 196-197; Gavrilov, "Pogrebal'nye obychai," 254; Il'ia Sofiiskii, "Zagovory i zaklinaniia kreshchenykh tatar Kazanskogo kraia," IKE, no. 2 (15 January 1878): 39; Maksimov, “Ostatki drevnikh," no. 20 (15 October 1876): 611.

19. Apakov, "Missionerskie besedy," 339.

20. "Keräšennärnen ıšana toryan kirämätläre (Simon Gäürlä ulı Boris jazүanča)," in Bálint, KazániTatár Nyelvtanulmányok, 59-64; K. Nasyrov, "Pover'ia i obrazy Kazanskikh tatar, obrazovavshiesia mimo vliianiia na zhizn' ikh sunnitskogo magometanstva," in Zapiski Imperatorskogo russkogo geograficheskogo obshchestva po otdeleniiu etnografii (SPb., 1880), 6: 247-270; Maksimov, "Ostatki drevnikh," no. 19 (1 October 1876): 566; Fäkhretdin, Tärjemäi khälem, 11. 
They were made of wood, and extraordinary trees were the privileged residences of spirits. Until the introduction of Il'minskii's schools, nineteenth-century Kräshens (as well as Tatars) called the icons Russian gods, and animist Chuvash understood the icons to be the residences of the Russian kirämät who could send disease if not properly honored or if not hidden during special ceremonies of indigenous kirämät. Finally, one Kräshen anecdote triumphantly reported that neither the prayers of the priest nor those of the mullah were able to chase the päri from the house they haunted, and in another tale, a Kräshen worker proved to be smarter than the devils who lived in a Russian priest's barn. ${ }^{21}$

Other legends recorded in the 1870 involving spirits and Christian priests echoed Tatar popular tales involving spirits and mullahs. In one of them the priest played a mediating role between the spirit and the human worlds. While attending a woman who was suffering terribly during labor, the priest discerned her spiritual problem: earlier in anger the woman had said that she would rather call on the water spirit (su khujasi) than her grandmother to help her deliver the baby. Thanks to the priest who interceded for her, the water spirit came and delivered the baby successfully. The priest then prayed and named the child, after which the water spirit returned to the lake. In that story, the priest, like the mullah in Tatar tales, acknowledged the power of the spirit world. At the same time the spirit, known for his mischievousness, did not do any harm and responded to the priest's invitation. This kind of acknowledgment, however, did not meet Russian missionaries' approval. Previously local priests saw no harm in their flock's attachment to the tutelary spirits, but in Il'minskii's schools, the children learned that spirits did not exist, and Kräshen teachers, graduates of the same schools, strongly associated the belief in spirits with paganism. ${ }^{22}$

Missionaries complained that the Kräshens' knowledge of biblical prophets derived from Islam and in particular from Sufi tales. However, in one interesting case, the army introduced a Kräshen from Elyshevo to stories about Jesus of peasant Russian origin that did not meet the missionaries' standards. Kondratii Filippov, a noncommissioned officer who traveled to the capital and opposed the apostasy, had heard miraculous apocryphal tales about Jesus. There Christ did not appear as the Savior of the world, but as an itinerant teacher accompanied by two disciples and the angel Gabriel. Jesus miraculously threshed the grain by setting fire to it and grew wheat inside a pit to thank his hosts. Strangely, Filippov's stories echoed tales collected by the lawyer Aleksandr Afanas'ev (1826-1871) in Voronezh province. They were not anti-Islamic per se. In fact, besides containing elements common to other animist cultures such as the regenerative power of fire, they also showed characteristics similar to Judaism, Christianity, and Islam. One story sharply contrasted a bad rich man to a good widow. When Jesus and his disciples asked a rich man for lodging, he refused

21. Maksimov, “Ostatki drevnikh," no. 19 (1 October 1876): 567, 571-572; no. 20 (15 October 1876): 612; Inorodets Iv. Belousov, "Vliianie shkoly na inorodtsev," IKE 38, no. 16 (22 April 1904): 521; Kräshen tales (1877) in NART, f. 968, op. 1, d. 35, 1. 11 ob.; L. G. Shatulova, "Istoricheskaia transformatsiia kul'ta ikon v protsesse khristianizatsii naseleniia Srednego Povolzh'ia," in Istoriia khristianizatsii narodov Srednego Povolzh'ia: Kriticheskie suzhdeniia i otsenka (Cheboksary, 1988), 72-73.

22. Maksimov, "Ostatki drevnikh," no. 19 (1876): 566, 579; Mikhail Apakov, "Rasskazy kreshchenykh tatar dereven' Tavelei i Alekseevskogo vyselka Iamashevskogo prikhoda, Chistopol'skogo uezda, o proiskhozhdenii kiremetei," IKE, no. 11 (1876): 322-337. 
them; but later a poor widow offered them all that she had, including her shelter and her last piece of bread. To her amazement, Jesus and his disciples multiplied the bread before her eyes. After leaving her house, Jesus and his disciples met a hungry wolf who asked them for something to eat. The disciples were about to direct him to the rich man's home but, to their consternation, Jesus stopped them and told the wolf to eat the widow's goat. The wolf immediately obeyed. When she realized her loss, the widow responded with the biblical words of the righteous Job: "The Lord has given and the Lord has taken away." Later, when the thirsty disciples came across a spring of brackish water, Jesus explained to them that the source of this spring was hell, the place where the rich man would be sent upon his death; a second spring of remarkably pure water came from paradise, the future abode of the widow. Submission to the will of God, the reward of the righteous in paradise, and the punishment of the wicked in hell were themes common to the three monotheistic religions. Filippov's stories could not disturb his fellow villagers' belief system. Islamized Kräshens had heard about 'Isa's miracles as they were recorded in Rabghuzi's Stories of the Prophets. They also imagined Jesus as a wandering teacher based on Sufi tales, and in particular, The Book of Mary. Rather, the difference between the commissioned officer and his fellow villagers lay in Filippov's strong conviction that Muhammad was a false prophet. He also believed that Muhammad forced people to convert by the sword, while in Christianity people were free to accept or reject Jesus as their savior. To back up his beliefs, he liked to emphasize Jesus's miracles over those of Muhammad. ${ }^{23}$

Filippov was also strongly attached to his icons and could not understand why they were so abhorrent to Muslims. Icons, he said, described the physical sufferings of saints who refused to give up their faith while persecuted. Especially dear to him was the fourth-century martyr Antony, officer of the Roman emperor Diocletian who refused to renounce his faith despite being beaten with iron rods. It could be that Filippov was simply trying to please Malov who stayed several days in his village, by telling him miraculous stories about Jesus, voicing his marvel about the icons' powerful imagery, and fully identifying himself with the early Christian martyrs. However, the former soldier also shared his tales about Jesus with his fellow villagers and was known for going to church and asking for prayers in honor of his guardian angel. ${ }^{24}$ In Filippov's exceptional case, to Malov's bewilderment, popular Russian thaumaturgical legends about Jesus's miracles had counteracted the effects of Sufi stories. Muslim Tatars used the same device as Filippov when Christian missionaries challenged their beliefs in Muhammad's miracles. As one Muslim said to another missionary, just as Joshua had stopped the sun for a whole day (Joshua 10: 12-14), Muhammad separated the moon in two halves. In Filippov's case, Russian tales constituted an important component in the construction of an identity separate from that of the apostates; these stories gave him the tools to articulate his "difference" in a verbal way. After twenty-five years of military service, unlike other former soldiers who had grown more attached to Islam during their time in the army, Filippov had become an outsider in the village life and also in his own family.

23. Malov, “Ocherk," 17, pt. 3 (1871): 245, 415-418; A. N. Afanas'ev, Narodnye russkie skazki i legendy (Berlin, 1922), 459-461.

24. Malov, “Ocherk," 18, pt. 1 (1872): 402; Men'shikov, "Achinskii prikhod," 450. 


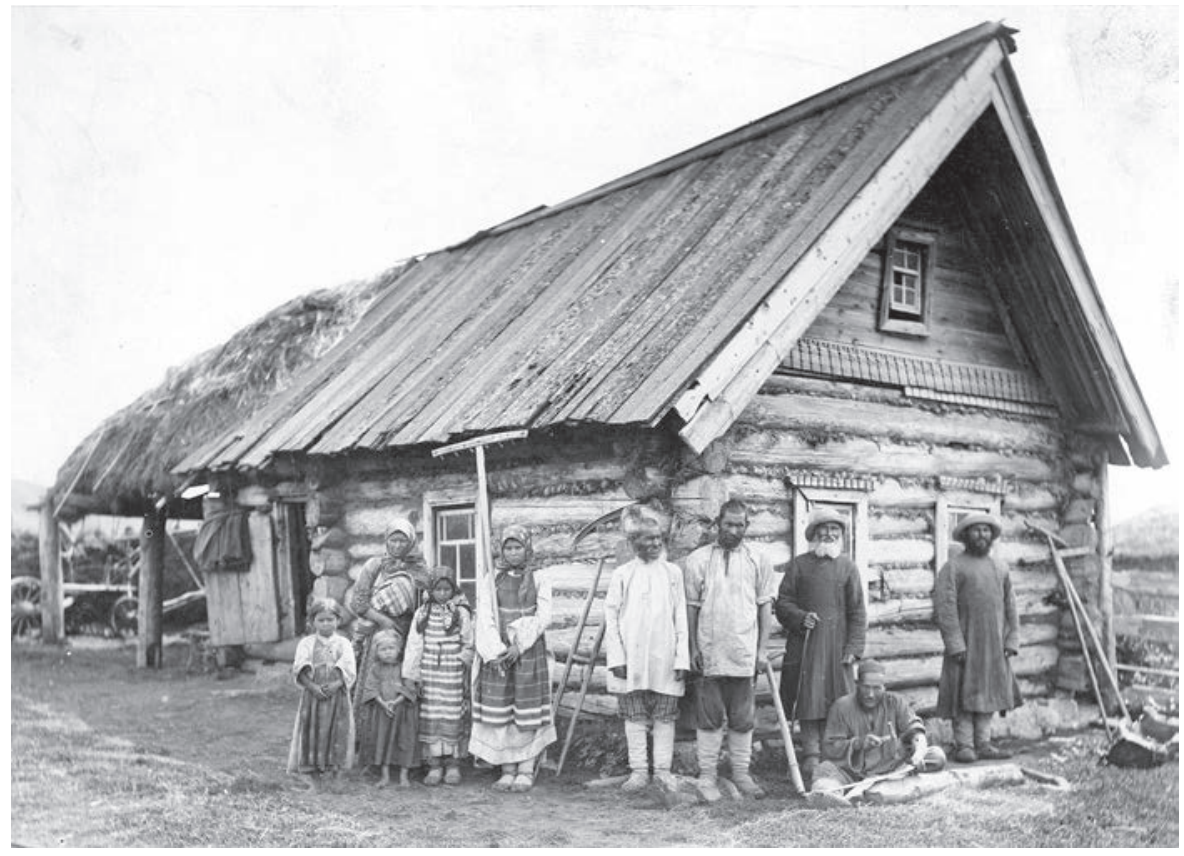

4.3: Kräshen family in the apostate village of Elyshevo, probably Kondratii Filippov's two sons (with a hat and beard). RGIA, f. 821, op. 4, d. 72, photograph no. 5. No date. Photograph courtesty of RGIA.

It is possible that Filippov found himself isolated from other Tatar-speaking soldiers during his service or that other personal issues in his village community had led him to separate himself from the others. During the apostasy of his village, elders kept him from participating in the affairs of the commune or in the games and dances of the spring feast. ${ }^{25}$

The later history of Filippov's family, caught between Islam and Christianity, constitutes a perfect example of identity making at the village level, and supports my initial argument that atavism had nothing to do with the Kräshens' so-called return to Islam; ultimately it was up to the individual and their communities to effectuate the transition to a particular worldview. One branch of Filippov's family chose Islamhis daughter was married to an apostate from Kibiak-Kozi-but his male descendants remained Christian, despite Elyshevo's adoption of Islam. His son Ivan became a priest. Filippov's other two sons kept a picture of Ivan in his priestly robe on the wall of their house long after his death sometime before 1904; they remained Christian despite village pressure to reduce their parcels of land. Contrary to the other peasants of Elyshevo who tailored in Ufa province among the Bashkirs, Ivan's brothers complemented their income among baptized Chuvash and Russians. One of them worked

25. NART, f. 4, op. 98, d. 23, 1. 156; Malov, “Ocherk," 17, pt. 3 (1871): 243, and (1872): 69, 77; Otdel rukopisei Instituta iazyka, literatury i istorii Akademii nauk Tatarstana, f. 56, op. 1, d. 4, 1. 69 ob.; Chicherina, U privolzhskikh inorodtsev, 144-148. 
in a Russian factory. It was during the famine of 1923 that Filippov's descendants left Elyshevo. After their departure, the village was entirely Muslim. ${ }^{26}$

In addition to trade transactions, the army, and schools, there was another space that Kräshen and Russian peasants shared occasionally: sacred sites of pre-Christian origin. To Timofeev's dismay, Russians joined Kräshens in their "pagan” festivities when drought threatened the fields; they marched with neighboring Kräshens and asked for rain. Russians also consulted Kräshen sorcerers for their wisdom. This type of rapprochement did not please missionaries and clerics: if Russians joined Kräshen ceremonies or consulted Kräshen sorcerers, Kräshens reluctantly visited the church and rarely consulted the priest. ${ }^{27}$

Occasionally, Orthodox Christian sites served as meeting places for Russians and Kräshens. Thus, Russians, baptized Tatars, Udmurts, and Maris of the Mamadysh parish village of Taveli, an old village that dated back to the Kazan kingdom, used to visit a little chapel, built near a sacred spring, which hosted a miraculous icon of St. Nicholas. Muslim Tatars lived originally in Taveli but according to a Russian legend, fled to the Laishevo district, after finding St. Nicholas's icon near their sacred spring. Upset by the presence of the icon, they tried to drown it, burn it, and bury it, but every time the icon reappeared at the same place, perfectly intact. As a result of their sacrilege, they fell ill, the land became sterile, their cattle died, and their houses burned; they had to flee and Russians took their place. The legend beautifully illustrated the Russian appropriation of Tatar indigenous land and sacred landscape. The sacred spring of Taveli village where Timofeev went to school competed successfully with other Islamized sacred springs in the same area. And members of the church, especially in the 1870 s, welcomed and encouraged this type of pilgrimage among Kräshens and other natives of the Middle Volga. ${ }^{28}$

\section{The Church Response to the Kräshen Apostasies, 1860-1905}

The Kräshen apostasies of the 1850 s and 1860 s prompted a new response from the church. Missionaries at the Kazan Theological Academy adopted two strategies. Some like Professor Malov, who became a priest in 1869, favored anti-Islamic polemical debates, while others, like Professor Il'minskii, supported the creation of a system of indigenous schools. Recent Tatar scholarship in popular and religious journals has focused its energy on denouncing Russian missionaries' hostility toward Islam and their failure to convert Tatars to Christianity, and Western scholarship, under the strong influence of Edward Said, has successfully deconstructed nineteenth-century European distorted images of Islam..$^{29}$ However hostile they were to Islam or however reified their idea of Islam was, these Russian anti-Muslim missionaries had some understanding of popular or "lived" Islam and the texts that undergirded it. Il'minskii and Malov aimed their discourse not only to the well-educated religious elite, but also

26. Chicherina, U privolzhskikh inorodtsev, 144-148; G. Khämidullina, interview by author, Kazan, 24 July 2008.

27. NART, f. 10, op. 2, d. 1360, 1. 208; Il'minskii, ed., Kazanskaia tsentral'naia, 169.

28. Istoriko-statisticheskoe opisanie tserkvei i prikhodov Kazanskoi eparkhii, 313-317.

29. Edward W. Said, Orientalism (New York, 1978); Geraci, Window on the East, 86-105. 
to the less educated indigenous population. Although Malov liked to polemicize with madrasa students in the Kazan Tatar quarter, he also traveled through Tatar, apostate, and Kräshen villages to apply his method, and attacked both literary Islam as well as its popular interpretation in folk poetry, song, and ritual.

\section{Attacks against Popular Knowledge of Islam}

Like jadids later, but with different goals in mind, missionaries challenged various aspects of so-called popular Islam: its exaggeration of prophets' and shaykhs' powers, its stress on Muhammad's miracles and his power of intercession, its visits to sacred tombs, and the belief in spirits. First they illuminated contradictions between the Qur'an and the hadith, then pointed to differences between the Qur'an and popular Sufi literature, and finally opposed various commentaries of the same event. Most interestingly they borrowed many of their arguments from the prereformist eighteenth-century Wahhabis of central Arabia who condemned the popular practice of seeking the intercession of holy men (including Muhammad) as idolatrous, for "no soul shall bear another's burden and each man shall be judged only by his labours" (Qur'an 53:39). Missionaries also borrowed from the Mutazilites who in the ninth century criticized the hadith literature and emphasized human responsibility on Judgment Day. The missionaries' goal was of course different from the Wahhabis who did not negate the Prophet's miracles but emphasized God's sovereignty. They sought to demonstrate that the Qur'an was not the Word of God, but the work of a poet inspired by his native paganism, Talmudism, and Christianity. Ultimately, Christianity was the panacea for the discrepancies found in Islamic literature, discrepancies that, according to the missionaries, originated from the deeper need for a Savior. ${ }^{30}$

The works of teachers and students at the Kazan Theological Academy offer a glimpse of the missionary understanding of popular Islam. The academy was reopened in 1842 partly in response to the Kräshen apostasies. Its goal was to prevent more religious defections among the natives of the Middle Volga by training new missionaries capable of using native languages in their proselytizing efforts. In $1854-1855$, an anti-Islam division was organized with language and culture classes. ${ }^{31}$

Thanks to the efforts of the Tatar and Arabic teacher Gordii Sablukov (1839-1918), as well as Il'minskii and Malov, anti-Islam missionary apprentices studied the Qur'an and its most famous commentators such as Sa'd ad-Din at-Taftazani (d. 1389). They also read Sufi religious literature in Turkic language, which had a pervasive influence on the Kräshens' worldview. According to Il'minskii and his disciples, the average Tatar peasant had no direct understanding of the Qur'an because of his ignorance of Arabic. Because most Muslims had learned about Islam from books like Rabghuzi's stories of the prophets or Yalchïghol's commentary of Sufi Allahiyar's poetry, the future missionaries called to proselytize among Kräshens and Tatars should study these works along with the Qur'an.

30. Nochnoe puteshestvie Mukhammeda v khram ierusalimskii i na nebo: Sochinenie Kazanskoi dukhovnoi akademii IX uchebnogo kursa (1858-1862 g.) Evfima Malova (Kazan, 1876); Mikhail Ivanov, O pochitanii sviatykh $v$ Islame s tochki zreniia pravoslavnogo bogoslova. Bogoslovsko-polemicheskoe issledovanie, vol. 24, MPMS (Kazan, 1914), 165-178.

31. On the Kazan Theological Academy, see Geraci, Window on the East, 29, 48-50. 
In his analysis of the Prophet Joseph in Islam and Christianity, student Nikanor Bobylev compared the Qur'anic narrative to the Bible, the Talmud, and apocryphal works. He concluded that their story lines did not differ much from one another, which demonstrated that the Qur'an was not of divine origin, but rather the creation of a mind conditioned by other traditions of its time and milieu. However, Bobylev insisted that most Tatars and Kräshens knew the story of Joseph through Qol 'Ali and Rabghuzi, whose metaphors dehumanized prophets and exaggerated their thaumaturgical powers. It was enough for a prophet to think or wish for something and his wish came true, regardless of the consequences. All nature was at a prophet's feet, exclaimed the missionary. ${ }^{32}$

By the same token, the missionary apprentices cast a critical eye on the Prophet Muhammad's miraculous powers. Taking the Qur'an as his main proof, student Nikolai Iordanskii demonstrated that Muhammad did not consider himself a miracle worker. If other prophets came with a divine book and miracles, said the Qur'an, Muhammad came only with the Word of God. Muhammad himself acknowledged his inability to perform miracles. The Prophet considered that faith was a gift of God that men could refuse or accept, independent of miracles. Moses and Jesus had come as miracle workers but failed in their mission. Conversely, various traditions, including those of Muhammad al-Bukhari, were filled with stories about the Prophet's miracles. Unlike the Sufi Yalchïghol, Iordanskii believed that those traditions could not be trusted partly because their sources were not adequately studied and scrutinized, and partly because the witnesses were either close friends or made-up names. Finally, Iordanskii stressed that Islamic commentators themselves were divided on the nature over the Prophet's so-called miracles. Thus, if some commentators read about the splitting of the moon as the most famous miracle attributed to Muhammad, others read it as an allusion to the Last Judgment Day. ${ }^{33}$

Another student at the Kazan Theological Academy, Tikhon Chizhov concentrated on the mi'raj, another of Muhammad's miracles. Like Iordanskii, he opposed the sober account in the Qur'an with the fantastic stories found in Rabghuzi's work and Yalchïghol's Risālä-yi 'Azīzä. Although the Qur'an did not mention the Prophet's ascension to heaven but only his nocturnal trip from the sacred mosque to the distant mosque, Arabic, Farsi, and Turkic commentators focused on the ascension, describing the seven skies and the Throne of God in lavish detail. Chizhov argued that if the ascension were true, there would not be so many inconsistencies in the descriptive details of the skies and their inhabitants: some said that the first sky was made of bronze, others of pure silver, others of turquoise; others disagreed on the number of curtains hiding the Throne of God, or on the location of the mythical rooster whose head rested on it. Not only did those traditions contradict one another, but the ascension to heaven challenged reason, physical laws, and geographical accuracy. Finally, like Iordanskii, Chizhov quoted several passages from the Qur'an that negated any miraculous powers in the hands of the Prophet. ${ }^{34}$

32. Bobylev, Patriarkh Iosif po Biblii i Koranu, 8-10, 61, 63, 114.

33. Nikolai Iordanskii, "Chudesa Mukhammeda v sravnenii s chudesami Iisusa Khrista" (Kursovoe sochinenie, 1853), in NART, f. 10, op. 2, d. 1049, 1l. 2 ob.-6, 10-12 ob., 25 ob.

34. Chizhov, "Migradzh," in NART, f. 10, op. 2, d. 1145, 1l. 7, 39, 48, 50, 52, 58-59, 63, 67, 72, 74, 99-100, 104. 
If Muhammad did not consider himself a miracle worker, neither did he call himself an intercessor, added missionaries. In the Qur'an, God alone is the intercessor. Each man, including the Prophet, will answer for himself individually. Baqïrghani's Ākhïr Zamān Kitābï and other Sufi books, however, gave a different version of Muhammad's mission. There, as Malov showed in his critical analysis of popular literature, the prophets and angels turned to Muhammad for his intercession. Even God Himself invited Muhammad to take His place as judge. Malov questioned why, if Muslims were so much in need of an intercessor, did they not turn to Jesus Christ as their Savior ${ }^{35}$ In a larger study of the traditional eschatology, student Aleksei Voznesenskii underlined its inconsistency: the age of the Mahdi and the duration of his stay on earth varied from one hadith to another, and the false messiah al-Masih ad-Dajjal, whom Jesus is supposed to kill before the Judgment Day was either a monster or a man of a great beauty. Those contradictions explained the decline of Islam. ${ }^{36}$

Missionaries also questioned stories that exaggerated the powers of Sufi shaykhs, especially their powers of intercession. Student Petr Pozdnev (1853-1934) translated and commented on a passage of Yalchïghol's Risālä-yi 'Azīzä, whose content in his view, contradicted the Qur'an. Despite the Qur'an's description of Muhammad as the last of God's prophets, Shaykh Naqshband in his hagiography displayed characteristics akin to the Prophet Muhammad as portrayed in popular Sufi literature. Like the souls of other prophets, Shaykh Naqshband's unborn soul orbited the Throne of God. Like the Muhammad of Ākhïr Zamān Kitābï, Shaykh Naqshband interceded for all believers: in exchange for a hat he had made while performing the $z i k r$, Allah had given him the power to rule over six of the seven spheres of hell. With his new power, the teacher of the Sufi path could keep most Muslim sinners from falling into hell. Shaykh Naqshband even considered his knowledge and power superior to that of the Prophet Elijah. According to Pozdnev, this emphasis on the teacher's sainthood challenged Muhammad's position as the Last Prophet. He concluded that ishans exploited people's wealth and religious credulity. Eighteenth-century Wahhabis made the same criticism. ${ }^{37}$

In an article, Stepan Danilov, a former apostate and teacher of old convert origin, attacked the popular belief in the sainthood of Naqshband in a cruder way. Taking the story about Naqshband's hat literally, the Kräshen missionary asked Kazan Tatars whom he met on his pilgrimage to Moscow: "Is it possible that God will wear this hat? Did God create the seven layers of Hell to exchange it for a hat? ... Why don't you hire one of your saints to sow another hat and exchange it for the last layer of Hell?" Muslims, he concluded, believed too easily that they could get away with their sins. This type of reasoning, which took metaphors literally, constituted a direct attack toward one of the pillars of popular belief: the prophets' and the shaykhs' powers of intercession. ${ }^{38}$

35. Malov, Akhyr zaman kitaby, 71-72, 77, 79, 91-92.

36. Aleksei Voznesenskii, "Mukhammedanskoe uchenie o konchine mira i razbor etogo ucheniia" (Kursovoe sochinenie, 1889-1890), in NART, f. 10, op. 2, d. 1392, 1l. 321-329.

37. NART, f. 10, op. 2, d. 1121, 1l. 55-58 (Petr Pozdnev, Prilozheniia k sochineniiu "Dervishi ili mukhammedanskii spiritualizm"); Petr Pozdnev, Dervishi ili mukhammedanskii spiritualizm (n.p., 1884), I-II.

38. Stepan Danilov, "Missionerskoe sobesedovanie khristianina iz staro-kreshchenykh tatar s mukhammedaninom," IKE 18, no. 17 (1 September 1874): 495; Otdel rukopisei Kazanskoi nauchnoi biblioteki im. Lobachevskogo, f. 7, ed. khr. 11, 1. 126. 
Missionaries also mocked popular beliefs in spirits. As remnants of a distant pagan past, the Qur'anic jinns, present in Tatar folktales, were the definite proof that the Qur'an was not the Word of God. ${ }^{39}$ Although Timofeev had expressed his relief that Kräshens' pre-Christian ancestral beliefs had shielded his fellow villagers, starokreshchenye, from further Islamization, pre-Christian/pre-Islamic culture, which was closer to the Tatar than to the Russian worldview, could also serve as a dangerous vector of Islamization. Tatars and Kräshens shared the same beliefs in spirits (spirits of the house, water, barn, and forest). Those spirits had the same beneficial or evil characteristics and bore the same names in both cultures. They lived close to humans in various spaces (baths, kitchens, madrasas, sacred books). Furthermore, Tatars and Kräshens shared the same pre-Islamic sites, and what is more important, both Tatars and Kräshens participated in the same agrarian festivals. Even when the dates of Kräshen festivals corresponded to important Christian events. these agrarian celebrations often offended the clerics' sense of solemnity just as much as Russian agrarian festivities did. In both Russian and Kräshen contexts, clerics were critical of their so-called pagan vestiges and tried to eradicate them. ${ }^{40}$

The students' understanding of Islam reached the apostates through sermons delivered by priests who came to the village after Kräshens had announced their decision to apostatize. They contained the same approach to Christianity and the same attacks on popular beliefs in spirits, Muhammad's miracles, and the shaykhs' intercession. However, those attacks did not have much impact on the Kräshen apostates. If missionaries portrayed Islam as a form of sensuous paganism, the apostates' response reflected the same distorted image of Christianity. They viewed Orthodoxy as a form of idolatry that relied on magic and immediate earthly rewards instead of faith. They also believed that after the coming of Muhammad, Russian faith had lost its thaumaturgical power. To a priest who had come to convert them back to Christianity, apostates from Otary village, Mamadysh district, asked with irony: "Will Jesus save all Russians because of the little copper crosses they wear? Why don't your crosses perform miracles anymore? Should we expect bread and wealth every day each time we recite Russian prayers?" During the priests' visits, Kräshen peasants often remained silent, or made such a noise that the church representatives could not speak. They also pretended to be ignorant, but at times, they either defended their beliefs or confirmed the priest's words, but in their own terms. In the Tetiushi district, the apostate Kräshens reasserted their belief that Muhammad's faith was the most ancient religion: Muhammad's soul had been created before the world and circled around the Throne of God. They also affirmed that the Prophet would guarantee them paradise, despite the priest's objection that God, and not Muhammad, would decide. When priest Gleb Liapidovskii from Chura parish in Mamadysh district, fluent in Tatar, talked about the angels in Christianity, an apostate added that each man was endowed with two angels (that is Munkar and Nakir, the angels of the grave), one on his right, the other on his left. Likewise, when priest Aleksandr Orlov in Chistopol' district spoke about Judgment Day, apostates confirmed that God would be the judge of their deeds, good

39. Vladimir Vasil'evskii, "O dzhinnakh po Koranu i po predaniiam Mukhammedan" (Kursovoe sochinenie, 1882-1886), in NART, f. 10, op. 2, d. 1164-1165, 1. 119.

40. NART, f. 10, op. 2, d. 1360, ll. 168-169, 202. 
and bad, and that they would be punished or rewarded accordingly. Contrary to what the priest expected, the apostates' belief in the intercession of Muhammad did not go against their conviction that they would be judged according to their actions. After all, Shaykh Naqshband guarded only six of the seven spheres of hell, and one sphere was still left to God's free will. ${ }^{41}$

Liapidovskii even met the approval of a literate peasant when he criticized the Sabantuy, an agrarian festival at the beginning of spring. Mullahs as well did not approve of such gatherings. Finally, the peasants' silence did not always mean disagreement or tenacious hostility. In fact, when priests expanded on the true definition of prophethood-true prophets healed the sick, resuscitated the dead, lived like saints, performed great miracles - these criteria fitted the image of the Prophet Muhammad in the Kräshen (Islamized or not) popular consciousness, and confirmed their faith in Muhammad's sanctity. ${ }^{42}$

Against the thaumaturgical aspects of popular Islam, Orthodox missionaries adopted two strategies: they presented Christianity as a religion which, contrary to Islam, allowed scientific inquiry and emphasized the miraculous as being the sole property of Christianity. They compared Muhammad's false miracles with the authentic ones performed by Jesus, the Orthodox saints, famous icons such as the Kazan Mother of God, the Smolensk Mother of God, and St. Nicholas, whose stories they translated in vernacular languages. They insisted that, unlike Jesus and the biblical patriarchs and prophets, Muhammad could not read the future and perform miracles. They also regarded with suspicion folk Christianity that assigned nonscriptural miracles to Jesus. For convinced apostates, the missionaries' emphasis on thaumaturgical Christianity did not change their opinion of Eastern Orthodoxy. On the contrary, Christian miracles were understood as the works of the devil. Yalchïghol had warned Muslim believers against miracles performed by non-Muslims. Their false and temporary miracles would lead only to their final downfall. Such was the case of the pharaoh at the time of Moses. ${ }^{43}$

Overall, the missionaries' exhortations had no effect on the apostates. They were dogmatic and left no room for a real dialogue, in which most apostates refused to engage anyway. The apostates remained silent, turned their heads away, and murmured Muslim prayers to themselves. The priests addressed their long monologues, recorded in their reports, more to the church hierarchy than to the Kräshens. They were primarily concerned to show that unreasoning fanaticism-not missionaries' incompetence-accounted for the apostasies. As a Kräshen himself, Timofeev gave a cautious but critical assessment of the priests' visits to the villages. He carefully praised their work, but also mentioned that while translating for them, he felt compelled to add his own clarifications. Timofeev's general conclusion was that instead of engaging apostates to enter a dialogue-which rarely happened-about the superiority of Christianity over Islam, it would be more effective to read stories of a moral

41. NART, f. 4, op. 97, d. 1, 11. 318-319; f. 4, op. 98, d. 9, 1. 74 ob.; f. 4, op. 77, d. 56, 11. 87-87 ob.

42. Jiyūn qïsșasï, 82-92; NART, f. 4, op. 98, d. 9, 1. 87 ob.; f. 4, op. 97, d. 1, 1l. 318-319.

43. NART, f. 4, op. 101, d. 11, 1. 15 ob., 19; Vasilii Petrov, "Prichiny upornoi priviazannosti Tatar Mukhammedan k svoei vere," vol. 1, MPMS (Kazan, 1873), 128-129; Kräshen priest David Grigor'ev, "K kharakteristike otstupnikov iz tatar," IKE, no. 37 (1 October 1906): 1166. 
and historical content on a regular basis, especially during the long winter nights. Il'minskii shared Timofeev's opinion and gave the priests of Sviiazhsk district the same advice. But as of 1895 , not all Russian missionaries agreed with their position. Father Kuz'ma Prokop'ev, a Kräshen priest in the village of Staraia Ikshurma, received Miropol'skii, the Russian priest of Apazovo village who visited and preached to apostates in the districts of Kazan, Laishevo, and Mamadysh, quite coldly. Prokop'ev tried to discourage the priest from gathering the apostates, but in vain, saying that such talks should be conducted more casually and regularly. Intimidated by Miropol'skii who could report on him in a negative way, Prokop'ev finally agreed to accompany him on his tour. ${ }^{44}$

In the case of convinced Muslims, Christian stories did not necessarily go against the apostates' Islamic code of conduct. Christian and Muslim lessons of wisdom were often interchangeable. Convinced Islamized Kräshens did not need to change their Islamic beliefs for another religion, which professed the same basic moral values, especially if Islam was understood as the true fulfillment of Jesus's message; Muslims hold that Christians have corrupted God's message in the Gospel. In Elyshevo, the priest Men'shikov noted that villagers visited him often and asked questions, but he knew that his answers would be reported to the mullahs who would provide their own interpretation, which would then be repeated in the homes of hesitant Kräshens still unsure about the way to go. Islamic-Christian polemics only fueled the movement toward Islam. However, villages where the community was equally divided between Islam and Christianity or where Islamic sympathizers constituted a minority, this type of reading among adults, supported by the introduction of school literacy among the young, did bring the expected change. ${ }^{45}$

\section{Il'minskii's Schools}

In the 1860 s, using more peaceful tools than those of the eighteenth century, Orthodox missionaries tried again to educate the Kräshens. Professor Il'minskii's school in Kazan introduced a new form of literacy in the countryside, destined to compete not with the sophisticated knowledge of the ulama but with popular Sufi culture. It rivaled the Qur'anic school along with the parish and Ministry of State Domains schools, which had been charged with the religious education of His Majesty's non-Russian subjects. ${ }^{46}$

In the same way that the later jadid schools partially duplicated the Russian gimnaziia's science and language curricula, Il'minskii's school was a conscious replica of the Tatar maktab and Islamic forms of proselytism in the countryside. Il'minskii believed that formal and informal traditional primary Islamic education-the education acquired at home, in community surroundings, and in self-supported schoolsplayed a vital role in shaping the Tatar peasants' worldview. Despite its so-called

44. "Otchet o deiatel'nosti Bratstva Sv. Guriia za shestnadtsatyi bratskii god s 4 oktiabria 1882 goda po 4 oktiabria 1883 goda," IKE, nos. 23 and 24 (1 and 15 December): 772; NART, f. 4, op. 101, d. 11, 11. 87-87 ob.; Il'minskii, "Ukazanie," 327-331; Otdel rukopisei Instituta iazyka, literatury i istorii Akademii nauk Tatarstana, f. 56, op. 1, d. 4, 1l. 42-44.

45. Letter of Priest Men'shikov to Il'minskii in April 1867, NART, f. 93, op. 1, d. 128 b, 1. 212.

46. Il'minskii, ed., Kazanskaia tsentral'naia, 80, 85-86. 
archaic pedagogical methods-which the missionary attacked-primary Islamic education won Il'minskii's admiration because of its ability to instill basic rudiments of faith and engage students from all backgrounds to learn more. In his attempt to keep Kräshens in the bosom of the Orthodox Church, Il'minskii took primary Islamic education as a model of informal, nonstandardized schooling for Christian missionaries to simulate and surpass. Thus, inspired by the madrasa system, the Russian missionary did not favor programs, separation of classes, accreditation for teachers, or exams for students in his schools. Like the mullahs, the Christian schoolteachers visited houses, sat at the family table, and read stories. ${ }^{47}$

Il'minskii's goal was to create an Orthodox Christian culture in the Tatar language that could compete with Tatar Islamic thaumaturgy and ultimately, in time, replace it. From 1863 to 1869 , Il'minskii's close friend and collaborator, Timofeev who became the first Kräshen priest in 1870, sought out children who had studied in the maktab. To demonstrate the superiority of his teaching, he asked the maktab students to read in public a page of the Gospel in Tatar in Arabic script and then to paraphrase it. Because it was a new work that they had never seen in the maktab, the children were usually unable to complete the task. They tried to read the text in the way that they had learned at school, by naming each letter (mim for $\mathrm{m}$, nun for $\mathrm{n}$ ), without understanding the sound the letter stood for. Thus, the meaning of the word escaped them. Timofeev then asked them to read one of the books that they had studied in the maktab. The children easily read the text, without spelling out the letters, but often were unable to paraphrase it; the literary calques from Arabic proved too difficult for them. ${ }^{48}$

Timofeev then called upon one of his own students, who was usually much younger than his competitors. He read the Gospel in Russian, translated it into Tatar, and then opened the Book of the True Faith (Chyn den keniagiase), Il'minskii's primer in vernacular Tatar. To the great astonishment of the Tatar and Kräshen adults, for whom the Qur'an remained immediately incomprehensible, the child was able to read in both Tatar and Russian. ${ }^{49}$

It goes without saying that Timofeev's testimony was partial. His accounts were designed to win the sympathy of the Holy Synod and the Ministry of Education. Probably the children failed to understand Timofeev's command because they were given little time to perform the task and felt intimidated. At the Qur'anic school they had not been trained to translate texts. Nevertheless, Timofeev's assessment of Muslim primary education is supported by the Tatars themselves; in the $188 \mathrm{os}$, Muslim Tatar modernists offered the same critique of maktab education. However, if young children were not capable of reading a text unknown to them, adults did perform the task magnificently. In one instance, Timofeev asked two literate Tatar women to read passages from the literary Tatar translation of

47. Troitskii, "Novokreshchenskie prikhody", in NART, f. 10, op. 2, d. 1383, 1. 126.

48. Il'minskii, ed., Kazanskaia tsentral'naia, 34-35, 42, 49, 51, 66, 175, 230-231. Probably Timofeev had the boys read Kazem Bek's translation of the New Testament. See Priest K. Prokop'ev, Perevody khristianskikh knig na inorodcheskie iazyki v pervoi polovine XIX v. (Istoricheskii ocherk) (Kazan, 1904), 36.

49. In Russian: Nachal'noe uchenie pravoslavnoi khristianskoi very. Il'minskii, ed., Kazanskaia tsentral'naia, 132, 224. 
the New Testament in Arabic script which, according to its critics, was filled with Arabic and Persian words. The women recognized the names of the prophets in Jesus's genealogy and discussed the differences between the Islamic account of Jesus's life and the Gospels. ${ }^{50}$

To compete with Islamic knowledge, Timofeev, probably under Il'minskii's influence, introduced three pedagogical practices unknown in the maktab before the rise of modernism: phonetic reading, immediate comprehension of the text, and the simultaneous translation of sacred texts into the vernacular. This approach was contrary to Muslim education, which insisted above all that every character of the text was inviolable and that every word of the Qur'an had so many meanings that it necessitated years of study, if not a lifetime, to apprehend. In traditional schools, before the rise of modernist schooling, shakirds had their first lessons of Arabic grammar in the madrasa when they turned teenagers and not at the elementary level.

By making Western pedagogy the norm for all forms of scientific and religious knowledge, Timofeev directly attacked peasant Islam and its magical components that inspired the Kräshens to apostatize. To struggle more successfully against its dangers, the missionary popularized Malov's polemical methods, opposing popular to literate Islam. He criticized the Muslim Tatars and the Kräshens for the faith they placed in healers and for their pre-Islamic animist beliefs that their ignorance of their own sacred texts encouraged. The Tatars, he said, do not know their own religion because the Qur'an is written in a language that they do not understand. For example, the Tatars of Mamadysh district believed that Muhammad worked miracles even though this directly contradicted the Qur'an. Timofeev ended his talks by claiming that he had studied the scriptures of both Islam and Christianity, compared the two religions, and consciously and scientifically chosen the latter. ${ }^{51}$

Similarly, Timofeev encouraged the Kräshens to pray freely in their own words rather than recite Muslim prayers that meant nothing and that the Tatars themselves did not comprehend. Timofeev also used history, politics, and science to attack Islam. Thus, when the Kräshens alluded to the Mahdi, he noted the weakness of the Ottoman Empire. When the Tatars claimed that Islam was the religion of Adam, he showed that historically the Christian faith was older than the Muslim faith, and therefore the true religion. He used globes and maps to prove that the earth was round, contrary to what most Tatar peasants believed..$^{52}$

Finally, Timofeev turned to music to spread the Gospel, which was also one of the media by which Sufi Islam spread in Kräshen and Tatar milieus. Missionaries favored the development of choral music, which did not exist among Muslim Tatars and taught notations with numbers. This had an enormous appeal for the Kräshens who could understand the Divine Liturgy for the first time..$^{53}$

50. Il'minskii, ed., Kazanskaia tsentral'naia, 51, 53, 54 .

51. Il'minskii, ed., Kazanskaia tsentral'naia, 69, 148.

52. Ibid., 37-38, 40, 44-46, 59, 61-62, 63, 65, 134, 162.

53. An Altai priest, Father Makarii (not to be confused with the famous Altai monk and missionary Makarii Glukharev) visited the Kazan Central Baptized-Tatar School in 1868 and introduced students to the simplified music notation system developed by Émile and Nanine Chevé in the $1840 \mathrm{os}-1860 \mathrm{os}$. "Ob otkrytii v g. Kazani Bogosluzheniia na tatarskom iazyke," 50-54. 


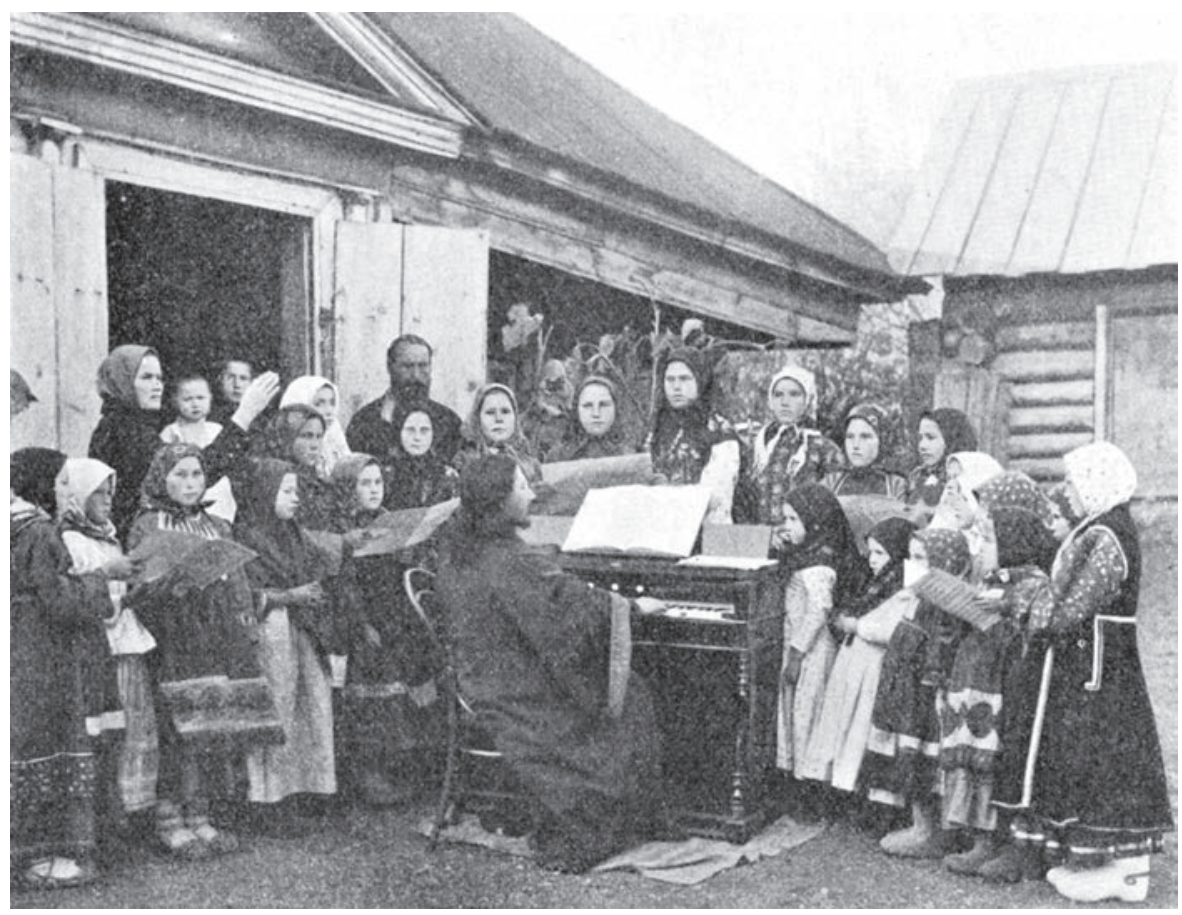

4.4: Choral music in a Kräshen school (Shumilov's picture). Rossiia: Polnoe geograficheskoe opisanie nashego otechestva (SPb., 1901), vol. 6, p. 134.

\section{Kräshen Hagiography, Iconography, and the Afterlife}

Il'minskii (in collaboration with Timofeev) published the first primer in Kräshen language in 1862 through the University of Kazan. Five years later, with the support of Malov, vice-governor Rozov, archbishop Antonii (1815-1879), and the curator of Kazan educational district Petr Shestakov (1826-1889), Il'minskii founded the Brotherhood of St. Gurii, which became responsible for the opening of native schools and the publication of religious literature. In 1868, the Brotherhood and the translation commission attached to it obtained the right of censoring its own publications, which greatly facilitated their diffusion. Probably because many of the books, but not all, involved translations of sacred scriptures and liturgical works, their content has not excited much interest from Tatar, Russian, or Western historians. ${ }^{54}$

54. Bukvar', kratkaia sviashchennaia istoriia, sokrashchennyi katekhizis, nravoucheniia $i$ molitvy, izlozheny dlia kreshchenykh iz tatar na ikh razgovornom iazyke po Bukvariu izdannomu $v 1861$ godu, $v$ Sanktpeterburgskoi Sinodal'noi tipografii (Kazan, 1862); Vitevskii, "Nikolai Ivanovich Il'minskii," 70-71 (Il'minskii and Timofeev worked together on the primer for a whole month before its publication, and in 1863, Timofeev suggested new ways to improve its translations); Protoierei Aleksandr Nikol'skii, Perevodcheskaia kommissiia pravoslavnogo missionerskogo obshchestva pri Bratstve Sv. Guriia v Kazani. Ocherk iz istorii pravoslavnoi missii sredi inorodtsev Rossii vo vtoroi polovine XIX-go stoletiia (Moscow, 1901), 8-21; N. V. Nikol'skii, Perevodcheskaia kommissiia v Kazani i ee prosvetitel'naia deiatel'nost' sredi inorodtsev (Kazan, 1905), 7; on the history of Kräshen publications, see Abrar Karimullin, Tatarskaia kniga poreformennoi Rossii (Kazan, 1983), 244-269; Geraci, Window on the East, 127. 
However, the choice of texts translated into the Turkic dialect of Mamadysh district, called Tatar and later Kräshen language in the Brotherhood of St. Gurii publications, indicated that the missionaries catered to their audience and favored aspects of thaumaturgical Christian Orthodoxy likely to compete successfully with Sufi narratives and ancestral worship. Il'minskii opposed the translation of the Russian Eastern Orthodox catechism whose questions and answers might work for Russian children already imbued with Christianity, but whose arid form could only repel native children. Stories of saints and martyrs worked better to touch the hearts of the baptized community of Tatars. Il'minskii in general discouraged the use of Arabic words to translate the names of the patriarchs and apostles and concepts proper to Christianity. However, the Kräshen publications retained some key words of Arabic and Farsi origins such as Alla or Kodai for God, pagambiar for prophet, piarishtia for angel, sadaka for alms, sauap for merit for a pious deed, uraza for fast, iman for faith, äüleia for saints, zhen for demons, sagat for the (last) hour, and azab for torments, which allowed Kräshen readers to establish first equality with their Tatar neighbors and later confessional superiority. When challenged by apostates or Muslim Tatars, Kräshens could argue that Christianity also had pillars of faith, ways of earning merit in this life and beyond, and saints. Among them was the famous Nikolai äüleia (or Izge Nikolai), known to all peoples of the world, be they Arab, Turkish, or Tatar. However, Il'minskii did not opt for du'a or namaz-Arabic words for prayer-but used the native word keläu (sacrificial prayer), which designated domestic offerings for the family tutelary spirits. ${ }^{55}$

While itinerant Sufis viewed apostates as shähidlär (martyrs of the faith, an Arabic word dubbed with a Turkic plural suffix), Kräshens came to identify themselves with mucheniklar, a Russian word referring to Christian martyrs. Il'minskii, emulating Apostle Paul, wrote touching Tatar epistles to his former students, now teachers in remote Kräshen villages and subject to discouragement and alienation. The missionary reminded them of the fate of the Christian martyrs, advising them and the village elders who suffered prejudice from younger apostates to hold fast. "Despite persecution," he wrote thinking of the fate of early Christians in the pagan Roman Empire, "faith has always increased." ${ }^{6}$ When she entered the houses of apostate families, the very first female Kräshen pedagogue, Feodora Gavrilova, fully identified herself with the saint after whom she was named. Her sufferings in apostate milieu, she wrote, were nothing compared to St. Theodora the Virgin who suffered persecution under the Roman emperor Diocletian (284-305) because she refused to marry a nonbeliever

55. Bukvar' dlia kreshchenykh tatar (zhazyu beldereu) (Kazan, 1875), 7-8; Bukvar' dlia kreshchenykh tatar (zhazyu beldereu) (Kazan, 1882), 9-10; “Čın den kenägäsennän alyän bülek," in Bálint, Kazáni-Tatár Nyelvtanulmányok, 67-68; Poucheniia na kriashenskom iazyke (Kazan, 1891), 6, 33, 74, 92; Kingiash izge zhazyuny ukyunyn paidasy turysynda (Nastavlenie o pol'ze chteniia sviashchennogo pisaniia na kriashenskom iazyke) (Kazan, 1892), 3-4; Bukvar' dlia kreshchenykh tatar (Kazan, 1911); Zemnaia zhizn' gospoda nashego Iisusa Khrista na kriashenskom iazyke (Khodaibyz Iisus Khristosnyn jirdiage tormosho) (Kazan, 1900), 50-51; Sviatoe Evangelie Gospoda nashego Iisusa Khrista na kriashenskom iazyke (Kazan, 1891), 90, 93, 169; Prokop'ev, Perevody khristianskikh knig, 13; Mashanov, Religiozno-nravstvennoe sostoianie, 23; Malov, "Ocherk," 17, pt. 3 (1871): 401. All these words are still part of the Kräshens' religious speech, see Flera Bayazitova, Älmät töbäge tatarlarï (Kazan, 2001), 168.

56. Pis'ma N. I. Il'minskogo k kreshchenym tataram (Kazan, 1896), 65-66. See also the Kräshen Stepan Danilov who identified himself with Christian martyrs, "Vospominaniia starokreshchenogo," 21. 
and wanted to dedicate her life to Christ. Ignoring her audience's initial hostility, Feodora made the sign of the cross and read stories of female martyrs, starting with her own saint. Miraculously, she exclaimed, apostate women, amused and stung by her courage, although literate in Arabic script, asked her about the saints they were named after and later invited her to read more stories while they were weaving cloth. ${ }^{57}$ And when the apostasy movement was once again raging in Ianasal, another young Kräshen teacher, Semen Maksimov, read excerpts from the lives of the saints to comfort his students who numbered five instead of the usual twenty-two. ${ }^{58}$

Thus hagiography constituted a central tool of proselytization and teaching. At the beginning of the twentieth century, villagers in Nikiforova knew up to thirty lives of saints and these stories, along with other prayer books, played an important role in the construction of Kräshen identity even during the Soviet period. ${ }^{59}$ Orthodox hagiographies contained stories of Christian martyrs from Rome, Egypt, Constantinople, but also from the land of Bolghar and Kazan. If in the Muscovite Russian edition of the Lives of the Saints the vita of the Turkic Bolghar St. Avraamii occupied only two lines, in the Kräshen edition it was three pages long. During his mission trips, Malov read to the baptized of Apazovo, who increasingly leaned toward Islam, that St. Avraamii was the first Turkic martyr to shed his blood in the land of Kazan, before the Mongol invasion of 1237-1240. Although Muslim and rich, this Bolghar merchant was celibate, lived soberly, and fed and clothed the poor. After his conversion-God granted him faith for his remarkable behavior-St. Avraamii gave up trade and taught the Gospel in market places. Upset, the Muslim Bolghars threw him into prison, tortured him for days, and on April 1229, cut his hands, his feet, and finally decapitated him, but St. Avraamii refused to renounce his faith. Taking Avraamii as their example, the villagers of Apazovo, Malov concluded, should remain dedicated to Christ, and God would reward their steadfastness. ${ }^{60}$

In the Lives of the Saints, a central piece of the religious curriculum of the Kazan Central Baptized-Tatar School, children learned that they were part of a global history

57. Feodora Gavrilova first taught reading and singing in the fall of 1865 in the girls' school of Nikiforova, Mamadysh district, founded by Timofeev. Istoricheskie svedeniia o nekotorykh shkolakh, sviashchennikakh, rukovoditeliakh i uchiteliakh Bratstva sv. Guriia (Kazan, 1892), 4-5; Il'minskii's letter (11 July 1866) in Materialy po istorii Tatarii vtoroi poloviny 19-go veka, 241; "Zhurnal obozreniia eparkhii ego vysokopreosviashchestvom v nastoiashchem 1870 godu," IKE, no. 20 (15 October 1870): 619; "Pis'mo sel'skoi uchitel'nitsy, kreshcheno-tatarskoi devitsy, Feodory Gavriloi, k sviashchenniku Vasiliiu Timofeevu ot 7 fevralia 1872," IKE, no. 22 (15 November 1877): 615-625 and "Perevod drugogo pis'ma uchitel'nitsy Feodory Gavrilovoi k o. Vasiliiu," IKE, no. 24 (15 December 1877): 689-691; "Izge Feodora tormosho," in Razskazy iz zhitii sviatykh na kriashenskom iazyke, 2nd ed. (Kazan, 1907), 162-165.

58. NART, f. 1, op. 3, d. 3272, 11. 6-6 ob.

59. Aleksei Voskresenskii, "Otchet o prepodavanii zakona Bozhiia v Kazanskoi tsentral'noi kreshcheno-tatarskoi shkole za 1890-1891," IKE, no. 20 (15 October 1891): 615; NART, f. 967, op. 1, d. 179, 11. $42-43$.

6o. Rasskazy iz zhitii sviatykh na tatarskom iazyke (Kazan, 1899), 10-13; "Izge Avraamii," in Zhitie sv. Avraamiia, muchenika Bulgarskogo. Izlozheno na kreshcheno-tatarskom iazyke, sperefrazirovannym russkim perevodom slushatelem Kazanskogo Chastnogo Missionerskogo Priiuta Dmitriem Timofeevym Medvedevym (Kazan, 1878), 4-10; Zhitiia sviatykh na russkom iazyke izlozhennye po rukovodstvu Chet'ikh-Minei sviatitelia Dimitriia Rostovskogo. Mesiats aprel' (Moscow, 1906; repr., Borovsk, 1997), 31; "Zhitiia sviatykh i Bogonosnykh Sviatitelei i strastoterptsev zemli Kazanskoi. Sv. Muchenik Avraamii Bolgarskii," IKE, no. 10 (15 May 1900): 420-426; Iapei babai, "O kreshchenykh tatarakh," no. 19 (1 October 1891): 605. 
of multiethnic martyrs, that Russians had suffered from the "Tatar yoke" in the same way Kräshens experienced pressure from Islamized neighbors, and that Russians admired and cared for their Bolghar and Tatar brothers in Christ. Thus martyrs were of Greek, Armenian, Syrian, and Turkic origin. Besides the Bolghar St. Avraamii, Kräshens could take pride in two other Turkic saints who had converted to Christianity after the conquest of Kazan: Stefan, whose faith in Christ healed his legs, and Petr, who came to Christ while working for Russian boyars. Both Tatars knew that their own people would persecute them for their faith and their Christian names, but they both accepted baptism and its painful consequences. ${ }^{61}$ Russians, including the martyred prince of Chernigov, had died in the hands of the Tatars. Thus, Russians and Kräshens had both suffered from infidel Tatar intolerance, and Kräshens in their Lives of the Saints learned that their martyrs were also a subject of awe for their older brothers in Christ. Russian merchants who traded in Bolghar city admired Avraamii so much that they gathered his truncated limbs and buried them in the Christian cemetery. Even the prince of Vladimir, Georgii Vsevolodovich, had heard of the Turkic saint. As soon as he made peace with the Bolghars, the prince asked the khan's permission to transfer Avraamii's remains to his capital city. Enshrined in the Dormition Cathedral, the Turkic saint's relics attracted Russian pilgrims who venerated him, wore his healing chains, and pleaded for his intercession. As for St. Stefan and St. Petr, the Russian Metropolitan Germogen of Kazan and Astrakhan who converted many Tatars in the sixteenth century, asked that they be canonized. ${ }^{62}$

In the chapel of St. Gurii, opened in 1871 and located on the second floor of the Kazan Central Baptized-Tatar School, the young students prayed to the icons of the saints who had spread Christianity in Russian and Turkic milieus. They asked for the intercession of St. Vladimir who was responsible for the baptism of all Russia in 987-988. Russians, as the students learned from their textbooks, did not differ much from the Kräshens when they accepted baptism. They worshiped Perun, Kupalo, Lado, and Koliado and up to this day mentioned the names of their pre-Christian pagan gods in their wedding songs and agricultural festivals. Kräshens could be better Christians than their Russian teachers if they were to give up their cult of the kirämät and let the priest bless their fields instead of performing animal sacrifices. Furthermore, Vladimir's conversion was the result of his search for the best religion: Muslim Bolghars as well as representatives of other religions came to the Kievan court to advertise for their faith and Vladimir sent about ten sages to these representatives' lands to observe their practices; in the end Vladimir chose the true religion for his people, the Greek faith through Constantinople. ${ }^{63}$

At the chapel, students and their parents could also pray to the icons of Kiril and Method who proselytized among Slavs in their vernacular languages and created the

61. "Stepan belian Petrnyn Kazan kalasynda Khristos dene öchön azablanyulary," in Rasskazy iz zhitii sviatykh na tatarskom iazyke, 30-34.

62. Voskresenskii, "Otchet o prepodavanii zakona Bozhiia," 615; E. A. Malov and P. N. Akhmerov, Sviatyi muchenik Avraamii Bolgarskii (Bu kitāb shähär Bulghārda shähīd bulghan 'Isawī Abrāhāmi wälī tughrïsïndadir) (Kazan, 1898), 7-13.

63. Russkie pervomucheniki na tatarskom iazyke (Kazan, 1898), 4-10; Rasskazy iz Russkoi istorii na tatarskom iazyke (Kazan, 1909), 5, 16, 18-19; “Čın den kenägäsennän alyän bülek,” in Bálint, Kazáni-Tatár Nyelvtanulmányok, 67. 
Russian alphabet, which served as the basis for the Kräshen alphabet. They could ask for the intercession of major Russian Kazan saints, in particular the first archbishop of Kazan St. Gurii (d. 1564), whose life echoed that of beautiful Joseph. Gurii, like the son of Jacob, served a prince who, because of his great piety and honesty, hired him to manage his household. As in the Genesis story, Gurii's enemies spread rumors that he had sexual relations with the prince's wife and imprisoned him. In jail, Gurii suffered torments for two years but remained dedicated to his faith and wrote catechisms for children. God delivered him miraculously and later Gurii spread the Gospel among the Tatars in the same way Joseph witnessed his faith in the land of Egypt. ${ }^{64}$ The icon of Saint Varsonofii, the first abbot of the Transfiguration Monastery in the Kazan kremlin, who learned to speak, read, and write in Tatar while prisoner among the Crimean Tatars, could also excite the children's interest. The saint's refusal to convert to Islam and his faith in Christ earned him the Tatars' admiration, and later his knowledge of the Tatar culture and language helped him spread the Christian faith among all peoples of the Middle Volga. Another icon, Germogen's, reminded children and visitors that the sixteenth-century metropolitan of Kazan did not distinguish between converted Russians and converted Tatars and treated them equally. ${ }^{65}$ Finally two icons-St. Avraamii's martyrdom and the parable of the Lost Son (Luke 15, 11:32) —addressed three important facets of the Kräshens' world: their Turkic roots, Islam, and the danger of apostasy. At the center of Avraamii's icon, the Bolghar saint stood with a cross in his hand. At the top Christ blessed him from the clouds and at the bottom a mullah donned with a white turban and a crowd of angry Muslims armed with axes and knives moved toward him. Close to Avraamii's icon was the parable of the lost Son reminding Kräshens that there was always room for repentance and forgiveness. During their visits to Kräshen villages tempted to apostatize, missionaries and former students of the Kazan Central Baptized-Tatar School liked to read this parable to their kin. ${ }^{66}$

The archbishop Antonii, strong supporter of Il'minskii, played a central role in the promotion of Avraamii as a Kazan saint among both Kräshens and Kazan Orthodox Russians. Islam had left a profound mark in the Volga sacred geography and Antonii, aware of it, sought to recuperate the sacred geography of the former Bolghar state. Thanks to him, the archbishop of Vladimir in 1873 sent a copy of the martyr's icon and a piece of his relics to the Annunciation Cathedral located in the Kazan kremlin. Five years later, Vladimir's bishopric donated another icon and relics to the church of St. Nikolai in Bolghar city, which was the center of a famous Muslim shrine frequented by Kräshens and Chuvash. Antonii also asked the journal of Kazan diocese (Izvestiia po Kazanskoi Eparkhii) to locate the little known miraculous icons of Kazan province. Among the icons cited in the journal was the one popularly called istochnitsa (from the Russian word istochnik, which means spring) or Mother of God of the Beautiful Spring, located in another ancient city, Biliarsk, at the famous

64. Akafist sviatiteliu Guriiu Kazanskomu i Sviiazhskomu chudotvortsu na tatarskom iazyke (Kazan, $1890)$

65. Zhitiia sviatykh na russkom iazyke ... Mesiats oktiabr' (Moscow, 1902; repr., Borovsk, 1997), 89-95; Mesiats noiabr' (reprod. Moscow, 1905), 129-130.

66. "Materialy dlia statistiki v istorii Kazanskoi eparkhii. 1: Istoricheskoe opisanie tserkvei g. Kazani (prodolzhenie). 12: Kreshcheno-tatarskaia shkola," IKE, no. 3 (1 February 1876): 87-94. 
Khojas' mountain, which miraculously had survived two fires. In times of natural catastrophe, Russians, Mordvins, Chuvash, and Kräshens came from surrounding villages to pray to this icon. Tatar legends claimed that forty young virgins who had led a secluded life in prayer and then taken arms against Tamerlane rested under the mount and the apostates of Verkhniaia Nikitkina believed that a forcibly baptized commander-of-chief was buried at the site as a Muslim saint. But Christian legends affirmed that long ago an icon disappeared from the neighboring church and called a young Muslim girl to embrace Christianity. The girl saw what she called "the Russian god" floating on the lake and alarmed everyone, but the icon refused to be held by anyone but her, even the Russian priest. When the icon disappeared from the church one more time, it refused to be taken back to the sanctuary unless the girl accepted baptism. The girl obeyed, then took the icon and placed it in the church. She dedicated her life to Jesus and became a Christian saint whose tears of love for Christ formed the spring of Khojas' mount. ${ }^{67}$

Despite the lack of information about the story's origin, it is undeniable that the sacred site of Biliarsk was the center of competing Muslim-apostate-Christian myths already in the 1860 s, and that there was room for Christian Tatars to identify themselves with saintly figures in the ancient Bolghar landscape. Antonii obviously was not directly responsible for the symbiosis of Christianity and sacred Volga geography; however, the church of Kazan province was willing to investigate and promote the miraculous within its own tradition to compete with Sufi Tatar legends. In the $1920 \mathrm{~s}$ the site of Biliarsk was still largely controlled by Muslim Tatars: Kräshens and Chuvash had to pay for the sacred water while Muslims could get it for free, and they continued to appeal to the intercession of Sufis, who lived in cells, for their ancestral sacrifices. ${ }^{68}$

Beside the stories of famous Sufi shaykhs and prophets, life after death constituted another important discourse among Kräshens and Tatars. Missionaries had to respond both to the powerful depictions of the afterlife in popular Islamic discourse and no less powerful conceptions of death in the Kräshens' indigenous tradition. Kräshens' understanding of the afterlife (be they apostates or not) was strongly influenced by Islam. In both popular Islamic and animistic understanding of the afterlife, the living and the dead were still connected after death. If the souls in prejadid religious literature asked for God's permission to descend on earth and if pious children could add religious merit (sawab) for their dead parents in whose name they recited prayers, animistic Kräshens believed that the dead descended on the earth every Thursday, and that it was the responsibility of the living to remember and honor them by heating the muncha and preparing a special meal. The afterlife for animistic

67. Malov and Akhmerov, Sviatyi muchenik Avraamii Bolgarskii, 17; "Chestvovanie pamiati sviatogo muchenika Avraamiia bolgarskogo," IKE 32, no. 10 (1898): 393-396; "Chudotvornye i osobenno mestno chtimye ikony i krestnye khody v Kazanskoi eparkhii. V gorode Sviiazhske,” IKE, no. 4 (15 February 1872): 115; "Chudotvornye ... V Chistopol'skom uezde," IKE, no. 11 (1 June 1872): 345-346; Viktor Vishnevskii (Kafedral'nyi protoierei), "Priobretenie dlia Kazanskoi eparkhii sv. ikony s chastitseiu moshchei sv. Muchenika Avraamiia Bolgarskogo," IKE, no. 22 (15 November 1873): 689-691; Tarzimanov and Rakhim, "Khuzialar Tauy," 177.

68. Tarzimanov and Rakhim, "Khuzialar Tauy," 174-175; "Chudotvornye ... V Chistopol'skom uezde," 345 . 
Kräshens was the continuation of their earthly life. The dead had the same needs as the living, and when people died, relatives placed money in the grave to insure that the deceased would find a place to live in the other world. ${ }^{69}$

The Russian Orthodox Church in Kazan found material within its own tradition, in the Life of Basil the Younger, a tenth-century Byzantine eschatological work, to reform Islamic and animistic representations of life after death among Kräshens. The St. Gurii Brotherhood translation commission published a portion of the text, the story of a pious but sinful woman, Theodora, whose soul was spared the ordeal of the twenty demonic tollgates thanks to the intercession of her confessor, the monk Basil the Younger (d. 944). After death, individual souls had the obligation to pay for their sins at tollgates. Each tollgate corresponded to a particular sin or sets of sins; but Theodora did not have to pay, thanks to her teacher and confessor who approached the angels and gave them a portion of his own merit to reimburse her debt of $\sin ^{70}$

In the same way Byzantine Christians had reckoned with pagan Greek practices and transformed the Greeks' conception of the afterlife through their biblical understanding of Christ's resurrection, Russian missionaries in the Volga region reckoned with the Kräshens' eschatological expectations to consolidate Christianity in their midst. The story of Theodora and Basil was potentially of great appeal for a Kräshen audience. Its imagery was not that different from Islamic eschatology and no less didactic. Angels of light who resembled young children took Theodora's soul toward heaven, while pig-like and wolf-like devils sought to grab her soul away. Sins and good deeds that comprised all Christian duties — church attendance, kissing icons, lighting candles, confession, alms-were weighed on a scale. Theodora passed an exam of her faith reminiscent of the questioning of the angels Munkar and Nakir in Islam. The ascent motive was already familiar to a Kräshen audience who had been exposed to the Prophet's celestial journey, which in talismans served to illustrate the wanderings of the soul after death. The story also had the characteristics of a dream-like reality. First Theodora appeared to Grigorii, a disciple of Basil the younger, in his sleep and told him in the first person of the state of her soul at the time of her agony and after death. Then Theodora's soul ascended from one station to the other and arrived at the gates of heaven on the fortieth day. In both Sufi and animistic milieus dreams constituted a communicative conduit between the living and the dead, between human beings and the divine. Kräshens quickly consulted the küremche or performed a sacrifice when they saw a deceased relative in their sleep, and the dead in Islamic religious books appeared to the living when they needed their community's support. ${ }^{71}$

Another important aspect of Theodora's tale was its emphasis on intercession, which was also a central theme in premodernist Islamic religious books. Theodora owed her deliverance from the ordeal of the demonic tollgates to the intercessory

69. Matvei Andreev, "Khristianstvo sredi tatar Srednego Povolzh'ia v XVI-XIX vekakh (istoricheskii ocherk)" (Kursovoe sochinenie, 1915), in NART, f. 10, op. 2, d. 1283, 1. 228.

70. Nicolas Constas, “'To Sleep, Perchance to Dream”: The Middle State of Souls in Patristic and Byzantine Literature," Dumbarton Oak Papers, vol. 55 (2001): 108.

71. O zagrobnoi zhizni po ucheniiu pravoslavnoi tserkvi na kreshcheno-tatarskom iazyke. (Kabergia kergiannian blaigy tormosh) (Kazan, 1892), 6-12; Brotherhood of St. Gurii’s report (Kazan, 1893) in Khristianskoe prosveshchenie, 289-291; Constas, “"To Sleep, Perchance to Dream,” 92; Iakov Emel'ianov, Stikhi na kreshcheno-tatarskom iazyke (Kazan, 1888), 23. 
powers of her confessor who prayed for her salvation and asked for God's permission to pay for her debts. In the same way shaykhs and the whole Muslim community could intercede for their disciples on Judgment Day, Christian confessors and the whole Christian community could also intercede for their dead ancestors. As in Kräshen animistic burial practices, money was involved in Theodora's demonic encounter; thanks to her confessor's gold, Theodora was able to find a home in God's presence. If in the Byzantine church early critics discussed the orthodoxy of intercessory prayers quoting Second Corinthians 5:10 ("For we must all appear before judgment seat of Christ, that each one may receive what is due him"), there was no formal condemnation of such practices in Eastern ecumenical councils. However, in the second half of the nineteenth century, some critical members of the Eastern Orthodox faith argued that Theodora's story should be interpreted metaphorically. Such criticism did not keep the Brotherhood of St. Gurii from having the text translated into Tatar and circulating it widely as an actual account of a celestial journey. Theodora's story could serve to spread the Gospel by counteracting Sufi influence and popular understanding of the afterlife. ${ }^{72}$

\section{The Impact of Il'minskii's Schools}

From its modest beginnings, the Kazan Central Baptized-Tatar School grew extremely rapidly from 4 students in $1863-1864$ to 117 in 1870-1871. More impressively, the school trained 636 male teachers, 260 female teachers, 167 priests, 30 deacons, and 45 psalmists between 1863 and 1913. Outside Kazan, the Brotherhood of St. Gurii established 61 schools with 2,040 students among Kräshen Tatars by 1886, with the support of Russian and Kräshen private, zemstvo, church, and Ministry of Education funds. Contrary to the past, children were not drafted and the schools were not imposed by the whip (qamchi) as a jadid journalist emphatically claimed in November 1917. In his "epistles," Il'minskii sought the village elders' support and wrote to them deferentially, explaining his method and learning goals in a clear, concise, and respectful language. ${ }^{73}$ In many cases though, the missionary was unable to open schools in committed apostate areas because of the community's hostility. Sometimes villagers refused to provide a home for the teacher or a place for the school. Such was the case in Verkhniaia Nikitkina, Samigulov's village, Porshur in the Chura parish, Kibiak-Kozi in Laishevo district, Khaivan in Kazan district, or in most baptized villages of the districts of Simbirsk, Tetiushi and Sviiazhsk. ${ }^{74}$

72. Zagrobnaia zhizn'. Razmyshlenie o kratkovremennosti zdeshnei zhizni, o smerti i o vechnoi zhizni (Moscow, 1898), 70, 74-75. This book addressed the Russian intelligentsia and presented Theodora's journey as a metaphor. Il'minskii opposed the use of explicative metaphors in translations. There was no need to argue for the veracity of the faith in intellectual terms. In other words, Kräshens were peasants, not theologians or agnostic intellectuals. "Prakticheskie zamechaniia o perevodakh i sochinenii na inorodcheskikh iazykakh," in Nikolai Ivanovich Il'minskii: Sbornik statei, 124, 126.

73. Chicherina, U privolzhskikh inorodtsev, 52; "K piatidesiatiletiiu kreshcheno-tatarskoi shkoly," IKE, no. 4 (22 January 1914): 109-110; "Raspredelenie shkol i uchashchikhsia po uezdam," IKE, no. 2 (15 January 1887), prilozhenie no. 5; K. Kärīm, "Köchläb chuqïrïndïrïlghan tatarlar Kräshenlär tārīkhïna 'āid,” Shūrā, no. 19 (November 1917): 439; Pis'ma N. I. Il'minskogo k kreshchenym tataram, 44-47.

74. Bobrovnikov, Inorodcheskoe naselenie, 31; "Otchet o deiatel'nosti Bratstva Sv. Guriia za desiatyi bratskii god ot 30-go oktiabria 1876 po 30-e oktiabria 1877 goda," IKE, no. 9 (1 May 1878): 227; Zagidullin, “Tatarskie krest'iane Kazanskoi gubernii," 125, 130; NART, f. 968, op. 1, d. 105, 11. 23-24 ob.; Chicherina, U privolzhskikh inorodtsev, 67 . 


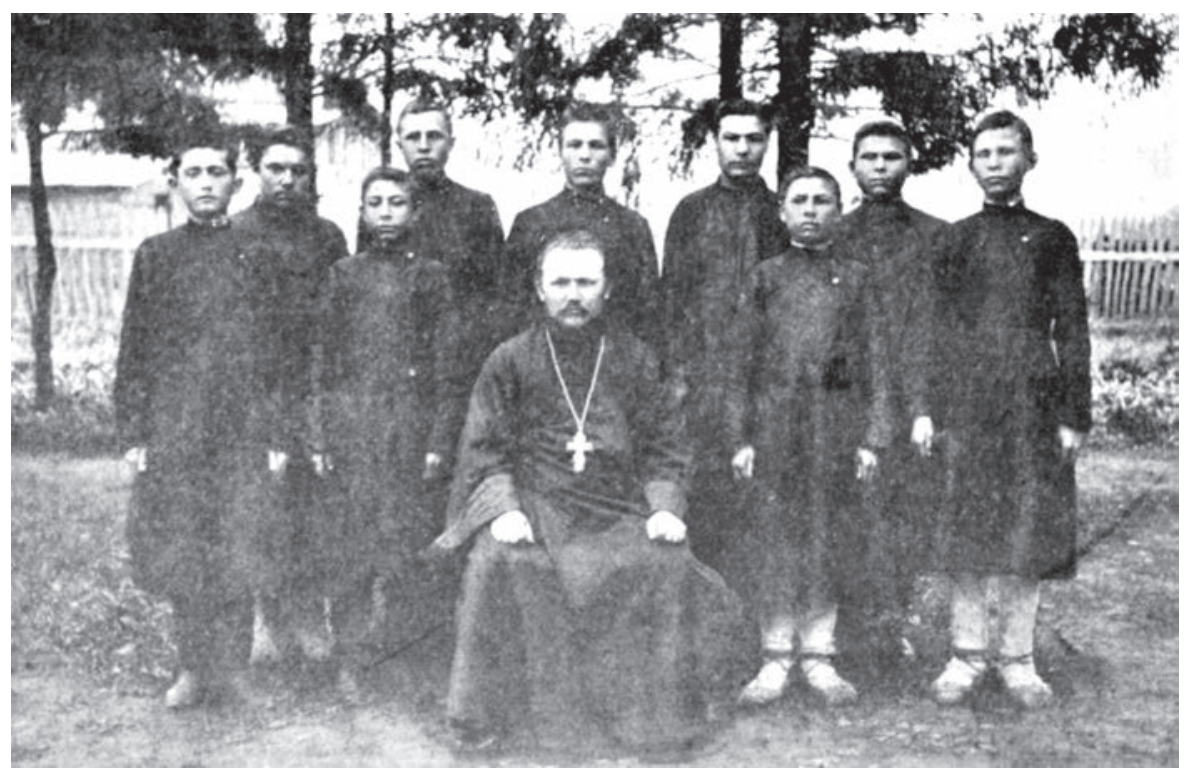

4.5: Boys' section at the Kazan Central Baptized-Tatar School. S. Chicherina, U privolzhskikh inorodtsev. Putevye zametki (SPb., 1905), unnumbered page.

When the community did not support the schools, the Brotherhood, which provided only funds for textbooks, teachers' salaries, and rent, had to terminate them. Such was the case in 1877 when ten schools had to close or be transferred to other villages. Among them was the school of Sosnovyi Mys, which had to cancel its lessons because the community preferred to support the opening of a clandestine maktab. In Apazovo, Ianasal, and Elyshevo, the Brotherhood was able to open schools despite local resistance, and it did so with the support of a portion of the population, sometimes a few individuals, willing to try. Remarkably, many villages that had been slightly exposed to Islam but showed greater attachment to their indigenous beliefs, embraced the schools so much that starting in 1868 they took upon themselves the construction of separate buildings for them. In Kovali, Laishevo district, Kräshens provided free labor and contributed fifty-six rubles toward the school construction. ${ }^{75}$ Later, in the villages of Ziuri, Eryksa, Shemorbash, Teploe Boloto, Tiamti, TomasovPochinok, and Ianyli in Mamadysh district, Ivanaevo and Verkhnie Kazyli in Laishevo district, well-to-do Kräshens opened Brotherhood schools at their own expense or donated their own houses. ${ }^{76}$ For other villages, like Urias'bash more exposed to

75. “Otchet o deiatel'nosti Bratstva Sv. Guriia za desiatyi bratskii god," IKE, no. 4 (15 February 1878): 89 and no. 14 (15 July 1878): 387; "Otchet o deiatel'nosti Bratstva Sv. Guriia za deviatyi bratskii god ot 4-go oktiabria 1875 goda po 20-e oktiabria 1876 goda," IKE, no. 10 (15 May 1877): 278-279; N. Il'minskii, "Shkola dlia pervonachal'nogo obucheniia detei kreshchenykh tatar v Kazani," Zhurnal Ministerstva narodnogo prosveshcheniia, pt. CXXXIV (1867): 317-318.

76. "Otchet o deiatel'nosti soveta Bratstva Sv. Guriia s 4 oktiabria 1869 po 4 oktiabria 1870 goda," IKE, no. 1 (1 January 1871): 24; "Izvlechenie iz otcheta Vysokopreosviashchenneishego Sergiia, arkhiepiskopa 
Islamic influence, the villagers refused to have a school in the 1870 s but twenty-five years later they donated the material and built the school with their own hands. In Nizhniaia Nikitkina, where Kräshens lived among Russians, the Brotherhood school took firm root; each household possessed Kräshen books and in each house a child or an adult could read these books aloud. ${ }^{77}$

There is little information about the patrons. A few were indigenous priests or teachers who saved money to support the building of separate schools, but most were well-to-do peasants or artisans. One of them, Nikifor Nikolaev in TomasovPochinok, was an Islamized illiterate tailor whose piety had gained him the

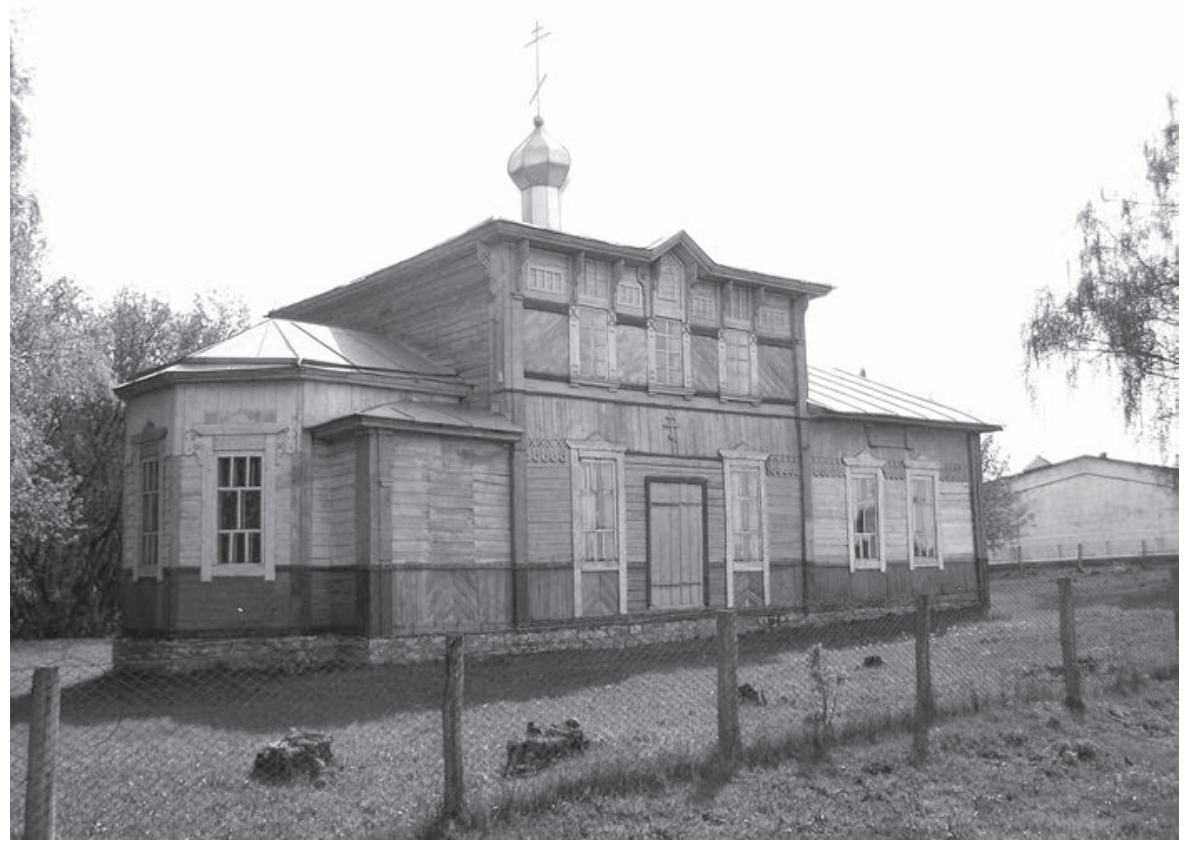

4.6: Church of Ianyli built in 1907. Photograph by the author.

Kazanskogo i Sviiazhskogo, o sostoianii Kazanskoi eparkhii," IKE, no. 12 (15 June 1880): 330; "Otchet o deiatel'nosti Bratstva Sv. Guriia za trinadtsatyi bratskii god ot 19-go oktiabria po 26-e oktiabria 1880 goda," IKE, no. 15 (1 August 1881): 392; "Otchet o deiatel'nosti Bratstva Sv. Guriia za chetyrnadtsatyi bratskii god," IKE, no. 18 (13 September 1882): 481; Otchet o deiatel'nosti Bratstva Sv. Guriia za semnadtsatyi bratskii god, 8-11; Otchet Bratstva Sv. Guriia za dvadtsatyi bratskii god s 4 oktiabria 1886 goda po 4 oktiabria 1887 goda (Kazan, 1887): 20; Otchet o deiatel'nosti Bratstva Sv. Guriia za dvadtsat' tretii bratskii god s 4 oktiabria 1889 goda po 4 oktiabria 1890 goda (Kazan, 1890), prilozhenie k IKE, nos. 22-24, 47; letter of Men'shikov, priest of Achi, to Il'minskii in October 1869, NART, f. 93, op. 1, d. 128b, 1. 191; "Iz zhizni kreshchenykh inorodtsev Kazanskogo kraia," 29, footnote 28.

77. "Otchet o deiatel'nosti Bratstva Sv. Guriia za tridtsatyi bratskii god s 4 oktiabria 1896 goda po 4 oktiabria 1897 goda," IKE 32, no. 24 (15-20 December 1898): 38; "Otchet o deiatel'nosti Bratstva Sv. Guriia za deviatyi bratskii god," IKE no. 6 (15 March 1877): 178; "Obshchii obzor deiatel'nosti Soveta Bratstva Sv. Guriia po ustroistvu inorodcheskikh shkol," IKE no. 14 (15 July 1878): 387-388. 
nicknames (qushamat) of Bik-Mökhämmät (literally, a real Muhammad) and Mulla Mikei. Thanks to Il'minskii's school, his family came to form the intellectual elite of his village. Before befriending Timofeev, Nikolaev used to send his children to the Qur'anic school, but after learning about the Kazan Central Baptized-Tatar School, he sent his son Ivan to acquire the Russian language, which he believed to be essential for business. After two years Nikolaev changed his mind about Christianity. For holidays Ivan returned home and read to him and his mother. Later Ivan became a teacher and a priest. His younger brothers, Efim and Filipp, following his path, taught in the sensitive areas of Tomasov-Pochinok, Bol'shie Savrushi, Tri Sosny, and Apazovo, and their sister Agaf'ia married a Kräshen teacher, Sergei Kuz'min. In his testament, Nikolaev donated his house and barns to the Christian school of his native village and let his family know that he wanted his funerals and wakes to be conducted in Tatar. One of the factors that facilitated Mulla Mikei's "return" to Christianity was that his wife had not been exposed to Muslim schooling and did not object to her husband's sending Ivan to Kazan. ${ }^{78}$

Teachers like Ivan, despite their youth, were very much committed to their mission. They were between twelve and fifteen years old, and Il'minskii, aware of their lack of experience, wrote them often. They sent him bilingual letters, filled with case and spelling errors in Russian, asking him for help and advice. In one of them, a young teacher assigned to the apostate village of Elyshevo expressed genuine commitment to the Christian faith and anxiety over the rapid Islamization of the village. Some people were nice to him, he wrote, but others refused to listen. What he feared most was the return of the tailors in the spring; then no one would listen. The young missionary, however, did not lose hope, remained committed to his mission, taught children, invited people to the school for tea, and read them stories from the Gospels and from the lives of Christian martyrs. ${ }^{79}$

If in places like Elyshevo Il'minskii's school knew little success, in other areas the school took firm root not only among the school-aged population but also among adults. What facilitated its influence was the official adoption of the Il'minskii system of education in 1884 by parish schools in indigenous areas. In 1876, a priest noted that since the foundation of a school in Tashkirmen', Laishevo district, seven years prior, the younger generation knew their prayers, and sang them for themselves at work. ${ }^{80}$ In 1882 and 1889 , other priests reported stronger successes in the parishes of Iukachi in Mamadysh district, Utiashki in Chistopol' district, and Pannovo in Laishevo district. There male adults, not just the schooled young, quoted passages from the Old and New Testaments and sang prayers. In addition to studying during the day, children also gathered in the schools in the evening to sing in front of their parents or listen to their teachers' edifying stories. Before the introduction of Il'minskii's school Nagaibak families in the settlement (poselok) of Parizh did not pray or sing for the dead at home, but now they possessed Orthodox memorial books and organized wakes in their houses. In Serda, villagers attended the church on the days devoted to the dead (roditel'skie subboty) and prepared the diptychs or lists of names for the

78. "Iz zhizni kreshchenykh inorodtsev Kazanskogo kraia," 26-30.

79. Letter from Il'ia Andreev, NART, f. 968, op. 1, d. 82, 1l. 44-45 ob.

8o. "Otchet o deiatel'nosti Bratstva Sv. Guriia za deviatyi bratskii god," no. 6 (15 March 1877): 179-180. 
living and the dead to be prayed for on their table before the priest's visit to their homes. Some women in the village of Baran, Tetiushi district, even took their children to far away parish churches to receive communion. At the end of the nineteenth century, despite the Brotherhood's limited funds, the thirty Kräshen parishes included nineteen priests and five deacons of Kräshen origin. In 1904, the number of Kräshen parishes increased to forty-two with twenty-seven Kräshen church servitors. ${ }^{81}$ The Brotherhood, however, was unable to open native churches among the apostates of Tsarevokokshaisk, Cheboksary, Sviiazhsk, and Tetiushi districts-thirteen parishes altogether. Without native support schools or churches could not survive. ${ }^{82}$

Even if in the 1890 os Kräshens did not follow the church fasts scrupulously, they still knew the rules (no dairy products, no meat) and acted as if they did fast when a Russian came to visit them. Parish statistics did not always register an increase in Kräshens' parish church attendance, but these statistics often failed to take into account the number of people who went to the schools to pray on Sundays. ${ }^{83}$ Starting in the 1890 os, birth registers of Laishevo district indicated that elderly women in the village of Verkhniaia Serda baptized babies even in the absence of a priest. ${ }^{84}$ The priest of the parish village of Mansurovo, Laishevo district, also noticed that if in the past only ten Kräshens took communion, now at the school of Tashkirmen' village, ten times more people came to kiss the icons, confess, and take communion. ${ }^{85}$

Thus thanks to the Kräshens themselves and their teachers, the schools came to fulfill the function of small chapels, especially during winter when the snow kept villagers from attending the parish church. In Mol'keevo, the school became a minichurch on Sunday eve and before major church holidays. It followed a simple ritual aimed at sanctifying the place. First, the teacher Timei, a Kräshen who was exposed to Russian and Christian literacy before meeting Il'minskii, rang the school bell donated by a Kräshen believer and then, once everyone gathered at the classroom, lit the icon lamp. People reverently placed candles, and one of the schoolchildren read the evening prayers. The school choir then sang prayers from all-night vigil service, and after the songs, the teacher shared the canon in Tatar, explained the Sunday reading from the Gospel, or holiday's meaning. As a rule, when a Christian school was present in a village inclined toward Islam, apostates preferred to meet the missionaries at the school rather than at the church, which they viewed as the devil's house, a place where people ate human flesh and drank blood. ${ }^{86}$

In another village also exposed to strong Islamic influence, Kreshchenye Ianasaly, at the border of Kazan and Laishevo districts, the nonapostates asked specifically for a bell to make the school look like a small church, hoping that the bell's ring

81. NART, f. 10, op. 2, d. 1383, 1l. 182, 204; NART, f. 10, op. 2, d. 1360, 1. 160; letter of priest Makarii Makyi at Parizh, NART, f. 93, op. 1, d. 128 b, 1l. 288 ob.-289; on Baran, parish of Polianki, Tetiushi district, see Otchet o deiatel'nosti Bratstva Sv. Guriia za semnadtsatyi bratskii god, 28; "Otchet o deiatel'nosti Bratstva Sv. Guriia za dvadtsat' piatyi bratskii god s 4-go oktiabria 1891 goda po 4-oe oktiabria 1892 goda," IKE, no. 2 (15 January 1893): 78.

82. NART, f. 93, op. 1, d. $618,11.9,62$.

83. Odigitrievskii, Kreshchenye tatary Kazanskoi gubernii, 47-48; "Otchet o deiatel'nosti Bratstva Sv. Guriia za desiatyi bratskii god," no. 4 (15 February 1878): 89.

84. NART, f. 4, op. 176, d. 1601, 1. 133 ob.; and f. 4, op. 176, d. 1455, 1. 409 ob.

85. "Otchet o deiatel'nosti Bratstva Sv. Guriia za deviatyi bratskii god," no. 6 (15 March 1877): 179-180.

86. Daulei, “O dobrom uchitele," 192; NART, f. 93, op. 1, d. 502, 1. 15; f. 2, op. 7, d. 1608, 11. 748-749. 
would cover the Muslim call for prayer they heard five times a day from the unofficial maktab-mosque located at the very end of the village. Both the school-church founded in 1872 and the maktab-mosque in Ianasaly were engaged in a spiritual and economic contest. Although Kräshens and tailor-apostates shared kinship ties and invited each other for the Christian and Muslim holidays, tensions existed at the level of the village commune: Kräshens were the poorest and had trouble paying their taxes, and apostates shared expenses related to the visits of the priest to the school; in particular they helped the teacher cover the priest's boarding and lodging during his three-day visit. In the end, Islam won when "apostates," now officially Muslims, obtained the opening of a mosque in 1908 right in the middle of the village. ${ }^{87}$

An even more interesting phenomenon was the Kräshens' active participation in pilgrimages and religious processions. Already in 1868 Kräshens in Verkhniaia Serda, Laishevo district, asked for the priest's permission to bring the icons themselves to the houses; before only Russians did so ${ }^{88}$ To the surprise of the priest of Karabaian, Laishevo district, women participated in the Easter icon procession, wearing their most festive hats. Before they used to stay at home, and as soon as the priest entered with the icons, hide behind curtains or the mich (Dutch oven). ${ }^{89}$ In 1893, thanks to the opening of a Brotherhood school, the starokreshchenye of Tashkirmen', Laishevo district, well known for their attachment to their indigenous beliefs but also for bringing offerings to the tomb of the sixteenth-century Yasawian Sufi missionary Shaykh Qasim Khoja and its caretakers in the old quarter of Kazan, offered to host and pray to the icon of the Kazan Mother of God, whose miracles in the sixteenth century brought Tatars to Christ. ${ }^{90}$ And in 1906, 220 villagers from forty-two different villages in Kazan, Ufa, Viatka, and Orenburg provinces, located between 72 and 400 kilometers apart, came to meet the wonder-working icon of the Smolensk Mother of God at the church of the Kazan Central Baptized-Tatar School. This icon portraying the Theotokos (Alla anasï) with Jesus holding a scroll in his left hand and blessing the world with the other was revered for having protected Smolensk from the Mongol hordes in 1238 and for performing many other miracles. After the liturgy, the villagers shared a meal and asked for books in their native language. Especially popular was the story of the miraculous icon of the Smolensk Mother of God, but also the lives of Jesus and the first archbishops of Kazan, Gurii and German, as well as the book about Theodora and the demonic tollgates. Such gathering and distribution of religious literature occurred every June up to the Revolution. Even illiterate Kräshens could name the titles they needed. ${ }^{1}$

87. "Otchet o deiatel'nosti soveta Bratstva Sv. Guriia ot 4-go oktiabria 1874 goda po 4-e oktiabria 1875," IKE no. 5 (1 March 1876): 153; NART, f. 1, op. 3, d. 9740, 1l. 1-15 ob.; f. 2, op. 7, d. 1608, 11. 357-362.

88. Nikolai Il'minskii, "Sochuvstvie inorodtsev k pravoslavno-tserkovnomu peniiu na ikh rodnom iazyke," IKE, no. 14 (15 July 1868$): 397$.

89. "Otchet o deiatel'nosti soveta Bratstva Sv. Guriia ot 4-go oktiabria 1867 do 13-ego oktiabria 1868 goda," IKE, no. 22 (15 November 1868): 638-639.

90. Otdel rukopisei Instituta iazyka, literatury i istorii Akademii nauk Tatarstana, f. 56, op. 1, d. 4, 11. $116-116$ ob.

91. Ochevidets (anonymous eyewitness), "Prigotovlenie kreshchenykh tatar ko vstreche chudotvornogo obraza Smolenskoi Bogomateri v gorode Kazani," IKE, no. 45 (1 December 1906): 1433-1440; "Otchet o sostoianii Kazanskoi tsentral'noi kreshcheno-tatarskoi shkoly za 1913-14 uchebnyi god," IKE, no. 25 (1 July 1915): 54; Skazanie o Smolenskoi ikone Bozhiei materi na tatarskom iazyke (Kazan, 1898), 22-44. 


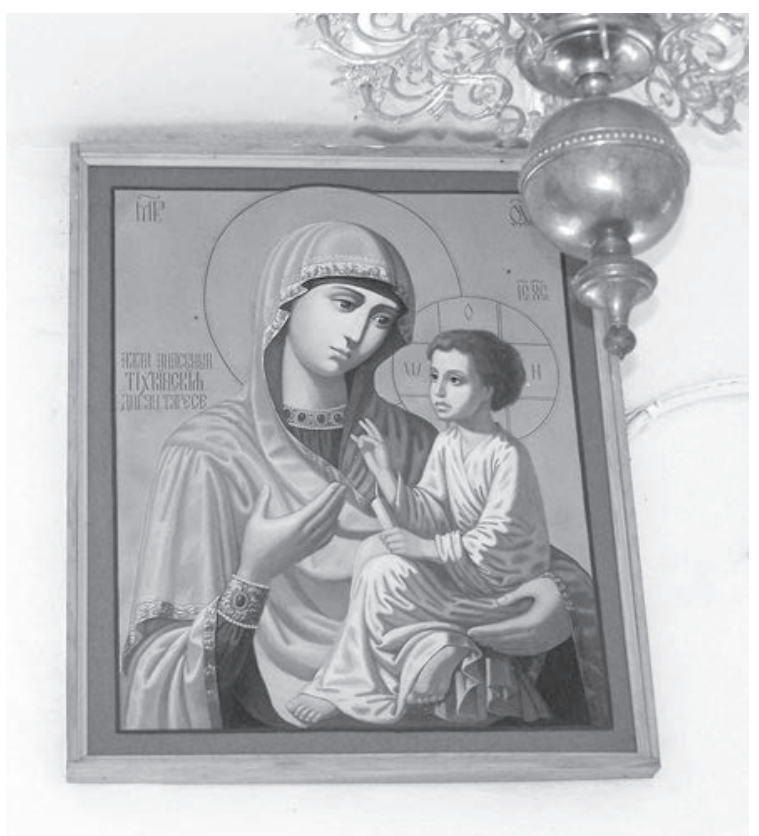

4.7: The Tikhvin Icon of the Mother of God. Note the Tatar inscription. Photograph by the author.

The use of music played a definite role in attracting Kräshens to church and sacred Orthodox places. Already in the 1870s, the orientalist Mashanov noticed that Kräshen women in Verkhnie Mashliaki, Mamadysh district, who did not set foot in church except for getting married, started attending the liturgy willingly. Two KräshensIl'ia Sofiiskii, a student of the Kazan Theological Academy and Mikhail Apakov, a deacon-organized choirs in villages. Not only did children perform in churches, they also accompanied the priest to sacred springs (as in Sheremet'evo parish village), and in Taveli they sang at the village festival that announced the beginning of field work (2 July). With undisguised satisfaction, the student noted that the songs had a calming effect on the peasants who restrained themselves from disturbances that usually accompanied this native rural festivity. Thus, pilgrimages to sacred springs and the blessing of the fields by the priest assisted by the school choir met church standards for decorum, and at the same time allowed illiterate Kräshen adults to participate in the religious life of their community. Later, Miropol'skii proposed to publish a small euchologion (malyi trebnik) in Tatar, containing prayers of blessing for water, fields, homes, and seeds to counteract Muslim and pagan prayers. ${ }^{92}$

92. Mashanov, Religiozno-nravstvennoe sostoianie, 59; "Otchet o deiatel'nosti Bratstva Sv. Guriia za desiatyi bratskii god," no. 12 (15 June 1878): 330; "Pokroviteliu Bratstva Sv. Guriia ego vysokopreosviashchenstvu Vysokopreosviashchenneishemu Palladiiu. Arkhiepiskopu Kazanskomu i Sviiazhskomu, missionera, Kazanskogo uezda, sela Apazova sviashchennika Aleksandra Miropol'skogo, Raport," IKE, no. 1 (1 January 1887): 92. 
But peasants did not stop giving monetary gifts or performing animal sacrifices for the kirämät spring to protect their harvest. In fact the older generation continued their traditional religious practices, despite the disapproval of the younger schooled one, especially in the 1890 s when famine struck. In Al'bedino, Laishevo district, the elders gave money to the protective kirämät of Al'bedino through their religious specialist Anton Kirillov who in the past, used to sacrifice a white cow bought by the whole village to the same kirämät, near the spring, every three to five years. People entered Kirillov's home without greeting him, crossed themselves three times before the house icon and made three ground prostrations; then they bowed three times before the same icon without crossing themselves and three more times before the cavity that contained the kirämät's money; finally they reverently placed the coins in the hole, bowed three more times, and only then greeted Kirillov. By first ignoring Kirillov, the visitors made clear that they did not come to see him but the kirämät; then by crossing themselves they recognized the presence of the Russian spirit in the icon but when they did not repeat the sign of the cross they clearly signaled that their plea was not addressed to the Christian god but to the village spirit itself. When the Kräshen deacon proposed that the village commune purchase an icon with the kirämät money, the elders opposed the move but the young people argued convincingly that the priest at church would bring offerings to the kirämät of Al'bedino in the name of the whole community. Similarly baptized Maris and Chuvash identified icons with particular kirämäts, whispered non-Christian prayers to them at church, and brought them candles to secure their blessings. ${ }^{93}$

As a general rule, Il'minskii and the young Kräshen teachers did not condemn directly these practices, which they believed would eventually disappear with education. Such has been the case among Kazan Tatars, who until the 1850 , sacrificed white horses and geese to the kirämät-even in the presence of their mullahs. When in Elyshevo the Kräshen sacristan accused the Kräshen priest, Ioann Krasil'nikov, of heating the muncha for the dead, the latter answered that he did it only once and according to the church calendar; in other words the priest did not prepare the muncha and serve a meal for the deceased every week, as was the custom in villages still attached to ancestral worship, who believed that the dead visited the living every Thursday and needed to be kept happy. ${ }^{94}$

Even more fascinating was the appearance among Kräshens of semiprofessional wandering bards who, like the Sufis who sang munajat, mastered a second trade, sewing and carpentry, and performed music on their quray (flute), qobiz (a two-string fiddle), and violins in the villages they visited. Thus in the region of Almet'evo, famous for its Sufi shaykhs, such bards played religious Christian songs in their "Kräshen language," among them "Khristos häm anïng öyränücheläre" (Christ and his disciples). If in the nineteenth century the village of Nalim could boast the presence of the famous Sufi saint and musician Yalchighol, in the twentieth century the nearby

93. NART, f. 10, op. 2, d. 1283, 1. 219; "Iz zhizni kreshchenykh inorodtsev Kazanskogo kraia," 23-24; Vasil'ev, "O kiremetiakh u chuvash i cheremis," 259-261.

94. Odigitrievskii, Kreshchenye tatary Kazanskoi gubernii, 29, 37; Koblov, Mifologiia Kazanskikh tatar, 37; NART, f. 4, op. 1, d. 124919, 1. 5 ob.; Il'minskii, ed., Kazanskaia tsentral'naia, 22-23. 
Kräshen village of Nalim could also pride itself for his famous Kräshen qobïz player Mikulay qart (Nikolai Nikolaev, 1892-1968). ${ }^{95}$

As impressive as Il'minskii's system of education was, it came too late to attract the intellectual elites of villages like Elyshevo whose sacred landscape with its kirämät mount, spring, and tree did not differ much from other more "pagan" Kräshen villages. When before the apostasy of 1865, the priest of Achi parish Porfirii Men'shikov, fluent in Tatar, read several chapters from the Book of James in Il'minskii's translation to families who welcomed him to their houses, the father of a prominent Islamized tailor proposed discussing the possibility of buying the book at the commune's next meeting. But the village apostatized and later, after the movement was crushed, its most prosperous and educated inhabitants refused Malov's entreaties to enroll their children in the newly opened Kazan Central Baptized-Tatar School. Only those who had never been to the Qur'anic school or reluctantly joined the apostasy movement allowed their children to enter Malov's classroom. But even they were hesitant; as Elyshevo became increasingly Islamized, would their children become outcasts for studying in an Orthodox school and spur more division?

Because Elyshevo was connected to a wider network of Islamic knowledge outside the village, the missionaries enjoyed only temporary success. Despite the construction of a wooden church by a Russian merchant Nikanor Ivanovich Shcherbakov and the opening of an informal school in 1869, despite the presence of a Russian Tatar-speaking priest and then of a starokreshchenyi priest, and occasional monetary support to ostracized Christian families, the apostasies continued. ${ }^{96}$ Even worse, in the 1870 s the three clandestine maktabs of Elyshevo successfully competed with the neighboring Brotherhood schools in Bol'shie Savrushi (opened in 1868) and Saltygan Kliuch (opened in 1873) and lured their students away. Still worse, at the end of 1874,437 parishioners threatened to burn down the church. ${ }^{97}$ Yet the Brotherhood of St. Gurii did not give up and sent new female Kräshen teachers to Elyshevo who could visit women in their homes and convince them to send their children to school. First, it opened a girls' school taught by Dariia Alekseeva at the church and a boys' school in a rented home in 1882-1883. And then, another woman, Anastasiia Zhirnova arrived to teach, but this time in a house especially built by Nikanor

95. Gennadii Makarov, Kräshen musicologist, interview by author, June 2008, Kazan Conservatory. Qart is a honorific title for elder. It also referred to the performers of sacrifices to the village tutelary spirits. Only recently scholars have started collecting Kräshen spiritual songs. I. I. Zemtsovskii, ed. and N. Iu. Al'meeva, comp., Pesni tatar-kriashen, vol. 1, Pestrechinskaia (primëshinkaia) gruppa (SPb., 2007), 92-93 (texts of Äy, Allanï tudïghan, Küktäge Atabiz).

96. "Ustroistvo i osviashchenie tserkvei v kreshcheno-tatarskikh mestnostiakh," in Il'minskii, ed., Kazanskaia tsentral'naia, 364; "O postroenii i osviashchenii novoi tserkvi v derevne Elyshevoi, Mamadyshskogo uezda," IKE, no. 13 (1 July 1869): 401-411; "Godichnoe sobranie Bratstva sv. Guriia 30 oktiabria 1873 g. i otchet o deiatel'nosti soveta sego Bratstva ot 4 oktiabria 1872 g. po 4 oktiabria 1873 g." PS (January 1874): 51; Narodnye uchilishcha $v$ Kazanskoi gubernii: Materialy dlia istorii narodnogo obrazovaniia: Mamadyshskii uezd (Kazan, 1888), 24-25; Pis'ma N. I. Il'minskogo k ober-prokuroru, 6; "Otchet o deiatel'nosti Bratstva Sv. Guriia za tridtsatyi bratskii god," 32, nos. 13-14 (1-15 July 1898): 18.

97. "Otchet o deiatel'nosti Bratstva Sv. Guriia za deviatyi bratskii god," no. 10 (15 May 1877): 278-279; NART, f. 4, op. 134, d. 58, 1. 1776; Izvlechenie iz vsepoddaneishego otcheta ober-prokurora sviateishego sinoda grafa D. Tolstogo po vedomstvu pravoslavnogo ispovedaniia za 1874 (SPb., 1876), 30; Evstafii Voronets, Materialy dlia izucheniia i oblicheniia mokhammedanstva (Orel, 1876), 12. 


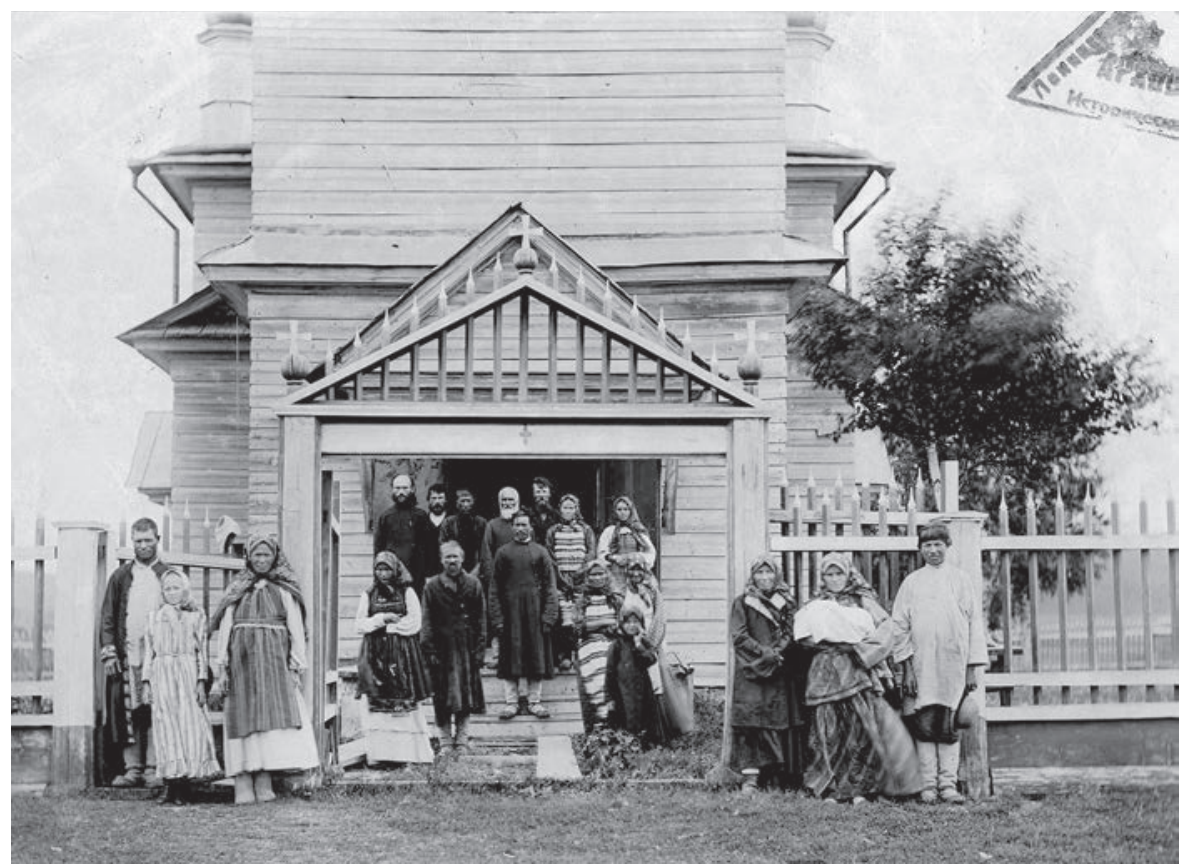

4.8: Church of the Archangel Michael in Elyshevo. RGIA, f. 821, op. 4, d. 72, photograph no. 4. No date. Photograph courtesy of RGIA.

Shcherbakov, which served as a free dormitory for the students who mostly came from neighboring villages but rarely from Elyshevo (except for the already ostracized Orthodox families). ${ }^{98}$

In 1887 , the new Kräshen priest Stepan Kirilov from Tashkirmen' conveyed his frustrations to Il'minskii. People, he wrote, refused to give him any material support; he had to till the land all by himself and buy his own bread. Bitterly he concluded that he did not have the necessary education to respond to the apostate villagers' arguments and for all these reasons, pleaded to leave the parish. In contrast, Il'minskii could read the enthusiastic letters of priest Simeon Maksimov who served in the mixed Russian-Chuvash-Kräshen parish of Kileevo. His parishioners loved him so much that they brought him flour, grain, bread, and sheep, and even offered to buy him a house. To earn their love, Maksimov accepted whatever villagers could offer as emoluments and visited them personally at funerals, sang hymns in Tatar, explained Christian funerary rites, and the proper ways people could remember the deceased.

98. "Otchet o deiatel'nosti Bratstva sv. Guriia za shestnadtsatyi bratskii god s 4-go oktiabria 1882 goda po 4 oktiabria 1883 goda," IKE, nos. 23-24 (1-15 December 1883): 754; V. M. Berkutov, Dorevoliutsionnye shkoly na territorii Tatarstana: Istoriko-pedagogicheskii spravochnik (Kazan, 2007), 321; Narodnye uchilishcha v Kazanskoi gubernii ... Mamadyshskii uezd, 24-25; "Elyshevskaia kreshcheno-tatarskaia shkola," IKE, no. 1 (1 January 1887): 65. 
Before his arrival, the Chuvash buried their dead in sheets and had the head of the deceased covered as Muslims did. ${ }^{99}$

The case of Elyshevo was not an isolated one. Most villages included in its kinshiptailor network in Mamadysh, Laishevo, and Kazan districts boycotted the lessons. One notable exception was Iantsovary in Laishevo district, which at first in 1868 did not show much enthusiasm toward the Brotherhood school but in 1878 petitioned for the building of a church. Thus, in the 1870 s and 1880s, new apostasies broke out in the parishes of Abdi, Iukachi, Nyr'ia, Chura, Venetino, and Staraia Ikshurma in Mamadysh district, despite the opening of schools with the initial approval of a portion of the population. Il'minskii was unable to keep the school open at Khaivani village, Kazan district, because of pressure from a neighboring mullah who came to the school and polemicized with the inexperienced young teacher. Priest Vasilii Kremkov in Chura parish complained that despite his efforts to promote church music among the Kräshens, apostates continued arguing that priests did nothing but take their money for their emoluments. Ten families who had been deported from Tavlarova to the Russian village of Tokhtamyshevo had left the church once again and the Kräshens of Otary village announced their apostasy, claiming that they had never heard of Christianity, which was not the case. A student from the Central Baptized-Tatar School of Kazan had taught them two winters in a row before their apostasy in 1870 , which, according to Malov, had already some effect on the adults who started quoting stories from the Gospel. To make things worse, the apostates opened an illegal Muslim school in the 188 os, and children attending the two schools got into fistfights. After 1905, all baptized Tatar villagers-despite earlier disagreement-switched to Islam officially, and the Eastern Orthodox school of Otary, originally founded by the Brotherhood of St. Gurii, was compelled to offer free schooling and boarding to Kräshen children living outside the village. Similarly, two other villages belonging to Elyshevo kinship network, Nizhnii and Verkhnii Aziak villages in Kazan district, apostatized, despite the opening of a Christian school with twenty-five children. After the apostasy in 1870, only five students remained at the Christian school. By contrast, the newly opened underground Muslim schools flourished. A Tatar shakird and a Tatar woman from Alichtarkhan village educated the children in two separate houses at Verkhnii Aziak, and two Muslim women, also from the same Tatar village, taught forty-three children at Nizhnii Aziak. Finally, Saltygan Kliuch turned overwhelmingly to Islam despite the early opening of a Brotherhood school in its midst; in 1914, it counted only eight Orthodox families versus forty-seven apostate families. ${ }^{100}$

99. NART, f. 968, op. 123, 11. 17-20; Istoriko-statisticheskoe opisanie tserkvei i prikhodov Kazanskoi eparkhii, 107; Otchet Bratstva Sv. Guriia za dvadtsat' pervyi bratskii god s 4 oktiabria 1887 goda po 4 oktiabria 1888 goda (Kazan, 1888), 17; letters of priest Simeon Maksimov (1881) in NART, f. 93, op. 1, d. 128 b, 11. $255-273$.

100. M. M. "Postroenie i osviashchenie khrama v sele Iantsovarakh," IKE, no. 3 (1 February 1885): 49-50; NART, f. 10, op. 2, d. 1383, 1. 236; f. 1, op. 3, d. 3048, 1l. 27 ob.-28; f. 1, op. 3, d. 3272, 1l. 2-2 ob., 11-11 ob.; f. 1, op. 6, d. 612, 1l. 7 ob., 9 ob.; f. 4, op. 98, d. 34, 1. 23; f. 4, op. 98, d. 23, 1l. 195-196; and f. 4, op. 101, d. 16, 1. 6 ob.; Vasilii Kremkov's letter to Il'minskii (November 1870) in NART, f. 968, op. 1, d. 124, 1l. 65-67; Otdel rukopisei Kazanskoi nauchnoi biblioteki im. Lobachevskogo, f. 7, ed. khr. 14, 11. 109-110; Otdel rukopisei Instituta iazyka, literatury i istorii Akademii nauk Tatarstana, f. 56, op. 1, d. 1, 1. 46; Il'minskii, ed., Kazanskaia tsentral'naia, 383-384; Nikolai Ostroumov, "Zametka ob otnoshenii mukhammedanstva k obrazovaniiu kreshchenykh tatar," Zhurnal Ministerstva narodnogo prosveshcheniia pt. 161 (May 1872): 
Il'minskii and his disciples faced even greater disappointment in 1871, when Apazovo-the only parish that had not apostatized officially in Kazan districtannounced unanimously its "return" to Islam, despite the opening of a boys' school in 1867. In villages, such as Apazovo, Tomasov-Pochinok, Savrushi, Ianyli, and Saltygan Kliuch, which were dominated by tailors, the schools had little religious impact. Children accompanied their itinerant tailor fathers as soon as they could read and write in Russian; consequently only very small children between the ages of six and nine studied at the schools. When they became older, boys with their fathers headed to Tiunter village, famous for its madrasa, leather shoe factories, tailor networks, and charismatic shaykhs. As for Savrushi, which had hosted a clandestine Qur'anic school since the $188 \mathrm{os}$, only half of the children of apostates studied at the schools created by the Brotherhood of St. Gurii in 1903. In general, school inspectors noted that the students' level in Slavonic and religious education was the lowest in villages where the number of apostates outnumbered Kräshens. ${ }^{101}$

Intelligently, missionaries sought to reach women in villages predominantly inhabited by seasonal workers, but the implementation of girls' schools or classes for girls met many challenges. Girls could be better missionaries for Christianity than boys and help save resources. Before marriage girls stayed in their native village (and thus the Christian schools) longer than boys, who left with their fathers to complement their families' income; after marriage, girls could carry their knowledge to other Kräshen communities. While a male teacher scared girls away (usually Kräshens did not send their daughters to boys' schools), a female teacher could teach very young boys and girls together and visit women in their houses. For these reasons, the Brotherhood of St. Gurii tried early to send female teachers to the apostate villages of Elyshevo, Savrushi, and Apazovo, knowing that the male population was gone for most of the school year, but in vain. Two years after Apazovo's first apostasy in 1871, the Ministry of Education had taken over the Brotherhood school founded in 1867 and transformed it into a native elementary school for boys and girls. Six years later, to his satisfaction, a student of the Kazan Theological Academy noticed that the few girls that attended the classes already recounted stories from the Bible and the Lives of the Saints to their parents. But other more pessimistic sources suggested that the school had little success because parents refused to send their daughters to a male teacher. This discovery prompted the Russian priest Miropol'skii in 1889 to open a girls' school

105; "Otchet o deiatel'nosti Bratstva Sv. Guriia za shestnadtsatyi bratskii god s 4 oktiabria 1882 goda po 4 oktiabria 1883 goda," IKE, nos. 23-24 (1-15 December 1883): 769; Pavel Zakhar'evskii, Otchet Kazanskogo eparkhial'nogo nabliudatelia o sostoianii tserkovnykh shkol Kazanskoi eparkhii v uchebno-vospitatel'nom otnoshenii za 1909-1910 uchebnyi god (Kazan, 1911), 15; Vasilii Eslivanov, “Trudnosti i nuzhdy Kazanskoi inorodcheskoi missii," IKE, no. 42 (8 November 1915): 1139.

101. Otdel rukopisei Kazanskoi nauchnoi biblioteki im. Lobachevskogo, f. 7, ed. khr. 8, 1. 154; Istorikostatisticheskoe opisanie tserkvei i prikhodov Kazanskoi eparkhii, 417-418; Otchet o deiatel'nosti Bratstva Sv. Guriia za tridtsat' piatyi bratskii god. S 4 oktiabria 1901 g. po 4 oktiabria 1902 g. (Kazan, 1902), 56; Petr Shestakov, "K voprosu ob ustroistve uchilishch dlia inorodcheskikh detei Kazanskogo uchebnogo okruga," Zhurnal Ministerstva narodnogo prosveshcheniia, pt. 184 (June 1867): 87; "Otchety studentov Kazanskoi dukhovnoi akademii o nabliudenii zhizni kreshchenykh tatar, sdelannykh v vakatsionnoe vremia, 1879," in NART, f. 967, op. 1, d. 168, 1l. 2-2 ob.; letter of Savrushi Kräshen teacher Nazar Serebrianov in Tatar, f. 968, op. 1, d. 175, 1l. 20-21 ob.; on Ianyli, IKE, no. 9 (1 May 1878): 226; "Otchet o deiatel'nosti Bratstva Sv. Guriia za tridtsatyi bratskii god," 32, nos. 13-14 (1-15 July 1898): 20-21. 
separate from the boys' school, financed directly by the Brotherhood and taught only by female teachers. As a result of his efforts, thirty girls took lessons in 1901 and satisfied the inspectors' expectations; they could understand basic colloquial Russian and knew their prayers in Tatar, even some in Slavonic. All these attempts to keep Apazovo from apostatizing proved to be in vain: the village sent petitions repeatedly for the recognition of its Islamic identity in 1881,1883 , and $1905 .{ }^{102}$

To attract female students who usually stayed at home to help their mothers, female teachers had to gain their mothers' approval. They first visited the houses, then organized gatherings at their own homes, read sacred stories, and had the children learn to sing, before introducing literacy at the mothers' and children's requests. Feodora Gavrilova, who taught in 1869 for a short time in apostate Elyshevo, was able to gather fourteen boys and four girls in her school after first reading the Gospel and the Lives of the Saints to women in their homes, but ultimately enjoyed little success. Young unmarried female teachers usually ran the risk of being called offensive names and suffered prejudice. Babina, the teacher of Dragun-Bekhmetevo in Belebei district, asked to go back to her native village because she could not endure the apostates' mockeries. Lack of funds also prevented the Brotherhood of St. Gurii from opening separate girls' schools in each Kräshen village at risk. ${ }^{103}$

Apostates did everything to stop the schools. They spread rumors to keep Kräshens from attending the Brotherhood's school and impede the work of Kräshen priests. At Staraia Ikshurma, Mamadysh district, they claimed that Kräshen priest Kuz'ma Prokop'ev (Kuzma ätäy) read the Qur'an at night and that mullahs often visited him. This picture reflected a common theme found in Fäża' ${ }^{\prime} l$ ash-Shühūr, where monks lived outwardly as Christians and inwardly as Muslims. ${ }^{104}$ In general, tailors were the most ferociously opposed to Il'minskii's schools. At the end of the 1860 os and in the 1870 s, they either refused to send children to school or took them away from their lessons as soon as they came back from their winter occupations. By the same token, Islamized Kräshen women kept their children from singing prayers or reading Russian books at home, considering Russian literacy as the devil's writing. Not only did the Brotherhood's schools but any other type of Russian school provoked the apostates' distrust. In 1893, a young Russian offered to teach Russian and joinery to the villagers of Bol'shie Kibiak-Kozi, but his proposition was immediately rejected. ${ }^{105}$

Nevertheless, toward the beginning of the twentieth century, male and female students in Elyshevo parish had been exposed to Russian Christian schooling

102. NART, f. 967, op. 1, d. 168, 1. 2 ob.; Istoriko-statisticheskoe opisanie tserkvei i prikhodov Kazanskogo uezda, 72; Priest E. Sosuntsov, "Kratkoe istoriko-statisticheskoe opisanie shkol tserkovno-prikhodskikh i gramoty g. Kazani i Kazanskogo uezda. Apazovskaia zhenskaia shkola gramoty," IKE no. 5 (1 March 1901): 231-233.

103. "Perevod drugogo pis'ma," 691; Nikolai Il'minskii, Svedeniia o tatarskikh-kreshchenskikh shkolakh $v$ Kazanskom uchebnom okruge za 1870 god (Kazan, 1 Mar. 1871), 15; letter of the Russian priest Flor Mal'gin, former student of Il'minskii (15 November 1884), in NART, f. 93, op. 1, d. 128 b, 11. 30-30 ob., 32; Istoriko-statisticheskoe opisanie tserkvei i prikhodov Kazanskoi eparkhii, 387.

104. Pis'ma N. I. Il'minskogo k ober-prokuroru, 65, 74; Otdel rukopisei Instituta iazyka, literatury i istorii Akademii nauk Tatarstana, f. 56, op. 1, d. 4, 1. 44; Fäżä'il, 2-3.

105. NART, f. 4, op. 134, d. 33, 1. 11 ob.; f. 93, op. 1, d. 436, 11. 40-42; Troitskii, "Novokreshchenskie prikhody," in NART, f. 10, op. 2, d. 1383, 1. 236; IKE no. 9 (1 May 1878): 226; Malov, “Ocherk," 17, pt. 3 (1871): 407 . 
through the Brotherhood or the Mamadysh zemstvo, which had taken over some of the Brotherhood's schools. A slight change of attitude toward Russian schooling was even noticeable. Male children of seasonal workers in Savrushi, Mamadysh district, started voluntarily attending the Brotherhood school opened in 1868 to acquire basic literacy in Cyrillic to use for trade. To Malov's surprise, in 1903, an apostate of Savrushi did not hide his knowledge of Russian even though earlier apostates had argued that their ignorance of Russian explained why they could not be Orthodox. The same phenomenon was apparent in Ianasal, Laishevo district, where children of apostates learned to read and sing Christian hymns at the Brotherhood school along with the children of Kräshens who wished to remain Christian. But this exposure to Christian schooling was not sufficient to eradicate the apostates' fascination with Islam. ${ }^{106}$

Following Il'minskii's advice, the Brotherhood of St. Gurii sent children of families strongly influenced by Islam but not firmly committed to the apostate cause to the Kazan Central Baptized-Tatar School (always with the parents' approval). The priest of Dragun-Bekhmetevo, aware that entrance to the Kazan school had become more competitive, recommended admission for a boy who had studied in a maktab, despite his poor knowledge of Christianity and Russian, because his father was related to Mikhail Fedorov-who had been exiled after leading the apostasy movement in the village in the 1880 os. ${ }^{107}$ The Brotherhood also opened schools on the outskirts of apostate villages. In the neighborhood of Elyshevo, for instance, the schools of Bol'shie Savrushi (1868), Tri Sosny (1869), and Saltygan (1873) were opened as counterweight, but most of their inhabitants apostatized despite their children's school attendance. Frustrated, the missionary society opened a boarding school for girls in Elyshevo in 1883 when the villagers refused to house the children in their homes. A co-ed boarding school was also opened in Apazovo in 1908 to educate children in a purely Christian environment, but again to no avail. The boarding school in Apazovo did not attract girls, and even though the boys sang Christian hymns and went to church during the school year, they did not continue these practices once they returned to their parents' houses. In 1907, the Ministry of Education introduced handicrafts into the curriculum to keep the children from tailoring outside Apazovo. The vocational school taught carpentry and turning, but all this had no effect. After the February Revolution, Apazovo obtained the right to build a mosque. In effect, Il'minskii's method knew most success in Iantsovary, Serda, and Nikiforova-the regions with little exposure to Qur'anic schooling, and in which the tailor trade was still embryonic. ${ }^{108}$

To counter Islamic influence, reduce the number of apostates that kept on increasing despite the missionaries' efforts, and respond to the lack of spiritual maturity in some of their very young teachers, Il'minkii and Timofeev organized special summer

106. Otdel rukopisei Kazanskoi nauchnoi biblioteki im. Lobachevskogo, f. 7, ed. khr. 8, 1. 184; Ivan Pokrovskii's preface to Istoriko-statisticheskoe opisanie tserkvei i prikhodov Kazanskoi eparkhii, XVII-XXX; Po povodu predstoiashchego razvitiia prosvetitel'noi i missionerskoi deiatel'nosti v Kazanskoi gubernii (Moscow, 1896), 5.

107. Il'minskii, ed., Kazanskaia tsentral'naia, 214; NART, f. 93, op. 1, d. 128 b, 1l. 43-43 ob.

108. Istoriko-statisticheskoe opisanie tserkvei i prikhodov Kazanskogo uezda, 72; Otchet o deiatel'nosti Bratstva Sv. Guriia za semnadtsatyi bratskii god, 21. 
courses at the Kazan Central Baptized-Tatar School. Teachers came from all Kräshen villages to perfect their knowledge of Orthodox Christianity, Russian, Slavonic, and arithmetic, learn new methods of teaching, and discuss their daily encounter with apostates and strategies of counterattack in what today would be called brainstorming sessions. They read the works of teachers and students of the anti-Islam division of the Kazan Theological Academy, compared tales of the prophets and patriarchs in Rabghuzi and the Old Testament, spoke of the major differences between Jesus and Muhammad, between Muslim and Christian marriage, and between mullahs and priests. ${ }^{109}$

During these memorable summers, teachers discussed the art of polemics, an art favored by Malov. They learned to answer a list of questions often asked by apostates caught between Islam and Christianity: How could God have a mother and a son when He was spirit only? Why did Russians cross themselves when prophets did not make the sign of the cross? Why did Russian priests then allow men and women to worship together in church? If the Russian Bible said to worship only God, why did Russians worship icons? More questions dealt directly with Christian sacraments: Why did Russians practice baptism when Jesus did not baptize anyone? What was the reason for baptizing children since they were innocent? How could a priest forgive sins when he was himself a sinner? Was it true that people at church ate human flesh and drank blood? Other questions implied that Islam was a truer fulfillment of the Jewish law as embodied by the prophets Moses and Jesus: Why did not Russians practice circumcision? Was Jesus not circumcised? All prophets brought sacrifices to God, why did Russians abstain from them? Moses and Jesus fasted for forty days, abstained from drink and food, so why did not Russians follow their example as Tatars did during the Ramadan? ${ }^{110}$

Bringing teachers to the Kazan Central Baptized-Tatar School was not enough to thwart Tatar influence and in the 188 os, when a new wave of petitions reached the chancelleries of the governor of Kazan, the Brotherhood of St. Gurii responded by publishing a short Tatar-Kräshen language brochure to further popularize antiIslamic methods of argumentation. The brochure reflected the methodology of the anti-Islam department of the Kazan Theological Academy, which used canonical Islamic sources to prove Christianity's superiority and Wahhabi arguments against popular expressions of faith. The Qur'an, after all, presented Jesus as the Word of God and a miracle worker, but emphasized the prosaic character of the Prophet Muhammad who was "from among the common people" (Sura 62:2). But Tatars, according to the brochure, wrongly believed that the Prophet read the future and divided the moon in two halves, and that the stones and the trees bowed before him and a roast lamb spoke to him. Kräshen teachers in villages exposed to Islam used the same

109. "Otchet o deiatel'nosti Bratstva Sv. Guriia za piatnadtsatyi bratskii god," IKE, no. 14 (15 July 1883 ): 430-431; "Otchet o deiatel'nosti Bratstva Sv. Guriia za shestnadtsatyi bratskii god s 4 oktiabria 1882 goda po 4 oktiabria 1883 goda," IKE, nos. 23-24 (1-15 December 1883): 746-749. Later, in 1910-1911, the bishopric of Ufa and Menzelinsk, concerned with the spread of Islam, started offering this type of courses in Kräshen and Chuvash villages. See Stefan Matveev, Pervye v Ufimskoi eparkhii kursy po prikhodskoi missii dlia kreshchenykh inorodtsev (Ufa, 1911), 3-10.

110. List of questions prepared by priest Liapidovskii at the summer course of the village of Iantsovary in 1894 , NART, f. 93, op. 1, d. 502, 11. 10-42. 
polemical arguments in the classroom to protect their students from their relatives or neighbors' Islamic influence. ${ }^{111}$

Even though the Brotherhood of St. Gurii was incapable of putting a stop to the apostasies, which increasingly grew in amplitude, it nevertheless succeeded in creating a new class of native missionaries who published their own encounter with apostates and Muslims in the local diocesan journals and became aware of their religiousethnic specificity. ${ }^{112}$ In a poem, the Kräshen deacon and future priest of Bol'shaia Chura, Iakov Emel'ianov (1848-1893), a product of the Iukachi volost' school and one of the first students of the Kazan Central Baptized-Tatar School, exclaimed that Kräshens had enough of the mockeries of the Muslim Tatars and their ishans whose faith was originally spread by the sword and who spoke of their faith ad nauseam; now the "Kräshen people" had awakened and stood for themselves. This "awakening" of the Kräshen people could not have been possible without the support of a large portion of the baptized community and of course, without the state and church's readiness to back up Il'minkii's new conception of indigenous schooling. ${ }^{113}$

\section{The State Response to the Apostasies}

\section{State Recognition of Il'minskii's Schools}

Very early on, Il'minskii and the supporters of Orthodox literacy in the indigenous language looked for supporters within the church and state apparatus. Il'minskii needed external support but at the same time was concerned about keeping the schools away from any external state regulation, which would have jeopardized their enrollment. In 1870, Count Dmitrii Tolstoi (1823-1889), the minister of education from 1866 to 1880 , who was greatly concerned with the spread of Islam, took Il'minskii's school as a model to introduce the Russian language into the curricula of Muslim Qur'anic schools.

The size and extent of Kräshen apostasies in 1866 came as an unpleasant surprise for the Russian state. Not only did these rebellions involve the novokreshchenye but also the starokreshchenye, Chuvash, Maris, and Udmurts. They epitomized a rural, fanatic, nonscientific, and subversive "Islam" that led to the rejection of Christianity, one of the basic components of Russian identity. Those apostasies occurred as the Russian state sought to involve more of its citizens in the building of a renewed society capable of taking its rightful place among the advanced European nations. Even worse, the apostasies happened at a time when the Muslim population of the Empire had significantly increased. After the capture of Imam Shamil in 1859, the Caucasus was mostly pacified, and by 1870 , Turkestan was almost entirely conquered.

111. Mokhammiat denenia karaganda Khristos dene artyk (Kazan, 1883), 3-80; The Koran Interpreted. A Translation by A. J. Arberry, 62:2, p. 277. Muslim lore held that a Jewish woman's roast lamb stood up on its four legs and warned the Prophet that it was poisoned, miraculously saving him from death. Schimmel, And Muhammad Is His Messenger, 75.

112. For example, see Kräshen priest David Grigor'ev's article, "Po missionerstvu sredi tatar," IKE, no. 32 (22 August 1906): 1001-1009, in which he denounced Muslim polygamy.

113. Emel'ianov, Stikhi na kreshchensko-tatarskom iazyke (1879), 20-22; a biography of Emel'ianov can be found in Maksim Glukhov, “Jïchï Jäkäü," in Bez ber tamïrdan, 8-11. Emel'ianov entered Timofeev's school in 1864 at the age of sixteen, then the Kazan Theological academy in 1874 . He became a priest in 1880. The Brotherhood of St. Gurii published his poems for the first time in 1867 . 
The state used the apostates' demands as an excuse to reconsider its policies toward Christianization of natives and Islamic schools. Orientalists, missionaries, members of the clergy, and functionaries of the Ministry of Education used the Kräshens' defections and their eschatological components as an unacceptable product of traditional Islamic schooling, alien to Russia and its quest for modernity. The ultimate danger was that if the state failed to come up with an alternative literacy program, Turkic and non-Turkic indigenous peoples of the Middle Volga would be entirely "Tatarized," that is Islamized. They would form separate "fanatic" autarkies, hostile to the postemancipation ideas of citizenship and modernization.

Military intervention rarely met its objective. It could not interrupt the flux of petitions, which continued to arrive individually at a slower speed. Troops disrupted village economies and stirred further discontent. Transfers of population had proven to be fruitless. The police or the church representatives could not divert indigenous trade, kinship, and sacred routes. Very few experienced local priests recognized kinship alliances, and the tombs of saints constituted the landmarks of an invisible sacred geography that overlapped the map of Russian settlements-the new homes for deported apostate families. Russians did try to curtail popular manifestation of Sufi piety by diverting the routes of wandering ascetics, but with little effect. In 1832 and 1834, they forbade Central Asian wanderers from traveling to Mecca through Russia, fearing that those ascetics who remained for an extended period of time in the interior provinces of the Russian Empire stirred more fanaticism and anti-Christian feelings among non-Russian subjects. This decree, however, did not forbid local ascetics, citizens of Russia, to move from one village to another. ${ }^{114}$

Around 1870, more progressive and enlightened solutions had to be found, first to keep Christian converts in the bosom of the church, and second to change Tatars' suspicion of the Russian world. Tolstoi opened an extensive debate about the education of the non-Russian peoples that involved the participation of missionaries, orientalists, and various district boards. The debates were recorded in Zhurnal Ministerstva Narodnogo Prosveshcheniia (Journal of the Ministry of Education). A major theme occupied the minds of the participants, the place of Russian language and religion in the natives' Russification. By Russification, officials meant the opening up of Tatar society to Russian values which would first lead them to perform their obligations as citizens of the Russian Empire, and ultimately, in an indefinite future, lead them to merge with the Russian population.

Even before he became minister of education, Tolstoi was familiar with the missionary schools. In 1861, he received a letter from Il'minskii explaining ways to expand his network of schools at a low cost. Four years later, after Tolstoi had become the over-procurator of the Holy Synod, Malov had written to him about the Kräshen apostasies and Timofeev's school. As a sign of support, Tolstoi then raised Timofeev's salary and the Holy Synod sent a 1,00o rubles to the school. Tolstoi visited the school in $1866 .{ }^{115}$

114. Otdel rukopisei Kazanskoi nauchnoi biblioteki im. Lobachevskogo, f. 7, ed. khr. 1, 1. 180 (Malov quoted PSZ 11, no. 8881).

115. Il'minskii, ed., Kazanskaia tsentral'naia, 177-179; Sbornik dokumentov i statei, 58, 64, 71, 157-160; Moskovskie Vedomosti no. 196 (20 September 1866): 2, cols. 3-4. 
Despite Tolstoi's initial support, Il'minskii's school emerged transformed following the 1869-1870 debates. The missionary considered the mother tongue as a tool for reinforcing Christianity; for him, learning Russian was secondary. Several school board members objected. By making nonliterary languages the language of the church and of instruction (as was the case among the Chuvash, Maris, and, to a lesser extent, the Tatars), they feared that these minorities would develop a sense of ethnicity, intellectual heritage, and ultimately nationalism. ${ }^{116}$

Others, including ministry agents, yielded to the evidence that the mother tongue facilitated Christianization of the indigenous peoples and above all their learning Russian. There was no question of returning to the baptized schools of the seventeenth and eighteenth centuries where the children, torn away from their language and families, died of grief. It was thus essential to speed the transition from the mother tongue to the state language. Thus, Russian always remained the dominant language as stipulated by the fifth article of the 1864 law on schooling. ${ }^{117}$

In 1870 the Ministry of Education adopted a series of regulations for the schooling of inorodtsy. The new rules provided for education in non-Russian languages, but they also emphasized the teaching of Russian. To Il'minskii's great disappointment, the natives were arbitrarily divided into three groups. Schools similar to those of Timofeev were to be founded for children who lived in a non-Russian environment. In places where the population was a mixture of Russian and native, the explanations in the native language were to be entirely oral, without recourse to textbooks. If this turned out to be insufficient, a supplementary class of "Timofeev's type" could be opened, but at local cost. Finally, in the case of the natives in a predominantly Russian milieu, Russian public primary schools were to be opened. But, Il'minskii asked, who would determine how Russified each student was? ${ }^{118}$

Overall, the text of the 1870 regulations insisted more on the importance of Russian than on the moral value of teaching the catechism in the native language. In the first group, even if schools of Timofeev's type were to be created, Russian language classes were to begin immediately at the same time as the study of the catechism in native language; by contrast, in practice, students in Timofeev's school began their study of Russian only after they had learned to read, write, and pray in their mother tongue. Always according to the new regulations, once the children had sufficiently assimilated vocabulary and grammar, the teaching of the catechism continued in Russian, with translation in the native language if needed. By contrast, Il'minskii's pedagogical methods made Russian secondary. The missionary used the native language in religion courses and in the teaching of Slavonic, the main liturgical language of the Russian Orthodox Church.

116. Sbornik dokumentov $i$ statei, 16.

117. Materialy po istorii Tatarii vtoroi poloviny 19-go veka, 285-286; Sbornik dokumentov i statei, 19, 28-29.

118. Materialy po istorii Tatarii vtoroi poloviny 19-go veka, 287-291; A. I. Anastasiev, Narodnaia shkola; rukovodstvo dlia uchitelei i uchitel'nits nachal'nykh narodnykh uchilishch: nastol'naia kniga, vol. 1 (Moscow, 1910), 127-128; Kreindler, "Educational Policies," 88, 143, 151; idem, "A Neglected Source of Lenin's Nationality Policy," Slavic Review 36, no. 1 (Mar. 1977), 86-100; idem, "Nikolai Il'minskii and Language Planning in Nineteenth Century Russia," International Journal of the Sociology of Language, no. 22 (1979): 5-26. 


\section{State Position toward Islamic Education}

Missionaries and state representatives agreed that Islamic literacy and schools were directly responsible for the baptized and "pagan" natives' defections. However, the state officials' position on Islam did not quite coincide with the missionaries' discourse. The Russian state declared itself to be the guardian of Christianity, but it also concerned itself with maintaining peace and order with its Muslim subjects. As early as in the middle of the eighteenth century, after the Pugachev uprising, state-minded enlightened bureaucrats sought to promote an Islam that could strengthen the Russian imperial state-an Islam opposed to the thaumaturgical Islam at work in the countryside, rational, modern, open to secular sciences, and loyal to the Russian state. Ultimately, this kind of Islam would drive Tatars closer to Russians.

Once Tatars had tasted the superiority of Russian knowledge, thought state officials, they would turn away from the Qur'anic school, be less "fanatical," and ultimately merge with the Russian people. The new goal was to penetrate the closed world of the maktab and turn confessional schools, which had excelled at maintaining an Islamic separate identity, into an efficient instrument of Russification.

In 1870, the Russians did not work in a vacuum. Besides Il'minskii's experiment in native milieus, they had different models at their disposal. Like the French in Algeria or the British in India, Russian enlightened bureaucrats considered two possibilities of reform: they could transform the curriculum of Tatar Qur'anic schools by introducing the Russian language and modern subjects, and/or they could create special classes for Tatars that would ultimately give them access to Russian schools, using the teaching of Islam as a strategic tool to attract children to the schools.

The Ministry of Education took a direct interest in the Tatar Qur'anic schools, which so far had been under the supervision of the Ministry of Interior. After the rebellions in Poland and Lithuania (1863-1864), Tolstoi conceived of education as the only way to reinforce the unity of the Empire. His plan was to place all Qur'anic schools under the control of his Ministry, just as he had done to the schools in Poland, in eastern Siberia, in the Caucasus, and in Turkestan. ${ }^{119}$

Most representatives in the Simbirsk and Mamadysh districts favored the introduction of Russian in the Tatar Qur'anic schools by opening up special classes that would be under the control of the school boards in each province. Russian was the state language and the language of a civilized nation; it gave access to scientific and technical discoveries, necessary to the well-being of all citizens in the Empire. The madrasa curriculum would remain intact, and Russian authorities would not interfere with affairs internal to the confessional school. According to this, the teachers of Russian could be the mullahs themselves, once the state had made the knowledge of Russian as a requirement of service for all citizens of Russia. ${ }^{120}$

The Kazan district school board did not share the position of the Simbirsk and Mamadysh district school boards. It refused to turn mullahs into agents of Russification. Learning the state language would not transform a mullah into a Russian. One

119. Allen Sinel, The Classroom and the Chancellery: State Educational Reform in Russia under Count Dmitry Tolstoi (Cambridge, MA, 1973), 78-79.

120. Sbornik dokumentov i statei, 238-239, 367-372. 
leader of the apostasy of 1866 had studied in a parish and a district schools, spoke Russian fluently, read newspapers, and worked at the zemstvo board. Likewise, Lithuanian Tatars who had forgotten their native language and did not know Arabic, wrote commentaries on the Qur'an in Polish. In their opinion, it was better to transform the Tatars' religious beliefs by spreading the word of Christ in their native language than to introduce Russian into the Qur'anic schools. Kräshen schools then should be open to Muslim Tatars. Members of the Viatka district held the same position, that is Russification via Orthodoxization of the natives' vernacular languages, and not through Russian. The translation of Christian books in vernacular Tatar was an efficient way to reach Muslim women whom they considered incapable of comprehending words of Arabic or Persian origins, and overcome their resistance. ${ }^{121}$

The Ministry of Education's program of 1870 turned out to be more intrusive than missionaries had wished. Russian classes were to be opened in Qur'anic schools and financed by local communities. The opening of new madrasas would not be permitted without the introduction of Russian classes placed under the supervision of primary public school inspectors. Russian would also become a condition for service. Future mullahs would have to prove their knowledge of the state language before being licensed to teach and serve in their communities. Finally, besides the opening of preparatory Russian classes in governmental schools, special statesubsidized Russo-Tatar schools for boys and girls would be established in Tatar densely populated areas. Two teachers' schools would provide them with properly trained native educators. The basic program would not differ much from the Kräshen schools' except that the sharia would be taught and financed by the community. Russian and the sciences would be emphasized, using the students' native language as a teaching tool. ${ }^{122}$

The program suffered from several flaws. First, it ignored local conditions. By declaring the study of Russian compulsory, the state ran the risk of fueling new fears of Christianization among the Tatars. The program also implied that the local population would welcome the changes, and finance Russian classes and sharia lessons. ${ }^{123}$ It conveniently forgot that communities elected their mullahs, and could petition to the state to expel those who did not comply with their wishes. In one village, Tatars sent a petition against their mullah who had agreed with the new state policy concerning the introduction of Russian into the madrasas. They cautiously did not allude to the mullah's bold support of the Ministry's regulations, but denounced his involvement with neighboring Kräshens. ${ }^{124}$

In 1874, the Qur'anic schools were officially placed under the jurisdiction of the Ministry of Education, but the Ministry enforced its control only with much difficulty. ${ }^{125}$ After the reprinting in 1888 of the new regulations in Russian and Tatar, the Spiritual Assembly of Orenburg received 1,000 petitions from 500,000 Tatars

121. Ibid., 269, 316-317.

122. See conclusions of the Ministry of Education Council in Materialy po istorii Tatarii vtoroi poloviny 19-go veka, 287-291; text of the 26 March 1870 law in Mir islama 2, no. 4 (1913): 260-261.

123. Sbornik postanovlenii Ministerstva narodnogo prosveshcheniia, vol. 6, 1874-1876 (1878): 1260.

124. NART, f. 1, op. 3, d. 3272, 1l. 44-46.

125. Anastasiev, Narodnaia shkola, 129-130. 
concerned about the opening of Russian schools in Tatar villages, the teaching of Russian in the madrasas, and the obligation for mullahs to know the state language. The petitioners called these measures a new attempt to Christianize their community. ${ }^{126}$

Tatar protests used the same strategies as the apostasies. Both movements called for jihad and opposed forced Christianization. Both followed the same patterns of resistance. Petitions were gathered and written at market places or in rich merchants' hostels. Not only did the Tatars in 1888 take the same trade routes as the Kräshen apostates, but they used the same sacred networks. Famous ishans located in Buinsk and Chistopol' districts, which had a strong proportion of apostates, called villagers of several different districts to gather signatures against the application of the 1870 laws. Among them was Mir Khäydär Jan, the son of Khäyrullah Mäkhdüm, whose silsila went back to Ni'mätullah al-Älmäti, the ishan buried in Al'met'evo who had brought many Kräshens from the Chistopol' district to Islam before his death in 1852. Coincidentally, the murids that Mir Khäydar Jan sent to gather signatures came from the villages of Almurzina and Chuvashskii Brod in Spassk district, which had a long and painful history of apostasies. ${ }^{127}$ Even the starokreshchenye apostates of Kibiak-Kozi joined the Tatar cause and sent a new petition signed in Arabic script by Ibrahim Fätkhullin (Ivan Matveev), contesting the new laws as declared Muslims. Fätkhullin-Matveev reminded that mullahs had no need for Russian. From early childhood madrasa teachers had to learn the necessary sciences for interpreting the Qur'an. They had no time for assimilating "foreign sciences," which the Qur'an condemned. The petition concluded: "We have to keep our religion and observe its purity." 128

In 1895, a new wave of protest against the teaching of Russian in madrasas coincided with a fifth mass apostasy: 30,000 petitions from Kräshen villages in Kazan province had been sent to St. Petersburg. Once again, ishans and mullahs in Muslim and apostate villages of Chistopol' district (Narat Ilga, Musliumkino, Azeeva, Novaia Kadeeva, Karamyshevo, Verkhniaia Kamenka), Spassk and Mamadysh district, in particular Elyshevo canton, urged Muslim believers to emigrate to the Ottoman Empire. They spread rumors that the government had confiscated all Qur'ans and religious books, that mullahs would be forbidden to teach, and would be replaced by priests in civil clothes, trained in Il'minskii's schools; that Tatars, like the Kräshen apostates, would be forced to bear two names and, in the case of Mamadysh district, compelled to join the newly built Kräshen church of Nikiforova. Apostates whose names were no longer in church registers would be baptized, and their children sent to the army and Siberia. ${ }^{129}$

Other rumors spread that the shaykh of Kazanchi Bigeneevo, Wäli Ähmäd, agitated the population, claiming that Russians wanted to Christianize the Tatars and re-Christianize the apostates. The police arrested the shaykh, but the Russian judge

126. RGIA, f. 821 , op. 8 , d. 1075, 1l. 15, 18, 239 ob.

127. RGIA, f. 821 , op. 8, d. 1075, ll. 49, 63 ob.-64, 237 ob., 269 ob.-273, 281-283 ob., 286 ob.; Malov, "Prikhody starokreshchenykh," 17 (August 1865): 465.

128. RGIA, f. 821 , op. 8, d. 1075, 1l. 189-191 ob.

129. NART, f. 1, op. 3, d. 9602, 1l. 28-30 ob., 97; Otdel rukopisei Instituta iazyka, literatury i istorii Akademii Nauk Tatarstana, f. 56, op. 1, d. 4, 1l. 48, 136; on rumors in Spassk and Chistopol' districts, NART, f. 1, op. 3, d. 9603, 1l. 7-7 ob., 11, 58; and f. 1, op. 3, d. 11399, 1l. 10-11; for the names of apostate villages, see Malov, "Statisticheskie svedeniia," Uchenye zapiski Kazanskogo universiteta, 324-328, 342-343. 
exonerated him on the basis that these rumors were spread by his enemies-the supporters of the older village mullah. On the first day of Ramadan, the shaykh did say that the end of time was near, that he opposed the new law, and that he was ready to go to Siberia. However he added that because children between the ages of seven and seventeen were now obligated to learn Russian, it was important for parents to teach their children in the Muslim faith more diligently than ever, and that in the end the knowledge of Russian might help those who tailor outside the village to earn a better living. In other words, Tatar Muslims now confronted the same challenge as the apostates of the Elyshevo volost', who had twenty-five years earlier witnessed the opening of Brotherhood schools, and who in the end did profit from their knowledge of Russian in their trade. Confronted with such resistance, Russian state officials did not cancel the regulations but applied them more cautiously. Similarly, after Elyshevo obtained the right to profess Islam officially in 1907, the former underground mullah of Elyshevo Ibrahim Bikmökhämmätov passed the Russian exam to become his village's official mullah, after writing and signing his request in Russian. ${ }^{130}$

When Russia moved into Islamic foreign lands (the Kazan Tatar Kingdom, the Caucasus, and Central Asia), it tried to reaffirm its European character. As a Christian nation struggling against Islam or paganism, Russia could emulate the British in India or the French in Algeria and uplift the obscurantist Orient. The historian Nikolai Karamzin (1766-1826) believed that Russia was an extension of Europe in her conquest of Asiatic lands. The salvation of the Tatar Orient could be done in two ways: through direct conversion to Eastern Orthodoxy or through education on Russian principles that might ultimately lead to conversion. ${ }^{131}$

If apostasies led the church to reconsider its methods of proselytism, they were not the direct cause for the state's adoption of a new policy toward Muslims. However, in official texts, they epitomized an Islam hostile to Russia. More significant, the state applied Il'minskii's methods of education to the Muslims. Missionaries, state representatives, and orientalists blamed Tatar confessional schools for attracting inorodtsy to Islam and encouraging Muslims' fanaticism. They adopted different strategies that involved all layers of the Islamized population. Whereas Il'minskii chose to work almost exclusively with the semiliterate peasantry, Malov paid more attention to the Islamic lettered elites, inviting mullahs and shakirds to polemicize with missionaries like himself. It comes as no surprise that in 1906, the Society of Orientology in St. Petersburg blamed Il'minskii, who had been dead for fifteen years, for having paid too much attention to peasant "superstitious" Islamic beliefs instead of praising the higher achievements of Islamic civilization. ${ }^{132}$

130. "Predvoritel'noe sledstvie proizvedennoe Sudebnym sledovatelem Kazanskogo okruzhnogo suda, 2-go uchastka Mamadyshskogo suda. Po obvineniiu ukaznogo mully der. Kazanchi Bigineevo Valiulla Galimova no. 932 i 274 st. Ulozh. o nak.," NART, f. 1, op. 3, d. 9603, ll. 100-120; Proshenie mully Ibragima Bikmukhammedova uchitel'-inspektoru Mamadyshskogo 3-kh klassnogo uchilishcha (April 1907), in Gölsinä Khämidullina's private collection, Elyshevo.

131. Seymour Becker, "The Muslim East in Nineteenth-Century Russian Popular Historiography," Central Asian Survey 5, nos. 3/4 (1986): 31-35; idem, "Russia between East and West: the Intelligentsia, Russian National Identity and the Asian Borderlands," Central Asian Survey 10, no. 4 (1991): 49.

132. RGIA, f. 733 , op. 173 , d. 103, 1. 109. 
Conversely, orientalists and state representatives sought to divide and gain the support of the elites by training a new body of Russian language teachers in specialized native Russo-Tatar schools and in the projected Russian classes attached to the Qur'anic schools. The Ministry of Education agreed to the teaching of Islam in state schools as long as primary Qur'anic education would be self-contained and reduced to the learning of basic Islamic rituals. But by the 189os, apostate Kräshens understood the necessity of knowing the state language and considered it an important tool of resistance. ${ }^{133}$

Tolstoi's initial hope that the introduction of Russian in the apostate Kräshen and Tatar milieu would ultimately change or detach them from their native religious worldview proved to be vain. Il'minskii's schooling did not succeed in regaining all defectors either. Nevertheless, in an incredibly short time it contributed to the creation of a separate group of Christian Tatars aware of its cultural and religious specificity. Although Il'minskii occasionally supported state methods of retaining the apostates in Christianity, his success was due to the baptized themselves. Those who did not accept Christianity as their identity marker skillfully sought different ways to evade Eastern Orthodox schooling and submit new petitions.

Il'minskii's system of literacy, which in many ways mirrored traditional Islamic ways of learning, constituted a new spiritual challenge for Islamic supremacy on literacy and knowledge among the natives of the Middle Volga. Thanks to the work of indigenous teachers and priests, Kräshens came to view themselves as Christian martyrs in the land of "Tartar" darkness. And missionary publications invited them to be better Christians than the Russians themselves who still held onto some of their pre-Christian beliefs during their agricultural festivals. Kräshen Christianity was not meant to be a carbon copy of Russian Christianity. While Russian Christians had to respond to internal schismatic and secular challenges, Kräshen-Tatar Christianity defined itself against animism and its nearest competitor, Islam. In 1902, a priest triumphantly reported a mullah's address to a crowd: "Strengthen yourselves! Now it is a difficult time for Muslims. Although Il'minskii and Priest Vasilii (Timofeev) have died, their disciples have spread out everywhere. They read our Qur'an and our books and point out the inadequacies in our faith. There will be a time that is even worse than the present. Strengthen yourselves!"134

If at first Tatars resisted the new state intrusive policy, after the rise of the jadid movement many embraced it and tried to cooperate with zemstvo authorities to reform elementary schooling and obtain subsidies for their maktabs. Movements that employed Mahdist rhetoric and called for the jihad became an embarrassment for jadid writers. In a novel, the famous jadid writer 'Ayaz Iskhaqi (1878-1954) denounced their xenophobic character. Tatar intellectuals believed that a more thorough knowledge of the state language would help them to defend their rights more effectively.

133. NART, f. 92, op. 1, d. 16128, 1l. 1-4; f. 92, op. 2, d. 2242, 47 ob.-48; f. 92, op. 1, d. $12513,11$. 38-39 ob.; f. 92, op. 1, d. 12513, 1l. 136-138; "O tatarskikh uchitel'skikh shkolakh v gorodakh Kazani i Simferopole," in Fal'bork, Nastol'naia kniga po narodnomu obrazovaniiu, vol. 3 (SPb., 1899): 1278-1286; P. V. Traubenberg, Tatarskaia uchitel'skaia shkola v Kazani (Kazan, 1890); Bobrovnikov, Nuzhny li tak nazyvaemye, 15; Ghosman, "Zur khislär," 7.

134. Otdel rukopisei Kazanskoi nauchnoi biblioteki im. Lobachevskogo, f. 7, ed. khr. 7, 11. 14-14 ob. 
This revolution in mentalité could not have happened without the apostates' earlier appeal to the Russian legal system and the Russian missionaries' attacks of Sufi popular Islam as it expressed itself in apostate eschatological discourse. Without underestimating external Ottoman, Egyptian, Crimean influences on the transformation of the Volga Tatar religious thought, the next chapter focuses on the Tatars' efforts to change the popular worldview of Islam in order to respond to the challenge posed by Il'minskii's criticism of Sufi poetics and the spread of Christianity in vernacular languages in the Volga-Ural region. ${ }^{135}$

135. Ghayaz Iskhaqïy, Ike yöz yïldan song inqüyraz (n.p., 1904), reprinted in Qazan utlarï 69, no. 1 (1990): 110-142 and no. 2 (1990): 109-148. See also his play, Qïyamät (The Last Judgment), where Iskhaqi ridiculed traditionalist mullahs who used Mahdist rhetoric and compared Russians to Gog and Magog. “Qïyamät” (Ike pärdäle komediia)," in Äsärlär (unbish tomda), vol. 4 (P'esalar, 190o-1918) (Kazan, 2003), 207-250. 


\section{Desacralization of Islamic Knowledge and National Martyrdom}

$O^{\mathrm{t}}$ tarting in the late eighteenth century, Sufi shaykhs, baptized abïstays, mullahs, itinerant students, and seasonal workers sought to preserve a Muslim identity from Russian assimilation and to expand the boundaries of Islam. They chose to challenge bureaucratic religious affiliation through legal negotiation. Naqshbandi shaykhs defended an Islamic identity for all the non-Russian peoples of the Middle Volga, completely ignored or rejected Russian Christian culture-except for the acquisition of Russian literacy-and emphasized the power of Muslim holy men and their relics who acted as mediators between God and man, subjects and rulers. To become Muslim was to join the community of Aydar, the Bolghar khan who first adopted Islam after three companions of the Prophet had miraculously healed his daughter. Islam brought knowledge and power, but Orthodox Christianity brought death and bondage.

In the third quarter of the nineteenth century, Volga Islam met a formidable opponent in Nikolai Il'minskii, who directly attacked the Sufi hermeneutic and successfully consolidated Christianity among some of the Finnic and Turkic minorities, who had, until then, been part of the Muslim world of the Turkic khans. While writing his history of the Volga region, Shihab ad-Din Märjani, himself a Mujaddidi Naqshbandi, took pride that the Maris still retained elements of Islamic culture in their everyday life and speech. Even after their baptism and 400 years of Russian rule they knew nothing about Christianity. ${ }^{1}$ But after Il'minskii's reformed missions took firmer root in the Volga region, the Khalidi Naqshbandi shaykh 'Alimjan al-Barudi (1859-1921) became concerned about the Maris he met, whose ancestors had converted to Islam before 1552 but now felt pressure from missionaries to abandon Islam. Barudi feared, as did his Mujaddidi-Khalidi teacher Zäynullah ar-Räsuli (1833-1917) of Troitsk, that Christianity might also make strides in the steppes and joined the latter in his call for the adoption of jadid pedagogy to fight back. Another famous Khalidi shaykh, Möhämmäd Murad ar-Rämzi (1854-1934), blamed the decline of Turkic civilization on the Russian conquest of Kazan and its missionary policies, including the Brotherhood of St. Gurii. Räsuli, whom Russian missionaries sought to discredit because of his charisma among Kazakhs and baptized Tatars, saluted the quality of his work and sponsored its publication. ${ }^{2}$ It did not mean that these shaykhs, praised by the

1. Märjānī, Mustafād, 1: 24-25; Kemper, Sufis und Gelehrte, 437.

2. Aqchura, Damella Ghalimjan äl-Barudi, 25-27; Algar, "Shaykh," 127; Zarcone, "Un aspect de la polémique autour du soufisme," 227; Vospominaniia rasskaiavshegosia otstupnika ot pravoslaviia v musul' manstvo (Ekaterinburg, 1911), 7, 52-66; on shaykh Rämzi and his history of the Tatar kingdom, see Danielle M. Ross, "From the Minbar to the Barricades: The Transformation of the Volga-Ural 'Ulama into a Revolutionary Intelligentsia” (Ph.D. diss., University of Wisconsin-Madison, 2011), 316, 332-333. 
jadid press in their obituaries or literature reviews, shared all aspects of modernist thought; in fact, it was far from it. Räsuli still defended the idea that Sufis possessed mediatory powers through the recitation of their silsilas, that their graves brought blessings, and that al-Khidr was immortal, a language not different from the older books that jadids wished to change. His portrayal of Muhammad emphasized the Prophet's beauty, and not his civilizational role. As for Rämzi himself, he compared Russians to Gog and Magog, an apocalyptic metaphor which often triggered jadids' sarcasms in their novels. ${ }^{3}$

Because of Russian missionary successes among the Kräshens, who now viewed themselves as descendants of the thirteenth-century Bolghar Turkic martyr Avraamii and as the light of Christ in "Tartar" Muslim darkness, a younger generation exposed to Russian and Ottoman cultures, proposed a new definition of Tatar as a member of a Muslim national (milli) community whose religion was a rationalized, desacralized Islam freed from "popular superstitions," an Islam that rested on the intelligibility of its faith and could, if necessary, be explained rationally to a critical audience. Traditionalist mullahs, Naqshbandi shaykhs, and jadids shared the same goals of creating a society modeled after the Prophet's political and social ideals, and they all dreamed of consolidating and expanding the realm of God in a land dominated by non-Muslims. The difference between the new and older generations was that modernists proposed a new reading of ancient texts, emphasized personal responsibility over intercession and the miraculous - and, insofar as possible, eagerly adopted Russian and Western methods of proselytizing. In the past an apostate or a Tatar who read Bāqürghān Kitāb $\ddot{i}$ accepted the existence of a giant heavenly rooster that awakened all earthly roosters for the morning prayer, but a jadid reader did not reject the story out of hand but sought confirmation in other authoritative Islamic books. ${ }^{4}$

During the apostasies, the rebels built the "City of Joseph" in the village, to take an image from Qol 'Ali's poem. They listened to itinerant preachers in market places, erected a community that conformed to their Islamic ideals, spread Islam to other Kräshen parishes, and challenged animist resistance to the Muslim faith. They associated Eastern Orthodoxy with paganism, symbolically rejected all elements of Russian culture, whether clothing or Cyrillic books, and opened new Qur'anic schools near their hastily constructed mosques. Despite this emphasis on literacy, Russian missionaries - in their critical analyses of the Islam at work among apostates-stressed that most of these new Muslims could not comprehend the Arabic Qur'an; and their Islam narrowly centered on the veneration of saints' tombs and relics, pilgrimages to local holy places, and the use of Qur'anic verses as magic tokens for warding off evil spirits and disease. By the end of the nineteenth century, these superstitious elements proved to be a growing embarrassment for the Tatar bourgeoisie and the reformist intelligentsia, despite their admiration for these oppressed Muslims. They claimed that aggressive Russian Orthodox missionaries, trained in Arabic at the Kazan Theological

3. "Bozhestvennye istiny, postizhenie kotorykh neobkhodimo dlia muridov sufiiskogo bratstva Nakshbandiia slavosloviia [Allakhu] i molitvy-'Salauat" (1899) and "Makalat 'Zeiniia"” (1908) in Sheikh Zeinulla Rasuli (Rasulev) an-Nakshbandi, Izbrannye proizvedeniia, trans. from Arabic by I. R. Nasyrov (Ufa, 2001), 23-49, 50-78; Sheikh Zeinulla Rasulev ob Ibn Taimii (Kazan, 2005/1426 A.H.), 3-21; A. Zeki Velidi Togan, Bugünkü Türkili (Türkistan) ve Yakın Tarihi, t. 1 (Istanbul, 1942-47), 542.

4. Shūrā, no. 24 (1913): 762. 
Academy, often knew the Qur'an better than the Muslims they were trying to convert. They complained that Russian missionaries used books such as Fäżं'il ash-Shühür, with its unrealistic miracle stories, to make Islam look ridiculous. Malov's analysis of $\bar{A} k h \ddot{r}$ Zamān Kitābï deeply disturbed some learned Muslim authorities who personally voiced their disagreement with the missionary. One of them warned Malov that books like Ākhïr Zamān Kitābï or Bädäwām should not be taken seriously because they were nothing but folk songs (munajat). Newly converted people, he argued, used poetry to express what they understood about Islam, but by lack of proper education, often distorted the Prophet Muhammad's fundamental message. ${ }^{5}$

Moreover, so-called popular Islam, by rejecting all that was Russian, condemned its community to economic decline. By favoring the knowledge contained in Tatar books only, it placed religious knowledge above science and technology and confused the latter with Christianity. The apostates in the 188 os, like their Muslim neighbors, viewed "Russian sciences" (e.g., mathematics, physics, chemistry, and agriculture) as inappropriate subjects for a confessional school. To meet these polemical and economic challenges, some mullahs and entrepreneurs considered it necessary to rebuild the "City of Joseph" on new principles. Beginning as religious reformers, jadids sought to create a new Tatar identity by making the Qur'anic message intelligible to their community. Against the popular Islam of the baptized apostates and their Muslim neighbors, most reformists discouraged but did not condemn mediators, be they Sufi saints or holy places, between God and the believer. The famous Tatar theologian Fäkhr ad-Din blamed Sufi missionaries for introducing legends and superstitions, compromising with local shamanistic and Christian beliefs, yet he acknowledged their success in winning new hearts to Islam. (After all, Fäkhretdin studied with Möhämmäd Mäkhdüm al-Kizlawi, a member of the famous ishan family of Kurmanaevo (Kizläw), who brought many baptized Tatars to Islam.) ${ }^{6}$

Western, Tatar, and Turkish historiographies have focused on four aspects of jadidism-its origins and the theological debates that led to its rise, its educational and cultural achievements, its impact on the formation of a secular society, and its contribution to the emergence of a Tatar national consciousness. This chapter looks into the ways modernists read the religious literature that had molded their childhood, responded to the Russian missionaries' critique of their beloved Prophet, and imagined their role as missionaries of Islam after 1905, when part of the Kräshens affirmed their Christian identity. ${ }^{7}$ In some way, the Tatars' challenge was not that

5. Otdel rukopisei Kazanskoi nauchnoi biblioteki im. Lobachevskogo, f. 7, ed. khr. 11, 11. 56 ob.-58 ob.; S. Bagin, "Musul'manskie poniatia o rae," PB 23, nos. 5-6 (May-June 1915): 212; idem, “Tatarskomusul'manskaia pechat'," PS 47 (April 1911): 531-545; Aqchura, Damella Ghalimjan äl-Barudi, 39.

6. Möhämmäd Mäkhdüm al-Kizlawi (d. 1878) was Shaykh 'Ubäydullah's third son (Märjānī, Mustafād, 2: 228-229); Fäkhr ad-Dīn, Jäwāmi‘, 514-517 (hadith no. 330); idem (Fäkhretdin), “Tärjemäi khälem,” 17.

7. Iakh"ia Abdullin, Tatarskaia prosvetitel'skaia mysl' (Kazan, 1976); Nadir Devlet, Rusya Türkleri'nin Millî Mücadele Tarihi (Ankara, 1985); Stéphane Dudoignon, "Qu’est-ce que la Qadîmiya? Djadidisme, Mirasisme, Islamisme," Cahiers du Monde russe 27, nos. 1-2 (1996): 13-40; Edward Lazzerini, "Ismail Bey Gasprinskii and Muslim Modernism in Russia, 1878-1914" (PhD diss., University of Washington, 1973); Christian Noack, Muslimischer Nationalismus im russischen Reich: Nationsbildung und Nationalbewegung bei Tataren und Baschkiren, 1860-1917 (Stuttgart, 2000); Rorlich, Volga Tatars; Mustafa Özgür Tuna, "Imperial Russia’s Muslims: Inroads of Modernity" (PhD diss., University of Princeton, 2009); Serge Zenkovsky, Pan-Turkism and Islam in Russia (Cambridge, MA, 1960). 
different from the nineteenth-century Muslims of India, who under British rule were confronted for the first time with the critical portrayal of their Prophet in the works of European orientalists. ${ }^{8}$

\section{A New Hermeneutic}

One of the most helpful Tatar textbooks for encapsulating the reformists' reconstruction of Islam as a response to Russian missionaries' criticisms of traditional Islam, which expressed itself so resourcefully among apostate Kräshens, is Riza' ad-Din b. Fäkhr ad-Din's Jäwāmi' al-Kälim Shärḥe (Commentaries on [the Prophet's] comprehensive words), an extensive commentary on the acts and sayings of the Prophet, designed for the lowest grades of the madrasa system and completed in 1916. Fäkhr ad-Din was a prolific theologian, pedagogue, novelist, and historian who became a qadi (Muslim judge) at the Spiritual Assembly of Orenburg in 1891 and according to his daughter, served there until 1909. Fäkhr ad-Din was also a talented journalist. In 1908, the qadi became the chief editor of Shürä (Counsel), a journal that covered all subjects from religion, education, history, science, philosophy, folklore, music, to literature in the Islamic world as well as Russia, Europe, and America. Elected deputy mufti in Ufa in December 1917, Fäkhr ad-Din served as mufti after the death of Shaykh Barudi in 1921 until his own death in 1936 in great poverty. A popular legend says that thousands of Tatars converged on his native village, Kichuchatovo in Samara province, to read his funeral prayers at night in secret. ${ }^{9}$

Fäkhr ad-Din sought to perfect a new Islamic theology for schools by reconsidering many aspects of popular knowledge of Islam and by familiarizing students with the thought of eminent Muslim intellectuals, both ancient and modern, Arab and Tatar. He was anxious to introduce students to classical writers such as the jurist Ibn Taymiyya and the mystic Ibn al-A $r a b i$, who had been neglected in the traditional curriculum. He also popularized some of the ideas of contemporary reforming theologians including Jamal ad-Din al-Afghani (1839-1897), his disciple Muhammad 'Abduh (1849-1905), and the Ottoman reformer Ahmed Midhat (1846-1913). Finally, Fäkhr ad-Din also highlighted the work of native Tatar theologians, such as Shihab ad-Din Märjani. Fäkhr ad-Din's textbooks were widely used in jadid schools. ${ }^{10}$

To liberate Islam from its petrified state (as the reformers themselves put it), modernists headed by the Crimean Tatar journalist and pedagogue Ismail Gasprinskii (1851-1914) urged Tatars to return to the foundations of their faith: the Qur'an (the holy revelation that God had given to the Prophet Muhammad) and the Sunna (the

8. Schimmel, And Muhammad Is His Messenger, 228; Säghïyt' Sünchäläy, “'Magomet' (Mökhämmäd gham khaqïnda kitap)," in Äsärlär häm khatlar (Kazan, 2005), 225-227 (reprint from Bayan al-Haq, 1910).

9. Äsma Shäraf, "Ätkäyem turïnda istäleklär” (1983-1988), in Rizaetdin Fäkhretdin: Fänni-biografik jïyintïq, 49. Other sources state that the qadi served until 1905 or 1906. K. Qazanlï, Törk-tatar khalqïnïng böyek möftiye Riza Fäkhretdin, in ibid., 180; Abdullah Battal-Taymas, Kazanlı Türk Meşhurlarïndan I. Rizaeddin Fahreddinoğlu (Istanbul, 1958), 12. On mufti Fäkhr ad-Din’s funerals, Mädinä Räkhimqulova, personal communication, Orenburg, August 1992 and "Fakhretdin, Rizaetdin," in Islam na Nizhegorodchine, 181-183.

10. Fäkhr ad-Dīn, Jäwāmi', 273-279 (hadith no. 167), 284-285 (hadith no. 171), 354-356 (hadith no. 220), 423-426 (hadith no. 275). 
example of the Prophet based on his sayings and actions). Märjani had reintroduced the direct study of hadith in his madrasa as a condition of renewal for the development of an independent theology, and his teachings remained confined to a very narrow section of the population. Fäkhr ad-Din went one step further. His Jäwāmi`al-Kälim Shärhe was a collection of hadith designed to popularize new codes of behavior through school or independent reading. It was aimed at students, teachers, and the general public. As in other parts of the Islamic world, Tatar students, before the rise of reformism, examined the hadith within the framework of Muslim jurisprudence. It was done at the highest stage of their education in the madrasas. Students then relied on Arabic texts, in particular on the commentaries of Abu Hanifa's texts (699-767) and the knowledge of their mentor. At a more popular level, mullahs and parishioners used the hadith as small talismans. ${ }^{11}$

Fäkhr ad-Din warned against this ritual use of hadith and instead encouraged believers to understand their meaning. The word of the hadith, he added, was superior to the word of those who studied the hadith; every Muslim had the obligation to read them directly and the freedom to model his or her behavior, according to their intent. Fäkhr ad-Din did not judge hadith by the degree to which they conformed to the tenets of a particular juridical school. Like many other modernists in the Islamic world, Fäkhr ad-Din did not advocate the supremacy of one law school over another. ${ }^{12}$

Fäkhr ad-Din's anthology was not written for religious scholars but for preteens who had just started the study of Arabic, the ordinary believer, and Muslim missionaries. Rather thick, it contained 345 hadith in their original Arabic; a translation of each hadith into a language closer to Ottoman Turkish than to vernacular Tatar; and the author's personal comments and observations on belief, character, and the different aspects of modern life. To make his volume easier to read, Fäkhr ad-Din rarely included the chain of transmission. The resulting work was above all a practical self-help guide for Muslims living in a changing world dominated by Christians. It encouraged Muslims to be industrious, independent, and confident in their future. Such an approach, however, alienated traditionalists who criticized the jadids for reducing Islamic verses to one meaning and bypassing earlier commentators and living authorities, who could restore the multilayered meaning of Qur'anic and hadith literature. ${ }^{13}$

To make sure that his message would be largely understood, Fäkhr ad-Din quoted popular tales, proverbs, regional newspaper articles, and contemporary Tatar poetry. ${ }^{14} \mathrm{He}$ also shared his personal observations, opinions, and prayers, using the first person. The anthology included a thematic glossary to help the reader to find

11. Howard M. Federspiel, The Usage of Traditions of the Prophet in Contemporary Indonesia (Tempe, AZ, 1993), 2-3; Barbara Daly Metcalf, Islamic Revival in British India: Deoband, 180o-190o (Princeton, 1982); Nikolai Katanov, Katalog knig otpechatannykh v tipografii Imperatorskogo Kazanskogo universiteta s 1800 po 1899 god (Kazan, n. d.), 341, 368, 389; Koblov, "Konfessional'nye shkoly," 29-30, 45; Deiatel', no. 1 (1898): 34, no. 3 (1900): 165, and no. 10 (1901): 390-391; Fäkhr ad-Dīn, Jäwāmi', 3-6, 184-187 (hadith no. 120), 479-485 (hadith no. 308).

12. Fäkhr ad-Dīn, Jäwāmi`, 184-187 (hadith no. 120).

13. Shäyekh Ishmökhämmät khäzrätläre Tüntäri, Shärighat'ne torghïzu shartlarï: Din Islamnï yanga ghasïrlarda torghïzu häm möjäddidlär turïnda (Kazan, 200o), 5, 11-14.

14. Fäkhr ad-Dīn, Jäwāmi', 36-38 (hadith no. 23), 63-65 (hadith no. 44), 72-74 (hadith no. 50), 91-92 (hadith no. 65), 92-93 (hadith no. 66), 284-285 (hadith no. 171), 50 (hadith no. 36). 
answers to specific issues such as medical care, worship at sacred tombs, marriage, and divorce. This original format made legal knowledge accessible to all believers. ${ }^{15}$

Fäkhr ad-Din's attempt to summarize the main goals of the sharia was crucial, because the population overall was still attached to popular forms of worship such as visiting sacred places. To make things worse, a new, more radical, religious trend had emerged among second-generation Tatar intellectuals. After 1905, some students in the madrasas neglected to perform their daily prayers and ablutions, refused to go to the mosque on Fridays, and shortened their fast. ${ }^{16}$ The famous playwright and novelist, Fatih Ämirkhan exemplified this new trend. In his novels and articles, Ämirkhan, who had participated in the 1905 student strikes in Möhämmädiyä madrasa (Barudi's school), attacked both prejadid and jadid books of adab (Islamic etiquette) literature. He believed that both literatures reduced Islam to a rigid set of rules that stifled faith and made it oppressive; the only difference was that Islamic tenets in jadid textbooks were better arranged and were written in clear, accessible language. With disgust, he recalled the ablution rules he had to memorize as a child. Some rules, he added, made him blush, presumably because of their explicit instructions about washing one's private parts. This argument was also used by Russian missionaries to critique Islam and Islamic pedagogy. In his mind, national literature was sufficient to teach children to live like Muslims in the modern world. ${ }^{17}$

In the same spirit, Ämirkhan in Fätkhulla Khäzrät (Reverend Fätkhulla) pictured a utopia where purity of heart was valued more than purity of body, and ritual vessels for ablutions (qomghans) had become museum pieces. His dream was to see a mosque with transparent windows erected in the middle of the forest where men and women, separated by a carpet instead of the traditional curtain, could freely gather without any pressure from their neighbors or parents. Ämirkhan's stress on personal religious experience derived from his reading of Ibn al-'Arabi whose teaching deemphasized ritual in favor of a more individualized experience of God. ${ }^{18}$

In response to this turbulent youth who lived Sufism as an ecstatic experience incompatible with obligatory daily acts of worship, Fäkhr ad-Din borrowed Sufi metaphors and argued, as a true student of the Naqshbandi way, that one should apply the rules, intents, and principles of the Divine Beloved, which were clearly spelled in the Qur'an and hadith. Like al-Ghazali, Fäkhr ad-Din's message combined the importance of outward and inward discipline in the worship of God. Thus, to correct popular understanding of Islam and prevent any form of intellectual radicalism, the former qadi revisited three important pillars of popular faith: prophethood, sainthood, and eschatology.

15. See examples in Fäkhr ad-Dīn, Jäwāmi`, 224-228 (hadith no. 144), 497-499 (hadith no. 319); $546-552$.

16. Mir islama 2, vol. 8 (1913): 515. One of 'Alimjan Ibrahimov's characters, a student who participated in the 1905-1906 shakirds' strikes, refused to perform his ablutions when forced to attend the mosque: 'Alimjan Ibrahimov, "Bezneng könnär" (1933), in Äsärlär (Sigez tomda), vol. 4 (Kazan, 1976), 68.

17. Amirkhan, Moia avtobiografiia, 82-83; idem, Mäktäpläremezdä ädäbiyat däresläre, in Äsärlär, vol. 4 (Kazan, 1986): 77-79 (originally printed in Al-Islah, 1908); idem, Mäktäpläremezdä tatar ädäbiyatï, in Äsärlär, vol. 4: 106 (originally printed in Yoldï, 1910) and Mädräsäläremezdä ädäbiyat däresläre, in Äsärlär, vol. 4: 122-125 (originally printed in Qoyash, 1913); Otdel rukopisei Kazanskoi nauchnoi biblioteki im. Lobachevskogo, f. 7, ed. khr. 1, 1. 201.

18. Ämirkhan, Fätkhulla khäzrät, 28-49, 79-84, 89-93; Lifchez, ed., Dervish Lodge, 19. 


\section{Prophethood and Miracles Revisited}

Fäkhr ad-Din and other jadid thinkers did not outright condemn equivocal practices. They chose to challenge the Tatar peasants' and village mullahs' knowledge of Islam in a subtler manner. As in eighteenth-century India, the reformists used the traditional channels of prophecy to convey their new message, downplayed the Prophet's image as a miracle worker, separated the world of the dead and spirits from the living, and gave a new eschatological meaning to the End of Times. ${ }^{19}$

In popular Sufi textbooks, the prophets were extraordinary thaumaturgical figures. Emphasis was placed on their miracles and the special relationship they had with God. Reformist works favored a more historical view of the prophets, but did not subject miracles to a historical analysis to show their irrationality. In his introduction to a children's textbook composed in 1884, the encyclopedist Nasïri, admired by Ismail Gasprinskii, argued that history was the best way to explain one's experience and teach men and women how to live an exemplary Islamic life. He emphasized the occupation and scientific interests of each prophet. After Adam departed from paradise, he became a farmer, and his wife turned to weaving wool. Not only did the Prophet Solomon understand the language of all animals (a recurrent theme in Rabghuzi's history of the prophets), but he also knew the medicinal properties of plants. Nasïri provided more specific information about the Prophet Idris (Enoch) who was the first man to write with a quill, and to devote his time to astronomy and medicine. 'Alimjan Barudi, who composed prophets' tales for children, stressed that Idris was the first prophet to introduce the concept of knowledge specialization, an important notion that reformers wished to promote in the creation of a new system of education that would allow children to choose secular careers. ${ }^{20}$

Reformers' biographies of the Prophet Muhammad scarcely mentioned Muhammad's miracles. However, like 'Abduh in Egypt, the Tatar modernists did not reject the Prophet's miraculous deeds, partly because the Qur'an mentioned miracles of the prophets as proof of God's support. ${ }^{21}$ Miracles were deemphasized, marginalized, or silenced, but not eliminated or subjected to criticism. In his calendars, Nasïri recalled one of the most popular miracles attributed to Muhammad, the splitting of the moon. This miracle was popular among Tatars and Kräshens alike. Nasïri's tale was not different from the itinerant Sufis' stories, except that in his conclusion Nasiri wrote that Muhammad refused to perform another miracle, since the faith was not based on supernatural proof. However, Nasïri named other miracles mentioned in Sufi literature, which he carefully listed as references, and exposed them in the same spirit as his predecessors. But Nasïri did not mention the fantastic story of the poisoned roast lamb who miraculously warned the Prophet not to eat it. Some of the miracles echoed those performed by Jesus: Muhammad raised the dead and fed entire crowds with little food. In one case a resurrected girl rejected her miracle and

19. Schimmel, And Muhammad Is His Messenger, $216 \mathrm{ff}$. For the most popular religious textbooks in the Middle Volga, see Möallimlär-i nämūnä: Qazān shähärendä möallimlär jäm‘̈̈yate tarafindan tärtīb itelmesh$\operatorname{der}$ (Kazan, 1906).

20. 'Abdulqayyūm Nāșiīī, Mokhtäsar-i täwārīkh-i änbiyä' (composed originally in 1884) (Kazan, 1899), 2-5, 7, 27; Deiatel', no. 2 (1900): 104-107; al-Rabghūzī, Stories, 49-52; 'Ālimjān al-Bārūdī, Tärīkh-i änbiyä (Kazan, 1899), 4.

21. Johansen, Sufism, 20. 
asked to be returned to her lifeless state, because she was content that her parents had accepted Islam as a condition for her resurrection, and because she found bliss in the grave. ${ }^{22}$

The journalist and linguist Ähmäd Hadi Maqsudi (1868-1941) adopted a different strategy. Only toward the end of his historicized biography of Muhammad did he hint at the miracles surrounding the Prophet's birth and childhood, but he did not elaborate on them. He merely pointed out the "books of the prophets" that contained full descriptions of those wonders, and expressed his belief that miracles confirmed the Prophet's mission as a guide to humanity. Because these miracles were known to his audience, he did not see the need to elaborate further. ${ }^{23}$

The pedagogue, literary critic, and historian Häbib Rahman Zäbiri from Chistopol' district (1880/81-1942) insisted on the Prophet's human nature and ignored the miracles recounted by Rabghuzi. In Rabghuzi's tales, the Prophet began to speak the day he was born, a white cloud raised him into the air, and the earth swallowed his feces. Given to a wet nurse whose right nipple was dry, the infant refused to take her left nipple, but drank instead from her dry breast, miraculously causing the milk to flow again. Zäbiri did not mention any of those wonders, but simply gave the date and time of the Prophet's birth. He only briefly referred to the wet nurse to say that she fed the child and gave him a good education before moving on to the time when the Prophet received the revelation. But because he never specified that Muhammad's only miracle was the Qur'an itself, it is still conceivable that a mullah-using Zäbiri's textbook-could have added more "thickness" to the text by drawing heavily from Rabghuzi's miracle stories. ${ }^{24}$

In 'Abd al-Mäjid Ghafuri's textbook, the same ambiguity remained. The poet and publicist from Ufa province (1880-1934), portrayed as an atheist by Soviet historians, wrote that the cattle's milk increased when the child-Prophet was brought into the wet nurse's household, thanks to his baraka (grace, blessing, divine gift). Ghafuri later added that the Qur'an was Muhammad's greatest miracle, implying that Muhammad was known for other miracles, but again Ghafuri avoided describing them, preferring to focus on the Prophet's earthly occupations, such as repairing boots or cleaning the house. Only Imam 'Ata'ullah Bayazitov (1847-1911), a Kasimov Tatar who composed pamphlets in Russian against Western detractors of Islam, affirmed categorically that the Qur'an was Muhammad's only miracle, stressing that the splitting of the moon never occurred. But Bayazitov addressed his pamphlets to Russians, not to the Muslim children that textbook writers sought to reach. He took pains to

22. Passage from Qayyūm Nāsirī, Mäjmū‘ al-äkhbār (1895) in Katanov, Materialy k izucheniiu kazansko-tatarskogo narechiia, 32-33; Qayum Nasïyri, Saylanma äsärlär (Kazan, 2006), 4: 39-50; Vasilii Doronkin, "O chem govorit polumesiats na mechetiakh nashikh magometan?" PB 23, nos. 5-6 (May-June 1915): 201. According to one tradition, Muhammad performed the miraculous "splitting of the moon" (shaqq al-qamar) in an unsuccessful attempt to convert the unbelieving citizens of Mecca.

23. Äkhmäthadi Maqsudi, “Ghïybadäte Islamiya," Miras 59, no. 10 (1996): 140-141.

24. H. Zäbīrī, 'Aqāìd (Kazan, 1910), 9-20; al-Rabghūzī, Stories, 524-528. Another jadid author, Șänatullah Bikbulat used the same sober approach as Zäbiri. He referred to the blessings the baby Prophet brought to his nurse but did not elaborate on them. What mattered was the date and city of his birth, the names of his tribe and kins, and the fact that those who had not given themselves to polytheism (among them the "peoples of the book") awaited for his coming. Ș. Bikbūlaț, Dīn däresläre: Tārīkh-i möqaddäs, ítiqādāt, 'ibādāt (Kazan, 1918), 19-21. 
refute Ernest Renan's (1823-1892) thesis that Islam was directly responsible for the

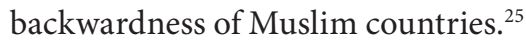

Like Zäbiri, Maqsudi, and Ghafuri, Fäkhr ad-Din insisted on the Prophet's human nature. He did so by situating the Prophet in his time and immediate environment, and by reconsidering his miraculous and healing powers. Muhammad was more than God's messenger; he was also a liberator, a transformer, and an innovator. Thanks to his spiritual and social reforms, the Arabs, a barbaric people, were able to develop into the most civilized nation on earth and resist the Byzantines' and the Sassanians' encroachments. ${ }^{26}$ Oppressed women of Arabia learned that if men had rights over them, they in turn had rights over men. For Fäkhr ad-Din Muhammad's reform of women's status was a striking innovation in world history. By contrast, pagan Arabs buried girls alive and forced widows to marry the man who inherited their husband's wealth; Jews considered women as their property and their prophets such as Solomon could marry as many women as they wished. Romans and Greeks married their daughters to friends and relatives at the age of fifteen without their consent and forced their wives to lead secluded lives. Compared to the Qur'an and the hadith, even the French Napoleonic code was deficient for it said nothing about how women should be loved. ${ }^{27}$

Contemporary Muslims were backward because they regarded the Prophet as a hermit and miracle worker rather than as a model for economic, social, and spiritual behavior. Itinerant and contemplative Sufis, according to Fäkhr ad-Din, were responsible for this unfortunate shift of perception. Their interest in the Prophet's miracles had made them abandon work and family to go to Mecca or pray in isolated cells, which had led to a total economic and social collapse in the Islamic world. Praying five times a day, as commanded by the sharia, was obligatory but not sufficient, Fäkhr ad-Din insisted. Acting for the good of the community was a vital part of believing in God. The Prophet Muhammad was above all a worker, a fighter, and an organizer of social life. He traded goods, fought against the infidels in memorable battles, borrowed from the Iranians in military matters, encouraged his companions to learn the languages of unbelievers, and had hospitals, shelters, and centers of learning built for the well-being of his people. ${ }^{28}$

Not only did Fäkhr ad-Din portray Muhammad as the builder of a new civilization, but he also gave a new interpretation of Muhammad's healing powers, one of the

25. Mäjit Ghafuri, Khäzräte Räsülullah Salallahu ghaläyhi wäsälläm vä dürt khälifä (Kazan, 1995, reprint of 1912 edition), 8-9, 30; Ataulla Baiazitov, Otnoshenie islama k nauke i $k$ inovertsam (SPb., 1906), 7.

26. Fäkhr ad-Dīn, Jäwāmi', 63-65 (hadith no. 44), 98-10o (hadith no. 72), 123-124 (hadith no. 89), 432-433 (hadith 283), 481-485 (hadith no. 308.); idem, Shākirdlek ādābe (Kazan, 1899), 32; idem, Fäkhr-i kānàt äfändemez Räsūl ākram sallā llāhu 'alayhi wä sallama Häżrätläreneng mubārak shäjäräse, näsele wä näsäbläre wä ba'żi ähwwäle yazïlmïsh ber risāläder (Orenburg, 1909), 38-39. Fäkhr ad-Din emphasized the Prophet's moral character and good deeds rather than his admittedly extraordinary beauty. Tuqay and the pedagogue Shähär Shäräf (1877-1938) shared the same approach. See children's anthology compiled by 'Abdullāh Tuqayev, Mäktäbtä milli ädäbiyāt däresläre (Kazan, 1911), 48-58. Another interesting biography of the Prophet by a different author (Șän'atullāh Bikbūlaț, Häżrät-i Muhammad [Sallā llāhu 'alayhi wa sallama] [Kazan, 1914]) situated the emergence of Islam in time and place with greater emphasis on preIslamic Arabia, using photographs as illustrations for the first time.

27. Fäkhr ad-Dīn, Jäwāmic, 214-216 (hadith no. 136), 494-496 (hadith no. 316).

28. Fäkhr ad-Dīn, Jäwāmi', 63-65 (hadith no. 44), 432-433 (hadith no. 283), 452-457 (hadith no. 295). 
cornerstones of popular Sufi beliefs. First, he carefully mentioned that the remedies found in the hadith were not part of the revelation; these remedies dated back to the time when medicine did not exist as a science. Second, he argued that the Prophet did not come to teach medicine, but faith. Third, Muhammad referred to kafir (infidel) doctors when necessary. Fourth, the Prophet's remedies achieved the desired results, if those who applied them did it with a pure heart. Nothing here suggested that the Prophet could heal by simple touch, as Rabghuzi's biography suggested, or that God answered his prophets' prayers automatically. Fäkhr ad-Din considered it wrong to turn to the prophets or the saints (living or dead), for miracles or healing. When adversity strikes, he advised, men should turn to God directly, and look for doctors' help (even if those doctors were infidels). ${ }^{29}$

At the same time as Fäkhr ad-Din reevaluated the Prophet's healing powers, he separated the world of the spirits from that of the living. In particular, he condemned the popular belief that jinns possessed people and made them sick. Fäkhr ad-Din recalled in his memoirs that when children fell ill, especially during winter, older shakirds prayed over them and asked them to name the spirit that they saw during the prayer. After the child had given the name, the shakirds wrote it on a piece of paper and burned it. If the child did not see anything, shakirds yelled to exorcize the spirit and even hit the child. Although appalled by such rituals, Fäkhr ad-Din did not deny the existence of jinns. According to the Qur'an, jinns indeed existed and performed supernatural feats, but after the time of the Prophet, no one could hold them responsible for bringing diseases. Consequently, it was superfluous to use magic to ward off evil spirits, and more efficacious to turn to modern medicine, as had the Prophet Muhammad. ${ }^{30}$

Thus reformist pedagogues and theologians presented the prophets as messengers of God, nation builders, liberators, and indefatigable teachers of human nature rather than as miracle workers or carriers of a special light or signs. In Fäkhr ad-Din's anthology, the Prophet Joseph gained freedom for his people not only by divine intervention but also through his belief in himself. In jadid stories of the prophets, angels did not bring Joseph cozy pillows when he was stuck in the well, and clouds did not protect him from the sun. However, reformists did not question miracles directly. Miracles that included answers to prayers, prophetic dreams, or travel through space were signs of God's support. But modernist thinkers exposed to Russian missionaries' critique of Muslim miracles argued that the supernatural could not be used as a support for changing the divine order, manipulating mankind, instilling or strengthening the faith. Nasïri reported a story in which Moses asked God to save a man from poverty. His prayer was automatically answered but later the same man got drunk and killed another person. Moses repented then for his arrogance at trying to change God's plans. ${ }^{31}$

Fäkhr ad-Din redefined the Prophet's miracles, which were not physical but verbal. He claimed that Muhammad had brought a new faith based on reason, but his

29. Fäkhr ad-Dīn, Jäwāmi‘, 102-104 (hadith no. 75), 253-258 (hadith no. 163); idem, Dīnī wä ijtimā'i mäs'älälär (Orenburg, 1914), 41-44.

30. Fäkhretdin, Tärjemäi khälem, 23-24; Koblov, "Mifologiia Kazanskikh tatar," 429-433.

31. Fäkhr ad-Dīn, Jäwāmi', 127 (hadith no. 89); Qayum Nasïyri, Kitab-ät-Tärbiyä (Kazan, 1992), 27-28. 
followers, under the influence of Indian monks and despotic Iranians, had ignored his message by placing their faith in miracle workers and itinerant Sufis. The jadids, the new Martyrs of Islam as portrayed by Fäkhr ad-Din, now had to restore the true meaning of Muhammad's revelation. ${ }^{32}$ The Prophet's true miracles were his sayings. Like Nasïri, Fäkhr ad-Din showed a Muhammad reluctant to perform miracles. When a man asked the Prophet to make him rich, the latter refused and explained that it was better to be satisfied with little than to be wealthy and unhappy. In this tale, the Prophet's word took the place of the expected miracle, and its wisdom extended to all times. ${ }^{33}$

Fäkhr ad-Din also used the Prophet's sayings to condemn certain traditional practices as innovations introduced after Muhammad's death. These hadith were examples of Muhammad's divine foresight, for the Prophet had attacked practices unknown in his time. For instance, Muslims in the seventh century did not visit the prophets' tombs, but Muhammad's sayings foresaw the visitation of tombs by believers and condemned such practice. Women in the time of the Prophet went to pray at the mosques, accompanied the dead to the cemetery, had an active role in community affairs, and gave advice to the Prophet but later Muslim scholars urged women to pray at home, barred them from visiting cemeteries, refused to give them a proper education that would allow them to support themselves in case they lost their husband's financial support. Again Muhammad's sayings criticized these later deviations that restricted women's activities. According to the former qadi, only God-not Muhammad-could have foreseen those alterations. Fäkhr ad-Din's interpretation was consistent with the Islamic idea that foreseeing the future was one of the attributes of prophethood and sainthood, bestowed by God alone. ${ }^{34}$

\section{Sainthood and Dream Interpretation}

If miracles could be attributed to prophets, as the traditional and reformist Islamic doctrine stated, reformers such as Fäkhr ad-Din were more suspicious of miracles performed by nonprophets. In his commentary on the hadith, the theologian did not openly attack miracles performed by living saints or shaykhs. In fact he accepted some of them, but he repeatedly criticized the external aspects of popular Sufi beliefs when he felt that they contradicted the sharia. In particular, Fäkhr ad-Din censured the cult of dead saints.

In popular Sufi books the line between the living and the dead, the natural and supernatural, was tenuous. Dreams and strange phenomena around the tombs revealed the fate of men after death. The Qur'an supported the belief that after death the living soul slept together with the spirits of the dead in God's presence. Dreams therefore offered a glimpse into the other world. Reformist works, however, drew a sharp line between the worlds of the dead and the living. ${ }^{35}$

In traditional textbooks, spirits of the dead interacted with the living in two ways: through dreams and the saints. Fäkhr ad-Din was very cautious when dealing with

32. Al-Rabghūzī, Stories, 489; Fäkhr ad-Dīn, Jäwāmi', 58-59 (hadith no. 41), 117-119 (hadith no. 85).

33. Fäkhr ad-Dīn, Jäwāmi', 291-292 (hadith no. 177).

34. Fäkhr ad-Dīn, Jäwāmi‘, 112-113 (hadith no. 80), 115-116 (hadith 82), 334-344 (hadith 208), 328-332 (hadith no. 204), 423 (hadith 274).

35. Valerie J. Hoffman, Sufism, Mystics, and Saints in Modern Egypt (Columbia, SC, 1995), 214. 
dreams and visions. For example, in his discussion of istikhara (asking for the best choice), a practice affirmed in the hadith in which believers sought guidance-which might come in the form of a dream-by performing a series of ritual and personal prayers, Fäkhr ad-Din also insisted that nothing bound people to act according to the content of their dream or its interpretation, even if the vision appeared not to contravene the sharia. Again very cautiously, Fäkhr ad-Din advanced that he had no proof that dream interpretation was not an innovation absent in the Qur'an (bid'a). Possibly, the Prophet or his disciples taught oneiromancy, but personally Fäkhr ad-Din believed that Muhammad's community had not resorted to dream interpretation. ${ }^{36}$

To change popular attitude toward dreams, Fäkhr ad-Din proceeded in two directions: first, he made a distinction between different types of dreams and, second, he challenged the power and authority of dream interpreters. Initially, the theologian cautioned that not all dreams came from God; in fact most originated from the devil. Among those sent by God, he distinguished between dreams in a sleeping state, such as the one the Prophet Muhammad experienced during his ascension to Heaven, and waking dreams, such as visions experienced by shaykhs traveling in spirit to the Ka'ba. Scientists, he added, had acknowledged the occurrence of those dreams where a person finds himself in several places at one time, but had been unable to determine their cause. Other dreams were the work of the devil. People who saw Satan in their sleep should not talk about it, but get up, spit three times on their left, ask God for His help, and go back to bed, on the other side. This magic panacea for bad dreams was based on a very popular hadith that said: "If one of you has a dream he dislikes, let him spit to his left side and seek God's protection from Satan, and it will not harm him." As much as satanically inspired dreams should not be shared, even visions that did not go against the sharia should not be subjected to dream interpretation. ${ }^{37}$

Fäkhr ad-Din also warned against those shaykhs who controlled their disciples through dream interpretation. Some, according to the former qadi, put their students to sleep with wine and had them recall their visions in order to manipulate their mind. In their turn, the shaykhs' disciples offered their services as professional dream interpreters. Fäkhr ad-Din's criticism, justified or not, ridiculed the role visions took in the spiritual growth of a Sufi, in particular in his relationship with his spiritual guide. Although the theologian did not question the possibility of true dream interpretation (practiced, for example, by the Prophet Joseph) or the ability of the shaykhs to travel through space in their dreams, he considered those experiences as extraordinary. Like Gasprinskii, he blamed people for believing that their shaykhs could read the hearts of all men, see God, and talk directly to the Prophet Muhammad. Only God had the knowledge of men's actions and thoughts, observed the theologian. Even Muhammad was unable to decipher people's hearts or uncover their faults. Fäkhr ad-Din also blamed the shaykhs for reciting evil prayers or curses. Popular opinion often attributed to women and shaykhs who had been unjustly harmed, the power to

36. Istikhara consists in praying two cycles (rak'at) of a supererogatory prayer and a du'a in which one asks for help. The practice is mentioned by the hadith compilers Bukhari and Tirmidhi. Fäkhr ad-Dīn, Jäwämi', 130-133 (hadith no. 91).

37. Fäkhretdin, Tärjemäi khälem, 26; idem, Jäwāmi', 45-47 (hadith no. 33), 130-133 (hadith no. 91); Hoffman, Sufism, 214; Muslim, 29: 5613. 
take revenge by appealing directly to God. Finally, Fäkhr ad-Din questioned the bond between the shaykh and his disciples, which took away the disciples' freedom and responsibility, and kept them from a direct relationship with Allah. ${ }^{38}$

Fäkhr ad-Din was even more critical about the cult of the saints. Just as it was wrong to seek help from living dervishes, it was even more sinful to worship saints and ask for their intercession. He agreed with the jurist Ibn Taymiyya, who condemned pilgrimages to saints' tombs as idolatry. Fäkhr ad-Din repeatedly affirmed that the saints' bodies, which worshipers thought to be alive, were in fact corrupt. The former qadi also denied the guardians of the shrines any grace (baraka) and called them charlatans who had turned their shrines into market places. He particularly warned Tatars about visiting sacred springs, hills, and ruins, which previously had constituted meeting points between Tatars and prospective converts, because village communities were unable to tell why and how those places came to be centers of devotion. In his criticisms, the theologian even saluted the British in Egypt for closing shrines, without however advocating such drastic measures for the Middle Volga. He believed that shrine visitation would fade away in the light of further education, and recommended patience. ${ }^{39}$

\section{Eschatology}

Tatar and Kräshen peasants believed that saints and prophets had a special insight in the supernatural world, and could transcend space and time. Hidden in rocks or mountains, Jewish shaykhs, descendants of Moses's people, performed the $z i k r$ for hundreds of years as they waited to see Prophet Muhammad. Similar to Gasprinskii's but contrary to Shaykh Räsuli's opinion, Fäkhr ad-Din contested the saints' immortality. Both criticized the popular idea, propagated by Rabghuzi's readers, that the mythical prophet al-Khidr who had drunk from the Water of Eternal Life, was still wandering in the countryside, helping out itinerant and needy shakirds. ${ }^{40}$

Tatar reformers attempted to change the popular vision of the afterlife. Sufi books were filled with concrete descriptions of paradise and hell. In Näsīhäat aṣ-Ṣālihīn, hell was a city of flame, and paradise-a city of delight. Compared to Muhammad, whose compassion prevented believers from entering hell, God appeared cruel. When describing hell and paradise, reforming pedagogues avoided concrete details that made the Last Judgment, in Fäkhr ad-Din's own words, appear to be a big bazaar where believers traded bad deeds for good ones. In a letter to the people of Kazan, Nasïri attacked the book Fäża'il ash-Shühür, with its absurd, unscientific, and unrealistic details about hell. Nasïri ridiculed the idea promoted in the book that sinners would be hung from a pole in the middle of hell. Ironically, he asked, would the pole be of iron or wood? If it were iron, it would melt, and if it were wooden, it would

38. Fäkhr ad-Dīn, Jäwāmi', 81-82 (hadith no. 57), 130-133 (hadith no. 91), 204-208 (hadith no. 132), 381-382 (hadith no. 242), 407-409 (hadith no. 263); Tärjümān, no. 36 (22 September 1902): 139.

39. Fäkhr ad-Dīn, Jäwāmi', 160-166 (hadith no. 104), 224-228 (hadith no. 144), 322-323 (hadith no. 200), 328-332 (hadith no. 204), 332-334 (hadith no. 206), 348-349 (hadith no. 214), 367-368 (hadith no. 228), 373 (hadith no. 235), 396-401 (hadith no. 256), 522-523 (hadith no. 336).

40. Al-Rabghūzī, Stories, 455; Fäżàill, 35-36; Näșîhät aṣ-șālihīn, 31-32; Fäkhr ad-Dīn, Jäwāmi', 260-273 (hadith no. 166); "Vera i sueverie," Tärjümān, no. 53 (2 July 1904): 107. 
burn. Such nonsense could only confuse Muslim children and provoke the contempt of the learned. ${ }^{41}$

Fäkhr ad-Din warned his readers to avoid literal interpretations of the many Qur'anic verses that spoke of hell and paradise. The scales, the bridge, the Book of Deeds, and the physical manifestations of suffering or joy were only metaphors designed to both express realities that differed from the experiences of this world, and transcend human disparity of perception. Fäkhr ad-Din carefully avoided hyperbolic images. In one instance he told the story of an unnamed prophet who visited hell which, to his surprise, was empty. The angels then explained that men brought their sins to hell, where they changed into snakes and fire. But Fäkhr ad-Din hurried to add that this story should not be taken literally, but rather should serve as a warning to prepare to meet God in the afterlife. ${ }^{42}$

Reformers transformed other metaphors, such as those describing the Throne of God. In one hadith, the reward for an exemplary moral life was to find shelter in the shadow of God's Throne. Biktashi had provided a hyperbolic description of the throne (that went far beyond the Qur'an). Covered with jewels, the throne was so large that it took 400,000 years to walk from one of its four legs to the other. Attached to the throne were a $1,600,000$ heads that continually cried out Subhanallah. Another popular legend added that the comb of a mythical white rooster lay on the throne and its legs emerged from underneath the earth. This giant bird awakened all the roosters of the earth before the morning prayer, winning the battle against Iblis, the devil, who tried to keep people asleep. By contrast, Fäkhr ad-Din, when quoting the hadith about the reward of an exemplary life, deliberately left out any mention of the Throne, for its hidden meaning was still unknown. Neither the reasoning of an Aristotle or a Fakhr ad-Din ar-Razi (1149-1209), a famous Islamic philosopher, could decipher it. Tentatively Fäkhr ad-Din suggested that some scholars believed that the Throne of God could be at the center of the universe, emitting an electric field that attracted and moved all galaxies in its periphery. Although Fäkhr ad-Din cautioned that this description was but approximate, his comments suggested a new strategy. Not only did he warn teachers and students against taking the Qur'anic symbols literally but, in order to win the battle against "popular superstition," he ascribed a new "scientific" meaning to them. ${ }^{43}$

Finally, the reformers deemphasized the Prophet Muhammad's place on the day of resurrection. Muhammad had said in a hadith that his human nature kept him from speculating his future role at the End of Times. In the same spirit, Zäbiri's textbook taught that each prophet, including Muhammad, would be judged. Although the popular Sufi book Ākhïr Zamān Kitābï emphasized Muhammad's intercessory powers, Zäbiri did not picture Muhammad as a future eschatological mediator for his

41. Näṣihät aṣ-șālihīn, 8-13; Fäżàil, 62; Nasïyri, Qazan khalqüna möräjäghate, in Saylanma äsärlär (Kazan, 1974), 1: 41-42.

42. Fäkhr ad-Dīn, Jäwāmi', 286-289 (hadith no. 173), 507-508 (hadith no. 324). This approach was not entirely novel. In Risālä-yi 'Azizzä, the Naqshbandi Yalchïghol already preferred to think of the scales as an allegory beyond human understanding and reason. Yālchïghol, Risālä, 70. In another book, Fäkhr ad-Din questioned the soundness of those hadith that exaggerated the torments of hell and the pleasures of paradise. See Dìñ̄ wä ijtimā'ì mäs'älälär, 46.

43. Fäżàill, 71; Fäkhr ad-Dīn, Jäwāmi', 231-233 (hadith no. 148), 260-273 (hadith no. 166). 
followers. Imam Bayazitov made the point for his Russian audience that all men in Islam were accountable for their sins before God, but God in all his almighty power was generous and forgiving. ${ }^{4}$

Bayazitov did not mention Muhammad as a possible intercessor, but Fäkhr ad-Din was not that categorical. According to the former qadi, Muhammad could intercede for a sinner, but only if the sinner truly repented; in other words, Muhammad's role demanded the sinner's participation and left enough room for God's will to operate. Intercession was also possible for those for whom Muhammad had prayed during his lifetime. This did not mean, as was often the case in popular Sufi textbooks, that all sins would be forgiven on Muhammad's request. Fäkhr ad-Din believed that God alone decided the fate of all. Like his friend, the famous jadid theologian Musa Jarullah Bigi (1875-1949), the former qadi did not deny that God could forgive all sins, including the sin of "unbelief," as long as the subject truly repented in front of Him. However, the same sin committed a second time after repentance would not be forgiven and hell would be the final judgment. Fäkhr ad-Din's main concern was to reaffirm God's transcendence, an idea that was sometimes lost in some Sufi books and in peasant discourse. While reaffirming God's position at the Last Judgment, the theologian strongly opposed the popular belief that shaykhs (dead or alive) were their murids' assistants and mediators on Judgment Day. ${ }^{45}$

\section{Jadid Strategies for Accommodating Popular Conceptions of Islam}

\section{Sacred Shrines and the Afterlife}

The worlds of the dead and the living were not entirely separated in Fäkhr ad-Din's worldview. Although animal sacrifices at Sufi shrines were contrary to the sharia, a believer could still dedicate good deeds (such as sadaqa or the reading of the Qur'an) to the spirit of a dead person, who could even be a saint as long as the believer did not ask for the saint's favor (baraka) in return for this devotion. A saint's shrine should serve only as a reminder of the last hour. Although Fäkhr ad-Din cautiously added that there was no proof that those good deeds would count as merit (sawab) for the dead in the afterlife, he, like the Sufis, nevertheless acknowledged that good deeds performed in the name of the dead could be beneficial. ${ }^{46}$ The qadi, on the strength of a hadith, allowed for pilgrimages to the Grand Mosque of Mecca, the al-Aqsa mosque in Jerusalem, and the Mosque of the Prophet in Medina; however, he discouraged Tatars and Bashkirs from visiting the shrines in Central Asia or the Middle Volga. He insisted that Muslims should have the right intention when they made any pilgrimage, whether to a local shrine or to one of the mosques mentioned in the hadith. However, a believer who was unable to distinguish between praying for the dead and asking

44. Fäkhr ad-Dīn, Jäwāmi, 267 (hadith no. 166); Baiazitov, Otnoshenie, 9.

45. Fäkhr ad-Dīn, Jäwāmi', 162 (hadith no. 104), 172-173 (hadith no. 111), 197-199 (hadith no. 129); 175 (hadith no. 114), 280-282 (hadith no. 169), 332-334 (hadith no. 206), 362-363 (hadith no. 223), 514 (hadith no. 329); Validov, Ocherk, 73-77; Musa Dzharullakh Bigiev, "Dokazatel'stva bozhestvennogo miloserdiia (Räkhmät ilahiyä borhannarï)," in Antologiia tatarskoi bogoslovskoi mysli (Kazan, 2005), 77-124.

46. Fäkhr ad-Dīn, Jäwāmi', 280-282 (hadith no. 169); 348-349 (hadith no. 214), 508-510 (hadith no. 325). 
for the saint's baraka should abstain from any pilgrimage; visits to the three mosques were not obligatory, contrary to what supporters of shrine visitations alleged. ${ }^{47}$

Prophets at times, although human and fallible, could have insights into the afterlife, despite Fäkhr ad-Din's argument that Muhammad had no knowledge of God's intentions at the Last Judgment. In one instance, Fäkhr ad-Din brought up a hadith that did not differ much from the stories of forgiveness found in traditional textbooks. A prostitute gave water to a sick dog and all of her sins were forgiven in exchange for this small act of service. God, added Fäkhr ad-Din, had directly informed the unnamed prophet of the time about the woman's fate. The difference between Fäkhr ad-Din's story and those recorded in Fäżä'il ash-Shühūr lay primarily in the way the stories were told. Unlike Biktashi, Fäkhr ad-Din did not resort to the traditional Sufi metaphors of light coming out of the tomb, but to the Word of God given to a prophet. ${ }^{48}$

\section{Martyrdom and Asceticism}

In addition to the afterlife, martyrdom was another important component of Tatar popular religion. Although ordinary Muslims celebrated the martyrs of the past who were buried in sacred shrines, for Fäkhr ad-Din, martyrdom was more of a present reality. ${ }^{49}$ The new martyrs were those scholars and shaykhs who worked for the nation's economic and cultural independence, and distinguished between the sharia and customary additions. Shaykhs still had a place in the reformist Weltanschauung, not as mediators between the worlds of the seen and the unseen, but as the carriers and models of a new knowledge and way of life. Like Gasprinskii, Fäkhr ad-Din insisted that submission to God as taught by Sufis did not imply complete withdrawal from society or beggary but participation in the world's economy. More important, he gave a new definition of an ascetic (zahid). Contrary to popular opinion, a zahid was not a man who chose to live in contemplation and poverty, but a man who had overcome the temptations of the world and submitted to God. Anyone-merchant, trader, peasant, teacher, or philosopher-could be a zahid inwardly, and be part of human society by trying to improve it economically and spiritually. As an example of martyrdom worth following, Fäkhr ad-Din cited Ibn Taymiyya who could have accepted the honors of the world, but chose to live as a dervish (literally, a poor person) and died in prison in the name of reform. Both Gasprinskii and Fäkhr ad-Din considered Barudi as a model because of his involvement in the jadid movement: the Naqshbandi shaykh had produced numerous textbooks for children and facilitated the introduction of the new method in his Kazan school and in the villages of the Kazakh steppes. ${ }^{50}$

Although Fäkhr ad-Din criticized the danger of heterodoxy in Sufism, whenever he wanted to stress the importance of rituals in worship, he reverted to popular

47. According to one hadith, Muhammad said, "Journeys are only undertaken to three mosques: the Holy precinct, al-Aqsa, and this mosque of mine." Johansen, Sufism, 141 (quoted by al-Ghazali); Fäkhr ad-Dīn, Jäwāmi', 328-332 (hadith no. 204).

48. Fäkhr ad-Dīn, Jäwāmi', 280-282 (hadith no. 169).

49. Fäkhr ad-Dīn explicitly raised doubts about the claims to martyrdom made for many of the saints buried in sacred shrines, Jäwāmi‘, 396-401 (hadith no. 256).

50. Fäkhr ad-Dīn, Jäwāmi ‘, 48-49 (hadith no. 35), 126 (hadith no. 89), 175-178 (hadith no. 115), 228-230 (hadith no. 145), 260-273 (hadith no. 166), 432-433 (hadith no. 283); "Vesy," Tärjümän no. 40 (21 October 1902): 153-154; “Arabskii rasskaz," Tärjümān no. 92 (16 November 1904): 186. 
images of Sufi piety. For example, traditional popular and scholarly belief held that women should pray at home rather than at the mosque, but Fäkhr ad-Din insisted that there was no reason to exclude them from the worship as long as they dressed and behaved like "dervishes." In the same spirit, Fäkhr ad-Din who found selfmortification offensive among the "naked dervishes," nevertheless used it as a symbol of true dedication to God. To encourage Tatars to observe Ramadan faithfully during the hot and long days of summer, he urged them to follow the example of pious Arabs whom the Prophet had commended for rolling naked on the sand hot enough to cook raw meat, and other martyrs who remained faithful to Islam, despite the burning of hot irons on their skin. ${ }^{51}$

The reformers did not reject Sufism. According to Fäkhr ad-Din, all believers should master Sufi techniques: meditation, prayer, and constant recollection of God. But to become a true murshid (that is a guide of the right road), these mystical sciences (tasawuf) should be studied in combination with modern sciences (taught in Russian if necessary). Here, Fäkhr ad-Din understood murshid as a propagator or teacher of God's will and not as a powerful charismatic figure-as imagined by peasants and spread in popular Sufi literature-who could turn a mountain into gold through God's will. In both Fäkhr ad-Din's and popular Sufi books, however, the emphasis was in empowering the nonelite with a knowledge mighty enough to turn them into spiritual guides of Islam. ${ }^{52}$

Fäkhr ad-Din also revised the performance of the $z i k r$. Although one could perform the $z i k r$ without a shaykh, ideally it should be led by an enlightened spiritual guide who did not accept alms, sell amulets, identify himself with the Prophet Muhammad, or demand that his disciples completely surrender themselves to his power. Concerned with maintaining God's transcendence, the theologian criticized the mechanical use of prayer beads, whose function was to aid the believer in recalling the names of God. The seeds that made up the prayer beads among the Tatars were the subject of various stories that stressed their sacred origins and attracted the scorn of Russian missionaries. In Mamadysh district, Tatars believed that the seeds came from a plant that had arisen from the Virgin Mary's tears. Tatars in Kazan district similarly held that when Abraham sacrificed a ram to God, he took its excrement and blood and threw them into the sea; from them arose a plant whose seeds were used for making prayer beads. Fäkhr ad-Din considered the performance of the actual $z i k r$ with the help of the prayer beads to be the last resort for unanswered prayers: it could be done after the believer had already made a request to God through simple prayer $\left(d u^{\prime} a\right)$, performed the obligatory namaz, and read the Qur'an. But prayers could still be left unanswered and fulfilled in the afterlife with God's consent. ${ }^{53}$

In general, Fäkhr ad-Din favored individual devotion, insisting that a spiritual guide was not necessary to earn one's salvation. Everyone could be his own shaykh. It was enough to know and understand the basic rules of Islam inwardly and apply

51. Fäkhr ad-Dīn, Jäwāmi‘, 334-344 (hadith no. 208), 377-379 (hadith no. 239).

52. Fäkhr ad-Dīn, Jäwāmi', 20-22 (hadith no. 8).

53. Fäkhr ad-Dīn, Jäwāmi‘, 30-31 (hadith no. 18), 204-208 (hadith no. 132), 212-213 (hadith no. 134), 260-273 (hadith no. 166); Malov, "Chetyre dnia sredi musul'man," in Missionerstvo sredi mukhammedan, 54. 
them outwardly. Those rules were simple but sometimes unjustly neglected by Sufi orders: the five daily prayers, the alms to the poor, and the fast. If anything appeared obscure in the Divine law, one could always turn to wiser, more knowledgeable Muslim believers (not necessarily ishans.) ${ }^{54}$

Individual devotion in Fäkhr ad-Din's or Zäbiri's worldviews did not imply that one could worship God whenever he or she felt like it. Both reformers dismissed the idea that believing inwardly was enough; rather it was essential to express faith with the right words. Consequently, all articles of faith had to be memorized in Arabic with their proper meaning. Repeated recitations of the $z i k r$ could not replace the five daily devotions. Fäkhr ad-Din even quoted a hadith that called for corporal punishment for children who refused to worship regularly. Fäkhr ad-Din's reference to this hadith comes as a surprise because Tatar novelists usually condemned physical punishment of students, which they associated with old-fashioned madrasas. Only if an individual had a specific request, could he recite the $z i k r$ or pray more often than the five times per day specified by the sharia. This individual, however, should not request anything beyond the laws of nature, or pronounce an evil prayer. In general, Fäkhr ad-Din discouraged supererogatory prayers or fasting favored by traditional authors such as Biktashi. By contrast, for Fäkhr ad-Din, heavenly merit could be earned by devoting one's time to a social cause. ${ }^{55}$

The reformers' stricter stand on prayer diverged from the flexibility Muslim preachers showed in the countryside among the Kräshens, the Maris, or the Chuvash. In the reformist worldview, the performance of daily prayers was a discipline to acquire at a very early age, and no one could abstain from it, not even a soldier. Fäkhr ad-Din, however, was not as strict as some early Tatar theologians were on the time the daily prayers should be performed. Märjani relied on mathematical calculations, but Fäkhr ad-Din trusted the individual to set the proper hours. ${ }^{56}$

\section{The Final Victory of Islam}

Western orientalists and philologists criticized the hadith for their lack of authenticity, which led some Muslim reformists such as al-Afghani to deny their relevance in Islam. Russian missionaries such as Malov, whose strategy was to polemicize with Tatar mullahs and students in the madrasas, showed how the Qur'an and the hadith contradicted one another. Fäkhr ad-Din, though an admirer of al-Afghani, retained them as one of the bases of the Muslim jurisprudence, along with the Qur'an, analogy, and consensus. The figh, he argued, was not a collection of dead fatwas (formal legal opinions) or fixed patterns of behavior but a dynamic, evolving body whose living cells were the hadith. The prophets' sayings, as they appear in Fäkhr ad-Din's commentaries, can be grouped in three categories: some were historically embedded in Muhammad's time, others constituted eternal truths, and still others were projections into the future. Muhammad was a man, thus fallible. Consequently, not all of his sayings were intended to become general truths for all times and places. Muhammad's

54. Fäkhr ad-Dīn, Jäwāmi‘, 204-208 (hadith no. 132).

55. Fäkhr ad-Dīn, Jäwāmi', 437 (hadith no. 285), 475-476 (hadith no. 304).

56. Fäkhr ad-Dīn, Jäwāmi‘, 55-58 (hadith no. 40), 98-100 (hadith no. 72), 174-175 (hadith no. 113); Rorlich, Volga Tatars, 51; Validov, Ocherk, 34-39. 
statement that women should not wear male clothes and vice versa was irrelevant for Chinese Muslims, for they dressed the same way regardless of sex. Similarly, remedies mentioned in the hadith could not be applied in this contemporary world because Muhammad was not an expert in medicine, and science had evolved since then. However, once the context of these hadith had been decoded, it was possible to define their intention or purpose. In the case of clothing or physical appearance, one could dress or shave whenever he or she wanted as long as the rules of decency and morality in one's culture were not broken or threatened. And in the case of healing, one should not wear talismans, brew pages of the hadith or the Qur'an in a cup of water, or rely only on prayer. On the contrary, one should consult doctors-even unbelieving ones-if necessary, and take the prescribed medicine even if one of its components were forbidden by Muslim dietary restrictions, unless another medication was available without this component. ${ }^{57}$

The second group of hadith included eternal truths that even Arab Christians quoted as proverbs without acknowledging their Muslim origin. Western nations, as well, followed those eternal truths: they studied modern sciences, created new technologies, opened societies of benevolence to promote prosperity on earth and alleviate poverty. Europe and America had not yet recognized Muhammad as their prophet, but they would, once their philosophers perceived the deep connection between reason and life in the Sunna. As for the Muslims, they had to understand that their happiness in the hereafter was linked to their happiness in this world, by borrowing from the West, crafting new technologies, and accumulating riches in order to build a fair society that was submissive to God. Finally, some hadith were premonitory: they foresaw future problems, and provided the Muslims with new solutions. The words of the Prophet were miracles per se. ${ }^{58}$

Despite Western criticism, Fäkhr ad-Din, unlike al-Afghani, did not conclude that the Qur'an was self-explanatory and could be interpreted without the support of the hadith, but neither did he affirm that the Prophet's word was absolutely trustworthy for all times and places, nor that it provided a set of fixed norms for every facet of communal and personal life. Each hadith had a hidden divine purpose, and provided guidance for the future generations. Students of Islam had to derive the purpose of each hadith in accordance with their time. But more important, the hadith testified to the period when Muhammad and his companions strived to establish their community. The Prophet's struggle did not differ from the ordeal Tatars faced in a nonMuslim environment. Fäkhr ad-Din implied that Islam would liberate the Tatars from the Russians and the West, in the same way that Muhammad had liberated the Arabs from the threat of the Byzantines and the Sassanians. It was sufficient to open schools, universities, and take advantage of the tools the enemy had, as long as they did not contradict the sharia. Muhammad and his companions had borrowed from the Sassanians in order to transform a people of Bedouins into a civilized and free nation. Thanks to the hadith and their testimony, the time of the Prophet and the

57. Fäkhr ad-Dīn, Jäwāmi‘, 209-212 (hadith no. 133), 253-258 (hadith no. 163), 461-470 (hadith no. 299).

58. Fäkhr ad-Dīn, Jäwāmi', 292-295 (hadith no. 178), 328-332 (hadith no. 204), 334-344 (hadith no. 208), 373-374 (hadith no. 236), 491-492 (hadith no. 313), 497-499 (hadith no. 319). 
time of contemporary Muslims were intimately connected. In Fäkhr ad-Din's view, contemporary Islamic revivalism was not unique in Islamic history. Other encounters with unbelievers strengthened Islam. Islamic reformism did not emerge from fear, but continued a pattern of progress, grounded in the Islamic tradition. Just as pagan Greek and Indian civilizations had enriched Islam with their new sets of knowledge, Christian Western cultural and economic supremacy would strengthen, not destroy Islam. Its main tenets (shahada, namaz, ruza, zakat, and hajj) would still survive the shock. Contrary to what itinerant mystics claimed, if Islam borrowed from unbelievers, time would not end with the subjugation of all Muslims and the coming of the Mahdi. Personally, the theologian did not expect the "guided one" to come at the End of Time, but all legal schools to unite, and all nations to embrace Islam. The End of Times was surely near, but nobody could tell exactly when. Hence, Muslims should not contemplate the Prophet exclusively as an intercessor or a model of union with the divine, but as a model civilizer and liberator. The early days of Islam when Muhammad was rejected by the Meccans and nevertheless fought for the survival of his community constituted a general pattern of action for the Muslims in the world, and more particularly, for Tatars in Russia. Other prophets such as the very popular Joseph had preceded Muhammad in this mission of liberation. ${ }^{59}$

Fäkhr ad-Din wanted his readers to believe in the final and global victory of Islam. The first line of his anthology was: "We, the Muslims, desire to spread our religion that will enlighten both East and West." 60 Toward the end of his book, the former qadi came back to this theme, declaring that a religion that does not expand, weakens. Until the twentieth century, because of the Muslims' poor understanding of their faith, Islam's growth, he believed, had been artificial. Fäkhr ad-Din called for a systematization of Islamic missions among nonbelievers on the model created by Christian missionaries. Like them, missionaries of Islam should study the cultures and religions of non-Muslims, evaluate their level of education, and learn their languages (had not Muhammad encouraged his companions to learn Hebrew?). And, like the prophets, they should be models of faith, knowledge, and patience. Islam, to survive, had to become the leading missionary force in the world and learn from the Russian missionaries. Indeed the process of Islamization of the world was already under way; as the argument went, Westerners had already adopted Muhammad's idea of progress; they needed only to recognize Muhammad as the Last Prophet. In this context, the baptized Tatar community became one more time the center of well publicized, and no longer clandestine, renewed missionary rivalry between Russians and Muslim Tatars. Both Russian nationalists and Tatars, however, confronted an unexpected new reality: the rise of Kräshen ethnic and religious self-identification. ${ }^{61}$

\section{The Rise of Kräshen Ethnic Consciousness and Its Critics}

After 1905, a new indigenous Christian elite among the Finno-Ugric and Turkic peoples called for a defense of Il'minskii's and Timofeev's legacies, which were under

59. Fäkhr ad-Dīn, Jäwāmi‘, 115-116 (hadith no. 82), 117-119 (hadith no. 85), 421-422 (hadith no. 272), 452-457 (hadith no. 295), 487-489 (hadith no. 310).

6o. Fäkhr ad-Dīn, Jäwāmic, 3 .

61. Fäkhr ad-Dīn, Jäwāmi', 292-295 (hadith no. 178), 497-499 (hadith no. 319), 514-517 (hadith no. 330). 
attack, and a redefinition of Russification to promote their own ethnic identity. Indeed, both before and after Il'minskii's death in 1891, members of the clergy, school personnel, and former supporters like Malov blamed his pedagogy in native languages for the emergence of a Kräshen clergy and intelligentsia that was, according to them, hostile toward the Russian people. As a sign of distrust, the enthusiastic poem of the Kräshen deacon Iakov Emel'ianov on the awakening of the "Kräshen people" was not republished in the 1888 edition of his poems. ${ }^{62}$ According to Il'minskii's critics, Kräshens who chose Christianity as their faith did not abandon their native costumes or learn Russian, but sought to have parishes strictly run by their native clergy. Malov in particular considered the native clergy partly responsible for the reinforcement of Muslim propaganda among the Kräshens. In his mind, indigenous teachers and clergymen were less competent than bilingual Russians to demonstrate the superiority of Christianity over Islam; some clergymen even had relatives who led apostasies into Islam. Indeed Kräshen clerics disagreed with Malov's and his friend Miropol'skii's understanding of mission and opposed Russian missionaries' visits in apostate villages, which challenged their pastoral authority. They preferred Timofeev's approach through example and regular story telling from Christian books than occasional dry sermons about the superiority of Christianity. They also promoted the image of Timofeev, as an exceptional character equal to the Russian writer, chemist, and astronomer Mikhail Lomonosov (1711-1765). Both were of humble origin and both were equally eager for knowledge. Thus, hiding from his mother, the ten-year-old Timofeev devoured the lives of martyrs and fighters for the faith, and left his village to find knowledge in a monastery. Without Timofeev's unique personality and genius, Il'minskii's school would have never taken root. ${ }^{63}$

Native clerics and teachers distinguished between a positive spiritual Russification-the love of the universal Orthodox faith and the Russian people who held it, and narrow Russification-dressing and speaking like Russians. Unlike Islam, they claimed, Christianity allowed new converts to keep their national (narodnyi) distinctiveness. A Kräshen man did not have to give up his clothing for the Muslim skullcap, and a Chuvash did not have to give up his language for Tatar. As pointed out by the young Kräshen Roman Daulei (1879-1953), then student at the Kazan Theological Academy, the history of Russians' and non-Russians' Christianization did not differ much: well before the conquest of Kazan, under Vladimir, non-Russians converted to Christianity, partly as a result of miracles and partly because of their contact with Russian monks who built churches on the sites of pagan sacred places. As in the case of the Finno-Ugric Zyriane or Komi of Perm' who converted to Christianity thanks to the native language translations of the monk St. Stephen (1340-1396), both Orthodoxy and enlightenment could be disseminated among peoples of different ethnicity through their native languages. This version of spiritual Russification through Orthodoxy meant that non-Russian indigenous peoples could also train

62. Roman Daulei, "Shkola sredi inorodtsev vostochnoi Rossii" (Kursovoe sochinenie, 1903), NART, f. 10, op. 2, d. 226, 11. 4-4 ob.; Emel'ianov, Stikhi na kreshchensko-tatarskom iazyke (1879), 20-22.

63. Otdel rukopisei Kazanskoi nauchnoi biblioteki im. Lobachevskogo, f. 7, ed. khr. 18, 1. 166; see tensions between Miropol'skii and priest Kuz'ma Prokop'ev in NART, f. 4, op. 131, d. 3, 1l. 36 ob.-43; S. D. G., “K 10-letiiu so dnia konchiny o. Vasiliia Timofeevicha Timofeeva (†1895 goda dekabria 2-go dnia)," IKE, no. 1 (1 January 1906): 62-66; Geraci, Window on the East, 229-230. 
and choose their own clerics. Orthodoxy was to serve as a powerful unifying cement among Maris, Chuvash, Udmurts, and Kräshens, caught between the Russian people, who did not always live up to their moral and religious standards, and the Muslim Tatars, their former masters. ${ }^{64}$

The difference between Il'minskii's indigenous students' vision for the use of native languages and that of the Ministry of Education, which recommended an earlier exposure to the state language, also became more distinct. Public school inspectors noted bitterly that in Kräshen schools, native languages had a dominant place. Because they did not speak Tatar, they could not evaluate the level of religious knowledge. Children prayed in Tatar and not Slavonic. Russian was taught only in the second or third year. In Apazovo, where a school had been opened as early as 1867 , first-year students pronounced Russian letters the Tatar way and read words mechanically, without comprehension. They could not even answer simple questions about their age or family, partly because the teachers spoke to them constantly in Tatar inside and outside school. In general Russian was poorly taught; the teachers always began with translation from Slavonic texts and did not use a more natural method. As a result, students spoke Russian with difficulty, even in their fourth year, and had trouble understanding the spoken language. Their spelling was also atrocious. As for the general level of education in these schools, the inspectors' conclusions were that the teachers were poorly qualified, had trouble teaching spoken Russian, and some showed no mathematical aptitude at all. ${ }^{65}$

Despite Malov's and public schools inspectors' criticisms, the Ministry of Education officially supported Il'minskii's program in 1905 during a conference on schools for non-Russians. The president of the conference, Anton Budilovich (1846-1908), a philologist, strongly reaffirmed the policy of promoting native languages to stop further Tatarization of the Chuvash and Maris. The laws of 1906 and 1907, a consequence of the conference, allowed teachers in mixed localities to use native language textbooks just as their colleagues did in prominently indigenous areas. Until this change, such teachers could use the native language only orally. The new laws also permitted the opening of special bilingual classes, partially financed by the central government. Finally, the catechism classes in indigenous languages were to continue through the third year of elementary school. As for Muslim Tatars, the conference reemphasized the need to increase the number of Russo-Tatar schools where Muslims would learn to master the state language. Suspicious of Islam, the Ministry of Education promoted the limited use of vernacular Tatar over the classical literary language, which contained many words of Islamic origin. Finally, the conference recommended the use of the Cyrillic transliteration of Tatar to ease students'

64. Daulei, "Shkola sredi inorodtsev vostochnoi Rossii" (Kursovoe sochinenie, 1903), NART, f. 10, op. 2, d. 226, 11. 9-12; Paul Werth, "Inorodtsy on Obrusenie: Religious Conversion, Indigenous Clergy, and the Politics of Assimilation in Late-Imperial Russia," Ab Imperio 2 (2000): 87-104; Geraci, Window on the East, 252-263.

65. Inspection of Apazovo and Nikiforova schools, NART, f. 93, op. 1, d. 419, 11. 4-7; zemstvo questionnaire for Nikiforova completed in 1903, NART, f. 93, op. 1, d. 751 a, 1. 29; A.S. Budilovich, Otchet o komandirovochnoi poezdke t. s. A. S. Budilovicha v Kazanskii, Orenburgskii i Zapadno-Sibirskii uchebnye okruga (v oktiabre, noiabre i dekabre 1904) (SPb., 1905), 56; N. V. Chekhov, Narodnoe obrazovanie v Rossii s 6o-kh godov XIX veka (Moscow, 1912), 180-181. 
passage to Russian. But Tatars protested against the use of the Cyrillic alphabet and the state backed down. ${ }^{66}$

The rise of Kräshen identity was not only a matter of concern for Malov and nationalist Russians, but also for the Tatar community, as represented by its new intelligentsia. If from a Russian nationalistic perspective, the Kräshens were meant to fuse with the Russian people in mores, faith, and language, from the Tatar point of view, all baptized Tatars were to return to the religion of their fathers-Islam. The jadids' discourse in the newspapers did not differ from the Muslim villagers of Baimurzino in Tetiushi district who, unable to open a mosque because of the presence of baptized Tatars and Chuvash in their midst, yelled in frustration to those who rejoiced at the opening of a Brotherhood school that the village had always been Muslim, not Russian, and that Ivan the Terrible had baptized them forcefully. ${ }^{67}$

\section{The "Apostates" as National Martyrs}

In 1905, when the political situation permitted it and at the time when Fäkhr adDin was still qadi at the Spiritual Assembly, Tatars began to support the apostate cause openly. They sent petitions to the czar in favor of the apostates that contained requests for halting the Christian missionaries' work among Muslims (i.e., the Kräshens) and allowing apostates to register officially within their proximate Muslim communities. ${ }^{68}$ The Edict of Religious Toleration of 17 April 1905 partially met their demand-under certain conditions, it allowed apostates who could prove Muslim ancestry to profess Islam openly, and mufti Möhämmädyar Sultanov (1836-1915), the official leader of the Muslim community in the Empire, published a circular in Tatar and in Russian explaining to apostates how to switch officially from Eastern Orthodoxy to Islam. Tatars' efforts also aimed at other peoples of the Middle Volga who wished to become Muslim officially and who, before the conquest of Kazan, according to Märjani, belonged to the sacred place of Islam. In practice, however, the Tatars' and the Russians' interpretations of the April manifesto, regarding conversion, did not coincide. Whereas Tatars understood that Christians and pagans had the liberty to convert to Islam, Russian authorities argued that only those who could prove a Muslim ancestry were authorized to return to Islam. Thus, in 1907, the Spiritual Assembly responded positively to the request of baptized Tatars and Chuvash living in Simbirsk province. But later, the Ministry of Interior refused to take the requests of several Chuvash and starokreshchenye communities into consideration because they had no Muslim ancestors. In other words, from the government's point of view and despite continued efforts by Tatar representatives at the Duma to legalize non-Christians' conversion to Islam and Muslim proselytism

66. A. S. Budilovich, Doklad predsedatelia osobogo soveshchaniia po voprosam obrazovaniia vostochnykh inorodtsev Gospodinu Ministru Narodnogo Prosveshcheniia, 15 avg. 1905 (Kazan, 1905), 53 p.; laws of 1906-1907 in Anastasiev, Narodnaia shkola, 130-133 and Mir islama 2, no. 4 (1913): 269-276.

67. NART, f. 1, op. 3, d. 6810 , 1l. 1-4.

68. Mikhail Mashanov, "Sovremennoe sostoianie Tatar-mukhammedan i ikh otnoshenie k drugim inorodtsam," PS 57, no. 2 (March 1911): 403; Kazanskii missioner, "O priemakh magometanskoi religioznoi propagandy," PB 16, no. 7 (April 1908): 316; Rorlich, Volga Tatars, 107-109. 
in 1909, one could not become officially Muslim unless the petitioners could prove that they had been historically Muslim. ${ }^{69}$

The procedure to apply for Muslim status was nevertheless greatly simplified. First, apostates sent individual or family petitions in printed forms to the governors of each province; as in the past, only governors could give permission to switch religion. Petitioners entered their names, ages, and the names of their villages, and if possible but not obligatorily attached a letter of support from their neighboring mullah, expressing his willingness to register them at the mosque he served. Then the governor turned to the council of the St. Gurii Brotherhood to verify their claim. In its turn, the council advised the governor to accept or turn down the petition. As a general rule the governor responded positively to petitioners who were born from apostate parents and whose names were not listed in the church registers. But he systematically denied petitions coming from starokreshchenye who had not apostatized before 1905 and whose baptism and church attendance could still be traced in local clerical registers. If the village enjoyed the presence of a Kräshen church or school-this was the case of Apazovo, Bol'shie Savrushi, Ianyli, Staraia Ikshurma, Pochinok Ponik-the Brotherhood argued that there was still a chance for them to return to Christianity; the governor denied such requests as well. The same treatment applied to Kräshens who lived in the Muslim milieus of Troisk, Chistopol', or Kazan for business but came originally from native villages, now firmly Christianized. ${ }^{70}$ For all these reasons, in 1912, church statistics indicated that 4,923 individuals were listed as apostates in Kazan province. Most of them were concentrated in Kazan $(1,411)$ and Mamadysh districts (3,255), and some in Laishevo district (205). There was only one apostate left in Spassk district and another in Tsivil'sk district. Until World War I, missionaries continued their visits to the villages of Elyshevo (where one family still held on to Christianity) and Apazovo, Bol'shie Savrushi, Saltygan Kliuch, Staraia Ikshurma, Nikiforova, Ianyli, Chura, Verkhnie Otary, at their Brotherhood schools. ${ }^{71}$

After the promulgation of the April manifesto, the sacred landscape changed considerably in mixed areas. Apostates, Tatars, and Kräshens sought to transform their villages' sacred territory each to their advantage. Azbaba's villagers used to go to their underground mosque in a tiny narrow street, crumbed with houses, but after 1909, they could go freely to their new one-story wooden mosque, centered in the middle of the village, this time in an open space. In Kreshchenye Ianasaly, for example, the

69. RGIA, f. 821 , op. 133 , d. 454 , 1l. $155-163$; f. 821 , op. 133 , d. 455 , 1l. $46,227-228,236-237$; f. 821 , op. 133 , d. 456 , 1l. $1-12$; f. 821 , op. 133 , d. 457 , 1l. 15, 89-90 ob. In May 1908, at the Duma, Sadri Maqsudi (S. Maksoudoff) (1878-1957) denounced the difficulties that Christianized Tatars still faced in their struggle for the recognition of their Islamic identity by the Russian state. He sent his complete speech to the Revue du Monde Musulman 5, no. 6 (June 1908): 353-358; Geraci, Window on the East, 267; Diliara Usmanova, Musul'manskaia fraktsiia i problemy "svobody sovesti" v Gosudarstvennoi Dume Rossii (1906-1917) (Kazan, 1999), 81-122.

7o. NART, f.2, op. 2, d. 12775, 1. 186; d. 12787 , 1l. 36-46, 50, 57, 74-77, 93, 99 ob., 105-106, 111-113 ob., 119, 122-123, 129, 136-137, 139, 140-145 ob., 151, 159, 162-162 ob., 167, 170, 173, 178-180 ob., 226, 247-248; 295-295 ob., 319; d. 12791, 1l. 23, 36-36 ob., 44-48 ob., 6o-61 ob., 74, 158, 178-179; d. 12824, ll. $1-334$; d. 12825 , 11. 77-79, 93-94, 251-274, 395; d. 12826, 1l. 103, 461, 463-470; d. 12934, 1l. 10-28; and RGIA, f. 821, op. 133 , d. 505, ll. 1-6, 76, 137-144.

71. Aleksandr Kremlev, Otchet Kazanskogo eparkhial'nogo inorodcheskogo missionera za 1912 god (Kazan, 1913), 3, 20, 23, 26, 31; Vasilii Eslivanov, "Otchet eparkhial'nogo inorodcheskogo missionera Kazanskoi eparkhii za 1914 g., IKE, nos. 47-48 (15-22 December 1915): 1260. 
situation was trickier because not all villagers had joined the apostasy movement. Kräshens and their priest complained that the former apostates' new mosque was built too high. And in Baimurzino, when Muslim Tatars finally obtained the right to open a mosque in 1907 despite the presence of baptized Tatars and Chuvash, the construction of their mosque spurred the baptized community to open a church two years later with the help of their school teacher, the local priest, and the archbishop of Kazan Nikanor. ${ }^{72}$

The battle to convert their sacred landscape to Islam was also in full swing in Elyshevo after the Ministry of Interior granted the villagers the right to open a mosque in December 1906. As in Azbaba, the former apostates chose the center of the village to build their mosque. They selected a small hill and-by law-they had to remove neighboring houses and fences that belonged to the most vocal Muslims of their village, the Wälitovs and the Bikmökhämmätovs, who agreed to move and had their houses rebuilt on the other side of the street. (The Wälitovs were the descendants of the famous ishan of Udmurt origin who led the apostasy movement in the 1860 , and the Bikmökhämmätovs, a family of unofficial mullahs and abistays.) Villagers also took great pain to paint their mosque with the brightest colors. In contrast, the decaying church of the Archangel Michael, founded in 1869 thanks to the donations of a rich Russian merchant, and its bell tower now lower than the new minaret, stood desolate at the margin of the village. But the transformation of the village sacred space would have been incomplete without the construction of a separate building for the Qur'anic school. Missionaries who still hoped for a return to Eastern Orthodoxy, lobbied to block the official recognition of the Qur'anic school. In response, the villagers sought to erase all signs of Christianity. They removed the crosses from the two Christian cemeteries, one in the middle of the village, and the other on top of the hill facing the village's main road, and did not spare the crosses on the tombs of the former Russian priest's children. Today, the fences around the two Christian cemeteries serve as a reminder of the contested religious history of Elyshevo. ${ }^{73}$

Villagers also petitioned but unsuccessfully for the removal of the wooden church: they tried to reduce the size of the priest's and sacristan's gardens and attacked the Kräshens of Saltygan Kliuch as they returned home after the Divine Liturgy. In the end Kräshen families of surrounding villagers migrated to other parishes more friendly to their Christian identity, which rendered the mission of the church obsolete. But clerical authorities and the Russian Shcherbakov family responsible for the founding of the church refused to recognize the victory of Islam and sought to revive the church with different projects. One of them consisted of transforming the church into a branch of the Trekhsviatel'skii Christian Tatar monastery founded in 1905 in Laishevo district, which was the home of ten Kräshen monks, visited by hundreds of Kräshen pilgrims. Monks, according to the petitioners, would have more authority among the Elyshevites than young inexperienced Kräshen teachers. In 1912, the

72. Petition and plan of the mosque of Baimurzino (Tetiushi district) in NART, f. 2, op. 7, d. 1608, 11. 143, 147-149; "K postroike tserkvi v derevne Baimurzinoi, Tetiushskogo uezda," IKE, no. 37 (1 October 1910): 1038-1039; on Kreshchenye Ianasaly (Kazan district), NART, f. 2, op. 7, d. 1608, 1l. 357-367; on Azbaba (Sviiazhsk district), NART, f. 2, op. 7, d. 1607, 1l. 279, 287, 291.

73. Chicherina, U privolzhskikh inorodtsev, 145; NART, f. 1, op. 4, d. 4775, 1. 5; f. 2, op. 7, d. 1606, 11. $738-743$. 


\section{Qepmessor}

sa nomporisy depebsinso u veremu bs zepebs

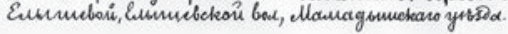
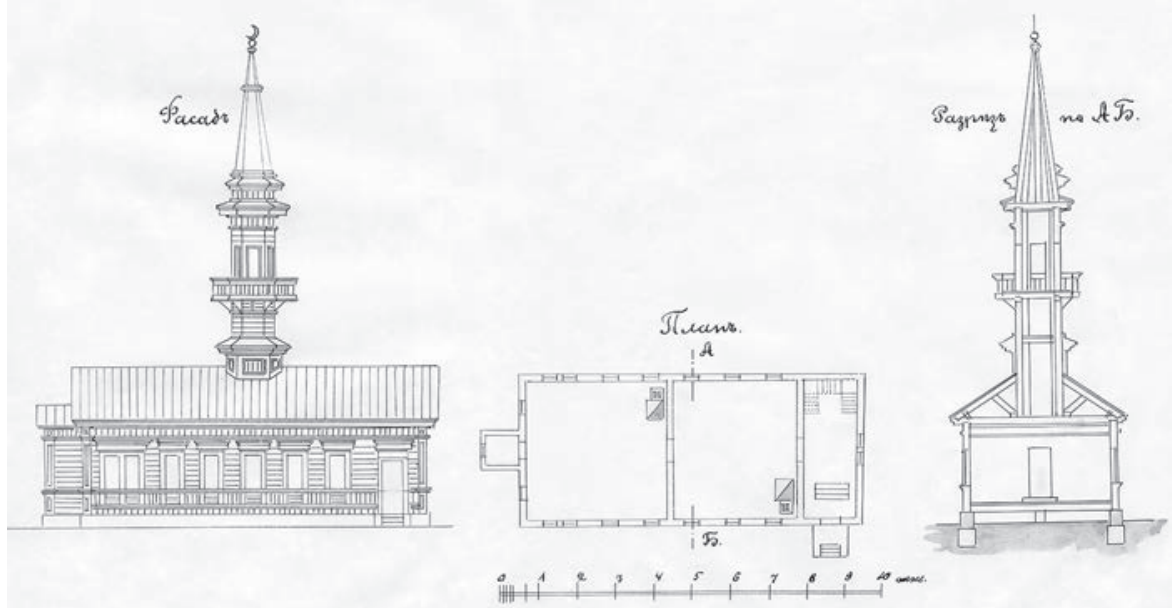

5.1: Plan of the new mosque in Elyshevo (1906-1907). NART, f. 2, op. 7, d. 1606. 1. 740. Plan courtesy of NART.

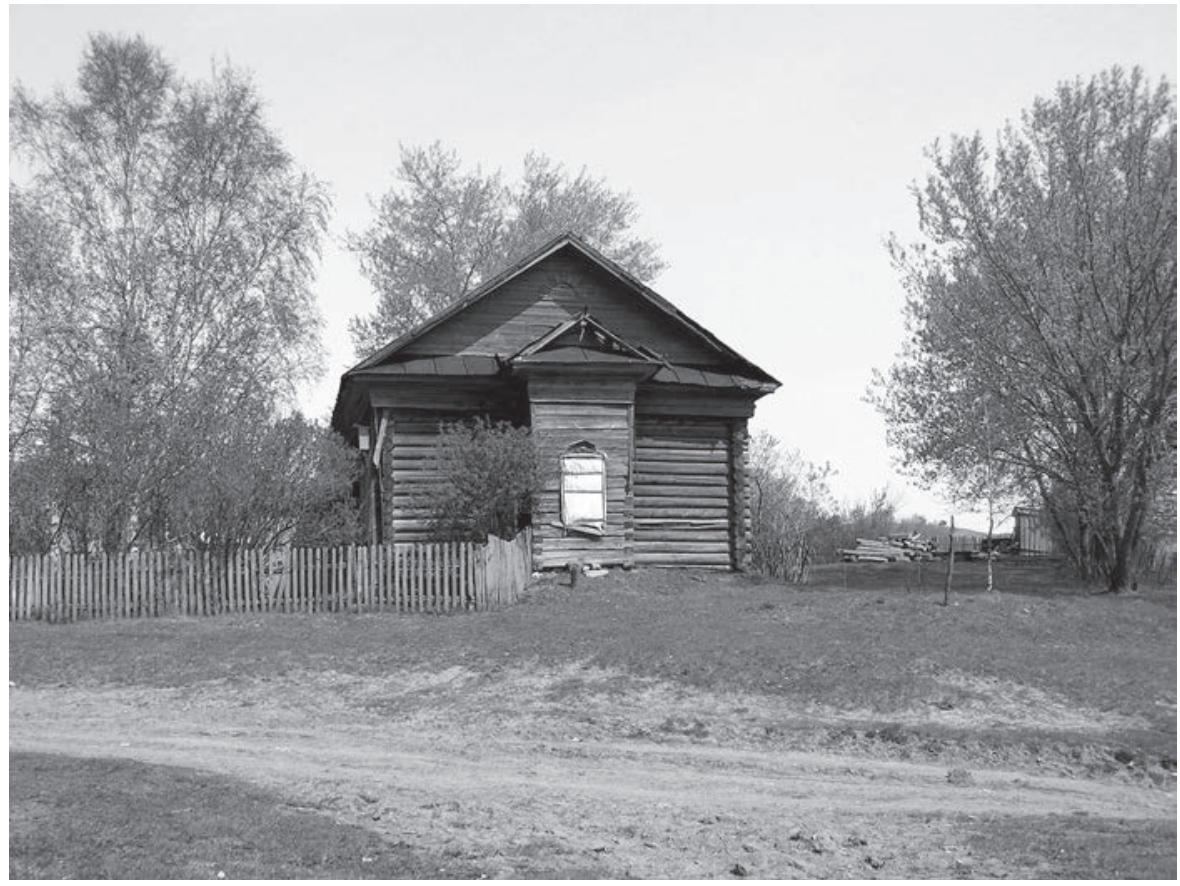

5.2: Elyshevo Mosque today. Photograph by the author. 
apostates finally obtained the official recognition of their maktab but the Orthodox school with its dormitory and fifteen students living at the expense of the Brotherhood of St. Gurii remained open. In 1914, however, the parish of Elyshevo was officially closed and in 1919 the church was removed and its impressive bell sent to the Kräshen village of Mäshläk. Elyshevo confessed Islam openly until their mosque was turned into a youth club and its minaret toppled down in 1937 by the Tatars of Kazanchi Bigeneevo, a village whose shaykh had long proselytized and healed the sick in Elyshevo and neighboring baptized villages. ${ }^{74}$

Jadid newspapers and printing houses welcomed the return of Kräshens to the bosom of Islam. Journalists mocked Russian missionaries, Il'minskii and Malov, who spent so many resources for the conversion of a few Muslims and thanked them for pointing what constituted bid' $a$ (innovation) in the popular understanding of Islam. The Tatar imam, historian, and socialist deputy at the second Duma in 1907, Hadi Atlasi (1876-1938), linked Christianity with colonialism and declared that as much as the Russian historian Vasilii Kliuchevskii (1841-1911) welcomed the "Tatar yoke" for uniting all Russia, he was grateful that Russian and European missionaries helped unite the world community of Islam against a common enemy. ${ }^{75}$

Using Russian missionary sources as evidence, a Tatar contributor to the French Revue du Monde Musulman trumpeted that over the centuries of forced Russification, Islamic education had proven to be superior to Russian education; it had led to the conversion of many Chuvash and Finns to Islam and had shielded the Kräshens from Russian influence. The journalist predicted that Kräshens would inexorably embrace Islam, partly because the Ministry of Education reluctantly supported instruction in native languages. Other journalists, this time in the local Tatar press, urged Muslims to be more aware of the Kräshens' fate, long neglected by the Tatar community and saluted the work of isolated mullahs who, at the peril of their lives, had let their forgotten brethren pray at their mosque. ${ }^{76}$

In 1906, the famous modernist Kärimi brothers published copies of the Edict of Religious Toleration in Tatar with attached blank petitions, later found in the Kräshen houses of Viatka province. They used the same linguistic tools as the Russian missionaries and published Isliam Dini (The Religion of Islam), a book in vernacular Tatar in Cyrillic script (although slightly different from the one created by Il'minskii). It explained to the Kräshens how to open schools and mosques. They should invite a shakird and marry him to a local literate woman, who would teach the girls. Isliam Dini defined Kräshens as Muslims whose ancestors had been Christianized by force and compelled to go to church, have icons at home, celebrate Easter, and endure the

74. NART, f. 4, op. 133, d. 7, 1. 16; f. 4, op. 134, d. 3, 1. 1; f. 4, op. 135, d. 8, 11. 25, 28-28 ob., 33-33 ob., 36 ob., 42; and f. 1, op. 4, d. 4775, 1l. 5, 11; Otchet o deiatel'nosti Kazanskogo Bratstva Sv. Guriia za 1914-i (47-i bratskii god) (Kazan, 1915), 31; V. M. Gorokhov, Reaktsionnaia shkol'naia politika tsarizma $v$ otnoshenii tatar Povolzh'ia (Kazan, 1941), 232; G. Khämidullina, interview by author, July 2008, Kazan. In 2008 the mosque building still served as a youth club.

75. Hādī Āțlāsof, "Missionerlar jämiïyätläre. IV Bez häm missionerlar," Shūrā, no 17 (1910): 527-529; "VII Missionerlarnï māqtāwïm," Shūrā, no. 22 (1910): 676-678.

76. Moulla Aminoff, "Les progrès de l'instruction chez les musulmans russes," Revue du Monde Musulman 9 (October 1909): 247-263; see regular reports on the apostasy movements gathered from Tatar newspapers in Revue du Monde Musulman 9 (October 1909): 294; 10 (March 1910): 413; FātiḥKärimi, "Rusiyadä inorodets mäktäpläre," Shūrā, no. 7 (1908): 202-205; "Iz tatarskoi musul'manskoi pechati," Tsirkuliar po Kazanskomu uchebnomu okrugu, prilozhenie 44, no. 8 (August 1908): 356-360. 
visits of popes (priests). The definition of the Kräshen community as being originally Muslim obscured the starokreshchenye's complex ethnic origin and animist religious roots, ignored that some novokreshchenye's ancestors could have accepted baptism willingly in order to be able to marry, avoid military service or other penalties. This definition also implied that those Kräshens who-thanks to Il'minskii's efforts to spread Christian Orthodox literacy among them-had remained Christians, should automatically return to the faith of their ancestors: Islam. However, it echoed the definition that apostate Kräshens advocated in their petitions and the suffering of many families whose members were still exiled in Siberia. On Judgment Day, the author added, Kräshens will enter paradise first, ahead of the prophets, as shahids because of the torments they had endured on earth. ${ }^{77}$

The book was clearly intended for starokreshchenye villages that had been exposed to Il'minskii's teaching. It pointed out the "fallacies" of Christianity, insisting that Russian icons were idols; that Mary gave birth to the Prophet Jesus and not God; and that Mary's title as Theotokos (God-bearer) was incompatible with the doctrine of God's eternal existence. To their dismay, Russian missionaries found a copy of Isliam Dini in the apostate village of Ianasal, Kazan district. This village had been the site of intense competition between apostates and nonapostates after the opening of a Christian school in 1869 and, earlier, of an underground maktab-mosque. ${ }^{78}$

Tatars went about the countryside spreading the word that Kräshens and animists could freely become Muslims, build mosques, and open separate cemeteries. In fact, the law still forbade the opening of new mosques in villages inhabited by animists, Kräshens, and apostates. Tatars, however, encouraged converts to apply directly to the Spiritual Assembly of Orenburg for permission to open schools, even as they arranged financing for these new enterprises. Merchants enthusiastically offered their services. In Samara province, Shakir Khäkimov materially aided Chuvash apostates and had his clerk write their petition after he had brought them a Tatar translation of the edict of 17 April 1905. The baptized Chuvash of Artem'evka village (also known as Bulantamak) in Buguruslan district, received a total of 8,00o rubles from the Orenburg Tatar community, famous for its trade with Central Asia: 500 rubles including a large donation of Muslim books for their new Qur'anic school (where forty-two boys and fifty girls over the age of five studied under two Tatar teachers); 500 rubles to feed the poor; and 7,00o rubles to build a mosque. In Staro-Afon'kino village, Bugul'ma district - another mixed village of Eastern Orthodox, animist, and Muslim Chuvash—an enterprising Chuvash apostate gained the patronage of wealthy Tatars from Kazan and Bugul'ma who supported the village's Qur'anic school. In 1908, they paid the mullah a salary of five rubles per month and an additional housing allowance of one ruble per month. In return, the mullah by day taught animist and apostate children who had been refused admission to the local Russian school for lack of space, and by night, adult courses. Finally, in Simbirsk province, Tatars supported financially the erection of a mosque in a baptized Chuvash village of Buinsk district, and in Kazan

77. Isliam dini. Musul'manlar echen tieshli bulgan eshliar: Iman, namaz, ruza, zakiat, khadzh shikel'li niastialiar (Kazan, 1906), 1-31; "Izvlechenie iz otcheta eparkhial'nogo inorodcheskogo missionera," 465-469; interview of Zöfär agha, inhabitant of Iske Qarmät in Tufan (Kazan, 2000), 106.

78. Bagin, "Ob otpadenii," 235-236; Mashanov, "Sovremennoe sostoianie," (February 1911): 278-279. 
province, a Tatar from Minger village, famous for its madrasa and its textile industry in the eighteenth century, offered one ruble for each log donated to the building of the mosque of Kibiak-Kozi, a Kräshen village in Laishevo district. ${ }^{79}$

Tatar assistance did not end there. Philanthropic societies, using the Brotherhood of St. Gurii as a model, also took an interest in the spread of Islam. A Muslim society opened a school in the village of Bazgievo, Belebei district, for Islamized Chuvash, and according to a secret police report, three jadid intellectuals created a missionary committee (most likely, a Muslim philanthropic society) to help Lithuanian Tatars, Chuvash children, and novokreshchenye matriculate at the madrasas of the Middle Volga. In 1907, because of the harvest failure, the starokreshchenyi mullah of Pochinok Ponik, Mamadysh district, a village with a Brotherhood school, turned to the Kazan Muslim committee and asked for monetary help. The society agreed to his demand and the mullah had enough to feed forty-three apostates for a month and a half. ${ }^{80}$

In 1910, the rise of the reformist movement among Tatars, in particular in places where Tatar merchants put financial pressure on the local mullahs who depended on their generosity, prompted the Minister of Interior Petr Stolypin (1862-1911) and the director of the Ministry of the Interior's Department of Religious Affairs of Foreign Confessions Aleksei Kharuzin (1864-1932) to organize an extraordinary conference about the Volga Tatars' growing particularism and influence in the Middle Volga. In its preamble, the conference alluded to the 1905 Kräshen apostasies, expressing its concern about the Tatarization (i.e., Islamization) of indigenous peoples in the center of Russia. About 49,000 apostates of Turkic and Finnic origin in the Kazan, Simbirsk, Penza, and Ufa provinces had asked to become officially Muslim. If this trend continued apostasies could constitute a threat for Russian nationhood. At the same time, the emergence of a Tatar nonconfessional school outside state control and dependent on mullahs confirmed the Tatars' desire to separate themselves from Russia. In this context, the apostasies of 1905 were regarded as the result of a renewed form of religious proselytism. Pan-Islamism was the new keyword used by police officials to describe any deviant movement in favor of a union of all Muslim peoples against Europeans and in particular Russia. Missionaries and state agents blamed jadid newspapers for the apostates' growing influence. Thus, when three starokreshchenye from Elyshevo were exiled to Smolensk province in February 1911, the official reason was not that they sought to have their Muslim school recognized but that they had spread "panislamic propaganda" among their covillagers. ${ }^{81}$

The final report had three sets of recommendations. First, it encouraged the creation of special programs for training missionaries in local languages and suggested that schools for Kräshens, Chuvash, Maris, and Udmurts could teach children to polemicize with Muslims, an idea dear to Malov. Second, it offered to decentralize the

79. RGIA, f. 821 , op. 133 , d. 464 , 11. $273-275$; f. 821 , op. 133 , d. 457,1 . 6; "Otchet Samarskogo eparkhial'nogo komiteta Pravoslavnogo missionerskogo obshchestva za 1906 g. (37-i god svoego sushchestvovaniia)," PB 2, bk. 2, no. 10 (May 1907): 121; Ivanov, “Tsarstvo islama," 113-117; idem, "Magometanskie shkoly v inorodcheskikh seleniiakh," Missionerskoe obozrenie 14, no. 2 (February 1909): 331; Näbiulla khäzrät Khämidulla, interview by author, 11 July 2000, Bol'shie Kibiak-Kozi.

8o. RGIA, f. 733, op. 173, d. 108, 1l. 73-75; NART, f. 1, op. 6, d. 612, 1l. 8 ob., 9 ob.; Rorlich, Volga Tatars, 80. 
Spiritual Assembly of Orenburg, which missionaries had blamed for hiring Kräshens or registering animists as Muslims. The exams would not take place in Ufa anymore, but at the provincial level, and the language of the exams would correspond to the candidates' vernaculars to avoid further Tatarization of the Kazakhs or Kirgiz. Third, Qur'anic schools ought to adopt a common religious curriculum with no Russian or sciences being taught. The jadid schools that refused to give up secular sciences could become private, under the supervision of the Ministry of Education. Soon, it was assumed, these schools would disappear and merge with the Russo-Tatar system of education. Overall, Stolypin's main concern was to control the emergence of a nonRussian school that provided a "general" education but developed outside state supervision. The Ministry of Education sought to take control of the burgeoning Russian zemstvo schools as well. Moreover, the Ministry of Interior did not have the means to close down all Qur'anic schools that had a mixed curriculum. This would have deprived a significant portion of the imperial population of an education. In other words, the Russian officials, who long believed in the assimilatory power of Russian culture, had to cope with new forms of self-identification. The same minorities they sought to Russify through language and/or religion had their autonomous understanding of Russification and citizenry. ${ }^{82}$

The 1910 commission surely exaggerated the impact of Islamic modernism in the countryside and falsely ascribed apostasy successes to jadid propaganda. Prerevolutionary pictures of apostates standing before their underground mosque in KibiakKozi displayed Bukharan fashion of dress, turbans and long robes, rather than Ottoman Turkish fashion, that is fez, Western cut suits, belted pants, and longer hair. However exaggerated the Russian official assessment was it did not mean that jadid literacy failed to penetrate the baptized milieu especially around the 1920s. Major Tatar trade and sacred centers in proximity of apostate communities had adopted the new method in primary schools: Tiunter in Malmyzh district, Kazaklar (Muslim Kibiak-Kozi) in Laishevo district, Bogatye Saby in Mamadysh district, St. Kiremet' (Qarmät) and Kutlushkino (Yäüshirmä) in Chistopol' district, and Sulabash in Kazan district. And certainly apostates in Chistopol' and Mamadysh districts, especially near local markets, took advantage of jadid schooling or modernist literature when it was available to them. In the late 189os, the famous Naqshbandi shaykh in Chistopol', Möhämmäd Näjib Ämirkhan (1859-1921) who initially opposed the introduction of Russian classes in his madrasa in 1891-1893 but like Barudi, integrated the new phonetic method of reading into his curriculum, let 1,00o Kräshens pray at his mosque publicly. There is no reason to doubt that their children attended the schools he directed in the first and second mahalla of the city, as they did in the madrasa of

81. "Zhurnal osobogo soveshchaniia po vyrabotke mer dlia protivodeistviia tatarsko-musul'manskomu vliianiiu v privolzhskom krae, 1910," entirely reprinted in "Iz istorii natsional'noi politiki tsarizma," Krasnyi arkhiv 4, no. 35 (1929): 107-127; 5, no. 36 (1929): 61-83; RGIA, f. 821, op. 133, d. 470, 1. 68.

82. For a different point of view see Yahya Abdoulline, "Histoire et interprétations contemporaines du second réformisme musulman (ou djadidisme) chez les Tatars de la Volga et de Crimée," Cahiers du Monde russe: Russie-Empire russe, Union soviétique-Etats indépendants 37, nos. 1-2 (January-June 1996): 67. In general Tatar historiography places the emphasis on the closing down of several jadid schools in 1910-1212 (M. Mähdiev, "Bubi mädräsäse," Qazan utlarï, no. 12 [December 1969]: 167-179). For echoes of the debates, see Revue du Monde Musulman 11, no. 5 (1910): 144; 12, no. 11 (1910): 460; 14, no. 4 (1911): $144-145$. 


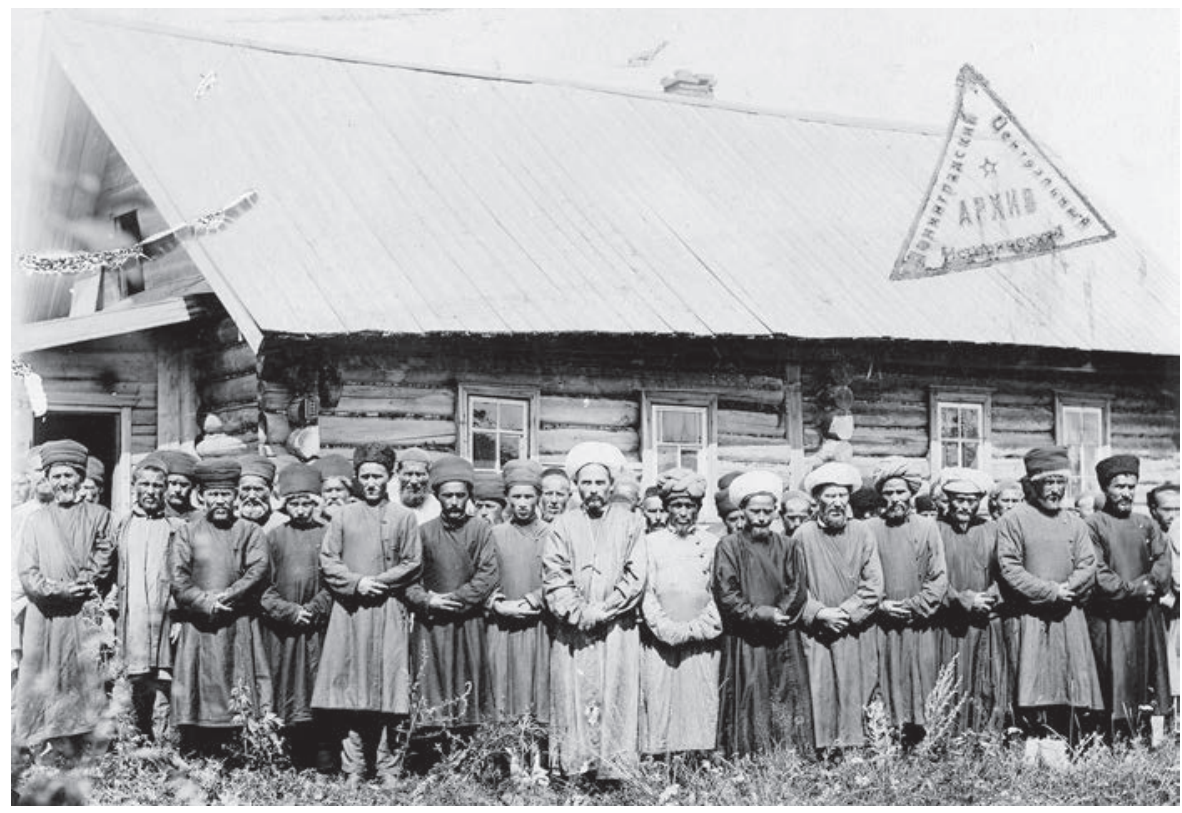

5.3: Apostates standing in front of their underground mosque in Kibiak-Kozi, Laishevo district. RGIA, f. 821 , op. 4 , d. 72 , photograph no. 9. No date. Photograph courtesy of RGIA.

the Naqshbandi shaykhs of Tiunter, descendants of 'Ali Säyfullah, who also adopted jadid curricula. ${ }^{83}$

According to zemstvo statistics, many Tatar schools-even those that did not offer a strictly jadid curriculum-used both traditional and jadid textbooks. ${ }^{84}$ In the apostate village of Kibiak-Kozi, when the mosque was officially opened, children studied the art of reading the Qur'an with one of Ähmäd Hadi Maqsudi's primers. The descendants of apostate families I visited in Ianyli possessed prerevolutionary editions of Maqsudi's textbooks in their private family libraries, along with Sufi Turkic poetry. On one photograph the future underground mullah, Ibrahim Bikmökhämmätov, appears in company of a madrasa student who wears a Turkish fez. Moreover, the poet Tufan-born in the village of Iske Qarmät, which became officially Muslim in 1905-regularly visited his village mullah; although the mullah did not teach modern sciences as was typically done in a jadid school, he did read jadid newspapers to Tufan and his schoolmates at home. Tufan was also acquainted with the works of the

83. RGIA, f. 821, op. 133, d. 465, ll. 67-68; NART, f. 2, op. 2, d. 5129, 1. 2; Chistopol' $i$ Chistopol'tsy iz proshlogo i nastoiashchego (Kazan, 2004), 133-134, 140-142.

84. M. I. Obukhov, Mekteby Ufimskoi gubernii: Statisticheskii ocherk tatarskikh i bashkirskikh nizshikh shkol (mektebov) Ufimskoi gubernskoi zemskoi upravy 1912-13 (Ufa, 1915), 30-32, 40, 83; A. Liubimov, "Maktaby i medrese g. Ufy i pervogo raiona Ufimskogo uezda," Vestnik Orenburgskogo uchebnogo okruga 3, no. 2 (1914): 85-94. Some schools reverted to the old ways of teaching if the community showed dissatisfaction toward the jadid approach and refused to support the school's financial needs. See secret communication of the Kazan governor to the Department of police on 13 May 1901, reprinted by Il'dus Zagidullin, "Islam i narodnoe prosveshchenie u Tatar v kontse XIX veka," Tatarskii gosudarstvennyi Gumanitarnyi institut: Uchenye zapiski 4 (1998): 189. 
prereformist encyclopedist Nasïri. Later he read jadid literature on his own and studied in the madrasa of 'Aliyä, a famous large jadid school in Ufa, where he read French novels in Turkish. ${ }^{85}$

Even more telling, the personal diary of Mahisärwär, the daughter of the underground mullah of Elyshevo, offered a patchwork of ancient and jadid nationalist literature, which reflected the depth of her education and the complex history of her native village. She included ancient Turkic munajat, mawlids (poems written in honor of the Prophet's birth), and qasida (hymnic poems with monorhyme used for encomia) in Persian as well as her own free Tatar translations praising the Prophet's physical beauty and extraordinary qualities of generosity and humility (with his wide dark eyes, long eyelashes, and spaced teeth that flashed each time he spoke, the Prophet's face shone like the sun). Mahisärwär's notebook also preserves an abbreviated version of the epic of Ismail-an apostate of Elyshevo sent to Siberia in 1878-and the famous epic of the last queen of Kazan, Söyem Bikä whose son was forcibly baptized. It also contained more contemporary religious and secular poems of the famous jadid authors Tuqay, his friend Sä id Sünchäläy (1889-1937), Äbrar Sä idi (1895-1939), and Jamal ad-Din Yumayev (1892-1940). ${ }^{86}$ Since Mahisärwär studied with her father, Ibrahim Bikmökhämmätov who was a friend of the famous socialist revolutionary 'Alimjan Ibrahimov (1887-1938), her selection confirmed that Elyshevo was exposed to some form of jadid literacy, although she probably would not have identified these texts as "jadid" but as part as her cultural heritage. In fact, some of her entries echoed the chants of revolutionary jadid students who called the Tatar people, their millet (nation), to wake up and spread the light of knowledge instead of eating, sleeping and praying with beads (tasbih). Could it be that Ibrahimov who participated in the students' strikes of 1905 and in the Revolution of 1917 brought her attention to these poems? Even her spelling in Arabic script echoed changes advocated by Tatar reformers in late nineteenth century and already reflected in print well before the official adoption in 1920 of the reformed Arabic alphabet. ${ }^{87}$

As religion became increasingly persecuted in the Soviet Union, Mahisärwär continued the work of her grandfather and father, teaching Islam underground to the children of Elyshevo, using older and newer Islamic primers (whichever was available), singing the munajat she recorded in her notebooks and reading Qur'anic prayers at various religious celebrations. Jadid tools of knowledge, available through book trade in village markets, did not erase older expressions of Islamic piety; in the same way young girls in the past copied ancient poetry and contemporary local songs,

85. Näbiulla khäzrät Khämidulla, interview by author, 11 July 200o, Bol'shie Kibiak-Kozi; Ähmäd Hādī Maqșūdī, Möallim-i sānī yāki älifbā-yi 'aräbī (Kazan, 1917); Tufan, "Bälki, shaghïyr bulmas ta idem," 5-7; Tufan, "O sebe," 12.

86. Mahisärwär Ibrahim qïzï Bikmökhämmätova’s notebook (däftär) (date of completion, 1919?), 11. 4-8 (Qașìda an-näbī), 25 and 76 (Mäwlid an-näbī), 59-60 (Söyem Bīkä bäyete), 71 (Ismāîl bäyete). Praises of the Prophet's physical beauty were based on early traditions of the Prophet collected by Tirmidhi (Schimmel, And Muhammad Is His Messenger, 33-34). Tuqay's poems included Bäyräm bügen, Allāh-i täbāräk wä tä'ālä, Tughan tel, Tughan awïl, Qarlïghach, Közge jillär, on 1l. 30, 31, 39, 47, 6o, Sünchäläy’sTaulargha qaraghanda and Säkhär, on 1l. 40, 61, Äbrar Sä'idi’s Mäktäb, 1. 44, and Yumayev’s Därestän elek, 1. 45.

87. Uyan, Tatar; Qoyash chïqtï; Balalar kingäshe; and Shī‘ ir in Mahisärwär's notebook, 11. 9, 18, 54, 58. Mahisärwär's spelling reflected the changes brought by Äḥmäd Hādī Maqșūdī in his primer (Möallim- $i$ äwwäl [Kazan, 1892-1910], 8 editions). 
Mahisärwär copied the poems of Tuqay or Sünchäläy by hand. Later authorities banned Tuqay's religious poems from Tatar schools, but until perestroika, they were still recited by Mahisärwär and her students, who could rely on their teacher's notes.

Just before and after the Revolution, the modernist intelligentsia, besides assisting apostates in their legal recognition as Muslims and providing them with occasional financial support, was also concerned with the "national" rehabilitation of their image, still soiled by their ancestors' acceptance of baptism. Neighboring villages still viewed apostates as opportunistic defectors from Islam. Eager to encourage the return of all converts to the faith of their ancestors, Baha' ad-Din Waysi (in Russian, Vaisov) (1819/20-1893), the head of the Naqshbandi antimufti movement who rejected Russian taxation, conscription, and the opening of Russo-Tatar schools, expressed the abomination of being a crypto-Muslim eloquently when mocking baptized Tatars who claim to be Muslim when they meet a Muslim but Orthodox when they meet a Russian. ${ }^{88}$ Apostatizing from Eastern Orthodoxy was the right cure to erase the original stain of defecting, but nevertheless prejudice against the "apostates" remained. Still today, villagers in the Kukmor area distinguish between Muslim aq (white) and qara (black) villages based on their ancestry and their perceived rusticity. The qara villages are Muslim Tatar villages marked by a history of religious defection and/or mixed ethnic Finno-Ugric or Chuvash ancestry while the aq villages can trace their ancestry back to migrants from the Saba region known for its madrasa in Bogatye Saby and economic dynamism in the eighteenth century.

Muslim Tatars were often reluctant to marry apostates, who until 1905 remained legally Orthodox. Imperial law did not recognize a marriage performed by a mullah when the bride or groom was officially Christian. Even for Muslims, such marriages could be tainted by the suspicion of adultery or fornication (zina). Children of apostates often bore the names of their mother: "Fatima ughlï" (son of Fatima) or "'Ayshä ughli" (son of Aisha), which implied that they were illegitimate. ${ }^{89}$

Fully aware of these prejudices against apostates, 'Ayaz Iskhaqi (1878-1954), a graduate of both the madrasa system and the Kazan Tatar Teachers' School, and leader of the Tatar Socialist Revolutionary movement, decided in 1907, while he was in the Chistopol' prison, to popularize and recast the tragic history of baptized apostates in nationalistic terms, offering simultaneously a new "reading" of past Sufi literature. His native village, Kutlushkino (Yäüshirmä) in Chistopol' district, where his father served as imam and taught according to the new method, was the home of thirty apostates in the 1860 s. $^{90}$ Amazingly, Iskhaqi-who believed that social class rather than religion was the basis for political organization, who tirelessly denounced traditional Islamic education as anti-modern, and who warned about the end of the Tatar nation if Tatars remained under the spell of Sufi ishans and did not embrace Russian civilization-drew on popular religious literature not only to erase internal fractures and facilitate the "return" of baptized Tatars to their so-called primordial community but also to delineate and solidify the boundary between Tatar and Russian identities.

88. Kemper, Sufis und Gelehrte, 409; Nikolai Katanov, Novye dannye o musul'manskoi sekte Vaisovtsev (Kazan, 1909), 10.

89. Äḥmärof, “Mükrehlär hālendän,” col. 7; NART, f. 2, op. 2, d. 3454, 11. 2-3. The poet Tufan’s family name before 1905 was Gölzizin, son of Gölziyä ("luminous flower” in Arabic). Ghosman, "Zur khislär," 6. 
In his earlier works, Iskhaqi sought to eliminate past religious practices to advance progress, but in Zöläykha-a drama he finished writing in 1912-he tapped into his audience's preexisting literary Sufi memories, glorifying the image of Kräshens as martyrs and warriors for the faith (ghazis). ${ }^{91}$

Iskhaqi's drama recounted the fate of Zöläykha, an apostate baptized Tatar who was taken away from her husband and children in the 1860 , married forcibly by a pope (kämish) to a Russian drunkard named Petr, and sent to Siberia for poisoning her new abusive spouse (after the latter caused the death of her first husband). An invisible shaykh who had sent one of his disciples to find Zöläykha served as a deus ex machina to bring her first husband and her daughters to the exiled heroine's door. Relentlessly, the Sufi disciple, who was not the target of typical jadid sarcasms, reminded the protagonists to be patient and to wait for God's mercy and blessings. If patient, Zöläykha would receive as many sawab (merits) as Rahma, who endured her husband Job's unfounded accusations of infidelity and Asiya, the pharaoh's wife who was abused and killed by her husband for praying relentlessly day and night.92

Zöläykha's fate was reminiscent of another martyr-Queen Söyem Bikä who, according to popular lore, had tried to poison the traitorous Tatar prince whom Moscow had placed on the throne of Kazan. Like the last queen of Kazan who was exiled and separated from her son, baptized Zöläykha was separated from her toddler who was later educated in a Russian school and prepared himself to become a priest. But most strikingly, the Kräshen Zöläykha evoked her namesake in the Book of Joseph. Similar to Potiphar's wife-the innocent pagan adulteress who was later transformed and forgiven by her search for God-Zöläykha was a "paganized" Muslim defiled by her baptism and rape by an infidel. From an Islamic point of view, she was like Potiphar's wife guilty of zina since the priest of her parish did not recognize her marriage to the apostate Sälimjan (Mitrofan) and married her forcibly to an Orthodox Russian. Finally, Iskhaqi's story echoed other prophetic events. In the same way Jacob clung to Joseph's bloody shirt, Zöläykha, after the murder of her first husband at Petr's instigation, pressed his bloodstained coat to her heart, and as Jacob lost his sight after weeping for his son's death, Zöläykha's mother became blind after her daughter was deported. ${ }^{93}$

Iskhaqi's portrayal of the apostate Zulaykha did not rest on the typical jadid reading of Joseph's story. In general, the tale about Joseph in modernist elementary textbooks skipped Zulaykha and her struggles on God's path as widely known to their audiences, to highlight Joseph's rise to power, growing maturity, and wise management of Egyptian resources. ${ }^{94}$ While in past stories of the prophets, the narrator recorded several traditions without privileging one over the other or reaching a final conclusion, thus preserving the multivocal character of the story and allowing differ-

90. On Kutlushkino, see Malov's “Statisticheskie svedeniia," Uchenye zapiski Kazanskogo universiteta, 343; list of new-method schools in 1911, RGIA, f. 821, op. 133, d. 465, 1l. 67-68.

91. Ghayaz Iskhaqïy, Zöläykha reprinted in Zindan: Saylanma proza häm säkhnä äsärläre (Kazan, 1991), 515-586 (it is a faithful transliteration of the original, 'Ayāż Ishāqī, Zulaykhā [Moscow, 1918]). Idem, Tormïshmï bu? reprinted in Zindan, 78-146; idem, Ike yöz yïldan song inqüyraz; R. M. Mukhametshin, "Islam i tatarskii natsionalizm v nachale XX veka," Islam v istorii $i$ kul'ture tatarskogo naroda (Kazan, 200o), 80-94.

92. Iskhaqïy, Zöläykha, 544, 547-551, 573.

93. Ibid., 538, 540, 543, 545, 575 . 
ent possible readings, modernist tales of the prophets tended to give a succinct outline of the story with the main facts. Zulaykha was mentioned only as the temptress who caused Joseph's imprisonment and, later, as Joseph's wife-without any extensive explanation for her transformation. The entertaining love story, which so delighted Rabghuzi but so shocked Russian missionaries for its sensuality, was eliminated and the story line was reduced to the growing pains of a boy-prophet to adulthood, offering less appeal for a female audience. When in the past male and female readers could identify themselves to both Joseph and Zulaykha, now boys and girls were invited to model their lives after the male hero. ${ }^{95}$

Instead, Iskhaqi drew from the tale of Joseph as narrated in Qol 'Ali and its interpretation by Jalal ad-Din as-Suyuti (ca. 1445-1505), an Egyptian Sufi and jurist whose work met Tatar modernist credentials and who presented Joseph's wife as the symbol of the Prophet Muhammad's umma, an idea totally absent in the Qur'an. ${ }^{96}$ Following asSuyuti, Iskhaqi portrayed Zöläykha as a symbol of the Muslim community subjected to infidel ridicule. As-Suyuti had drastically reinterpreted one Qur'anic episode in which Potiphar's wife took vengeance on a group of women who gossiped about her infatuation with Joseph. Offering them fruit and peeling knives, Zulaykha then presented her handsome slave to the gossiping women; stunned by his beauty, the women sliced their fingers instead of the fruits, as Zulaykha mocked them. Whereas in the Qur'an, Potiphar's wife appeared malicious, as-Suyuti depicted Zulaykha as the Muslim community drunk with divine love who had recognized the true prophet of God, while the gossiping women resembled the infidels and the idolaters who ignored the true God. ${ }^{97}$

As-Suyuti's Zulaykha and Iskhaqii's Zöläykha were both symbols of the Prophet's community subjected to infidels' mockery. Like Joseph himself, who was betrayed by his brothers and then sold into slavery, Iskhaqi's Zöläykha was sent to a monastery, and her husband to prison as a consequence of their Muslim neighbors' denunciations. In short, Iskhaqi forced his audience to wonder who truly embodied the Volga Islamic community: Zöläykha, a member of the despised Kräshen community, or the so-called original Muslim Tatars who despised their baptized brethren?"

The play unambiguously affirmed that Zöläykha's ancestors were baptized against their will; there was no hint that they could have been baptized to escape

94. Riza' ad-Din b. Fäkhr ad-Din preferred to use Joseph as an example of moral excellence to stress the equal importance of human agency and divine support for achieving earthly advancement. Jäwämi', 127 (hadith no. 89). In general, Fäkhr ad-Din was critical of the historian Tabari's and later Turkic accounts of Joseph story. According to the Tatar scholar Nurmukhammet Khisamov, Fäkhr ad-Din supported the Qur'anic commentator Abu al-Qasim Mahmud al-Zamakhshari (1074-1143) in his criticism of Tabari's fantastic description of the scene when Joseph, facing Zulaykha, started loosening his pants. If the figure of his father had not appeared to him, Joseph would have succumbed to his desire; however the Qur'an made no mention of the sexual titillating details. It simply mentioned that Joseph would have taken Potiphar's wife if he had not seen a sign from God. Khisamov, Poema, 52; The History of al-Tabari, 155; Qurān, 12: 24.

95. Häbīb ar-Raḥmān az-Zäbīrī, Mukhtașar tārīkh-i möqaddäs (Kazan, 1906), 19-21; Fātih Kärīmof, Tārīkh-i änbiyà' (Orenburg, 1911), 14-18; Bārūdī, Tārīkh-i änbiyà', 9-12; Shahīd 'Ownī, Tārīkh-i änbiyā' yāki tārīkh-i möqaddäs (Kazan, 1913), 15-18; al-Rabghūzī, Stories, 2: 164-165; Bobylev, Patriarkh Iosif po Biblii i Koranu, 249-250.

96. Nasïri translated Imam Suyuti's work, Anīs al-Jalīs (The Familiar Companion) in 1882. See "Jäwahirel khikäyat," in Qayum Nasïyri, Saylanma äsärlär, vol. 2 (Kazan, 2004), 266. Gasprinskii recommended its reading. Mebadi-yi temeddün-i Islamiyan-i Rus, 269.

97. Qurān, 12: 30-32; Al-Rabghūzī, Stories, 2: 214-219; Kitāb-i qïșsa-yi Häżrät-i Yūsuf, 37. 
taxes, corporal punishment, or prison, to advance in the hierarchy of service, or to receive money and clothing. All the characters-Zöläykha, her father, and her first husband-performed the namaz scrupulously; they clung to their prayer carpets and amulets-which Iskhaqi criticized in other literary contexts as symbols of obscurantism; their speech was fully Islamized and monologues took the shape of long $d u^{\prime} a$ (spontaneous prayers). Because of their sufferings, Kräshens turned to be much stronger Muslims than their Tatar neighbors who mocked them. A day before Zöläykha died, angels with large blue wings appeared to her, healing Zöläykha's swollen foot, deformed by her chains of servitude, pouring the same water that the angel Gabriel used in one occasion to cleanse Job's face devoured by worms and in another, to purify Muhammad's heart when he was four years old. Angels compared Zöläykha to Saladin and Mehmet the Conqueror who fought against the infidels, and called Jesus's mother, Mary, and the Prophet's daughter, Fatima, both powerful intercessors for women, to prepare a palace for her in paradise. Finally, Zöläykha was a shahid and a ghazi, killing God's enemy, and praying for her Russified son to convert back to Islam. ${ }^{99}$

Whereas in the past Sufi epics served to expand the realm of Islam across ethnic boundaries, in Zöläykha, the same religious references served to crystallize group belonging. If Russians could only be Eastern Orthodox Tatars were meant to be Muslim. Attracted by an ancient Tatar song he heard while a child, Zöläykha's Russified son, Zakhar, witnessed the descent of the angels upon his mother and converted back to Islam. Emphatically he declared that Tatar blood run in his veins; that he could not renounce his mother's family, who had suffered and died for their faith while priests like his fiancée's father cared more about emoluments than about God. In other words, Islam was the true faith because its holders were morally the purest. Conversely, Russians could only be Eastern Orthodox. Zakhar's Russian fiancée, shocked and distressed but still loving, refused to follow her beloved after he joined Islam. And a Russian old man, who took Zöläykha's defense against her abusive husband, told the tragic story of a Russian girl whom Poles wanted to convert forcibly to Catholicism; thus one could not expect Zöläykha, a Tatar girl, to be converted forcibly to the Russian faith. In Iskhaqi's play, ethnicity, language, and religion determined national identity for both colonized and colonizers; and the Kräshen space belonged exclusively to Islam. A Christian Tatar was an oddity, a product of Russian colonialism, condemned to disappear-in other words the starokreshchenye who embraced Il'minskii's education had to disappear and merge with the Tatar ethnos; and apostates who still suffered some form of estrangement or shame from their Muslim

98. Iskhaqïy, Zöläykha, 540, 543, 545. In the play the villagers reported to the priest that their mullah taught baptized children, married the young, and buried the dead among the Kräshens. Iskhaqïy, Zöläykha, 535, 537-538, 540. Muslim Tatars who did not approve of their mullahs' village politics occasionally used their involvement in the baptized community as a weapon to denounce them to the authorities. For good examples, see RGIA, f. 821, op. 8, d. 763, 11. 224-225; Crews, For Prophet and Tsar, 134-140.

99. Iskhaqïy, Zöläykha, 517, 523, 524, 540, 569-571. For a different reading of the play, see Madina Goldberg who emphasized elements of Tatar folklore over Islamic metaphors, "Russian Empire-Tatar Theater: The Politics of Culture in Late Imperial Kazan" (PhD diss., University of Michigan, 2009), 83, 102-104. 
brothers, were to be treated as privileged members of the Tatar community, because their Islam was undisputedly pure..$^{100}$

The Tatar modernist discourse, as illustrated in Iskhaqi's play, did not differ much from the early Russian state discourse in which religion was always linked to ethnicity as part of a people's customs and not as an individual relationship to God. As in the Ottoman Empire, where the emerging national identities of Armenians and Bulgarians were defined in part by their religion, the nationalistic intelligentsias that emerged among the ethnic minorities of Russia in the early twentieth century demanded unconditional confessional loyalty and unity from all the members of their nations. Tatars should be Muslim, Russians-Orthodox. In this model of the nationstate, there was no room for identity negotiation or bargaining between converters and converted. If from a government point of view a Christian could not become a Muslim, from a Tatar nationalistic point of view, a Muslim could not become a Christian. Faith was articulated in nationalistic terms. Togan, who published a high school history of the Turko-Tatars, taught that the faith of all Turkic people was Islam. When Turkic people happened to be Christian, Christianity was no more than an official category. Later, this nationalist discourse survived in Kemalist Turkish and Soviet Tatar historiographies: Kräshens who did not revert to Islam could not be true Christians but only remnants of a glorious ancient Turkic pre-Islamic past worthy of investigation. ${ }^{101}$

After the February Revolution ended czarist censorship, the father of Tatar theater 'Abdullah Qariyev (1886-1920) staged Zöläykha for the first time in Kazan on 17 March $1917 .^{102}$ According to witnesses, the Bol'shoi Theater (currently, V. M. Kachalov Kazan Academic Russian Dramatic Theater on Bauman Street) was so full that there was no room left to sit or stand, forcing audience members to sit on windowsills. The resulting pressure caused all the windows to crack, but no one paid attention to the noise, for everyone was focused on the tragic fate of Zöläykha, played by the famous actress Ömmelgölsem Bolgharskaya (1891-1968). As in the Shi'i passion plays (ta'ziya) commemorating the killing of Husayn (where Joseph's story is also used as a parallel to the torments of the Prophet's immediate family), the audience identified themselves so much with the characters that they jumped onto the stage and joined Zöläykha during her prayers. The audience bodily and spiritually experienced a mass catharsis, a reactivation of common religious values, and communal unity against a common abuser. ${ }^{103}$

On 4 May 1917, Qariyev staged the play in Moscow at the private Korsh Theater, known for promoting Anton Chekhov's plays, during the All-Russian Muslim

100. Iskhaqïy, Zöläykha, 543, 569, 576 .

101. Werth, "Limits of Religious Ascription," 496; Reinkowski, "Hidden Believers," 432-433; Äkhmäd Zäki Wälidi, Qïsqacha törek-tatar tarikhï (Kazan, [1917]; reprint, Kazan, 1992), 13; Battal-Taymas, Kazan Türkleri, 108-109. Battal-Taymas (1880-1969), a Tatar nationalist, who migrated to Finland in 1921 and Turkey in 1925, published the first edition of this book in 1925 .

102. Sh. Ä., “Zulaykhā”, Yoldïz, no. 1773 (22 March 1917): 2-3; 'Abdullah Qariyev was a pseudonym. The director's real name was Minglebay Khäyrullin. Khäyrullin received the honorific title of qari (Qur'an reciter) for memorizing and reciting the whole Qur'an. In 1908, Qariyev turned “Säyar," an informal group of young actors into a professional theater. See Ismäghïyl' Rämi and Räis Dautov, Ädäbi süzlek (Kazan, 2001), 129, 216, and Hänüz Mäkhmütov, Il'tani Ilyanova, Bäyan Ghïyzzät, "Oktyabr'gä qadärge Tatar teatrï (Kazan, 1988). 
Congress that addressed the reorganization of the Spiritual Assembly and cultural life. ${ }^{104}$ There too, the audience experienced an outpouring of emotion. Four thousand spectators covered Iskhaqi with ovations, and he received a symbolic present from an eighty-year-old Kräshen Muslim woman from Kazan province, a pair of chabata (bast shoes), which also epitomized Iskhaqi's ideal that the peasantry would be the driving force of the revolution. During the same month in Kazan, the Kräshens and other baptized non-Russian communities, now organized in a Society of the Small Peoples of the Volga, held their own congress, fighting their own battle against Russification and asking for cultural autonomy in both church and school matters-especially, the promotion of native clerics in native parishes and native bishops. $^{105}$

The Tatar press in both Kazan and Moscow saluted the play enthusiastically but critically. It denounced the Russification policies of the previous regime, and thanked the new regime that had authorized the performance. It also praised its realism and recalled the old myths that Kräshens had been forced to accept baptism in overheated munchas. But it also criticized the sudden unrealistic conversion of Zöläykha's son to Islam and blamed Qariyev's performance for being too Christian and not Muslim enough. When Zöläykha prayed, one critic noticed, she looked at the sky the way Christians do, rather than keeping her head and eyes down. More disturbing for another critic was the angels' costumes at Zöläykha's final hour: they looked too much like Christian angels in European medieval paintings with their blond and curly hair, wings, and their belts (zünnar) over long white robes. Since Zöläykha's Russified son saw the angels, it could be, the same critic conceded, that he saw them through his distorted Orthodox lens but the problem remained that the angels also appeared in the same form to Zöläykha when she was alone-and was not Zöläykha a true Muslim? Because in Islam there had not been any drawings of angels, added the critic, the proper depiction of the angels definitely constituted a hurdle. Hesitantly he suggested the angels should wear a Muslim Bukharan robe (jubba) and small turbans. Ironically the performance unintentionally reintroduced forms of religious and cultural hybridity the play sought to suppress. But discussions over the Islamic character of the performance did not last very long: in 1922 the play was censored-Iskhaqi who opposed the October Revolution had already emigrated-and in the 1930s, it was violently criticized for its being anti-Russian and for its religious propaganda. Despite the play's shortcomings, it constituted an interesting attempt to integrate former apostate communities, still marginalized by their baptism, into the

103. Ghayaz Iskhaqïy, Äsärlär, vol. 4 (Kazan, 2003): 488; Goldberg, "Russian Empire-Tatar Theater," $83,102-104$. The Säyar troupe was the only Muslim theater that allowed women to act. Goldberg, "Russian Empire-Tatar Theater," 87. On Joseph in Shi'i ta'ziya plays, see Renard, Seven Doors to Islam, 262.

104. Iskhaqïy, Äsärlär, vol. 4 (Kazan, 2003): 488; vol. 8 (Kazan, 2001): 305.

105. Ramazan Tyumenov, “Zöläykha Mäskäwdä," in Iskhaqïy, Äsärlär, vol. 8 (Kazan, 2001): 309 (reprint from $I l, 10$ May 1917); Ghayaz Iskhaqïy, “Artist Ghabdulla Qarïy," in Khatïp Mingneghulov, Ghayaz Iskhaqüynïng möhajirlektäge ijatï (Kazan, 2004), 315-321 (reprint from Yanga Milli Yul, 1936); on Korsh Theater, founded in 1882 by entrepreneur Fedor Korsh (1852-1923), see Louise McReynolds, Russia at Play: Leisure Activities at the End of the Tsarist Era (Ithaca, NY, 2003), 55-57; on the Kräshen congress (15-20 May 1917) in Kazan, see Werth, "From 'Pagan Muslims' to 'Baptized' Communists," 508; Kuz'ma Kulikov, Natsional'no-gosudarstvennoe stroitel'stvo vostochno-finskikh narodov v 1917-1937 (Izhevsk, 1993), 44. 
religious landscape of the Middle Volga. But from a Kräshen point of view, the play solidified the idea that a Christian Tatar, as a product of Russian colonialism, had no place in the making of a Tatar nation. ${ }^{106}$

Turkic Sufi literature that constituted the main intellectual capital of Tatars in the villages and cities of the Middle Volga had many readers: peasants and urbanites in the Muslim Tatar and Tatar baptized milieu, Russian missionaries, and Tatar thinkerstheologians, political leaders, poets, writers-exposed to European thought. Muslim Tatars and their converts "read" and used medieval religious folklore, which reflected earlier encounters between Islam, Christianity, and shamanism in Eurasia and Central Asia, to construct normative models for dealing with their Russian overlords in the nineteenth and the twentieth centuries. Zöläykha's world created by Iskhaqi was deeply encoded in symbols drawn from Sufi oral and written literature. The angels' scene, despite its awkward representation on stage, was no less than a dramatization of the afterlife as chanted in popular munajat. Once again, ancient religious literature served to delineate the Russian from the Tatar worlds.

The polyphony of these texts allowed for creative interpretations about crucial issues, including gender roles and Islamic identity under Christian rule. Thanks to Il'minskii's genius, who actually visited indigenous villages and understood the centrality of this literature in Tatar peasant and urban worldview, these works became part of the Kazan Theological Academy's curriculum. To reaffirm the supremacy of Christianity, missionary teachers and students borrowed from the ninth-century Mutazilites and the eighteenth-century Wahhabis to attack the miraculous and the intercessory elements of Sufi tradition as expressed in these books. Intercession and miracles were the sole property of the Christian tradition. But while Russian missionaries mocked the content of these books to destroy their influence and turn Kräshens into martyrs and vectors of Christianity in Bolghar land, modernist Tatars did not abolish this ancient literature but recalled its colorful images to create a national Tatar identity, which embraced, without reservation, the baptized apostates as Muslim martyrs of the faith.

When Tatars became increasingly involved in the Russian economic world and Russians in turn became more intrusive into the lives of their schools, mullahs, theologians, and pedagogues became fully aware of missionary criticisms of their popular tradition, and defended it, while subjecting it to an internal process of desacralization and historicization. Reformist pedagogues adopted a common strategy: they popularized the teachings of Tatar theologians in textbooks by desacralizing the role of prophets, making Muhammad's sayings relevant to modern times, and attributing new meanings to popular Sufi metaphors. The Tatars' reform of their textbooks still did not meet the approval of Russian orientalists who, when consulted for approving the adoption of jadid textbooks for the Russo-Tatar schools financed by the zemstvos,

106. F., “Zöläykha”, in Iskhaqïy, Äsärlär, 8: 288-289 (reprint from Qoyash, 19 March 1917); Shähit Äkhmädiev, “Zöläykha," in Iskhaqïy, Äsärlär, 8: 293 (reprint from Yoldïz, 22 March 1917); G. Käram, "Ghabdulla Qariyev Benefisï," in Iskhaqïy, Äsärlär, 8: 300-301 (reprint from Ang, 20 April 1917); Tyumenov, “Zöläykha Mäskäwdä,” in Iskhaqïy, Äsärlär, 8: 305-308; Anonymous, “Zöläykha," in Iskhaqïy, Äsärlär, 8: 311 (reprint from Qorïltay, 19 July 1917); Iskhaqïy, Äsärlär, 4: 489-490. 
voiced their profound distrust and Christian biases. The famous orientalist Nikolai Katanov (1862-1922), who presided over the translation commission of the Kazan Educational District Board, warned in 1910 that Maqsudi, Zäbiri, and Kärimi's textbooks presented an aberrant view of the prophets' stories, which diverged from the Bible. In accordance to Islamic tradition, the Tatar authors had written that Adam and Eve lived on the land of what is now called Mecca, that Adam's tomb was located on an island in India, and Judas, not Jesus, had been crucified. Katanov also criticized the use of sexual terms in children's books, instructions in how to wash the genitals, which constitute an important factor in Islamic ritual law, references to menstruation, and all allusions to sex. Because of Katanov, the committee concluded that those textbooks could be used only if they were significantly altered and if they were introduced at an age when students had already assimilated "Russian sciences" and had developed a critical mind of their own. ${ }^{107}$

The differences between the jadid and prejadid religious conceptions of the world, both attacked by Russian missionaries and orientalists, should not overshadow their continuity. If jadids challenged early mystical literature for its portrayal of women as deceptive or for praising asceticism as the only way to paradise, they also borrowed its metrical schemes and many of its themes. Despite the jadid critique, traditional Sufi literature also offered positive images of women as well as other ways besides asceticism to please God. Traditional textbooks indeed encouraged both sexes to acquire knowledge, and in case of men, a trade. Warning believers against false miracles and greedy saints, they acknowledged that if all men and women could not be hermits, shahids, or shaykhs, they could still avoid hell if they followed Islamic rituals with their heart and showed commitment to the well-being of their fellow Muslims. Islam in mystical literature was a religion of empowerment. Thanks to Muhammad and his law, all individuals of both sexes could gain the rewards of all prophets (i.e., paradise). Naqshbandi shaykhs also encouraged the use of Russian literacy to restore the realm of God's justice. Jadids built on those previous trends while changing the actual content of Islamic knowledge and competing openly with Christian missionaries among Finno-Ugric and Turkic minorities.

Even as the reformist Tatars in their articles strongly critiqued older literature for being too hyperbolic, they also acknowledged its importance in Tatar cultural history. Often jadid authors referred contemptuously to the older books as the "literature of our mothers and grandmothers" (and Iskhaqi was no exception)-although, contrary to jadid literature, past scholars did not write specifically for girls, and boys did memorize these books. Such sexism shocked the novelist Mäkhbübjämal Aqchurina (1869-1948). To those who blamed Turkic-Persian love epics for keeping girls ignorant and wished to trash them she responded that as well as Russians valued their older epics, boys too could still benefit from their recitation. Some of these poems could even be used as libretti for future Muslim operas. Even Alimjan Ibrahimov, the future Bolshevik revolutionary, who had been expelled from a jadid

107. RGIA, f. 733, op. 173, d. 108, 1l. 135, 150. "Perevodcheskaia komissiia pri upravlenii Kazanskogo uchebnogo okruga. Protokol zasedaniia 30 noiabria 1910 g. (no. 17)," Tsirkuliar Kazanskogo uchebnogo okruga, prilozhenie 3 (November 1910): 515-518. 
madrasa for questioning the Qur'an's divine authorship, complained that some publishing houses in Kazan focused more on school books than older Tatar literature. The publishing house 'Asïr (The century) for instance did not publish Fäża'il ashShühūr or Bāqürghān Kitābï anymore. Although the leftist pedagogue agreed with Nasïri, Tuqay, Ämirkhan, and Iskhaqi that books such as Fäżāil ash-Shühūr did not meet class requirements, he considered them as valuable pieces of Tatar literature, worth studying in a pure historical perspective. ${ }^{108}$ In July 1915, the Ufa provincial zemstvo organized a commission that included pedagogues from the most important Ufa jadid madrasas_-Aliyä, Khäsäniyä, 'Osmaniyä, and Khäkimiyä—to draw a fouryear program and a list of Tatar textbooks in language, science, and religion in the zemstvo's Russo-Tatar and Russo-Bashkir schools. Even though some of the criteria of book selection excluded the use of the ancient Sufi books, the children would learn to sing munajat in choir, which included Bädävām, the books of Joseph, Bāqïrghān, or Mary. The zemstvo of Ufa supported the list of religious textbooks, which was a victory for the jadids. ${ }^{109}$

Reformists also called for the preservation of sacred places (Söyembikä tower and the ruins of Bolghar city in Spassk district) as remnants of past Bolghar and Kazan kingdoms. The young should visit these places, not only for praying-because prayers can also be performed at home-but to reflect on the past and unite as a people. Spirits were "folklorized" in Tuqay's children's poetry. And in a 1902 speech addressed to madrasa students in Buinsk, the publicist Shakir Mökhämmädev (1865-1923) declared that if popular festivals were considered sinful, it was still possible to purify them by giving them a patriotic meaning; the money made at those festivals could be used to foster education. In 1913, the newspapers Seber (Siberia) and Yoldiz (Star) narrated the celebration of the Sabantuy at Tomsk, Ufa, and Orsk. They saluted the games, music, and in particular the collection of clothing for the poor. ${ }^{110}$ Finally, in the schools that emerged in 1905 among the former baptized Muslims of Elyshevo and Ianyli, Maqsudi's primers - which introduced children to the reading of the Qur'an-found their ways in their curriculum. The poet Tufan who was born in an apostate village, which became officially Muslim after the 1905 Revolution, went to a neighboring Chuvash school to learn Russian before entering jadid schools. Although apostates had long suffered from the Russian state unconditional support of the Orthodox Church, they

108. Mäkhbübjämal Aqchurina, "Iske ädäbiyatïmïz" in Ömet yoldïzlarï, 127-131 (reprint from Shura, 1911); Ghayaz Iskhaqïy, “Tolstoynïng tatar ädäbiyatïna täesire”, in Mingneghulov, Ghayaz Iskhaqïynïng möhajirlektäge ijati, 329 (reprint from Milli Yul, 1929) (Iskhaqi referred to Näșị̂ät aṣ-Ṣālihīn); Ghalimjan Ibrahimov, Ädäbiyat häm sänghat' turïnda mäkalälär, khezmätlär (1910-1933), in Äsärlär, vol. 5 (Kazan, 1978), 9, 51, 339, 355, 439, 463; Ghalimjan Ibrahimov, “Avtobiografiialär” (1929 and 1936), in Äsärlär tughï tomda, vol. 9 (Kazan, 2000), 17, 53 .

109. RGIA, f. 821 , op. 133 , d. 467 , no. 10 , ch. 5 , ll. $178,181,184,189-192$; GAOO, f. 44 , op. 1 , d. 171 , 11. 12-13 ob. For music notations, see Makarov, Därwishlärneng sökhbätendä, 38-39, 92-93, 96-99 (Kitāb-i qïșsa-yi Häżrät-i Yūsuf, Bädävām, and Bāqürghān kitābì).

110. RGIA, f. 821, op. 133, ed. khr. 472, ch. 4, ll. 126-126 ob.; "Ostatok ot vremen khanstva," Inorodcheskoe obozrenie, bk. 8 (September 1914): 577-578 (translation of an article originally in Tatar from Qoyash, no. 355 [7 March 1914]); "Ṣabïygha," in 'A. Tuqay, Balalar küngele (Kazan, 1917), 7; Shakir Mökhämmädev, "Khamiyätle äfändelär, kändzhi taläbälär!” in Saylanma äsärlär (Kazan, 1958), 313 (reprint from Al-Asr al-Jadid, 1907); “Obzor musul'manskoi zhizni," Mir islama 2, no. 6 (1913): 408-411. 
still knew of the importance of mastering the state language, which had helped them not only in the recognition of their religious identity but also in their trade. In some regard, the story of the apostates of Kazan province and their encounter with Russian missionaries prepared the way for the transformation of Tatar religious discourse and the preservation of Islamic knowledge during the Soviet period. 


\section{Conclusion and Epilogue}

$\mathrm{B}$ efore the rise of modernist Islam, traditional education with its Sufi components helped to Islamize animist and baptized Finno-Ugric and Turkic peoples. Islam's enthusiastic carriers-madrasa students, itinerant Sufis, traders, neighbors, but most of all "baptized" literati of both genders-established clandestine mosques and schools in officially Christian Orthodox villages, despite imperial and church prohibitions. Far from showing ethnic communal homogeneity along religious lines, Turkic genealogies and village traditions indicated that religious and ethnic identity often mutated from one generation to another. The contest between Eastern Orthodoxy and Islam in the Middle Volga involved volition and strategies by individuals and village communities who actively chose to be Christian or Muslim by using stories to defend or expand their realm of faith. More than trade and coercive power, religious myths and tales of struggle to defend or expand the frontiers of either Islam or Christianity helped draw and cement new communal boundaries.

Economic transformations among the Tatars of the Kazan province-in particular the development of textile and leather industry at the end of the eighteenth century-did facilitate the Islamization of a portion of the baptized community. The Islamic community grew thanks to intensified economic and spiritual contacts with Central Asia and India through the work of Mujaddidi and Khalidi Naqshbandi Sufis. But even more than Russian imperial or local Tatar economic power, myths were responsible for shaping or reshaping community boundaries. People drew from the stories of saints or prophets-which dated back to the fourteenth century when the Golden Horde converted to Islam - to change, negotiate, or sustain identity boundaries. Aware of their importance, Eastern Orthodox missionaries found parallel eschatological myths in their own tradition to substitute for the powerful Muslim tales of divine empowerment. As a result, many baptized villages, not entirely immune to Islamic influence, but ambivalent about their relationship with their Tatar neighbors, used the ancient stories of Christian martyrs (mucheniklar) of Roman, Greek, Turkic origins to construct their lives and solidify their own communal differences.

Likewise, in areas where Tatar trade mixed with Sufi charisma, apostates who had also been in contact with some aspects of Russian Orthodoxy but did not accept them as useful supplements or substitutes for their own sets of belief, identified themselves with the martyrs of their favorite Turkic literature. The mythical, more than the political and the economic, wove a powerful invisible shield against either colonial (Russian) or, in the case of Kräshen communities attached to their own indigenous religion and understanding of Christianity, local (Tatar) intrusion. At times, one may 
wonder whether economic forces brought the baptized Tatars to either embrace Islam or remain Christian, or whether the stories themselves engaged them to find work in Muslim or Orthodox territories. In any case, more than imperial and ecclesiastical power, myths and symbols, family and communal relations, and broader economic and cultural connections to the outside world influenced the choice baptized villages made between Islam and Christianity.

The apostate discourse did not diverge from the Tatar mullahs' understanding of Islam. It was not a lesser Islam than the Islam lived and understood by their Tatar neighbors, even if their access to Islamic learning was occasionally obstructed by the local police, missionaries, or even unsympathetic local mullahs who refused to let them attend their mosques. Both the apostates' and their Tatar proselytizers' knowledge of Islam had a scriptural basis embedded in Sufism. Most Tatar peasants failed to go through all the steps of Islamic learning and their experience of Islam was essentially drawn from Sufi literature, spiritual songs, tales of the Prophets, talismans, images of the Prophet's belongings, tomb inscriptions, and visits to ancient Bolghar sacred places. When confronted by Russian and Kräshen missionaries who emerged from their midst, apostates were obligated to defend their faith. They drew their arguments from past mystical literature, which provided models of action in an environment hostile to the expansion of Islam and from the experience of previous Turkic encounters with paganism, shamanism, and various Christianities. Sufi-inspired books also addressed different levels of integration of Islamic literacy, offered hopes of redemption for all, and promised miraculous empowerment for both genders.

For the Tatar community, Il'minskii's successes demonstrated the problematic fluidity of religious allegiance. Tatar scholars, exposed to Russian thought and modernist trends in the Ottoman Empire and India, became aware of the threat posed by the Russian missionaries' "rational" and "scripturally based" attacks on the popular mystical literature that had molded their childhood and perceptions of the non-Muslim "Other." Their new schools attempted to use Western and Ottoman Turkish educational practices to teach a rationalized Islam purified of the thaumaturgical emphasis that characterized the traditional village maktab curriculum. Believing that the Muslims of the Russian Empire had to adopt Western science and technology to survive in the modern world, Tatar reformists gave science and modern Western languages a more visible place in the curricula of their schools and created new textbooks emphasizing the Prophet's justice and his role as a builder of civilization. Although critical of the thaumaturgical content of popular Sufi literature, jadid intellectuals continued to use images from these tales to bring change and a greater openness to Russian civilization, predict the triumph of Islam in both East and West, and integrate the story of former apostate communities, still marginalized by their baptism, into a more dignified narrative of sacred resistance to colonial power.

Despite the jadid critique, traditional textbooks nevertheless prepared the way for Islam's reformulation of its tradition. Sufis-whom the jadids considered partly responsible for the decline of Islam-did not preach asceticism, call for a relaxation of rituals, or show uncritical receptivity of pre-Islamic practices. Instead, they called for social and economic involvement in the society, strict observance of rituals, expansion of literacy, and caution with regard to miracles. Moreover, jadids were not the representatives of the secular eighteenth-century European enlightenment. In particular, 
they did not subject miracles to historical or scientific analysis. They did challenge the authenticity and worship of some anonymous saints' tombs, which had constituted an important religious network for future converts, but they rarely challenged miracles outright, partly because miracles were one of the attributes of Islamic prophets. If displaced at school, Sufi traditional textbooks, which were under attack by Russian missionaries, could still be read at home, chanted as munajat in school choirs, or studied as ancient Turkic literature. Furthermore, not all reformers called for a relaxation of rituals. Thus Sufism, as reflected in the old school books, and jadidism had more in common than usually suggested in Tatar or even Western historiography. Neither the modernists, such as Fäkhr ad-Din, nor the authors of prejadid books contended that believers should neglect Islamic rituals in the name of spirituality. Instead, they all held that Islamic rituals were an organic part of Islamic spirituality and intellectual life. This ultimately explains the penetration of jadid forms of literacy in many villages in the Middle Volga. Even apostate villages of Mamadysh were exposed to some form of jadid elementary literacy. Acceptance of new forms of knowledge, however, did not mean radical substitution of older patterns of learning, which were still at work throughout the Soviet period. According to zemstvo reports in Ufa and Kazan provinces, Tatar maktabs used both traditional books and jadid readers at the elementary level. It was up to the teachers and later to the students to pick what they deemed useful in jadid religious books.

After the 1917 revolutions, Kräshens attempted to defend their separate identity, but later in the 1930s the divide between Kräshens and Tatars disappeared on paper. Starting in February 1917, Kräshens avoided associating themselves with Tatar political associations, which to their view were too Muslim in orientation, and formed alliances with other baptized non-Russian indigenous communities. They created the Society of the Small Peoples of the Volga Region to reiterate their prerevolutionary demand for the promotion of indigenous priests in non-Russian parishes and even indigenous bishops for each ethnic group. Kräshen intellectuals, in particular the publishers of a new journal Kriashen Gazite (May 1917) - Ivan Mikheev (1872-1937) and Nikolai Egorov (1870-1922) — strove for the recognition of a separate "Kräshen nation" and the creation of an autonomous Kräshen republic inside the projected Idel-Ural State (formed on 19 November 1917). They obtained the creation of a traveling Kräshen theater, the opening of Kräshen sections at the Oriental Conservatory and the musical school, and the transformation in 1922 of the former Kazan Central Baptized-Tatar School into a Kräshen pedagogical technical school (Kriashpedtekhnikum). The Bolsheviks were willing to promote national status for all minorities in order to consolidate their power, but the Kräshens' case posed a hurdle as Orthodoxy and prerevolutionary missionary work had been instrumental in shaping elements of their identity. To the amazement of many Kräshen leaders who supported the teaching of religion in schools to avoid the further Tatarization (Islamization) of Kräshens in mixed villages, a younger generation of Kräshen communists rejected religion as an identity marker for their community, advocating Kräshen particularity based on their community's unique historical development, material culture, and alphabet. In 1922, local communists went further than these young Kräshen communists and denied Kräshens the status of a separate nation on the grounds that the Kräshen community was a product of Russification policies. Kräshens were merged with the Tatar 
nation, a new secularized entity. As a result, in the 1930s, they lost the privilege of having their own newspaper, technical school, and theater. The 1926 census still registered Kräshens under their "national" name, but the next censuses classified them as Tatars. Historiographically, a new search for "pagan" and "Turkic" common roots began. In this context, popular expressions of Islamic and Christian devotion were to be understood as remnants of a distant "pagan" past common to Kräshens and Muslim Tatars. ${ }^{1}$

In the countryside, however, despite the antireligious campaigns of the early $1930 \mathrm{~s}$ that resulted in the destruction of Kräshen churches by Tatars and Tatar mosques by Kräshens, religion continued to serve as an essential identity marker in both communities. In Chura, a persistent legend claims that when Tatars destroyed the church bell tower, the Gospel miraculously flew away and the desecrators died mysteriously. During the relatively more religiously tolerant period of World War II, when Josef Stalin sought to gain the support of the entire population against a common enemy, the Kräshens of Chura, Staryi Karabaian, Ianyli, and Nalim painted their own icons and kept them in full view, copied portions of the Liturgy in their diaries and recited them at home, and diligently taught their children basic prayers privately-a practice they continued to the present day. Kräshens celebrated Eastern Orthodox festivals, even sharing Easter eggs with their Muslim neighbors who descended from apostates. Reciprocally, descendants of apostates invited Kräshens to their holiday celebrations. ${ }^{2}$

During the Soviet period, many of the descendants of apostates reverted to the clandestine religious practices of their ancestors. They relied on the elders' knowledge of prayers, visited sacred tombs and springs, and buried their dead in Muslim ground. Because World War II took the lives of many men, the transmission of Islamic knowledge and in particular of the munajat fell mainly on women. As in the past, girls kept diaries of their favorite prayers, spiritual songs, and epics, first in Arabic script, then in the Latin and Cyrillic alphabets; they shared their notes with other girls who added their favorite poems to what was already written. One such epic told the story of a mullah who went astray and sold his daughter, Zölkhäbirä, to a pope in a card game. The young girl, now condemned to wear a small copper cross, longed for her Qur'an and Muslim books. Such epics expressed the girls' commitment to their religious identity despite the Soviet state's anticlerical policies. More important, these diaries served as the foundational source for the girls' chants during the month of Ramadan, on the Prophet's birthday, or at wakes memorializing the dead. The Muslim children of Ianyli, all descendants of apostates, observed Ramadan scrupulously and defied their Tatar atheist teachers who came from outside the region and ordered them to

1. Werth, "From 'Pagan' Muslims to 'Baptized' Communists," 508-523; A. V. Fokin, "Kriashenskii vopros v Tatarstane: Etnoistoricheskii obzor," in Sovremennoe kriashenovedenie: Sostoianie, perspektivy (Materialy nauchnoi konferentsii, sostoiavsheisia 23 aprelia 2005 v g. Kazani) (Kazan, 2005), 90-92.

2. Field notes, Staryi Karabaian, June 2000; Tat'iana Pavlova (from Nalim village), interview by author, March 2008, Tikhvin church, Kazan; Anatolii Nikolaevich Afanas'ev (director of Chura public school) and Andrei Nikolaevich Afanas'ev (both came from a priestly family repressed in the 1930s), interview by author, 12 May 2008, Chura; Andrei Fedrov, Nastia Grigor'eva, Räshidä Il'yäsova, Nail Khismätov, Anastasiia Kirilova, and Petr Stepanov, interviews by author, May 2008, Ianyli. Ibn Taymiyya condemned the participation of Muslims in Christian festivals, Jacques Waardenburg, "Official and Popular Religion as a Problem in Islamic Studies," in Official and Popular Religion: Analysis of a Theme for Religious Studies, ed. Pieter Henrik Vrijhof and Jacques Waardenburg (The Hague, 1979), 340. 
drink water. Christians also resisted pressure to abandon their faith: in Nalim village, the daughter of a former Kräshen priest refused to throw away her cross and for this was expelled from school. Although on paper Kräshens had merged into the Tatar nation, they continued burying their dead in separate cemeteries. ${ }^{3}$

In the 1930s, collectivization accelerated earlier trends of Islamization and Christianization in the Kukmor and Teliache regions (formerly Mamadysh district). On the one hand, Chura, which formed a collective farm with other Kräshen and Udmurt villages, grew to be a stronghold of Kräshen identity with only one Tatar family as of 2008. ${ }^{4}$ On the other hand, neighboring Ianyli, which had partially apostatized in 1883 and 1905 but was the target of constant Eastern Orthodox missionary activity, became a strong bastion of Islam after being absorbed by Vakhitovo, a large Tatar village, also the center of an important collective farm. ${ }^{5}$ Whereas Chura church, restored in the years following perestroika, is now open for the Sunday Divine Liturgy, the beautiful prerevolutionary wooden church of Ianyli-built in 1907 and named after the apostles Peter and Paul-functions only for funerals and memorials. ${ }^{6}$ There are still a few Kräshens in Ianyli, but they are all elderly; their grandchildren all identify with Islam. Whereas the school museum of Chura exhibits traditional Kräshen dresses and artifacts, Ianyli's includes only Tatar feminine outfits, qomghans for Islamic ablutions, and a shäjärä (genealogy) with purely Muslim names. With Ianyli's inclusion into the Tatar Vakhitovo collective farm, earlier marital networks, which survived in Chura, broke down. Whereas parents in the past had arranged marriages according to the degree of attachment of their future daughter-in-law's village or family to Islam or Christianity, the younger generation came to form new marital alliances with their parents' tacit agreement, after attending the same schools and working together at the farm. ${ }^{7}$ As for Elyshevo, the last Kräshen family, all descendants of Kondratii Filippov, left during the famine of the 1920s. Although officially part of the Tatar ethnos, the remaining inhabitants continued marrying within their prerevolutionary apostate

3. Tat'iana Pavlova (from Nalim village), interview by author, April 2008, Tikhvin church, Kazan; diaries of Märyäm Yaghqub qizï Shärifullina, born in Elyshevo, property of Gölsinä Khämidullina. In her notebooks (ca. 1948), Märyäm transliterated sections of the eighteenth-century primer Sharā'it al-İmān into Cyrillic and copied epics whose main characters were women. Zölkhäbirä was one of them.

4. Chura was the church where the Kräshen poet Iakov Emel'ianov, former student of Il'minskii and Timofeev, served as a priest. In a letter to Il'minskii, Emel'ianov wrote of his efforts to bring the old converts of Ianyli back to Orthodoxy. NART, f. 968, op. 1, d. 105, 11. 23-24 ob.

5. The Brotherhood of St. Gurii opened a school in Ianyli (also called Novaia Semen-Golovina) in 1872. Narodnye uchilishcha $v$ Kazanskoi gubernii ... Mamadyshskii uezd, 77.

6. Otchet o deiatel'nosti Bratstva Sv. Guriia za semnadtsatyi bratskii god, 19; "Otchet po obozreniiu khramov i shkol v selakh Kazanskogo, Laishevskogo i Mamadyshskogo uezdov s 15-25 noiabria vkliuchitel'no, proizvedennomu vikariem Kazanskoi eparkhii Aleksiem episkopom Chistopol'skim-15 noiabria," IKE, no. 12 (22 March 1906): 392; Iakov Koblov, “Torzhestvo osviashcheniia khramov v sele Apazove Kazanskogo uezda i der. Ianyliakh Mamadyshskogo uezda," IKE, no. 6 (8 February 1908): 194-195.

7. Currently Kräshen leaders worry that the further consolidation of villages through land reform will lead to the disappearance of more Kräshen villages. A new challenge awaits the Kräshens of Chura who, in 2008, have been attached to the same Vakhitovo kolkhoz, which was partly responsible for the Islamization of the Kräshen community of Ianyli. Anna Egorovna Alekseeva, Anna Terenteevna Alekseeva, Zoia Mikhailovna Egorova, Anastasiia Nikolaevna Tukacheva, interviews by author, 12 May 2008, Chura; Liudmila Muliukova (vice-director), Aysïlu Khismätova (Tatar language teacher), interviews by author, 13 May 2008, Public School of Ianyli. 
network well into the Soviet period, still experiencing discrimination from the neighboring Tatar village of Shittsy, center of their collective farm. ${ }^{8}$

After perestroika the Tatar community faced new challenges to the maintenance of its communal cohesiveness and new threats of apostasy. Freedom of religion brought new choices. Some Tatars showed responsiveness to other nontraditional creeds, in particular Evangelical Christianity brought by Western missionaries, the Hare Krishna movement, and alternate forms of Islam. Unexpectedly the Kräshens reasserted their separate identity in 1989, organized ethnographic conferences and unions in Kazan and Naberezhnye Chelny, and in 1992 asked for government funding for their religious and cultural needs, including the Kräshen newspapers, schools, theater, and churches closed in the 1920 s and $1930{ }^{9}{ }^{9}$ The Kräshens also demanded their inclusion as a separate group from the Tatars in the 2002 census to facilitate their access to state funds. Tatar nationalists regarded these demands as an attempt by Moscow to divide the Tatar ethnos and reconsider the sovereign status of Tatarstan; they feared that if the percentage of Tatars in Tatarstan fell below 50 percent, the Tatars could lose their political leadership..$^{10}$ Another challenge for the Tatars came from foreign Muslim missionaries who brought petrodollars from Saudi Arabia to rebuild Tatarstan's Islamic infrastructure, but who questioned the Islamic character of Tatar practices - in particular the very rituals that had served to spread and consolidate Islam among the apostates of Imperial Russia. Wahhabi Saudis condemned prayers to the Prophet and the saints, visits to local shrines, votive rituals, commemorative ceremonies for dead relatives, celebration of the Prophet's birthday, amulets, music, dance, and songs, and participation in Christian holidays. Such condemnations echoed earlier Russian missionary attacks on thaumaturgical Islam. All these new challenges prompted the reactivation of older myths that solidified community, in particular the forced Christianization of Tatars by Ivan the Terrible and the struggle of the baptized apostates for the recognition of their true faith. ${ }^{11}$

8. Field notes, Elyshevo, 1996 and 2008. Brides, during the Soviet period, came overwhelmingly from starokreshchenye villages. Novaia (Yanga), Kibech', Kibiak-Kozi (Kibä-Khuja), Bol'shie Savrushi (Sawrïsh), Sosnovyi Mys (Jänäy), Saltygan Kliuch (Köyek; because of land redistribution, this village no longer exists), Tri Sosny (now part of Staraia Ikshurma), and Ianyli. Except for Kibech' these villages are all currently Muslim. Other brides came from the Kukmor area.

9. Kräshens currently maintain a Web site (http://kryashen.ru) and publish two newspapers in "Kräshen language": Keräshen süze (The Kräshen Word) and Tughanaylar (Countrymen) in Naberezhnye Chelny, which include reprints of Il'minskii's translations of sacred texts. Another interesting review, ANKO (Aktual'noe Natsional'no-Kul'turnoe obozrenie), contains articles about Finno-Ugric and Turkic minorities living in Tatarstan. Addresses of restored contemporary Kräshen churches are available on the Kazan diocesan site, http://kazan.eparhia.ru.

10. According to the 1926 census, the Kräshens, numbering 99,000, constituted 7.8 percent of the Tatar population of the Tatar Autonomous Republic. D. M. Iskhakov and R. N. Musina, eds., Sovremennye mezhnatsional'nye protsessy v TSSR: Programma issledovaniia $i$ instrumentarii (Kazan, 1991), 61; Fokin, “Kriashenskii vopros," 94-100; Dmitry Gorenburg, “Tatar Identity: A United, Indivisible Nation?” (Harvard University, 19 July 2004), 1-31, http://www.people.fas.harvard.edu/ " gorenbur/gorenburg\%2otatar\%20 identity.pdf (accessed 24 May 2009); Liudmila Belousova, "Kereshen: Pravo na samobytnost'," Tatarskii mir, no. 6 (2003) in http://www.tatmir.ru/article.shtml?article=47 (accessed 25 May 2009).

11. In the 1990s, a number of historical novels decried the Tatars' forced Christianization and celebrated national Tatar resistance: Ilghaz Wahap Näwrüzkhan, Söyembikä (Challï, 1992); Jämit Räkhimov, Batïrsha (Kazan, 1994) on the Bashkir-Tatar rebellion of 1755; Wakhit Imamov, Säyet batïr (Yar-Challi, 1994) on an earlier rebellion in 1704-1722. See also Zölfät Khäkim, Äwliyä qabere (Qïyssa) (1989-1994) in 
Vehemently hostile to the Kräshens' reassertion of separate identity, the youth journal Idel published excerpts from the Orthodox missionary Malov's diaries and a very suggestive cartoon of a young Tatar adolescent in traditional costume, wearing the traditional Muslim skullcap, crucified on the cross. An article in the same journal held Kräshens responsible for the fall of Kazan, suggesting that they should be ashamed of their origins and "return" to Islam. ${ }^{12}$ Under the direction of Wäliulla Yaghqubov (1963-2012), the publishing house Iman (Faith) published Tatar translations of Malov's diaries in its yearly Islamic calendar. ${ }^{13}$ In addition to promoting an interpretation of the apostasies as the return of an oppressed people to their original faith, Iman also favored prejadid religious literature. In particular Yaghqubov adopted its conceptions of the afterlife with its strong emphasis on collective responsibility for the salvation of family and neighbors over the jadids' emphasis on personal responsibility for one's salvation. Jadid criticisms of popular Islam sounded too much like the attacks formulated by Saudi missionaries. But even secularized Tatars who rarely set foot in the mosque or prayed at home associated Islam with the gathering of elderly women chanting the munajat for religious festivals, visiting sacred tombs, the healing properties of sacred springs, and repasts memorializing the dead. ${ }^{14}$

By reprinting ancient Sufi literature and munajat as conduits for re-Islamization of the Tatar population and repositories of forgotten Tatar words of Farsi and Arabic origin, Yaghqubov emphasized the continuity between pre-Soviet past and the present. The ancient story of Joseph and Zulaykha, which offered models of action and resistance in an environment hostile to the expansion of Islam, continues to represent symbolic resources from which contemporary Tatars may redraw their image as a "national" Muslim community separate from Eastern Orthodox Russians. Imams still use the tale to reintroduce both sexes to their obligations as missionaries of Islam. They call their flock to follow the example of Joseph who never ceased to witness for his faith, even in prison and to imitate Potiphar's wife who was once pagan but then repented; thus Tatars should spread their faith in all secular spaces and reject atheism

Saylanma äsärlär, vol. 2 (Kazan, 1997), 67-125. In his tale, Ivan the Terrible forcefully baptized Söläyman, a Tatar who defended Kazan in 1552. Despite being rejected by his own countrymen, Söläyman remained faithful to Islam, carrying Islamic books in his bags. After his death, his tomb became the focus of a holy pilgrimage. In the 1990 os the Tatarstan Ministry of Education actively promoted these novels by providing pedagogical guides to help teachers use them in the classroom. Khatïyp Mingneghulov and Shäykhelislam Sadretdinov, Urta ghasïr ham XIX yöz tatar ädäbiyatï (Kazan, 1998), 44, 124, 169,174 .

12. Fanis Baltach, “Gordit'sia ili stydit'sia dolzhny kriasheny?” Idel, nos. 5-6 (1994): 61-66. Excerpts from Malov's diaries were published in Tatar in the religious calendar, Möselman jädwäle, 1414-1415, Tatar kalendare 1994 (Kazan, 1994), composed and edited by Shäekh Zäbirov and Fäniyä Khujakhmät, and in the youth journal Idel, nos. 5, 6, 7, 8 (1993) and 6 and 9 (1994). See also "Evfimii Malov: Sezdän iman, bezdän imana!" Idel, no. 1 (1996): 6o. The cartoon was published in “Bezdän imana, sezdän iman," Idel, no. 5 (May 1993): 71.

13. Yaghqubov (Iakupov in Russian), former chief assistant of the Mufti at the Muslim Religious Board of Kazan, was killed in July 2012. Andrew Roth, “Two Muslim Officials Attacked in Southern Russia," New York Times, 19 July 2012.

14. A. Timerghalin, "Ruslashtïru häm chuqündïru tarikhïnnan säkhifälär," Iman nurï (Islam zhurnalï), no. 3 (1995): 16-29. 
and consumerism for a sharia-based life. ${ }^{15}$ Iskhaqi's Zöläykha, an apostate reincarnation of Joseph's Zulaykha, has also reemerged as a powerful symbol of national and religious resistance to spiritual Russification, and as a means to reintroduce the idea that a Tatar can be only Muslim and a Russian only Orthodox. Censored in the $1920 \mathrm{~s}$ for its religious content and anti-Russian rhetoric, Iskhaqii's play has been made into a film by Ramil Tukhvatullin sponsored by the Republic of Tatarstan and distributed by mosque and madrasa vendors. Shown for the first time in 2005, the film opened with a discussion between Il'minskii and Malov plotting for the Russification and total annihilation of the Tatar people, anachronistically linking the horrifying fate of Zulaykha with Il'minskii and Malov. ${ }^{16}$

The play has also become part of the Tatarstan public school curriculum, along with samples of Sufi literature. ${ }^{17}$ Whereas Tatar teachers welcome the return of their national ancient and jadid literatures, Kräshen teachers find the reading of Tatar Sufi literature and the learning of the Arabic alphabet a challenge for their students because, as they confided to me, Islamic culture is alien to them and their language is devoid of Arabic and Farsi loanwords. Nevertheless Kräshen teachers take the opportunity to emphasize the religious differences between Orthodoxy and Islam. When the time comes to read the story of apostate Zöläykha, these Christian teachers inform students of their true origin: the Kräshen people descended from Turkic peoples who accepted baptism well before Ivan the Terrible at the time of the Bolghar kingdom and the Golden Horde. Contrary to Islam, Christianity of the Greek faith allowed Russians, Chuvash, Maris, Udmurts, and Kräshens to preserve their native customs. As for Kräshen historians and activists, they concentrate their efforts on the search for their complex origins, the rehabilitation of Il'minskii, the discovery of Kräshen agency in Il'minskii's pedagogical reforms, the search for Kräshen role models for the next generation, and evidence of their struggle against Russification after the death of Il'minskii when his system of native instruction came under attack. They look into the histories of their villages and seek to preserve the songs and dances of their elders. To the credit of the Tatarstan Ministry of Education, Kräshen and Tatar children can now read samples of Iakov Emel'ianov's poems and get acquainted with the Kräshens' unique culture and history in some of the textbooks used in the

15. See reprints of the tale in modern Tatar illustrated by Ildar Äkhmädiev in the children's journal, Salawat küpere, no. 3 (May 1990): 9-10 (“Qol Ghali, Yosïf Kitabï”); “Qïyssai Yosïf”, opera based on Qol 'Ali's epic directed by K. Bikmökhämmätov, Tatarstan TV, 1996; Leonid Liubovskii (composer) and Renat Kharis (poet and librettist), Skazanie o Iusufe, ballet in three acts first staged at the Kazan Theater named after M. Dzhalil' in 2003; Ramil Khäzrät Yunïs, Qur'anic readings, chapter 12, Qol Shärif mosque, Kazan Kremlin, 17 and 24 April 2008 (author's field notes); Pokornaia Bogu ili poslushnaia d'iavolu (Moscow, 2008), 108-122.

16. Ramil' Tukhvatullin (director and producer), Zuleikha. Collection of historical films on DVD distributed by Firdaus Studio; Entsiklopediia Islam v sovremennoi Rossii (Moscow, 2008), 127.

17. Tatar mäktäplärendä Tatar ädäbiyatïnnan belem birü standartï (Kazan, 2004); Tatar urta mäktäpläre öchen ädäbiyat programmalarï 5-11 sïynïflar (Tatarstan Respublikasï Mägharif häm fän ministrilighi tarafinnan raslanghan) (Kazan, 2005); Kh. Y. Mingneghulov and N. S. Ghïymadieva, Tatar ädäbiyati (Rus telendä urta ghomumi belem birüche mäktäpneng 10-nchï sïynïfi öchen däreslek-khrestomatiya (Tatar balalarï öchen) (Kazan, 2006), 3-90; Sämigha Säwbanova, Bügen bäyräm, bügen tuy: Mäktäp uquchïlarï, uqïtuchülar, ata-analar häm mädäni-aghartu uchrezhdenieläre öchen bäyräm kichäläre ütkärü ürnäkläre tuplanghan däreslek-qullanma (Kazan, 2005), 21-47. 
republic's schools. ${ }^{18}$ At the same time, while Russian Orthodox priests preach on TV at major festivals, Kräshen priests are still barred from the opportunity to share the "good news" in what they call their Kräshen language. More troublesome is the antiKräshen rhetoric of the ultranationalist writer, Fäwziyä Bäyrämova (b. 1950), who associates Kräshen Christianity with sorcery. ${ }^{19}$

From the mid-nineteenth century on, female religious specialists, Sufi imams, Eastern Orthodox missionaries, state bureaucrats, Muslim reformists, local Russian notables, humble villagers, Soviet communists, and Tatar post-Soviet politicians have clashed as they sought to fashion new collective identities for the peoples of the Middle Volga. Culture with its myths and symbols has persisted throughout the Soviet period and still constitutes an important source of imaginary power for both Kräshens and Tatars. If Tatars were quick to revive their visits to the sacred ruins of Bolghar, the Kräshens took the same route to pray at the site where their Turkic saint, Avraamii, was martyred. To my remark that some prominent Tatar figures declared that Kräshens should return to the faith of their ancestors, an elderly Kräshen woman answered that no one had forced her to be Orthodox, that Orthodoxy did not belong to Russians alone but belonged to all people, and that in biblical times, when God destroyed the Babel tower and scattered all nations, Kräshens, Maris, Chuvash, Udmurts, Russians were present, but not the Tatars. In other words, because the Tatars did not originate in biblical times, they could not be part of God's plan to save humanity. Her story echoed earlier nineteenth-century tales of the prophets, which served to defend Islam or solidify Christianity among the baptized Tatars. Another prominent eighty-year-old Kräshen woman who saw an apostle in a dream claimed that her prerevolutionary books (including stories about the eschatological toll gates and the superiority of Christianity over Islam) miraculously escaped a fire. Similar stories about the Qur'an circulate among female students of the Möhämmädiyä madrasa in Kazan. ${ }^{20}$

Contemporary analysts have focused their energies on counting the number of mosques and churches, checking church or mosque attendance, or delving into church and mosque politics to measure the population's level of commitment to religion, which often led to conclusions that religion was a veneer or a temporary fad. However, nothing has been written on the reappropriation by Tatars and Kräshens of their prerevolutionary religious literature, myths, and sacred spaces in a largely

18. Field notes (interviews by author of Galina Pavlovna Azina, Marina Vasil'evna Igushina, and Anatolii Nikolaevich Afanas'ev), Chura, May 2008. Teachers turn to the history of the Kräshen people (Sud'ba gvardeitsev Seiumbeki) as interpreted by Maksim Glukhov-Nogaibek who views Kräshens as the very first Christians of Eastern Europe. They have also created their own textbook of Kräshen songs: Keräshen jïru äytä (Challi, 1999). Finally, Kräshen children can read Emel'ianov's poems in a ninth-grade anthology Tatar ädäbiyatïnnan khrestomatiia (Borïnghï häm urta ghasïr, XIX yöz ädäbiyatï) (Kazan, 2000), 290-293. The editors, however, exclude the priest's controversial poem about the awakening of the Kräshen people and overemphasize his dependence on Russian writers.

19. Gennadii Makarov, "Perspektivy razvitiia traditsionnoi kul'tury Kriashen v sovremennykh usloviiakh," 39-40; Fäwziyä Bäyrämova, Songghï namaz (2000), in Qïrï sïrt: Romannar (Kazan, 2005), 654-656.

20. For a critique of the Tatar press, see T. G. Dunaeva, "Sovremennoe polozhenie kriashen Tatarstana: Analiticheskaia informatsiia respublikanskoi pechati za poslednee desiatiletie," http://kryashen.ru/index5. php?link=5 (accessed 17 May 2009); field notes, Tikhvin church and Möhämmädiyä madrasa, Kazan, April 2008; M. Martïnova, “Ul töshendä Apostolnï kürgän,” Tughanaylar (31 January 2008), 5. 
secular environment. The Russian conquest, the physical ruins of the Bolghar and Kazan pasts, the "forced" Christianization of the Tatars, the nineteenth-century apostasy movements, and the prerevolutionary religious literature constitute important clusters of memory that both religious and secular teachers seek to reactivate in order to solidify communal boundaries, first shattered by the Russian conquest, then by the Revolution, and today by globalization. 


\section{Selected Bibliography}

\section{Archival Sources}

Gosudarstvennyi Arkhiv Orenburgskoi Oblasti (GAOO), Orenburg

Fond 44 Orenburgskaia Uezdnaia Zemskaia Uprava

Fond 55 Orenburgskaia Palata Ugolovnogo i Grazhdanskogo Suda

Narodnyi Arkhiv Respubliki Tatarstan (NART), Kazan

Fond 1 Kantseliariia Kazanskogo Gubernatora

Fond 2 Kazanskoe Gubernskoe Pravlenie

Fond 4 Kazanskaia Dukhovnaia Konsistoriia

Fond 10 Kazanskaia Dukhovnaia Akademiia

Fond 13 Kazanskaia Palata Ugolovnogo Suda

Fond 93 Kazanskaia Uchitel'skaia Seminariia

Fond 967 M. A. Mashanov

Fond 968 Kazanskii Professor-Orientalist N. I. Il'minskii

Otdel Rukopisei Instituta Iazyka, Literatury i Istorii Akademii Nauk Tatarstana, Kazan

Fond 56 Evfimii Aleksandrovich Malov

Otdel Rukopisei Kazanskoi Nauchnoi Biblioteki im. N. I. Lobachevskogo, Kazan

Fond 7 Evfimii Aleksandrovich Malov

Rossiiskii Gosudarstvennyi Istoricheskii Arkhiv (RGIA), SPb.

Fond 383 Pervyi Departament Ministerstva Gosudarstvennykh Imushchestv

Fond 733 Departament Narodnogo Prosveshcheniia Ministerstva Narodnogo Prosveshcheniia

Fond 821 Departament Dukhovnykh Del Inostrannykh Ispovedanii Ministerstva Vnutrennikh Del

\section{Personal Archives}

"Ghabdräkhim Ghabdrakhman ughlï Wälidovnïng tereklektäge khäle häm Qarghala tarikhï," unpublished manuscript (Kargala, 1924) transliterated in the Cyrillic alphabet by Mädinä Räkhimqulova.

“Ismäghïyl bäyete." Epic song performed by Ghajilä Khanova, 18 November 1947. Copy typed 22 June 1991. Gölsinä Khämidullina’s private collection in Elyshevo.

"Keche Chura." Memoirs collected by the head of the after-school Kräshen program of Chura High School, Galina Azina, n.d.

Women's diaries, pictures, talismans. Gölsinä Khämidullina’s private collection in Elyshevo.

\section{Printed Tatar Sources}

Äḥmärof, 'Ayn ad-Dīn. "Mükrehlär hạāendän.” Qazān Mokhbire (Kazanskii Vestnik), no. 78 (May 1906).

Ämirkhan, Fatikh. Äsärlär, 4 vols. Kazan, 1984-1986. 
—. Fätkhulla khäzrät. In Äsärlär, 2: 7-118. Kazan, 1985.

—. Izbrannoe (Rasskazy i povesti). Trans. G. Khantemirova. Moscow, 1975.

Aqchura, Yosïf. Damella Ghalimjan äl-Barudi. Kazan, 1997.

Bädäwām kitābï. Kazan, 1861.

Bāqürghān kitābï. Kazan, 1904.

Al-Bārūdī, 'Ālimjān. Tārìkh-i änbiyā'. Kazan,1899.

Dớa-yi ism-i äzam wä häm bashqa shärîf doálar. Kazan, 1898.

Fäkhretdin, Rizaetdin (Riżāa ad-Dīn b. Fäkhr ad-Dīn.) 'Áìlä. Orenburg, 1902.

—. Āsār. Orenburg, 1903, 1907-1908.

—. Dìn̄̄ wä ijtimā'ì mäs'älälär. Orenburg, 1914.

—. Jäwāmi al-kälim shärhe. Orenburg, 1917.

—. Shākirdlek ādābe. Kazan, 1899.

—. Tärbìäle ana. Kazan, 1898.

—. Tärbìyäle khātūn. Kazan, 1899.

—. Tärjemäi khälem (Ufa, 1905). In Rizaetdin Fäkhretdin: Fänni-biografik jüyïntïq, 7-38. Kazan, 1999.

Fäkhreddinev, Rizaeddin. Bolghar wä Qazan Törekläre. Kazan, 1993.

Fäżäil ash-shühūr. Kazan, 1869.

Gasprinskii, Ismail bey. Mebadi-yi temeddün-i Islamiyan-i Rus. Trans. Edward J. Lazzerini. In "Ğadidism at the Turn of the Twentieth Century: A View from Within." Cahiers du Monde russe et soviétique 16, no. 2 (April-June 1975): 245-277.

Ghabderäkhim Utïz Imäni äl-Bolghari, Shighïr'lär, poemalar. Kazan, 1986.

Häżrät-i Märyäm rażì Allah ta'ālà 'anhā. Kazan, 1909.

Husām ad-Dīn b. Shäraf ad-Dīn al-Bolghārī. Risālä-yi täwārīkh-i bolghāriyya wä zikr-i

Mäwlānā Häżrät-i Āqsāq Timur wä khärāb-i shähr-i Bolghār. Kazan, 1887.

Iskhaqïy, Ghayaz. Ike yöz yïldan song inqüyraz. Reprinted in Qazan utlarï 807, no. 1 (1990): 110-142; 808, no. 2 (1990): 109-148.

—. Zöläykha (1918). Reprinted in Zindan: Saylanma proza häm säkhnä äsärläre.

Pp. 515-586. Kazan, 1991.

Isliam dini. Musul'manlar echen tieshli bulgan eshliar: Iman, namaz, ruza, zakiat, khadzh shikel'li niastialiar. Kazan, 1906.

Jìūn qüsșasï (1881). In N. Katanov, Materialy k izucheniiu kazansko-tatarskogo narechiia. Pt. 1, pp. 82-92. Kazan, 1898.

Kärīm, K. “Köchläb chuqïrïndïrïlghan tatarlar Kräshenlär tārīkhïna ‘ảid.” Shūrā, no. 19 (Nov. 1917).

Kärīmof, Fātiḥ. Tārīkh-i änbiyā'. Orenburg, 1911.

Kisekbash kitäbï. Kazan, 1846.

Kitāb 'izzät màāb näșìhät aṣ-șālihīn. Kazan, 1908.

Kitāb-i qïsșa-yi Häżrät-i Yūsuf an-nabì 'alayhi as-salām. Kazan, 1880.

Marjānī, Shihāb ad-Dīn b. Bahā’ ad-Dīn. Mustafād al-akhbār fì aḥwāl Qazān wa Bulghār. Vol. 1. Kazan, 1897. Vol. 2. Kazan, 1900.

Qïṣaṣ-i Rabghūzī. Kazan, 1859.

Al-Rabghūzī. The Stories of the Prophets: Qiṣaṣ al-Anbiyā', an Eastern Turkish Version. Vol. 1, ed. H. E. Boeschoten, N. Vandamme, and S. Tezcan. Vol. 2, trans.

H. E. Boeschoten, J. O’Kane, and M. Vandamme. Leiden, New York, and Köln, 1995.

Risālä-yi nurnāmä. Kazan, 1910.

Sharäit al-īmān. Kazan, 1904.

Tatar khaliq ijatï. Riwayätlär häm legendalar. Kazan, 1987.

Tuqay, 'Abdullāh. Isemdä qalghanlar. Kazan, 1909.

Yālchïghol, Tāj ad-Dīn. Risālä-yi 'Azīzä. Shärḥ Sabāt al-'Ájizīn. Kazan, 1905. 


\section{Printed Russian and Kräshen Sources}

Akafist sviatiteliu Guriiu Kazanskomu i Sviiazhskomu chudotvortsu na tatarskom iazyke. Kazan, 1890.

Akhmerov, P. N., and E. A. Malov. Sviatyi muchenik Avraamii Bolgarskii (Bu kitāb shähär Bulghārda shähīd bulghan 'Isawī Abrāhāmi wälī tughrïsïndadïr). Kazan, 1898.

Anastasiev, A. I. Narodnaia shkola; rukovodstvo dlia uchitelei i uchitel'nits nachal'nykh narodnykh uchilishch: Nastol'naia spravochnaia kniga. 2 vols. Moscow, 1910.

Andrei, and N. V. Nikol'skii, eds. Naibolee vazhnye statisticheskie svedeniia ob inorodtsakh vostochnoi Rossii i zapadnoi Sibiri, podverzhennykh vliianiu islamu. Kazan, 1912.

Apakov, Mikhail. "Missionerskie besedy s kreshchenymi i nekreshchenymi tatarami i votiakami Kazanskogo kraia.” IKE, no. 13 (1 July 1881): 330-343.

—. Rasskazy kreshchenykh dereven' Tavelei i Alekseevskogo vyselka Iamashevskogo prikhoda, Chistopol'skogo uezda, o proiskhozhdenii kiremetei. Kazan, 1876.

Babai, Iapei (pseud. E. A. Malov), "O kreshchenykh tatar (iz missionerskogo dnevnika)." IKE 25, nos. 18-20 (1891): 555-576, 596-606, 618-640.

Bagin, S. A. "Musul'manskie poniatia o rae." PB 23, nos. 5-6 (May-June 1915): 208-213.

_. "Ob otpadenii v magometanstvo kreshchenykh inorodtsev Kazanskoi eparkhii i o prichine etogo pechal'nogo iavleniia." PS 46 (Jan. 1910): 118-127; (Feb. 1910): 225-236; (Mar. 1910): 391-401.

—. “Tatarsko-musul'manskaia pechat'” PS 47 (Apr. 1911): 531-545.

Baiazitov, Ataulla. Otnoshenie islama $k$ nauke i k inovertsam. SPb., 1906.

Bálint, Gábor. Kazáni-Tatár Nyelvtanulmányok: Kazáni-Tatár Szövegek és Forditás. Vol. 1. Budapest, 1875 .

Bobrovnikov, N. A. Inorodcheskoe naselenie Kazanskoi gubernii. Vol. 1, Tatary, votiaki, mordva. Kazan, 1899.

—. Nuzhny li tak nazyvaemye protivomusul'manskie i protivoiazycheskie eparkhial'nye missionery v guberniiakh Evropeiskoi Rossii? (Po povodu otcheta Kazanskogo eparkhial'nogo missionera. Izv. Kaz. ep. Nos. 42-46, za 1904 g.). Kazan, 1905.

—. Shkol'naia set' Kazanskoi gubernii (proekt). Kazan, 1905.

Bobylev, Nikanor. Patriarkh Iosif po Biblii i Koranu. In MPMS. Vol. 16. Kazan, 1882.

Budilovich, A. S. Doklad predsedatelia osobogo soveshchaniia po voprosam obrazovaniia vostochnykh inorodtsev Gospodinu Ministru Narodnogo Prosveshcheniia, 15 Avg. 1905. Kazan, 1905.

_. Otchet o komandirovochnoi poezdke t. s. A. S. Budilovicha v Kazanskii, Orenburgskii i Zapadno-Sibirskii uchebnye okruga (v oktiabre, noiabre i dekabre 1904 g.). SPb., 1905.

Bukvar' dlia kreshchenykh tatar (zhazyu beldereu). Kazan, 1875 and 1882.

Bukvar', kratkaia sviashchennaia istoriia, sokrashchennyi katekhizis, nravoucheniia i molitvy, izlozheny dlia kreshchenykh iz tatar na ikh razgovornom iazyke po Bukvariu izdannomu, $v 1861$ godu, $v$ Sanktpeterburgskoi Sinodal'noi tipografii. Kazan, 1862.

Chicherina, S. U privolzhskikh inorodtsev. Putevye zametki. SPb., 1905.

"Chudotvornye i osobenno mestno chtimye ikony i krestnye khody v Kazanskoi eparkhii. V Chistopol'skom uezde." IKE, no. 11 (1 June 1872): 345-348.

Danilov, Stepan. "Vospominaniia starokreshchenogo tatarina iz ego zhizni." Strannik vol. 3, 13th year (1872): 8-31.

Emel'ianov, Ia. E. Stikhi na kreshcheno-tatarskom iazyke. Kazan, 1879 and 1888.

Eruslanov, P. "Magometanskaia propaganda sredi cheremis Ufimskoi gubernii (iz lichnykh nabliudenii)." $P B$ 3, no. 8 (1895): 422-426; no. 9: 20-27; no. 12: 181-184; no. 13: 225-227; no. 14 : 275-279; no. 16 : $382-391$; no. 18 : 82-88; no 19: 133-141; no. 21 : 220-226; no. 22 : 253-261. 
Firsov, N. Inorodcheskoe naselenie prezhnego Kazanskogo tsarstva v novoi Rossii do 1762 goda $i$ kolonizatsiia zakamskikh zemel' v eto vremia. Kazan, 1869.

Fuks, Karl. Kazanskie tatary v statisticheskom i etnograficheskom otnosheniiakh. Kazan, [1844] 1991.

Gavrilov, Boris. "Pogrebal'nye obychai i pover'ia starokreshchenykh tatar derevni Nikiforovoi Kazanskoi gubernii Mamadyshskogo uezda.” IKE 8, no. 9 (1 May 1874): 250-26o.

Ignat'ev, R. "Skazaniia, skazki i pesni, sokhranivshiesia v rukopisiakh tatarskoi pis'mennosti i v ustnykh pereskazakh u inorodtsev-magometan Orenburgskogo kraia." In Zapiski Orenburgskogo otdela Imperatorskogo russkogo geograficheskogo obshchestva. Vol. 3, pp. 183-236. Orenburg, 1875.

Il'minskii, Nikolai, ed. Kazanskaia tsentral'naia kreshcheno-tatarskaia shkola: Materialy dlia istorii khristianskogo prosveshcheniia kreshchenykh tatar. Kazan, 1887.

_. Opyty perelozheniia khristianskikh verouchitel'nykh knig na tatarskii i drugie inorodcheskie iazyki v nachale tekushchego stoletiia: Material dlia istorii pravoslavnogo russkogo missionerstva. Kazan, 1883.

- "Prakticheskie zamechaniia o perevodakh i sochinenii na inorodcheskikh iazykakh." In Nikolai Ivanovich Il'minskii: Sbornik statei po povodu 25 -letiia ego dnia konchiny $(\dagger 27$ dek. 1891 g.). Pp. 121-141. Kazan, 1916.

Iskhakov, Radik, ed. Khristianskoe prosveshchenie i religioznye dvizheniia (reislamizatsiia) kreshchenykh tatar $v$ XIX-nachale XX vv.: Sbornik materialov i dokumentov.

Kazan, 2011.

Istoricheskie svedeniia o nekotorykh shkolakh, sviashchennikakh, rukovoditeliakh i uchiteliakh Bratstva sv. Guriia. Kazan, 1892.

Istoriia Tatarii v materialakh i dokumentakh. Moscow, 1937.

Istoriko-statisticheskoe opisanie tserkvei i prikhodov Kazanskogo uezda. Vypusk III-i (AlatyIvanovskoe). Kazan, 1916.

Istoriko-statisticheskoe opisanie tserkvei i prikhodov Kazanskoi eparkhii. Vol. 6, G. Mamadysh i Mamadyshskii uezd. Kazan, 1904.

Iuzefovich, B. Khristianstvo, magometanstvo i iazychestvo $v$ vostochnykh guberniiakh Rossii. Moscow, 1883.

Ivanov, Antonii. "Magometanskie shkoly v inorodcheskikh seleniiakh." Missionerskoe obozrenie 14, no. 2 (Feb. 1909): 331.

—. "Otstupnicheskoe dvizhenie kreshchenykh i nekreshchenykh chuvash Samarskoi gubernii v magometanstvo." PB 16, no. 14 (July 1908): 249-256.

- "Otstupnicheskoe dvizhenie kreshchenykh i nekreshchenykh Chuvash Samarskoi gubernii v magometanstvo. Derevnia Alekseevka, Bugul'minskogo uezda.” PB 22, no. 1 (1914): 143-162.

— "Tsarstvo islama sredi chuvash." PB 15, no. 19 (October 1907): 104-118.

"Izvlechenie iz otcheta eparkhial'nogo inorodcheskogo missionera o sostoianii inorodcheskoi missii v Viatskoi eparkhii za 1909.” Viatskie eparkhial'nye vedomosti no. 22 (2 June 1911): 461-475.

"Iz zhizni kreshchenykh inorodtsev Kazanskogo kraia za 1887 god." IKE, no. 1 (1 Jan. 1888): 5-32.

Katanov, N. Katalog knig otpechatannykh v tipografii Imperatorskogo Kazanskogo universiteta s 1800 po 1899 god. Kazan, n.d.

-. Materialy k izucheniiu kazansko-tatarskogo narechiia. Pt. 1. Kazan, 1898.

_ . "Narodnye sposoby lecheniia u bashkir i kreshchenykh tatar Belebeevskogo uezda Ufimskoi gubernii." IOAIE 16, no. 1 (1900): 1-14. 
_. "Otchet o poezdke sovershennoi s 1 iiunia 1897 goda po 20 avgusta togo zhe goda v Belebeevskii i Menzelinskii uezdy Ufimskoi gub." Uchenye zapiski Imperatorskogo Kazanskogo universiteta 65, no. 11 (Nov. 1898): 18-33.

Kazanskaia guberniia. Spisok naselennykh mest po svedeniiam 1859 goda. SPb., 1866.

Kingiash izge zhazyuny ukyunyn paidasy turysynda (Nastavlenie o pol'ze chteniia sviashchennogo pisaniia na kriashenskom iazyke). Kazan, 1892.

Koblov, Ia. O. "Konfessional'nye shkoly Kazanskikh tatar." Inorodcheskoe Obozrenie 2, no. 1 (1915), supplement to PS (Jan.-Feb. 1917): 1-48.

—. "Mifologiia Kazanskikh tatar." Tsirkuliar po Kazanskomu uchebnomu okrugu, prilozhenie 43, no. 9 (Sept. 1909): 389-436.

—. Mifologiia Kazanskikh tatar. Kazan, 1910.

—_. "O tatarizatsii inorodtsev Privolzhskogo kraia." In Missionerskii s"ezd v gorode Kazani. 13-26 iiunia 1910 g. Pp. 351-375. Kazan, 1910.

—. "Religioznye obriady i obychai tatar magometan." IOAIE 24, no. 6 (1909): 521-564.

Maksimov, Semen. "Ostatki drevnikh narodno-tatarskikh (iazycheskikh) verovanii u nyneshnikh kreshchenykh tatar Kazanskoi gubernii." IKE 10, no. 19 (1 October 1876): 565-582; no. 20 (15 October 1876): 607-618.

Malov, Evfimii. Akhyr zaman kitaby. O konchine mira, perevod s tatarskogo (s tekstom $i$ primechaniiami). Kazan, 1897.

- Missionerstvo sredi mukhammedan i kreshchenykh tatar. Kazan, 1892.

—. Nochnoe puteshestvie Mukhameda v khram ierusalimskii i na nebo: Sochinenie Kazanskoi dukhovnoi akademii IX uchebnogo kursa (1858-1862 g.) Evfima Malova. Kazan, 1876.

—. "Nyneshnee religioznoe polozhenie kreshchenykh tatar zavolzhskogo kraia." $P O 7$ (1866): 62-83; 8 (1866): 116-128. Also printed in Strannik 7, vol 3, no. 8 (Aug. 1866): $67-86$.

—. "O Novokreshchenskoi kontore." PS 24, no. 12 (Dec. 1878): 1-208.

—. "O tatarskikh mechetiakh v Rossii." PS 13, no. 12 (Dec. 1867): 285-320; pt. 1 (1868): 3-45.

_. "Ocherk religioznogo sostoianiia kreshchenykh tatar, podvergshikhsia vliianiiu magometanstva.” PS 17, pt. 3 (1871): 234-55, 397-418; 18, pt. 1 (1872): 62-78, 124-39, 237-50, $377-405 ; 18$, pt. 2 (1872): $38-78$.

—_. "Pravoslavnaia protivomusul'manskaia missiia v Kazanskom krae v sviazi s istorieiu musul'manstva v pervoi polovine XIX veka." PS 14, pt. 2, no 7 (1868): 225-253 and no. 8: 316-342; 14, pt. 3, no. 9 (1868): 10-47 and no. 10: 135-161; 15, pt. 1 (Feb. 1869): 135-156; 16, pt. 1 (Jan.-Feb. 1870): 31-48 and 115-129; 16, pt. 2, no. 5 (May 1870): 233-260.

__. "Prikhody starokreshchenykh i novokreshchenykh tatar v Kazanskoi eparkhii." PO 6, tom 17 , no. 8 (Aug. 1865): 449-494; tom 18, no. 10 (October 1865): 283-308; tom 18, no. 12 (Dec. 1865): 477-513.

—. Prikhody starokreshchenykh i novokreshchenykh tatar v Kazanskoi eparkhii. Moscow, 1866.

__. "Statisticheskie svedeniia o kreshchenykh tatarakh Kazanskoi i nekotorykh drugikh eparkhii, v Volzhskom basseine." Uchenye zapiski Kazanskogo universiteta vol. 3 (1866): 311-320; vol. 4 (1866): 321-387. Reprinted and updated in Missionerstvo sredi mukhammedan i kreshchenykh tatar. Pp. 373-462. Kazan, 1892.

Mashanov, M. A. Religiozno-nravstvennoe sostoianie kreshchenykh tatar Kazanskoi gubernii Mamadyshskogo uezda. Kazan, 1875.

_. "Sovremennoe sostoianie tatar-mukhammedan i ikh otnoshenie k drugim inorodtsam." PS 57, no. 2 (Feb. 1911): 235-282; no. 3 (Mar. 1911): 401-414. 
_. "Zametka o religiozno-nravstvennom sostoianii kreshchenykh tatar Kazanskoi gubernii Mamadyshskogo uezda." IKE 9, no. 1 (1 Jan. 1875): 12-32; no. 2 (15 Jan. 1875): 44-64; no. 3 (1 Feb. 1875): 81-94; no. 4 (15 Feb. 1875): 113-138.

Materialy dlia sravnitel'noi otsenki zemel'nykh ugodii v uezdakh Kazanskoi gubernii. Vol. 6: Uezd Mamadyshskii. Kazan, 1888. Vol. 7: Uezd Laishevskii. Kazan, 1889.

"Materialy dlia statistiki i istorii Kazanskoi eparkhii. I. Istoricheskoe opisanie tserkvei. O sel'skikh tserkvakh i prikhodakh Kazanskoi eparkhii. I. Kazanskii uezd. 2. O sele Apazove i tserkvi vo imia Rozhdestva Bogoroditsy." IKE, no. 2 (15 Jan. 1880): 56-61.

"Materialy dlia statistiki v istorii Kazanskoi eparkhii. 1: Istoricheskoe opisanie tserkvei g. Kazani (prodolzhenie). 12: Kreshcheno-tatarskaia shkola," IKE, no. 3 (1 Feb. 1876): 87-94.

Materialy po istorii Tatarii vtoroi poloviny 19-go veka: Agrarnyi vopros i krest'ianskoe dvizhenie $v$ Tatarii XIX veka. Moscow and Leningrad, 1936.

Matveev, S. M. "Dva dnia sredi kreshschenykh i otpavshikh inorodtsev (iz dnevnika missionera)." PB 10, no. 1 (1902): 21-24; no. 2: 70-75; no. 3: 112-116; no. 4: 151-159; no. 5: 201-210; no. 6: 256-263; no. 7: 302-310.

—. "Mukhammedanskii rasskaz o Sv. Deve Marii. Tekst i perevod." IOAIE 13, no. 1 (1895): 19-34.

—. O kreshchenykh inorodtsakh Ufimskoi eparkhii. Ufa, 1910.

—. Pervye v Ufimskoi eparkhii kursy po prikhodskoi missii dlia kreshchenykh inorodtsev. Ufa, 1911.

Men'shikov, Porfirii. “Achinskii prikhod, Laishevskogo uezda, v nastoiashchem sostave," IKE no. 16 (15 Aug. 1868): 442-460.

Mikhailov, A. "Kriticheskii razbor i perevod s tatarskogo iazyka na russkii broshiury 'Rasskazy o Solomone." Orenburgskie eparkhial'nye vedomosti 17, no. 10 (15 May 1889): 280-84.

Miropol'skii, Aleksandr. "Sposob mukhammedanskoi propagandy sredi kreshchenykh tatar." IKE, nos. 5-6 (1-15 Mar. 1894): 158-162.

Missionerskii s"ezd v gorode Kazani 13-26 iiunia 1910 goda. Kazan, 1910.

Mokhammiat denenia karaganda Khristos dene artyk. Kazan, 1883.

Mozharovskii, A. F. "Izlozhenie khoda missionerskogo dela po prosveshcheniiu Kazanskikh inorodtsev s 1552 po 1867." Chteniia v imperatorskom obshchestve istorii i drevnostei rossiiskikh, bk. 1 (Mar.-Apr. 1880).

Narodnye uchilishcha $v$ Kazanskoi gubernii: Materialy dlia istorii narodnogo obrazovaniia: Laishevskii uezd. Kazan, 1887. Mamadyshskii uezd. Kazan, 1888.

Nikol'skii, N. V. Perevodcheskaia kommissiia v Kazani i ee prosvetitel'naia deiatel'nost' sredi inorodtsev. Kazan, 1905.

N. N. "Osviashchenie khrama v sele Staroi Ikshurme." IKE, no. 22 (15 Nov. 1891): 678-689.

O zagrobnoi zhizni po ucheniiu pravoslavnoi tserkvi na kreshcheno-tatarskom iazyke. (Kabergä kergännän blaigy tormosh). Kazan, 1892.

“Ob otkrytii v g. Kazani Bogosluzheniia na tatarskom iazyke." IKE, no. 2 (15 Jan. 1870): $48-55$.

Odigitrievskii, N. "Kreshchenye tatary Kazanskoi gubernii (etnograficheskii ocherk)." $P B$, bk. 1, no. 1 (Jan. 1894): 13-18; bk. 1, no. 3 (Feb. 1894): 106-112; no. 7 (Apr. 1894): 284-292; no. 11 (June 1894): 115-124; bk. 2, no. 12 (1895) 185-191; bk. 2, no. 13 (July 1895): 228-235; bk. 1 , no. 17 (Sept. 1895): 22-33.

—. Kreshchenye tatary Kazanskoi gubernii (etnograficheskii ocherk). Moscow, 1895.

Ostroumov, Nikolai. Kriticheskii razbor mukhammedanskogo ucheniia o prorokakh. Kazan, 1874 .

__. "Predvaritel'nye zamechaniia o tatarskom iazyke v sviazi s priniatym v slovare alfavitom." In Pervyi opyt slovaria narodno-tatarskogo iazyka po vygovoru kreshchenykh tatar Kazanskoi gubernii. Pp. 5-43. Kazan, 1876. 
—. Tatarsko-russkii slovar'. Kazan, 1892.

__. "Zametka ob otnoshenii mukhammedanstva k obrazovaniiu kreshchenykh tatar." Zhurnal Ministerstva narodnogo prosveshcheniia, pt. 161 (May 1872): 87-110.

"Otchet o deiatel'nosti Bratstva Sv. Guriia za desiatyi bratskii god ot 30-go oktiabria 1876 po 30-e oktiabria 1877 goda." IKE, no. 4 (15 Feb. 1878): 84-92; no. 9 (1 May 1878): 226-237; no. 12 (15 June 1878): 328-343; no. 14 (15 July 1878): 385-393.

"Otchet o deiatel'nosti Bratstva Sv. Guriia za deviatyi Bratskii god ot 4-go oktiabria 1875 goda po 20-e oktiabria 1876 goda." IKE, no. 4 (15 Feb. 1877): 104-116; no. 6 (15 Mar. 1877): 177-184; no. 10 (15 May 1877): 269-280.

"Otchet o deiatel'nosti Bratstva Sv. Guriia za piatnadtsatyi bratskii god." IKE, no. 14 (15 July 1883): 427-444.

Otchet o deiatel'nosti Bratstva Sv. Guriia za semnadtsatyi bratskii god s 4 oktiabria 1883 goda po 4 oktiabria 1884 . Kazan, 1884.

"Otchet o deiatel'nosti Bratstva Sv. Guriia za tridtsatyi bratskii god s 4 oktiabria 1896 goda po 4 oktiabria 1897 goda." IKE 32, nos. 13-14 (1-15 July 1898): 1-28; no. 24 (15-20 Dec. 1898): $32-38$.

"Otpadeniia iz pravoslaviia v magometanstvo i ikh prichiny." PB 2, bk. 2, no. 16 (Aug. 1908): 353-356.

"Perevod drugogo pis'ma uchitel'nitsy Feodory Gavrilovoi k o. Vasiliiu." IKE, no. 24 (15 Dec. 1877): 689-691.

Pis'ma N. I. Il'minskogo k kreshchenym tataram. Kazan, 1896.

Pis'ma N. I. Il'minskogo k ober-prokuroru sviateishego sinoda K. P. Pobedonostsevu. Kazan, 1895.

Polnoe sobranie zakonov, first series, 45 vols. SPb., 1830.

Poucheniia na kriashenskom iazyke. Kazan, 1891.

Prokop'ev, K. Perevody khristianskikh knig na inorodcheskie iazyki v pervoi polovine XIX v. (Istoricheskii ocherk). Kazan, 1904.

Rasskazy iz Russkoi istorii na tatarskom iazyke. Izdanie Perevodcheskoi Kommissii pri Upravlenii Kazanskogo uchebnogo okruga. Kazan, 1909.

Rasskazy iz zhitii sviatykh na tatarskom iazyke. Kazan, 1899.

Reshetnikov, M. “O nuzhdakh pravoslavnoi missii sredi magometan Viatskoi gubernii." Viatskie eparkhial'nye vedomosti, no. 20 (16 October 1905): 1092-1105.

Rittikh, A. F. Materialy dlia etnografii Rossii. Kazanskaia guberniia. 2 vols. Kazan, 1870.

Runovskii, N. "Ocherk istorii khristianskogo prosveshcheniia inorodtsev VolzhskoKamskogo kraia v sviazi s istoriei perevodov na ikh iazyki do poloviny XIX st.” Simbirskie eparkhial'nye vedomosti no. 2 (15 Jan. 1901): 49-57; no. 4 (15 Feb. 1901): 128-135; no. 7 (1 Apr. 1901): 237-243; no. 10 (15 May 1901): 339-345; no. 11 (1 June 1901): 383-392; no. 12 (15 June 1901): 417-423.

Russkie pervomucheniki na tatarskom iazyke. Kazan, 1898.

Rybakov, S. Islam i prosveshchenie inorodtsev v Ufimskoi gubernii. SPb., 1900.

_. "Otpadenie kreshchenykh inorodtsev v islam i ikh prosveshchenie." PB no. 14 (July 1899): 241-248.

Rychkov, Petr. Topografiia Orenburgskoi gubernii. Ufa, [1762] 1999.

Sbornik dokumentov $i$ statei po voprosu ob obrazovanii inorodtsev. SPb., 1869.

Sh. S. “Tatary-musul'mane. Smert' i pokhorony." Inorodcheskoe obozrenie, supplement to PS, bk. 2 (Mar. 1913): 117-120.

Shpilevskii, S. M. Drevnie goroda i drugie bulgarsko-tatarskie pamiatniki v Kazanskoi gubernii. Kazan, 1877.

S. M. P. "Polozhenie inorodtsev v Volzhsko-Kamskom krae i prosvetitel'naia sistema N. I. Il'minskogo." In Nikolai Ivanovich Il'minskii: Sbornik statei po povodu 25-letiia so dnia konchiny ego (†27 dek. 1891 g.). Pp. 3-105. Kazan, 1916. 
Sofiiskii, Il'ia M. "O kiremetiakh kreshchenykh tatar, iz derevni Tavel', Chistopol'skogo uezda Kazanskoi gubernii.” In Trudy Chetvertogo arkheologicheskogo s'ezda v Rossii. Vol. 2, pp. 73-75. Kazan, 1891.

—. "O kiremetiakh kreshchenykh tatar Kazanskogo kraia." IKE, no. 24 (15 Dec. 1877): 674-689.

_. "Zagovory i zaklinaniia kreshchenykh tatar Kazanskogo kraia.” IKE, no. 2 (15 Jan. 1878): $38-55$.

Speranskii, Aristarkh. Kazanskie tatary (Istoriko-etnograficheskii ocherk). Kazan, 1914. Tufan, Khasan. "O sebe." In Stikhotvoreniia. Moscow, 1970.

Vasil'ev, M. “O kiremetiakh u chuvash i cheremis." IKE, no. 8 (22 Feb. 1904): 237-267.

__. "Rasprostranenie khristianstva v Kazanskom krae.” IKE, no. 32 (22 Aug. 1904): 10461062.

Vitevskii, Vladimir. "Nikolai Ivanovich Il'minskii, director Kazanskoi uchitel'skoi seminarii († 27 dekabria 1891 goda)." IKE, no. 4 (15 Feb. 1892): 65-80; no. 5 (1 Mar. 1892): 95-112. Voskresenskii, Aleksei. "Otchet o prepodavanii zakona Bozhiia v Kazanskoi tsentral'noi kreshcheno-tatarskoi shkole za 1890-1891." IKE, no. 20 (15 October 1891): 610-615.

"Zakladka tserkvi v derevne Staroi Ikshurme." IKE, no. 15 (1 Aug. 1891): 468-475.

Zhitie sv. Avraamiia, muchenika Bulgarskogo. Izlozheno na kreshcheno-tatarskom iazyke, s perefrazirovannym russkim perevodom slushatelem Kazanskogo Chastnogo Missionerskogo Priiuta Dmitriem Timofeevym Medvedevym. Kazan, 1878.

Zhitiia sviatykh na russkom iazyke izlozhennye po rukovodstvu Chet'ikh-Minei sviatitelia Dimitriia Rostovskogo. Mesiats Aprel'. Borovsk, [1906] 1997.

Znamenskii, P. B. "Kazanskie tatary." In Zhivopisnaia Rossiia, Otechestvo nashe v ego zemel'nom, istoricheskom, plemennom, ekonomicheskom i bytovom znachenii. Vol. 8: Srednee Povolzh'e i priural'skii krai. Pt. 1, Srednee Povolzh'e. Pp. 119-145. SPb. and Moscow, 1910.

\section{Secondary Works}

Akhmet'ianov, R. G. Obshchaia leksika dukhovnoi kul'tury narodov Srednego Povolzh'ia. Moscow, 1981.

Akhunov, A. M. Arabskii istochnik srednevekovoi tiurko-tatarskoi literatury. Kazan, 2001.

Algar, Hamid. "Shaykh Zaynullah Rasulev: The Last Great Naqshbandi Shaykh of the VolgaUrals Region." In Muslims in Central Asia: Expressions of Identity and Change, ed. Jo-Ann Gross, pp. 112-133. Durham and London, 1992.

Baiazitova, Flera. Govory Tatar-Kriashen v sravnitel'nom osveshchenii. Moscow, 1986.

Battal-Taymas, Abdullah. Kazan Türkleri. Ankara, 1966.

Bez ber tamïrdan: Keräshen tatarlarïnïng etnogenezïn häm etnografiiasen öyränü buÿ̈ncha urta ghomumi belem mäktäpläre öchen uqu yardämlege. Kazan, 2002.

Bombaci, Alessio. Histoire de la littérature turque. Paris, 1968.

Bringa, Tone. Being Muslim the Bosnian Way: Identity and Community in a Central Bosnian Village. Princeton, NJ, 1995.

Brinner, William M., trans. The History of al-Tabari (ta'rīkh al-rusul wa'l-mulük). Vol. 2: Prophets and Patriarchs. Albany, 1987.

Buehler, Arthur. Sufi Heirs of the Prophet: The Indian Naqshbandiyya and the Rise of the Mediating Sufi Shaykh. Columbia, SC, 1998.

Constas, Nicolas. “'To Sleep, Perchance to Dream': The Middle State of Souls in Patristic and Byzantine Literature.” Dumbarton Oak Papers 55 (2001): 91-124.

Crews, Robert. For Prophet and Tsar: Islam and Empire in Russia and Central Asia. Cambridge, MA, 2006. 
Farkhshatov, Marsil. Narodnoe obrazovanie v Bashkirii v poreformennyi period 6o-9o-e gody XIX v. Moscow, 1994.

Fäsiev, Fazil, ed. Qol Ghali: Qïyssai Yusuf: Yusuf turïnda qïyssa. Kazan, 1983.

Fokin, A. V. "Kriashenskii vopros v Tatarstane: Etnoistoricheskii obzor." In Sovremennoe kriashenovedenie: Sostoianie, perspektivy (Materialy nauchnoi konferentsii, sostoiavsheisia 23 aprelia 2005 v g. Kazani). Pp. 88-102. Kazan, 2005.

Frank, Allen. Islamic Historiography and "Bulghar" Identity among the Tatars and Bashkirs of Russia. Boston, 1998.

—. Muslim Religious Institutions in Imperial Russia: The Islamic World of Novouzensk District and the Kazakh inner Horde, 1780-1910. Leiden and Boston, 2001.

Geraci, Robert. Window on the East: National and Imperial Identities in Late Tsarist Russia. Ithaca, NY, 2001.

Ghaynetdin, Mäsghud. Khaqïyqat' yulïnnan. Ädäbi tänqüyt'. Kazan, 2001.

Glukhov-Nogaibek, Maksim. Sud'ba gvardeitsev Seiumbeki. Kazan, 1993.

Grigor'ev, A. N. "Khristianizatsiia nerusskikh narodnostei, kak odin iz metodov natsional'nokolonial'noi politiki tsarizma." In Materialy po istorii Tatarii 1. Pp. 226-285. Kazan, 1948.

Haddad, Yvonne, and Smith, Jane. The Islamic Understanding of Death and Resurrection. Albany, 1981.

Halevi, Leor. Muhammad's Grave: Death Rites and the Making of Islamic Society. New York, 2007.

Hasluck, F. W. Christianity and Islam under the Sultans, vol. 1. New York, 1973.

Hoffman, Valerie. Sufism, Mystics, and Saints in Modern Egypt. Columbia, SC, 1995.

Iskhakov, Damir M. "Etnodemograficheskoe razvitie Nagaibakov do pervoi chetverti XX v." In Nagaibaki: Kompleksnoe issledovanie gruppy kreshchenykh tatar-kazakov. Pp. 4-18. Kazan, 1995.

—. Etnograficheskie gruppy tatar Volgo-Ural'skogo regiona: Printsipy vydeleniia, formirovanie, rasselenie i demografiia. Kazan, 1993.

_. "Mol'keevskie kriasheny: Problema formirovaniia i demograficheskoe razvitie v XVIII-nachale XX veka." In Mol'keevskie kriasheny, ed. Damir Iskhakov. Pp. 4-19. Kazan, 1993.

Iskhakova-Vamba, R. A. Tatarskoe narodnoe muzykal'noe tvorchestvo. Kazan, 1997.

Islam na nizhegorodchine. Entsiklopedicheskii slovar'. Nizhnii Novgorod, 2007.

Johansen, Julian. Sufism and Islamic Reform in Egypt: The Battle for Islamic Tradition. Oxford, 1996.

Kemper, Michael. Sufis und Gelehrte in Tatarien und Baschkirien, 1789-1889: Der islamische Diskurs unter russischer Herrschaft. Berlin, 1998.

Kemper, Michael, Anke von Kügelgen, and Dmitriy Yermakov, eds. Muslim Culture in Russia and Central Asia from the 18th to the early 2oth Centuries, vol. 1. Berlin, 1996.

Khalid, Adeeb. The Politics of Muslim Cultural Reform: Jadidism in Central Asia. Berkeley and London, 1998.

Khasanov, Kh. Kh. Formirovanie tatarskoi burzhuaznoi natsii. Kazan, 1977.

Khisamov, N. Sh. Poema Kyssa-i Iusuf Kul Ali. Moscow, 1979.

Khösnullin, Qotdus. Mönäjätlär häm bäyetlär (Köyläp uqugha nigezlängän janrlar). Kazan, 2001.

Kreindler, Isabelle Teiz. "Educational Policies Towards the Eastern Nationalities in Tsarist Russia: A Study of Il'minskii’s System.” Ph.D. diss., Columbia University, 1969.

Lifchez, Raymond, ed. The Dervish Lodge: Architecture, Art, and Sufism in Ottoman Turkey. Berkeley, 1992.

Liubomirov, Pavel. Ocherki po istorii metallurgicheskoi i metalloobrabatyvaiushchei promyshlennosti v Rossii (XVII, XVIII i nach. XIX vv.). Leningrad, 1937. 
Makarov, Gennadii. "Perspektivy razvitiia traditsionnoi kul'tury Kriashen v sovremennykh usloviiakh." In Materialy nauchno-prakticheskoi na temu "Etnicheskie i konfessional'nye traditsii Kräshen”: Istoriia i sovremennost'. Pp. 17-44. Kazan, 2001.

Mökhämmätov, Ildar. “Tatar-törek ädäbi baghlanïshlarï yassilïghïnda Mökhämmäd Chäläbineng 'Mökhämmädiyä kitabï.” Kand. diss. Kazan University, 2006.

Mukhametshin, Iu. G. Tatary-kriasheny. Istoriko-etnograficheskoe issledovanie material'noi kul'tury-seredina XIX-nachalo XX vekov. Moscow, 1977.

Näjmiev, Tälghat and Mäghsum Khujin. Yashä, Saba-Yort. Kazan, 1999.

Nolde, Boris. La formation de l'Empire russe: Études, notes et documents. Paris, 1952.

Ömet yoldïzlarï: XIX yöz akhïrï häm XX yöz bashï tatar khatïn-qïz yazuchïlarï äsärläre. Kazan, 1988.

Rakhim, A., and F. V. Tarzimanov. "Khuzialar Tauy." Vestnik nauchnogo obshchestva tatarovedeniia 8 (1928): 174-176.

Reinkowski, Maurus. "Hidden Believers, Hidden Apostates: The Phenomenon of Crypto-Jews and Crypto-Christians in the Middle East." In Converting Cultures: Religion, Ideology and Transformations of Modernity, eds. Dennis Washburn and A. Kevin Reinhart. Pp. 409-433. Leiden and Boston, 2007.

Renard, John. Seven Doors to Islam: Spirituality and the Religious Life of Muslims. Berkeley and London, 1996.

Rorlich, Azade-Ayshe. The Volga Tatars: A Profile in National Resilience. Stanford, CA, 1986.

Sadekova, Aisylu-khadzhi. Ideologiia islama i tatarskoe narodnoe tvorchestvo. Kazan, 2000.

Schimmel, Annemarie. As through a Veil: Mystical Poetry in Islam. New York, 1982.

—. Deciphering the Signs of God: A Phenomenological Approach to Islam. Albany, 1994.

- And Muhammad Is His Messenger: The Veneration of the Prophet in Islamic Piety. Chapel Hill and London, 1985.

—. My Soul Is a Woman: The Feminine in Islam. New York, 1997.

—. Mystical Dimensions of Islam. Chapel Hill, NC, 1975.

- A Two-Colored Brocade: The Imagery of Persian Poetry. Chapel Hill, NC and London, 1992.

Shärifullina, Gölsinä. “Urïs-kyäfer kilgänder Yïlïsh awïlï ilenä.” Idel, no. 5 (May 1993): 66-70. Shevzov, Vera. Russian Orthodoxy on the Eve of Revolution. Oxford, 2004.

Tatary Srednego Povolzh'ia i Priural'ia. Moscow, 1967.

Urazmanova, Raufa. Obriady i prazdniki tatar Povolzh'ia i Urala (Godovoi tsikl XIX-nach. $X X v v$.). Kazan, 2001.

Urazmanova, R. K., and S. V. Cheshko, eds. Tatary. Moscow, 2001.

Validov, Dzhamaliutdin. Ocherk istorii obrazovannosti i literatury Tatar (do revoliutsii 1917). Moscow and Petrograd, 1923.

Werth, Paul. At the Margins of Orthodoxy: Mission, Governance, and Confessional Politics in Russia's Volga-Kama region, 1827-1905. Ithaca, NY, 2002.

—. "Coercion and Conversion: Violence and the Mass Baptism of the Volga Peoples, 1740-55." Kritika: Explorations in Russian and Eurasian History 4, no. 3 (2003): $543-570$.

- "From 'Pagan Muslims' to 'Baptized' Communists: Religious Conversion and Ethnic Particularity in Russia's Eastern Provinces." Comparative Studies in Society and History 42, no. 3 (July 2000): 497-523.

—. "The Limits of Religious Ascription: Baptized Tatars and the Revision of Apostasy, 1840s-1905." Russian Review 59, no. 4 (Oct. 2000): 493-511.

Zagidullin, Il'dus (Zahidullin, Ildus). Perepis' 1897 goda i tatary Kazanskoi gubernii. Kazan, 2000. 
_. "Jilïsh awili mäk'ruhlari." Miras 46, no. 9 (1995): 111-115; 48, nos. 11-12 (1995): 138-148.

Zagidullin, I. K., L. F. Baibulatova, and N. S. Khamitbaeva, eds. Tatarskie musul'manskie prikhody Rossiiskoi Imperii: Materialy vserossiiskoi nauchno-prakticheskoi konferentsii, g. Kazan', 27-28 sentiabria 2005 g. Kazan, 2006.

Zäynullin, Jamil. XVIII-XX yöz bashïnda tatar rukhani ädäbiyatï: Qor'än täfsirläre, khädislär h. b. chïghanaqlar. Tärjemä printsiplarï häm tel üzenchälekläre. Kazan, 1998. 



\section{Index}

Page numbers in italics refer to illustrative material.

Abdi parish, $x$ viii- $x x, 125 \mathrm{n} 21,199$

Abdiushev, Gizetulla (Aleksei Fedorov), 42n120, 49

'Abduh, Muhammad, 216, 219

abistay (female teacher), 55, 57, 140, 141, 144, $148-49,159$

abjad (letter combinations with numeric value), 72,73

Abla village, 67

Abraham (Ibrahim), 65, 76, 106, 229

Abu Bakr (caliph), 77, 96

Achi parish, $x x, 27,120,197$

Adam (prophet), 65, 73, 76, 79, 87, 106-7, 109, $181,219,252$

Afanas'ev, Aleksandr, 170

Afghani, Jamal ad-Din al-, 216, 230, 231

afterlife: jadids on, 227-28; Kräshen beliefs regarding, 111-14, 187, 188; popular Islamic and animist understanding of, $187-88$; in popular Islamic literature, 79-80; Russian Orthodox understanding of, 188-89

Ähmäd, Shakir, 67

Ähmäd, Wäli (shaykh), 130, 209-10

Ahrar, Khoja Nasr ad-Din 'Ubaydullah, 132, 133, $137 \mathrm{n} 57$

Aisha (younger wife of Muhammad), 90, 156

$\bar{A} k h$ ir Zamān Kitābi (The Book of the End of

Time), 51, 78-79, 137, 176, 215, 226

Aksarino village, 63

Al'bedino village, 18, 196

Alekseeva, Dariia, 197

Alexander I (czar of Russia), 29

Alexander II (czar of Russia), 42

'Ali (Muhammad's son-in-law), 93, 109

Alichtarkhan village, 142, 199

Alkin, 'Abd al-Latif, 135, 136-37, 138

Allahiyar (Samarkandi Sufi), 69, 87

Älmäti, Ni'mätullah al- (shaykh, son of 'Ubäydullah), 133, 135-36, 137, 138, 209

Al'met'evo village, $x v i i i, 39,69 n 25,135,196,209$
Almurzina village, 46, 126, 209

Altïnchäch (Bolghar princess), 96

Ämin, Wälid b. Möhämmäd al-, 135

Ämirkhan, Fatih, 71n31, 218, 253

Ämirkhan, Möhämmäd Näjib (shaykh), 242, 253

ancestor worship, 78, 80, 108

Andirjan (shaykh), 82, 84

Andreev, Sil'vestr, 43

animism: and afterlife, belief in, 112, 187-88; and ancestor worship, 78, 80; Christian beliefs compared to, 189; and Christianity, hybridity of, 169-70, 196; novokreshchenye and, 20; and popular Islam, 60, 70, 130; powerful influence of, 17-18, 104; and sacred geography, 99-101; starokreshchenye and, 11, 15, 17-18, 168-70; women and, 17, 55, 139-40

Anna Ivanovna (empress), 14

Antonii (archbishop), 182, 186, 187

Apakov, Mikhail, 16n23, 195

Apazovo village, $x v i i, 12,66,105,129$, 234; fluidity of religious affiliations in, 15,168 ; Il'minskii school in, 190, 200-201, 202; strategies to counteract apostasy in, 123, 184, 200-201, 236

apostasy movements, 1-2, 26-27; agrarian festivals and, 126-28, 146; April manifesto of 1905 and, 235-40; Brotherhood of St. Gurii's response to, 122-23, 200-204; czarist policies and, 24-25, 29, 32-33, 39-44, 58; economic forces and, 4, 117-29, 255-56; ethnic groups participating in, 15, 21-23; Il'minskii's response to, 161-62, 199200; Islamic knowledge and, 30-32, 49-59, 60; jadidism and, 241, 242-45; kinship networks and, 45-46, 55, 117, 123-24, 143-47; mullahs and, 52-53, 54, 59; novokreshchenye and, 19, 20, 21; Orthodox Church response to, 173-204; as process of acculturation/identity formation, 6 , $8,29,33-34,58,117$; returning soldiers and, 43 , 166-67; Russian peasant riots compared to, 30 ; sacred networks and, 129-39; scholarship on, 3 , 4; starokreshchenye and, 21, 47, 117, 236; state 
apostasy movements (continued)

response to, 23-26, 204-10; Tatar communities' response to, $161,235,239-41$; trade networks and, 4, 45, 84, 118-21, 124, 126; women and, 35, 45-46, 50, 55, 57, 86, 117, 139-6o. See also apostates; leaders of apostasies

apostates: children of, separation of, 137-38; Christian knowledge among, 167-73; descendants of, during Soviet period, 258-59; Islamic customs adopted by, 33-34; jadid criticism of, 214; as martyrs, portrayal of, 246-48; Orthodox missionaries and, 39, 41, 139, 150, 177-79, 183-84; petitions by, 33, 44-45; punishment of, 23-24, 37-38, 162; relations with non-apostates, 30, 34-37; religious discourse of, 104-16, 214, 256; Russian literacy among, 49-51, 58, 163-66, 201, 202; statistics regarding, 28, 28, 29; Tatar prejudice against, 104, 245; use of term, 5; wives of, 139. See also novokreshchenye; starokreshchenye

April manifesto (1905), 235-40

Aptrakhimov, Feodor, 114

Aqchurina, Mäkhbübjämal, 252

Arabic literacy: jadids on, 230; Kräshens and, 100, 105, 183; Orthodox missionaries and, 214-15; popular Islamic literature and, 69-70; primary Islamic education and, 72-73

army service: and apostasy movement, 43, 16667; and Russian literacy, 166-67, 170-72

Arsk trade route, $x$ viii, 34, 63, 125n21, 145

Artem'evka village, 240

Artyk village, 105, 139, 140, 142

asceticism, 114, 132, 205, 228, 252

Ashiti, Möhämmäd Rähim b. Yusuf al- (shaykh), 133-34, 135

Asian printing house, Kazan, 51, 72

Asiya (martyr), 92-93, 156, 246

'Ata'ullah (Shaykh Ni'mätullah's son), 136, 137

Atlasi, Hadi, 239

Attar, Farid ad-Din, 87, 89

Aty village, 63, 161

Avraamii, St., 160, 184-85, 186, 214, 263

Aydar (Bolghar khan), 62, 63, 213

Aynullah (Tatar scribe), 135

'Ayshä Bikä (Sufi saint), 95

Ayyub. See Job

Azbaba village, 54, 98, 99, 131, 138, 236, 237

Azeeva village, 40, 164, 209

Aziak villages, 55, 120, 125n21, 142, 146, 199

Baba Tükles (Sufi saint), 96

Babina (Kräshen teacher), 201

Bädäwām Kitābï (Forever), 68, 86, 87, 100

Baiazitova, Flera, 12

Baidankino village, 63
Baigulovo village, 63

Baimurzino village, 36, 235, 237

Baitiariakova village, 54

Bakyrchy village, 98-99

Balandysh village, $x x, 127,134,140$

Bálint, Gábor, 61

baptism: as ethnic bond, 12, 15; Tatar views on, 111-12. See also Kräshens

Baqïrghani, Sulayman (Hakim Ata), 78, 108, 114; $\bar{A} k h \ddot{r}$ Zamàn Kitābï (The Book of the End of Time), 51, 78-79, 137, 176, 215, 226; The Book of Mary, 93-94, 157-58, 171

Bāqürghān Kitābï (The Book of Baqïrghan), 139 , 214

Baran village, 193

bards, Christian, 196-97

Barudi, 'Alimjan al- (shaykh), 213, 216, 219, 228, 242

Bashkirs, 2, 14, 24, 67n17

Basil the Younger, 188-89

Bayazitov, 'Ata'ullah, 220-21, 227

Bäyrämova, Fäwziyä, 263

Bazgievo village, 241

beggars, and spread of Islam, 130-31

belt, symbolism of, 71

Biagitinovo village, 64

Bibei (Evfimiia Efremova), 151

Bigenei village. See Kazanchi Bigeneevo

Bigi, Musa Jarullah, 227

Bigiyev, Zahir, 98

Bikkinin, Abdul Zhälil, 53

Bikmökhämmätov, Ibrahim, 56, 210, 243; daughter of, 57, 101, 244-45; descendants of, 237

Bikovo village, 19, 165

Biksutana (Evfimiia Ivanova), 144, 148

Biktashi, Jamal ad-Din, 80-81, 84, 112, 114; Fäkhr ad-Din compared to, 228; Fäżàil ash-Shühūr, $68-69,78,79,80,81,85-86,94,95,108,138$, 152, 201; hadith literature and, 79; jadid criticism of, 225-26, 228, 230; portrayal of women by, 92, 94; on sacred geography, 98, 99

Biktimer, Jarullah b. Bikmöhämmäd b., 138

Biktimeriya, 'Alimätelbänat, 140

Biliarsk village, $x$ viii, 95, 102, 103, 137, 138, 18687

Bilqis (queen of Sheba), 91

Bishevskii, Ivan, 168

Bitoman village, 34

Blagoveshchenskoe village (Omar), 128

Bobylev, Nikanor, 175

Bogady village, 130

Bogatye Saby village, xix, 62, 118, 119, 124, 126, 129, 242

Bolghar, ancient city of, xvii, xviii, 95, 98, 160, 263 
Bolghari, Husam ad-Din b. Shäraf ad-Din al-, 63-64

Bolghar kingdom: books associated with, 63 , $68 \mathrm{n} 20,69,72$; legends from, 97; territorial divisions of, 127, 137; tombstone inscriptions from, 98

Bolghars, Islamization of, 62-63

Bolgharskaya, Ömmelgölsem, 249

Bol'shaia Chura village, 204

Bol'shaia Nurma village, xviii, 145

Bol'shaia Taiaba village, 126

Bol'shie Aty village, 63

Bol'shie Kibiak-Kozi, 5on155, 105-6, 201

Bol'shie Savrushi village, 55, 109, 147, 151, 163 , 192, 197, 202, 236

Bol'shie Sulabashi village, 136

Bombaci, Alessio, 158

The Book of Mary (Baqürghani), 93-94, 157-58, 171

books. See under literature

Brotherhood of St. Gurii, 26; religious literature published by, $182-83,188-89$; response to apostasy movement, 38, 122-23, 200-204, 213; schools established by, 26, 189-91, 200, 239; Tatar philanthropic societies modeled after, 241

Budilovich, Anton, 234

Buinsk (town), xviii, 117, 120

Bukhari, Muhammad al-, 175

Catherine II (Catherine the Great), 24-25, 39-40, 58,165

Chally village, 102, 142-43

Cheremis. See Maris

Chicherina, Sofiia, 61, 64

children, of apostates: separation from parents, 137-38; Tatar attitudes toward, 245

Chirtushi, 'Abdullah b. Yahya al-, 138

Chizhov, Tikhon, 175

choral music, and spread of Christianity, 181, 182, 195

Chrismation, 111-12

Christianity. See conversion to Christianity; Orthodox Christianity

Christian Tatars. See Kräshens

Chura village, xix, 5, 122, 123, 126, 145, 161, 162, 204, 236, 258, 259. See also Malaia Chura

Chuvash, 2; in apostate villages, 15; ethnic identity preserved by, 23, 24; Islamization of, 21, 22-23, 46, 111, 240, 241; Kräshens compared to, 14 ; literacy among, 58 ; migration to Ottoman Empire, 32; punishment for apostasy, 24; sacred geography and, 102-3

circumcision, $34,112,151$

clothing: Kräshen, 13, 14; religious symbolism of, 71 conversion to Christianity: forced, Tatar narratives of, $9,11,15,161,235$; vs. Islamization narrative, 62-63; methods of, $11-12,15-16,18$; reasons for, 19, 161; Vladimir and, 233; waves of, 9-11

Cosmas, St., 167

Cossaks, 14, 27, 125

czar, Russian: apostates' reliance on, 30, 40, 41, 42; pharaoh compared to, 84, 86, 93

czarist policies, and apostasy movements, 24-25, $29,32-33,39-44,58$

Damian, St., 167

Danilov, Stepan, 176, 183n 56

Daulei, Roman, 233

Davletkil'deev family, 124

Dawud, Qara, 110

deportation. See exile

dervishes, 71, 82, 95-96, 129, 228; and Book of Mary, 156; jadids on, 7, 225, 229; women as, 95-96, 139, 229

Dragun-Bekhmetevo village, 14, 201, 202

drawings, Islamic, 64

dreams and visions, jadids on, 223-24

economic forces, and apostasy movement, 4, 11729, 255-56

Edict of Religious Toleration (1905), 235-40

education, Islamic: stages of, 148; among Tatars, 103-4; among women, 86-87, 140-41. See also jadid schools; madrasa; maktab; Qur'anic schools

education, Russian Orthodox: before Il'minskii school, 165-66; in local languages, 26, 206, 233, 234; and unity of empire, 207. See also Il'minskii schools; Russian literacy

Efremova, Evfimiia (Bibei), 151

Egorov, Nikolai, 257

Elyshevo village, $x v i i-x x$; and apostasy movement, 48, 54-55; after April manifesto of 1905, 237; Christian knowledge in, 156, 167-68; church of, 198, 237; copper mines in, 125-26; distinct identity of, 21; education networks and, 140; epic of, 138; ethnic groups in, 15; female teachers in, 148-49; fluidity of religious affiliations in, 16; funerary rites in, 151, 152-54; Il'minskii school in, 190, 192, 199, 201-2, 239; Islamic customs adopted in, 33-34, 35; Islamic knowledge in, 107-8, 114, 141, 150-51; jadid literacy in, 244-45; kinship networks and, 123, 124, 143-46, 147, 149; leaders of apostasy in, 54-55; mosque in, 237, 238, 239; mullah of, 54, 56, 210; non-apostates in, 35-36, 155, 170-73, 172; Orthodox missionaries in, 192, 197-98, 236; punishment for apostasy in, 37, 39, 241; Qur'anic school in, 57, 237, 239; Russian literacy in, 165; 
Elyshevo village (continued)

sacred landscape in, 100-101, 152, 237; sacred networks and, 134; soldier households in, 167; in Soviet period, 259-60; tailors from, 70, 119, $121,126,131$; tombstone inscriptions from, 56-57, 57; trade network and, 118, 119; women and Islamic knowledge in, 57, 141, 150-51

Emel'ianov, Iakov, 204, 233, 262

Enoch (Idris), 131-32, 219

Eruslanov, Petr, 61, 153

Estifeev, Vasilii, 45, 51, 52-53, 165

Eve (Hawwa), 65, 87, 87n89

exile: of prophets, 76 ; as punishment for apostasy, $24,37,38,39,41,42,124,199,241$; and spread of apostasy, 46, 47, 126

exogamy, and spread of apostasy, 45-46, 143-47, 148,159

faith, and salvation, $81,84-85$

Fäkhr ad-Din, Riza' ad-Din b., 35, 74, 86, 98, 100, $158,169,215,216,257$; on cult of saints, 225; on dreams and visions, 223-24; on forgiveness, 228; on hadith, 230-31; Jäwāmi' al-Kälim Shärhe, 216, 217-18; on literal interpretation of Qur'an, 225-26; on Muhammad, 221-23, 227; popular Islam and, 228-40; on story of Joseph, 247n94; on victory of Islam, 232

Fatima (Muhammad's daughter), 95, 156

Fätkhullin, Ibrahim (Ivan Matveev), 209

Fäża'il ash-Shühūr (The Qualities of the Months), $68-69,78,79,80,81,85-86,94,95,108,138$, 152, 201; jadids on, 225-26, 253; Russian missionaries and, 215

Fedor (czar of Russia), 24

Fedorov, Aleksei (Gizetulla Abdiushev), 42n120, 49

Fedorov, Mikhail, 202

Fedorova, Avdot'ia, 149

Feodor (Aptrakhimov), 114

fertility, in Islamization narrative, 62-63

festivals, agrarian: and apostasy movement, 12628, 146; jadids on, 253; and kinship networks, $127-28,144-45,147,159,177$

festivals, Russian, 154-56, 167; and kinship networks, 147

Filippov, Kondratii, 35-36, 153, 155, 170-72; descendants of, $172,172-73,259$

Filippova, Domna, 153-54

Finno-Ugric peoples, 10, 14, 27, 63; animist beliefs of, 71, 169; Christianization of, 213, 233; Islamization of, $1,4,7,31,39,58,76,115,129,134,160$

forgiveness: in jadid literature, 228; in popular Islamic literature, $77-81,114,115$

Frank, Allen, 4

Fuks, Karl, 88n91, 140 funerary rites: Islamic literature used in, 65; Orthodox Christian, 192; Tatar, 80, 112; women's role in, 151-58. See also tombs

Gasprinskii, Ismail, 216, 219, 224, 225, 228

Gavrilova, Feodora, 183-84, 201

geography, sacred, 97-103; animism and, 99-101; April manifesto of 1905 and, 236-39; Islamization of, 160; jadids on, 225, 253; Kräshens and, 99, 100, 101-2, 103, 173; Orthodox clergy and, 186-87; Russian appropriation of, 103, 152, 173, 205

German (archbishop), 9-10

Germogen (Kazan metropolitan), 9-10

Ghafur, 'Abd al-Jäbbar b. Jä‘fär b. 'Abd al-, 136

Ghafuri, 'Abd al-Mäjid, 220

Ghazali, Imam al-, 79, 81-82, 83, 87, 218

Ghijduwani, 'Abd al-Khaliq, 101

Glukhov, Maksim, 102, 263n18

Golden Horde, Islamization of, 96, 255

Grigor'ev, Iarofei, 50

Grigorii (Kazan bishop), 25-26

Gurii (archbishop), 9-10

Gurii, St., 186; chapel of, 185-86. See also Brotherhood of St. Gurii

Habibullah (shaykh), 82, 84, 101

hadith (reports on deeds and sayings of the Prophet): jadids on, 217, 230-31; Orthodox missionaries on, 174; popular Islamic literature compared to, 79; women in, 94

Häft-i Yäk (seventh part of Qur'an), 51, 54, 65, 73

Hamza, Sheyyad, 71

Hanafi Islam, 75, 82

Hanifa, Abu, 81-82, 83, 151, 217

Hasan, Khoja, 20

Hidayatullah, Shaykh, 102, 142

Hösäyen, Haji Shams ad-Din b., 64

Iadyger-khan, 161

Iadyger' village, $x i x$

Iakovlev, Ivan, 22

Iakovlev, Vasilii, 167

Iakovleva, Elena, 55

Ianasal village, xix; apostasy movement in, 34, 35, 112, 184, 240; Il'minskii school in, 190, 202; maktab in, 55, 148, 149; in trade network, 118

Iangozino-Surinskoe village, 20

Iantsovary village, 16, 122, 123, 199, 202

Ianyli village, 5, 15, 128, 200, 243, 259; antireligious campaigns of 1930 s and, 258; apostates from, 64, 65; church of, 191, 236, 259; ethnic groups in, 15; and kinship networks, 124

Ibn al-Arabi, Muhyi ad-Din, 67, 216, 218

Ibn Taymiyya, Taqi ad-Din Ahmad, 79, 83, 216, 225,228 
Ibrahimov, 'Alimjan, 244, 252-53

icons: animist beliefs and, 169-70, 196; in chapel of St. Gurii, 185-86; jadids on, 240; Kräshens and, 194, 195, 196; miraculous, 186-87; Tatars on, $109,128,156,168,171$

Idegäy (khan), 96

Idris (prophet). See Enoch

Idris Khalifa, St., 102, 111, 142

Il'minskii, Nikolai, 13, 25-26, 117, 213, 251; on animist practices, 196; criticism of pedagogy of, 233, 234; on exiling of apostates, 38; in film, 262; on Islamization of Kazan Tatars, 13; legacy of, 211, 232-33; on primary Islamic education, 179-80; publications under, 182-83; response to apostasy movement, 161-62, 179, 202-3; stories recorded by, 61; students of, 210, 234; translation of Gospels, 139, 166, 168

Il'minskii schools, 26, 179-81, 189-91; as chapels, 193-94; Christian education before, 165; for girls, 200-201; impact of, 163, 194-99, 202, 204, 211; local languages used in, 26, 206, 233, 234; vs. maktabs, 148; patrons of, 191-92; Qur'anic schools and, 179-80, 181; resistance to, 198, 199-202; teachers at, 192, 197, 199; Timofeev and, 233

India: Muslims of, Tatar experience compared to, 216, 219; Russia compared to, 133; Sufi network in, 133. See also Mughal Empire

Inozemtsev, Petr and Semen, 125

intercession: jadids on, 226-27; Kräshen beliefs regarding, 114; Orthodox Christianity and, 174, 176, 188-89; popular Islamic literature on, 77-79, 115; prophets and, 74-79, 115, 158, 176; women and, 153

Iordanskii, Nikolai, 175

'Isa. See Jesus

ishans. See shaykhs

Ishkeevo village, 155

Ishniyaz b. Shirniyaz, 69

'Ishqi, Abu'l-Hasan, 101

'Ishqiyya Sufism, 101

Ishteriakovo village, 125

Iskändärev, Kämal ad-Din, 165

Iskhaqi, 'Ayaz, 211, 245-51, 252, 253, 262

Islam: Christianity compared to, 114, 160; and Eastern Orthodoxy, frontier between, 2, 117, 168-69; state officials' position on, 207; women's status in, 221, 223

Islam, spread of, 2-5, 158-59; economic forces and, 255-56; jadids on, 232; popular Islamic literature and, 64-76; primary education and, 2-3, 74, 255; women and, 4-5, 95-96. See also apostasy movements

Islamic knowledge: and apostasy movement, 30$32,49-59,60$; drawings as source of, 64; global- ization of, 6; jadidism and, 218, 257; Orthodox missionaries challenging, 174-79; popular Islamic literature as source of, 61-96; sacred topography as source of, 97-103; and salvation, 81-82; sources of, 61-69, 256; Sufism and, $81-82,256$; talismans as source of, $64,65,98$, 130; testing of, 103-16; women and, 139-43, 258. See also literature, Islamic; popular Islam

Isliam Dini (The Religion of Islam), 239-40

Ismä il ughlï, 'Alim. See Samigulov

'Ismämullah b. Ähmäd, 138

Istärlibashi, Ni‘mätullah b. Biktimur al-, 133, 135

Iukachi parish, xix, 192, 199, 204

Ium'ia village, $x i x, 169$

Iuzefovich, Mikhail, 13

Ivanov, Larion and Vasilii, 50

Ivanova, Evfimiia (Biksutana), 144, 148

Ivanova, Matrena, 149

Ivan the Terrible: conquest of Kazan, 9, 10, 106; myths about, 62, 103, 137, 161, 235; relations with Tatars, 9, 96

jadid schools, 179, 216, 242-43, 256

jadids/jadidism, 213-15, 218, 256-57; and apostasy movement, 241, 242-45; criticism of Kräshen religious discourse, 114-15; criticism of mullahs and shaykhs, 7, 129, 224-25; criticism of popular Islam, 4, 60-61, 69, 215, 223 224-26; criticism of primary Islamic education, 180 ; criticism of sacred places, 98 ; female networks and, 159; interpretation of Qur'an, 216-17, 220, 225-26; literature of, 216-27, 242, 244-53; popular conceptions of Islam accommodated by, 227-40; prophets in, 219-23, 228, 246-47, 251; and Russian literacy, 211, 215, 253; state response to, 241-42; Sufism compared to, 257; and Tatar national identity, 214, 215, 246-49, 251; women, 140, 229, 246-48

Jäwāmi al-Kälim Shärhe (Commentaries on the Prophet's Comprehensive Words), 216, 217-18

Jazuli, Abu 'Abdullah Muhammad b. Sulayman al-, 110

Jesus ('Isa): apostates' view of, 105, 108; Islamic literature on, 73, 76, 95, 157, 170-71; in Mahdist tradition, 114; Muhammad and, 108, 109, 178

jihad: apostasy movements as, 30, 31, 33; jadid criticism of, 211,222

jinns, in Islamic literature, 88, 100, 177, 222

jïÿ̈ summer festival, 127-28, 144-45, 159

Job (prophet): story of, 76, 90, 108; wife of, 92, 246 Joseph (prophet): apostates' identification with, 115; in Bible vs. Tatar books, 108-9; contemporary appeal of, 261-62; examples of trickery in, 88-89; grave of, 99; Gurii compared to, 186; jadid reading of, 222, 232, 246-51; Orthodox 
Joseph (prophet) (continued) missionaries on, 175; as paradigm for living in non-Muslim state, 86; popularity of, 51,52 ; portrayal of women in, 88-90, 94, 95, 159; story of, 66-67; superiority of Islam demonstrated in, 76; supernatural powers in, 75; Turkic poetic tradition and, 70-71; women's interest in, 150

Judgment Day. See Last Judgment

Ka'ba, 64, 110

Kabuli, Fayd Khan al-, 31, 133, 135

Kainsar village, 128

Kalmyks, 2, 12, 25

Karabaian village (Qulbaghïsh), 5, 122, 168, 194, 258

Karamzin, Nikolai, 210

Karatun village, $47-48$

Kärimi brothers, 239, 252

Katanov, Nikolai, 252

Kazan: monasteries in, 12; printing house in, 51, 72; after Russian conquest, 11; Tatar neighborhood of, 51; Tikhvin church in, 164, 164

Kazan Central Baptized-Tatar School, 26, 184; chapel of St. Gurii at, 185-86; growth of, 189 ; icon at, 194; students at, 190, 192, 197, 202; summer courses at, 203; transformation after 1917,257

Kazanchi Bigeneevo village (Bigenei, Qazanchï Bigänäy), xix, 127, 130, 209

Kazan Mother of God icon, 147, 194

Kazan Theological Academy, 25, 173, 214-15, 251; anti-Islam division of, 174-76, 203; and Kräshen intelligentsia, 233

Kazantsev, Nikodim, 42

Kemper, Michael, 4

Khadija (wife of Muhammad), 90, 156

Khaivani village, 145, 199

Khäkimov, Shakir, 240

Khalid Baghdadi, Mawlana, 133

Khalidiyya Sufism, 133

Kharuzin, Aleksei, 241

Khäyrullah (Shaykh Ni'mätullah's son), 136

Khidr, al- (prophet), 82, 225

Khisamov, Nurmukhammet, 247n94

Khojas' mountain, 103, 137, 138, 187

Kholmskii, Sil'vestr, 24

Kibä-Khuja village. See Kibiak-Kozi

Kibech' village, 145, 163, 260n8

Kibiak-Kozi village (Kibä-Khuja), $x x, 105-6$; agrarian festivals in, 145, 163; apostasy of, 34, 121, 149, 209; apostates in, 107, 243; kinship networks and, 123, 124, 145, 147; literacy in, 50; mosque in, 241, 243; non-apostate family in, 121; Qur'an school in, 55, 243; resistance to Orthodox missionaries, 189; Russian festivals in, 167; trade networks and, 118, 119; women's role in apostasy of, 149. See also Bol'shie KibiakKozi

Kileevo village, 198-99

kinship networks: agrarian festivals and, 127-28, $144-45,147,159,177$; and apostasy movement, $45-46,55,117,123-24,143-47,149$; changes over time, 145-46; exiled apostates and, 126; Il'minskii schools and, 163

kirämät, animistic cult of, 17-18, 99-101; and Christian beliefs, hybridity of, 169-70, 196; vs. Sufi ishans, 130; women and, 17, 55

Kirillov, Anton, 196

Kirillov, Stepan, 198

Kirilov, Efrem, 134

Kirilov brothers (Elyshevo village), 54-55

Kisa'i, Muhammad b. 'Abdullah al-, 67

Kisekbash (The Severed Head), 75, 93

Kiselev, P. D., 41-42

Kizlawi, Möhämmäd Mäkhdüm al-, 215

Kizläw village. See Kurmanaevo

Kliuchevskii, Vasilii, 239

knowledge. See Islamic knowledge; literacy

Konashevich, Luka, 18, 133

Kostrov family, 124

Kovali village, 122, 190

Kräshens, 1, 2, 9-20; animistic traditions and, 11, 15, 17-18, 104, 108; antireligious campaigns of early 1930 and, 258; apostasy movements and, $1-2,8,27,161$; on apostates, 30; choices made by, 163,172 ; Christian community among, survival of, 2, 3, 9, 15, 28, 161, 163; Christianity of, vs. Russian Christianity, 211; in contemporary Tatarstan, 6, 26, 257-58, 262-63; as cryptoMuslims, assumptions regarding, 3; economic networks and, 125-26; ethnic consciousness of, rise of, 232-35, 246-49, 257, 260-61; ethnic descent of, 14; jadids on, 239-40; as martyrs, portrayal of, 246-48; migration under pressure from Muslims, 237; relations with apostates, 36-37; religious beliefs of, $15-17,20-21,104-$ 16, 168-69; after revolutions of $1917,257-58$; Russian literacy among, 163-66; Russian missionary successes among, 213-14; sacred places for, 99, 100, 101-2, 103; during Soviet period, 258-60; Tatar attitudes toward, 8-9, 21, 142, 161, 239-40; Tatars distinguished from, 13-14; use of term, 5, 9. See also apostasy movements; novokreshchenye; starokreshchenye

Krasil'nikov, Ioann, 196

Kremkov, Vasilii, 199

Kreshchenye Ianasaly village, 193-94, 236

Kubra, Najm ad-Din, 101

Kubrawiyya Sufism, 101

Kuiuki village, 164 
Kukmor region, $x v i i i, x i x, 14,15,19,21,62,64$, $102,124-25,128,134,245,259-60$

Kukshum village, 58

Kulmaksa village, 164

Kurmanaevo village (Kizläw), 39, 135, 138, 215

Kutlushkino village (Yäüshirmä), 242, 245

Kuz'min, Sergei, 192

land, quality of, and apostasy movement, 119, 122 landscape, sacred. See geography

languages. See Arabic literacy; local languages; Russian literacy; türki

Last Judgment: jadids on, 225, 227; Kräshen beliefs regarding, $113,114,177-78$; in popular Islamic literature, $78-79,81,115$

leaders of apostasies, 44, 46-48, 117; exile of, 39 , 46, 47, 48; kinship networks and, 45, 149; literacy of, 49-59; popular Islam and, 60; prophets' fate compared to, 76 ; returning soldiers as, 43 , 166-67; seasonal workers as, 40, 48; strategies used by, 44-45, 47-48, 58

Liapidovskii, Gleb, 177-78

Life of Basil the Younger, 188-89

literacy: among Tatar women, 180-81. See also Islamic knowledge; Russian literacy

literature, Islamic: influence on apostate leaders, 54, 59; jadid, 216-27, 242, 244-51; popularity in Volga region, 51-52; Turkic poetic tradition and, 70-71; written in türki, 67. See also popular Islamic literature

literature, Orthodox Christian/Kräshen, 182-89, 191, 194

The Lives of Saints, 184-85

local languages: Il'minskii's pedagogical methods and, 26, 206, 233, 234; Islamic literature written in, 67, 69-70; in Kräshen schools, 234-35; Orthodox clergy's use of, 168; Orthodox texts translated into, 183; prophets' use of, 76; state policies promoting, 234-35, 241-42; Sufi teachers' use of, 62

Lost Son, parable of, 186

Luka (Kazan archbishop), 40

madrasa (school of higher learning): Al'met'evo, 39, 135; and Il'minskii schools, 180; Kurmanaevo, 39, 135; Maskara, 69, 134-35, 138; Ovechii Vrag, 53; Perevo, 136; Russian literacy requirements for, 207-10; Satysh, 118, 127, 138; Sterlibashevo, 135; Tiunter, 39, 133, 200; Toygil'dino, 56; training in, 52-53, 56

Maghlum Khoja, 102

Mahdism, 114; and apostasy movements, 30, 3132; and Islamic revival, 59; jadid criticism of, 211

Mahisärwär (daughter of Bikmökhämmätov), 57, 101, 244-45
Mäkhdüm, Khäyrullah, 209

Maksimov, Semen, 184

Maksimov, Simeon, 198-99

Maksiutov family, 124

maktab (Muslim school): female teachers at, 14849; vs. Il'minskii schools, 199; vs. jadid schools, 256

Malaia Chura village, 125,128

Malov, Evfimii, 26, 173-74, 239; and apostate women, 106, 112, 154; diaries of, publication of, 261; on Elyshevo, 10, 65, 138, 152, 154; and Filippov, 155, 171; in film, 262; and Il'minskii, $26,182,210,233,234$; on Islamic knowledge, spread of, 67, 68, 72, 73, 136; and Kazan Central Baptized-Tatar School, 197, 199; and Kazan Theological Academy, 174; polemics used by, 210, 230, 241; on popular Islamic literature, 176, 215; on Russian literacy, 202; statistics compiled by, $10,28,28,126$; stories recorded by, 61, 67; teachings of, 184, 203; and Timofeev, 181,205

Mamalai village, $x x, 127$

Maqsudi, Ähmäd Hadi, 220, 243, 252, 253

Maris, 2; festivals of, 156; Islamization of, 21, 22, 131, 213; Kräshens compared to, 13, 14; sacred geography of, 102

marital links: agrarian festivals and, 127-28, 14445, 147; and apostasy movement, 55, 123-24, 143-47; in Soviet period, 259. See also kinship networks

marital relations: mixed marriages, 146 ; in Turkic religious literature, 92-93

Märjani, Shihab ad-Din al-, 13, 14, 21, 22, 23, 72, $124,213,216,217,230,235$

markets, and apostasy movement, 42, 45-47, 49, 128-29, 135

martyrs, Christian: Kräshen self-perception as, 211; Orthodox missionaries and stories of, $183-87,255$

martyrs, Muslim: apostates as, portrayal of, 24648 ; jadids on, 228,229

Mary (mother of Jesus): jadids on, 240; Kräshen perceptions of, 156-58; in popular Islamic literature, 93-94, 157-58, 171

Mashanov, Mikhail, 61, 95, 120, 143, 195

Maskara, 69, 128, 134-35, 138

Matveev, Ivan (Ibrahim Fätkhullin), 209

Matveev, Mikhail, 1, 4

Matveev, Stefan, 61

Melekes village, 63

Meleuz village, 59

Men'shikov, Porfirii, 179, 197

Midhat, Ahmed, 216

Mikheev, Ivan, 257

Minger village, 241 
mining, 19, 119, 122, 125-26

miracles: jadids on, 219-23, 257; Orthodox missionaries on, 175,178 ; saints and, 98 ; women and, 95

miraculous stories: and apostasy movements, 1-2; and popular Islam, 61-62, 65-66, 74-77, 82-84; in Sufi books, 75; women as carriers of, 5

mi'raj (the Prophet's heavenly ascent): and apostates, 64, 110; and Russian missionaries, 175

Mir Khäydär Jan, 209

Miropol'skii, Aleksandr, 66, 67, 113, 179, 195, 200, 233

Mishars, 10, 27, 45, 52, 130, 136, 147, 152, 154, $155 \mathrm{n} 110$

modernists, Tatar. See jadids/jadidism

Möher-i Shärif (sacred seal), drawings of, 64

Mökhämmädev, Shakir, 253

Moklokovo village, 27, 45, 52, 165

Mol'keevo village, 20, 166, 193

Mongols: conversion to Islam, 62, 76, 101; invasion by, 6, 95, 96, 101, 137, 184, 194

Mordvins, Kräshens compared to, 14

Moses (prophet), 65, 76, 81-82, 222

mosques: antireligious campaigns of early $1930 \mathrm{~s}$ and, 258; czarist policies on, 25; destruction as punishment for apostasy, 24; growing numbers of, 39; in Kazan province, 53

mothers, portrayal in popular Islamic literature, 93-94, 97

Mughal Empire: Russia compared to, 133; and Sufi revival, 4,132

Muhammad (prophet): apostates' views of, 76 , 109-11; followers of, salvation for, 84 ; as illiterate, 82 ; as intercessor, 77-78, 115, 158, 176; jadids on, 219-23, 226-27, 232; Jesus and, 108, 109, 178; Joseph as archetype of, 66-67; as miracle worker, 75, 82; Orthodox missionaries on, 175-76; Turkic Islamic literature on, 77-79; wives of, 90

Muhi ad-Din, 54, 55, 149

Mujaddidiyya Sufism, 132, 133, 135, 138

mullahs: agrarian festivities and, 127; daughters of, $86-87,140-41$; healing powers of, 115 ; intercessory powers of, 103; itinerant, 54; vs. Orthodox missionaries, 160; role in apostasy movement, 52-53, 54, 59; Russian literacy requirements for, 207-10; Tatar reformists' criticism of, 7; unofficial, 54, 56, 124

munajat (spiritual songs), 65, 68; Arabic words in, 70 ; female figures in, 156; in funerary rites, 153; in jadid schools, 253; tailors and, 131; women and, $68,86,87,258$

muncha (outer bath house), 17, 62, 111, 112, 187, 196, 250

Musaev family, 124 music: Kräshen, 14; and spread of Christianity, $181,182,192,193,195,196-97,201$. See also munajat

myths, as sources of knowledge: Christian, 255-56; Islamic, 62-63

Nagaibak Kräshens, 14, 15, 125; Islamization of, 27

Nalim village, 196-97, 258, 259

Naqshband, Muhammad Baha' ad-Din, 79, 82, 84, 101, 132, 139; Muhammad compared to, 176; tomb of, 98 ; wife of, 93

Naqshbandiyya Sufism, 30-31, 49, 101; Mujaddidiyya branch of, 132, 133, 135, 138; religious texts introduced by, 51, 62

Nardughan festival, 147

Nasafi (Central Asian scholar), 75

Näșīhät aṣ-Ṣālihīn (Pious Admonitions), 77-78, $79,80,81-82,84,85,87-88,113,140$

Nasïri, 'Abd al-Qayyum, 69, 98, 158, 219, 222, 225-26, 253

Nasïybullin, Khajï, 118

Nasreddin, Khoja, 137n 57

native languages. See local languages

Navoi, Nizam ad-Din Mir Alisher, 87

Nicholas I (czar of Russia), 25

Nikanor (archbishop of Kazan), 237

Nikiforova village (Shiyä-Bash), $x i x, x x, 16,55$, $118,119,202,236$; church in, 209; hybridity of religious beliefs in, 169; kinship network and, 144; Kräshens from, 155; Russian literacy in, 164, 184; sacred network and, 134, 155; trade network and, 118, 119, 121

Nikodim (bishop of Cheboksary), 42

Nikolaev, Ivan, 192

Nikolaev, Nikifor, 191-92

Ni'mätullah b. Biktimur, Shaykh. See Istärlibashi, Ni'mätullah b. Biktimur al-

Nizhniaia Nikitkina village, $x$ viii, 191

Nizhnie Shelcheli village, 100

Nogaevo village, 138

Nolde, Boris, 12

non-Muslim state, literature as paradigm for living in, $85-86$

novokreshchenye (new converts), 3, 10-11, 18-21; animism among, 20; apostasy among, 19, 20, 21; in contemporary Tatarstan, 26; number in Kazan province, 10 ; religious hybridity among, 20

Nurma village, 34, 46, 125n21, 145

Nurnāmä (The Book of Light), 106

Nyr'ia parish, xix, 145, 199

objects: and salvation, in popular Islam, $80-81$; as source of Islamic knowledge, 64, 65, 98; as symbols of Islamic conversion, 71 
Öch Narat village. See Tri Sosny

Old Believers, apostates compared to, 30

Orlov, Aleksandr, 177

Orthodox Christianity: afterlife in, 188-89; and animism, hybridity of, 169-70, 196; antireligious campaigns of 1930 and, 258; apostates' distorted image of, 177; apostates' familiarity with, 167-73; Chrismation in, 111-12; economic networks and, 125-26; festivals in, 147, 154-56, 167; and Islam, frontier between, 2, 117, 168-69; Islam compared to, 114, 160; Kräshens and, 2, 3, 9, 15, 28, 161, 163; Kräshen vs. Russian, 211; literature of, 182-89, 191, 194; music and spread of, 181, 182; myths and spread of, 255-56; and spiritual Russification, 233-34. See also conversion to Christianity; Orthodox missionaries

Orthodox missionaries/clergy: apostates and, 39, 41, 177-79, 183-84; Arabic literacy of, 214-15; criticism of Kräshen religious discourse, 11415; female apostates and, $139,150,183-84$, 200-201; jadid response to, 213, 215-16, 232; vs. mullahs, 160; popular Islam and, 4, 7, 60, $61,174-79,251,256$; response to apostasy movements, 2, 38, 122-23, 173-204; state and, 40-41; successes of, 213-14, 256; Tatar literacy of, 168

Otary village, $34,123-24,177,199$. See also Verkhnie Otary

Ottoman Empire, Tatar migration to, 32, 136, 209

Ottoman sultan, as Mahdi, 32

Ovechii Vrag, madrasa of, 53

pan-Islamism, 241

päri (evil spirit), 139-40

Pavlova, Akulina, 34, 151, 168

Perevo village (Paraw), 136

Pestretsy village (Peträch), xviii, 122

Peter I (Peter the Great), 11, 26

petitions, by apostates, 33, 44-45; cost of, 45, 48, 50; Russian literacy and, 164-65; strategies used in, 44-45, 50; tailors and, 120; women and, 150

Petr, St., 185

Petrova, Evdokiia, 55

pharaoh: Russian czar compared to, 84, 86, 93; wife of, 246

pilgrimages: jadids on, 227-28; Kräshen participation in, 194, 195

Pobedonostsev, Konstantin, 38

Pochinok Ponik village, 236, 241

poems: Turkic, and popular Islam, 70-71. See also munajat

Pokrov, feast of, 154-55, 156

Pokrovskii, Ivan, 122
Poltoratskii, Petr A., 43-44, 57

popular Islam, 60; animism and, 60, 70, 130; jadid accommodation of, 227-40; jadid criticism of, 4, 60-61, 69, 215, 223, 224-26; myths and, 62-63; Orthodox missionaries and, 4, 7, 60, 61, 174-79, 251, 256; sacred geography in, 97-103; sources of, 61-69; talismans and, 64, 65; Turkic poetic tradition and, $70-71$

popular Islamic literature, 61-96, 251, 256; authors of, 68-69; different readings allowed by, 115; forgiveness in, 77-81; and jadid literature, 25153; local languages/customs and, 69-71; myths and, 62-63; paradigm for living in non-Muslim state in, 85-86; prophets in, 74-77; Qur'an contrasted with, 74-75, 77-81; recording of, 61-62; salvation in, 77-82, 84-85; signs and miracles in, 82-84; spirits in, 79-80; women in, 86-97, 139, 159, 252

Porshur village, 128, 189

Postnikov, Grigorii, 25-26

Pozdnev, Petr, 176

prayer: jadids on, 229-30; in popular Islamic literature, 85

primary education, Islamic. See Qur'anic schools primers, Islamic, 68-69

Prokop'ev, Kuz'ma, 179, 201

prophets: as intercessors, 74-79, 115, 158; jadids on, 219-23, 226-27, 228, 246-47, 251; Kräshens' belief in, 106-11; learned men of Islam compared to, 81-82; Orthodox missionaries on, 175-76; tales of, 74-77. See also Qïsas al-Anbiya (Stories of the Prophets); specific prophets

Pugachev, Emelian, 24, 207

punishment, for apostatizing, 23-24, 37-38, 162; exile as, 24, 37, 38, 39, 41, 42, 124, 199, 241

purification: in animistic tradition, 111; in Islamic tradition, 35, 62

Qalandar (Sufi vagabond), 131

Qariyev, 'Abdullah, 249-50

Qarmät village. See St. Kiremet'

Qasim Khoja, Shaykh, 102, 194

Qazanchï Bigänäy village. See Kazanchi Bigeneevo Qïsas al-Anbiyā' (Stories of the Prophets), 68, 73, $76,78,85,94,107-8,110,132,137,158,171$, 174, 219, 220, 222

Qïșa-yi Sulaymān (Tale of Solomon), 75, 88

Qișṣa-yi Yūsuf (Story of Joseph), 66-67; examples of trickery in, 88-89; Orthodox missionaries on, 175; as paradigm for living in non-Muslim state, 86; popularity of, 51, 52; portrayal of women in, 88-90, 94, 95, 159; superiority of Islam demonstrated in, 76 ; supernatural powers in, 75; Turkic poetic tradition and, 70-71

Qïz Qïsun, tale of, 90-91 
Qol 'Ali, 66, 70, 75, 86, 89, 91, 99, 175, 247 qomghan (bronze ritual vessel used for ablutions), 80, 218, 259

Qulbaghïsh village. See Karabaian

Qur'an: commentary on (tafsir), 54, 54n170, 73, $85,88,105,116$; cost of, 51; Häft-i Yäk in, 51, 54, 65, 73; jadids on, 216-17, 220, 225-26; Kräshens' view of, 106; Orthodox missionaries on, 174-76, 177; popular Islamic literature contrasted with, 74-75, 77-81; and women's status, 221; Yā Sìn in, 65, 103

Qur'anic schools (Islamic primary education), 72-74; and apostasy movement, 1, 53-54, 59; Arabic words used in, 72-73; financial support for, 240; and Il'minskii schools, 179-80, 181; and Islamization of Volga peoples, 2-3, 74, 255; Kräshens' exposure to, 53 ; literature used in, 51 , 65, 72, 257; Orthodox missionaries on, 7; and popular Islam, 60; and Russian literacy requirement, 207-10, 211; shaykhs and, 131; state policies on, 207, 242; Tatar modernists' critique of, 7, 180; underground network of, 55-56, 57; vs. volost' schools, 166; women and, 140-42

Rabghuzi, Nasir ad-Din ar-, 66; hadith literature and, 79; jadid criticism of, 225; Qïsas al-Anbiyā', $68,73,76,78,85,94,107-8,110,132,137,158$, 171, 174, 219, 220, 222; Qïsṣa-yi Yūsuf, 66, 71, $89-91,175$; view of women, 87

Räkhim, 'Ali, 98

Ramadan: apostates during, 33, 47, 120, 123; jadids on, 229; prophets and, 203; rituals before/during, 78, 81; women during, 92, 148, 258

Rämiev brothers, 119

Rämzi, Möhämmäd Murad ar-, 213, 214

Räsuli, Zäynullah ar-, 213, 214, 225

Razi, Fäkhr ad-Din ar-, 226

Razin, Stenka, rebellion of, 12

religious affiliations, fluidity of, 15-17, 20-21, 256 religious liberty, Catherine II's policies of, 24-25, 39-40

Renan, Ernest, 221

revolutions of 1917, Kräshens after, 257-58

Risālä-yi 'Azīzä (Treatise for 'Azizä), 76, 82, 98, $110,113,115,175,176$

rituals: and salvation, $84-85,115$; tailors and, 120 , 131-32; women and, 151-58

Rozov, Emel'ian, 37-38, 48, 182

Rumi, Jalal ad-Din, 87

Russian literacy: apostates and, 49-51, 58, 163-66, 201, 202; Il'minskii's pedagogical methods and, 206; jadids and, 211, 215, 253; in Qur'anic schools, efforts to introduce, 207-10, 211

Russian peasants: and Kräshen ceremonies, 173; riots by, apostasy movement compared to, 30
Russification policies, 205, 207-8; Kräshen intelligentsia on, 233-34; Tatar protests against, 208-10

Russo-Tatar schools, 251-52

Ruza, 232. See also Ramadan

Rybakov, Sergei, 22

Rychkov, Petr, 137n57

Sabantuy festival, 20, 127, 178, 253

Sablukov, Gordii, 174

Said, Edward, 173

Sä'idi, Äbrar, 244

saints: female, 95, 142-43, 187; jadids on, 223, 225, 227-28; Kräshens' beliefs in, 111; miracles of, 83 ; Orthodox missionaries and stories of, 183-87

Saltygan Kliuch village, $x x, 35,121,197,199,200$, 202, 236, 237

Saltyganovo village, 37, 47n144, 136, 139

salvation: collective responsibility for, 79-80; faith and, $81,84-85$; learning and, 81-82; objects and, in popular Islam, $80-81$; prophets' intercession and, 77-79; rituals and, 84-85, 115

Samigulov (Egor Fedorov or 'Alim Ismä'il ughli), $46-48,50,102,135,136,137$; literacy of, 49, 50

Sämitova, 'Azizä, 140

Sartyk village, 155

Satysh village, $x x, 118,124,127,138,142,144$

Saudi missionaries, 260, 261

Savrushi village, xix, 119, 121, 149, 200, 202. See also Bol'shie Savrushi

Säyf ad-Din, Möhämmäd Shärif b., 128

Säyfullah, 'Ali (Shaykh 'Ali), 133, 134-35, 243

schooling. See under education

sciences, jadids on, 226, 229

seasonal workers, 119-21; and kinship networks, 146; as leaders of apostasies, 40, 48; Russian literacy of, 164. See also tailors

Semitbash village, 165

Serdauch village, 169

Serda village, $x$ viii, 122, 168, 192-93, 202. See also Verkhniaia Serda

Serdous village, 163

sexuality, women's, portrayal in popular Islamic literature, 66-67, 88-89

Shadchi village, 69

shahada (Muslim creed or witness of faith), 57, 78, $85,89,105,111,113,131,152,158$

shama'il (sacred illustrations), 64

Shamil, Imam, 204

Sharāiṭ al-İmān (Muslim primer), 51, 69, 72, 73 , $85,101,105$

sharia, approach to study of, 84

shaykhs (ishans): and apostasy movement, 12939; healing powers of, 130; jadids on, 7, 129, 
224-25, 229; Kräshens' attitudes toward, 111, 114; as mediators, 133; Orthodox missionaries on, 176 ; as spiritual guides, 82

Shcherbakov, Nikanor Ivanovich, 197-98

Sheba, Queen of, 91

Shemordan village, $x i x, 123,124,125,128,145$

Shemutbashi village, 120

Shepsheik village, 34, 136, 151, 168

Shestakov, Petr, 182

Shevzov, Vera, 156

Shittsy village, $x i x, 21$

Shiyä-Bash village. See Nikiforova

Shonguty market, xviii, 47, 135

Shpilevskii, Sergei, 137n 57

Siberia, apostates exiled in, 37, 38, 42, 48, 124; prophets' fate compared to, 76 ; and spread of Islam, 126

Sirhindi, Ahmad, 4, 132, 133

Sluzhilaia Maina village, 137

Smolensk Mother of God icon, 194

Sofiiskii, Il'ia, 137n57, 195

Sokol'ie Gory village, xviii, 129

Solomon (prophet), 65, 75, 76, 107-8, 219, 221

Sönatullah (Shaykh Ni'mätullah's son), 136

Sosnovyi Mys village, 55, 167, 190, $260 n 8$

Soviet Union, Kräshens in, 258-60

Söyem Bikä (queen of Kazan), 96, 244, 246

spirits: animist beliefs in, 17-18, 55, 80, 99-101; and icons, hybridity of, 169-70; jadids on, 211, 222, 253; jinns, in Islamic literature, 79-80, 88, 100, 177, 222; Orthodox missionaries on, 177; päri, women's belief in, 139-40. See also kirämät

Spiritual Assembly of Orenburg, 39, 50, 134, 138, $160,208,240,242$

Stalin, Josef, 258

Staraia Ikshurma village, $x i x, x x, 55,113,119,123$, 134, 142, 144, 167, 236; economic networks and, 118, 128, 129; education networks and, 148; priest of, 179, 201

Staro-Afon'kino village, 240

starokreshchenye (old converts), 3; animistic traditions and, 11, 15, 17-18, 168-70; apostasy movement and, 21, 47, 117, 236; in contemporary Tatarstan, 26; economic forces and apostasy of, 117, 119; Finnic roots of, hypothesis regarding, 14; Islamic knowledge of, 105, 111, 113 ; jadids on, 240 ; in Kazan province, 10 ; origins of, 10-18; religious hybridity of, 168-70; sacred places for, 99, 100, 101-2, 103

Stefan, St., 185

Stepanov, Semen, 36

Stephen, St., 233

Sterlibashevo, madrasa of, 135

St. Kiremet' village (Qarmät), 56, 242

Stolypin, Petr, 241, 242
Subash village, 123

Sufism: agrarian festivals and spread of, 146; initiation in, 131; and Islamic knowledge, 81-82, 256; and Islamic revival of 18 th century, 59; and Islamization of Volga Tatars, 30-32; jadidism compared to, 257; jadids on, 224-26, 228-40, 256; Khalidiyya, 133; Kubrawiyya, 101; miracle stories in, 75; Mujaddidiyya, 132, 133, 135, 138; Naqshbandiyya, 30-31, 49, 51, 62, 101; Orthodox missionaries on, 174-76; and poetry, 7374, 140; and popular Islam, 60, 61, 62; reform movement within, 4, 129; sacred networks of, and apostasy movement, 129-39; as shared culture, 159; women's status in, 87, 89, 93, 95, 159; Yasawiyya, 30-31, 62

Sulabash village, 34, 242. See also Bol'shie Sulabashi

Sultanov, Möhämmädyar, 235

Sünchäläy, Sä‘d, 244, 245

Suncheleeva village, 164

Sunni Islam, apostates' beliefs compared to, 104

Suyuti, Jalal ad-Din as-, 247

Tabari, Abu Ja'far Muhammad ibn Jarir at-, 74, 88, 89, 91, 247n94

tafsir (commentary on Qur'an), 54, 54n170, 73, 85, $88,105,116$

Taftazani, Sa'd ad-Din at-, 174

Tahir, Fäkhrulla, 56

tailors: and apostasy movement, 119-21, 124, 126, 135, 159; Arabic words used by, 70; economic alternatives for, Orthodox missionaries and, 122-23; and marital links, 145; resistance to Il'minskii schools, 200, 201; Russian literacy of, 164; Sufi rituals and, 131-32; talismans associated with, 64

talismans: jadids on, 231; as sources of Islamic knowledge, 64, 65, 98, 130; supernatural power ascribed to, 80-81; use of hadith as, 217

Tamerlane (Turko-Mongol ruler), 97, 187

Tängre babay (Grandfather sky), 169

Tarlau village, 124, 128

Tashkirmen' village, 14, 102, 103, 169, 192, 194, 198 Tatar modernism. See jadids/jadidism

Tatar nation, Kräshens included in, 257-58

Tatars, 9; apostasy movements and, 161, 235, 23941; Catherine II's policies and, 25, 39-40, 58; Islamic education among, 103-4; and Kräshens, 8-9, 13-14, 21, 142, 161, 239-40; migration to Ottoman Empire, 32, 136; minorities absorbed by, 23; national consciousness of, emergence of, $214,215,246-49,251$; ostracism of apostates, 104, 245; Sufism and Islamization of, 30-32; and trade, 39; Volga, 2. See also conversion to Christianity; Kräshens 
Tatarstan, contemporary, 6, 260-63

Taveli village (Chistopol' district), 16-17, 55

Taveli village (Mamadysh district), $x v i i i-x x, 155$, 166,173

Tavlarova village, 199

Tavliar village, 36

Täwārīkh-i Bolghāriyya, 63-64

Taz ad-Din, 165

teachers: in apostate villages, 56, 59; at Il'minskii schools, 192, 197, 199, 200; women as, 55, 57, 140, 141, 144, 148-49, 159, 197, 200, 201. See also mullahs

Teberdi Chally village, 102

textile and leather industries: and apostasy movement, 119-21, 124, 126, 135; shaykhs involved in, 129

Thalabi, Abu Ishaq Ahmad ath-, 67

theater, Tatar, 249-50

Theodora, in Life of Basil the Younger, 188-89

Theodora the Virgin, St., 183-84

Tiamti village, $x i x, x x, 36,149,190$

Tikhon III (Kazan metropolitan), 24, 165

Tikhvin icon of Mother of God, 195

Timei, Timofei Ivanovich, 166

Timofeev, Vasilii: and Biksutana, 148; and Il'minskii, 182; and Kazan Central Baptized-Tatar School, 26, 166, 192, 202, 205; legacy of, 211, 232-33; and Malov, 181, 205; native village of, 134 ; observations of, 112, 124, 169, 173, 177; pedagogical approach of, 178-81, 233; schooling of, 166,173 ; stories recorded by, 61,111 ; students of, 100

Tiunter village, 39, 128, 133, 134, 135, 200

Togan, Zeki Velidi, 98, 249; mother of, 86-87

Tokhtamïsh (khan), 96

Tokhtamyshevo village, 55, 131, 134, 148, 199

Tolstoi, Dmitrii, 204, 205, 207, 211

Tomasov-Pochinok village, 111, 143, 190, 191, 192, 200

tombs: Islamic inscriptions on, 56-57, 57; sacred, Muslim, 97-98, 101, 102-3; of saints, jadids on, 223, 225, 257

Toygil'dino village (Toygilde), 56, 126

trade: and apostasy movement, 4, 45, 84, 118-21, 124, 126; and marital links, 145; Tatars and, 39

trees: in animist cosmology, 100; in Islamic cosmology, 63, 95

Tri Sosny village (Öch Narat), $x x, 55,108,119$, $144,148,163,168,202$

tsar'-batiushka, apostates' reliance on, 30, 40, 41, 42

Tubïlghïtaw village. See Verkhniaia Nikitkina

Tufan, Khäsän, 56, 75, 97, 243-44, 253

Tukhvatullin, Ramil, 262

Tuqay, 'Abdullah, 74, 244, 245, 253 türki (Turkic literary language): Islamic literature written in, 67, 69; prayers in, 105; Sufi poetry in, $73-74$

Turkic poetic tradition, and Qur'an, 70-71

Turkic tribes, conversion to Islam, 62

Turkmani, Niyaz Quli b. Shah Niyaz at- (shaykh), 31, 133

Tuy Bikä (Bolghar princess), 62, 63, 95-96

'Ubäydullah b. Jäfär, 135, 138

Udmurts, 2; in apostate villages, 15; Islamization of, 21, 145; Kräshens compared to, 14

University of Kazan: Muslim texts published by, $64,116,182$; rector of, $88 \mathrm{n} 91,140$

Urazbakhtino village, 128

Urias'bash village, 190-91

Urmaeva village, 157

Ütämesh-Gäräy, 96

Utïz Imäni, 'Abd ar-Rähim al-, 71, 124, 132, 133 , 151, 158

Utyamïshev, 'Abdullah, 134, 145

Utyamïshev, Musa, 134

Vaisov (Waysi), Baha' ad-Din, 245

Vakhitovo village, 259

Varangush village, $45-46$

Varsonofii, St., 186

Vasil'ev, Kiril, 124

Verkhniaia Nikitkina (Tubïlghïtaw), 102-3; apostasy of, 34, 46-47, 63; ethnic groups in, 15, 22; and kinship networks, 124 ; literacy in, 58 ; punishment for apostasy of, $37-38$; resistance to Orthodox missionaries, 189; sacred geography and, 187; sacred networks and, 132, 136, 137; women in, 151

Verkhniaia Serda village, 122, 126, 145, 193, 194

Verkhnie Chelny village, 63

Verkhnie Kibiak-Kozi village, 106

Verkhnie Mashliaki village, 141, 144, 195

Verkhnie Meretiaki village, 122

Verkhnie Otary village, xix, 50, 145, 236

Vladimir, St., 185, 233

Vladimirova village, 99, 142

Volga region: fluidity of religious affiliations in, $15-17,20-21,256$; as frontier between Islam and Christianity, 2, 117; spread of Islam in, 2-5, 72-74, 158-59, 255. See also Tatars

volost' schools, 166, 204

Vorob'ev, Nikolai, 127

Votiaks. See Udmurts

Voznesenskii, Aleksei, 176

Wahhabis, 174, 176, 251, 260

Wali Allah, Shah, 4, 132 
Wälitov, Yaghfär, 134, 237

water: role in Muslim rituals, 35 . See also purification Waysi, Baha' ad-Din, 245

women: and animistic traditions, 17, 55, 139-40; and apostasy movement, 35, 45-46, 50, 55, $57,86,117,139-60$; apostate, Orthodox missionaries and, 139, 150, 183-84, 200-201; and childbearing rituals, 99, 113; and death rituals, 151-58; dervishes, 95-96, 139, 229; diaries, 68, 97n119, 140, 244, 258; education of, 86-87, 140-41, 144, 200-201; heroic, in Tatar epics, 95-97; intercessory power of, 153; Islam and status of, 221, 223; and Islamic knowledge, 139-43, 258; jadid literacy of, 244-45; jadids on, 140, 229, 246-48; Kräshen, clothing of, 13 , 14; literacy among, 180-81; love for, as love of God, 67; as mothers, 93-94, 97; and munajat poems, $68,86,87,258$; in popular Islamic literature, 86-97, 139, 159, 252; in Russian Orthodox literature, 188-89; saints, 95, 142-43, 187; and spread of Islam, 4-5, 95-96; Sufism and, $87,89,93,95,159$; teachers, 55, 57, 140, 141, $144,148-49,159,197,200,201$; wifely duties of, popular Islamic literature on, 92-93
Yaghqubov, Wäliulla, 261

Yalchïghol, 79, 83, 101, 114, 132, 174, 175, 178, 196; Risālä-yi 'Azìzä, 76, 82, 98, 110, 113, 115, 175,176

Yasawi, Ahmad, 78, 87, 93, 157

Yasawiyya Sufism, 30-31, 62

Yã Sīn (thirty-sixth Sura of Qur'an), 65, 103

Yäüshirmä village. See Kutlushkino

Yunusov, 'Abd al-Kärim 'Abd ar-Räshid, 118

Yusuf (Noghay khan), daughter of, 96

Zäbiri, Häbib Rahman, 220, 226, 230, 252

Zamakhshari, Abu al-Qasim Mahmud al-, 247n94 zemstvo schools, 242, 251-52

Zhirnova, Anastasiia, 197

$z i k r$ (Sufi prayer or litany), 138, 156, 176, 225; jadids on, 229, 230; Kräshens and performance of, 131, 135, 137; and Muslim identity, 81, 85; origins of, 101 ; in story of Job, 108; women and, 92, 142

Ziuri road, 63

Ziuri village, $x$ viii, xix, 148, 190

Ziuri volost', 69

Zöläykha (Iskhaqi), 246-51, 262

Zulaykha, 88-91, 150, 246-51, 261-62 
